

\section{Cormell älniwersity folbrary}


The date shows when this volume we To renew this book copy the call No. and $g$. the librarian.

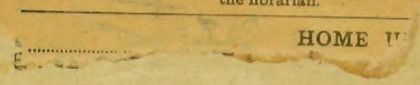

Cornell University Library

QL 561.T7S78

Insecta britannica.

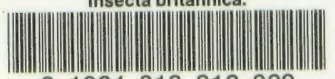

31924018312029 



\title{
INSECTA BRITANNICA.
}

\section{LEPIDOPTERA:}

\section{T I N E I N A.}

\author{
H. T. STA I T T
}

\section{LONDON :}

LOVELL REEVE, HENRIETTA STREET, COVEN'T GARDEN.

1854 . 


\section{Q $L 5-61$ T7S 78}

9591 E 29.

A. 35483

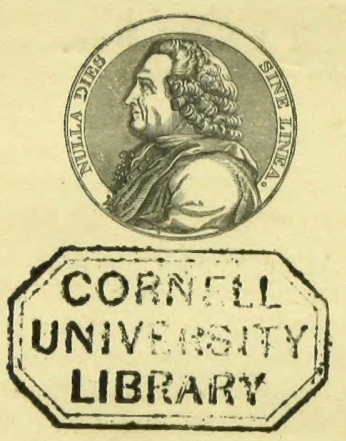

JOHN SDWARD TAYLOH, FRLNTER,

LITSLE QUENA BTREIT, LNCOZN'S INN FIELDS. 


\section{PREFA C E.}

THe object of this volume is to furnish descriptions of all the species of Trnerna (a group of Lepidoptera) at present known to inhabit Great Britain, and at the same time to give as much information concerning their habits and transformations as the limited space would allow. Each species is carefully described from actual specimens, and each genus is founded on the microscopical investigation of all (or nearly all) the species comprised in it. In some few instances, to avoid a premature multiplication of genera, species are placed in a genus though not quite agreeing with its essential characters; in such cases care has been taken to point out wherein these differences consist, so that, should the further progress of the science require the creation of new genera, this will be facilitated by the details here given. The habits noticed are in most instances the result of personal research, although advantage has been taken of the observations of others where there was no doubt to what species they were intended to apply. The transformations of the species, from their great variety, offer an endless field of amusement; and my object being to give full but concise details, general observations thereon are placed at the commencement of each genus. In every case where no observations occur concerning the larva of a species, it must be understood that we are still unacquainted with it. As a rule, 
uo descriptions of larvæ are introduced, as the space would not permit it. With reference to the synonymy, the works of the principal writers were carefully gone over, and the descriptions identified with known species, or set aside as undistinguishable. The synonymy of the species described in this volume is given more fully in the Catalogue of British Micro-Lepidoptera (Tineina), which I have been conducting through the press, for the Trustees of the British Museum, simultaneously with this volume; but neither did that Catalogue, any more than the present volume, admit of the introduction of critical disquisitions on the synonymy of the species.

To have gone minutely and critically into the synonymy, to have described the larva of each species and its entire habits in detail, would have completely altered the design of this work; but I purpose at no distant date, in conjunction with others, to edit a more detailed and voluminous work, "The Natural History of the Tineina.'

To avoid misconception, it is however necessary to remark that the present volume does not-cannot contain descriptions of all the British Tineina; the number of these is increasing upon us daily; all that has therefore been accomplished has been to describe all the known and distinguished species : the latter expression is used advisedly, for it frequently happens that a so-called new species is not really new, having lain dormant in our collections for years, but mixed with some other species, from which we have ouly at length learnt to distinguish it. Consequently, in addition to the new species that will be met with in the course of a few years, it may be also found that many of the species of this volume are little groups of species, which further investigations will enable us to separate; and as the transformations of many species not now known to us will be discovered, this volume will gradually fall in arrear of the progressive science, and a new edition will become requisite. 
Of the ten plates, which have been carefully executed by Mr. Wing, eight illustrate the generic characters, one the various forms of the larvæ, and one the perfect insects of several of the most important genera (especially representing those which have any peculiarity in their posture when in repose).

It will be found by those who study this volume, that, even with the help of the descriptions and the plates, it will be a matter of considerable difficulty to name with certainty many species; those who do not associate with other entomologists are not aware to how great an extent the comparison of specimens with named collections is carried. To all who meet with any difficulties of this nature I offer my services; and if they apply to me by letter or personally, their wants shall be immediately attended to. In order to be readily accessible without any previous appointment, I have followed the example of the late Mr. Stephens, and "my collections are thrown open for inspection, etc., every Wednesday evening, to any gentleman, upon the presentation of his card."

In concluding the labour of my leisure hours of three successive winters, I have to express my sincere thanks to all those who have assisted me, either by the loan of specimens (frequently unique), by the communication of original observations, or in the more laborious operations of denuding wings, preliminarily investigating genera, or reviewing the descriptions of species : assistance on all these points has been so freely given, that I have felt my position more that of an Editor, taking advantage of the labours of others, than that of an Author; yet, at the same time, for all the errors and imperfections of this book I am solely responsible.

H. 'T. Stainton.

Mountsfield, Leivisham, July 1st, 1854. 


\section{.}




\section{EXPLANATION OF THE CONTRACTTONS IN T'HE}

\section{REFERENCES.}

Bjerk. N. A. II.-Bjerkander, Nova Acta Holmix.

Bouché, Natur, - Bouché, Natargeschichto der Insekten.

Cl. I--Clerck, Icones Insectorum rariorum.

Curt. B. E.-Curtis, British Entomo$\log y$.

Don. B. I.-Donovan, Natural History of British Insects.

Dougl. Ent. Irans.; Zool-Douglas, Transactions of the Entomological Socicty of London; Zoologist.

Dup. Cat.-Duponchel, Catalogue des Lépidoptères de France.

Dup. I. F. xi.; Sup. iv,-Duponchel, Lépidoptères de France, vol.xi. ; and Supplement, vol, iv.

Edl.-Fdleston.

Evers.-Dversmann, Fauna Lepidopterologica Volgo-Uralensis,

Fab. S. E. ; G. I. ; S. I. ; Man.; E. S.; E. S. Sup.-Fabricius, Systema Entomologix; Genera Insectorum; Species Insectorum; Mantissa Insectorum; Entomologia Systematica ; Entomologix Systematice Supplementum

F.? $v . I R,-$ Kischer vou Röslerstamm.

Four-Foureroy, Entomologia Parisiensis.

Frey, N. B.-Freyer, Nene Beitrïge zur Schmetterlingskunde.

Godart. - Godart, Lépidoptères ¿ de Irranco, vol. $\nabla$.

Goeze, E. 13.-Goeze, Entomologische Beiträge, vol. iii. part 4.
Guenée, - Guenée, Index Methodicus Micro-Lepidopterorura Europscorum.

Iaw. L. B.- Haworth, Lepidoptera Britannica.

H.-S.-Herrich-Schäfler, Systematische Bearbeitung der Schmetterlinge von Europa.

Hüb. Tin.; V.-IIübner, Sammlung Turopäischer Schmetterlinge; Verzeichniss bekannter Schmetterliuge.

Hummel, Ess. Ent.-Irummel, Essais Entomologiques.

IIump. et West. B. M.-Humphreys and Westwood, British Moths, vol. ii.

Kollar, Verz. der nied, ost. Schm. Kollar, Verzeichniss der niederöster. reichischen Schmetterlinge.

Lat. G. C. et I. ; H. N.; R. A.-I. treille, Genera Crustaccorum et Insectorum; Histoire Naturelle des Crustacés et des Insectes; le liègnac Animal.

Lewis, Ent. Mag.-Lewis, Entomolo. gical Magazine.

Lin. F, S. S, N.-Linnæus, Fauna Sueciea; Systema Natura.

N. A. 11.-Nora Acta Holmix.

Och,-Ochsenheimer, dic Schmetterlinge von Europa.

Panz. I. G.-Panzer, Fauna Inscctorum Gcrmania.

Ratz. F, I. - Katzeburg, Forst Insecten.

Retz. G, et S, - Retzius, Genera et Species Insectorwa.

Roemer, G, I.-Rocmer, Genera Insectorum Linnei et Fabricii.

Rossi.-Rossi, Hauna Etrusca.

Schr. F. 13.-Schrank, Fauna Boica. 
Scriba, Beit.-Scriba, Beitröge zu der Insekten Geschichte.

Scop. E. C. - Scopoli, Entomologia Carniolica.

Sta. Cat.; Sup. Cat.; Ent. Trans.; Zool.-Stainton, Catnlogue of British Tineidre and Pterophoride; Supplementary Catalogue of British Tineid $\infty$ and Pterophoridø; Transactions of the Entomological Society of London; Zoologist.

Step. II. - Entom.-Stephens' Illustrations of British Entomology, Haus. tella, vol. iv. ; Entomologist.

Tengst. F. F.-F, - T'engström, Bidrag till Finlands Fjaril-Fauna.
Thuщ. I, S.; M. N.A. U.-Thunberg, Insecta Suecica; Museum Naturalium Academin Upsaliensis.

Treit. E. S.-Theitschke, die Schmetterlinge von Europa.

Vill. E. L. - Villers, Entomologia Fauns Succicre deseriptionibus sucta, Caroli Linnæi.

IV. V. - Systematisches Verzeichniss der Schmetterlinge der Wienergegend.

Zell. Isis; L. E.; Ent. Ztg.-Zeller, Isis von Oken; Linnea Entomolo. gica; Entomologische Zeitung.

Zett. I, L,-Zetterstedt, Insecta Lapponica.

Z. g. S.-Zincken, genannt Sommer. 


\title{
INSECTA BRITANNICA.
}

\section{LEPIDOPTERA.}

\author{
Alo quatuor, squamis imbricala. \\ Os haustellum maxillis colecerentibus compositum. \\ Larva pedibus ad summum 10 instructa. \\ Metamorpliosis perfecta.
}

\section{Synonyma.}

Lepidoplesn, Linnai, 1753, De Geer, aliorumque nuctorum. Glossata, Fabricii, 1775.

Wings four, clothed wilh scales*, which are inserted on both sides of the membranc; mouth a tubular tongue t composed of the united maxille protected on each side by the palpit. The lared furnished at the most with sixteen legs, rarcly with less than ten. Metamorphosis complete, i.e. the larva changes to a quiescent masked pupa, which differs both from the larva and from the imago.

None of the insects of this order are liable to be mistaken for any other, but several of the Trichoptera approximate so closely to the Lepidoptera, that it is with the greatest difliculty they can

* Some speeies of the Psyclides have all the wings clothed with hairs, and in some speries of Ineurearia, Lamproma, Microptery, and Neptienla the posterior wings are furnished with hairs instead of seales. The females of Lleterogyius, I'syche, and Talaporia, ete., are entirely destitute of wings.

+ In some of the Psychida, and in Aglossa, the tongue is alsent.

+ The palpi are sometimes wantiug, e.g. Bucculatrix und some of the l'syrlider.

VOL. III. 
be distinguished; and Acentropus has been placer in this order by Westirood (Introd. to Mod. Classif. of Insects, vol. ii. p. 412), and by Kolenati (Genera et Species 'Trichopterorum, p. 6), who had himself taken forty specimens of the insect : it is possible that future investigation, and the discovery of the primary states of this insect, may show that their views of its affinities are well founded. The llomopterous Alleyrodes proletella was described by Linneus as a Tinea, but the resemblance of the perfect insect is very superficial. 'The resemblance of the Dipterous genus Psychoula would appear to mislead some entomologists, Professor Zeller having had specinens sent him to name as species of the Psychida.

The two main divisions of the Lepidoptera are:-

I. With the apex of the antenne thickened . Rhopalocers.

II. With the apex of the antennæ not thickened Heterocers.

\section{RHOPALOCERA, Duméril, Boisdwval.}

Diuma, Latreille.

Antenna apice incrassato, articulis mediis elongatis.

Ala in quiele erecta, posteriores sine retinaculo.

Prothorax sine collari.

Antenne with the apex incrassated (a few exceptions occur among the Alorplides); the middle joints elongated. Wings in repose erect (IIesperio malvarum and Tages sleep with the wings decumbent); the posterior without a bristle. Prolhoraw without a collar (in the Ilesperide there is a slight development of a collar).

\section{HETEROCERA, Boisdwal.}

Antenna setacea vel fusiformes, apice attenuato.

Ala in quiete plana, posteriores cum retinaculo vel sine co, Prothorax collari tectus.

Antenua setaceonts, or fusiform with the apex allemuted (Castuia forms an exception, and was therefore placed by early writers among the diurnal Lepidoptera; the development of the collar, and the bristle of the postcrior wing, show that it belongs to the Heterocera); vings in 
repose flet (a few Geometride, c. g. Piniaria, Illustraria, Zebraria, ctc., slecp with the wings erect); posterior wings generally furnished with a brislle, if it be wanting the form of the costa* is sufficient to distinguish the insect from Rhopalocera; the prolhorax covered by a collar.

Of the IIeterocera there are nine groups, which are thus divided :-

A. Antennæ fusiform

1. SPIINGINA.

A A. Antenna setaceous.

B. Wings undivided.

C. Wings witl short cilia.

1. Wings ample, the posterior gaily coloured, or more so than the anterior wings.

E. Body thick, rather short, and posteriorly obtuse; posterior legs hardly longer than the middle paix . E E. Body slender; posterior legs considerably longer than the middle pair . . . . a

v v. Wings moderate; the posterior of dingy colours. Borly moderate, posteriorly attenuated

2. Bombycins.

4. Geometiona.

3. Noctuina.

D $D$. Wings rather long, triangular. Body slender, elongate . . . .

D D D D. Wings broad, the anterior subtruncate; the costa at the base suddenly convex : -

c c. Wings with long or very long cilia.

Wings clongate; body slender

13 13. Wings divided.

F. Anterior wings bifid; posterior trifid.

F $\mathrm{F}$. Each wing divided into six . . .

5. P’yralidina.

6. Tortricina.

7. Tinetna.

8. J'TEROPHORIN.t.

9. Alucitina.

The first four of these groups, with the Rhonalocera, are frequently called Maero-Lepidoptera; the remaining five being termed Miero-Lejidoptera: there is a certain convenience in these terms, as they will apply to the average size of the insects in the respective groups, for of course there are many exceptions of small species among the Macro-Lepidoptera, and large species among the Micro-Lepidoptera.

* In the Rhomalocera the bristle appears absent, becnuse prolonged iuto an entire nervure, which is in the membrane; in the ICetrocere this membrane is wauting, wherefore the eostal cell is narrow and the nervure abbreviated to n bristle. 


\section{SPHINGINA, Stainton.}

Crepuscularia, Stephens.

Antenna fusiformes, i.e. in medio crassiores, utrinque attenuale, subprismaticre.

The untenne fusiform, i.e. thicher in the middle, attenuated at each end, subprismatic.

\section{BOMBYCINA, Stainton.}

Pomeridiana, Nocturna partim (Ijithosiida), et Semidiurna partim (Platyptcricidx), Stephiens.

Autenne setacec, plerumque pectinatc, vix thorace longiores. Ocelli nulli.

Corpus crassum, breviusculum, postice obtusum.

Pedes postici mediis vix longiores.

Ala ampla, anteriores sine pictura typica, posteriores late coloralc.

Larva non minus 14 pedibus instructa.

Antenuc selaceons, mostly pectinated (Tithosia and Platyptery. have simple setiform antenna), hardly longer than the thorax. Ocelli none, excepting in the Chelonids. Body thich, rather stort, and posteriorly obtuse. Posterior legs hardly longer than the middle pair. Wings broad, the anterior vithout any typical markings (e.g. the markings of the Saturnides are quite difierent from those of the Chelonide, Liparidee, ete. ; thus not as in the Noctuina). Posterior wings bright-coloured, frequently more vivid than the anterior wings (thus not so much contrasted as in the Noctuina); the larva with not feroer than fourteen feet.

\section{NOC'TUINA, Stainton.}

Noctux, Boisduval.

Noctuidx, Herrich-Schäffer.

Nocturna (excl. Lithosididx), Stephens.

Antenne selacer, raro pectinate, thorace longiores. Ocelli plerisque.

Corpus mediocre, postice attenuatum.

l'edes postici mediis longiores.

Ale mediocres, anteriores longiuscula, signis constantibus piche, posteriores

latiuscula obsolete colorata.

Larva non minus 12 pedibus instructa.

Autemure setaceons, rarely prectinated, most frequently ciliated, longer than the thorke (exeept in Cocylin). Ocelli in most. Body moderate, posteriorly allenualed; posterior leg.s longer than the middle pair. Wings moderate; anterior valleer long, adomed wilh characteristic merkings 
(the three spots on the middle of the wing, and the thece transverse lines, vary ouly in intensity or sharpuess of design); posterior voings rather broad, of dingy colours (Catocala and a few others differ, forming a section more allied to the Geometrina).

Though few would mistake a Noctua for a Bombyx, it is not easy to define in words distinetive characters which shall be constant.

\section{GEOMLLRINA, Siainton.}

Geometra, Boisduval.

Geometridx, Stephens; IIerrich-Schëffer.

Autenno setacece (sape ciliatie aut pectinatie), thorace longiores. Ocelli nulli.

Corpus yracile.

Pedes postici mediis sensim longiores.

Ala ample, tenera, posteriores late colorata.

Larva pedibus 10 instructa.

Antenne setaceous, frequently ciliated or pectinated, longer than the thorax. Ocelli none. Body slender (Boarmia and Biston have the body thick, and thereby resemble the Bombycina, from which they are however distinguished by the larva). Wings broad, of slight structure, the posterior yaily coloured (those species which have the posterior wings covered in repose have only the rudiments of markings on the projecting imer margin). Larva will ten feet (in some there are onc or two pair more of ill-developed ventral feet; otherwise the larva gives the most certain character of this group).

\section{PYRALIDINA, Stainton.}

Crambides, IIerrich-Schüffer.

Pyralides ct Crambides, Guénée.

Pyralida et Crambidic, Stephens.

Intenne selacere, rarins pectinate, thorace plus duplo longiores. Ocelli plerisque.

Corpus gracile, elongatum.

P'edes elongati, posteriores reliquis longiores.

Ale longius triangulares, rarius subparallele, mediocriter ciliale, posteriores piclo, tribus rarius duabus venis subdorsalibus liberis.

Antenne setaceous, but rarely pectinated (IIerminia), more than twice the length of the thortax. Ocelli in most (the ocelli are wanting in Calrclysta lemmalis, the Gullerie, Anerastia, etc.). Body slender, elongatul. lege long, the posterior longer thun the others. II ings rather lonig, triangular, rerely subparalled (e.y. the Gallerice, Plyycidec, and many 
Crambi), wilh moderately long cilia (the Crambida have the cilia a little longer thim the other families, yet not as long as in the Tineina); poslerior wings adorned wilh markings (excepting the Crambidse), with three, rarcly soith two free subdorsal nervures (the Crambida have three, in complete accordance with the Bolydes; Chilo agrees in everything so closcly with Pyralis angustalis that not even the length of the cilia serves as a distinctive character, only is the colouring of the posterior wings less developed).

The removal of the Crambide into this group had long been rendered probable, from the extreme difficulty of otherwise finding a suitable position for Eudorea, which indeed has alternately been placed in each family; its triangular position in repose and unconvoluted wings separating it from the Crambi, whereas its general appearance caused it ill to accord with the Pyralide. Therc is no denying that some of the Pyraliule have great affinities with the Noctuina, indeed Herminia is placed by Herrich-Schäfler among the latter; but this only corroborates what lias so frequently been ascertained, that no linear arrangement of species can be in exact accordance with a natural system: if the Pyratides be placed in juxtaposition with the Nocluina, the Bonbycoidnl-Geometrina might be with equal justice placed next to the Bombycina.

\section{TOR'TRICINA, Stainton.}

Tortricidx, Stephens; Herrich-Schäfler.

P'latyomida, Duponchel.

Antenne setaces, thorace multo longiores, rarissime ciliate. Ocelli omnibus?

Corpus mediocre, postice subobtusum.

Ale late, mediocriter ciliate, anteriores subtruncale, cosla e busi subilo convexa, posteriores latiuscula, trapczoidales, sine pictura.

Larva 16 pedibus instrucla.

Chrysalis abdominis segmentis spinuloso-coronatis.

Antenna setaceous, much longer than the thorax, very rarely ciliated (Amphisa ס). Ocelli alwayss? present. Isody moderate, posteriorly rather blume. Wrings broad, will moderately long cilia (hardly longer than in the Crambide); the anterior subtruncate; the costa ai the buse abruptly convex; the posterior rather broad, trapezoidal, without marlings (the Choreutida appear to be nore properly placed amongr the P'yralidina, where they are the analogues of the Echmice). Larva wilh sixleen feet; mupa woith spiny coronets on the segments of the abdomen (cxecptions, Quercuna, Chlorana).

The patpi of the Tortrictna are also extremely characteristic of 
the group, but not being nsed to distinguish the other groujs, are not incluted in the essential characters; they are rather short, triangular, compressed, with thin, short, not recurved terwinal joint.

\section{TINEINA, Stainton.}

Tinencen, Zeller.

'Tineidx, Duponctel, ILerrich-Schueffer.

Tineida partim et Yponomeutidac, Stephens.

Antenne setacer, raro pectinato vel ciliate, corpore longiores. Ocelli adsunt rarius.

Corpus gracile.

Ale elongala, longe vel longissime ciliale, prasertim posteriores, the raro elongato-trapezoidales, plenumqe sensim altenuato, sine pictura.

Larva 16 aut 14 pedibus instructa.

Antenne setaceons, rarely pectinated or ciliated, longer than the body. Ocelli rarely present. Body slender. Wings elongate, wilh long or very lony cilia (this is probably the most distinetive chaxacter of the Fineine; indeed there appears to be a gradual progression from the Diurnal Lepidoptera, where the cilia are shortest, to the P'lerophorina and Alucitina), more especially the posterior pair; these are rarely of an clongatetrapezoidal form (in Depressariu, Semioscopis, and Euplocamus, the posterior wings are rather broad, but liave not the form or shortness of those of the Tortricina; IIypercallia has regular Tortriciform posterior wings, but the antenux and palpi show it to be a true member of the Tineina), mostly remarkably attenuated, without markings. The larva generally wilh sixteen, many with fourteen feet; the development of the fcet varies greatly.

\section{PTEROPHORINA, Slainton.}

Pterophorida, Zeller; IIerrich-Schïfler.

Pterophorites, Duponchel.

Alucitidac pars, Sleplens.

Antenno setacere.

Corpus gracile, elongatum, pictum.

Pedes elongati.

Ala longe ciliata, anteriores bifida, posteriores trifida.

Antenuse setaceons. Botly slender, elonguled, with marlings. Leys elongated. Wings with long ciliu, the anterior bifid, the posterior trifid. (Agdistes has the wings entire, but the place where the lissure of the anterior wings should be is seantily furnislicd with seales.) 


\section{ALUCITINA, Zeller.}

Orneodites, Duponchel.

Orneodidx, Herrich-Schïfler.

Alucitidx pars, Stephens.

Antenne setacea.

Corpus gracile, breve, piclum.

Ale longe ciliato, singule sexpartitce.

Antenna seduccous. Body slender, short, with markings. II ings with long cilia, each divided into six.

The Tineina, which form the subject of this volume, are an extremcly interesting group in many respects. It has been the remark of every writer, that the smaller the species the more splendid the colouring and the more sharply-defined the markings; but one of the greatest points of attraction to the study of this group is atlorded by the condless variety in the habits of the species. It is preciscly anong the smallost species that we find the characters of the families most strongly defined; and whereas among the larger species it is extremcly difficult to arrange them in families with good distinctive characters, in the smaller species no such difficulty exists.

The most generally known species of this group are those included in the genus Tinea, which are commonly termed "clothesmoths;" these however give but a very faint idea of the whole group, which are mostly vegetable-fecders, and, with some few exceptions, do not cause us any great amount of injury; on the other hand, from their small size and secluded mode of living, their beautics are seldoin displayed to any but those who collect them.

The larve of many construct portable cases, of which that of Tinea pellionella is but a too fimiliar instrnec, being found abundantly in houses, on furs or coats that have been put away and neglected. Some few larvæ live entirely exposed, but more frequently they shelter themselves between united leaves, or by drawing together the terminal shoots of plants, thus betraying themselves to the experienced cye, and being far easier found than if the larve were themselves exposed to view; the great bulk of the smaller farnilies mine between the enticles of leaves, and the consequent ease with which they may be detected is surprising, 
for the mined place becoming discoloured can be distinguished from a considerable distance; and not only so, but the mined place remains a sign-post that such a larva had been feeding there as long as the leat remains on the plint; thus, whereas in the Rilopralocera and larger groups of the IIeterocera, it would be impossible, from the sight of a lualf-eaten leaf, to name the species or even the genus to which the larva that had eaten it belonged, in the smaller fumilies of the Tineina not the slightest difficulty occurs.

Some of the perfect insects fly during the hot sumshine, but the greater portion fly in the early morning or in the evening twilight. That many species fly during the night I have palpable demonstration, from the numbers that have occasionally been attracted by my light.

The summer months, May to August, are those in which the Tineina most abound; in September and October they are far more plentiful than is usually imagined, ouly that alter the midelle of Augrust they keep themselves so well conccaled, and so rarely stir abroad, that they are searcely ever scen, but by collecting the larvac previously the perfect insects may be frecly bred in those months.

In the winter months but very few species cmerge from the pupa state, though many of those liatehed in the autumn liybernate, and are secn commonly in the spring (as, for instance, Depressaria applana).

The great bulk of the species pass the winter in the larva state, generally without feeding; some, whose tastes are adapted for the consumption of decaying wood, of which a supply is at all seasons available, continue to feed throughout the winter, and some, which feed on plants whose stens or leaves remain through the winter, also abstain from fasting.

Little is as yet known of the geographical distribution of this group, but few speeies having been collected out of liurope; with regard to the Luropean species there is this peculiarity, that the species secm far more generally distributed than we find to be the ease in the larger groups of Lepidopteru, and if it be true that Fingland was separated from liurope before the lihopalocera were distributed over that continent (henee accounting for the extreme pancity of species with us), the Iincina must have preceded the Rhopalocera, since of the contincntal species by far the greater portion are indigenous to these islands.

The fanilies of the Tincina which are represented in this comtry may be arranged in the following table:-

VOI, III, 
A. Wings of the o much less teveloped than in the $\delta$, short and pointed. P'osterior wings of the or broad, not cmarginated

A A. Wings of the $f$ wanting. (Tineidas pars.)

A $\Delta$ A. Wings of the $q$ as fully developed as in the $\delta$.

B. Antennæ not porrected in repose.

c. Antenna with basal joint not expanded into an eye-cap.

D. Labial palpi short and thick.

E. Anterior wings oblong; maxillary palpi generally well developed . . . . . .

E E. Anterior wings elongate; maxillary palpi never developed.

F. Posterior wings ovato-lanceolate. (IIyponomentidee pars.)

F F. Posterior wings lanceolate.

1) D. Labial palpi rather short, terminal joint pointed.

G. Anterior wings elongate; cilia of the posterior wings not nearly so long as the breadth of the posterior wings . . . .

c a. Anterior wings oblong; cilia of the posterior wings nearly as long or longer than the brcadth of the posterior wings ...

D D D. Labial palpi lorg and pointed.

II. Posterior wings broad or emarginated before the apex . . .

II II. Posterior wings narrow, not emarginated before the apex.

1. Maxillary palpi ill-developed, hardly perceptible; the perfect insect reposes flat on the surface on which it rests .

I I. Maxillary palpi well-developed, filiform, projecting; the perfect insect reposes with its head elevated, the body forming an angle of $30^{\circ}$ with the surface on which it rests.

D D D D. Labial palpi short, obtuse, and drooping. Postcrior wings lanceolate
1. Exapatid/F.

2. Tineide.

7. ARGYRESTHIDE.

3. HyPonomeutide.

6. Glyphitereryide.

5. GELECIID F,

10. Blaciustid 死.

8. ORNICHIDE.

11. LithocorLeTI F. 
c c. Antenne with basal joint expanded into an eye-cap.

к. Antennx more than half the length of the anterior wings . . 12. LYoNaTID

к $\mathrm{K}$. Antenna not half the length of tho anterior wings . . . 13. Neptrculide.

B B. Antenna porrected in repose.

L. Head rough. Anterior wings oblong or elongate . . . . . .

L t. Head smooth. Anterior wings lanceolate

\author{
4. Plutellids. \\ 9. Coleophoride.
}

\title{
FAMILY I. EXAPATIDA.
}

Alo maris ample, fomince valde abbreviale et acuminats. Antenne crassiusculie, pubescentes vel dense eiliate. II austellum breve, aut nullum. l'alpi labiales breves, aut longiusculi; palpi maxillares desunt. Iarva 16 pedibus instructa; tertio pari claviformi; inter folia victitat.

Wings of the males of larere size, of the females extremely abbreviated and pointed. Antenne rather thick, pubeseent or densely ciliated. 'Tongue short or cntircly wanting. Labial palpi short or moderately long; maxillary palpi undeveloped. Larve with sixteen legs, the third pair elub-shaped. 'This charaeter does not appear quite universal in this family; it occurs both in Sulicella and Fugella, but in Fleryyanella, according to Mdme. Lienigr's observations (Isis, 1816, p. 269), this peculiarity is restricted to the young larvo of the males; the arlult male larva and the female larva always having the third pair of legs of the ordinary form, and the larve of Gelatelle never have this peculiar formation of the third pair of legs.

'I'his family contains thee generi, consisting of four species, and no other European species are at present known.

The larve feed in the summer and autumn between united lcaves, and the perfect insects appear at the commeneement of winter (when $C$. Phiyganella inay frequently be observed on the wing in the day-time), or carly in the spring.

The three genera may be readily distinguished as follows:Tongue none.

Labial palpi of the $\delta$ very short. 1. Exapate.

Labial palpi porrected. 2. DAsxsToma.

'Iongue short.

Labial palpi asecnding; terninal joint smooth and pointed. 3 . Chimabacoire. 


\section{Genus I. EXAPATE.}

Exapate, Hüb. V. 387 (1817). Cheimaphasia, Curt. Oxypate, Stcp. Cheinonophila, Dup. Diurnea p., IIaw. Lemmatophila p., Treit. Exapate p., Zell.

Caput superne ac in fronte hirsutum. Occlli supra oculos. Antemie crassiusculie, of pubesecntes, $q$ pilis parce vestitic. Palpi labiales ( $\delta$ ) brerissimi, pilis vestiti ( $q$ longiores, porrecti). II austellum nullum. Ale mediocriter ciliate, anteriores oblongo-ovate ( $q$ angustatic, abbreviate), posteriores ovatic ( $q$ unlla) ; anteriores : vena apicalis simplex ante apicem cxit, infra cam venæe sex, quarum ultima a peuultima longe distant, submedima abest, sublorsalis furea superior obsoleta; posteriores: vena apiealis longe furcata supra et infra apjecm exit, infia cam veno dux e venula transersa angulata, mediana bifida.

IIcad above and in front hairy. Ocelli placed above the cyes. Antenne rather thick, in the $\delta$ pubesent, in the of sparingily elothed with hairs. Labial palpi of the $\delta$ very short, clothed with hairs, of the o longer and porrected. Tongue wanting. Wings with moderate cilia, the anterior in the of oblong-ovate, in the o very narrow and very short, the posterior in the $\delta^{\circ}$ ovate, in the $q$ wanting. In the anterior wings the simple apical vein rums into the costa before the apex, below it are six veins, of which the last is at a considemable distance from the penultimate, the submedian vein is not indicated, and the upper branch of the subdorsal vein is obsolete. In the posterior wings the apical vein is extensively forled, terminating above and below the apex of the wing, beneath it are two veins from the angulated transverse vein, the median vein is bifid.

There is only one species in this genus. The perfect insect appears at the end of autumn, and is vecasionally met with on old palings at rivglit; the larva feeds in the summer (according to Lienirs and lireyer) between united leaves of liawthom and other plants (but according to other observers, in decayed wood).

1. gelatella, I. T. S. 1450 (1761) ; Fab.; 'Treit.; Step.; Frey. N. 13. pl. 350, f. 2; J)up.-grelatana, Hüb. Alis anticis grisco-fuscis vix purpurascenti-tinctis, costam versus saturatioribus, vitta lata disci a basi fere ad marginem posticum albirla, in qua macula ante medium, alterague celludam discoidalem termiumte saturate fuscis, macula parva fusca supra plicam pone molium, macula costali apicem versus saturate fusca, punctisgue parvis marrinis postici saturate fuscis; $q$ alis anticis brevissimis, angustissimis, albido-griscis fusco-marginatis. Exp. al. o $9 \frac{x}{2} \operatorname{lin} . ;$ o 4 lin.

Ilead, fice, and palpi black. Antemne dark grey. Anterior wings greyish-fuscons, with a slight purplish gloss, towards the costa rather durker, and with a broad streak on the dise, from the base to near the 
hinder margin whitish; in this before the middle is a dark fuscous spot, and another dark fuscous spot lies in the streak at the termination of the discoidal cell, below which, but above the fold, is a small fuscous spot; on the costa rather before the apex is a dark fuscous spot, and there are some small fuscous spots along the hinder margin; cilia pale grey. Posterior wings pale greyish-fuscous, with palcr cilia.

The female has the anterior wings very short and extreinely narrow, whitish-grey, with the margins somewhat fuscous.

South of Lingland, November and December; not common.

\section{Genus II. DASYSTOMA.}

Dлsчsтом а, Curt. Ent. Mag. i. 190 (1933); Step. Diumen p., Haw. Cheimophila p., Ilüb. Lemmalophila p., Treit.; Dup. Exapate p., '̌ell.

Caput pilis decumbentibus vestitum, epistomio levigato. Ocelli supra oeulos. Antenue crassiuscule, ơ dense ciliatie. Palpi Jabiales porrecti, pilis vestiti. Ifaustellum nullum. Alic mediocriter ciliats, anteriores oblongo-ovatac ( $q$ angustate, abbreviate), posteriores ovate ( $q$ nullex); anteriores: vena apicalis furcala supra et infra apicem exit, infra eam vene quatuor, ultima parum curva, subdorsalis furcata; posteriores: vena apiealis simplex ante apicem exit, infra eam vene dux e veuula transversa, vena mediana bifida.

Itead elothed with decumbent hairs, in fiont smooth. Ocelli placed above the cyes. Antenme rather thick, in the of densely ciliated. Isabial palpi porrected, elothed with hairs. Tongue wanting. Wings with moderate cilia, the anterior in the of oblong-ovate, in the of extremely narrow and very short, the posterior in the of ovate, in the of wanting. In the anterior wings the furcate apical vein terminates in the costa, and in the hinder margin; below it are four veins, of which the last is slightly curved; the subdorsal vein is fureatc. In the posterior wings the simple apical vein terminates on the costa immediatcly before the apex, below it are two veins from the transverse vein; the median vein is bifid.

There is only one species in this genus; the perfect insect appears in the spring among sallows, flying by day; the larva fecds in the summer and autumn between united leaves of sallow, the third pair of feet are club-shaped (according to Licnig, but not so according to Freyer).

1. Salicella, Hü̈l. Tin. f. 9 (1801); 'Treit.; Curt.; Stcp.; Frey.; Dup.; Lieng. - Salieis, IIaw. Alis anticis dilute grisco-fuscis roseosuflusis, disco dilutiore, macula transversali saturate fusen fere in medio, punctis duobus disci fere conuexis pone suedium, waregine postico sa- 
turatiore fusco; $q$ alis anticis brevissimis angustissimis dilute griseis (vix rosco-suffusis) fasciis duabus nigris, altera in medio, altera ante apicem. Exp, al. $\delta 8$ lin.; $\& 3 \frac{2}{3}$ lin.

IIead, face, and palpi reddish-fuscous, Antenne dark fuscous. $\Lambda$ nterior wings pale greyish-fuscous, with a strong rosy tint, palest on the dise, with a lark fuscous fascia-form mark nearly in the midclle, and two dark fuscous spots on the dise, alnost united, beyoud the middle; hinder margin rather dark fuscous; cilia pale reddish-fuseous. Posterior wings fuscous, towards the base rather paler, with pale fuscous eilia.

The female has the anterior wings extremely abbreviated and very narrow, pale grey, with a very slight rosy tinl, with a black fascia in the middle, and another immediatcly before the apex.

England and (south of Scotland?); April; not uncommon.

\section{Genus III. CHIMABACCHE.}

Chmabaceme, Zell. Isis 1839, p. 181. Diurnen, Curt. Dimrnea p., IIaw. Lemmatopleila p., Tr. Chimabacche et Cheimophila p., Ilüb. Cheimophila et Diurnea, Step. Dimmen et Lemmatophila p., Dup.

Capilli superne suberecti, in fronte decumbentes. Ocelli mulli. Antemue crassiusculac, of dense ciliatre, vel pubescentes. P'alpi libiales adscendentes, articulo sccundo dense squamato, trrlio lervi acuto. IIaustellum breve, basi parce squamata. Ala mediocriter ciliate, anteriores oblongo-ovate ( $q$ abbreviate acuminatx), posteriores ovate ( $q$ abloreviate acuminate) ; anteriores : vent apicalis furcata supra et infra apicem exit, infra can veno quinque, ultima parum curva, subdorsalis furcata; posteriores: vena apicalis simplex ante apicem exit, infria cam vene due e venula transversa, mediana trifida.

Ilead above with the hairs rather erect, in front smooth. Ocelli none. Antenno rather thick, in the of densely cilinted or pubescent. Iabial palpi ascending; the sccond joint thickly scalod; the terminal joint smooth and pointed. Tongue short, with a few scales at the base. Wingrs with moderate cilia; the anterior in the of oblong-ovate, in the of short and pointed; the posterior in the of ovate, in the of short and narrow. In the anterior wings the furcate apical vein terninates in the costa, and in the hinder margin; bolow it are five veins, of which the last is slightly curved; the subdorsal vein is furcate. In the posterior wings the simple apical vein terminates in the costa before the apex; below it are two veins from the transverse vein; the median vein is trifid.

This genus comprises only two species, one of which appenrs in autumn, the other in spring; from the structure of the palpi and antennæ they may be separated thus:- 
a. Third joint of the palpi crect, rather long. Antenna of the $\delta$ densely ciliated. Species 1.

a a. Third joint of the palpi ascending, rather short. Antenna of the $\delta$ pubescent. Species 2.

1. phryganella, IIüb. Tin. f. 10 (1801); IIaw.; Treit. ; Step.; Dup.; Lienig. \& Novembris, IIaw.: Step.; Curt. B. E. fo. 743. Alis anticis dilute brumneis, costan versus saturatiorilus, squamis sparsis disci albidis, maculis dhabus ferc obsoletis fuscis, altera in medio, altera pone medium; $q$ alis anticis brevibus et postice acutissimis, albido-griseis, fusco-siguatis, stria angulata saturate fusca in medio, utrum marginem non attingente, punctis duobus disci, maculaque obliqua transversali apicem versus saturate fuscis. Exp. al. of $10 \%$ lin.; 8 lin.

IIcad and face reddish-grey. Palpi fuscous; the base of the second joint greyish-ocheous; terninal joint ochreous, with a fuscous ring before the apex. Antemne greyish, anuulated with fuscous. Anterior wings rather pale brown, darker towarks the costa, with some senttered whitish seales on the dise, and two faintly indieated oblique fuscous blotches, one in the midlle, the other beyond the middle; before the apex near the costa is a faint fuscous blotch; cilia pale fuscous. Posterior wings fuscous, with paler cilia.

The female has the anterior wings short, and posteriorly extremely acute, whitish-grey, marked with fuscous; in the middle is a clark fuscous or black amgulated mark, not reaching cither margir, beyond are two dark fuseous spots on the disc, followed by an oblique dark fuscous fascia-form mark.

Generally distributed. The perfect insect appears in October and Novernber; the of flying frecly in the daytime, the $q$ may be found resting on the trunks of trees. The larva (according to I fienig) feeds in June on oaks; that of the of when young having the third pair of feet club-shaped.

2. Faggella, W. V. 135. 31 (1776); Fab.; Hüb.; Treit.; Step. ; Dıр. I, li. xi. pl. 287. f. 1, 2.-F'ugi, l'ab. ; Ilaw.; var. Dormoyella, 1) up. J. F. xi. pl. 287.f. 3, 4. Alis anticis albidis lutescentibusve, fusco (interdum valde) suffusis, stria angulata saturate fusca ante mediun, infia plicam intermpta et dorsum non attingente, punclis duobus disci fere in medio (inferione posteriore), tertio disci pone medium, striaque transversali cellulam discoidalem terminante, saturite fuscis, strign obsoleta angulata ac iudentata marginem posticum versus, margine postico apiceque costa saturate fusco-punetatis; $f$ alis anticis angustioribus brevioribus, apice acuto, saturatioribus, signis obsoletioribus. Exp. al. $\delta 13 \mathrm{lin}$; $99 \mathrm{lin}$.

IIead and face whitish-grey, mixed with fuscous. Palpi whitishgrey, mixed with fuscous; tip of the terminal joint pale-ochrcous. Antenne whitish-grey, ammulated with fuscous. Anterior wings vehilish, more or less inclining to yellowish, sulfused (sometimes very much so) 
with fuscons scales, with an angulated dark fuscous striga before the middle, interrupted however soon after erossing the fold, and not reaching to the inner margin; on the disc, nearly in the middle, are too small durli frescous spols, of which the lower one is the posterior, another dark fuscous spot lies on the dise a little beyond the middle, and at the ternination of the discoidal cell is a small transverse dark fuscous struak; towards the linder margin is a faint, angulated, and indented striga; the hinder margin and ajex of the costa are spotted dark, with fuscous; cilia whitish, interrupted with fuscous opposite tho marginal spots. P'osterior wings rather palc-grey, dirker posteriorly with whitish cilia.

The female has the anterior wings narrower, shorter, and abruptly acute, generally darker than in the male, and the markings less distinct.

An abundant species throughout the combry, sitting on the trunks of trees during the cold showery weather of $A$ pril. The larva (with the third pair of fect club-shaped) is polyphagous, feeding between united leaves in September and October. 1 have found it on birch, sallow, and mountain-ash.

\section{Family II. 'IINEIDA。}

Capul lanatum ; palpi latiales breves, crassi ; palpi maxillaves plerisque 5-vel 6-articulati. Larva saccophore, vel in fungis intra cuniculos sericeos vivens.

Ifead rough, having a woolly appearanee (Lampronia and some of the Adele are exceptions); labial palju short and thich; maxillary palpi in many of the genera extremely developed, five- or six-jointed; antenna extremely variable, pectinated, ciliated, or simple, short, of moderate length, or very long; tongue rarcly alssent. Larve case-bearers, or feeding in fungi, or decayed wood, in galleries lined with silk, or in the pith of the stems of plants. The larve of the singular genus Ochsenheimeria burrow down the stems of grass.

It is to this family that those pests of our houses, the clothesmoths, belong; they form the bulk of the genus Tinea, but only a few species annoy us by their ravages.

The first two genera, having apterous females, are the representatives of the frumee amongst the Tineina. The three last genera of this family (the long-horns) might at first sight appear to form a natural group by themselves, but the development of the maxillary palpi in Nemopleore, and the want of them in Adela and Nemotois, show that they are not sufliciently related inter se to warrant such a step, and to place Adela and $\lambda^{\top}$ emotois in a dis- 


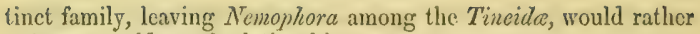
outrage our ideas of relationship.

This family contains fourteen genera which are represented in this country (two or three others, Eriocoltis, IIapsifera, etc., occurring on the continent); they may be distinguished as follows :a. Maxillary palpi undeveloped.

๖. Antenna of moderate length.

c. Head rough.

d. Fiemales wingless.

e. Ocelli distinct. 1. Talmororia.

e e. Ocelli none. 2, Solenomia.

d d. Temales winged.

f. Labial palpi short, not thickened with scales.

g. Ocelli distinct. 3. Diplodoma.

g g. Ocelli none. 4. Xуsmotodom.

$f f$. Labial palpi porrected; second joint very hairy, and with a projecting tuft. Anterior wings with raised scales. 5. OCIISENIEIMERIA.

c c. Ilend smooth. 9, LAMProsetia.

b b. Antenna very long.

h. Eyes of the males distant. 13. Adela.

$h h$. Eyes of the males large, approximating. 14. Nestotors.

a a. Maxillary palpi 5-6-jointed.

b. Antennaz of moderate leugth.

c. Head rough.

i. 'Terminal joint of labial palpi slender, ascending. 6. EupLocamus.

$i$ i. 'Terminal joint of labial palpi thick, not ascending.

k. Posterior wings clothed with scales. 7. Tinc..

$k k$. Posterior wings clothed with hairs.

l. Ocelli none. 10. IncURVAria.

ll. Ocelli distinct. 11. Micropteryx.

c c. Head in front and on the crown smooth. 8. LAMPRONIA.

b b. Antenne very long. 12. Nemopirons.

\section{Genus I. TALfEPORIA.}

Talmorora, Zell. L. E. vii. 331 et 336 (1852). Cochleophasia, Curt.; Step. Taleporia p., Hüb. Solenolia p., Dup.

Caput superne et in fronte hirsutum. Ocelli distincti pone oculos. Antenna ठ̀ setacex, crenulata, ciliate. Palpi maxillares uulli. Palpi labiales cylindrici, pilosuli; articulo secundo infra, et apice stpra sctoso. IIaustellum nullum. Nle oblongx, mediocriter ciliatie; anteriores: cellula discoidalis venas sex in marginem posticum enaittit, supreman furcatam. i splera, mo lanato. Larva saccophora, sacco longo, gracili, granulato, anum versus attenuato.

VOL. III. 
Head above and in front hairy. Ocelli distinct behind the eyes. Antenne of the $\delta$ setaceous, eiliated. Maxillary palpi none. Labial palpi cylindrical, hairy; the second joint armed with bristles beneath, and above at the apex. Tongue wanting. Wings oblong, with moderate cilia. From the discoidal ecll of the anterior winess six reins run to the hinder margin; of these the uppermost is furcate. Female apterous, with the anus woolly. Jarva case-bearing; the case long, slender, granulated, attenuated towards the anus.

The food of the larvac is probably lichen; the cases are found on the trunks of trees and palings, the larve being full fed in the early spring. The only two British species may be easily distinguished:-

u. Anterior wings reticulated. Species 2.

$a$ a. Anterior wings unicolorous. Species 1.

The latter (muticomis) hardly belougs to this genus, laving the antenno pulescent, not ciliated, the palpi less hairy, and a short tongue: its transformations are unknown.

1. pubicormis, Haw. L. B. 523 (1829); Curt.; Sta. ; Zell.; Step.? Alis anticis nitidis fuscis immaculatis, costa basim versus saturatiore. Exp, al. $7 \frac{1}{2}$ lin.

Heart and face ochreous. Palpi fuscons, tip of the terminal joint yellowish. Anteme fuscons. Antcrior wings shining-fuscous, immaculute; the costa towards the base rather darker; cilia pale fuscons. Posterior wings grey, with paler cilia.

Temale unknown.

Taken by Mr. Allis, near Grassingion, Yorkshire, in June.

2. pseudobombycella, Hüb. Tin. f. 212 (1801); Z. ‥ S.; Treit.; 1.. v. R.; Zell.--glabrella, Ochsenh.--lessellea, J Faw.; Curt.; Step. Alis anticis fusco-cinercis, maculis numerosis ditute luteis, quasi reticulatis, macula disci ponc medium saturatiore, maculis duabus dorsi dilute lutcis, altera in medio, altera ad angulum analem. Exp. al. 8 lin.

Ifead and face pale ochrcous. Palpi pale fuscous, terminal joint pale grcyish-ochreous. Antemne fuscous. Antcrior wings greyishfuscous, wilh numerons faint pale yellowish spols (except towards the base and basal half of the costa), which give the wing an alinost reticulated appearanee, in which there appears a darker spot on the disc, beyond the middle; on the inner margin are two longer pale yellowish spots, one in the middle, the other at the anal angle; cilia grey. Posterior wings grey, with paler cilia.

Female fuscous, with the anal tuft greyish.

Common in the south of England; the larva on the trumks of trees and palings in $\Lambda$ pril and Mny; the perfect insect in June. 


\section{Genus II. SOLENOBTA.}

Solenobra, Zell. L. E. vii. 332 et 343 (1852). Taleporia p., IIüb. Solenobia p., Dup.

Caput superne et in fronte hirsntum. Ocelli mulli. Antennx ò setacere, ciliatx. Os pilosun, palpis submullis. Nlic oblongre, mediocriter ciliatr; anteriores: cellula discoidalis renas quinque in marginem posticum cmittit simplices. I Aplere, ano lanato. Larva saccophora, sacco breviuseulo, granulato, anum versus attenuato.

IIead above and in front hairy. Ocelli none. Antennxe of the of setaceous, eiliated. Maxillary palpi undeveloped. Labial palpi extremely short, almost concealed in the hairs of the mouth. Wings oblong, with moderate cilia. From the discoidal cell of the anterior wings fire simple veins run to the hinder margin. \& Aplerons, with the anus woolly. Larva case-bearing; the case rather steort, granulated, attenuated towards the anus.

The food of the larve is probably lichen; the cases are found on the trunks of trees, palings, and rocks; the larva being full fed in the early spring.

The only two British species, of which we know the males, are very closely allied. We appear to have sereral species of larva, but from some only females have yet been obtained, from which, without continued observations of the larva, eases, and whole habits of the insects, it is impossible to distinguish the species. It is in this genus that we meet with the singular physiological fact of unimpregnated females laying fertile egres, and not as the exception, but as the rule. (Sec 'Trans. Lint. Soc. London, vol. i. N. S. p. 234.)

1. inconspicuella, Sta. Cat. p. $6(18.19)$; Zell. Alis minticis angustulis, apiec rotumlato, cincre-fuscis, maculis numerosis irregularibus mediocribus albidis vix distinclis, margine postico fusco-punelato. Exp. al. $5 \frac{1}{2}-6$ lin.

Jlead and face grey. Antenme dark-grey. Anterior wings rather narrow, with the apex rounded, greyish-fuscous, with numerous irregular ratlier large whitish spots, nol sharply defined; on the hinder margin is a row of dark spots; cilia altcruately whitish and greyish-fuscous. Posterior wings palc-grey, with paler cilia.

Not common. The larvie are full fed before the end of March, when they may be fouml on palings; the perfect inseet appears early in $\Lambda$ pril.

2. Douglasii, n. sp. Alis anticis vix angustis, apice paullulum rotundato, cincreo-fuscis, apicen versus saluratioribus, maculis numerosis irregularibus mediocribus fere distinctis albidis. Exp. al. 6 lin.

llead, face, and antenne greyish-fuscons. Anterior wings hardly narrow, with the apex slighlly rounded, greyish-fuscous, towards the 
apex rather darker, with numerous irregular rather large whitish spots ruther sharply defined; cilia whitish, with some fuscous patehes opposite the fuscous portions of the hinder margin. Posterior wings palegrey, with paler cilia.

$\Lambda$ single specimen, in the collection of Mr. Douglas, taken by him at Birch Wood in the spring.

\section{Genus III. DIPLODOMA.}

Drplodoma, Zell. L. E. vii. 332 et 359 (1852). Lampronia p., Step.

Caput superne et in fronte hirsutum. Ocelli distincti pone oculos. Antenne setacere, of ciliate, o subdentate. Palpi maxillares nulli. Palpi labiales cylindrici pilosi. Ala anteriores, oblonga, mediocriter ciliate; antcriores: cellula discoidalis venas sex in marginem posticum emittit, supremam simplicem subapicalem. of Alata, ano lanato. Larva saccophora, sacco in indusium incluso.

IIcad above and in front hairy. Ocelli distinct behind the eyes. Antenna setaceous, of the $\delta$ ciliated, of the of subdentate. Maxillary palpi nonc. Labial palpi cylindric, hairy. Wings oblong, with moderate cilia. From the discoidal ecll of the anterior wings six simple veins run into the hinder margin. Female winged, with the anus woolly. Larva casc-bearing, the case enclosed in an outer covering.

But one species is known in this genus.

1. marginepunctella, Step. II. iv. 358 (1835); Zell. I. T. vii. - siderella, Zell. Isis. 1839 ; H.-S. Tin. pl. 46. f. 319. Alis anticis saturate fuscis vix purpurascente tinctis, punctis numerosis dilute luteis, quasi in fascias duas, costam versus fureatas, aggregatis, quarum prima ad dorsum conspicuore. Exp. al. 5 r lin.

IIead greyish-ochreous, mixed with fuscons. Tace fuscous. Palpi fuscous, terminal joint whitish. Antenne fuscous. Anterior wings dark-fuscous, with a slight purplish gloss, with numerous small paleyellow spots, which appear to form two fascix, one rather broad before the middle, and one narrower towards the hinder margin, both are furcate on the costa, the anterior appears on the inner margin as a conspicuous spot; cilia dark-fuscous, interrupted with pale-yellowish. I'ostcrior wings dark-fuscous, with a slight purplish gloss; cilia grey.

Not common. 'The perfect insect appears in June and July; the food of the larva (remarkable for its donble case) has not yet been ascertained.

\section{Gicnus IV. XXSMATODOMA.}

Xysmatonoma, Zell. L. E. vii. 332 et 362 (1852). Lampronia p., Step. 
Caput superne et in fronte hirsutum. Ocelli nulli. Antennæ setacere, of sctoso-ciliata. Palpi maxillares nulli. Palpi labiales cylindrici, breves, hirsuti. Mla ( 9 graciliores) oblonge, mediocriter ciliatie; anteriores: cellula discoidalis venas quinque in marginem posticum cmittit. I Alala, ano lanato. Larva saccophora, sacco simplici, breviusculo, granulato.

IIcad above and in front hairy. Ocelli none. Antenna setaccous, in the $\delta$ strongly ciliated. Maxillary palpi none. Labial palpi short, cylindric, hairy. Wings oblong (of the o narrower), with moderate cilia. Trom the discoidal cell of the anterior wings five veins run to the hinder margin. Finale minged, with the anus woolly. Larva casebearing; the case simple, rather short, granulated.

But one British species is known in this genus; on the continent is another closely allied to it. Argentimaculella I refer to the genus Tinea.

1. melanella, Haw. L. B. 566 (1829); Step); Zell. L. E. vii.atrella, Step.-stelliferella, F. v. R. pl. 59,-sequella, Haw.? Alis anticis nigris, punctis numerosis sparsis lutco-albis, fascia obsoleta ad dorsum distinctiore ante medium luteo-alba, macula parva dorsi pone medium punctoque costie apicem versus albidis, apice costie margineque postico albido-punctatis. Exp. al. $5 \frac{2}{3}$ lin.

Ifead and face black. Palpi fuscons; terminal joint whitish. Anterior wings black, with numcrous seattered yellowish-white spots, with an indistinct rather interrupted yellowish-white fiscia before the midelle, most conspicuous on the inner margin; a small whitish spot lies on the inner margin beyond the middle, and on the costa, rather posterior, is another small whitish spot; the apex of the costa and hinder margin are spotted with whitish; cilia dark-fuscous, externally with some whitish patches. Posterior wings greyish-fuscous, with palcr cilia.

In the south of Fingland; not senxee. The larve feed on lichen, and are found on old palings, etc., in April and May, the perfect insect appearing in June.

\section{Gcnus V. OCHSENHEIMIERIA.}

Ocirseniemmeris, Hüb. V. 416 (1817); Zell. Lepidocera, Curt.; Step. Phygas, Treit, ; Dup.

Caput superne valde lirsulum, in fronte squamaccum. Ocelli distincti pone oculos. Antenna crassiuscular, interdum squamis nsqne medium incrassate. Palpi maxillares mulli. P'alpi labiales porrecli; articulo secundo valde hirsulo, articulo tertio levi "adscendente acuminato. IIaustellum breve, nudum. Als mediocriter ciliatie; anteriores oblongx, squamis exasperatis, posteriores oblongo-ovate; anteriores: veua apicalis fureata ante apicem exit, infra cam vena quatuor, submediane 
apex incrassatus, subdorealis longe fureata ; postcriores : venæ apicalis furcate ramus inferior in apicem exit, infra cam vene dux c venula transversa; mediana bifida.

Ilearl above very latry, in front morc clothed with scales. Ocelli distinet behind the eyes. Antenne rather thick, about hitt the length of the anterior wings, sometimes thickened with scales to the middle. MIaxillary palpi undereloped. Labial palpi porrected, the second joint very hairy, and with a prolonged tuft, the third joint smooth, ascending, pointed. Tongue short, not elothed with scales. Wings with moderate cilia, the anterior oblong, with semi-erect scales (having a rugged appearance), the postcrior oblong-ovate. In the anterior wings the apical vein is furcate, terminating in the costa before the apex, beneath it are four veins; the apex of the submedian vein is thickened, and the subdorsal vein is for a considerable length furcate; in the posterior wings the lower branch of the forked apical rein terminates in the apex, below it two veins run from the transverse vein, and the median vein is bifid.

The perfect insects of this genus are found anong grass, but, except during the very midlle of the day, from 12 to 2 P. M., are rarely met with; at that hour they are very active, hopping about on the stems of the grass, and taking short flights, but their period of flight onee over, they conceal themselves so well that it is almost impossible to detect them. 'The larva of one species ( $O$. Birlella) I have oceasionally met with, when full fed, crawling on grass; but it feeds inside the stems, and in one instance had bored down the stem of Daclylus glomeralus almost to the root, and was unly detected by the fact of an Elachistu liaving taken a fancy to the same plant of 7 actylus, which led Mr. Wing to the discovery of the concealed Ochsenheineria. Mr. Scoth also found these larva in the stems of grass.

We have only three British species in this genus (two others are known on the continent); they may be readily distinguished by the antennos.

a. Antenue much thickened with scales to the midelle. ipecies 1 . a a. Antenne very slighily thickened with seales nearly to the middle.

Species 2.

a a a. Antenno perfectly simple. Species 3.

1. Birdella, Curt. B. F. fo. 3 H. (1831); Step.; Sta,-Bisontclla, Sta.-Mediopeclinella, Haw.? Step.? Alis anticis grisco-fuscis vel obscure ochreis, squatuis mumerosis exasperatis fuscis, albidisve; alis posticis purpureo-fuscis, ipsa basi luyalina. Capillis grisen-fuseis. Antranis usque merlium valde incrassalis squamis crectis projicientibus. Exp. al. 5 $\frac{x}{2}-6 \frac{1}{2}$ lin.

IIairs of the head. and face greyish-fuscous. Antenne at the base 
greyish-fuscous, then dark fuscous, much thickened to the middle with projecting scalcs. Autcrior wines greyish-fuscous or dingy ochrcous, with numcrous scaltered dark fuscous and whitish elevated seales; cilia greyish-fuscous or clark ochreous, with the lijs dark fuscous. Postcrior wings purplish-fuscous; the rextreme base almost transparent; cilia grey.

'This variable species is in some incadows cxtremely aluundant towards the end of July. The dirty-whitish larva feeds insicle the stem of Dactylus glomeratus in May.

2. Bisontella, Licnig et \%el. Isis, 1816, p. 274.-Taurella, Curt.; Ilaw,? Step,P-I acculella, Sta. $\mathrm{Alis}$ anticis griseo-fuscis, saturate-fuseo valde suffusis; alis posticis dilute griscis, vix purpureotinctis, ipsa basi hyolina. Capillis saturate ochreo-fuscis. Antennis basim versus squamis paullutum incrassatis. Lxp. al. $+1,2-5$ lin.

Hairs of the head and face dark ochreous-fuscous. Antenne dark fuscous, towards the base slightly thickened with scules (most clistinctly in the f). Anterior wings greyish-fuscous, almost entirely suftuscil with dark fuscous (in the of more ochrcous); cilia greyish-fuscous, darkest before the tips. Posterior wings pale grey, with a slight purple tinge, at the extreme base transparent; cilia pale grey.

Occurs in grassy places among fern in July, at Dartford IIcath, near Manchester, and Torwood, Stirlingshire.

3. Vacculella, F. v. R. Ent. '/tg. 1812, p. 213; H.-S. Tin. pl. 36.f. 21.7.-Tunella, Hiib.-Chenopodiella, Sta.; Stcp.? Alis anticis grisco-fuscis vel obscure-ochrcis, saturate fusco-suffusis, fascia obsoleta saluratiore pone medinm, in plicre ut nacula distinctiore; alis posticis dilutc-griscis, vix purpurco-tinctis, dimidio basali hyyalino. Capillis saturate ochnacen-fuscis. Anfennis non incrassatis. Exp. al. $5^{\frac{1}{2}}$ lin.

IIairs of the head and face dark oclreous-fuscous. Antenue dark fuscous, not thickened. Anterior wings greyish-fuscous or dingy ochreous, suflused with dark fuscous, and beyond the middle there is a faint appearance of an indistincl dert fascia, of which at any rate a spot on the fold is visible; cilin greyish-fuscous. l'osterior wings pale grey, with a slight purplish tinge, uearly the whole of the basal half transparent; cilia greyish.

$\Lambda$ rare species, found in houses in July. How it gets there is a mystery!

\section{Genus VI. EUPIOCAMUS.}

Euplocamus, Iat. G. C. ct I. iv. 223 (1809); Step.; Curt.; Zell. Euplocamus p., Dup. Scardia p., 'L'reit.

Caput superne ac in fronte hirsutum. Ocelli nulli. Antenna crassiuscula, ơ pectinate vel piloso-fasciculate. Palpi maxillares plicati, 
sex-articulati. Palpi labiales articulo secnndo infra fusciculato-piloso, ultimo tenui adscendente. IIaustellum breve. Alx anteriores: e cellula discoidali venx 4 in marginem costalem prodeunt.

IIead above and in front hairy. Ocelli none. Antenne shorter than the anterior wings, in the $\delta$ cither pectinated or with tufts of fine hairs (the latter is the ease in the only British species known). Maxillary palpi folded, six-jointed. Labial palpi with the second joint beneath with a tuft of kair, thirl joint slender, erect. 'I'ongue short. Wings oblong, with rather short eilia. From the discoidal cell of the anterior wings four veins run to the hinder margin.

In this genus occur some of the largest species of Tineina; the only one yet detected in the country is however of moderate size. The larva feed in fungi.

1. Boleti, Fab. E. S. iii. 2. 26 (1794); Zell. E. Z. 1816. p. 178. -Mediella, Och.; 'Treit.; Step.; Curt. 13. E. fo. 591 ; II.-S.-Chortgella, W. V.? $\Lambda$ lis anticis dilute ochreis fusco-nebulosis saturate fuscopunctatis, ncbula basali costre plicam tangente, macula costali ei contigua, maeula costali pone medium, cum altera majore in medio dorsi fere connexa, maculisque duabus parvis costalibus apicem versus fuscis, punctis quatuor oblongis disci marginem posticum versus saturate fuscis: cilies saturate fuscis, meculis quatuor dilnte ochreis. Exp. al. 12 lin.

IIead and face ochreous, mixed with fuscous. Palpi pale ochreous, mixed with fuscous; terminal joint palc ochrcous, with a ring at the basc and anotlicr before the apex, dark fuscous. Antenne fuscous. Antcrior wings pale ochrcous, elouded with fuscous and spotted with dark fuscous; at the base of the costa is a large fuscous cloud reaching to the fold, immediately beyond it is a fuscous bloteh on the costa, and beyoud the middle is another fuscous blotch on the costa, which almost appears connected with a large fuscous blotch on the micklle of the inner margin; on the costa towards the ajex are two small fuscous spots, and on the dise before the hinder margin are four oblong dark fuscous spots placed on the nervures; cilia dark fuscous, weilh four pale ochreous patches; one on the costa, one in the middle, and one at the bottom of the hinder margin, and the fourth at the anal angle. Posterior wings rather dark fuscous, with paler cilia.

Not common; occasionally found in the south of Tingland. The larva feeds in fungi. The perfect insect appears in July.

\section{Genus VII, TINEA.}

Trnes, Zcll. I. T. vi. 8.4 et 100 (1852); Step. ; Curt. ; Latr.-Tinea p., Haw.; Dup.-Thea et Scardia p., Treit.; Zett.

Caput superne ct in fronte hirsutum. Occlli nulli. Antenne cras- 
siuscule, ơ ciliatre. I'alpi maxillares plicati, b-articulati. J'alji labialss cylindrici pilosi, articuli secundi apice suma setis una pluribusve instrueto. ILaustellum subnullum. Ala anteriores oblongo-

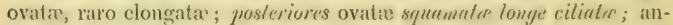
teriores: e cellula discoidali vene 5 in martinem costalem prodeunt. IIcad above and in front hairy. Ocelli none. Antemue moderatcly thick, not so long as the anterior wings, in the of slightly cilinted. Maxillary palpi folded, five-jointed. I abial palpi cylindrie, hairy, the apex of the second joint furnisled above with one or more bristles. Tongue liardly perceptible. Interior wings oblong-rovite, rarely elongrate ( $T$. nigripunclella); posterios wings ovate, clotherd wilh scales, milh long cilin. From the discoidal cell of the anterior wings five veins rum inte the costa, and five terminate on the margins below the apex.

The maxillary palpi do not appear to be developed in Cochyliatella, biselliellu, or nigrimenotella; T. bisulliella even shows a slight diflerence in the neuration of the wings. 'The small species T!. bistrigella, etc., liave only fonr veius from the tiscoidal call to the costa, and four others terminating on the margins below the apex of the anterior wings.

The perfect insects of this gems appoar in summer, those which oceur in houses are liable to be found throughout the year; they fly but for slort distances, but run very nimbly and keep their antenna in a continuous state of agitation. Some of them are gaily coloured, but most of the species generally found in houses are of sombre hues. 'The larva feed on various kinds of sub. stances, cloth, horse-hair, feathers, cte., cork, fungi, decaycel wood. Many of them, like $T$. pellionella, construct portable cases in which they reside, exserting only the three first segments for the purpose of locomotion; others, like T. tupetzella, construct covered galleries of the substance on which they are feeding, thus destroving much more than they artually consume; ofhers, like $T$. biscllicllu, do not construct cases nor have regular galleries, but spin together portions of the substance they are cating for the purpose of a cocoon, preparatory to assuming the pupa state. 'Those which feed on fungi and decayed wood, form galleries in the solid substance, which they line with silk.

A great deal has been written on these insects with a view of preventing their ravages, but hilherto with little success. Where they once gain a footing it is very difficult to get rid of them; and I have myself been annoyed by 1 . biselliclla establishing itself in the linings of sofa, chairs, ete., and in the carpets. In occasional baking of the furniture will help to keep their numbers in check.

These insects became known from their ravases at a very early

VOL. III. 
period, and are on sereral ocensions inentioned in Seripture. St. James, in his (ieneral lipistle, chap. v. ver. 2, says " your yarments are moth-eaten," thus showing a similatity of habit, probably arising from the same species as those we still sullier from.

Of this genus we have thirty-one species in this comtry, which may be arranged in the following table (many others occur on the continent).

a. Anterior wings with a hyaline spot on the dise. Species 1-4.

a $a$. Anterior wings with no hyaline spot on the dise.

b. Anterior wings dark, with large whitish spots on the costa and inner margin.

c. Large-sized species. Species 5.

c c. Small-sized specics, Species 17.

b b. Anterior wings with the basal half black, appical half whitish. Species 6.

b 6 b. Anterior wings whitish, with an angulated lslack fascia. Sp. 7.

b 6 b 6 . Anterior wings pale, with a dark streak or streaks from the base. Species 8 and 9 .

b 8686 . Anterior wings with a mottled appearance. Species 10-16.

$6 b \quad b \quad b \quad b \quad b$. Anterior wings nearly micolorous, with a few dark spots on the disc. Speeies 18-23.

6666666 . Anterior wings ochrcous.

d. Unicolorous. Species 24 and 31 .

d d. With a dark spot at the anal angle. Species 27.

$d d d$. With numerous marginal dark spots. Specics 26.

$b 6 b b b b b b$. Anterior wings unicolorous, violet-brown. Sp. 25.

$b \quad b \quad b \quad b \quad b \quad b \quad b \quad b \quad b$. Anterior wings dark, with pale fascix or transverse spots. Small species. Species 28-30.

1. imella, Hiib. 307 (1816); /4H.; I)u1.; H.-S. Alis anticis nitidis fuscis, squamis sparsis dilute ochrcis, costa ipsa apicem versus clilute ochree, macula disci fere in medio pallida. Lixp. al. 6.5 lin.

Head and face ochreous. I'alpi pale ochreous. Antennec fuscous. Antrrior wing, shining fusconts, with a few pale ochreons scales, the axtreme costa from brfore the middle to nure the apex pule vchreoss; on the dise nearly in the middle is a small pale spot; cilia fiscous, at the anil annle pale orhreous. P'osterior wings pale greyish-fuscous, with greyish-ochreous cilia.

$\Lambda$ scarce species; appearing in June and August.

2. ferruginella, Hül. 343 (1816); Trit.; Dup.; Zell.-splendella, Iliib.-uslella, Ilaw.; Step.-obriella, W. V.?-mendicella, Ilüb.? Alis anticis saturate fuscis, vix purpurasecute tiuctis, postice griseoochreo irroratis, dorso dilule ochreo, macula disci, paullo post medium, albida. Exp. al. $5 \frac{1}{2}$ lin.

IIead and face pale ochreous. Pialpi pale greyish-ochrenus. $\Lambda \mathrm{n-}$ tonn:e dark futscous. Anterior wings dark fuscous, with a slight pur- 
plish tinge, posteriorly irrorated with pale greyish-oclireous; the inmer margin, nearly to the fold, pale ochreous; on the disc, a little beyond the middle, is a whitish spot; cilia greyish-ocheous, varjed with fuscous. Posterior wings whitish-grey, towards the apex darker, with paler cilia.

Not uncommon; the perfect insect appearing in June, July, and October; found abundantly in 1819 by Mr. Scott, in a coalmine near Glasgow.

3. rusticella, Müb. 339 (1S16); 'T'rcit.; Dup.; Zcll.-saturclla, Ilaw.-vestianella, Step.-leceigella, W. V.? Alis anticis saturate grisco-fuseis, vix purpuriscente tinctis, dilute ochreo irroratis, macula disci ante medium dilute ochreo. Exp. al. 6-8 liu.

Head and face ochreous. l'alpi palc ochreous; second joint extermally, aud the basal half of the terminal joint dark fuseous. Anteme greyish-fuscous. Anterior wings dark greyish-fuscous, with a very faint purplish tinge, irrorated with pale ochreous, with a pale ocheons spot on the dise, near the costa before the middle; cilia pale ochreous, somewhat varied with fuscous. P'osterior wings pale grey, with paler cilia.

$\Lambda$ rather common species in louses, outhouses, ete. Mr. Weaver has taken several specimens of a variety (?) with an ochrcous spot at the anal angle rumming into the cilia; these he found in fir-woods, Perthshirc.

4. monachella, Ilül). 14:3 (1S01); 'Treit.; Sta.; Zell.-mediellä, Tab.? Alis auticis salturate fuscis, macula costali magna alba, dorsum versus indentalu, punctis minutis apjocm versus albis. Exp. al. $5 \frac{1}{2}$ lin.

Ilead and face white. Palpi white; second joint externally dark fuscous. Antenna fuseous. Auterior wings rather dark fuscons, with a large inregular while bloteh on the costa, extending from before the middle to the apex, renching half across the wing, but with a rounded indentation in its side towarls the inner margin; the base of the costa, and the margin of this white blotch, are dark purplish-fuscous; towards the apex of the wing are some small white spots; cilia dark purplishfuscous. Y'osterior wings pale grey, with paler cilia.

Oceurs in the Cimbridgeslite fens; appearing in May and August.

5. fulvimitrella, sod. 33ull. N. M. 1830. 74. pl. 1. f. 6; Treit.;

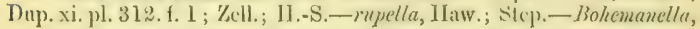
bett. Alis anticis salurale purymro-fuscis, maculis qualuor conspicuis albidis, dunbus dorsi, duobus costee, squanis sprarsis clisci allidis. Exp. al. 8 lin.

Ilead and face bright ochrous. l'alpi pale ochreons ; sccond joint externally and the base of the terminal joint dark fuscous. Antemne dark fuseous. Auterior wings durk purplish-fuscons, wilh four ronsyjicuons whitish spols, of which two, somewhat triangular, on the inner 
maryin (one near the base, the ofler a little beyond the middle), and tro oblicpuely beyond them on the costa, of which the first is rather small, pointing posteriorly; the second is larger, pointing towards the anal angle; on the disc are severnl seattered whitish scales; cilia dark purplish-fuscous, the (ip) of the apex whitish, and frequently some patches at the extremity of the hinder margin whitish. Posterior wings greyish-purple, with paler cilin.

Oecasionally met with on the trunks of trees in June.

6. tapetzella, Lin. S. N. 536. 253 (1759); Cl.; Tab.; Hüb. 'Tin. 91; Ilaw.; Treit.; Step.; Dup.-lapezana, Fab.; Lat.-tapetielln, \%cll. Alis anticis dimidio basali nigro, apicali albo grisco-nebuloso, puncto minuto ad angulum analem, punctisque duobus apicis nigris. Exp. al. 9 lin.

Ilead and face white. Palpi white; sccond joint cxternally dark fuscous. Antennic fuscous. Anterior wings black from the base to the middle, then white; on the inner margin the black terminates very abruptly a little before the middle; on the costa, where it is continued furfher, the termination is less abrupt; the apical portion of the wing . is clouded with dark grey, and there is a small black spot at the anal angle, and two or three at the apex of the wing; cilia whitish, at the apex dark grey. l'osterior wings pale grey, with whitish-grey cilia.

i common species, frecuently occurring in carriages, the larva focding on the lining under a gallery constructed from the lining; the perfect insect appears in Jume and July.

7. arcella, Fab. G. I. $295(1776)$; schr. ; Kell.-niveella, Fab.repandella, II iib.; 1)up. xi. pl. 289. f. 9.-clemater, Haw.-clemalella, Step.; Jab.? Alis anticis allois puncto dorsi basali, stria cosice basali, fasciu merlia latiusmela angulale, punctisque duobus costiv apiecm versus salurate fuscis. Exp, al. $6 \frac{1}{2}$ lin.

Head and face white. Palpi white; second joint beneath grey. Autcune grevich-fuscous. Autcrior wings white, with a snull spot at the base of the juncr margin, and a costul strent at the base dark fuesrous, in the mildle is a moderately brout unguluted durk fuscous fuscin (the :urgulation is near the costa and is rather produced posterionly on the dise); on the ensta before the aljex are two dank fuscous spots, and the apical portion of the wing has severil fuscous clouds; cilia whitish, at the extreme apex fuscous. P'osterion wing grey, with palce cilia.

Not rare in the south of lingland; it is probibly doublebrooted; I have met with it in old ledge's in June, July, and August.

S. picarella, Jin. I. S. 1399 ( $17(\mathrm{i} 1)$; Cl.-Rigälla, Sod. ; Treit.;

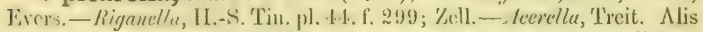
anticis albis villa longifudinali ex basi juxla costum, postice paullulum "urvata, in apiem dristentos nigra, maculis parvis dorsun versus nigris. Exp. al. $7 \frac{1}{2}$ lin. 
Ilead, face, and palpi white, or whitish. Antenne pale fuscous. Anterior wings white, will ablack streak from the buse near the costa, continnerl, with a slight curve beyond the middle, to the apese; on the costa before the midelle are two small white spots, and beyond the micldle is a larger triangular white spot, in which, on the extreme costa, are three or four small black spots; at the base, on the inner margin, is an irregular black spot pointing upwards, beyond it are three small black spots olliquely placed; one on the inner margin, one below, and onc above the fold; a small black spot lies on the inner margin before the antal angle, and above the anal merle is an oblong black streak along the hinder ntargin; cilia white, varied with dark fuscous or black. Posterior wings rather dark grey, with paler cilia.

$\Lambda$ single specimen of this conspicuous insect is in Mr. Edleston's collection.

9. arcuatella, Sta.-picarella, IIüb. Tin. 219; Treit.; Dup.; Kett.; Hivers.; 1I.-S.; Zcll. $\Lambda$ lis anticis albidis, fuscescente suffusis, striis dualus ox basi saturate fuscis, altera dorsmm versus pone medium desinente, ulleru costam versus ante medium desinente, macula costali pone medium cum stria disci confluente, saturate fusea. Wxp. al. 9? lin.

Ilcad, face, and palpi pale ocheous. Antemne grey. Anterior wing whitish, much sullused with pate fuscous with tuo durk fuscous strenlis from the base, one rather simuated almost in the fold terminating beyond the midelle, the other near the costu terminating before the middle; on the costa, beyond the middle, is a dark fuscous spot, below which is a dlark fuscous streak on the clise which is prolonged in a curved direction and terminates on the costil before the apex; hinder margin spotted with dark finscous; cilia altcrnatcly white and fuscous. Posterior wings greyish-fuscous, with paler cilia.

Several specimens have been taken at Ramnoch, in Perthshire, in the summer, by Mr. Todykinson and Mr. TVeaver. 'The larva feeds in fungi in September.

10. corticella, Curt. B. E. fo. 511 (1831); "/chl. (I. E. vi.)-emortuellu, Zell. (Isis 1\$39).-granella, var., Dup.-concimnella, I [üb.?clorema, II.-S.? Alis anticis albillis, fuscescente paullulum suflusis, punctis parvis costiv I vel 5 salurate fuscis, triangulo in medio dorsi orlirer-fuser (apice suo supuri dorsum), punctis minoribus dorsi malginisque postici saturate fuscis; capillis albis. Exp. al. $7 \frac{1}{2}$ lin.

lleud and face while. Palpi internally whitish, extemally dark fuscous; tip of the terminal joint entirely whitish. Antema pale grey. Anterior wings whitish, rather suflised with pale fuseons, especially towarls the costa; along the costa are several small dark fuscous spots, of which the largest is rather beyond the middle; nearly opposite, on the middle of the inmer margin, stumling on its apex, is an ochreons-finsons (rinengulur spol; on the inner margin towards the base is frequently a dark fuscous spot, and there is another at the anal 
angle; hinder margin interruptedly dark fuscous; cilia ochreous-fuscous, with some whitish patches. Posterior wings dark greyish-fuscous, with paler cilia.

Not common; the perfect insect appears in May and August. The larve were found by Mr. 'Thomas I)esvignes in fungi on the lornbeams in Epping Forest in June and July.

11. parasitella, ILüb. Tin. 16 (1801); ITaw.; 'Treit.; Step).; Dup.; Hers.; II.-S.; Kell.-(carpinetella, Sta. Cat.) Alis anticis albiclis, suturate-fusco marmorutis, punctis quatuor vel quinque coste saturite fuscis, secundo ante, et quarto jonc inedium eum puncto dorsali saturate-fuseo connexis, margine postico apicerue costes saturatefusco-punctatis; capillis ocltreis. Exp, al. 9 lin.

Mead and face ochreous. Palpi internally pale ochreous, extermally dark fuscous; tip of the terminal joint entirely pale ochreous. Antemne greyish-fitscons. Anterior wings whitish, chergueded and spottert. with durk Juscons; along the costa are four or five dark fuscous spots, one at the base, one before the middle connected aeross the wing with a dark fuscous spot on the midalle of the imer margin, one nearly in the middle, ene beyond the middle likwise connected with the spot on the midlle of the inner margin, and also with a spot at the anil angle; the hinder margin and apex of the costa are spotted with dark fuscous; cilia, at first fuscous, the ends pale ochreous, interrupted by tour fuscous patches. P'osterior wings dark grey, with a slight purple tint, witl dark grey cilia.

Not an uncommon species; the perfect insect appears in May and June. 'The larva feeds on fungi (and decayed woorl?) during the winter.

12. Granella, Lin. S. N. 537. 259 (1758); IV. V.; Fab.; IIuib. 'Tin. 16.5; Ilaw.; 'lrcit.: Step.; 1)up.; \%ell. Alis anticis albis, maculis numerosis saturate-fitscis nigrisve, quanum septem costre (uma busali plicam langente et snpra eam joroducta, una abbreviata ante, una majore pone medium, maculis (quatuor costa apjiceu versus uninoribus), macuda parva dorsi juxta basin, alteraque majore plicae ante medium saturate fuscis; capillis albis, albidisve. Exp. al. $4 \frac{1}{2}-7 \mathrm{lin}$.

/lrat and face relike, or whitish. I'alpi white; second joint externally fuseous, Antenne fuscous. Anterior wings white, with numcrous dark fiscous almost black spots, of which seven are on the costa; the

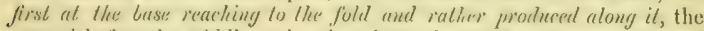
second before the middle and rather short, the third and latrest beyond the middle prolonged oblignely and rearehing half' across the wing, the fourth and fith are very small, the sisll is generally comected with the sevently which lies in the aprex of the wing; on the inner margin near the base is a small dark fuscous spot, and a larer one lies on the: fold before the midsle; eilia darh lissous, baried with white. l'osterior wings greyish-fuseous, with pale grey cilia. 
'This benutiful insect is abundant in granaries (throughout the globe?); the larva is stated to reside in a case comnecting several grains of com logether by means of its silken threads; its ravages have been most observed in September and Oetober (but $I$ think a sccond brood feeding in July cxtremely probable); the perfect insect appears in Junc.

13. cloacella, Haw. L. 13. 563 (1829); Step.; \%oll.-granella, var., Dup. xi. pl. $25 \%$. f. 13 ct $1 \%$. $\Lambda$ lis anticis albito-ochrcis, fuscescente paullulum suftusis, maculis conspicuoribus costie saturate fuscis tribus (una basali plicam non tantyembe, una abbreviata ante suedium, altere elmugula cnu stria longiludinati disci connear, pone medium) maculis duabus parvis, tertiacue majore apicem versus; macula plice ante medium silurate fusea, margine postico interrupte saturate fusco; copillis dilute-ochreis. Exp, al. $6 \frac{\pi}{3} \mathrm{lin}$.

Ilerd and fates pule ockreous. Palpi whitish; second joint cxternally fuseous. Antemie fuscons. Anterior wings whitish-ochreous, somewhat suffused with pale fuscous, and with several dark fuscous spots, of which, three on the costa are very conspienous, one at ller base not reseding to the fold, a short one before the midelle, and a somenchat elon-

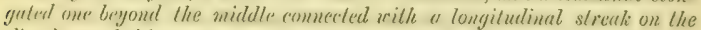
dise, bryond this are two smaller fuscous spots, and a larger dark firscous spot lie's towards the apex; on the fold before the milldle is a dark fuscous spot; the hinder inargin is interruptedly dark fuscous; cilia dark fuscous, with pale ochreous patches. l'osterior wings dark grey, with a slight purplish tinge, with paler cilia.

Abundint throughout the comntry, firequenting old hedgerows in May and August. The larva fecls in fungi and decayed wood, and probably does not do us any mischief.

11. ruxicolella, Sta. Cat. p. 7 (1819),-granclla, var., Dup. xi. 1l. $24 y$. f. 12,-cloncella, var. 6., Zell. Alis anticis grisco-ochreis, maculis saturate fuscis, tribus coste conspicuoribus, una basali plicam non tangrnle, una aute medium, altera majore pone medium in diseo prostice non producla, macula plice ante medium saturate fusea, margine postico apiceque coste saturate fusco-punctatis; copillis dilute ochreis. Exp. al. $5 \frac{1}{2}-6 \frac{1}{2}$ lin.

Ilead and finec pale oclereons. P'alpi whitish; second joint externally luscous. Antemes pale grey. Anterior wings greyish-ochreous, with dark fuscous spots, of which thee on the costa are comspicuous, one al the base not reacling to the fold, one before the micldle, and a linger one beyond the niddle reaching nearly late aeross the wing, but not produect posteriorly on the disc; on the fold before the midelte is a clark fuseous spot; hinder margin and apex of the costa interuptedly clark fuscous; cilia fuscous, interrupted with pale ochreous patches. Posterior wings grey, with a slight purplish tinge, with paler cilia.

()eers in the same places and at the same tines as the preced- 
ing ( $I$. cloucella), of which it is perhaps only a variety. The discovery of the larva must decide this point.

15. Cochylidella, n. sp. Alis auticis grisco-ochreis, paullulum fusco-sullusis, nebula in medio plice albida, in qua macula curvalu fusca ex medio dorsi, uebula obsoletiore disci pone medium allida, macula abbreviata costa paullo post medium, et marginc postico apicepuc costa: saturate fuscis. Iixp. al. 6 lin.

Head and face pale yellowish. Palpi pale grey. Antenne fuscous. Anterior wings greyish-ochreous, slightly suflused with fuscous, with $a$ whilish bloteh in the middle of the fold, intermpted by a dark fuscons curved spot from the middle of the imer margin (like the typical marking of a Cocthylis); on the tise beyond the middle is mother indistinet whitish spot, and on the costa a little beyoud the middle is a rather short dark fuscous spot; hinder nargin and apex of the costa dark fuscous; cilia pale greyish-ochreous. P'osterior wings rather dark grey, with the cilia a little paler.

A single specimen in the collection of Mr. Douglas, taken by him near Sanderstead in Junc, 1852.

16. albipunctella, Ifaw. I. B. 561. (1829); Stcp.; Sta.; Zell. Alis anticis nitidis salurate fuscis, punclis numerosis albitis, duobus costie ante, tribus coste pone medium, uno dorsi ante, duobus siepe comnexis dorsi pone medium, atomis disci sparsis albidis; capillis albidis. Exp. al. 5 lin.

Head and fice whitish. Palpi whitish; second joint externally fuscous. Antenne pale fuscous. Antcrior wings shining, dark fuscous, with numcrous whilish spots, of which two are on the costa belore the middle, and three or four on the casta beyond the middle, one on the inner margin before the middlle, and two beyond the middle frequently united; on the dise are several whitish atoms; cilia dark fuscous, with two whitish patches. Posterior wings greyish-fuscous, with paler cilia.

Sicarce ; occurs in June at Iturstpierpoint, Sussex; taken by Mr. Weir.

17. Caprimulgella, (v. Ilcyd.) Sta. Supp. Cat. p. 2 (1851);

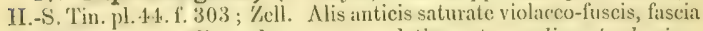
subobliqua ante modium, dorsum versus latiore, et necenlis cosla dorsique dilute luteis. Exp. al. $5 \frac{1}{2}$ lin.

Ilead and face dark ochreous. Palpi pale grey. Antenux dark fuscous. Antcrior wings dark violet-fuscous, wilh pale yellowish spots on the costa and inner margin, of which the first is a spot on the imer marrin near the base, then follows a rather oblique fascia before the middlle, broadest on the inner margin; beyond are two small spots at the costa and onc at the amal angle; cilia dark greyish-purple. l'osterior wings grey, with grey cilia.

$\Lambda$ scarce species; I have secn only three British specimens, 
one of which was taken by Mr. Wilkinson, on a paling near llackney, in July; the larva feeds in decayed wood (v: IIeyden ).

18. misella, Zell. Isis, 1839 , p. 181 ; II.-S. Tin. 41. f. 277. Knockiella, Sta.; IIüb.? Alis anticis luteo-Lrunneis, lutescente manmoratis, macula distincta disci pone medium saturate fusea, interdum macula clongata obsoleta in medio plicie saturate fusca, cilis fuscis diluteochreo maculatis; alis posticis griseis, purpureo-linclis. Exp. al. 6-7 lin.

II and and face ochreous-fuscons. Palpi pale grey, externally fuscous. Antenux fuscous. Anterior wings yellowish-broxn, marbled reilh pale yellow, with a distinct dark fuscous spot on the disc beyond the middle, and frequently an clongate dark fuscous, rather obsolete spot in the middle of the fold; cilia alternately fuscous and pale ochrcous. Posterior wings grey, with a purple gloss; cilia grey.

Not common; the perfect insect appears in June and $\Lambda$ ugust. I have met with it in old hedges.

19. fuscipunctella, Haw. I. B. 562 (1S29); Stcp). ; St:1.; II.-S. Tin. 4.. f. 300 - spretella (Sta.); Zell.; II. V.?-fuscella, Limn.? Alis anticis dilute griseo-fuscis, fusco valde sufiusis, macula dorsi basin versus, punctis tribus disci saturate fuscis, cilies costulibus fuscis diluteochrco variegatis, marrinis postici dilute griseo-ochreis; alis posticis ci-

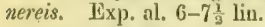

Head and face ochreous-fuscous. Palpi pale ochreous, externally fuscons. Antenux fuscons. Anterior wings pale greyish-ochereons, much suffised with fuscous, with a dark fuscous blotch on the inmer margin near the base, and a spot on the disc, one rather posterior to it on the fold, before the middle, and a larger spot on the dise beyond the middle dark liscous; ciliu, at the apex of the cosia fuscons, varied with pale ochreous; at the hinder margin pale greyish-ochreous, with a dark fuscous line. Posterior wings whitish-grey, with paler cilia.

Not uncommon in houses; probably a general feeder, I have bred it from dry peas; the perfect insect appears in Jume and Septembcr.

20. pellionella, Jinn. S. N. 536. 254 (1758); Fab.; IUüb. 15; IIaw.; 'Treit.; Step.; Dup.; Zell.; II.-S.-sarcitella, Linn.?-Zoolegella, Scop.? Alis anticis griseo-ockreis, punctis tribus disci obsoletis fuscis, macula dorsi basim versus obsoletiorc, ciliis dilute griseo-ockreis; alis posticis cinereis. Exp. al. $5 \frac{2}{2}-6 \frac{2}{2}$ lin.

Ilead and face ochreous, slightly mixed with fuscous. Palpi and antennic fuscous. Auterior wings greyish-ochereous, with three rather obsolete fuscous spots, one on the dise, and one rather beyond it on the fold before the middle, and one on the dise beyond the middle; there is sometimes a faint dark spot on the inner margin near the base; cilia wnicolorous, pale greyish-ochreous. Posterior wings whitish-grey, with whitish-ochreous cilia.

An abundant species in houses, found nearly throughout the VOL. III. 
year; the larva constructs a portable case of the substance on which it is feeding; it appears very partial to feathers.

21. pallescentella, Sta. Sup. Cat, p. 2 (1851). Alis anticis cinercis, striis duabus er basi (alteri ubbreviata costan versus, altern clongata plica) fuscis, punctis duobus pone medium disci albis. Exp. al. 7 lin.

"Like a large Pellionella, but wilh two brown streaks from the base of the wing; one along the costa, which soon eeases, the other in the fold extenting nearly to the anal angle; beyond the middle are some brown seales on the ilisc, and among them two white spots, having an ocellated appearance; cilia pale cincreous, with some brown scales round the extreme apex of the wing."

The above description is eopied from my Sup. Cat.; nol having had an opportunity of again examining this species, of which I believe two or three other specimens hive oecurred in Liverpool.

22. flavescentella, IIaw. I. B. 564 (I829); Stcp. Alis allticis dilute ochreis fusro-irroralis, punctis tribus disci saturate fuscis, basique costre saturate fusca. lixp. al. $5 \frac{\pi}{3}$ lin.

Head and face pale ochreous. Palpi pale ochrcous, externally fuscous. Antenna fuscous. Anterior wings pale ochreons, dusted wihl finscous, with three dark fuscous spots, one on the disc, one beyond it on the fold before the middle, and one on the dise beyond the middle; the extreme base at the costa is dark fuscous; cilia pale ochreous. Posterior wings pale grey, with paler cilia.

In the collections of Mr. Shepherd and Mr. Curtis; I have only seen two specimens.

23. Lapella, IIiib. Tin. 232 (1501).-Isppella, Haw.; Step.; Dup.; 11.-S.- Cripunctelle, Don.-ganomella, Treit.; Kell. Alis anticis dilute ochereis, postice grisescente suffusis, cosla busim versus saturate fusca, puncto ovato plice, puncto puroo disci ante medium, punctoque rotundo disci pone metlum nigris, squamis paucis dorsi, angrulum analem versus nigris. Exp. al. $7-7 \frac{1}{2}$ lin.

Head and face bright yellowish. Palpi dark fuscons; terminal joint pale yellowish. Antenna dark fuscous. Anterior wings pale velereons, rather suffused with pale grey towards the apex; the basal half of the costa dark fuscous; on the fold before the middle is an oval black spot, above which, on the disc, is a smaller blact spot, and beyond the middle: of the disc is a round black spot; there are a few black seales on the inner margin a little before the anal angle; cilia ochreous. Posterior wings grey, with a slight purple gloss, with pale greyish-purple cilia.

Not uncommon in old hodges, in May and August.

24. biselliella, Hummel, Ess. Ent. 3. 13. p. 6-13 (1823); \%ell.; II.-S._-crinella, Treit.; I)ıp.; Kett.-destructor; Step.-flavifrontella, IV. V.?; Fab.? Alis anticis nitidis dilute ochereis immarulatis, costam versus juxta basion firsco-tinctis. Exp. al. $6 \frac{1}{2}-8$ lin. 
Head and face reddish-ochreous. Palpi pale ochırcous. Antennæ pale greyish-ochrcous. Anterior wings shining pale ochereons, immaculale; towards the costa, near the base, slightly tinted with fuscous; cilia pale ochreous. Posterior wings whitish, with pale ochreous cilia.

$\Lambda$ very abundant and destructive species, most partial to horsehair linings of chairs, etc. 'The larva, which is dirty-whitish, and makes no case, may be found nearly throughout the year.

25. simplicella, II.-S. Tiu. 47. f. 322 (1851); Zcll.-angusticostella, Sta. Alis anticis fuscis, lutescente-tinctis, dorsum versus dilutioribus, ipsa cosla pone medium anguste lutea. Exp. al. 6 lin.

ITead and face ferruginous. Palpi pale greyish-ochreous; second joint extcrnally fuscous. Antemne dark fuscous. Anterior wings fusrous, with a slight yellowish tinge, paler towards the inner margin, and with the costa beyond the middle narrowly pale yellowish; cilia pale greyish-fuscous. Posterior wings greyish-purple, with the cilia at first fuscous, then whitish-orrey.

Not common; occurs near Dover and near Mickleham in July.

26. nigripunctella, Haw. L. 13. 50.4 (1829); Step.; Zell.-parietariclla, II.-S. Alis anticis lntescentibus, punctis numerosis nigrescentibus, margines versus conspienoribus. Exp. al, $4 \frac{3}{2}$ lin.

Head and face yellowish. l'alpi pale grey. Antcuma greyish. Anterior wings yelloxish, with memerous blaclish spots, of which one in the middle of the cost: sometimes united with one rather beyond it on the inner margin, and two opposite spots beyond the middle, also sometimes united into a fascia, are the most conspicuous; the hinder margin and apex of the costa are spotted with dark fuseous; cilia pale yellowish-grey. Posterior wings pale grey, with paler cilia.

This species, by no means common, has been taken in August, near Bristol. It is probably double-brooded, appearing also in May; the larva (according to Bruand) fects in a case, on old fences.

27. semifulvella, Haw. L. B. 562 (1829); Stcp.; II.-S.; Zell. $\Lambda$ lis anticis dilule ochreis, mufo-ochreo suffusis, pracipue apicem versus, costa basim versus rufo-fissea, macula minula dorsi, angulum analem versus, salurate fusca. Lxp. al. 8 lin.

Ifead and face deep ferrugrinous. Palpi pale greyish-ochreous, cxterually dark fuscous. Antemme greyish-fuscous. Anterior wings pale ochreons, suffised with redish-ocheous, especially towards the apex; the basal half of the costa is reddish-fuscous; a small dark fuscous spot lies on the inner margin before the anal angle; cilia reddish, extcrially pale oclurcous. Posterior wings grey, with paler cilia.

Not common; found occasionally on palings and among old herlges in June.

25. bistrigella, Haw. I. 13. 573 (1829); Step.; Sta.; /ell.- 
abalienella, 7ett.-dilorella, II.-S. T'in. 39. f, 266. Alis anticis nitidis fiuscis, fuscia recta ante medium, fuscia intcrdum internpta pone medium, punctoque posteriore disci (interdum obsoleto) albis; capillis saturate oclerco-fuscis. Exp. al. 4 lin.

Ilead dark ochreous-fuscous. Face pale ochreous. Palpi whitish. Antennie fuscous. Anterior wings shining fuscous, with a straight thite fuscia before the middle, and a rather curved one beyond the middle, sometimes divided into two opposite spots; beyond the latter, on the disc, is a small whitish spot, sometimes lowever absent; cilia fuscous, with the tips whitish. Posterior wings pale grey, with paler cilia.

Not common; in woods anong mixed underwood in June; in England and the south of Scotland.

29. subammanella, Sta. Cat. p. 9 (184.9); Id. Ent. Trans, i. n. s. pl. 3. f. 8; Zell. Alis anticis purpureo-fuscis, fasciis duabus rectis luteo-albis (altera ante, altera paullo post medium) puncto lutco-albo, disci pouc medium, ciliis purpureo-fuscis, ad apicem albidis. Exp. al. 3 lin.

Anterior wings purplish-fuscous, with two straight yellowish-white fascies, one before, the other rather beyond, the middle; beyond the latter is a sinall yellowish-white spot on the dise; cilia purplish-fuscous, at the apex of the wing whitish.

My specimen, taken in Scotland in July 184.8, among mixed underwood, still remains unique.

30. argentimaculella, Sta. Cat. p. $6(1819)$; Zell. Alis anticis nilidis salurate fuscis, fuscia obliqua ante, maculis oppositis pone medium, punctisque apicem versus argenteis. Exp. al. 4 lin.

Head pale fuscous. Face and palpi white. Antemae dark fuscous. Anterior svings dark fuscous, rather shining, wilh an oblique silvery fascia before the middle, sometimes interrupted on the fold; beyond the middle are two nearly opposite silvery spots; the costal spot is narrow, reaching half across the wing, the spot on the inner margin is somewhat triangular, hardly reaching to the fold; a little above the anal angle is a small round silvery spot, at the apex of the costa are two, and on the hinder margin are three silvery-achite spots; cilia fuscous, tips whitish. Posterior wings greyish-fuscous, with paler cilia.

$\Lambda$ searee species; in the collections of Mr. Shepherd, Mr. Doubleday, and Mr. Douglas; the latter took his specimen on the Dartford Heath fence early in July.

31. ochraceella, Tengst. F. F.-T. 111. 15 (184.8); Sta.; Zell.; Scott (\%ool. 1853, 4.075). Alis anticis oclucis immaculatis, ipsa costa ad basim nigrescente. Exp. al. 8-9 lin.

IIead and face dark ochreous. Palpi dark fuscous; terminal joint dark ochreous. Antenna greyish. Anterior wings unicolorous-ochreous; the edge of the costa at the base blackish; cilia rather paler. Postcrior wings rather dark grey, with pale ochreous cilia. 
Not uncommon, in the Black Forest, in Perthshire, in ants' nests, in July.

\section{Genus VIII. LAMPRONIA.}

Lampronia, Zell. L. E. vi. 84 et 180 (1852).-Lampronia p., Step.; Curt.-Esperia p., IIüb. V.-Tinea p., 'Zell. Isis, 1839.-Lampros p. et Adela p., Zett.

Caput postice hirsutum, capillis in verlice ac fronte decumbentibus. Ocelli nulli. Antenne alis anterioribus breviores. Palpi maxillares 5-articulati, plicati. P'alpi labiales cylindrici, pilosi; articuli secundi apice supra setis paucis instructo. Haustellum subnullum. Alæ anteriores oblongo-ovatx: e cellula discoidali ven 5 in marginem costalem prodeunt; posteriores ovata, ciliis breviusculis.

IIcad hairy bchind, on the crovon and in frout the hairs decumbent. Oeclli none. Antemme moderately thick, not pectinated or ciliated, shorter than the anterior wings. Maxillary palpi five-jointed, folded. Labial palpi cylindric, hairy; the apex of the sccond joint furmished above with a few bristles. Tongue hardly pereeptible. Anterior wings oblong-oval. Posterior wings oval, witl rather short cilia. From the discoidal cell of the anterior wings, five veins run into the costa.

The perfect insects of this genus are gaily coloured, and fly freely during the sunshine. The larva of only two of them are known, L. prelatella and $L$. Rubiella: these differ so much in habit that they would hardly be expected to occur in the sitme genus. That of J. prelatella feeds under the leaves of the wild Strawberry, in a flat case, shaped rather like the figure 8 , which it applies by one of its flat sides to the under side of the leaf; it does not devour the leaf at the spot where it is applied, but takes the precaution to bring with it to its place of concealment a piece cut ofl from the edge of the leaf, or of some neighbouring leaf, which it then fastens to the under side of its ease and consumes it at leisure; when the piece of leaf it has in store is large, the case is completely concealed between it and the leaf under which it reposes. 'This peculiarity in the labit of this larva was detected by Mr. 1)onglas, who found the larva at West Wickham Wood, in September. L. Rubiella, in the larva state, bores down the stem of the young shoots of the Raspberry, as recorded by Bjerkander in in the 'Nova Acta IIolmix,' in 1781, and recently observed by Messrs. Doublerlay, Logan, and Westwood. 'The larva of $L$. quadripunctella feeds on the rose, but its habits have not yet been observed. 
The species of this genus may be easily recognized thus:a. Anterior wings with indistinct, almost obsolete, pale spots. Sp. 1 . a a. Anterior wings with a pale fascia before the middle, and.pale opposite spots beyond the middle. Species 2 and 3. a $a$ a. Anterior wings with numerous small distinct pale spots. Sp. 4.

1. quadripunctella, I’ab. S. I. ii. 298.52 (1781); Haw.; Step. -morosa, Zcll.-bipunctella, Dup.? Alis anticis obseure fuscis, macula triangulari dorsi punctoque parvo disci pone medinn dilute lnteis, puncto costali posteriore dilutiore, interdum obsoleto. Exp. al. 6 lin.

Head and face greyish-fuscous. Palpi whitish. Antenna fuscous. Anterior wings dull frescous, will a pale yellowish, somewhat triangular spol on the inmer.margin beyond the middle, above which, on the disc, is a minute pale yellowish spot, and on the costa, rather beyond, is a very indistinet pale spot, in many specimens entircly wanting; cilin greyishfuscous. Posterior wings greyish-fuscous, with paler cilia.

Common among hedge-roses in June; flying frecly in the carly morning in the sumshine. The larva feeds in May(?).

2. Luzella, IIüb. 'Tin. 430 (1816); Step.; Curt. B. E. fo. 639 ; Zell.-flavipunclella, IIaw.; Step. Alis anticis saturate purpureo-fuscis, fascia obliqua prope basim, maculis oppositis poue medium (dorsali

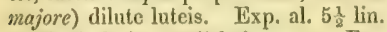

Ilead dark purplish-fuscous. Face grey. Palpi pale grey. Anteme fuscous. Anterior wings dark purplish-fuscous, with a pale yellow, ralher oblique fascia near the base, attenuated on the costa, and sometimes interrupted; beyond the midclle are two pale yellow opposite spots, of which that on the inner morgin is the larger, and nearly triangular; cilia dark purplish-fuscous, the tips round the apex whitish. Posterior wings dark fuscous, with a slight purple tinge; cilia paler.

Not common; occurs ncar Lonion (at West Wickham), in Devonshire, and in the north of England, in June.

3. praelatella, W. V. 320 . 46 (1776); Fab, ; Ilïb.; Haw.; Step.; Yell.; II.-S.—mestella, Iriib.—Luzella, 'Treit.; Trey. N. 13. ii. 60. pl. 132.-Aavimitrella, Dup.-Lifasciella, Tab.? Alis anticis saturate fuscis, vix purpure-linetis, puncto in medio laseos albido, fascia fere recta ante medlun, maculis suboppositis pone mediun (costali majore) albidis. Exp, al, 9 lin.

Head pale ochreous. Face whitish. Palpi whitish. Antenne fuscous. Antcrior wings dark fuscons, with a slight purpliste gloss, with a small whitish spot in the tniddle of the base, a nearly straight whitish fascia before the middle sligrhtly attenuated on the costa, and two whitish nearly opposite spots beyond the middle, of which that on the costa is the larger and posterior ; cilia dark purplish-fuscous, externally whitish. Posterior wings greyish-fuscous, with a shight purplish gloss; cilia grey. 
Common in woods in June. The larva fects on Goum urbanum and Fragaria vesca, from September to May.

4. Rubiella, 13jcrk. N. A. II. 1781. p. 20. pl. 1. f. 6-10--variella, Tab.; Treit.; F. v. R. ; Zell.—narmorella, Pab._corticella, IIaw.; Step.-multipunctella, Dup. Alis anticis nitidis fuscis luteo-punclatis, maculis duabus dorsi majoribus, quatuor coste minoribus luteis. Exp. al. 5 lin.

Ilead ochrcous-grey. Face and palpi dirty-yellowish. Antenme fuscous. Anterior wings shining fuscous, wilh numerous yelloro dols, and troo conspicuous yellow spots on the inner margin, one before the middle, the other near the anal angle, and four simaller yellowo spots on the costa; cilia fuscous, with the tips round the apex white. Posterior wings fuscous, with paler cilia.

Not uncommon among raspberry-bushes in Junc. The larva feeds under the fruit when young, hybernates without feeding, and in the spring bores down the stems of the young shoots.

\section{Genus IX. IAAMPROSETIA, n. g.}

Capilli superne ac in fronte depressi, whroque latere supra oculos flocculo usque ad verlicem producto. Ocelli nulli. l'alpi maxillares breves. Palpi labiales cylindrici, tenues. Antenne alis anterioribus breviores. IIaustellum subnullum. $\Lambda$ la latiuscula, mediocriter ciliatæ.

Ifead above and in front smooth, willh hairs arising on each side above the eyes, reaching nearly to the crown. Ocelli none. Maxillary palpi short. Labial palpi cylindrical, slender. Antemme shorter than the anterior wings. 'Iongue hardly perceptible. Wings rather broad, with moderate cilia.

This singular genus contains only one species; the larva of which feeds on "capillaire" (according to Bruaud).

1. Verhuellella, v. IIcyden (in litt.) Alis anticis nigrescentibus violace-tinctis; alis posticis dilute fuscis violaceo-tinctis. Exp. al, 4t. lin.

Ilead and face black. Palpi whitish. Antemme black. Anterior wings blackish, with a slight violet gloss; cilia paler. Posterior wings pale fuscous, with a violet gloss, with grey cilia.

The only British specimens I have seen were taken by Mr. Allen Hill, near Bristol; they are in very bad condition. Von Heyden says of it, "very easily rubbed."

\section{Genus X. INCURVARIA.}

Incurvaria, IIaw. I. 13. 559 (1829) ; Step.; Curt.; Zell. I. L.v.- 
Incurvaria p., Dup.-Tinea p., Zell. Isis, 1839.-Esperia p., IIïb. V.-Adela p., Treit.; Zett.

Caput superne et in fronte hirsulum. Ocolli nulli. Antennæ alis anterioribus breviores. Palpi maxillares 5-articulati, plicati. Palpi labiales eylindrici, pilosi ; articuli secundi apice supra setis paucis instructo. IIaustelfum breve. Ala anteriores oblongo-ovate; c cellula discoidali vene 5 in marginem costalen prodcunt; posteriores ovate (plerumque piloso-squamala) cilis breviusculis.

Ilead above and in front hairy. Ocelli none. Maxillary palpi fivejointed, folded. Labial palpi cylindrieal, hairy; the apex of the second joint furnished above with a few bristles. Antenna shorter than the anterior wings. Tongue short. Auterior wings oblong-ovate. Posterior wings ovate (generally with hair-scales), with shortish cilia. From the discoidal cell of the anterior wings five veins run into the costa.

The perfect insects delight to fly in the sunshine, and $I$. mus calella is generally abundant at the begimming of May. The larve live in cases formed of pieces of dead leaves, and feed on the fallen leaves during the autumn and winter. 'The larva however of $I$. capitella burrors down the stems of the young shoots of currantbushes.

'The specics may be thus recognized:-

$a$. The postcrior wings with elongate, hair-like scales.

6. Antennx of the of pectinated. Species I, 2.

b b. Antenna of the of simple, slender. Species 3.

$a$ a. The posterior wings with broad scales. Species 4,5 .

I. muscalella, Fab. Man. ii. 249. 91 (1787).-masclelella, ILüb.; 7.g. S. ; Treit.; Step.; Curt.; Dup.; Yett.; Zcll.-muscula, IIaw.+ spuria, IIaw; Step.; Curt.-var. o rufimilrella, West.; Sta. $\Lambda$ lis antieis nitidis saturale brumneis, maculis duabus dorsi dilute luteis ( $q$ macula parva costali pone medium); capillis ferrugineis; antennis $\delta$ pectinatis. Exp. al. 6 lin.

Ilead and face ferruginous. Palpi palc grey. Antennæ (of the of pectinated) dark fuscous. Anterior wings glossy dark brown, postcriorly with a few scattered ycllowish scales, with two pale yellowis/ spots on the inner margin; one in the middle reaching to the fold, the othes smaller at the anal angle (the o has frequently a small pale yellowish spot on the costa beyond the middle); on the dise, beyond the middle, is a faint indication of a dark spot; cilia dark brown. Posterior wings greyish-fuscous, with a slight purplish gloss, with paler cilia.

Abundint in hedges in May. 'The larva feed in cases, on fallen leaves during the autumn and vinter.

2. pectinea, Haw. I. B. 559 (1829).-pectinclla, Step. ; Curt.Zinckenii, Zell.; H.-S.-masculella, var. 7. g. S.; Treit.-masculella, IV. V.? Alis anticis nitidis fıscis, maculis duabus dorsi dilute al- 
bido-lnteis; copillis fuscessentibus: antemis of pectinatis. Jixp. al. 6 lin.

Ilead and fice dark ocheons-firsous (in the of almost entircly fuscous). Palpi pale grey. Antennax (of the of pectinutenl) dark fuscons. Anterior wings sthining, firsons, with ratlere a yellowish tint; on the inner mangin are two pale yellowisterlite spots, one nearly in the middle reaching to the fold, the other smaller, at the anal angle; on the dise, beyond the middle, is a faint indication of a dark spot; cilia fuscous. Posterior wings greyish-fuscous, with paler cilia.

Common among birelies, at the ent of April. 'Tlie larve feed in cuses on fallen leaves during the autumm ant winter; when young they mine (aecording to Veller) the leaves of the birch, in May and June, then deseend loy threads to the ground anomg the fallen leaves.

3. tenuicomis, n. sp. Alis anticis unicoloribus, fuscis; alis ponticis dilute grisco-fuscis; capillis luteis; antennis tonibus. Exp. al. $7 \frac{1}{9}$ lin.

Jeul and face prete yellowish. Antemne slenter, datk fuscous. Antrrior wiugs nuicolorous fuscons, with paler cilia. l'osterior wings pale greyish-fuscous, with paler cilia.

'T'wo specimens; one in Mr. Shepherel's and one in Mr. Tompkins's collection.

1. Oehlmanniella, Müb. T'in. 1S1. (1801); Treit.; Step.; Curt.; 1)up..; Zell.; Lienig; II.-s.-Ochlunnni, Haw. Alis anticis nitidis siturate fuscis, maculis duabus dorsi macnluque minore costec apjecen versus dilute luteis; antennis on non pectiuatis. Lxp. al. 6 lin.

Ilead and face ochreous. Palpi whitish. Antemuat simple in both sexes, fuscous. Anterior wings dark ghlosy fuscons, with two pale rellowish spots on the inner marerin, one belore the midclle, the other at the anal angle; posterior to the latter, is a smaller spot on the costa. In the of this spot is condluent with one inumediately preceding it, and thewefore of Jarger size; cilia clark fuscous. P'ostcrior wings pale grey, with a slight purplish tint, with paler cilia.

Not scaree; occurring in woods in lune. The larra feed in flat cases under the fallen leaves during the winter.

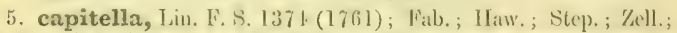
II.-S. Ilis anticis saturate fuscis, ferscine oblique costant corsus aflemeale (interdum costan non tungenle) ante medium, maculisgue oppositis pone medium, dilute luteis. Exp. al. $7 \frac{1}{3}$ lin.

Ilead and face ochreous. Palpi pale grey. Antenna fuscous. An-. tcrior wings dark fuscous, with a slight purple gloss; before tlic

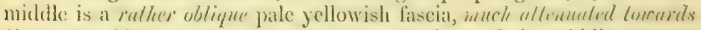

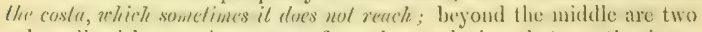
pale yellowish opposite spots, of nearly cqual size, that on the immer margin somewhat triangular, that on the costa more rounded and

YOL. III. 
slightly posterior; cilia dark purplish-fuscous, the tips at the apex whitish. P'ostcrior wings pale grey, with a shight purplish tinge; cilia pale grey.

Common among currant-bushes at the end of May. 'The larva is very injurions, cating the pith of the young shoots, and betrays its presence by the withering of the young leaves; when quite young it is dark red, but when full-fed it is greenish-white.

\section{Genus XI. IMCROPTERYX.}

Microptenyx, Zell. Isis, 1839. p. 185; Dup. Cat.-Microplerix, Muib. - linincrphala, Curt.-Tinea p., Haw.-Adela p., Treit.; I)up. I. li. xi.; Zett._Lampronia p., Step.

Caput superne hirsutum, orlitis supcrioribus late nudis. Ocelli dis/ineti, ab oculis distantes. Palpi maxillares 6-articulati, plicati. Palypi labiales breves, cylindrici, pilosi. Antenna alis anterioribus breviores. Haustellum breve. $\Lambda$ la anteriores oblongo-ovatic; vena subcostalis ramos 4 in costam cmittit. Posteriores ovate, piloso-squamata, ciliis mediocribus.

Ilead above elothed with long hairs, a broad space atone each eye naked. Ocelli distinct, rather remoto from the eyes. Maxillary palpi six-jointed, folded. Isabial palpi short, eylindrical, hairy. Autemue shorter than the anterior wings (in some of the species much shorter). Tongue short. Anterior wings oblong-ovate, glossy and rather transparent. P'osterior wings ovate, rather transparent, clothed with long hair-formed scales, with moderate cilia.

The perfect insects fly in the sunshine; the smaller species among flowers in June; the larger species among birches, etc., in $\Lambda$ pril and May. None of them appear to be double-brooded. The larva are still cutirely unlmown to us: this is the more unfortunate, as some of the sjecies are so very similar in markings and habits, that till we ascertain their transformations we camot fecl confident of their distinctness.

The British species may be arranged in the following table:a. Small species.

b. Head ferruginous.

c. Anterior wings unicolorous in both sexes. Species 1.

$c$ c. Anterior wings of the $\delta$ with silvery fascix. Species 2, 3.

b b. Head black. Species 4.

a a. Species of intermediate size. Inead ferruginous. Species 5, 6. a a $a$. Species of larger size.

d. Head dark fuscous. Spccies 7, 10.

$d d$. Head cincreous. Species 8, 9, 11, 12.

1. Calthella, Lin. F. S. 1432 (1761); Pab.; W. V.; Schr.; Iaw.; 
Treit.; Step.; Dup.; Curt. B. E. fo. 751; Zell.; Sta.-sulcatellu, I3ent. $\Lambda$ lis anticis viridi-aureis, paullulum purpurco-tinctis, basi usque ad dorsum purpurea; capillis ferrugincis. Exp. al. ot $3 \frac{1}{2} ; q 4$ lin.

llead and face ferruginous. Antemae dark fuscous. Anterior wings grecnish-grolden, slightly tinted with purple, with the entire base (from the costa to the inner margin) purple; cilia golden-grey. Posterior wings pale grey, towards the apex purplish, with greyish cilia.

Abundant in May and June, on the flowers of the Callha yalustris, and other Ranunculacece; also frequenting Carices.

2. Aruncella, Scop. F. C. 254. 660 (1763); Zell.; Sta.-concinnella, Step.? Alis anticis aurco-brumneis, basi costre purpurea ( $\delta$ puncto disci basim versus fasciaque tenui recla in medio argenteis); capillis ferrugineis. Exp. al. $3 \frac{1}{2}$ lin.

Ilead and face ferruginous. Antenna dark fuscous. Anterior wings golden-brown, with the costa at the base purple (in the male with a small silvery spot on the dise, not far from the base, and a straight, slender, silvery fascia in the middle); cilia golden-grey. l'osterior wings grey, towards the apex purplish, with greyish cilia.

Not common; appears in June.

3. Seppella, Fab. G. I. 296 (1776); Haw.; Step.; Sta.-I'odevinella, Iup.; IIüb.? 'Treit.?-eximiella, \%cll.-q Calthella, Bent. Alis anticis viridi-aurcis, basi cosice purpurea, (o macula transversa antc medium, firscia subobliqun in medio, punctoque costan versus pone mediun argenteis); capillis ferrugineis. Exp. al. $\delta 3$; 93 lin.

Head and face ferruginous. Antema dark fuscous. Anterior wings greenish-grolden, with the costa at the bese purple (in the male a little before the middle is a transverse silvery spot, not renching either margin, and in the middle is a rather oblique silvery fascia, beyond the widdle is a swall silvery spot near the costa) ; cilia golden-grey. Posterior wings pale grey, towards the apex purplish, with pale grey cilia.

C'ommon in Jume among various flowers; particularly partial to the Veronica Chamadrys.

4. I Iansuetella, /ell. Schles. Schm. tausch-ber. 181\%, p. 16; Sta. Nis anticis dilute viridi-aureis, basi, fascia ante medium, apiecque obsolcte purpureis; capillis atris. Exp. al. 4 lin.

IIead aud face deep bluish-black. Autemua black. Anterior wings pale grolden-green, with the base, a fascia before the midelle, and the entire apical portion of the wing, indistinetly purplish; cilia grey. Posterior wings greyish-purple, with grcyish cilia.

Frequents woods in May and June; among Merentialis percmis and other flowers.

5. Allionella, Fab. E. S. iii. 2. 321. 148 (1794); Zell.; Stu.-

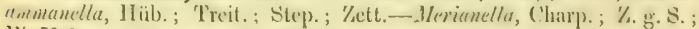
IV. V.?-var.? ammunellu, 1hup. Alis auticis purpureis, lisseia fere 
recta prope basim, fascia obligua in merlio naculague pone mectium juxta costam dilute atureis; eapillis formurincis. Exp. al. t.' lin.

llend and face forragimons. Palpi pale grey. Antemue black. Anterior wings purple, with a pale golden almost straight fascia not far from the base, a mather oblique pale golden fasciat in the midele and towards the apex, a pale golden spot inmediately below the costa; cilia greyish-purple. Posterior wings pale greyish-purple; cilia greyish.

()ecurs in woods in May and dume. Not common in the south of England; more frequent in the midland connties and the Nortls. 'Taken abumelantly among oaks and honeysuckle, near Birmingham, by the Rev. Mr. Simkiss.

6. Tunbergella, Fab. Man. ii. 253. 131 (1787).-Thmbergrlla, (imel.; Vill.; liab. L. S. P-mbrifasciclla, IIaw.; Sta.; Yidl.-Inderschella, Treit.; Dup.; Lienig.-Ilellneigella, Step. Alis anticis dilule viriti-aureis, macula costali, faseia abbreviata obliqua ante meclimm, fiscia arl costam furcata pone medium, maculacue apieen versus rufescentibus; capillis ferrugincis. Wxp. al. the lin.

Head and face fermoginous. Antemue dark fuscous. Anterior wings shining, pale golden-grecn, with redelish makings, vi\% a spot on the costa near the base, an oblipue fascia before the michlle, not reaching to the inner margin, a faschi beyond the mithlle, fureate on the costa, and frecunently comected with is spot towards the apex of the wing; cilia purplisti-fuscous. P'osterior wings pale grey, with a purplish tint towards the apex; cilia pale grey.

Not scaree, among beeches, in May.

7. puxpurella, Haw. L. 13. 571 (Lא2?); Stcp.; Sta.; Zoll.mbro-aurella, IIaw,? Step.?-cicatricella, Zett.? Alis anticis dilute aturis purpuren-reticulatis, renisyus purpureis, macula pone medinn dorsi dilute aurea; copillis suturute fuscis; autemuis distidio alarum anticarum brevioribus. Exp. al. 5 lin.

IIead and face dark, fuscous. Antenna not lalf the lenglh of the anterior wings, dark liscous. Anterior wings pale colden, with a slight erecenish tinger, much reticulated with purple, and with ller evins also purple, a pale spot of the ground-colone apyears beyond the midalde of the inuser margin; cilia grey. Posterior wings aney, slightly purplish towards the apex; cilia grey.

('ommon in April among birehes, preforring calm, sumy afternoons; it is especially abundant at Darenth Wood.

S. Salopiella, n. sp. Mis anticis latiusmlis dilute aureis, pur-

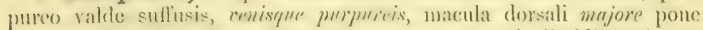
medium dilute aureas; cropillis lulen-rineress; antenuis dimidium alamm anticarum xquantibus. Exp. al. $4 \frac{2}{2}-5$ liu.

Ilend and faces yollowish-yjey. Antenuar dark fuseress, about half the lingth of the interior wings. Anterior wings rather short and hroad, pale golden, much sulfused with purple, the reins atso purple, beyond 


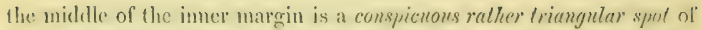
the pale around-colour, which reachess fully half aeross the wing; on the (osta, a litte beyond it, is a small less dislinet pale spot, amd there are lisint indications of a pale spot on the fold before the midclle; cilia purplish-fuscous, opposite the pale spot of the imer margin pale golden. Posterior wiog pale grey, towards the anex purplish, with paler cilia.

'Taken frech, along with the preceding, by Mr. Silt, near Shrewsbury, in $A$ pril, 1853, in a wet place among birches.

9. semiparpurella, Step. H. iv. 359 (1\$35); Sta.; \%ell.? T. F. v.

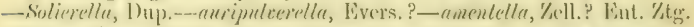
18.50. Alis antieis purpurcis, dilute aureo-irtorat is, macula transversa pone medium dorsi, dilute: aurca; cafrillis cincro-fuscis; antemis dimidio alarum anticarum longioribus. Exp. al. 5\%-6 lin.

Head and face greyish-fuscous. Antenne dark fuscous, more than half the length of the anterior wings. Anterior wings purple, irrorated with pale: erolden, and with a lange pale golden spot beyond the middle of the imer margin, reaching lialf across the wing; cilia grey. Postorior wings grey, with a slight purplish tinge towats the apex; cilia grey, paler towards the anal angle.

C'ommon anomer birches in Aprit. (In Continental specimens of 1\%. amentellu I lave before we, the anterior wings appear shorter and more rounded than in $\lambda$. semipurpurella.)

10. unimactlella, \%.t. I. L. l00s (1510); sla.-purpumlle,

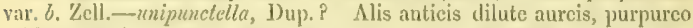
valde sufiusis, macula transversa temi, pone medium dorsi, plicam

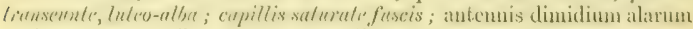
anticarum sequantibus, Exp, al. 5 lin.

IIead and fice dark fuscous, mixed with grey. Antcmno dark fuscous, about hatf the length of the anterior wings. Anterior wings pale grolden-green, alnost cutirely sullused with purple, leaving howerer a

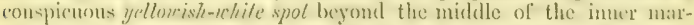

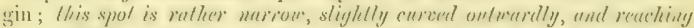
ulont hulf across the teing; cilia grey. l'osterior wings pale grey, with a purplish tinge towards the apex; cilia greyish.

Oecurs among birches in $\Lambda$ pril. Not uncommon at West IVickham Wood; hut does not sem to occur at I)irenth Wood, where $\mathbb{M}$. purpurella is so plentiful.

11. Sparmannella, Bosc. Lin. T'rans, i. 197. pl. 17. f. 6, 7 (1791); lab.; Dup.; '/ell.; Sta.-auropurpurella, Hav.; Step. Alis

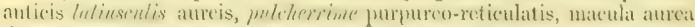
dorsi pone medium; capillis cincreis. Exp. al. $4 \frac{1}{3}$ lin.

Hend and lase greyixhe, slimbly mived with dark liseons. Antenue dark fuscous, not half as long as the anterior wings. Anterior wings golden, delicately reticulated will purple, with a spot on the inner

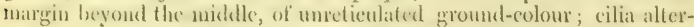


natcly yellowish-grey and fuscous. Postcrior wings pale greyish-purple; cilia pale yellowish.

Less common than the allied species; oceurs anong birches in April and May.

12. subpurpurella, IIaw. I. B. 571 (1829); Step.; Sta.; Zell.Donzelella, 1)up.?-var.? fastuosella, Zell.; Sta. Alis anticis dilute virili-aureis, macula obsoleta dilutiore pone medium dorsi, squanis sparsis disci purpureis; capillis cinereis. Exp. al. 6 lin.

ILead and face palc greyish-fuscous. Antenna fuscous, more than half the length of the anterior wings. Anterior wings pale rrokdengreen, with a faint appearance of a palcr spot on the inner marein beyond the middle, and between this and the apex of the wing, is a still more indistinet pale spot; on the dise are a few isolated purple seales (in some specimens these are much more numerous, these then become M. festuosella); cilia greyish-fuscous. Posterior wings pale grey, with the apex purplish; cilia greyish.

Common among oaks in May. I have taken many of the varicty fastrosella, on a paling under coks, near Beckenham.

\section{Genus XII. NEMOPFORA.}

Nemoriora, Hüb. V. 417 (1816); Dup. Cat.; Zell. L. E. v, $N e$ matopogon, Zell. Isis, 1839. Alucila p., Fab. Capillaria p., Haw. Adela p., 'Treit.; Curt. ; Step.; Dup., L. F. xi. ; Kett.

Giput superne hirsutun, capillis in fronte decumbentibus. Ocelli nulli. Antenne longissine, articulo basali incrassato. Palpi maxillares 5-articulati, plicati. l'alpi labiales breves, eylindrici, pilosi. Ilaustellum mediocre. Alie anteriores elongaton-ovates; venat subcostalis ramos tres in costam emittit, guorum tertius furcatus est. Posteriores ovata, basim versus piloso-siguamata, ciliis mediocribus. Ilead above hairy; hairs in frout decumbent. Ocelli none. Antemese very long, more than twice the length of the anterior wings; the basal joint thickened. Maxillary palpi five-jointed, folded. Iabial pal) pi short, cylindrical, hairy. Tongue of moderate lenegth. Anterior winges elongate-ovate. l'ostexior wings ovate, towards the base with clongate hair-like seales, with moderate cilia. (N. pilella has all the seales of the posterior wings of the elongate hair-like form, and $N$. Curleri has none of this form, and is further singular in the shape of the posterior wings, the apical vein of which is furcate.) The subeostal vein of the anterior wings enits three branches towards the costa, of which the third is furcate.

These innects frequent hedges aud wooks ; they fly in the dusk of evening, but are readily started from their retreats during the 
day. The larva of none of them are yet known. The British species are all very similar, with pale ochreous-grey anterior wings.

1. Swammerdammella, Lin. S. N. (10) 5 1.0. 284 (1758); Tab.; IV. V.; Hüb.; Schr.; Treit.; Step.; Dup.; Zell.; Sta.-Sroammerdami, IIaw. Alis anticis micoloribus seriecis, dilute ochreis, obsoletissime obscuriore-reticulatis, ciliis dilute ochrcis, externe fuscis; alis posticis dilute griscis, ciliis dilute ochreis. Exp. al. 10 lin.

Ilead dark ochreous. Face and palpi pale greyish-ochrcous. Antemnx whitish-ochreous. Anterior wings unicolorons, shining, pale ochreous, with very obsolete darker reticulations; cilia pale ochreous, the tips somewhat fuscous. Postcrior wings pale grey, with pale ocherous cilia.

Common in woods, from the end of May to the middle of June.

2. Schwarziella, Zell. Isis, 1839. p. 185; Sta.; II.-S.-var. sericinella, Sta. (non Zell.)-liobertella, Lin.?-I'anzeri, IIaw.?-pilea, Ilaw.?-Panzerella, Step.?; Dup.? Alis anticis elongalis scriccis dilute ochreis, obsolete obscuriore-reticulatis, eiliis dilute ochreis; alis posticis dilutis griseis, ciliis dilute griseis. Exp. al. $8 \mathrm{lin}$.

Mead dark ochrcous. Face and palpi pale ochreous-grey. Antenne whitish. Anterior wings ralher elongale, with the apex somewhat. pointed, shining, palc oclurcous, obscurcly reticulated with darker, amd a faint fuscous spot at the termination of the discoidal cell; cilia pale ochreous. P'osterior wings pale grey, with pale grey cilia, towarls the anal angle rather inclining to ochreous.

Commoner than the preceding; frequent in hedges in May and June.

3. Carteri, n. sp. $\Lambda$ lis anticis clongatis scriceis ochreis, posticc vix olscuriore-reticulatis, ciliis dilute ochreis, externe fuscis; alis posticis apice acuto, saturate griseis, ciliis inteme griseis, externe dilute ochreis. Exp. al. 9 lin.

Ilead dlark ochreons. Face and palpi whitish. Antemme white. Anterior wings rather long, with the apex somewhat pointed, shining oclurcous, posteriorly with hardly perceptible darker articulations; cilia pale ochrcous, the tips somewhat fuscous. Postcrior wings with the apex rather pointed, dark grey; cilia at first grey, then pale ochreous.

$\Lambda$ single specimen, in the collection of MLr. Carter, of Manclicster.

4. pilella, W. V. 142. 6 (1776); Tab.; IIüb.; Trcit.; Zell.; II.-S.; Sta.; Dup.?; Y/sett.? Alis anticis brevizsentis sericeis dilule fuscis, obseuriore-reticulatis, ciliis grisco-fuscis; alis posticis grisco-fuscis, ciliis saturate griseis. Exp. al. 8 lin.

Ilead dark ochreous. Face and palpi whitish. Antenux whitish. 
Anterior wings rolher shorl, with the apes slightly rounded, shining, pale feseross, with darker retienlations; cilia greyish-fuscous. l'osterior' wings greyish-fuscous, with a slight violet gloss, with dal grey cillin.

Not common; appears in June. Mr. Weaver las met with it in Scotland.

5. Tretarella, IIïb. Tin. 413 (1S16); 'I'rit.; Dıр.; \%cll.; Sta. - Loberlellu, Step.? Alis anticis brevinsculis, apice rolumdalo, scriceis dilute ocheris obsolete fusecserule-reticulatis, ciliis dilute ochreis, ex-

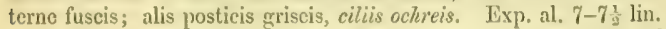

IIead dark oclucous. Face and palpi whitish. Antenna white.

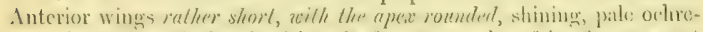
ous, obserurely reliculated with pale fuscous, and a liniut fuscous spont at the termination of the discoidal cell; cilia pale ochreous, with the tips somewhat fuscous. Posterior wings grey, with ochreous cilia.

Not uncommon in chalky places, in May and June.

\section{Genus XIII. ADELA.}

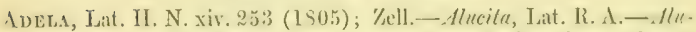
cita p., Fab.-Capillaria p., IIaw.-Adela p., 'Treit.; Curt.; Step.; Dup.; 'Lett.

('iput superne hirsutum, rpistomio plerumgyue leveigato. Oeelli mulli. Palpi maxillares mulli. P'alpi labiales cylindrici, inlra lirsuti. Ilanstellum mediocre. Oculi in utroqne sext valde distantes. Antemna corpore mullo longiores, basim versus incrassata, f lreviores basi villosil. Mlic anteriores oblongar, venis gunque in marginem posticum excuntibus; alie posteriores oblongo-ovale, nediocriter ciliatac.

IIcad above hairy; the face mostly swoolh. Ocelli nome. Maxillary palpi none. Tabial palpie eylindric, bencath hairy. Tongue ol modevate length. Lijes rentere in bolle seares. Antemie much longer than the body, slightly thickened towards the base; in the of shorter and at the base downy. Anterior wings ollone. P'osterior wings oblongovate, with moderate cilia. From the discoidal cell of the anterior wings, five veins run into the hinder margin.

The perfect insects of this gemus frepuent flowers and trees, and rleight to fly in the sunshine. A. viritelle flies in swarms like guats round the twigs of oaks. At. fibuldla often abounds on the

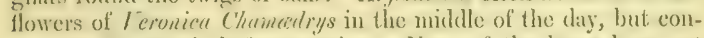
eents itself sceurely betore evening. Nome of the larrat have yet been delected, excepling that of $A$. Degerelle (liggured by ['ischere von kïslerstamn), which lives in a fhat case, moler fallen leares in the winter, and feeds in the early spring on fluemone acmorosa, Tiumex, and Alsine media. 
This genus certainly requires subdivision, harlly two species showing an entire accordance; the Britisl species may be arrangerl in the following table:-

a. Antemne not much longer than the body, in both sexes nearly of equal length. Face roughly haired nearly to the mouth. Species 1 . a a. Antenna considerably longer than the body, in the of generally shorter than the $\sigma^{\pi}$. Face, at least bencatli, elothed with smooth senles.

8. IIead densely haired. Antenne of the $q$ nearly as long as in the $\delta$; only the lower part of the face smooth. Species 2 .

b b. Head thinly haired. Antemme of the of very long, of the $q$ much shorter. liace quite smooth. Species 3, 4.

" a $a$. Antenne long, in the $q$ shorter. Face and legs of the $\delta$ very hairy.

c. Tongue and basal joint of the antenne of the of very hairy. The basal half of the anteune of the $q$ much thickened; fice of the $q$ smooth. Species 5 .

c c. Tongue and basal joint of the anteme in the $\delta$ not hairy. The basal half of the anteme of the $q$ not thickened; face of the o hairy. Species 6.

Several other species are known on the continent.

1. Fibulella, W. V. 143. 33 (1776); Dup.; II.-S.; Zell.; Fab.? - Frischii, Haw. - Latreillella, Step).? Alis anticis cuprco-fuscis, macula dorsi pone medium transversa dilute lutea. Exp. al. 4.13 lin.

IIead, face, and palpi black. Antenna black, the last fourth white. Anterior wings coppery-fuscous, with a pale yellowish spot near the base, not touching either margin (sometimes wanting), and on the inner margin beyoud the middle a transverse pale yellowish spot, frequently reaching more than half across the wing; cilia coppery-fuscous. Postcrior wings dark violet-fuscous, with paler cilia.

Abundant in May and Junc on the llowers of Feronica Chamadiys.

2. rufimitrella, Scop. T. C. 251. 649 (1763); 7ell. L. E. viii. -Trischella, ITüb.; Treit.; Dup.; Z/cll. Isis, 1839.-lieammurella, Step.? Alis anticis saturate viridi-iencis, costan versus paullulum cu-

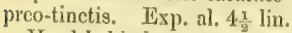

Ifead behind greyish-ochreous; in front and the ficc dark fuscous, inclining to black. Antemme purplish-black. Anterior wings dark bronzy-ercen, towards the costa rather coppery; cilia bronzy-erey. Posterior wings wings ditrk violet-fuscous, with dark grey cilia.

Common in May, in mealows, on the flowers of Cardamine pratensis.

3. Sulzella, IV. V. 1 13. 2٪ (1776); Irüb.; Treit.; Step.; Dup. $\rightarrow$ Sultzii, II Itw:-Sulzerielln, H.-S.; Yell.-Podaella, Don.; Lim.? Alis anticis luteis, saturate violaceo-fusco striatis, fascia paullulum pone

VOI. III. 
medium lutca (ad dorsum latiore) saturate violaceo marginata. Exp. al. (sex) 6 lin.

IIcad dark greyish-ochreous. Tace silvery-grey. Antenne towards the base black, then white (in the of the basal half is much thickened with violet-fuscous seales). Anterion wings yellow, with the base and numerous longitudinal streaks to the middle dark violet-fuscous; $"$ lille beyond the middle is a slightly curverd yellow fascia, broalest on the inner margin, bordered on each side by dark violet fascie; the apical portion of the wing is yellow, with the veins and all the margins dark violet-fuscous; cilia dark violet-fuscous. Posterior wings dark purplish-fuscous, with paler cilia. Junc.

On chalky soils in the south of Ingland; not uncommon in

4. Degeerella, Linn. T. S. 1393 (1761); Fab.; Lat.; Treit.;

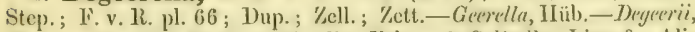
IIaw.-Croescllu, Scop.-striatella, liab.- o Sultzella, Iim.? Alis anticis ochreo-fuscis, obscure lutco-striatis, fascia postica lutea saturate violacco-fusco marginata. Lxp. al. (novem) 9 lin.

Ilead dark yellow. Face silvery-violet. Antenne towards the bise violet-fuscons, then white (in the of the basal half is much thickened and violet-black). Anterior wings violet-fuscons, streaked with dingyyellow, with a nearly strainht bright yellow fascia, decidedly beyond the midclle, slightly expanded on the inner margin, and bordered on each side with dark violet-fuscous; the apical portion of the wing is entirely violet-fuscous, except the space between the veins, which is frequently dark yellow; cilia dark violet-fuscons. l'osterior wings dark violetfuscous, with dark grey cilia.

$\Lambda$ common species in June in woods in the south of Fingland; also at Keswick; grenerally flies in sinall companies of half-adozen (male) individuals. The larva feeds in flat cases moder fallen leaves on the wood anemone, and other low-growing plants, in the spring.

5. viridella, Scop. F. C. 250.645 (1763); W. V.; Treit.; Step.; Zcll.; II.-S.-viridis, IIaw.-vindella, Fab.-Sphingiella, IIiib.-Reranmurclla, 1)up.; Clerek? Alis anticis nilidis viridi-concis, costa pone medium cupreo-tincta. Lixp. al. $7 \frac{\pi}{2}$ lin.

Head, fice, and palpi black. Antenne white, towards the basc spotted with black (in the o the head is dark grey, and the slightly thickened anteme violet-black at the base). Anterior wings bright bronzy-yreen, with a slight coppery tinge along the costa beyoud the midclle; cilia bronzy-fuscous. l'osterior wings dark violet-fuscous, with dark grey cilia.

Mbumlant in most oak-woods; the males flying in little swarms of about twenty individuals round the ends of the oak-boughts ; at the end of May and beginuing of June. 
6. cuprella, Fab.; Trcit.; Dup.; Zell.; Sta.; II.-S.; IV.V.? Iiib.? Step.?- $\delta$ aneella, Zett.-q crinitella, Zett.-Reaumurella, Iimu. $\Lambda$ lis anticis viridi-rencis, cupreo-violaceo-tinctis, precipuc costam et marginem posticum versus. Exp. al. $7 \frac{1}{2}$ lin.

IIead, face, and palpi black (in the of forruginous). Antenne white, towards the base spotted with black. Antrpior wings bronzy-green, will a coppery-violet tint, especially towards the costa and linder margin ; cilia bronzy-fuscous. Postcrior wings dark purplish-fuscous, with slightly paler cilia.

$\Lambda$ ppears at the end of $\Lambda$ pril, frequenting the sallows while in bloom; occurs on Wimbledon Common.

\section{Genus XIV. NEIMOTOIS.}

Nerorors, Zell.; Dup. Cat. Alucita p., lab. Capillaria p., Haw. Adela p., Treit.; Curt.; Step.; Dup. L. I.; Zett. Epilyphia et Nemotois p., Ilüb.

Caput superne hirsutum, epistomio lavigato. Ocelli nulli. Palpi maxillares nulli. Palpi labiales cylindrici, infra hirsuti, of breviores. ITaustellum medioere. Oculi ơ magni, approximati; of minores, valde distantes. Antemac corpore multo longiores, basin versus incrassatac, ac plerumǫuc barbate; $q$ breviores. Alx anteriores oblongæx; venis quinque in marginem posticum excuntibus. Nla posteriores oblongo-ovatic mediocriter ciliate.

Ilcad above hairy; the face smooth. Ocelli nonc. Maxillary palpi none. Labial palpi cylindric, beneath hairy (in some species extrencly so), in the $q$ shorter. Tongue of moderate length. Eyes of the of large and approxinating, of the $q$ smaller and remote. Antennie very considerably langer than the borly, thickened towards the base, and not unfrequently with projecting seales; in the o shorter. Anterior wings oblong. l'ostcrior wings oblong-ovate, with moderate cilia. From the discoidal cell of the anterior wings, five veins run into the hinder margin.

The perfect insects of this genus are mostly splendid beyond description; they frequent flowers in the sunshine. Of the habits and food of the larva nothing is known; the acuminate, elongate abdomen of the $q$ of $N$. Sctubiosellus would imply that the egregs were deposited in some substance, and Zeller has observed them boring into the flowers of Sealiosa arvensis (as though with in view of depositiug their eggs there).

The genus is susceptible of subdivision, from the structure of the abdomen of the $q$. The British species may be easily distinguished as follows:-

a. Abdomen of the o very narrow; the terminal half nearly bare. Anterior wings with no dark fascia; yellowish-lronze. Sprecics 1. 
a a. Abdomen of the $q$ rather narrow, with the ovipositor bare. Anterior wings with a shadowy dark fascia.

b. Antenna of the $q$, towards the base, thickened. Species 2.

$b$ b. Antenna of the $q$, towards the base, not thickened. Sp. 3, 4 .

1. Scabiosellus, Scop. T. C. 250.64 (1763); Trcit.; 1)up.; Zett.; II.-S. ; Zell.-cupret, IIaw,-Frischella, Curt. 13. L. fo. 163 ; Step. Alis anticis flavido-enris, costam versus saturatioribus, apjecm versus flavido-suftusis. Exp. al. 9 lin.

Ilead ferruginous. Face silvery-errey. Palpi oclircous-fuscous. Antemes at the base violet-black and rather thickened; the last two-thirds white. Anterior wings yellowish-bronze, along the costa rather danker, towards the apex more yellowish; cilia bronyy-fuscous. Posterior wings dark purplish-fuscous, with cilia of the samc colour.

Not uncommon (but rather local) in June, frequenting the flowers of Scaliosa arvensis and Columbaria.

2. cupriacellus, Hïib. Tin. 415 (1822); \%ell.-cypriacella, Dıр.; II.-S; Treit.? \& Alis anticis antice viridi-aureis, postice nitide cupreis, fascia media saturatiore obsolcta; antemis dimidio basali incrassatis. Exp. al. 7 lin.

Female. Head fertuginous. Face brilliant metallic. Palpi pale ferruginous, mixed with fuscous. Antenna towards the base rither thickened, bluish-black, with the last third white. Anterior wings golden-green nearly to the middle, there brilliant coppery, with only a faint indication of a darker fascia ; cilia coppery-fuscous. Postcrior wings purplish-fuscous; cilia the same colour.

I am unacquanted with the male of this species. Mr. Douglas took several fine specimens (all females) at Sanderstead in June.

3. fasciellus, Fab. S. L. 670. 18 (1775); Stcp.-fuscir, IIaw.Schiffermüllerella, W. V.; Ilüb.; Treit.; 1)ıp.; II.-S.-Schiffermillerellus, Zell. L. E. viii. Alis anticis nitide cupreis ijosa basi viridiaurea, linca brevissima basali costam rersus nigra, fascia salurate violacer paullulum pone merlium; alis posticis griseo-fuscis; $q$ alis posticis saturate violacco-fuscis, antennis non incrassalis. Exp. al. 7 lin.

Male. Head, face and palpi black. Nutemue white; the basal and several of the suceceding joints black. Anterior wings brilliant coppery, at the extreme base grecuish-rgolden, with a very stort black streak at the base near the costa; a little beyond the middle is a roell-defined, darli violet fascia, rather expanded towards the costa; cilia coppery. l'osterior wings greyish-fuseous, with paler cilia. Female. ITead ferruginous. Fice brilliant metallic. l'alpi greyish-ochreous. Antcnue not thickened, black, with the last third white. P'osterior wings dark violet-fuscous, with similarly coloured cilia.

Apparently scarcer than formerly; I know of no recent specimens. Frequents flowers in Jume and July. 
4. minimellus (Mann), Sta. Cat. p. 10 (1819); \%cll. L. E. viii. 76 ; II.-S.?-var. $\sigma^{7}$ ? Dumerilella, Sta. o $\Lambda$ tis anticis viridi-aurcis posticc cupreis, lineu basuli costan versus nigra, fascia nebulosc saturatc violace pone nedium; alis posticis violaeco-griseis (interdum albidogriseis, apice violaceo-griseo); $q$ alis anticis saturatioribus; alis posticis saturate violaceo-griscis; antenuis non incrassatis. Lixp. al. $5 y$ lin.

Male. Head, face, and palpi black. Antenne white; the basal joint and several of the succeding joints black. Anterior wings greenish-golden, towards the apex coppory, with a bluck streak at the base near the costa, and beyond the middle an olscure decp violet fascia, outwardly concave and rather expanded on the costa; cilia eopperygolelen. P'Psterior wings greyish-violet; cilia pale grey. (In some specimens the posterior wings are whitish, with only the apex violet-rirey). remale. Ilead ferruginous. Antema not lhickened. Anterior wings. darker than in the males. P'osterior wings dark violet-grey, with the cilia a little paler.

()ccurs in moist places in July, anong Scabiosa succisa, in Scotlame; also in the hilly field, near Mickleham. (The specimens with dark underwings agrec preciscly with the continental species; and those with light underwings I am quite unable to distinguish specifically; all have the chancteristic black streak at the base well-defined. The discovery of the larve will throw light on this, at present, "vexata quicstio.")

\section{FAMIIY III, HYPONOMEUTID出, Sta.}

Palpi labiales mediocres. Palpi maxillares desunt. Caput lamatum vel levigatum. Ocelli unlli. Haustellum mediocre, rarius squamatum. Ala anteriores elongatec, ciliis mediocribus. Larva sape gregaria.

Labial palpi of moderate length. Maxillary palpi wanting. IIcad rough or smooth. Ocelli none. Tongue of moderate length, mostly naked. Anterior wings elongate, with moderate or rather short cilia. Larva frequently gregarious, living in a common tent.

Although the species composing this family appear to have considerable affinities with each otlıer, it scems impossible to bring them under any general definition.

The two first genera have been placed with Tinea, but are in many respects very discordant there; morcover a conneting link between Seyltropice and IIyponomenta is furnished by the continental species IIyponomenta mefimitrellus, '/ell., which, though in other respects a true 1 yponomeuta, has a rough head; the larva 
of Seythropia being gregarious, furnishes another point of resemblance with Hyponomenta.

The six genera of this family may be easily distinguished, as follows :-

a. Hend rough.

b. Palpi porrected. 1. Swammerdama.

b b. Palpi drooping. 2. Scrtirropia.

a a. Head smooth.

c. Palpi reflexed.

$d$. Terminal joint blunt.

e. Posterior wings with a hyaline patel at the base. 3. IYYoNOMEUTA.

$e e$. Posterior wings with no hyaline patch at the base. 6 . Prays.

$d d$. Terminal joint pointed. 4. ANesycura. c c. 1'alpi porrected, short. 5. Cualybe.

\section{Genus I. SWAMMERDÅMIA.}

Frminea p., Maw. Lita p., Treit. Telea p., Step. Tinea p., Dup.; Zell. ITomplia p., Tebenna p., et Sroammerdamia p., Hüb.

Capilli lirsuti. Ocelli nulli. Palpi labiales porrecti, breves, filiformes, subattenuati. Haustellum breve, nudum. Ale anteriores clongatie, mediocriter ciliate. $\Lambda$ le posteriores clongato-ovatex, foveola hyalina basali. Nlec anteriores: vena apicalis simplex ante apicem exit, infra cam tantum rami qrinque; stigma distinctum; vena subdorsalis simplex; submediana a mediana distat, in fine incrassata; posteriores: cellula costalis subito coarctata, ante medium desinente; vena mediana bifida; cellula discoidalis obtusa.

Itead rough. Ocelli none. Labial palpi porrected, short, filiform, rather attenuated. Tongue short, naked. $\Lambda$ nterior wings clongate, with moderate cilia. Posterior wings clongate-oval, wilh a liyaline palch at the base. In the anterior wings a simple apical rein runs into the costa before the apex, below it are only five veins to the hincler margin; the stigma is distinct; the subdorsal vein simple; the submedian vein remote from the median vcin is posteriorly thickened. In the posterior wings the costal cell is suddenly narrowed, and terminates before the middle of the wing; the median vein is bifid, and the discoidal cell obtuse.

The perfect insects of this genus have a pleasant wavy zigzag flight, and frequently disport themselves during the hot sunshine. When they repose, it is with the abdomen considerably elevated, so that they appear to stand somewhat on their heads; this position, their greyish-white colour, and their cylindric form when the wings are closed, cause them to be easily mistaken for the faces 
of small birds. S. apicella and S. Pyrella appear in the first burst of spring, and are indelibly associated in the mind of the collectors with those few warm days at the end of $\Lambda$ pril, "too bright to last." The other species do not appear till considerably later; probably all, with the exception of $S$. apicella, are doublebrooded. The larve of this genus are long and slender (especially anteriorly), with sixtecn fect, and reside singly in webs on the upper surface of the leaves of liawthom, apple, pear, birch, ctc. They are casily frightened from their place of abode, and readily descend to the ground by their silken threads; when fullferl they spin rather dense cocoons of very fine white silk. The five British species are all rather closely allied.

1. apicella, Don. 13. I. ii. pl. 57 (1792)._comptella, IJüb.; Stcp. ; 'Kell.; H.-S.-compla, Haw.-arerofinitelle, Dup. Alis anticis albidis grisco-ochreisve, squamis fuscis in sericbus longitudinalibus dispositis, macula costa ante apicem albida, apice ochreo interne fusco-marginato. Exp. al. 8 lin.

II cad and face white, with a few grcy hairs. Palpi dlark grey; terminal joint white. Anteme dark grey. Anterior wimes white or greyish-ochreous, with the extrene base dark ochreous; along the disc are several longitudinal rows of dark fuseous seales; a spot on the costa before the apex is whitish; the entire apex of the wing is bright oetereus, margined internally by some dark fuscous scales; cilia dark coppery-orey, at the anal angle pale grey. Yostcrior wings pale grey, with paler cilia.

'This insect appears at the end of $\Lambda$ pril and beriuning of May; not uncommon in mixed liedges in the south of England.

2. Casiella, IIüb. 172 ct 360 (180l et 1816); Licnig; H.-S. -Heroldella, Treit.; F. v. R. pl. 13; Dup,-lutarea var, $\gamma$, IIaw.lutarella, Step.? Alis anticis griscis, atomis fuscis in scrichus longitudinalibus dispositis, dorso albido, macula dorsali saturate fusea ante medium, plicam non transeunte, nebula saturate fusca paullulum posteriore, macula parva costa saturate fusca apieen versus, inter squamas albas posita; alis posticis dilute griseis; eapillis albi salbidisve. Exp. al. 6 lin.

Ileal and face vfile or whitish. Palpi dark grey, tip of the terminal joint whitc. Antemes with the basal joint white, remainder grey. Anterior wings grey, with a slight violet tint, with several longitudinal rows of fuscous atoms; the inner margin is whitish, interrupted before the middle by a diark fuscous spot, which does not cross the fold; rather beyond this, towards the costa, is an obscure dark spot; a small dark fuscous spot lies on the costa before the apex, and is precerled and followed by some whitish scales; below the latter are some black scales, forming a short streak, and at the extremity of the fold are a few dark 
fuscous scales; cilia coppery-grey. Posterior wings pale grey, with pale grcyish-fuscous cilia.

Cominon among mixed hedges in June (and I think again in August); the larva in S(ptenber is not uncommon, and appears polyphagous, unless we have several closely allied, yet-to-be-distinguished species; I lave found it on birch.

3. griseocapitella, Stat. Sup. Cat. p. 2 (185 l).-oxyacanthella, 11.-S.? Alis anticis salurale griseis, atomis saturate fuscis in seriebus obsoletis longitudinalibus dispositis, dorso anguste allbido, nebula transver'sa dorsi ante medium, macula parva albida coste ante apicem; alis posticis griseo-fuscis; mpillis saturate griseo-fuscis. 16xp. al. $5,-6$ lin.

Heal darli-greyish fuscous, Tace whitish. Patpi dark grey, tip of the terminal joint white. Antenua whitish, ammulated with fuscous. Anterior wings rather dark grey, with a slight violet gloss, with several rather indistinct longitudiual rows of dark fuscous atoms; the inner margin is narouly whitish, interrupted before the middle by a dark fuscous fasciaform blolch; on the costa before the apex is a small whitish spot; cilia dark coppery-grey. Posterior wings greyisk-fuscous, with paler cilia.

Abundant in June among birches, in Torwood, Stirlingslire; the larva (almost gregarious) on the birches in September.

4. Iutarea, Haw. L. 13. 515 (1829),-oxyacanthella, Sta.-comgunetellu, II.-S. Alis anticis griscis, atomis saturate fuscis in seriebus obsoletis longitudinalibus dispositis, nobula basali, altcra transver'sn ante medium, tertia ad apiecon saturate fuscis, macula obsoleta albida coste ante apicem; alis posticis griseis; capillis albidis. Lxp. al. 69 lin.

Ilead and fice yellowisk-2okils. Palpi dark grey ; tip of the terminal joint white. Antennæ dark fuscous. Anterior wings grey, with a slight violet tint, with dark fuscous atoms arranged ratlier indistinetly in rows longitudinally, and with some dark fuscous clouds, one at the base, one arising on the imer margin before the middle and frescieform, and another at the apex; on the costa before the apex is a faint white b) lotch, immediately bolow which are a fow black seales; cilia coppery grey, at the anal angle grey. Posterior wings grey, with paler cilia.

Not commonly met with, probably often confounded with $S$. Casiclla; appears in July and August.

5. Pyrella, Vill. T. I. ii. 515. 1020 (1789).-Cerasiclla, IIüb. ; 'Treit.; H. v. R. pl. 1.t; Dup.; 11.-S.-Cresin, Haw.-C'resiella, Step.? Alis anticis solurele rriscis, atomis fuscis olssoletissime in sericbus dispositis, macula transversa obliqua ante medium dorsi saturate fusen, macula parvia costac ante apicem albidal, apice cupreo-griseo; alis posticis dilute griscis, basin versus albidis; eapillis albidis. Exp. al. 5$5 \frac{1}{2} \operatorname{lin}$.

IIead and face whitish. Palpi dark grey; tip of the terminal joint 
whitish. Antenne dark fuscous. Anterior wings rather dark grey, with in slight violet tint, with very faint indications of longitudinal rows of fuscous atoms; before the middle of the whitish inner margin is a dark fuscous spot, which appears to be continued obliquely, nearly across the wing; a small whitish spot lics on the costa before the apex; apex of the soing and cilia coppery-grey. Posterior wings rather pale grey, toroards the base volilish, with pale greyish-fuscous cilia.

$\Lambda \mathrm{n}$ abundant species in hedges and gardens, appearing in $\Lambda$ pril and May, and again in August. The larva fecds on liawthom, apple, pear, etc., in July and September.

\section{Genus II. SCYTHROPIA.}

Scylliropia p., IIüb. Iponomenta p., Treit. Telea p., Step. Tinca p., Dup.; Zell.

Capilli hirsuti. Ocelli nulli. Haustellum brevissimum, nudum. Palpi labiales breves, filiformes, penduli. Alie anteriores clongata, mediocriter ciliate. Ala posteriores oblongo-ovatie, foveola hyalina mulla. Alie anteriores: vena apicalis simplex ante apicem cxit, infra can ranni $s e x$; vena subdorsalis furcata, sed furce ramus superior debilis ; posteriores : cellula costalis elongala, coaretata ; vena mediana trifida. Head rough. Ocelli none. Tongue very short, naked. Labial palpi short, filiform, drooping. Anterior wings clongate, with moderate eilia. Posterior wings oblong-ovate, not with a hyaline patch at the base. In the anterior wings the simplex apical vein runs into the costa before the apex; below it six veins run to the hinder margin; the subdorsal vein is furcate, but the upper branch of the fork is rather obsolete. In the posterior wings the costal cell is narrow and elongate; the median vein is trifid.

This genus only contains oue species, of which the larva is gregarious, thus approacling in habit towards the following genus.

1. Cratagella, Linn. S. N. (12) 885,353 (1767); W. V.; Fab.; Ilïb.; Godart; Treit.; Stcp.; Frey.; Dup.; Zell. $\Lambda$ lis anticis albis, fuscescente-irroratis, fasciis duabus obliquis ochrco-fuscis, margine postico apiceque coste fusco-punetatis. Exp. al. 7 lin.

Head and face white, mixed with pale fuscous. Palpi pale fuscous; the terminal joint with a ring near the base, and the apex white. $\Lambda \mathrm{n}$ tenne greyish-fuscous. Anterior wings white, irrorated with pale fuscous, with an ochreous-fuscous fascia placed rather obliquely in the middle, and sometimes not reaching to the costa ; beyond the mildle is auother oblique fuscous fascia beginning on the costa beyond the middle, and terminating at the anal angle; the hinder margin and apex of the costa are spotted with fuscous; cilin whitish, with a pale fuscous line. Posterior wings pale grey, with pale greyish-fuseous cilia.

VOL. III. 
Not uncommon in July; the gregarious larva feeds on hawthorn in June.

\section{Genus III. HYPONOMEUTA.}

IIyponomevta, Zell. Isis, 1344. p. 199. Iponomenta, Step.; Dup. Nygmia, Hüb. Yponomenta p., Lat.; Treit. Frminea p., IJaw.

Capilli depressi. Ocelli nulli. Palpi labiales breviusculi, reflexi, filiformes, subacuti. Uaustellum mediocre, nudum. Nla elongate, breviter cilintas; posteriores foreola hyalina basali. Alic interiores: vena apicalis simplex; cellula secundaria perfecta; vena subdorsalis furcata; posteriores : cellula costalis in medio contracta; vena mediana bifida.

IIead smooth (in a single continental species, II. mfimilrellus, Kell., rough). Ocelli none. Labial palpi rather short, reflexed, filiform, hardly pointed. Tongue of moderate length, naked. Wings clongate, with short cilia; the posterior with a hyaline patch at the base. In the anterior wings, the apical vein is simple; the sccondary cell is complete; the subdorsal vein furcate. In the posterior wings, the costal cell is contracted in the middle; the median vein is bifid.

The perfect insects of this genus are readily known by the numerous small black spots on the white or grey anterior wings; their flight is sluggish. Only one species, II. vigintijnnctutus, is double-brooded; of all the others there is only one brood each year. 'This is fortunate; for the gregarious habits of the larvae, and their numbers, render them extremely destructive to our fruittrees and hedges. $\Lambda$ spindle-tree or an apple-tree, stripped of its leaves in the middle of summer, and covered with white webs formed by these larva, is no uncommon sight. The larve of most of the species are liatched in the autumn, but remain under a glutinous covering during the winter, and do not commence their depredations till the appearance of the young leaves in spriug, when a sudden blight changes the face of vegetation, or in other words these larva quit their winter-quarters, having been fixed throughout the winter on the very same twigs where their ravages now become so conspicuous. The larvac xemain in company during the whole period of their existence, and spin their cocoons in close proximity with each other.

Much confusion has prevailed with the synonymy of two of the species of this genus, Limmeus having described the larva of one species, naming the insect from its habits, whereas the perfect insect he describes is a distinct species; it therefore becomes an 
impossibility now to discover which species he intended by the name of Litonymella; and Scopoli having correctly described, under that name, the larva and imago of one species, I have had no hesitation in adopting his name, as the carliest name to which no doubt is attached. Almost every succeeding writer has followed the bad example of Linnous, without attempting to prove the correctness of his assertions.

Of this genus we have six British species (two others are known on the continent) which may be easily distinguished as follows:-

a. Anterior wings leaden-grcy.

b. With a black spot in the cilia of the hinder margin. Species 1.

$b$ b. With no black spot in the cilin of the hinder margin. Species 4 (some varieties).

a $a$. Anterior wings white.

c. With dark blotehes or clouds. Species 2, 3, 4. (some varieties).

c c. With no dark blotches or clouds. Species 5, 6 .

1. vigintipunctatus, Ret\%. G. ct S. 52. 153 (1783); Zell. Isis, 1814.-Sedella, Treit.; Dup, ;tep. Zool. 18.1. p. 687; Sta. Zool. 184.9. p. 2272, Alis anticis saturale plumbro-griseis, seriebus tribus longitudinalibus punctorum nigrorum, ciliis dilute griseis, macula infra apicem saturate fusca, Exp. al. 7 lin.

Head and face dark grey. Palpi palc grey. Antenne greyish-fuscous. Anterior wings rather dark leaden-grey, with three longitudinal rows of black spots; the first near the costa terminating rather beyond the middle, the other two on each side of the fold not reaching to the hinder margin; cilia pale grey, with some dark fuscous scales immediatcly below the apex. P'ostcrior wings greyish-fuseous, with paler cilia.

Alnost unique in this country; one specimen taken by Mr. Stephens at Norwood. 'The perfect insect is double-brooded, appearing in $\Lambda$ pril and May, and again in August. The larva appears in June and July, and again in September and October; it feeds on the Sedum Telephizum.

2. plumbellus, W. V. 139. 3. (1776); Fib.; Hüb.; Godart; Treit.; Step.; Du1.; 'Zell.; Frey. N. B. v. pl. 420.-plumbea, Haw. Nlis anticis albis, grisescente-suffisis, apice salurate fusco, seriebus quatuor longitudinalibus pumctorum nigrortum, punetulis nigris marginem posticum versus, nacula nigra in medio plica; cilis saturate fuscis, angulum analem versus albidis. Exp. al. $8 \frac{x}{2}-9$ lin.

IIcad, face, and palpi whitish. Antenne dark fuscous. Anterior wings white, with a slight greyish tint, with four longitudinal rows of black spots, two near the costil and one on each side of the fold; near the hinder margin is a trausverse row of small black spots, preceded by a few black spots irregularly placed ; in the middle of the fold is a 
conspicuous black blotch, and the apex of the wing is durk fuscous; cilia dark fuscous, at the anal angle whitish. Posterior wings greyish-fuscous, with paler cilia.

Not uncommon in hedges in the south of England, in July and August. The larva feeds on the spindle (Euonymas Europeus) in June.

3. irrorellus, IIüb. Tin. 93 (1801); Godart; Trsit.; Step.; Dup.; Zell.-irroret, Haw. Alis anticis albidis, seriebus tribus longitudinalibus, serieque curvata marginem posticum versus, punctorum nigrorum, nebula plicre ante medium, nebulaque majore elongata disci pone medium, fuscis. Exp. al. $11 \frac{1}{2}$ lin.

IIead and face white. Palpi benenth dark grey, above white. Antennie whitish. Anterior wings whitish, with three longitudinal rows of black spots; one near the costa and one on each side of the fold, and a curved row of spots near the hinder inargin; on the fold before the middle is a fuscous blolch, and a larger elongated one is on the disc beyond the middle; hinder margin clouded with grey; cilia pale grey. Posterior wings greyish-fuscous, with paler cilia.

A scarce species, appearing in July, among Euonymus; the larva, gregarious when young, feeds on that plant in June.

4. Padellus, Limn. S. N. (10) 535. 240 (1758); Scop.; Fab.; IIüb.; Step.; I)up.; Guén.—variabilis, Zcll. Isis, 1844.-var. P malivorella, Sta. Cat. Alis anticis albis grisescente-suffusis vel plumbeogriseis, sericbus tribus longitudinalibus, serieque transversa marginem posticum versus, punctorum nigrorum; ciliis dilute griseis, albisve apicibus dilute griseis. Exp. al. 7-10 lin.

IIcad, face, and palpi white. Antenne whitish. Anterior wings white, will a more or less decided greyisfe tinge, sometimes with a greyish blotch extending from the costa to the fold (frequenlly the wings are entirely gr(y), with three rows of black spots, one near the costa, and one on each side of the fold ; towards the hinder margin is a row of sinall black spots, generally preceded by a few irregularly placed; cilia pale grey, or white with the tips pale grey. Posterior wings greyish-fuscous, with paler cilia.

An abundint species, on lawthorn and apple (if indeed the apple species, malivarclla, be really identical), appearing in July and Aigust. The larve appear about the middle of May, and continue their devastations throughout June.

5. Evonymellus, Scop. F. C. 246. 631 (1763); Schr.-Tvonymi, Zell. Isis, 18t t.-cagnagella, Ilüb.-cognatella, Step.; Dup.; Freyer; latz.; Guénéc. Alis anticis albis, sericbus tribus longitudinalibus, serieque transversa marginem postieum versus, punctorum nigrorum; ciliis albis. Exp. al. 11 lin.

Hearl, face, and palpi white. Antenne whitish. Anterior wings ekhte, with three longitudinal rows of black spots, one near the costa, 
and one on each side of the fold, the lower one consisting of about five or six spots; before the hinder margin is a row of smaller black spots, preceled by a few spots irregularly placed; cilia white. Posterior wings dark greyish-fuscous, with paler cilia.

Plentiful in the south of England among spindle (Euonymus Europeess), in July and $\Lambda$ ugust. The larva defoliates the spindle in June; when they have devoured all the leaves, huuger compels them to gnaw the bark of the young stems.

6. Padi, Zell. Isis, 1844. p. 225.-Evomymella, Ilüb.; Freyer; Gućnćc; Linn.?; Fab.?; Haw.?; Godart?; Step.? Dup.?. Alis anticis albis, scricbus quatuor longitudinalibus, duabus transversis margrinem posticum versus, punctorum nigrorum; ciliis allis. Exp. al. $11 \frac{1}{2}$ lin.

IIcad, face, and palpi white. Antennæ whitish. Anterior wingrs white, with four longitudinal rows of black spots, two near the costa, and one on each side of the fold, the lower one consisting of from ten to twelve spots; towards the hinder margin is a row of small black spots, preceded by a short row nearly parallel to it; cilia white. l'ostcrior wings dark greyish-fuscous, with paler cilia.

Not uncommon where the foor of the larva grows; appearing in July and August. The larva feeds on the bird-cherry (Prunus Padus), in June.

\section{Genus IV, ANESYCHIA.}

Anesycira, Step. HI. iv. 239 (1834). Iponomeuta p., Treit.; Curt. LEdia p., Dup. Psecadia p., Zell.

Capilli depressi. Ocelli nulli. Antemne of articulis subrentatis, pubescente-ciliatis. Hanstellum mediocre, squamatum. Palpi labiales mediocres, reffexi, arliculo tertio acuminato. Alie oblonga vel elongatie, breviter ciliatic. Ale anteriores: vene apicalis furcate jamus inferior ante vel in apicem exit; cellula sccundaria lantun indicala; rami infra venam furcatam quinque separati; vena subdorsalis furcita; posteriores: vena mediana trifida; cellula costalis elongata, in medio non coarctata.

Head smooth. Ocelli none. Antenna of the male with the joints rather dentate and pubescent-ciliated. 'Tongue of moderate length, clothed with seales towards the base. Labial palpi moderately long, reflexed, with the third joint pointed. Wings oblong or elongate, with short cilia (the posterior with no hyaline pateh towards the base). In the anterior wings the lower branch of the forked apical vein runs into the ensta before or at the apex; below it are five separate veins from the discoidal cell; the secondary cell is only indicated; the subdorsal rein is furcate. In the posterior wings the median vein is trifid, and the elongated costal cell is not contracted in the middle. 
The species of this genus, many of which are highly beautiful, secm exclusively attached to the Boraginee, on which their larvac feed. One species, A. bipunctella, is known to be double-brooded, but others probably have also two generations in the year.

Of the four British species, two remain at present extremely rare, though by no means scarce on the continent, where a fiftl species also occurs.

1. pusiella, Roemer, G. I. 22. pl. 23. f. 9 (1789); Panzer; Godart; Curt.; Step.; Dup.-sequella, W. V.-Lithospermella, IIüb.; 'Treit.-scalella, Zell.; Scop.? Alis anticis albis, vilta media irregulari nigra, quasi maculis tribus utrinque conflucutibus, maculis punctisque nigris, abdomine albo. Exp. al. $13 \frac{2}{2}$ lin.

Ifead and face white. Palpi white; the base of the second and terminal joints black. Antemna dark fuscous. Anterior wing's white, with an irregular black streak running along the middle of the wing, from the base of the costa to near the hinder margin; its irregular form appears to arise from three pair of spots being attached to it, of which those towards the costa are placed posteriorly to the others; near the costa towards the base is an oblong black spot, and a small round black spot lies beyond and below it; in the middle of the costn is a black bloteh, and beyond the middle are two small black spots obliquely placed, and beyond them are three black spots obliquely placed; near the inner margin towards the base, and below the fold towards the middle, are two other black spots; the hinder margin and apex of the costa are spotted with black; eilia white, with a black dash immediately below the apex. Posterior wings pale fuscous; towards the inner margin white; cilia white. Abdomen white.

British specimens are extremely rare; the insect appears in Jume and July; the larva fecding on Lithospermum and I'ulmonaria in May.

2. bipunctella, Fab. S. E. 668. 7 (1775).-Echiella, W. V.; Ilüb.; (iodart; Curt.; Trcit.; Step.; Dup.; Zell.-IIochemoartiella, Rossi. Alis anticis costam versus salurate fuscis, dorsum versus albis, margine postico, apiceque costa nigro-punctatis, abdonine luteo. Exp. al. $11 \frac{2}{3}$ lin.

IJead and face white. Palpi black; terminal joint white. Antennæe fuscons. Anterior wings dark fuscous along the cosla ; along the inner margin while, with two dark fuscous spots in the fold, one before and one in the middle, attached to the dark half of the wing; beyoud the middlle the white projects a little into the dark fuscous, but immediately beyond is again a dark fuscous projection into the white; the hinder margin and apex of the costa, which latter is white, are spotted with black; cilia whitish, with a dark fuscous dash immediately below the apex. Posterior wings whitish-grey, with paler cilia. Abdomen dirly yellow. 
This pretty species is no commoner with us than the preceding; it appears in May and August; the larva feeds on (Fichium vilgare) viper's bugloss in July and October.

3. funerella, Fab. Man. ii. 247. 74. (1787) ; IIüb.; Godart; 'Treit.; Step.; Dup.; Zcll.-funerea, IIaw. Alis anticis latioribus albis postice nigris, costa proter maculam albam pone medium late irregulariterque nigra, punctis duobus basim versus migris. Lxp. al. 7 $\frac{1}{2}$ lin.

IIead white; in the middle black. Face white. Palpi dark grey; terminal joint black. Antennæ dark fuscous. Anterior wings ratlier broad, white, with deep black spots and markings; at the base of the costa is an oblong spot, and short streak immediately beyond it on the costa; beyond is an irregular-shaped costal blotch (leaving only a triangular white spot on the costa beyond the middle), which projects towoards the base and towards the inner maryin, and generally zonites with the black apical portion of the wing; in the latter, towards the hinder margin, are a few whitish scales; towards the base, near the inner margin, are two round black spots obliqucly placed; cilia dark grey, with the tips whitish. Posterior wings dark fuscous; towards the inner margin whitish, with paler cilia.

Long doubted as a British species; recently taken in tolerable plenty in the Cambridgeshire fens in June.

4. decemguttella, IIüb. Tin. 303 (1816); Trcit.; Frcy.; Dup.; Vscll.-dodecea, Haw.; Step. $\Lambda$ lis anticis albis grisescente-suffusis, punctis undecim magnis irregularibus atris. Exp. al. $10 \mathrm{lin}$.

IIead and face white. Palpi black; internally whitish; terminal joint whitish, with a black ring at the base and another towards the apex. Antenna dark fuscous. Anterior wings white, with a slight greyish tint, wilh eleven rather large dark black spots, viz. two small at the base, one on the subcostal vein, and one on the fold; nearly following the line of the fold are four others, the first in the fold not far from the base, the second a little below the fold, the third is larger, and lies in the fold about the midlle of the wing, the fourth and larrest is above the fold towards the anal angle; on the dise before the middle are two spots, the anterior nearer to the costa; in a line with the lower one on the disc are two others, one beyond the middle, the other towards the hinder margin, and near the costa, nearly between these two, is another spot; cilia whitish. Postcrior wings diurk greyish-fuscous, with paler cilia.

Not common; the perfect insect appears in Many and June, sitting on the tops of the flowers of the Lithospermum (according to the interesting account of its habits given by Mr. Harding, in the 'Zoologist' for 181.8 , p. 2332). The larva feeds on that. plant in September and October. 


\section{Genus V. CHALYBE.}

Cualybe, Dup. L. F. х. 343 (1836). Psecadia p., Zell.

The much shorter, porrected, not reflexed palpi, as woll as the general fucies of the insect, point this out as distinct from Anesychia; the want however of a serics of specimens for investigation prevents me from giving the generic characters more in detail. Wherens in Anesyctiva the ground-colour of the anterior wings is while, with black spots and markings, in this genus the ground-colour is black or bluc-black, with decp black spots. Five very closely allied species are known on the continent, one of which was detected in Sutherlandshire last May, by Mr. Buxton.

1. pyrausta, Pallas, Iicisen, i. 176 (1774) ; 'Gcll. (Ent. Ztg. 1844). -atropuctella, Wenner (Thunb.). Alis anticis atro-fumosis, punctis tribus atris longiludinaliter dispositis; alis posticis fumosis; ano luteo. Exp. al. 8 lin.

IIead, face, palpi, and antenne black. Anterior wings sooly-blnck, with three deep black spots, placed nearly in a line longitudinally, the first not far from the base, the second a little before the middle, both on the fold, the third and most conspicuous at the termination of the discoidal cell; cilia sooty-black. Posterior wings and cilia dark smokygrey. 'The posterior half of the abdomen yellow.

$\Lambda$ single specimen of this conspicuous specics was taken in Sutherlandshire, last May, by Mr. Buxton.

\section{Genus VI. PRAYS.}

Prays p., IIüb. Telea p., Step. Lidia p., Dup. Fcophora p., Zell. Caput obtusum, pilis appressis. Ocelli nulli. Palpi labiales breviusculi, filiformes, apicem versus vix attenuati. IIaustellum mediocse, nudum. Alx anteriores oblongre, posteriores latiusculic breviter ciliata. Ala anteriores: stigma distinctum; vene apicalis ramus inferior sub apicem exit; subdorsalis longissime furcata; posteriores : cellula costalis ablreviata.

IIead obtuse, smooth. Ocelli none. Labial palpi rather short, filiform, hardly altenuated towards the apex. Tongue of moderate length, naked. Anterior wings oblong; posterior rather broad, with short cilia. In the anterior wings the stigma is distinet; the lower branch of the apical vein runs into the lineler margin; the subdorsal vein is furcate for a considerable length. In the posterior wings the costal cell is abbreviated.

The perfect insect of the only species in the genus has a considerable prima facic resemblance with Anesychia. Its larva 
feels on the buds of the ash-trec, and forms an open network cocoon, but its habits have not yet been fully investigated.

1. Curtisellus, Don. B. I. ii. pl. 63 (1793); Step.-Curtisii, IIaw.—maculella, Tab.—cenobilella, Ilüb.; Iup.-Sraxinella, IJjerk.? -var. rustica, Haw. Alis anticis albis, macula magna costali nigra, basim versus attenuata, in medio plican superante, dorso basin versus striis abbreviatis, transversis, fuscis, marone postico nigro nebulosis (var. alis anticis unicoloribus obscure fuscis). Exp, al. $7 \frac{1}{2}$ lin.

Head and face white. I'alpi dark fuscous; tips of the terminal joint white. Anteme dark fuscous. Anterior wings white, with a dark fuscous, almost black blotch on the costa, extending fiom the base to beyond the middle of the wing; at the base it is extrencly narrow, but in the middle it reaches across the fold ; in it, on the costa beyond the middle, is a small whitish spot; on the inner margin near the base are some short transverse fuscous streaks, along the hinder margin are several dark fuscous or black blotches; cilia dark fuscous. Posterior wings greyish-fuscous, with paler cilia. In the variety rustica of Ifaworth, the hend and face are clirty ochreous, and the anterior wings unicolorous, dingy fuscous. Intermediate specimens, in which the costal blotch is dimly shadowed, occur.

Not uncommon among asll-trees in June aut July. Mr. IIenry Doubleday found the full-ferl larve deseending fiom the trees by their threads, and bred from them both the typieal insect and the variety. Mr. Preston had previously found the larva feeding on the hardly-developed leaf-buds of the aslt.

\section{Family IV. PLU'TELLIDAD.}

Caput hirsutum. Palpi labiales articulo sceundo infra in fisciculum producto. Antenne in quicte yorrecte. Larva fusiformis, non saccophora.

Ifead rough. Labial palpi with the second joint furnished beneath with a projecting tuft of scales. Antenuc porrected in repose. Larta fusiform, not living in a case.

The porrected antenno of these insects give them it certain resemblance with the Coleophlioride, from which the broader posterior wings and rough head sufficiently distinguish them, independent of the difference in the habits of the larvie.

The greater breadth of the anterior wings of the only species known in the first genus, does not interfere with its aflinities in other respects, and its true place is certainly here. thus :-

The four genera in this family may be easily distinguished

VOL. III. 
a. Antenne thickencl with seales, towards the base. I. Eidoriasi1. a a. Antenna not thickencd with scales, towards the base.

b. Posterior wings with moderate cilia.

c. Posterior wings rather narrow. 2. Puurella.

c c. Posterior wings rather broad. 3. Cerostoma.

$b$ b. Posterior wings with long cilia. 4. Tuenrstis.

\section{Genus I. EIDOPHASIA.}

Erdopinsia, Step. Entom. 118 (Add. et Comig. 18.12). I'arasemia, Step. Ent. 202.

Caput hirsutum. Antenne supra basim squemis incrassale, cxtcrum cremato-dentate, articulis subelongatis. Haustellum breve, squanatum. P'alpi maxillares nulli. Palpi labiales tenucs, articulo secundo infria in fasciculuin tenuem producto, tertio aculciformi. $\Lambda$ lic oblonga, mediocriter ciliate, apice obtuso. Ale anteriores: vena apicalis simplex ante apiecm cxit, infin cam rami sex, quorum infimus cum jenultimo nou coalescit; cellula secundaria bene indieata: vena subclorsalis longe fureata; ale posteriores : cellula costalis clongata; vena subcostalis simplex supra apicen exit, cum sequente nou coalescit; vena mediana trifida.

Head rough. Antennic thickened with scales towards the base, the remainder almost dentatc, with rather clongate joints. Tongue short, elothed with scales. Maxillary palpi undereloped. Labial palpi slender, with the second joint produced beneath in a slender tuft; third joint acuminate. Wings oblong, with moderate cilia; the apex obtuse. In the anterior wings the simple apical vein runs into the costa before the apex; below it six veins run into the hinder margin, of which the lowermost is not united with the penultimate; the sccondary cell is well indicated; the sublorsal vein is forked for a considerable length. In the postcrior wings the costal coll is elongate, the simple subcostal vein ruas into the costa before the apex, and is not united with the following; the median vein is trifid.

Only one species is yet known in this genus, and of the habits of that but little has been observed; according to MIr. Sircom's remarks, it flics in woods among oaks at dusk, keeping very near the ground.

1. Messingiella, F. v. R. 193. pl. 68. f. 3 (1839),-transversella, Step. (Entom.) Alis anticis fuscis, fascia fere recta costam versus attenuata, dilute luten, macula coste pone medium, fere obsoleta, pallida. Exp. al. 6 lin.

IIead and face ochreons-fuscons. Palpi fuscous; teminal joint palcr. Antenue fuscous. Anterior wings fuscous, with a nearly straight pale ycllow fascia, almost in the middle, attenuated on the costa, where it is rather nearer to the base; a small nearly obsolete pale spot lics on the costa beyond the midlle; cilia pale fuscous. Posterior wings grey- 
isth-fuscous, with paler cilia. In some specimens the fascia of the anferior wings is ablureviated, hardly reaching beyond the fold, appearing as a spot on the inner margin.

Not common; the perfect insect appears in June.

\section{Genus II. PLUTELIA.}

P'luteris, Schr. F. B.ii. 169 (1802) ; Zctt. Cerostoma, Curt.; Step. Alucita p., J'ab.; Lat.; Dup. Anadelia p., Ilüb. I psolophus p., Haw. Plulella p., Treit.; Zell.

Caput hirsutum. Antenna simplices, articulis valde distinetis. IIaustellum mediocre, mulum. P'alpi maxillares filiformes, breves. Palpi labiales articulo secumbo infra in fisciculum subattenuatum producto, tertio erecto, aculciformi. Nlic elongate, ciliis longiusculis infra alarum apicem non impressis, posteriores lanceolate. Nlac auteriores: vena apicalis simplex ante apicem excurrit, infra eam rami sex, quorum infimus a penultimo longe distat; penullimns et antepenullimus rex codem punclo prodeunt; cellula secundaria indicata; vena subdorsalis longe furcata; ala posteriores: cellula costalis subito attenuata ; vena apicalis simplex; vena subapicalis fureata. Folliculus larve reticuliformis.

Hetd rough. Antenne not thickened with scales, with the joints very distinet. Tongue of moderate length, naked. Maxillary palpi short, filiform. Labial palpi with the sccond joint prolonged beneath in a rather slender tuft; the third joint erect, acuminate. WVings elongate, with rather long cilia not indented below the apex; the posterior wings lancelate. In the anterior wings the simple apical vein runs into the costa before the apex; below it are six reins from the discoidal cell, of which the lowermost is remote from the penultimate, and the pemulimate and antepenultimate proceed from the same point; the secondary ecll is faintly indicated ; the subdorsal vein is fureate for a considerable distance. In the posterior wings the costal cell is suddenly attenuated, the apical vein is simple, and the subapical vein furcate. The larva constructs an open network cocoon. (P. Dalella shows several discrepancies from the generic chatracters above given: the maxillary palpi are rather long; the second joint of the labial palpi is seareely produced to a tuft; and in the posterior wings the costal cell is more gradually attenuated, and the subapical vein is simple.)

The insects of this genus make but short, rather straight flights, specdily scttling again on the low herbage. 1'. porrectella appears solely attached to the Hesperis matronalis, but $P$. Cruciferarm cats with avidity most of the Cruciferous plants. In the year 1851 this inscet was excessively abundant throughout the country, and from Southend in I'ssex, to Belfast, the same enormons multiplication of the species was observed; the turnip-growers 
thought some new blight liad fallen upon their crops, but fortunately subsequent years have not shown a continuance of the inordinate numbers of this species, which was probably checked by a timely increase of its parasitic foes.

There are only four British species, of which the first three are very similar in markings.

1. Cruciferarum, Zell. Ent. 7tg. 1843. p. 283.-Xylostella, IIüb.; Treit.; Step.; Dup.—o macnlipennis, Curt.; Step.; Sta. Mlis anticis grisco-fuscis, saturate fusco punctatis, dorso dilute ochreo, dentibus tribus rotundatis plicam superantibus ( $q$ dorso vix distincte di-

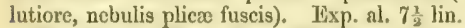

Head, facc, and palpi greyish-ochreous. Antennx whitish, anmulated with fuscous. Anterior wings greyish-físcous, spotted with dark fuscons; the inner margin palc ochireous, with theree rounded projections across the fold (in the of the inner margin is less decidedly paler, and there are some fuscous spots along the fold); cilia grey, varied with fuscous. l'osterior rvings grey, with paler cilia.

Always common, and sometimes very abundant among cabbages and other C'ruciferous plants; the perfect insect appears in May and August; the larva in June, July, and September.

2. porrectella, Lim. S. N. (10). 540. 282 (1758); W. V.; Treit.; Step.; Duy,-IIssperidella, Ilüb.-IIesperidls, IIaw.-Folleviellus, ])ahllb. (N. A. II.) Alis anticis albidis, ochreo vel fuscescente striatis, dorso dilutiorc, vitta sinuata supra plicam saturate fusca, margine postico fusco nigro-punctato. Exp. al. 7 lin.

Ilead, face, and palpi whitish. Antenne whitish. Anterior wings whitish, streaked with ochreous or pale fuscous, the inmer margin paler; a sinuated fuscous streak above the fold runs from the base nearly to the apex; the hinder margin is fuscous, spolted with black, and along the costa and imner margin are some small dark fuscous spots; cilia whitish, varied with black. Posterior wings grey, with paler cilia.

Common in gardens among Ilesperis matronalis in May and July. 'The larva feeds on that plant in April and June.

3. annulatella, Curt. B. E. fo. 120 (1832); Step.-Zicingulata, II.-S. Nlis anticis dilute griseo-ochreis, costam versus valde fuscosullusis, dorso dilutiore, dentibus duabus plicam superantibus, vitta sinuata plice usque ad mediun saturate fusca, margine postico fuscopunctato. Lxp. al. 8 lin.

Head and face greyish-ochrcous. Palpi pale ochrcous. Antennac ochreons-fuscous. Anterior wings pale greyish-ochrcous, much suffused with fuscous towards the costa ; the immer margin paler, with two projections across the fold, the first in the middle, the other towards the anal angle; a sinuated dark fuscous streak ruus above the fold to a little before the middle; the hinder margin is spotted with fuscous; cilia pale greyish-ochreous. Posterior wings grey, with paler cilia. 
A northern species, in few collections: my specimens were taken on the coast near Belfast in September.

4. Dalella, Sta. Cat. p. 11 (184.9).-vittella, Hüb. Tin. 164. Alis anticis griscis, griseo-fusco marmoratis, postice albido-squamatis, triangulis tribus dorsi dilutioribus, spatiis interjectis saturate griseo-fuscis, maculis duabus costæ pone mediun fuscis, apice marginis postici nigropunctato. Exp, al, 10 lin.

IIead, face, and palpi dark greyish-fuscous. Antennæ dark fuscous. Anterior wings grey, marbled with greyish-fuscous, posteriorly with some whitish seales; on the inner margin are three pale triangles, the first near the base very small, the sceond in the middle reaching to the fold, and sometimes produed posteriorly beyond it, and the third beyond the middle reaching beyond the fold; the spaces between these triangular marks are dark greyish-fuscous; on the costa beyond the middle are two fuscous spots; towards the apex of the hinder marnin are two or three black sjots; cilia greyish-fuscous, with two darker lincs. l'osterior wings grey, with paler cilia.

Not uncommon in the north of Englaud and Scotland, in September. Many specimeus lave been taken near IIuddersfield by the Rev. J. Jolinson.

\section{Genus III. CEROSTOMA.}

Cerostoms, Iat. II. N. xiv. 247 (1802). IIarpipleryx p., Curt. Ilutella p., Yoll. Iypsolopha, Rhinosia p., ct IIarpiplery.x p., Trcit.; Dup. Harpipteryx, IIypsolopha, et Chatochilus, Step.

Caput hirsutum. Antenna simplices, rix crenulate. Haustellum mediocre, nudum. Palpi maxillares distineti, filiformes. Palpi labiales, articulo secundo infra in fasciculum producto, tertio crecto aculeiformi. Ale anteriores clongate vel oblonge, interdum caudata; alas postcriores ante angulum analem leviter retusa, lanccolatr, mediocriler ciliale; ala anteriores: vena apicalis furcata supua et infra npicem cxeurrit, infra eam rami quinque; cellula sceundaria perfecta; ala posteriores: cellula costalis elongata, postice attenuata; vena apicalis furcata. Folliculus larve solidus.

Ilead rough. Antemne not thickened, slightly indented between the joints. The tongue of moderate length, naked. Maxillary palpi distinct, filiform. Labial palpi with the second joint prolonged beneath in a tuft; terminal joint erect, acuminate. Anterior wings elongate or oblong, sometimes caudate; posterior wings slightly emarginate before the anal angle, lanceolate, with moderalely long cilia. In the anterior wings the furcate apical vein rums out above and below the apex; below it are five veins from the diseoidal ecll; the sccondary cell is complete. In the postcrior wings the clongate costal cell is poste- 
riorly attenuated; the apieal rein is furcate. The larva forms a close silken cocoon.

The inscets of this genus appear at the end of summer and autume; many of the late species hybernating, and being again met with in the spring; when at rest they are easily disturbed, but gencrally drop only from one portion of the bush or hedge to another, and rately make use of their wings. The larva of $C$. rylostella (green, with a broal red stripe on the back) is the most generally met with: it is attenuated anteriorly, extremely active, and, when full-fed, construets a very firm, close silken cocoon.

'ilhe neuration of the anterior wings is not identical in all the species, as may be seen from the following table:-

A. Apieal vein fureate; below it five veins from the discoidal cell.

3. The three lowermost of these veins are not united at their origin. Species 1-5.

B 13. The two lowermost of these veins are united at their origin. Species 11, 12.

A A. Apical vein simple; below it six veins from the discoidal cell.

c. The three lowest of these veins are not united at their origin. Species 7.

c c. The penullimate and antepenultimate of these veins, procecd from the same point. Species 6, 8-10.

The twelve British species may (without denuding the wings) be placed in the following table:-

a. The eilia of the anterior wings not retuse below the apex. Sp. 1-4. a $a$. The cilia of the anterior wings retuse below the apex. Sp. 5-7.

a $a$ a. The anterior wings slightly caudate. Species 8-10.

a $a$ a $a$. The anterior wings caudate. Species 11, 12.

1. sequella, Clerek, I. Pl. x. f. 1\%(1759); Linn.; Fab.; Godart; II:a.; 'Treit.; Step.; ])up.-nyctemerellu, WV. V.; Iab.-pusiella, Linn,? Alis anticis allis, vitta dentata dorsali nirral, striis numerosis costie abbreviatis nigris, apice costo margineque postico nigresente-punctatis. Exp. al. 8 lin.

Ilcad, face, and palpi white. Antenna blackish. Anterior wings v7eite, with an indented black blotch on the inner margin, reaching beyoud the midelle; at the base and between the indentations it touches the fold, and at its hinder end it crosses the fold; along the costa are several short black streaks, a more conspicuous oue in the midclle, sopine inwartly, reaches nearly half across the wing, and an irregular black mark beyond the middle of the eosta, almost unites with the termination of the bloteh on the inuer margin; along the apex of the costa and hinder maroin, and at the anal angle, are some black or blackish marks; cilia white at the apex, in the miclde of the hincler margin and at the anal angle blackish. P'osterior wings grey, with paler cilia. 
Not common, appears in July and August. The larva (according to Madame Lienig) feeds on limes and sallows, in May and June.

2. vittella, Liun. S. N. (10) 538. 26 ! (175S); Cl.; Tab.; llaw.; Dup.—vitella, Ilüb.; Step.; Zell.-sisymbrella, WV. V.-var. mantellus, Step. Alis anticis griseis saturatiore varicgatis, vitta dentata dorsali nigra, puncto ad angulum aualem, striaque apicis nigris. Exp. al. 8: lin.

Head, face, and palpi grey. Antenua dark fuscous. Anterior wings grey, mottled with darker, with a black blotch on the inncr margin, from near the base to beyond the middle, indented or interrupted in the midclle and not reaching to the fold; a small spot at the anal angle and a streak at the apex of the wing black; cilia pale grey, oppositc the apical streak dark grey. l'osterior wings pale grey, palce forrards the base, with palcr cilia. In the varicty manerellus, Step., the cntire dorsal half of the anterior wings is blackish, only a narrow space along the costa boing greyish-ochreous.

Sometimes not uncommon among elıns in July and August. The larva feeds in May ou elı, beech, and (according to Madame Lienig) honcysuckle.

3. radiatella, Don. B. I. iii. pl. 77 (1791); Step. - radiatus, Haw,-variclla, Ilïb.; Step.-varians, IIaw.-fissella, IIïib.; Step.; Treit.; Dup.; Zell.-fissus, 1Iaw. Alis anticis ochreis, grisco vel rufo mixtis, fuscisve, puncto saturate fusco pone medium supra plicum; interdum vitta media saturate fusea, interdum striis numerosis palliclis. Exp. al. 8 lin.

$A$ most variable species. IIfead, face, and palpi greyish-ochreous or fuscous. Anteune pale or tark fuscous. Antcrior wings cither greyish-ochreous, pale ochreous, reddish-ochrcous, or fuscous, with a dark fuscous spot above the fold beyond the middle; sometimes with a thick dark fuscous streak along the middle of the wing, sometimes with numerous pale streaks upon a dark ground; cilia usually paler than the wing, frequently with the apex dark. Posterior wings grcy, with paler cilia.

Abundant among oaks in August and September; hybernated specimens are not unfrequent in the spring. The larva, which (according to Madane Lienig) is almost as variable as the perfect insect, feeds on oaks in May.

4. costella, Kab. S. E. 668.10 (1775); IIaw.; Treit.; Step.; Dup.-maculella, Fab.? Alis anticis grisco-ochreis, vel rufo-ochreis, macula basali prope costam alla araro obsoleta, interdum puneto pone medium supra plican saturate fusco, apice marginis postici fusco punctato. Exp, al. 8 lin.

Ilead, fiee, and palpi whitish-ochreous. Antemme whitish, with fuscous annulations. Anterior wingrs variable in colour, greyish-ochreous, reddish-ochreous, or almost dark brown, with a white blotch (rarcly ob- 
solcte) tonards the costa extenting from the base to the middle of the wing; there is frequently a conspicuous dark fuscous spot above the fold beyond the middle, and the costal half of the wing is frequently spotted with fuscous; at the apex of the hinder margin are some fuscous spots; cilia paler than the wing, with a fuscous streak in the apex. Posterior wings grey, with paler cilia.

The perfect insect occurs from the end of July to September, among oaks, less commonly than the preceding.

5. sylvella, Linn. S. N. (12) 893. 413 (1767); Fab.; Hï̈b.; Treit.; Step.; Dup.-bifascialus, Ilaw. Alis anticis dilute ochreis, vix fusco reticulatis, fusciis cluabus obliquis, costam versus intermptis, saturate fuscis. Exp. al. 9 lin.

IIead, face, and palpi palc ochrcous. Antenne whitish-ochrcous, annulated with fuscous. Interior wings pale ochrcous, slightly reticulated with fuscous, with two oblique dark fuscous fascice (onc before, the other beyond the midrlle), somewhat internipted towats the costa; cilia pale ochreous. Postcrior wings grey, with paler cilia.

Not uncommon among oaks in August and September. The larva feeds (according to Madame Licnig) on the oak in June.

6. alpella, W. V. 135. 20 (1776); Fab.; Treit.-persicellus, Step.? Alis anticis dilute ochreis, obsolete fuscescente-reticulatis, striis duabus dorsi obliquis, plicam vix superantibus, fuscis. Exp. al. 8 lin.

IYead, face, and palpi pale ochreous. Antcuno whitish-ochreous, annulated with fuscons. Anterior wings pale ochreous, indistinctly reticulated with pale fuscous, with two oblique fuscous strealis from the inner margin (one before, and one beyond the middle), neilher reaching more than half across the wing; cilia pale ochrcous. Posterior wings grey, paler towards the base, with pale greyish-ochreous cilia.

Not scarce among oaks in August.

7. Iucella, Fab. S. E. 667. 4. (1775); Schr--antennella, W. V.; Treit.; Step.; Dup.-retusana, Borgrst. - mucronella, Hüil.; IHaw. Alis anticis ochreis fuscescente-reticulatis, dorso obsolcte albo usque pone medium; capite albo. Exp. al. 8 lin.

llead and face while. Palpi white; second joint beneath ochreous. Antenne white, annulated with black. Anterior wings ockreous, reticulated voith pale fuscous, with the inner margin indistinctly white to beyond the middle; near the inner margin are two dark ochreous blotehes, one towards the base, the other beyond the midelle; cilia pale reddishochreous. Posterior wings grey, with paler cilia.

Not uncommon in many localities in July.

8. borridella, Treit. E. S. x. iii. 191 (1835); Dup.; Gućnée?-

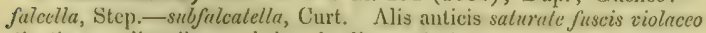
tinclis, maculis tribus scabris sub plican nirris, macula sinuata obsoleta dorsali saturate fusca. Exp. al, 9 lin. 
Ifead and face greyish-fuscous. Palpi pale grey; second joint beneath greyish-fuscous. Antenne fuscous. Anterior wings dark fuscons, woilh a slight violet lint, with three tufts of elevated black seales bolow the fold, and an obsolete sinuated dark fuscous bloteh along the inner margin; cilia greyish-fuscous. P'osterior wings pale greyishfuscous, with paler cilia.

Taken occasionally in the New Forest in July, among the wild apple-trees.

9. scabrella, Lim. F. S. 1446 (1761); Fal.; Treit.; Step.; Curt. bifissella, W. V.-pterodactylella, IIüb. ; Ilaw.-IIeluigella, Tab.? Alis anticis dilute griseo-ockreis, fusco-striatis, maculis tribus scabris snls plicam nigris, macula sinuata dorsali saturate fusca, margine postico saturate fusco-punctato. Exp. al. 10 lin.

Ifead pale greyish-ochreous; in the middle fuscous. Face pale grecyish-ochrcous. Palpi pale greyish-ochreous; second joint benealh whir fuscous; terminal joint with a fuscous ring near tle base. Antemla palc ochreous. Anterior wings pale greyish-oclereous, streaked with fuscous; towards the inner margin almost suffised with dark fuscons; with three tufts of elevated black scales below the fold, and a sinuaterl dark fuscous bloteh along the inner maryin; hinder margin spotted with dark fuscons; cilia greyish-fuscous. P'ostcrior wings pale greyishfuscous, with paler cilia.

Not scarce in the Now Forest and near Bristol, in July and August. The larva feeds on apple-trees in May.

10. asperella, Limu. F. S. 1117 (1761) ; W. V.; Tab. ; ILaw. ; Treit.; Step.; Dup.-Clairvillella, lab.-falcalclla, Don. Alis anticis luteo-albis, dilute fusco nebulosis, macnla manna triangulari interne scabra in medio dorsi, fusce et cartelo-nigra, puncto mrarginis postici cxrulco-nigro. Exp, al, 10 lin.

Head, face, and palpi yellowish-white. Antemax yellowish-white, with pale fuscous amulations. Anterior wings yellowish-rkite, clouled with pale fuscons, with a large trimgulur blotch on the mitdle of the inner margin, consisting of several tufts of raised seales, prale fuscous on the fold, and bluish-black along the imer margin; in the middle of the hinder margin is a small bluish-black spot; cilia yellowish-white, bclow the apex dark fuseons. P'osterior wings grey, with paler ciliat.

This beautiful insect is extremely rare with us; it appears from the end of August to October. The larva feeds on apple-trees in June.

11. nemorella, Linn. S. N. (10) 536. 217 (1758); Wenner (Thum.); Step.-Zumella, IIüb.; Treit.; Dup.-cullreu, Ilaw. Alis anticis albidis, venis ochreo fuscove striatis, puncto plice ante medium nigro. Exp. al, 11 lin.

Head and face whitish. Palpi whitish ; second joint beneatls pale fuscous. Antenne whitish, ammulaterl with pale fiscous. Anterior vol. III. 
wings whitish, with the veins streaked with ochreous or fuscous, and with numcrous seattered fuscous scales; on the fold before the middle is a black spot; cilia pale greyish-ochreous. Postcrior wings pale grey, with pale greyish-ochreous cilia.

Not searce in the neighbourhood of ILuldersficld: the imago appears in June and July. The larva feeds on the bark of the honeysuckle in May.

12. Xylostella, Linn. S. N. (12) 890. 389 (1767).-dentella, Fab.; Iraw.; Step.-Karpella, W. V.; Irüb. ; Treit.; Dup.; Zell.hamatus, Fab. Mlis anticis rufo-brunneis, dorso late lutco-albo, stria tenuissina obliqua pone medium, plicam superantc. 1xp. al. 10 lin.

Head and face yellowish-white; at the sides brown. Palpi ycllowishwhite; second joint beneath brown. Antenux white, anmulated with black. Anterior wings reddish-brown, darkest above the fold and in the middle of the wing, posteriorly paler and of a greyish tint; the inner margin rather broadly ycllowish-white, with an extremely narrow oblique white streak, running half across the wing beyond the middle; in the extreme apex is a fuscous streak; cilia pale fuscous. Postcrior wings dark grey, with palcr cilia.

Common in gardens and hedges among honeysuckle in July and August. The larva feeds on the leaves of the honeysuckle in May.

\section{Genus IV. THERISTIS.}

Theristis p., Hüb. ; Step. IIarpipleryx p., Treit.; Curt.; Dup. Plutella p., Zell.

Capilli hirsuti. Antenne simplices. Inaustellum mediocre, nudum. Palpi maxillares filiformes. Palpi labiales, articulo secundo in fasciculum tenuem longum producto, articulo tertio erecto brevi aculeiformi. Alæe anteriores elongatie acuminate; alic postcriores (ante angulum analem leviter retusæ) lanceolat $x$, longe ciliatx.

IIead rough. Antenne simple. Tonguc of morlerate length, nakcr. Maxillary palpi slender, filiform. Labial palpi with the second joint prolonged into a long sleuder tuft; the third joint mech shorter than this tuit, erect, acuminate. Anterior wings clongate, acuminale; posterior wings (slightly cmarginate before the anal angle) lanceolate, with long cilia.

Only one species is known in this genus; it appears in the autumn, and, hybernating, is again seen in spring.

1. caudella, Limn. S. N. (12). 894. 417 (1707).-Panzerella, Don.; Curt.-cullrella, Hüb.; T'reit.; Dup._acinacidella, IIüb.; Step. Alis anticis dilute rriseo-ochreis, stria supra plicam ex basi usque ad medium, maculaque plice ante medium, saturate fuscis. Exp. al. 13! liv. 
Ilead and face pale greyish-ochrcous. Palpi pale greyish-ochreous; tuft of the secoud joint bencath pale fuscous. Antenne pale greyishochreous. Anterior wings pale greyish-ochreous, with a dark fuscous streak above the fold, from the base to beyond the middle, a dark fuscous spot on the fold before the middle, and another on the dise beyond the middle; cilia pale ochrcous. Postcrior wings whitish-grey, with whitish-ochreous cilia.

In the rariety acinacidella of IIibner, the anterior wings are very much streaked with dark fuscous, and there is an additional dark fuscous spot towards the imer margin near the base.

Not common; most frequently found on the chalk; appears in August and September, and again in sporing. The larva feeds on the spindle in June and July.

\section{Family V. GELEChID疗。}

Caput lave. Palpi labinles recurvati, raro breves, interdum articulo sceundo in fasciculum producto. Ale posteriores latiuscula, sæpc trapezoilales vel ovato-lanceolatre, raro acuminatæ (Pancalia, Butalis). Larva pedibus 16 prodita.

Ilead smooth. Labial palpi recurved, generally long, sometimes with the sccond joint prolonged as a tuft. Posterior anings rather broud, often trape\%oidal, or ovate-lanccolate, rarely acuminate (Puncalia, Bu(alis). Larva with sixteen feet.

There is great discrepancy between the species composing the f:mily, and no doubt future investirgations, and the study of exotic forms, will cnable us to subdivide it. Many individual genera are perhaps only types of extensive families, which have no other represcntatives in the temperate climate of Europe; and the discovery of species in India, Brazil, etc., may hereafter show that these isolated species are there represented more numerously, just as we find to be the case among the Nocrursa with Calje Thalictri and Calyptra libatrix, which, though anomalous among our liuropean species, are the representatives of extensive tropical families.

The genus Gelechia, which forms so important a part of this family, is far more numerous in species than any other genus of 'Trxisa with which we are acquainted. In some of the genera of this family (I'Hibalocera, Muryella, IIypercallia, and Dasycera), the species are remarkably for their gay colouring; but the great bulk of the species in the other genera, would, in ordinary parlance, be termed inconspicuous insects. Many of the species keep themselves so well concealed, that they are rarcly met with in the 
perfect state. Harpella, some of the Eicophore, and Gelechice 1ly in the early morning, but most of the species fly in the evening dusk.

The twenty-five genera represented in this country, may be arranged in the following table:-

$a$. Posterior wings broad, or emarginate before the apex.

b. Second joint of the palpi not very long.

$c$. Second joint of the palpi thin.

d. Anterior wings truncate.

e. Antennx shorter than the anterior wings, 1. OrTHoteuIA.

e e. Antenna longer than the anterior wings. 4. P'uBArocera.

$d d$. Auterior wings ovate. 2. Semroscoprs.

c c. Sicond joint of the palpi considerably thickened beneath with scales.

f. Anterior wings ovate, with raised tufts. 3. ENrcostoms.

$f f$. Anterior wings emarginate below the apex. 5. Exareria.

fff. Anterior wings ovate, smooth. 6. Depressaria.

s c c . Second joint of the palpi slightly thickened bencath with scales.

9. Terminal joint of the palpi thin. 8. Gelecira.

g g. Terminal joint thickened above with scales.

h. Posterior wings deeply emarginate before the apex. 9. PAIRASIA,

h 7 . Posterior wings stighlly emarginate before the apex.

$i$. Anterior wings smooth. 11. Cirelaria.

$i i$. Anterior wings rough. 7. PHoricortera,

$c c c c$. Second joint of the palpi with loose projecting seales.

10. Cleodora.

$c c c c c$. Second joint of the palpi with a projecting tuft.

$k$. Anterior wings not emarginate below the apex.

l. Anterior wings rather acute. 12. ANarsia.

$l l$. Anterior wings rounded. 13. Ypsolopirus.

$k k$. Anterior wings emarginate below the apex.

$m$. 'Terminal joint of the palpi concealed in the seales of the second joint. 14. $\Lambda$ pLots.

$m \mathrm{~m}$. Terminal joint of the palpi projecting beyond the seales of the second joint.

n. Cilia of the antcrior wings without markings. 15. NoTIIRIS.

$n n$. Cilia of the anterior wings with markings. 16. SoPIIHONIA.

6 b. Sccond joint of the palpi very long.

o. Second joint of the palpi very much thickened with senles.

p. Anterior wings elongate. 17. P'LEURo'rA.

$p$ p. Anterior wings oblong. 18. UARPELLA. 
o 0 . Second joint of the palpi not much thickened with scales. 19. Ify perRoalima.

$a \alpha$. Posterior wings narrow, ovate or ovate-lanceolate.

q. Antenne thickened with seales towards the base. 20. Disycera.

q q. Antennæ not thickened with seales towards the base.

$r$. Posterior wings with a transparent patel at the base. 23. L'NDrosis.

$r r$. Posterior wings with no transparent patch at the base.

s. Posterior wings not acutely pointed.

$t$. Antennx slender. 21. CEcopiona.

$t t$. Antenna rather thick. 22. (Eooconia.

$s s$. Posterior wings acutely pointed; body thick.

$u$. Anterior wings unicolorous, grey, or bronze, or with white spots and marks. 24. Butalis.

$u u$. Anterior wings reddish-orange, with gold spots. 25 . Pancalia.

\section{Genus I. ORTHOT FELIA.}

Ontrotemin, Step. H. ir. 195 (1834). Agoniopteryx, Treit. Canlobius, Dup. Illomylis, Zell.

('apilli depressi. Ocelli nulli. Antenna mediocres, artieulis distinetis, of microscope ciliatis. ILaustellum brevissimum, nudum. Palpi maxillares brevissimi, distincti. Palpi labiales brevinsculi, reflexi, cylindrici, tenues, acuminati, articulo tertio sceundo longiorc. $A b$ dowen elonyatum, convexum. Alx oblongie, breviter ciliatæ, anteriores postice dilalate, truncate; posteriorcs ante angulum analem non sinuatæe.

Ilead smooth. Ocelli none. Antenne of moderate length, with distinct joints, microscopically ciliated. Tongue very short, naked. Miaxilliny palpi very short, distinct. Labial palpi rather short, reflexed, cylindrical, slender, pointed; the third joint longer than the second. Abdomen elongate, convex. Wings oblong, with short cilia; the anterior ditaled posteriorly and truncale; the posterior not sinuated before the anal angle.

Only one species is known in this singular genus; it flies at dusk among Sparganium, heavily and sluggishly. The larva, when young, mines the leaves, and afterwards bores down the stems of thic Sparganizm; it is dirty greyish-white, remarkably elongated, with a peculiarly flattened tail; it clianges to a pupa inside the stem of the plant.

1. Sparganella, Wenner (Thun.) I. S. 7. 83 (1794).-Sparganiella, 'Treit.; Dup.; 'Zell.-venosa, Haw.; Step.-tostella, Ilüb. Alis anticis ochreis, dorso ac vitta media saturate fuscis, venis ommibus dilute luteis, punctis plicx saturate fuscis. Exp. al. 10-11 $\frac{1}{2}$ lin. 
Ilead, face, and palpi pale ochreous. Antennac ochrcous, with darker ammulations. Anterior wings ochreous, with the imner margin and a broad space between the fold and the costa dark fuscous, in which lowever all the reins are conspicnous as pale ochreous streaks; along the fold are four or five dark fuscous spots, of which the two first are the most conspicuons, and on the dise beyond the midelle is a dark fuscous blotch; cilia fuscous. Posterior wings white, with a pale fuscous cloud near the base; cilia whitish.

In some specimens the anterior wings are of a uniform purplish-fuscous, with only the costa narrowly pale ochreous.

Not scarce among Syarganizm in July and August. The larva feeds in tho Sparganium in May and June.

\section{Genus II. SEMIOSCOPIS.}

Semroscor'Is, Hüb. V. 402 (1816); Step.; Zell. Epigraphia, Dup. Lemmatoplitla p., Treit.

Capilli appressi, in conulum frontalem producti. Ocelli parvi, pone oculos. Autenne crassiuseula, $\delta$ pubescentes. Haustellum breve, squamatum. I'alpi labiales arcuati, arliculo secundo squamis appressis, articulo tertio acuminato. Ale mediocriter ciliate, anteriores oblongo-ovate, posteriores ovate. $\Lambda$ la anteriores: venxe apicalis furcate ramus inferior supra vel in apicem exit, infra cam vena quinque, ultima interdum cum penultima connexa, valde curvus; vena subdorsalis furcata; als posteriores: vena apicalis ante apicem exit, infra eam venæ dux e venula transversa, vena mediana bifida.

Head smooth, the scales prolonged in front, forming a little cone. Ocelli small, behind the eycs. Antenne rather thick, in the $\delta$ pubescent. 'Tonguc short, clothed with scales. Labial palpi arched; the second joint with appressed scales; the third joint acuminate. Wings with moderately long cilia; the anterior oblong-ovate; the posterior ovate. In the anterior wings, the lower branch of the forked apical vein runs out in or above the apex; below it are five veins from the discoidal eell, the last much curved, sometimes united with the penultimate; the subilorsal vein is furcate. In the posterior wings the apical vein rums out before the apex, below it are two veius from the transverse vein; the median vein is bifid.

There are only two British species in this genus, although two others are known on the continent. 'Ihey both appear in the carly spring, and being sometimes met with on palings and on the trumks of trees, are the objects of many a healthful walk to the young collector.

The structure of the palpi affords sufficient character at once to recognize our species. 
a. Terminal joint of the palpi almost porrected, short, naked. Sp. 1 . a $a$. Terminal joint of the palpi crect, rather long, clothed with scales. Species 2.

1. Avellanella, IIiib. Tin. 27 (1S01); Trcit.; Step.; Dup.; Erers. Alis anticis dilute grisco-ochreis, fusco-irroratis, stria basali plica, ante medium angulata et in medio disci desinente, saturate fusca. Lxp. al. 11 lin.

IIead and face greyish-ochreons. Palpi dark fuscous; sccond joint internally at the base pale ochreous; terminal joint entirely pate ochreous. Antenna greyish-fuscous. Anterior wings pale greyish-ochrcous, somewhat irrorated with fuscous, with a dark fuscous strrati from the base along the fold, angulated towards the costa, and teminating on the dise about the middlle of the wing; on the costa beyond the middlle is a pale fuscous blotch, and an angulated fuscous mark lies at the ternination of the discoidal cell; hinder margin and anex of the cosla spotted with dark fuscous; cilia pale grey. P'osterior wings pale greyish-fuscous, with paler cilia.

Not common; appears at the end of March and beginning of April among birches.

2. Steinkellneriana, W. V. 130. 16 (1776); Schr.; Lienig.Sleinkelnerana, Fab.; Step.-Sleinkelneri, IIaw.-Sleinkellnerella, Treit.; Dup.-characterella, Hüb. Alis anticis griseo-fuscis, vix rosco-tinctis, macula angulata disci ante medinm (angulo dorsum versus), striolaque postica angulala (angulo apicem versus) nigvis. Exp. al, 10 lin.

IIead and face greyish-fuscous. Palpi grcyish-fuscous; terminal joint somewhat ochreous, with a dark fuscous ring before the apex. Autcmue fuscous. Auterior wings greyish-fuscous, with a slight rosy tinge, with a small black spot near the bise on the subeostal vein; before the middle is an angulated black mark on the disc (with the angle towards the inner margin), beyond it is a dark fuscous cloud on the costa, below which is a small angulated black mark (the angle of which is tumed towards the apex of the costa); the hinder margin and apex of the costa arc delicately spotted with black; cilia greyish-fuscous. l'osterior wings palc greyish-fuscous, with pale fuscous cilia internally darker.

Not scarce in April. The larva fecds (according to Madame Iicnig) in August and September, on hawthorn and mountainash, between turned-down leaves.

\section{Genus III. ENICOSTOMA.}

\section{Enicostous, Step. H. iv. 226 (1834). Gelechia p., Zell.}

Capilli superne suberecti, in comulum frontaleu producti. Ocelli nulli. Antemic setacen. Haustellum mediocre, squamatum. Palpi labiales arcuati; wrliculo secundo longo, squamis appressis; tertio lacvi, 
adsecndente, acuminato. Nhe mediocriter ciliats, anteriores latiusculce ovate, posteriores ovate ante apicern levissime retuse. Alat anteriores: vena apicalis furcata ante apicen exit, infra eam vena quinque, vene submediane apex, medianam valde approximans, incrassatus; vena subdorsalis fureata. Ale posteriores : vena apjealis simplex ante apicem exit, infra eam venæ duw e venula transversa; vena mediana trifida.

IIcad almost rough; scales produced in front in a little cone. Ocelli none. Antenne setaccous. Tongue of moderate length, scaled. Labial palpi arched; the second joint long, with appressed scales; the third joint smooth, aseending, pointed. Wings with moderate cilia ; the anterior rather broad, ovale; the posterior ovate, very slightly retuse before the apex. In the anterior wings the furcate apieal vein runs out before the apex; below it are five veins from the discoidal cell; the apex of the submedian vein, which closely approximates to the medim, is thickened; the subdorsal vein is furente. In the posterior wings the simple apical vein runs out before the apex, below are two veins from the transverse vein; the median vein is trifid.

Only one species is known in this genus; it is occasionally beaten out of hedges, and, both in flight and when first scen in the net, has some resemblance to a Sciaphila. The pale green larva fecds in August and September, on the underside of the leaves of the sloe, spinning a slight web, and causing the leares to assume a slightly deflexed form.

1. lobella, IV. V. 138. 9 (1776); IIüb.; Schr.; Treit.-Thunbergana, Fab.; Step.-Thunhergii, Haw.-Ingubrella, Dup. Alis anticis saturate griscis, punctis quinque scabris (tribus fere fiscian obliynam ante medium formantibus, duobus disci oblique positis pone medium) nigris. Exp. al. 8 lin.

Head and face dark grey. Palpi dark grey; terminal joint whilish, with the base and a ring before the apex black. Antenna dark fuscous. Anterior wings dark grey, with five spots of clevated black scales, three before and two beyond the middle; the first three are placed obliquely in a transverse line, the other two are placed obliquely on the dise (the lower one being the posterior); the hinder margin is spotted with dark fuscous, and there are some small dark fiscous clouds along the costa; cilia pale grey. Posterior wings pale grey, with paler cilia.

Not searce, in hedges in June. The larva plentiful in August and September on the sloc.

\section{Genus IV. PHIBALOCERA.}

Punulocers, Step. H, iv. 192 (183.6). Carcina, '/ell. Carcina p., ILüb. Lampros p., Treit. 
Capilli ilepressi, frons obtusa. Antenue alis multo longiores, articulis compressis. Haustellum mediocre, squamatum. Palpi maxillares brevissimi. Palpi labiales mediocres, idseendentes, articulo secuudo longiore infra pilis appressis, apjicem versus incrassato, tertio suberecto, teuni, acuminato. Alac oblonge, mediocriter ciliatie, anteriorum costa conerara, apice aculo. Ale anteriores: vena apicalis rami supra et infra apieem exeunt; cellula secundaria indicata; vena mediane ramus primus a secundo longissime distat, sccundus ct tertius in fur-

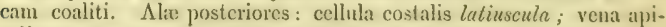
calis a sequente separata; vena mediana trifida.

IIead smooth, in front obtuse. Antenne mueh longer than the wiseg.s; the joints compressed. 'Tongue of moderate length, sealed. Maxillary palpi very short. Iabial palpi moderately loug, ascendiner the lonerer second joint with appressed scales beneath, thickened towards the ajex, third joint netrly erect, slender, pointed. Wings oblong, with moderate cilia; the costa of the anterior wings convex; the apex acute. In the anterior wings, the branches of the apical vein run out above and below the apex; the sccondary cell is indicated; the first branch of the median vein is very remole from the sccond; the second and third are united into a fork. In the posterior wings the costal cell is ratleer broad; the apical vein is unconnected with the following; the median vein is trifid.

'This genus contains only one British species (another is, I believe, known on the continent); it is frequently beaten from helges and bushes, when it may be observed flying sluggishly, or rather filling to the ground; for inded it only applears to make use of its wings to break its fall. The larva is polyphagous, fecting mnder a web on the underside of the leaves of the oak, beech, pear, bramble, etc.

1. Quercana, Fab. S. 13.652. 39 (1775); Don.; ILaw.; Stel.-Fagana, IV. V. ; IIüb.; Schr.-Faganclla, 'Treit.-cancella, Iluib. Nlis anticis dilute grisco-rufis, costie basi, macula quadrata coste pone medium ciliisque dilute flavis. Lxp. al, 9 lin.

IIead and face pale rosy-grey. l'alpi pale recldisli-ochreous, internally palcr. Antemus pale rosy-grey. Anterior wings pale rosy-grey, sonewhat suflused with resy, with an obseure oblique dark strigil hefore the middle, and two fisseons spots on the rlise, one in the midulle, the oflere beyond the middle, somelimes united to a fuseous bloteh on the fold; the base of the costa, and a quadrate spot on the costa beyond the michlle, are pale yollow; the himber marnin and atpex of the costa rosy-fuscous; eilia pate yellow, at the anal angle pale rony-grey. P'osterior wings whitish, with a slight rosy-fuscous tint, with paler rilia.

An abumelant species in July and August. I'le larva polyphagous in May and June. 


\section{Genus V. EXFRETIA.}

Exarexia, Sta. Ent. Trans. v. 152 (1849).

Capilli depressi. Ocelli nulli. Antemne $(\delta)$ pubescente-ciliatis. IIanstellum mediocre, squamatum. Palpi maxillares brevissimi. Palpi labiales mediocres, reflexi, articulo secundo infra scopiformi, tertio teuni, levi, acuto. Ale oblonga brevins ciliate, anteriores costa leviter sinuata, ciliis sub apieem leviter retusis, posteriores marginc postico ante angulum analem rotundatum sinuato. Ala anteriores: venx apicalis furcata ramus inferior in ajiccm exit; infra cam rami quinque; veno medians rami cluo primi in fuream conjuncti; submediana a mediana distat, apice incrassato. Ale posteriores: venæ subdorsales tres, tertia in basi pliceformis; vena mediana trifida; cellula costalis sensim coarctata; vena apicalis simplex.

IIead smooth. Ocelli none. Antenure (of the male) pubescent. 'Tougue of moderate length, sealed. Maxillary palpi very short. Labial palpi moderately long, reflexed; the second joint beneath resembling a brush; the third joint slender, smooth, pointed. Wings oblong, with short cilin; the costa of the anterior vings slightly sinuated, and the cilin below the apex very slightly emarginate; the hinder margin of the posterior wings sinuated before the rounded anal angle. In the anterior wings the lower branch of the furcate apical vein runs into the apex; below it are five veins from the discoidal cell; the two first branclies of the median vein are united into a fork; the apical portion of the submedian, which is remote from the median vein, is thickened. In the posterior wings are threc subdorsal veins; the third thin towards the bnse; the median vein is trifid; the costal cell is perecptibly narrowed, and the apical vein is simple.

Of this peculiar genus only one species is known, which till last year was very rare; it appears more frequent in the northern counties of England, but one specimen was taken in Norfolk by Mr. Wing. 'The species is thought to frequent the Artemisia vulgaris.

1. Allisella, Sta. Ent. Trans. v. 152. pl. 17. f. 1 (1849). Alis anticis plumbeo-griseis, stria obliqua costali pone medium rufo-grisca, in qua macula disci saturate fusca. Exp. al. 10 lin.

IIead reddish-grcy. Face lcaden-grey. Palpi reddish-grey, intermally leaden-grey. Antemua dark fuscous. Anterior wings leadengrey, with a reddish-grey bloteh near the immer margin towards the base, a short redelish-yrey oblique streak from the costa before the middle, terminating in a small dark fuscous spot, and an oblique reddishgrey streak from the costa a little beyoud the middle, rcaching nearly latil across the wing; in this streak on the dise is an oblique dark fuscous spot; the apical portion of the wing is rather clouded with reddishgrey, and there are some reddish-grey spots along the apex of the costa; 
cilia leaden-grey, with a slight reddish tinge. Posterior wings pale greyish-fuscous, with paler cilia.

Occurs in the north of England in July; taken also on the coast, in Norfolk and Kent.

\section{Genus VI, DEPRESSARIA.}

Depiessaria, IIaw. L. B. 505 (1812); Curt, ; Step.; Zell. IIamylis, Dup. Hamylis p., Treit, ; Zett.

Capilli depressi. Ocelli nulli. Antenna articulis confertis, vix denticulatis. IIaustellum mediocre, squamatum. Palpi maxillares brevissimi. Palpi labiales mediocres, reflexi, articulo sceundo infia scopiformi, tertio tenui, lecvi, acuto. Abdomen planum, squamis marginatum. $\Lambda$ lie oblongxe mediocriter ciliata, posteriores margine postico ante angulum analen rolundatum plerumque sinualo. Nlo anteriores: vena apicalis furcata ramus inferior ante apicem exit; infra cam rami quinque; vene mediane rami duo primi in fuream conjuncti; subincliama a medima distat, apice incrassato. Ale posteriores: vene sublorsales tres, tertia in basi pliceformis; vena mediana trifida; cellula costalis sensim coaretata, vena apicalis simplex. Head sinooth, Ocelli none. Anteme with the joints compressed, hardly denticulate, not pubescent. Tongue of moderate length, sealed. Maxillary palpi very short. Labial palpi moderately long, reflexed; the sccond joint beneath resembling a brush; the third joint slender, smooth, pointed. Abdomen flat, with projecting scales at the sides. Wings oblong, with moderate cilia; the anterior not emarginate on the costa, slightly romuded at the apex; the posterior wings generally with the linder margin emarginate before the rounded anal angle. In the anterior wings the lower branch of the furcate apical vein runs into the costa before the apex; below it are five veins from the discoidal cell; the two first bramclies of the median vein are united into a fork; the apienl portion of the submedian, which is remote from the median vein, is thickened. In the posterior wings are three subdorsal veius, the third attenuated at the base; the median vein is trifid; the costal cell pereeptibly narrowed; the apical vein is simple.

An extensive but very natural genus, of which we have no less than thirly-seven British species, and many others are known on the continent. The perfect insects of several species are extremely retired in their habits, and keep themselves so well concealed that they are rarely or never seen: some come out from their lurkingplaces after dusk, and, crawling up the stems of the plants on which they feed, may be seen by the aid of a lantern, but readily lake alarm and drop again to the ground; a few, such as applana, are less anxious for concealment, and may be met with pleutifully 
in the carly spring, llitting about the leafless heclges. Most of the species appear at the end of summer, and, after having hybernated, are met with in Mareh and $\Lambda$ pril in rather wasted condition. There is a peculiarity in the perfect insects of this genus, that they have the power of sliding about when laid on their backs, shooting forwards much in the style of Nocture Tragopogonis. The larve are extremely active, and feed on a variety of substances, some feeding in rollecl-up leaves of composite plants, some in the leaves and others in the umbels of the limbellifere ; many of the latter descend from the plant on the slightest agitation of it, and considerable cantion is neessary in the attempts to collect them. The full-ferl larve deseend to the ground, and change to the pupa state among the fallen leaves; the larva of IFeracliana frequently enters the stem of the IIcraclium Syliondylium, undergoing its changes there.

The extreme similarity of many of the species renders the determination of them a matler of some difficulty, and unfortunately the genus hardly admits of a good subdivision; the best I have been able to accomplish is by the following table:-

4. Anterior wings dusted and spotted, or veined, but not with numerous short longitudinal streaks.

b. Anterior wings whitish. Species 11 .

b b. Anterior wings pale greyish-ochreous. Sp, 6, 12, 19, 20, 24 .

$b \quad b \quad$. Anterior wings ochrcous. Species $1,2,3,4,5,8,9,10$.

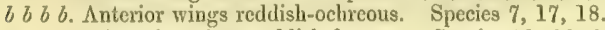

$\begin{array}{lllll}b & b & b & b & b\end{array}$. Anterior wings reddish-fuscous. Species 21, 22, 23 .

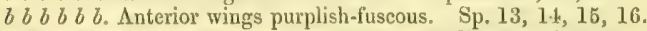

a a. Anterior wings with numerous short longitudinal streaks. Species $25-37$.

1. costosa, IYaw. L. B. 508 (1812); Step.; Sta. - Spartiana, ITuib.—depnectella, Hüb.; Trcit.; Dup. Alis anticis acutiusculis, diluto ochucis, rufo-fusco nebulosis, punctis cluobus disci ante medium nigris, nebula pone medium fore costam tangente salurate fusea, in ea pruncto disci albo; ciliis rufo-fuscis, angulum analem versus griscis. Kxp. al. 10 lin.

IIead and face palc ochreous. Palpi pale ochreous; second joint beneath fuscous; terminal joint with a narrow ring before the apex, and the extreme apex fuscous. Antenux fuscous. Anterior wings rather acute, pale ochreous, clouded with reddish-fuscous, with an oblique dark fuscous streak near the base of the inner margin, not reaching to the subcostal vein; on the disc before the middle are two blick spots, of which the anterior and upper one is frequently obsolete; beyond the midnle is a dark reddish-fuscons blotch, alnoost lonching the costa, and in it on the dise is a white spot; the pale hinder fascia is 
rather indistinct, and not acutely angulated; the veins posterionly are more or less distinctly indicater by fuscous streaks; cilia rerldish-fuscons, towards the nual angle grey. I'osterior wing whitish-grey, a little darker postcriorly, with whitish cilia.

Common in July and August among broom and furze (Ulex Europacus), on which plants the larva feeds in Junc.

2. liturella, IF. V. 237. + (1776) ; Schr.; Treit.; Dup.; Sta.Sparmanniana, Lab.; Step.-Glavella, Ilüb.-flarosa, Haw. Nlis anticis latiusculis dilute ochreis, saturate ochreo-nebulosis, punctis duobus disci nigris, stria saturate ochere obliqua in dorso prope basim incipicnte, in nebulam parvam pone medium fuscan desincnte. Exp. al. 10 lin.

IIead and face pale ochreous. I'alpi pale ochreous; sceond joint bencath pale fuscous. Antemne dark fuscous. Anterior wings ratleer broud, pale ochreous, with some darker ochreous clouds; on the inner margin near the base is a small dark fuscous spot; on the dise are two black spots, one before, the other beyond the middle; bencath the latter is a small fuscons blotch, in which a dark octreous streak from the inner margin near the base appears to terminate; beyond is a pale fuscous oblique streak, often very indistinet; hinder margin spotted with fuscons; cilia very palc ochrcous. P'osterior wings whitish-grey, with some dark spots towards the apex of the hinder margin; cilia whitish.

A common species, appearing in July and August; the larva fects in rolled-up leaves of the knapweed (Cenianrea vigia) in June.

3. pallorella, 7ell. Isis, 1839 , p. 195 ; Sta. Alis anticis angustulis dilute ochreis, punctis duobus disci nigris, stria lata fusca prope dorsum ante medium incipiente, costam versus subcurvata, pone punctum secundum desinente, venis postice saturate fuscis. Exp. al. $10 \mathrm{lin}$.

Head and face pale ochrcous. Palpi pale ochreous; sceond joint bemeath pale fuscous. Antema dark fuscous. Anterior wings ralher narrox, pale ochreous, with a black spot near the inner margin towards the base; on the dise are two black spots, one before, the other beyond the middle; a broad fuscons streak arises near the inner margin not far from the base, and, curvingr a little upwards, terminates rather beyond the second spot of the dise; all the veins are posteriorly indicated by dark fuscous scales; the hinder margin is spotted with black; cilia very pale ochrcous. Posterior wings greyish-white, with a slight fuscous tinge; some spots towards the apex of the hinder margin rather darker; cilia whitish.

'Taken in the autumn in several places on the coast; at Dover' and the Isle of Wight.

4. Umbellana, Stcp. II, iv. 197 (1934).-Ulicetclla, Sta. Alis 
anticis dilute ochrcis, punctis duobus disci nigris, venis omnibus dorsoque saturate fuscis, Exp. al. 10 lin.

Head and face pale ochreous. Palpi fuscous, interually pale ochreous; terminal joint pale ochrcous, with the tip dark fuscous. Antenue fuscous. Anterior wings pale ochreous, with all the veins and the inner margin dark fiescons; on the dise are two black spots, one before, the other, smaller, beyoud the middle; hinder margin spotted with black; cilia pale greyish-ochreous. Posterior wings whitish-grey, a little darker posteriorly, with some dark fuscous spots at the apex of the hinder margin; cilia whitish.

Not uncommon among furze-bushes from August to October.

5. assimilella, Treit. E. S. ix. 1. 259 (] 832 ); F. v. R. ; Dup.; 7ell.; Stit. - imorella, Step. - atomella, Step,? Alis anticis dilute ochreis, fusco-nebulosis, nebula dorsali prope basim saturate fusca, puncto disci ante medium nigro, nebuia fusca in medio obsoletius plicam versus producta; ciliis dilute ochreis. Exp. al, 9 lin.

ILead pale ochreous. Face whitish. Palpi pale ochreous; second joint slightly fuscous beneath; terminal joint with a dark fuscous ring before the apex. Antenne dark fuscous. Anterior wings pale ochreous, clouded with fuscous, with a dark fuscons blotch on the inner margin near the base, hardly reaching across the fold; a black spot on the disc brfore the middle is followed by a fuscous bloteh, of which a paler continuation extends to the fold; hinder margin spotted with dark fuscous; cilin pale greyish-ochicons. Posterior wings whitish-grey, a little darker posteriorly, with the apex of the hinder margin spotted with dark fuscous; cilia whitish.

Common among broom in June and July; the larva fecd between united twigs of broom in March and April.

6. nanatella, Str. Ent. Trans. v. 15\%.pl. 17. f. 2 (18\%9). Alis anticis breviusculis, albido-octureis, fusco-irroratis, posticc fusco-suftusis, puncto disci ante inclium nigro, nebula fusen in medio, costam fere tangente; alis posticis grisco-fuscis. Exp. al. 7 lin.

IIead and face whitish-ochreous. Palpi very pale ochreons; torminal joint spotted with fuscous below the apex. $\Lambda$ ntenne pale fuscous. Anterior wings rather short, whilish-ochrcous, irrorated will fuscous; towards the atpex much suflused with fuscous; on the dise, a little beforc the middle, is a black spot; beyoul which, and almost touching the costa, is a fuscous bloteh; the hinder margin and apex of the costa are spotted with pale ochreous; cilia pale greyish-ochreous. Posterior wings greyish-fuscous, with paler cilia.

Not common; has occurred at Charlton, Mickleham, and near Dover, in August.

7. atomella, W. V. 137. 6 (1776); IIüb.; Sta.-atomosa, IIarv. -pulverella, Treit.; T. v. 1R.-respersella, T'rcit.-intermediella, Sta. $\Lambda$ lis anticis ochreis rufo-griseo fore suffusis, stria obliqua dorsali prope 
basim saturate fusen, punctis duobus disci ante medium nigris, punclis rlnobus disci pone medium albis obsolelis, sub nebula parva fusca. Exp. al. $9 \frac{x}{2}$ lin.

Head greyish-ochrcous. Face palc ochrcous. Palpi redlish-grey, internally pale ochreous; terminal joint pale ochrcous, with a ring at the bisc, a ring before the apex, and the extreme ayex lark fuscous. Antennac pale fuscons. Anterior wings ochreous, somewhat suflused with reddish-grey, with an oblique dark fuscons streak nere the base of the inner margin, reaching only half across the wintg; on the disc before the midlle are teo black spots (the antcrior nearer to the costa), followed by a few white scales, and in a line with the lower one are two faint white spots, above which is a small fuscous blotch; the pale hinder fascia is not sharply angulated and very indistinct; along the linder margin are some dark fuscous spots; cilia greyish-ochrcous. Posterior wings pale grey, with paler cilia.

Not common; appears in August and September. The larva fecds on broom and Cicnista tinctoria in May and June.

8. arenella, W. V. 137. 3 (1776); Treit.; F. v. R.; Dup.; Sta.

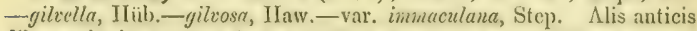
dilute ochreis, saturate fusco maculatis et uchulosis, stria obliqua dorsali prope basim saturate fusca, punctis duobus disei ante medium nigris, nebula in medio, punctoque posteriore saturate fuscis. Exp. al. 10 lin.

Ilead ochreons. Tare pale ochreous. l'alpi ochreous, internally paler ; terminal joint with a ring at the base, a ring before the apex, and the extreme apex dark fuscous. Antenne dark fuscous. Anterior wings pale ochreous, spolled and clouded with darli fuscous; on the inmer margin near the base is an oblique dark fuscous streak, reaching nerrly to the subcostal vein; on the disc before the middle are two black spots (the anterior nearer to the costa), followerl by a dark fuscous bloteh, beyond which and further from the costa is a dark fuscous spot; the indications of a pale linder fascia are very indistinet; the costa is spotted with dark fuscous, and there are some black spots along the hinder margin; cilia pale ochreons. P'osterior wings whitish-grey, with some dark fuscous spots towards the apex of the hinder margin; cilia yellowish-white.

Common, appearing in August; lybernated sjecimons are not unfrequent in April. The larva feeds on Centanrea nigra in June and July.

9. propinquella, Treit. F. S. x. 3. 18.1 (1835); F. v. R.; Sta. -gilvosa var. $\beta$. II aw. Alis anticis breviusculis, dilute ochreis, saturate ocheromarmoratis, stria oblipua dorsali prope basim saturite fusca, punctis duobus disci ante noclium nigris, nebula in medio saturale fusca nigrave costam fere tangente. Exp. al. 8: lin.

Head and fice pale greyish-ochreous. P'alpi pale fuscous, internally palc ochreous; terminal joint pale ochrcous, with a fuscous ring at the base and a dark fuscous ring before the apex. Antenna pale fus- 
cous. Anterior wings rather short, palc ochreous, mavbled wilh darker octereous; near the base of the imner margin is an oblique dark fuscous streak reaching nearly to the subeostal vein; on the disc before the mildle are two small black spots (the anterior nearer to the costai), beyond is a darli fuscous, alnost black bloteh reaching nearly to the costa; the indications of a pale hinder fascia are extremely indistinct; the costa and hinder margin are spotted with dark fuscous; cilia pale greyishochreous. I'osterior wings pale grey, with pale yellowish-grey cilia.

Not uncommon; appening in September and October. The larva feeds on the underside of the leaves of thistles (Cirsium lanceolatum, etc.), making a gallery of silken web, in July and $\Lambda u$. gust.

10. subpropinquella, Sta. Ent. Trans, v. 156. pl. 17.f. $3(18.19)$. - Heracliella, I)up.? Alis anticis longiuseulis brumeo-ackereis, stria obliqua dorsali prope basin fere obsoleta fusca, punctis duobus disci ante medium nigris, nebula fusca in medio, putucto fusco interdum obsoleto pone medium. Exp. al. 10 lin.

Ilead greyish-ochreous. Face pale greyish-ochreous. Palpi pale fuscous, internally pale ochreous; terminal joint pale ochrcous, with a ring at the base, a ring before the apex, and the extreme apex dark fuscous. Antenne fuscous. Anterior wings brownish-ochreous, with an almost olsolete fuscous oblique streak on the inner mitrgin near the base; on the dise before the midldle are two black spots; the anterior ncarer the costa and beyond is a fuscons (rarely dark fiscous) bloteli, beyond which and further from the costa is a fuscous spot, sometimes obsolete; the hinder margin is spotted with dark fuscous; cilia greyish-ochreous. Posterior wings pale fuscous, towards the base paler ; cilia pale yellowish-grey.

Common near l'olkestone, in September ; also oceurs at Epping; and last summer Mr. Shicld, of Dublin, bred a specimen from a larva which fed (like that of propinquellue) on the underside of the leaves of thistles in June, producing the perfect insect in August.

11. Alstrcemeriana, Clerck, I. pl. x. f. 1 (1759); Limu. (S. N.); Step.-Alstremiena, Linn. (1i. S.) ; Lab.-Alstrermeri, llaw.-Alstromerella, Ireit.; Dup.-monilella, W. V.-puella, Ilüb-—albidella, Evers. Alis anticis albis, dilute griseo-ochreo irroralis, macula dorsali prope basim dilute fusca, punctis duobus parvis disci ante mediun uigris, ncbula in medio saturate fusca costam tangrente, in maculam salurate rufan terminata. Lxp. al. 8 lin.

Ilead and face white. l'alpi pale grey, internally white; terminal joint with a ring at the base, a ring belore the apex, and the extreme

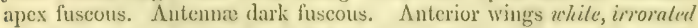
will pule greyish-ocheons; on the inner maryin near the base is an oblique pale fuscous bloteh reaching nearly to the subcostal vein; on the dise before the middle are two small black spots (of which the anterior 
is nearer to the costa); beyond is a dark fuscous bloteh touching the costa, and terminating in a dark red spot; the indications of a pale linder fascia are extremely slight; along the costa are some short dark fuscous streaks, and at the apex of the hinder margin are a few black spots; cilia pale greyish-ochreous. l'ostcrior wing's pale grey, towards the apex ratler darker, with whitish-grey cilia.

Not a common species; apprears in August, and hybernaterl specimens sometimes oceur in April. Mr. II arding discovered the larva last summer, feeding in the umbels of hemlock (Conium maculatum).

12. ciniflonella, Lienig et '/ell. Isis, 184.6. p. 2S0; Stn. $\Lambda$ lis antieis rufo-yriseis, albilo-irroretis, basi costaque usque ad medium albis, stria dorsali prope basim saturate fusca, punctis duobus disei sorpo comnexis nigris, posteriore et inferiore clonyato, strigulis duabus ablurevintis disei pone medium uigris, sape in maculam comnexis. lixp. al. 9? lin.

IIead and face white, mixed with reclelish-grey. Palpi fuseous, internally whitish; terminal joint whitish, with a fuscous ring at the base, and a broad black one before the apex. Antenua fuscous. Anterior wings reddish-grey, irrorated wilh wehilish, with the bise and the costa to near the midlle white; on the imer margin near the base is a dark fuscous streak reaching to the fold; on the dise before the midctle. are two black spots frequenlly connected, the lower and posterior one is rather elongated; on the disc beyond the middle: are two shore black streaks, frequently uniled inlo a bloted; at the extremity of the lower one is a white spot; the whitish hinder fiscia is not shorrply andoulated; the costa is spotted with fuscous, the hinder margin with dark fuscous; cilia reddish-grey. Posterior wings grey, with paler cilia.

This elegant species has been met with by Mr. Weaver, at liammoch, on the trunks of fir-trees.

13. purpurea, llaw. L. 13. 5ll (1812); Step.-vaccinelln, Ilïb.; Treit.; Dup. Alis anticis nufo-fuscis, basi ablupte, maculisque cos/alibus luteo-griscis, punctis dnobus disci ante medium nigris, melmen magnu in medio saturate fusca costam tangente. Exp. al. 8 lin.

Tleal yellowish-grey, mixed with datk fuseous. Face pale yellowish-grey. Palpi greyish-fuseous, internally whitish; torminal joint whitish, with two riugs and the extrene lip dark fuscous. Antrima dark fuscous. Anterior wings redilish-fuscons, irroruled with pale yolloncish-grey alony the costa; the base is almost rntircly pale yellowislgrey, abruptly terminated by an oblique streak from the immer margin extending to the subeostal vein; on the dise before the midtle are two black spots (the anterior nearer the eosta), they are followed by some: white scales; beyond them is a largr drati fuscous blolch fouching the costa, after which is a small white spot on the disc surrounded with dark fuscous; the pale hinder fascia is very indistinct, and rather acutcly angulated; cilia roldish-fuseous. P'osterior wings pale fuscous, whitish towards the base, with paler cilia.

VOL. III. 
Not rare, but nowherc abundant; witely distributed, appearing in August; lybernated specimens not uncommon in $\Lambda$ pril.

14. capreolella, Zcll. Isis, 1839. p. 196._caprella, Sta.-Zeplyyrella, Iliib.? Alis anticis griseo-ochreis, dorsum versus rufo-suffusis, basi dilutiore, punctis duobus disci ante medium nigris, duobus longitudinaliter positis pone medium albis. Exp. al. 7 lin.

IIead pale greyish-ochrcous, with some fuscous seales. Face pale greyish-ochrcous. l'alpi pale fuscous, internally pale ochrcous; terminal joint pale ochreous, with a fuscous ring at the base and nnother before the apex. Antenma fuscons. Anterior wings greyish-ochreous, along the inner margin with a slight reddish tint; on the inner margin near the pale greyish-ochreous base is an oblique fuscous streak renching to the subcostal vein; on the dise before the middle are two blick spots (of which the anterior is nearer the costa), they are followed by some white scales, and beyond in a line weille the lower one are two whilish spots surrounded by some dark fuscous seales; the pale hinder fascia is very indistinct and not acutely angulated; the hinder margin spotted with dark fuscous; cilin greyish-fuscous. Posterior wings greyish-fuscous, towards the base praler, with greyish-white cilia.

liew specimens of this have hitherto been taken; most of those have been beaten out of old thatch in September.

15. Hypericella, Hüb. Tin. 441 (1816); 'Treit.; Dup.; Sta.liturella, Hüb.? Step.?-litwosa, Iraw.? Alis anticis rufo-fuscis, caruleo-nigro (precipue costam versus) su!fusis (basi sape lutca), stria curvata disci ante medium nigra, maculis duabus coste dilute luteis; thorace, capillis, palpisque flavidis. Lxp. al. 9 lin.

Ilead and face pale yellow, intermixed with brownish. P'alpi pale yellow, with a few fuscous seales; the terminal joint with a black ring iminediately before the apex. Antenne dark fuscous. Anterior wings recl, with a slight fuscous tinge, suffused with bluish-black, especially towards the costa; the extreme base and the bisal portion of the costa is frequently pale yellow; on the dise before the middlle is a curred black streak, followed by a few pale yellow seales; above it is a pale yellow blotch on the cosia, and beyond ihe middle of the costa is another pale yellow blotch, which forms, as it were, the commencenent of a pale angulated hinder fascia; the hinder margin dark fuscous; the apex of the costa dark fuscous, spotted with pale yellow; cilia dark greyish-fuscous. P'ostcriogr wings grey, a little paler towards the base, with paler cilia.

The perfect insect is rarely scen. T'le larva is common, feeding in the tops of Ilypericum perforalum, in May and June.

16. conterminella, \%cll. Isis, 1939. p. 196; Sta.—curvipunclosa, IHaw.? Step.? Alis anticis rufo-fuscis, dilute luteo-griseo irroral is (basi sxpe dilute lutco-grisen), punctis duobus disci ante unedium in striam curvatam comnexis, squamis dilute lutco-griseis seruentibus, puncto 
disci pone medium dilute luteo-griseo, nigro-cincto; thorace, capillis, palpisque interdum dilute luteo-griseis. Exp. al. 9 lin.

Head and face pele yellowish-grey, mixcd with dark fuscous. Palpi reddish-fuscous, internally pale yollowish; terminal joint with a dark fuscous ring before the pale yellowish apex. Antennac fuscous. Antcrior wings reddish-fuscous, irroraled with pale yellowish-grey; the pale yellowish-grey base contains a small dark fuscous spot on the imner margin; on the dise before the middle are two black spots united into a curved streak, they are followed by some pale yellowish-errey scales, and beyond the middle on the dise is a yellowish-grey spot encircled with black; the pale hinder fascia is ruther obtusety angulated and somewhat indistinct; the hinder margin and apex of the costa spotted with dark fuscous; cilia greyish-fuscous. Posterior wings whitish-grey, darker towards the apex, with paler cilia.

Occurs occasionally among sallows in July and August. The larva plentiful in the terminal shoots of sallows and osiers in May and June.

17. Angelicella, Hüib. Tin. 337 (1816); Treit.; Zell.; Sta.-rubidella, I)up. Alis anticis dilute luteis, mfo-suffusis, puncto disci ante medium, puncto posteriore plice nigris, nebula nigra disci pone mediun; palporum articulo tertio immaculato flavido. Exp. al. $8 \frac{1}{3}$ lin.

IIead and face pale yellow. Palpi pale yellow, mixed with fuscous; terminal joint entirely pale yellow. Antenne fuscous. Anterior wings pale yellow, suffiesed with redelish, with a dark fuscous spot at the base of the costa, a reddish-fuscous streak from the imner margin reaching nearly to the costa, bordering the palc yellow base of the wing; on the dise before the middle is a black spot, and a little posterior is another on the fold; beyond the middle is a black blotch on the disc (which sometimes appears as though pleced in an oblique cloudy fascia); the hinder marrin and apex of the eosta are spotted with dark fuscous; cilia palc reddish-yellow. losterior wings whitish-grey, with paler cilia.

Not uncommon in the fens of Cambridgeshire, and near Bristol, among Angelica sylvestris; the perfect insect appears in July, the larva fecling on the Angelica in Jume (I am credibly informed that the larva feeds also on sallow).

18. Carduella, IIüb. Tin. 439 (1816); Step._mbidelln, Ilüb.? Alis anticis dilute rufo-ochereis, fusco-irroratis, punctis duobus disci ante medium nigris, duobns aliis ponc medium minus approximatis (anteriore ferc obsoleto). Exp. al. $7 \frac{\pi}{2}$ lin.

Head pale reddish-ochrcous. Face pale ochreous. Palpi pale reddish-ochreous, internally palc ochreous; terminal joint pale ochreous, with a ring at the base, a ring before the apex, and the cxtreme apex fuscous. Antennat fuscous. Sintcrior wings pale reudish-ochreous, wilh numerous scaltered fuscous scales; from the imer margin near the base is an oblique dark fuscous streak reaching only half across the wing; 
on the dise before the middle are two black spots (of which the anterior is nearer the costa); beyond the middle are two more remote, of which the anterior is rather obsolete; a pale hinder fascia is hardly indicated at all; the hinder margin spotted with dark fuscous; cilia pale greyish-ochreous. Posterior wings whitish-grey, with paler cilia.

A scarce species, hitherto only taken singly in various loculities in the south, in July and August.

19. ocellana, lab. S. L. 652.40 (1775); Step.-characterella, W. V.; Treit.; Dup.; Sta.-signella, Irïb.-signosa, IIaw. Mlis anticis dilutissime grisco-ochreis, squamis sparsis fuscis, punctis duobus disci ante medium saturate fuscis, macula fusea in medio infra coccineo-squamalo, puncto posteriore albo coccinco-cincto. Wixp, al. 10-11 lin.

Ilead and face pale greyish-ochrcous. Palpi pale greyish-ochreous, internally pale ochreous; terminal joint pale ochrcous, with a ring at the base, a ring before the apex, and the apex itself fuscous. Antenne fuscous. Anterior wings very pale greyish-ochrcous, with numerous fuscous scales, with a reddish-fuscous eloud on the imer margin near the base, extending rather obliquely towards the subeostal vein; on the dise before the midelle are two dark fuscous spots (of which the anterior is nearer the costa, and the posterior is rather clongated); in a line with the upper spot is a fuscous blotch, beloro vethich are some crimson scales, which also encircle a white spot beyond, and nearly in a line with the lower of the first two spots; the pale angrulated hinder fascia is rather inclistinct; the binder margin and costa are spotted with dark fuscous; cilia pale greyish-ochreous, with a slight reddish tinge. l'osterior wings whitish, with paler cilia.

Not unfrequent among sallows in the spring. 'The perfect insect appoars in August, but is then rarely met with. 'The larva fceds on sallows in July.

20. Yeatiana, Fib. S. I. ii. 286.60 (1781); Sta.-Ieatsii, IIaw, Yenlsanr, Step.-pulridulla, IIaw.; Step.; W. V.? Uiib.?-Boieclla, l'reyer.-albidana, 1)on.?-adspersella, Treit.? Alis anticis dilute griseoochreis, punctis duobus disci ante medium nigris, macula fusca in medio costiun versus, puncto postcriore albo fusco-cincto (venis omnibus interdum fuscescentilus). Exp. al. $9 \frac{1}{2}$ lin.

llearl pale greyish-ochreous. Face pale ochrcous. Palpi pale ochreous; sccond joint externally palc fuscous; terminal joint with a ring at the base, at ring before the apex, and the apex itself fuscous. Antenux fuscous. Anterior wings pale greyish-ochreous, with a dark fuscous streak from the inner margin near the base, extending obliquely nearly to the subcostal vein; on the dise before the midelle are two black spots (the anterior nearer the costa); they are elosely followed by a fuscous bloteh, beyond which and nearly in a line with the lower of the first two spots is a white spot surrounded by fuscous; hinder margin spotted with dark fuscous (in some specinens all the veins are 
indicated by fuscous streaks); cilin pale grcyish-ochrcous. Postcrior wings pale grey, towards the base whitish, with paler cilia.

Taken in many places near London in the autumn, by beating thatch.

21. applana, Tab. G. I. 294 (1776); IIaw.; Step.; Sta.-applanella, Fab. (L., S. Sup.) ; F. v. R.-Cerefolii, Retz.-Cicutella, Iü̈b.; Treit.; Dup. Alis anticis mufo-fuscis, fusco-nebulosis, punctis duobus disci ante medium nigris, squamis sequentibus albis, punctis duobus in cadem linea cum puncto inferiore allsis, saturate fusco-cinetis; ciliis alarum posticarum albido-griscis, apicibns non rufo-linclis. Exp. al. 10 lin.

IIead and face greyish-oehreous, mixed with fuscous. Palpi fuscous, internally pale greyish-ochreous; terminal joint pale ochreous, with a ring at the base, a ring before the apex, and the extreme apex dark fuscous. Antenne fuscous, more than tro-thirds the length of the antcrior wings. Anterior wings reddish-fuscous, clouded with fuscous; the bloteh near the base of the inner margin is sharply defined towards the pale greyish-ochircous base of the wing; but less sharply defincd towards the subeostal vein, where it terminates; on the dise before the middle are two black spots (of which the anterior is nearer the costa); they are generally followed by a fero white scales, and beyoud, in a line with the lower one, are two white spots, surromed by some dark fuscous seales; the pale hinder faseia is indistinet and obtusely angulated; the costa and hinder margin are spotted with dark fuscous; cilia redJish-fuscous. Posterior wings pale grey, paler towards the base; cilia whitish-grey, with the tips not rufous.

A most abundant species, flitting merrily along the leafless hedges in the carly spring. The perfect insect appears in July, and during the autumn is frequently met with by those beating thatch for the rarer species of the genus, but is rarely seen on the wing of its own accord. The larva feeds in June on the leaves of Authriscus syleestizs, Cherophyllum temulentum, and several other Umbellifere, turning over a small portion of the leaf; it is extremely active.

22. ciliella, Sta. Ent. Trans. v. 161. pl. 17. f. 7 (1819). Alis anticis dilute rufo-brunneis, punctis duobus disei ante medium nigris, squamis sequentibus albis, punctis duobus in eadem linea cum puncto inferiore albis, saturate fusco-cinctis; ciliis alarum posticarum albidogriseis, apicibus rufo-tirctis. Exp. al. 11 lin.

Ifead and face reddish-brown. Palpi xeddish-brown, interually pale ochrcous; terminal joint dirty ochrcons, with a ring at the base, a ring before the apex, and the apex itself lark fuscous. Antemme fuscous. Anterior wings pale reddish-brown, with a darker bloteh on the inner margin near the base, reaching to the subcostal vein (the space between it and the base being frequently paler than the rest of the wing); on the dise before the middle are two black spots (the anterior nearer the 
costa); they are followed by some white scales, and beyond, in a line with the lower one, are two white spots surrounded by some dark fuscous scales; the palc linder fascia is indistinct and obtusely angulated; the costa and hinder marnin are spotted with fuscous; cilia reddishfuscous. Posterior wings pale greyisl-fuscons, paler towards the base; the cilia paler, with the tips tinged with rufous.

Not common; sometimes obtained by beating old thatch in the autum. The larva feeds (according to $\mathrm{Mr}$. Allen IIill) in July, on the leaves and umbels of Angelica sylvestris.

23. granulosella, n. sp. $\Lambda$ is anticis griseo-ochreis, fusco-nebulosis, punctis duobus disci ante medium nigris, inferiore panllulum elongato, puncto pone medium subobsoleto albo. Exp. al. 8 lin.

Head greyish-ochreous. Tace pale ochreous. Palpi pale fuscons, internally palc ochreous; terminal joint pale ochrcous, with a ring at the base, a ring before the apex, and the extreme apex dark fuscous. Antenne fuscous, little more than half the length of the anterior wings. Anterior wings greyish-ochreons, clouded with fuscons, with a dark fuscous blotch on the inner margin near the base, sharply defined towards the base, less so at the subcostal vein, where it terminates; on the dise before the middle are two black spots obliquely placed, the lower and posterior one is ralleer elongated; in a line with it, beyond the midclle, is an almost obsolete white spot; indications of a pale linder fascia are not pereeptible; costa spotted with dark fuscous, hinder margin with a few fuscous spots; cilia pale greyish-ochrcous. Posterior wings pale grey, with whitish-grey cilia.

'laken at Deal, in September.

24. rotundella, Dougl. Zool. 1270. f. 8 (1816).-peloritonelln, Zell. Alis anticis angustulis dilute griseo-ochreis, puncto prope basim dorsum versus, puncto disci ante medium, punctoque (dor'so propiore) disci pone medium saturate fuscis. Wxp. al. $7 \frac{1}{2}$ lis.

Ilead and face palc greyish-ochreous. Palpi dirty ochrcous, internally whitish ; terminal joint palc ochreous, with a ring at the base, and another before the apex, pale fuscous. Antenne pale fuscous. Anterior wings rather narrow, pale greyish-ochreous, with a spot towards the inner marrin near the base, a spot on the disc before the middle, and another (rather nearer the inner margin) beyond the midille dark fuscous; at the apex of the hinder margin are a few dark fuscous spots; cilia pale greyish-ochrcous. Posterior wings pale grey, towards the base whitish, with palex cilia.

'Taken in September at Mickleham, Sanderstead, and near Folkstone; also near Dover, and in the Isle of Wight. Mr. Iarding lias bred a specimen (I believe) of this species, from a larva feceling on the flowers of Echium vulgare.

25. depressella, IIüb. Tin. 107 (1816); Dup.-depressana, Zell.; Sta.; lab.?-Bluntii, Curt.; Step.-collarella, Zett. Alis anticis fusco- 
mufis, dorsum versus saturatioribus, squanis sparsis dilute luteis, macula dorsali pone medium, fasciaque postica angulata (infra plicam obsoleta costam versus vix indicata) dilute luteis. Exp. al. 7 lin.

Ilead and face pale yellow. Palpi dirty yellow, internally whitish; terminal joint pale yellow, with a ring at the base and another before the apex, fuscous. Antenna reddish-fuscous. Anterior wings reddishfuscous, darker towards the inner margin, wilh some scatlered pale yetlow scales, and beyond the middle of the inner margin is a large pale yellonoish spot, followed by a pale yellowish angulated fascia, of which that portion only from the midalle of the dise to the fold is distinct (of the costal half especially ouly a few scales are present); cilia pale reddishgrey. Posterior wings pale fuscous, with paler cilia.

Few British specimens have yet been taken. Mr. Blunt met with it at Soutlichurch, Essex, in July, and Mr. Douglas took it at Folkstone in October. The larva feeds on the secds of the carrot and parsnep in July and August.

26. Pimpinellæe, Zcll. Isis, 1839. p. 196; Sta.-Pimpinalla, Dup.,- pulverella, Evers.—characterosa, IIaw.? Step.? Nlis anticis angustulis fuscescentibus, costam versus rufescentibus, squamis sparsis alhidis, striolis numerosis disci saturate fuscis, quamen zua ante, altera pone medium conspicuce. Exp. al. $8-8 \frac{2}{2}$ lin.

Head and face reddish-fuscous. Palpi redlish-fuscous, internally pale ochrcous; terminal joint reddish or pale fuscous, with a ring at the base and another before the pale ochrcous apex, dark fuscous. Antenna dark fuscous. Anterior wings rather narrow, rather pale fuscous, towards the costa rectdish, with several scattered white scales; towards the inner margin near the base is a dark fuscous dash; on the dise are numerous short dark fuscous streaks, of which one before and one beyond the middle are conspicnous; the pale hinder fascia is very indistinet and rather sharply angulated; the hinder margin and apex of the costa are spotted with dark fuscous; cilia reldish-fuscous. T'ostcrior wings greyish-fuscous, towards the base whitish, with pale greyish-fuscous cilin.

Not a common species; taken near Stout's Nest by Mr. Bedell, by beating old thatch, in September. The larva feeds in July and August on Pimpinella saxifraga.

27. albipunctella, Irüb. Tin. 149 (1801); Treit.; Step.; Dup.; 7,cll.; Sta.-albipuncla, Ilaw. $\Lambda$ lis anticis fisco-rufis, saluratius fusconebulosis, stria obliqua abbreviala disci ante medium salurate fusca, punclo disci pone medinm albo, fascia postica dilutiore angulata, inter nebulas fuscas posita. Exp. al. $8 \frac{\pi}{2}$ lin.

II and and face dark reddish-fuscous. I'alpi datrk reddish-fuscous, internally whitish; terminal joint cntirely clark fuscous, except the pale ochreous apex. Anterior wings reddish-fuscous, clonded wille dark fuscous, especially towards the base (whereby the ordinary dark spot 
on the costa, and larger dark spot towards the inner margin neate the base, are almost lost in the dark ground-colour); on the disc before the middle is a short oblique dark. fuscons strenk, and beyond the middle is a white spot on the dise, closely followed by the pale, not acutely angulated fascia, which is placed between two fuscous clouds; the hinder margin and apex of the costa are spotted with dark fuscons; riliat greyish-fuscous. Posterior wings jalc grey, towards the aljex inclining to fuscous, with paler cilia.

Not a scarce species; formerly I used to take it, at sugar, in July and August.

23. emeritella (v. IIcyd.), Sta. Eint. Trans. v. 167 (181.9). Alis anticis fusco-rufis, basin versus saturatioribus, squemis spursis albidis, puncto clongulo ante, puncto rotundo disci pone medium allidis, spatio interjecto siturate fusco, fascia postica pallida acute angulata, infra plicam valde obsoleta; thorace ac capile dilute luteis. Exp. al. 11 lin.

Ifered and fice pale yollow, with a slight reddish tinge. Palpi rectdish-fuscous; internally and the tip of the terminal joint pale yellowish. Antenne dark fuscous. Anterior wings reddish-fitscous, towards the base darker (wherehy the dark spot at the base of the costa and the rlark dash towards the imer margin near the base are almost obliteratcd), with numerous whitish scales; on the disc before the middle is an elongated whitish spot, and beyond the middle is a round whitish spot, the space between them being dark fuscous; the pale hinder fascia formed of whitish seales, begins on the costa rather before the middle, is rather sharply angulated and beeomes very indistinet below the fold; cilia pale reddish-grey. l'osterior wings whitish-grey, with paler cilia, with a slight reddish tint.

$\Lambda$ specimen of this conspicuous species, unique as 13ritish, is in Mr. Shepherd's collection. 'The perfect insect appears in August. The larva fecling on the tansy ('lenaetum vulgare) in July.

29. pulcherrimella, Sta. Ent. Trans. v. 16.4. pl. 17. f. 8 (1S19). Alis anticis fusco-rufis, squanis numerosis albidis, striolis multis disei saturate fuscis, quarmin une obliqua disci ante medium cum squanis sequentibus albidis conspicun, puncto albido pone strian alleran pone medimen, fascia postica pallida acute angulata; thorace ac capile dilute mufogriseis. Exp. al, $8 \frac{1}{2}$ lin.

Head and face pale reddish-grey. Palpi reddish-fuscous, internally whitish; terminal joint fuscous, with a ring at the base and another before the pale ochrcous apex, dark fuseons. Antemue dark fuseots. Anterior wings reddish-fuscons, soilh numerous whitish scules; a small spot at the base of the costa and a dash towards the inner margin near the base dark fuscous; on the dise are several short dark fuscous stroaks, of which an oblique one before the middle, folloned by some ichitish scules, is conspicuons; beyond a fuscons streuk on the dise beyond the middle is a small volitish spot; the pale hinder fascia is 
whitish and rather acutely angulated; the hinder margin and apex of the costa are spotted with dark fuscous; cilia redelish-grey. Poxterior wings grey, paler towarks the base; cilia pale grey, with a slight reddish tinge.

Occurs sparingly at Sinderstead and Mickleham in July.

30. Douglasella, Sta. Ent. Trans. v. 165 (1919). Alis anticis griseo-fuscis, squanis sparsis albilis, striolis mumcrosis saturate fuscris,

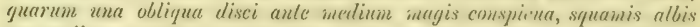
sequentibus, punclute albido pone striam saturate fuscum, disci pone. medium, fascia postica albida obuse angulata, au costam in maculan saturate fuscam cxcunte; thorace ac capile albis. Lixp, al. 8? lin.

Itead and face while. P'alpi fuscons, interaally palc ochrcous; terminal joint fuscous, with a dark fuscous ring at the latse and another before the pale ocheous apex. Anteme dark luscous. Anterior wings greyish-fuscous, woilh serallered whitish serles, with a small dark liuscous spot at the base of the costa, and a dark fuscous dash towards the inner margin near the base; on the dise are numerous sliort dark fitscous strenks, of which an oblique one before the middle is conspicuons, being followed by some whitish scrtes, and bryond anolher dert fircons. streali, on the dise beyond the middle, is a small whitish spot; the whitish linder fascia is almost oblusely angulated, and terminates in a dark fuscous bloteh on the costa; the hinder margin and apex of the costa are spotted with dark fuscous; cilia greyish-fuscous. l'osterior wings grey, towards the apex somewhat fuscous, with paler cilia.

A scatre specics, appearing in July and August; it has been taken at Mickleham, lolkstone, Dover, and the J.sle of Wight.

31. Weirella, Sta. Bint. Trans. v. 165. pl. 17. f. i) (1949).-npiost, IIaw.? Alis anticis fusco-rufis, saturatins fusco-ncbulosis, squamis sparsis albidis, stria ante, puncto prone disci metlum, squentis relbidis nolato saturate fuscis, fascia postica acute angulata obsoleta; alis posticis albidis, apiccm versus fuscescentibus. Exp. al, $9 \frac{1}{2}$ lin.

Tlead and face greyish-fuscous. Palpi dark reddish-îtscons, intermally pale ochrcous; terminal joint paler, with a dark fuscous ring before the pate ochreous apex. Antenne dark fuscous. Anterior wings reddish-fuscous, clouded with darker fuscous, and w ith seatlered whitish

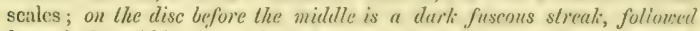
beyond the middle by a dark fuscons spot, in which are some velilish scales; the hinder fascia is indistinet and hardly acutely angulated; the hinder margin and apex of the costa are spotted with dark fuscous; cilia pale fuscous, varied with darker fiuscous. I'osferior wings whilish at the base, towards the apex pale fuscous, with paler cilia.

The perfect insect appear's in July, but is lardly ever seen ; a few specimens have been obtained by beating thatch in the atutumn. The larva (which I have found abundantly) feeds on $\mathrm{An}$ VOL. III. 
thriseus sylvestris in May and June, curling down a piece of the leaf; it closely resembles the larva of $D$. applana.

32. Chærophylli, Zell. Isis, 1839. p. 196; Sta-Iferacleana, Fab. (1. S. iii. 2).-badia, IIaw.? Alis anticis griseo-fuscis, maculu oblonga coste basali mfo-fusea, striolis numerosis nigris, squanis albiclis intermixtis, fiscia postica pallicla acute angulata. Exp. al. $9 \frac{1}{2}$ liu.

IIcal and face dark greyish-fuscous. Palpi dark fuscous; the sccond joint internally and at the tip pale ochrcous; terminal joint dark fuscous, with the tip pale ochrcous. Antenna dark fuscous. Anterior wings greyiste-fuscors, with the extreme baec of the costa and an oblique dash from the base to the immer margin dark fuscous; lovurds the base of the costa is a large reddish-fuscons blotch; along the dise are numerous short black strenks interspersed will whitish seales, and beyond the middle is a pale acutely angulated fascia, of which the costal arm reaches nearly to the middle of the wing; the hinder margin and apex of the costa are spotted with dark fuscous; cilia pale fuscous. Posterior wings pale greyish-fuscous, with paler cilia.

Not an uncommon species, appearing in August. 'The larva, which is extremely lively, fecds in July, in the umbels of Cheroj) flyllum temulentum, devouring indifferently the flowers or seeds.

33. ultimella, Sta. Ent. Trans. v. 166. pl. 17. f. 6 (1849). $\Lambda$ lis anticis griseo-fuscis, dilute rufo-linctis, striolis numerosis snturate fuscis, puncto elongato ante, puncto pone disci medium, saturate fuscis, squamis nomnullis albidis interjectis, fascia postiea pallidil acute angulatil, fere obsoleta. Exp. nl. 9 lin.

IIead and face greyish-ochrcous. Palpi fuscous, intemally pale ochreous; the terminal joint with the base and a ring before the julc ochreous apex, dark fuscous. Antemne fuscous. Anterior wings greyish-fuscous, with a reddish linge, with numerous longitudinal dark fuscous streaks; at the base of the costa is a dark fuscous sjot, and another larger towards the inner margin near the base; on the dise before the middle is an elongated dark spot, and a shorter dark spot follows it beyond the middle, between these spots are some whitish scales; the pale hinder faseia is acutely angulated, but rather indistinet; the hinder margin and apex of the costa are spotted with dark fuscous; cilia greyishfuscous. Posterior wings pale whitish-grey, posteriorly inclining to fuscous, with paler cilia.

Appears in September, when the species may sometimes be met with by beating old thatch; occurs at Lewes and l'olkstonc.

34. nervosa, IIaw. L. 13. 506 (1812); Step.; Sta.-Dancella, IV. V.? 'Trcit.? '/ell.?-apiella, 1lüb.?-apicella, Stcp.? Alis anticis griseo-fusces, dilule rufescente-tinetis, striis numcrosis saturate fuscis, junctis duobus disci, altero ante, allero post mediun saturate fuscis albillo-cinclis, fascia postica pallida valde angulatal, apjece sno ad alse apicem accedtente. Exp. al. 10-11 lin. 
IIead and face greyish-fuscous. Palpi dark fuscous, internally pale greyish-ochrcous; terminal joint rather paler, with the base and a ring before the palc ochrcous apex, dark fuscous. Antenne fuscons. Anterior wings greyish-fuscous, with a very slight reddish linge, with numerous longitudinal fuscous streaks; the base of the costa and a small spot near the imer margin, towards the base, are dark fuscolis; on the dise are two dark fuscous spots (one before, the other beyond the mid(lle), surrounded by soinc whitish seales; the pale linder fiscia is extremely angulated, and its apex approximates towards the apex of the wing; the hinder margin and apex of the costa are spotted with dark fuscous; cilia greyish-fuscons. l'osterior wings pale grey, with palcr cilia.

MIany specimens have been obtained in various parts of the country in September, by beating old thatel. The larva feeds (according to MIr. Allen 1lill) in July in the umbels of Cienta virosa. (If the continental Dancella be identical, the larva also fecds on Phellandrinm aqualicum, changing to the pupa state within the stcm of that plant.)

35. badiella, Ilüb. Tin. 92 (1801) ; Treit.; Zell.; Sta. ; Stcp.? $\Lambda$ lis anticis latiusculis salurale fusco-bromneis, striis numerosis saturate fuscis, punctis duobus disci, altero ante, altero pone medium saturate fuscis, squamis albidis interjectis, fascia pallida postica angulata obsoleta. Exp. al. 11 lin.

Ilead and face greyish-fuscous. Palpi dark fuscous, internally pale greyish-ochrcous; terminal joint paler, with the base, and a ring before the pale ochrcous apex, dark fuscous. Anterior wings rather broad, dark fuscons-browen, with some obseure darker longitudinal streaks; towards the inner marrin near the base is a large dark fuscous blotels; on the dise is a dark fuscous spot before the middle, and another beyond the middle, generally accompanied. with some whilish scales; a pale amgulated hinder fascia is indistinetly indicated by some whitish seajes; the hinder margin and apex of the costa are spotted with dark fuscous; cilia pale fuscous. P'osterior wing grey, with greyish-fuscous cilia.

$\Lambda$ varicty occurs of which the brush bencath the second joint of the palpi is bright ochreous.

Occurs at Sanderstead and Stoat's Nest among the jumiperbushes in August.

36. Pastinacella, Dup. L. T. xi. 153. pl. 291. f. 4 (1838); Sta. $\Lambda$ lis anticis angustulis dilute grisco-fuscis, punctis tribus ante mediums saturate fuscis, penclis duobns disci, altero in medio, altero pone mediun saturate fuscis, spatio interjecto dilutiore, fuscia postica pallida obsolcta angulata. Exp. al. 11잘 lin.

llead and faec pale greyish-ochreous. Palpi pale greyish-ochreous; terminal joint with the base, and a ring before the pale yellowish apex, dark fuscous. Anteme fuscous. Anterior wings rather narrow, pale greyish-fiscons, with a dark fuscons spot at the base of the costa, anch a 
dark fuscous blotch near the inner margin towards the basc; before the midlle are three dark fuscous spots (one on the fold, one above it on the dise, and one rather anterior a little towards the costa); in a line with the middle one are two other darle fuscons spots on the disc, the space betreen which is generally puler than the ground-colour of the wing; beyond is the pale rather indistinct angulated fascia; the hinder margin and apex of the costa are spotted with fuscous; cilia pale greyishochreous. I'osterior wings whitish-grey, posteriorly fuscescent, with very pale greyish-ochreous cilia. ber.

Not common; occurs at Mickleham and Folkstone, in Septem-

37. FIeracliana, De Gecr, ii. 1. 407 (1771); Step,-IIeracleana,

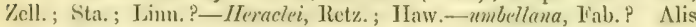
anticis latiusculis grisco-ochreis, striis numcrosis fuscis, muctis tribus disci (primo ante, sceundo et tertio post medium) sulurutioribus albidocinctis, fascia postica pallida angulata. Kixp. al. 12-13 lin.

Ilead and face greyish-ochreous. Pilpi fuscous, internally palc ochreous; terminal joint with a dark fuscous ring before the paile yellowish apex. Anteuna greyish-oclereous, with fuscous annulations. Anterior wings rather broad, yreyish-ochreous, with numerous short fuscous longitudinal streaks; at the base of the costat is a fuscous spot, and a fuscous dash lies near the inner margin towards the basc; on the disc are three darlier spots (one before, the others beyond the middle), surrounded by some whitish scales; the pale hinder fascia is rather arutely angulated; the himder margin and apex of the costa are spotted with dark fuscous; cilia palc greyish-ochreous, varicd with fuscous. Posterior wings pale grey, with paler cilia.

Generally distributed throughout the comtry; appearing in August and September, but hybernated specimens are more frequently met with in $\Lambda$ pril. The larva fecls on the leaves and in the nimbels of Iteructeme Sphondylimm, changing to the pupa either on the ground or within the stem of that plant.

\section{Genus VII. PSORICOPTERA.}

P'soricorterA, n. g. Gelectia p., Zell.

Capilli depressi. Ocelli nulli. Antcune articulis confertis. IIaustellum mediocre, squamatum. Palpi maxillares brevissimi. Palpi labiales medioeres, reflexi, articulo sccundo infra scopiformi, lertio lemui, uculo, supre squamis projicientibus. Alx anteriores clongatre, Lubereulata, mediocriter ciliate; posteriores trapezoidales, margine postico ante angulum analem leviter simuato, ante apjecm leviter cmarginato, longius ciliate. 
Ilead smooth. Ocelli none. Antenno with the joints thickly set. Tongue of moderate length, clothed with scales. Maxillary palpi very short. Iabial palpi moderately long, reflexed; the second joint beneath resembling a brush; the terminal joint thin and pointed, above wilh projecting scales. Abdomen rather depressed. Antcrior wings elongate, with raised tufts of scales; the cilia moderately long. Posterior wings trapezoidal, the hinder margin slightly sinuated before the anal angle, and slightly emarginate below the apex, with longer cilia.

Only one species is at present known in this genus.

1. gibbosella, //cll. Isis, 1839. p. 202.-Zeplyyrella, Step.? Alis anticis griseo-marmoratis, costam versus dilutioribus, ipsa basi dorsi albida, striga obliqua juxta basim nigra, macula oblonga costa medie fusca, fascia postica angulata allida obsoleta, maculis tribus scabris supra plicam fuscis. Exp. al. 8 lin.

IIead and face greyish-fuscous. Palpi yellowish ; terminal joint fuscous, execpt the apex. Antemne fuscous, with paler amulations. $\Lambda \mathrm{n}$ terior wings marbled-grey, with the extreme base of the inner margin whitish, and an oblique black streak very near the base (as in many of the Depressurice); the costal half of the wing is generally paler, but there is a conspicuous fuscous bloteh on the costa about the micldle; the pale angulated fascia is rather indistinet; along the fold are three fuscous tufts of clevated seales; cilia greyish-fuscous. Posterior wings fuscous, paler at the base, with greyish-fuscous cilia.

Not common; has occurred in I Ininault forest in July. The larvin (aceorting to licnig) foeds in Junc, on sallows, turning down a corner of a leaf.

\section{Genus VIII. GELECHIA.}

Gelechiat p., Kcll. Isis, 1839, p. 197. Recurearin P., ITaw. Anacanpsis p., Curt. IIcomylis p., Lita p., et Eicophora p., 'Treit. Anacampsis p., Acompsia, of Marpagus, Step. Anacampsis, Acompsin, et Lila, Џuр. Mesophlepes p., Acompsia p., Nolhris p., Scylhropia p., Gelechia, Brachmia p., et Chionodes p., llüb.

Capilli depressi. Oeclli nulli. Antenue articulis confertis. Hanstellum medioere, sçuamatum. I'alpi maxillares brevissimi. P'alp̧ labiales mediorres vel longi, reflexi, articulo secuudo infra vix seopiformi (interdum lavi), tertio tenui, levi, ncuto. Ala anteriores oblongit: vol clongat:e, mediocriter ciliatie; posteriores lrapezoidales, ante apicem leviler vel multo emaininata. Ala anteriores: vena apicalis fureata ante apiecm exit, infra cam venic quinque (rarius vena apicalis trificla ante et infra apicem exit, infra cam vene quatuor); posteriores: vena apiealis furcata supria el infra apicem cxit, infra 
cam vena unica, c venula transversa (vel venn apjealis simplex in a) trifida.

Ilead smootl,. Ocelli none. Antennx with the joints thickly set. Tongue of morlerate length, elothed with seales. Maxillary palpi very short. Irabial palpi moderately long, or long, reflexed; the second joint beneath slightly broader, with appressed scales, hordly resembling a brush, sometimes quite smooth ( $G$. naviferella); the third joint slender, smoolh and poiuted. Anterior wings oblong or clongatc, with moderately long cilia; the posterior vings trapezoidal, slightly or deeply cmarginate below the apex. In the anterior wiungs the furcatc apical vein terminates in the ensta before the apex; below it are five veins from the discoidal cell; more rarely ( $G$. lencatella, bifructella, etc.) the apical vein is trifid, the third branch ruming into the hinder margin below the apex, and below it are only four veins from the discoidal cell. In the posterior wings the apical vein is furcate, terminating above and below the apex; below it is only one vein from the transverse vein; or clse (costelln, tricolorella, cte.) the apical vein is simple, and bclow it are two veins from the transverse vein; the median vein is trifid.

$\Lambda$ genus of great extent, and comprising a great diversity of species, but which unfortunately we camnot subdivide into other genera. In this country we liave no less than ninety-five species, and probably as many more are known on the continent.

As might be expected, there is considerable diversity in the habitats of the species; some frequenting stems of trees, other taking sliclter in the grass. All the species are extremely active in the perfect state, and their flights are only for a short distance at a time; when they settle, they frequently immediately seek a place of concealment, whereby the collector is often baulked in his pursuit of some rarity. The habits of the larve are extremely varied: that of $G$. Populclla rolls up the leaves of the poplar and sallow much like a Iortrix-larva; that of $G$. rufescens twists up grass-leaves, bleaching them by eating them half through ; that of $G$. Malvella feeds in the seeds of the hollylock, procecding regularly through the circular row of seeds, much to the anmoyance of the horticulturist; that of $G$. mulinella enters the unopened flower-buds of the furze and broom, and devours the incipient fructification of the flower, after having eaten which it procecels to the next flower and repeats the process; that of $G$.diffinis, which is extremely active, fecils near the root of the dwarf sorrel (Rinmex Acetosella); that of $G$. acuminatella mines in the leaves of the thistle; that of $G$. nolatella burrows in the woolly substance on the underside of the leaves of the sallow; that of $G$. scriplella turns down a piece of maple-leaf, fastens it in its position by several silken cables, and eats the leaf half through; that of $G . f r a$ - 
temella, a fat sluggish larva, fects in the young shoots of Slellaria uliginosa, which, from the presence of the larva, assume a peculiar knobbed and contorted appearance; that of Gíf Lifraclella feeds in the seeds of the Conyza squarrosa, which it by some means unites together, forming a firm, almost impenetrable substance, within which it is completely sheltered from all the vicissitudes of the weather; that of G. Cerealella (according to Réaumur) feeds in the interior of grains of barley and whent, entering the grain immediatcly it is hatched, and remaining within till it has undergone its transformations, and only coming out in the perfect state; that of $G$. subocellea (in other respects the most aberrant species of the genus) feeds on the flowers of the inarjoram (Origanum vulyare), of which it constructs a case, thcreby resembling the Coleopstiorce. The species that feed in buds and shoots are of course mostly in the larva state in spring and the begiming of summer, those that feed in or on leaves are met with in summer and autumn, and those that feed on seeds do so in the autumn and winter. The perfect insects are successively to be met with from $\Lambda$ pril to October, and several species are known to liybernate.

It is not easy to tabulate the species of this genus; the best I have been able to accomplish is as follows:-

a. Anterior wings not rounded at the apex.

b. Anterior wings unicolorous. Species I, 2.

$b$ b. Anterior wings with spots. Species 3, 4.

a $a$. Anterior wings rounded at the apex.

c. P'osterior wings broader than the anterior wings. Specics 5-69.

$c c$. Posterior wings as narrow as, or narrower than the anterior wings.

d. Anterior wings with no sharp markings in the cilia.

c. Anterior wings without markings. Species 70, 71 .

$e$ e. Anterior wings with a single white fascia. Species 72-74.

e e e. Anterior wings with one or more dark spots on the disc. Species 75-89.

e e e e. Anterior wings with oblique silvery streaks from the costa. Specics $90-92$.

e e e e e. Anterior wings with longitudinal dark streaks (like a Coleoplora). Species 93, 94.

$d d$. Anterior wings with sharp markings in the apical cilia. Species 95.

1. cinerella, Limn. F. S. 1445 (1761); Tab.; Treit.; Step.; Dup.; Irüb.P-cineren, IInw.-ardeliella, Hlüb. Alis anticis nitidlis Inteo-cinercis immaculatis. Exp. al. 8-9 lin.

IIcad and face yellowish-grey. Palpi y'ellowish-grey, internally paler. 
Antenne fuscous. Anterior wings shining, yellowish-grey, wilhoul any markings; cilia rather paler. Posterior wings pale grey, with greyishfuscous cilia.

Appears in June and July, in bushy places of mixed growth; not uncommon.

2. rufescens, IFaw. I. B. 555 (1829); Step); Curt.-tinchelle, Step.-diaphanella, Jicnig.-Isabella, Kell. Alis anticis mufo-ochreis, venis vix dilutioribus, puncto fuscescente obsoleto disci pone merlium. Exp. al. 8 lin.

IIcad and face reddish-ochreous. P'alpi recklish-ochtrous, intemally pale ochrcous. Antennes pale ochreous, anmulated with pale fuscous. Anterior wings reddish-ockreons, wilh all the veins slighlly praler, and some faint indication of a fuscous spot on the dise beyond the middle; cilia pale ochreous. Posterior wings whitish-grey, with whitish-ochreous cilia.

Not uncommon in Junc and July in grassy banks, but very retired in its labits. The larva is abundant in $\Lambda$ pril and May in rolled grass-leaves, and is probably identical with that figured by Fischer as the larva of G. terrella.

3. inornatella, Dougl. Ent. Trans, i. n. s. 65 (1850). $\Lambda$ lis anticis dilute griseo-ochreis, punctis tribus nigris (uno plicar, altero disci posteriore ante medium, tertio disci pone inclium), nebula fusca costo pone medium, maculis oppositis obsoletis dilutioribus marginem posticum versus. Exp. al, $6_{\frac{1}{3}}^{\frac{1}{3}}$ lin.

Ilead and face pale greyish-ochreous. Palpi pale greyish-ochreous, internally rather paler; terminal joint with a fuscous ring before the apex. Antenne greyish-ochreous, aunulated with fuscous. Anterior wings pale greyjish-oclureous, with thrce black spots (one on the fold, one rather posterior to it on the dise, both before the middle, and one on the dise beyond the middle); above the latter is a slight fuscous clond on the costa; very near the linder margin are two pale opposite spots, which nearly form a straight fascia, attenuated in the middlle, immediatcly beyond are a few black scales; the hinder margin is spotted with dark fuscons, and in the apex of the wintr is a slight fuscous cloud; cilia pale yellowish. Posterior wing's pale grey, with paler cilia.

Not uncommon in the Cambridgeshire fers in Junc.

4. gerronella, Zcll. Ent. Ztg. 1850. p. 155 ; Dougl. Alis anticis ocluraceis fusco-nebulosis, praceipue costam et marginem posticum versus, fascia indistincta obliqua fusca pone medium, fascia angulata dilutiore in nebulam posticum, punctis tribus (primo plicx ante melium, secundo disci in medio, tertio disci pone medium) nigris. Exp. al. 5a-6 lin.

1Iead and face ochreous. Palpi pale ochreous; terminal joint with a fuscous ring before the apex. Antennie ochreons, annulated with 
fuscons. Antcrior wings octereous, cloulenl with fuscons, especially towards the costa and hinder margin; an oblique rather indistinct fiescous fiescin goes from the midtle of the costa to the anal angle; near the hinder margin is an indistinet pale angulated fascia; on the disc are three blact spots (one on the fold betore the middle, one on the rlise in the midelle, and the third on the dise at the commeneement of the obligue fuscous fascia); cilia ochreous. Posterior wings grey, with paler cilia.

Occurs at Dartford IJeath and West IVickham, among forn, in July.

5. vilella, Zell. Isis, 1847. p. 815; Dougl--subcinerea, Ilaw.? Step? Alis anticis angustulis dilut" griseo-oclireis, squnmis mumerosis fuscis, priecipue apjecm versus, pencto busali coste , punclo prope dersum juxla basin, puncto minore basali plicer, nigris, punctis duobus dilutis disci, in quibus squame nonnulløe fusex. Exp. al. $9 \frac{1}{3}$ lin.

Ilead and fiee palc ochreons. Palpi pale ochreons, internally whitish; terminal joint pale ochreous, with a dark fuseous ring lefore the apex. Antemex fuscescent, diaker at the base. Interior wings rather marrom, pale greyish-ochreons, with muncrous firscous scales, espectilly towards the apex, with a black spot at the bese of the coste, and owe newr the inner margin close to the base; at the base of the fold are a fow black scalcs; on the dise are two pale spots (one before, the other beyond the middle), in the centre of each are a few fuscous scales, giving them an ammulated appearanec; cilia pale ochreous. P'osterior wings whitishgrey, with greyish-ochreous cilia.

'This occurs in company with the Depressarie, which it somewhat resembles, in old thatch at Folkstone in September; also in the Isle of Wight. I have a specimen taken at Lewisham in June; hence tho species is probably double-brooded.

6. basalis, 1)ougl. n. s.-Ilippopteailln, Schr.? Alis anticis dilute griseo-ocheris, uncula oblonga coste basuli nigra, punctis tribus (uno) pliea, altero majore disei ante, tertio obsoleto disei pone medium) nigris, fascia pallida angulata pone medium, Exp. al. 8 lin.

Ilead and face greyish-ochreous. I'alpi greyish-ochreous; termiual joint with two faint finscous rings, one at the liase, the oflere below the apex. Antemix greyish-ochreous. Anterior wings pale greyish-ochere ons, with an oblonig blach spot at the base of the custa; near the base of the inser margin is a minute black spot; a small black spot lies on the fold, and a larerer one beyond it on the dise before the middle; an almost obsolete black spot lies on the dise beyoud the middle; beyond this is a faintly indieated, pale, angulated fitscia; on the hinder margin are a few black spots; cilia grcyish-ochreous. P'ostcrior wings pale greyish-fuscous, with pale ochreous cilia.

T'aken at Deal in September.

7. Malvella, IIüb. Tiu. 281 (1812); T. v. R. pl. 4.6; Dup.; 7cll.; Dougl.-Listeri, Haw.?-Jisterellu, Step)? Mis anticis dilute VOL. III. 
brunneo-ochercis, apiccm versus fusco-suffusis, punctis tribus (primo plien, secundo posteriore disci ante medium, tertio disci pone medium) fuscis, fuscia pone medium fusca aul costam et dorsum saluratiore, postice in medio producta, fisciaque postica augulata pallida. Exp. al. 9 lin.

Head and face pale ochreous. Palpi pale ochreous, internally whitish. Antenne fuscous, amnulated with ochueons. Anterior wings pale broucnish-ochreous; before the middle are two fuscous spots, one on the fold, the other posterior on the dise; beyond the middle is another fuscous spot on the disc; it is followed by a fuscous fusciu, which is most distinct on the costa and inner margin, in the middle it is a little produced posteriorly; beyond it is a palle angulated fascia of the ground-colour, the apical portion of the wing being suflused with fuscous; the hinder margin and apex of the costa are alternately fuscous and pale ochreous; cilia pale greyish-ochreous, interseeted by a fuscous line. Posterior wings pale grey, with greyish-ochrcous cilia.

A common species in gardens, frequenting hollyhocks in June and July. The larva fecds in the sects of the hollyhock in September and Oetober; when full-fed desecnding to the earth, in which it constructs a cocoun, and remains unchanged thronghout the winter.

8. Populella, Linn. F. S. 1442 (1761); Tab.; Trcit.; Step.; Dup.; F. v. R. pl. 76. pl. 77. f. 1.-Populi, Ilaw.-tremella, W. V.blatlariella, IIüb.-Juniperella, Step.-Iremulella, 1)up. $\Lambda$ lis anticis cinereis, dorsum versus fusco-suffusis, fusco-maculutis, fuscia posticu diluta angulata, costam versus dentata. Lixp. al. 8 lin.

IIead greyish-fuscous. Face palcr. Palpi greyish-fuscous, interually pale ochrcous. Antenuac whitish, amnulated with dark fuscous. Anterior wings greyish-fuscous, clouded with fuscous along the imer margin, and with several dark fuscous spols (of which one at the base of the costa, one above the fold not far from the base, one on the fold, and one posterior to it on the dise before the middle, and one on the dise beyond the middle, which is freguently followerl by two olliers, one rather towards the costa, and the other a little above the fold); beyond the middle is a pale angulated fascia, which is indented below the subcostal vein; beyond it is a fuscous cloud; the linder maryin and apex of the costa are spolted with black; cilia pale greyish-fuscons. P'osterior wings greyish-fuscous, with paler cilia.

Extremely variable in the colour and intensity of the markings of the anterior wings. In one varicty (of not unferuent oceurrence) the anterior wings are alnost sutirely suffused with clark fuscous, leaving only the costi of the pale ground-colour, and the hinder fascia, remaining of the usual colour, is remarkably conspicuous.

Abundant among poplars and sallows, resting on the trunks, or on palings in the vicinity; the perfect insect appents at the cud of June, and kecps out a long while. 'The larva feeds at the end of May and beginming of June, in rolled-up leaves of poplar, sallow, and birch. 
9. nigra, IIaw. L. 13. 550 (1829); Dougl.-rusticella, Stcp.-cautella, Zell.; 1)up. Alis anticis saturate fuescis, albido-squmatis, stries tribus in merlio nigris, fascin postica valde obsoleta, squamis albidis composita. Exp. al. 7\% lin.

Ilead dark fuscous. Faee whitish. Palpi dark fuscous, interually whitish; tcrminal joint whitish, with two broad fuscous rings. $\Lambda$ temna fuscous. Anterior wings dark fuscous, with some obseure darker markingrs, and with memerous whilish scales; the most distinct of the dlark markings are three elongate black spots in the middle (one on the fold, one on the dise, and one towards the costa); beyond the iniddle the whitish scales form an indistinct angulated fascin; cilin grreyishwhite. Posterior wings pale grey, with greyish-fuscous cilia.

Not uncommon in June and July on the stems of the white poplar trees at Wanstead; it is difficult to sccure, as on the approach of the collector it flies away.

10. temerella, Lienin, Isis, 1846. p. 284.-pernigrella, Dougl. $\Lambda$ lis anticis nigris, punctis tribus atris obsolctis, fascia postica nebulosa atra. Exp. al, $5 \frac{\lambda}{2}$ lin.

IIead black. Pace dark fuscous. Palpi grey, internally whitish; terminal joint externally dark fuscous. Antenne dark fuscous. Anterior wings black, with three rather indistinct deep black spots (one on the fold, one posterior to it on the dise before the middle, and one on the disc beyond the middle); beyond the middle is a deep black cloudy fascia; and on the hinder margin and apex of the costit are some deep black spots; cilia blackish. Posterior wings dark greyish-fuscous, with paler cilia.

Hitherto found only in Lancashire and Cheshire, where it is not unfrequent among sallow's in July. The larva feeds in the terminal shoots of the sallows in June.

11. Ientiginosella (Tischer), Zcll. Isis, 1839. p. 198; F. v. R. 1). So. f. 3; Dougl.-obscurellu, IIub.? Ireit.? Alis anticis saturate brunne-fuscis, punctis tribus (uno plice, altero posteriore disci ante medium, tertio disci pone medium) nigris rufescente-cinctis, maculis posticis oppositis dilute rufescentibus, costali distinctiore. Exp. al. 7? lin.

IIend and face dark fuscous. Palpi dark fuscous, internally pale oclireous. Antennac fuscous. Anterior wings dark broonish-fuscons, with three black spots (one on the fold, a sccond posterior to it on the dise before the middle, the third on the dise beyond the middle), ench surrounded by reldisti-oclereous; beyond the middle are two small pale reddish-ochreous opposite spots, of which that on the costa is the more distinct; cilia pale fuscous. P'osterior wings pale grey, with pale greyish-fuscous cilia.

The perfect insect has very rarely been met with; it appears in July and August among Crenista tineloria, and has occurred near Bristol, Epuing, and T'unbridge Wells. The larva feeds in May 
and June on the Genista tinctoria, drawing together the terminal shoots.

12. velocella (Tischer), Dup. L. F. xi. 287. pl. 297. f. 3 (1838); I. v. R. pl. 77. f. 4; Zell.; Dougl.-subsequella, Treit. Alis anticis saturate fuscis, punctis tribus (uno plien, altero posteriore disci ante, tertio disci pone medium) saturate fuscis, subscabris, maculis posticis oppositis albidis, costali distinctiore introrsum speclante. Exp. al. 7! lin.

IIead and face dark fuscous. Palpi dark fuscous, internally palc vellowish. Antenner dark fuscous. Anterior wings dark fuscous, with ilnce dark fuscous spots (one on the fold, one posterior to it on the dise before the middle, and one on the dise beyond the middle), slightly raised; beyond are two whilish ill-defined opposite spols, that on the costa being the more distinct, and with its apex pointing raller incurds; along the hinder margin are some dark fuscous seales; ciliat pale fuscons. Posterior wings grey, with greyish-fuscous cilia.

$\Lambda$ ppears at the end of $\Lambda$ pril and beginning of May, and again in August; frequent on Barnes Common, llying freely in the hot sunshine in the middle of the day.

13. fumatella, 1)ougl. Ent. Trans. i. n. s. 67 (1850). Alis anticis yrisero-fuscis, apicem versus saturate finseis, puncto elongato plicer, puncto posteriore disci ante, puncto disci pone medium nigris, squamis pracerdentibus ac sequentiluess allielis, maculis posticis oppositis, fere fasciam vix angulatam formantibus, subochraceis. Exp. al. 7 lin.

I Lead greyish-fuseous fare pale greyish-ochreous. Palpi fuscous, intermally pale ochreous; terminal joint pale ochreous, with the basc ind a ring before the apex dark fuseous. Antemax fuscous. Anterior wings greyish-fuseons, pos riorly much sullused with dlark fuscous, with three blach spots, one on the fold, rather etongated, one on the dise posferior to it before the midelle, and the third on the dise beyond the middle; these spols are preceded and folloned by some whilisith scales; the two pale dingy oclireous opposite spots almosl form "slighlly anguluted fascia ; the hinder margin and apex of the cosia are varied with black and whitish; cilia greyish-fuscous. P'osterior wings grcy, with grcyish-fuscous cilia.

A searce species, litherto enly met with among the sand-hills of the Cheshire coast, and at Dawlish Warren.

14. ericetella, Hüb. Tin. 470 (1829).-Betulen, IIaw.; Step.yullinella, Treit.; Dup.; Zell.-lanceolella, Step. Alis inticis fuscis, punclis qualuor saturate fuscis, migrisere, ante et post squamas albas (primo supra plicam basim versus, secundo plices, tertio disci ante, quarto disci pone medium). Exp. al. $7 \frac{2}{2}$ lin.

Ilead and face dark fuscous. Palpi dark fuscous, internally whitisls. Antemer dark fuseous. Anterior wings fuscons, with funt dark fuscons (i) black spots, cach preceded and followed by some whilish seales; the 
first is above the fold not far from the base, the second on the fold, the third on the disc is larger and before the micldle, the fourth is on the disc beyond the middle; the hinder margin and apex of the costa are spotted with black, with a few whitish scales; cilia fuscous, with a centril darker linc. Postcrior wings pale grey, with pale greyish-fuscous cilia.

Abundant among heatlicr in May, Junc, and July, in most parts of the country.

15. mulinella (Tischer), /4chl. Isis, 1839. p. 199; Dougl-interruptr, Ilaw.-intemuptella, Step.? Alis anticis griseo-ocheres, stria basali prope costam, stria latiuscula plice pone medium desinente, stria disci ante medium incipiente, usque ad "picen producta, saturate fuscis. Exp. al. $6 \frac{1}{3}$ lin.

II ead and face greyish-oclureons. Palpi pale ochreous; terminal joint slightly spotted with fuscous. Antenne fuscous. Anterior wings greyisle-achreous, with a dark fuscous streak at the base near the costa, and the costa cloudcd with fuscous (narrowly at first, but broader bcyond the middle); a rather broud dark fuscous streak runs along the follt to beyond the middle, it is connceted with a dark fuscons streak on the disc beginning before the middle and rumning to the apest in the latter is an appearance of a darker fuscous spot beyoud the middle; the apieal portion of the wing is much suffused with fuscons; the linder margin and apex of the costa are spotted with dark fuscous; cilia greyish-ochreous, varied with fuscous. Posterior wings pale grey, with greyish-ochreous cilia.

Very common among broom and furze in July and August. The larva feeds in April and May in the flowers of those plants.

16. divisella, 1)ougl. Ent. 'Trans. i. II. s. 60 (1850). Alis anticis costam versus dilule ochreis, dorsun versus dilule fuscis, divisione coloris fure lineain rectane ex basi nsque ad apicen formanle, ipsa costa pone medium breviter fusea, puncto plice ante medium, alteroque disci pone medium saturate fuscis. Kxp. al. $7 \frac{1}{2}$ lin.

Ilead, face, and palpi pale ochreous. Antcure palc ochreous, annulated with pale fuscous. Anterior wings pale ochreous toucards the costa, pale fuscous lowards the inmer mergin, the division of the colour forming nerrily a straight line from the midlle of the buse to the apex of the ving; on the costa beyoud the middle is a short fuscous line; a dark fuscous spot lies on the fold before the middle, and another on the dise beyond the midclle, and there are frequently a few dark scales on the subcostal vein near the base; cilia ochrcous. Posterior wings pale grey, with greyish-ochrcous cilia.

Not common; occurs in June in the ('ambridgeshire fens.

17. palustrella, Dongl. Int. Trans, i. n. s. proc. 1t (1550). $\Lambda$ lis anticis dilute grisco-ochreis, venis fere ommibus suturate fuscis, postice interlum in maculan saturate fuseam confluentibus, punclo clon- 
gato disci in medio, punctoque rotundo pone medium nigris. Exp. al. $8 \frac{1}{3}$ lin.

IIcad and face palc greyish-ochreous. Palpi fuscous, internally pale greyish-ochreous; terminal joint palc greyish-ochreous, with a fuscous ring before the apex. Antenne dark fuscous. Anterior wings pale greyish-ochreous, with nearly all the veins indicated by darli fuscous streaks, those below the apex of the wing most strongly marked and sometimes confluent, forming a dark fuscous blotch; on the dise in the micldle is an clongate black spot, and beyond the middle is a nearly round black spot; cilia pale greyish-ochrcous, tinged with fuscous. Posterior wings pale grey, with palc fuscous cilia.

But few specimens have yet occurred, and all those in the Cambridgeshire fens in July.

18. sororculella, Hüib. Tin. 440 (1816); Treit.; Frey; Zell.; Dougl. Alis anticis griseo-fuscis, dorsum rersus sxepe dilutioribus, puncto nigro elongato plice ante medium, linea longiludinali disci nigra, ocello albido ante, puncloque albido post medium interrupta, fascia postica angulata, vix indentata, cineren. Exp, al. 7 lin.

IIead and face greyish-fuscous. P'alpi dark fuscous, internally pale ochreous. Antennic dark fuscous. Anterior wings greyish-fuscous, with the inner margin usually paler, with an elongate black spot on the fold before the middle, a longitudinal black line on the disc inlerrupted before the middle by a whilish ocellus, and beyond lhe middle by a whitish spol; the hinder fascia is somewhat cincrcons, angulated and slightly indented; the hinder margin and apex of the costa are spotterl with dark fuscous and whitish; cilia greyish-fuscous. Postcrior wings pale greyish-fuscous, with paler cilia.

Not rare among sallows in July. The larva, which is more easily met with, feeds in the shoots of the sallow in May and June.

19. cuneatella (7cll.), 1)ougl. Ent. Trans, i. n. s. 242 (1852). $\Lambda$ lis anticis grisco-fuscis, striis longibudinalibus cuneiformibus nigris, quatuor in medio conspicuoribus, oblique pone squamas albidas positis, fascia pallida angulati, plicam versus extrorsum curvata. Exp. al. $7 \frac{1}{2}$ lin.

ILead grreyish-fuscous. Tace whitish. Palpi greyish-fuscous, internally whitish; termiual joint internally whitish, with a dark fuscous ring before the apex. Antenne greyish-fuscous. Anterior wings greyish-fuscous, with several longitudinal dark fuscous wedge-shaped streuks; of which four in the middle of the wing placed obliquely beyond some whitish scales are conspicuous; beyond some ratlser conspicuous streaks near the costa beyoud the midelic is the pale angulated fascia, which towards the fold bends outwardly; the hinder margin and apex of the costa are spotted with black; cilia pale greyish-fuscous. Posterior winga pale fuscous, with paler cilia. 
A specimen is in Mr. Bedell's collection, taken in Tower-street, some years back. Mr. Boyd took two specimens among willows at Hackney, last September.

20. peliella, Treit. IS. S. x. 3.198 (1835); Dup.; Zell.; Dougl. Alis anticis nifricantibus, puncto plica basin versus, punctis duobus ante medium (altero plice, altero vix posteriore disci), nigris, squamis sequentibus albidis, puncto disei pone medium nigro albido-cincto, maculis posticis oppositis albidis, dorsali posteriore. Exp. al. 7 lin.

IIcad dark fuscous. Face palc ochreons. Palpi dark fuscous; internally and the tip of the terminal joint pale ochreous. Antenne fuscous. Anterior wings dark greyish-fuscous, wilh a bluck spot on the fold not far from the base, and two black spots a little before the middie, one on the fold and one hardly posterior on the dise, both followed by some whitish scales; on the dise beyond the middle is a black spot almost encircled by some whitish scales; beyond are two whitish opposite spots, which almost form an angulated fascia, that on the imner margin is posterior to the coslal spot; in the apex of the wing are a few whitish seales; cilia greyish-fuscous. Postcrior wings grcyish-fuscous, with paler cilia. July.

Hitherto only taken at West Wickhan Wood, in June and

21. alacella (Zell.), Dup. L. Ir. xi. 296. pl. 297. f. 12 (1838); Zell.; Dougl. Alis anticis corulescente-nigricantibus, punctis duobus ante medium, altero pliex, altero disci paullo posteriore, squamis sequentibus lutescentibus, puncto disci pone medium, squamis lutesecntibus utrinque marginato, nigris, guttula dorsi, lunulaque posleriore costa, lutescentibus. Exp. al, $6 \frac{1}{2}$ lin.

IIcad very dark fuscous. I'ace paler. Palpi dark fuscous; tip of the terminal joint pale ochreous. Antenne dark fuscous, Anterior wings blackish, voith a bluish tinge, with two black spots beforc the middlle, one on the fold, and one rather posterior on the dise, both followed by some pale yellowish seales, and a black spot on the dise beyond the middle, preecded and followed by some pale yellowish scales; beneath it is a sinall pale yellowish spot on the immer margin, and beyond it on the costa is a larger lunular pale yellowish spot; the hinder margin and apex of the costa are spotted with black and pale yellowish; cilia dark fuscous. Posterior wings greyish-fuscous, with paler cilia.

$\Lambda$ scarce species; has occurred near Lentherhead in July.

22. longicornis, Curt. 13. E. fo. 189 (1827); Step.-histrionella, IIüb.; Dup.-zebrellu, 'Treit. Alis anticis albido-griscis, rufo-suffiesis, basi dorsi, stria obliqua coste prope basin saturate fuscis, fascia in medio recta, saturate fusea, in qua puncta duo ovala saturatiora (alterum plicis, alterum disci), puncto ovato disci pone medium saturate fusco. Exp. al. $7 \frac{x}{2}$ lin.

Ilead dark fuscous. The greyish-fuscous. Palpi greyish-fuscous, 
internally whitiah. Antemnn fuscous, Anterior wings pale whilishgrey, much suffiesed rith rendelish, with the base of the iuner margin and an oblique streak from near the base of the costa dark fuscous; in the middle is a dark fiscia, in which are two dartier orate syots (one on the fold, and one on the (lise); beyond the middle is a dark fusenus ovale spot on the dise, and heyond it are two other dark fuscous spots, one on the costa, and onc on the imer margin; parallel to the hinder margin is a long fuscous spot; the hinder margin and apex of the costa are spottel with fuscous; cilia grey. Posterior wings greyishfuscous, with paler cilia.

Common on the moors in the north of England, in May and June.

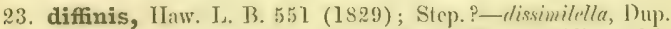
pl. 297, f. 4.-scabidella, Zell.-nebulea, Haw.? Step.? Mlis anticis rufo-brusueis, stria abliqua costali prope basin, saturate fusea, rem mrecule transcersali domi seabre confluente, punctis duobus disci, in nchulam fuscim costalem inclusis, saturate fuscis, macula postica costec, maculayue minore dorsi fuscis, fascia postica, fere obsoleta, angulata ochrea. Exp. al. 7 $\frac{1}{3}$ lin.

Head and face greyish-fuscous. l'alpi greyish-fuscous, internally paler ; terninal joint pale ycllowish, with two dark fuscons rings. $\Lambda$ ntemax pale greyish-fuscous, with darker amulations. Anterior wings reldish-broun (sometimes with a slight violet tint), with an oblique dark fuscous streak near the base of the costa, meeting in the fold "tufl of dart: fuscous raised scales, situated perpendicularly on the inner margin; in the mildle are two or threc small tufts of dark fuscous seales, comected with the costa by a fuscous blotch; beyond the middle is a small fuscous spot on the costa, and a smaller one opposite to it on the inner margin; immediately beyond them is a ratlier indistinet angulated ochreous fiscia (sometimes interrupted by a dark fuscous streak); the hinder margin and apex of the costa are spotted alternately with prile: and dark liuscous; cilia fuscous. Posterior wings pale grey, with greyish-fuscous cilia.

Common on Dartford Mcatl,, Barnes Common, ete., in May, Junc, and August (?). The larva feeds in April on liumea Aerlosella, forming a burrow down towarts the root of the plant.

2., terrella, W. V. 1+0.49 (1776); IHiib.; Trcit.; I)uj); Zcll.; T. v. R. pl. 80. f. 1. pl. 96.-lutarea, Haw.; Step,-zephyrella, 'Treit. $\Lambda$ lis anticis ochreo-brumeis, punctis tribus (uno plicer, altero posteriore disci ante, tertio disci pone medium) nigris, fascia postica angulata obsoleta dilutiore. Lxp. al. 7즐 lin.

llead and fice greyish-fuseous. I'alpi fuscous, interually pale ochreous. Antenne fuscous, with paler annulations. Anterior wings ochreous-brown (varying considerably in the shade of (olour), with three black spots (one on the fold, one posterior to it on the dise before the middle, and one on the dise beyond the middle); beyond this is a rather 
indistinct pale angulated fascia; the hinder margin and apex of the costa are spotted with dark fuscous; cilin rather paler than the wing. Posterior wings pale grey, with greyish-fuscous cilia.

$\Lambda$ most abundant species everywhere among grass, in June and July. 'The larva figured by risclier' appears to be that of $G$ ' rufescens; the larva of $G$. terrella still remains to be riscovered.

25. desertella (1idl.), Dougl. Ent. Trans. i. 11. s. 62 ( 18.50$)$. Alis anticis dilute ochreo-brumucis, puncto plicre prope basim fresco, punctis duobus ante medium (altero plice, altero posteriore disci) punctoruc disci pone unedium nigris, fascia postica dilutione obsoletissina. Exp. al. $6(\operatorname{sex})$ lin.

Head pale greyish-ochreous, darker in the midale. Fare pale grey. Palpi pale fuscous, intermally pale ochreous. Antemne fuscous, with paler annulations. Anterior wings pale ochreous-brown, with a fuscons spot on the fold near the base, two black spots before the midille (one on the fold, the other a little posterios on the dise), and one on the dise beyond the middle; the indications of a pale hinder fascia are Jeradly perepplible; the linder margin and apex of the eonta are spotted with dark fuscous; ciliat pale fuscous or pale oclureous. l'osterior wings pale grey, with pale greyish-fuscous cilia.

Common on the simd-lislls of the Cheshire coast, and in the Isle of Portland, in June and July.

26. politella (1)ougl.), Sta. Sup. Cat. p. 1. (1551); 1)ougl. Nlis anticis nitirlis, of ulivaceo-griseis, ( $q$ angustioribus dilute vel brummenochreis,) punctis tribus (uno plica, altero posteriore disci ante, tertio disei pone medium) of subobsoletis fuscis ( $q$ distinctis subnigris). Exp). al. $\delta 7 \frac{1}{2} ;$ i $6 \frac{1}{2} \mathrm{lin}$.

Ilead and face greyish-fuscous. Palpi fuscous, infernally pale ochreous. Antemax fuscons, Anterior wings shining olivaceons-grry, with a spot on the fold, one on the dise ratlier posterior before the midalle, and one on the dise beyond the middle, fuscons, but ralher indistinet; the hinder margin and apex of the costa are spotted with fuscous; ciliz pale fuscous. Posterior wings pale grey, with greyish-fuscous cilia.

The female has the head, face, palpi, and narrower anterior wings pale ochreous, or pale brownish-ochrcous, and the spots on the anterior wings more distinct and almost black.

Common at the foot of Slidldaw, among licather, in June, IS \$.6 ; since taken by Mr. Logan, on the Pentlands.

27. acuminatella, Sircom, Zool. $1850, \Lambda$ pp. Ixxii. ; Dogul.-Cirsiella, Sta.-pulliginella, Sircom? Alis anticis dilute brunmeis, fuscosuffusis, plica lincaque superiore parum suflusis, puncto pliear, puncto posteriore disci (interdum in duo cunciformia diviso) ante mediun, punctoque disei pone medium nigris, maculis oppositis dilutioribus fore fasciam subangulatam formantibus. Exp. al. $6 \frac{1}{3}$ lin.

Ilead greyish-fuscous. Face pale greyish-ochreous. l'alpi pale fuscous, internally pale ochrcous ; terminal joint pale ochreous, witlı a fus-

VOL. III. 
cous ring before the apex. Antemne lisscous, beneath spotted with pale ochreous. Anterior wings (in the o rather acuminate) pale brown, very much sullused with fuscons, the fold and a line above it being almost the only unsuftused portions of the wing; a black spot lies on the fold before the midllle, and on the dise a little posterior is another, sonetimes divided into two weelge-shaped spots; on the disc beyount the midkle is another black spot; beyond are two pale opposite spots, which appear to form a slighlty angulated fiscia; between them is sometimes a dark fuscous elongated spot; the hinder margin and apex of the costa are almost uninterruptedly dark fiuscous; cilia pale fuscons. Posterior wings pale grey, with greyish-ochreous cilia.

Not uncommon; appearing in May and August. The larva, which is more casily seen, mines the leaves of the thistle (Cirsium 7ancolatum) in July and September.

28. Artemisiella (Tischer), Treit. E. S. ix. 2. 97 (1833); F. v. R. pl. 30. f. 2; Dup.; Yell.; Dougl. $\Lambda$ lis anticis rufu-brunneis, dorso dilutione, punclis duobus plice, dnobusque disci oblique positis posterins nigris. Exp, al. 5-5: lin.

Ileal greyish-fuscous. Face paler. Palpi dark fuscous, internally paler; terminal joint with two fuscous rings. Antenne fuscous, with paler annulintions. Anterior wings reddish-brom, acilh the inner maryin pater; on the fold are two bluck spots, one being in the midtlle, and one beyond; abliquely beyond these are troo olleres on the thise; on the hinder marefin and apex of the rosta are some black spots; cilia greyish-ochreous. Posterior wings pale grey, with greyish-fuscous cilia.

Common in Junc and July among the short grass in samily and gravelly places, near lipsom, Box IXill, Dawlish Warren, the Cheshire coast, etc. 'I'lie larva (according to 'Jischer) feeds in May in the terminal shoots of Artemisia campestris.

29. senectella (I. r. T.), \%cll. Isis, 1S39. p. 199; Dougl. $\Lambda$ lis anticis dilule grisco-ockicis, fusco-suffirsis (sirpe omnino fuscis), macnla busali costre, macula winore costee pone medium, puncloque clongatulo plice prope besim fuscis, puncto no plica, altero posteriore disci ante, tertio disci ponc medium nigris, fiscia posticis dilutiore angulata subdistincta. Exp. al. $5 \frac{1}{2}$ lin.

Ifead pale greyish-ochreous. Lace pate ochreons. Palpi pale ochreons; tominal jojut bencath spotted with fuscous. Intemie fuscous. Auterior wings prele gromish-ockreous, considerably suffused wilh fuscous (sometimes cutircly -o), will a darl, fuscons spot at the base of the costr, a sudnller one on the costa beyond the middle, and a vather elongated one on the fold near the buse; on the fold is a black spot, and another posterior to it on the dise before the mieldle, a third being on the dise beyoud the midelle; heyond this is a rather distinct pale angulated fascia ; cilia pale grevish-oclucous. L'osterior wings pale grey, with pale greyish-fuscous cilia.

Not rare in dry places among fern, in July; Darlford Heath. 
30. mundella, 1)ougl. Ent. 'Trans. i. n. s. $6 \mathrm{f}$ (1850). Ali. anticis dilue lnescenle-griscis, punctis sex nigris, quorum duo minula hasalia costam et dorsun versus, duo plice (prius prope basim, postrius ante medium), duoque disci; margine postico fusco. Exp. al. 5 lin.

Ifead and fiec pale yellowish-erey. Palpi yellowish; terminal joint fuscous. Antenne fuscous, with paler ammulations. Anterior wings pale yellowish-ygey, wilh sive bluck spols, two very minute at the base: (onc near the costa, the other on the inner margin), two on the fold (one near the base, the other before the middle), and two on the dise (the first being in the middle of the wing); hinder margin fuscous; cilia greyish-fuscous. Postcrior wings whitish-grey, with yclowishgrey cilia.

'This pretty litle species occurs among the samd-hills at New Brightou, and clsewhere on the Clieshire const, in May ant Jume.

31. similis, Dougl, n. sp. Alis anticis saturate brunne-fuscis, munctis dubbus clongatis ante medium (altero plica, altero posteriore (lisci), puncto terlio rotundo disci pone medium, obsoletis nigris, fiscia postica angulata obsolcta lutescente, ad costun distincliore. Exp. al. 6 lin.

Ifead dark fuseous. Face greyish-ochreous. Palpi greyish-ochreous; second joint exterually lrownish; terninal joint tark fuscous. Anterion wings darl brom ish-fuseons, with turo dongule, rather obsolete black spols before the midelle (one on the fold, the other posterior to it on the (lise); an obsolete ronnd black spot is on the disc beyond the misldle; beyond this is a faint pale: amentateal liscial, most distinet on the costr, where it appears as a pale yellowish spot; cilia greyishbrown. Posterior wings pale grey, with pale fuscous cilia.

'I'aken by Mr. Ioughlas in July, at Stoat's Vest, ('tarlton, aud ncar Mickleham, flying in the evening among thatel.

32. affinis, Haw. L. 13. 551 (1829); Step.; Dougl.-unbrosella, Zell.; Dup.? Nis anticis fuscis, punctis quatuor nigris externe albo. squamalis, primo pliea basim versus, secundo plicee medie, dutshus disci pone medium, maculis posticis oppositis, dorsali posterione, albidis. Fxp. al. $5 \frac{x}{3}$ lin.

IIcad dark fuscous. Face whitish. Palpi ochreous; terminal joint fuscons, with one or two pale ochreous spots. Antenuse unamulated, fuscous. Anterior wings fuscous, will four blast spots, each, followed by some white scales; the first is on the fold near the base, the sceond in the middle of the fold, the other two are on the dise beyond the middle; towards the hinder margin are two opposile whitish spots, of which that on the imer maryin is rather posterior; in the apex of the wing are a few white seales; cilia greyish-fuscous. P'osterior wings pale grey, with greyish-fuscous cilia.

Taken in various localities in July. I onec bred it from a larva foumd (when full-ferl) crawling on in mossy wall, in Fehruary. 
33. boreella, Dougl. Lut. Trans. i. u. s. 105 (1851). Mlis anticis nilidis yrisro-fuscis, punctis duobus ante medium (altcro plice, altero posteriore disci) punctorue disci pone medium nigris, squamis nonnullis lutescentibus pone punctum plice el inter puncta disci, fascia postica angulata et dentata lutescente. Exp. al. 6-2 lin.

1 cad dark fiscous. Fiace dark fuscous, rather shining. Palpi dark fuscous, internally a little paler. Antenne dark fuscous, bencath spotted with pale fuscous. Antcrior wings shining greyish-fuscous, with two black spots before the middle (one on the fold, the other, posteriorly placed, on the dise), and a black spot on the dise a little beyond the midalle; beyond the spot of the fold and between the two spots of the disc are some yellowish scales, and beyond the middle is a somewhat indented, slightly angulated pale yellowish fascia ; the hinder margin and apex of the costa are dark fuscous; cilia greyish-fuscous. Posterior wings pale grey, with paler cilia.

1 have a single specimen, taken in a boggy place near J)unoon, in the middle of July.

34. galbanella ( $\mathrm{k}$. v. R.), Kcll. Isis, 1839. p. 200; Dougl. Alis anticis latiusculis luteo-yriseis, punctis duobus ante medium (altero plice, altero posteriore disci), punctoque disci pone mediun nigris, spatio ponc punctum plicis, ct inter puncta disci fere lutescente absque griseo, fascia postica subolsoleta angulata non dentala dilutiore. Exp. al. $7 \frac{1}{2} \operatorname{lin}$.

Ilead ycllowish-rrey. Face paler. P'alpi extemally dark fuscous, internally pale ochreous. Antenne yellowish-grey, annulated with dark fuscous. Anterior wings rether broad, yellowish-grey, with two black spots liefore the midlle (one on the fold, and one rather posterior on the dise), and a black spot on the dise beyond the midllle; the space beyond the spot on the fold and between the spots on the dise is pule yellowish, with hurdly amy grey sertes; the pale hinder fascia is rather indistinct, not indented, and slightly angulated; the hinder margin and apex of the costa are spotted with dark fuscous; eilia grey. Posterior wings grey, with grcyish-fuscous cilia.

'Taken by Mr. Weaver, in the Black Forest, in Perthshire, in July.

35. basaltinella, /ell. Isis, 1839. p. 198; Dougl--domestica, var. $\beta$, Haw, $\Lambda$ lis anticis fuscis, punctis quatuor nigris (primo plice basim versus, secuudo plice, et tertio approximato disei ante medium, quarto disci ponc medium), spatio interjecto dilutiore, maculis posticis oppositis (dorsali nomihil posteriore) dilute ochreis, fere fusciun rectam formantibus. Exp, al. $5 \frac{1}{2}$ lin.

Ilcad dark fuscous. Face pale greyish-ochreous. Palpi dark fuscous, internally pale ochreous. Antemiac dark fuscous, with paler anmulations. Anlcrior wings fuscous, with four black spots, one on the fold not fir from the base, two a little before the middle (one on the fold, the other very near it on the (lise), and one on the dise beyond 
the middle; the space between these spots is palcr than the rest of the wing; beyond the fourth spot are troo pale oclereous oprosite spots (that on the inner margin being slightly postcrior), almost forming a straight fascia; cilia fuscous. Posterior wings grey, with greyishfuscous cilia.

Taken by Mr. Bedell, among old thatch at Adilington, in June and July; also by Mr. Douglas, in a similar locality.

36. domestica, Ilaw. L. B. 55l (1829); Stcp), Alis anticis ochreo-griseis, ficsco-mixtis, puncto humernli nigro, puncto costac pone medium saturate fusco, punctis quatuor nigris (primo plicac basim versus, sccundo plice, tertio approximato disei ante medium, quarto disci pone medium), spatio interjecto dilutiore, fascia postica subdistincta dilutiore angulata. Exp. al. 6 lin.

Ilead pale grey. Face whitish. I'alpi whitish; terminal joint externally with a few fuscous spots. Antenna dark fuscous, with pale grey anuulations. Antcrior wings greyish-ochreous, more or less dusted with fuscons, with a small black spot at the base of the costa, and a dark fuscous spot on the costa beyond the middle; a black spot lics on the fold, not far from the base, another is on the fold, and a thirel just above it on the dise a little before the middle, and a fourth on the dise beyond the middle; the space between these spots is paler than the rest of the wing; towards the hinder margin is a tolerably welldefined pale angulated fuscia; cilia pale grey. Posterior wings whitishgrcy, with pale greyish-fuscous cilia.

Oceurs in July and $\Lambda$ ugust, most frequently in houses; rarely on fences in the country.

37. rhombella, TIüb. 'Tin. 277 (1S12); Treit.; Dup.; Dougl.; IV. V.?-rhombea, II aw. Alis anticis cinereis, macula basali coste nigra, puncto postico costae saturate fusco, puncto plice prope bisim fusco, prnetis dnobus disci ( $p$ rino in medio, secumlo majore pone medium) saturate fuscis, nebula dorsi pone incdium fusca, fascia postica indistineta dilutiore angulata. Exp, al, 6 ${ }_{2}^{\lambda}$ lin.

Head and face greyish-fuscous. l'alpi dark fuscous, internally pale ochreous. Antenne very palc fuscous, with dark fuscous ammulations. Anterior wings ashy-grey, vith a long black spot at the base of the costa, and a smaller dark fuscous spot beyond the middle of the costa; near the base towards the inner margin is a fuscous spot, and another, rather indistinet, lies on the disc a little beyond; in the middle of the disc is a dark fuscous spot, and another, rather larger, is on the disc beyond the middle; a fuscous bloteh is on the inner margin beyond the middle; beyond this there are faint indieations of a pale angulated fascia; on the hinder margin and apex of the costa are some small dark fuscous spots; cilia greyish-ochreous. Posterior wings pale grey, with paler cilia.

Oceurs among apple-trees in July; taken formerly by Mr. S. 
Slevens, at IIammersmith; not common. 'Tle larva (aecording to Tienig) feeds on apple, in May and June, turning down a corner of the leaf.

38. proximella, Ilïb. Tin. 228 (1801); Treit.; Dup.; Zell.; 1)ougl.- rhombella, Step.?-pullatella, I)up.? Alis anticis caneserentiUus tenerime obsrurius irroratis, punctis striolisve sparsis nigris, liturit costali post medium fuscescente. Exp. al, 8 lin.

Head and face pale grey. Palpi pale grey ; terminal joint whitish, with the base and two rings black. Antenne pale grey, annulated with dark fuscous. Anterior wings hoary-grey, with mumerous black strulis and spots; a black streak from the base of the wing near the costri, a sliort black streak on the costa in the midalle, and a dark fuscous blotels on the costa beyoud the middle; on the imner margin is a dark fuseous blotch near the mikldle, and a smaller one beyond the middle; very near the base on the fold is a smaller black spot, and before the midille are two black spots, one on the fold, the oflier anterior on the dise; in the middle are two rather long blick spots (the smaller one on the fold, the larger and rather posterior on the dise); beyond the middle on the disc are two small round black spots, followed by a short black streak; the apical portion of the wing is clouded with dark fuscous, and the hinder margin and apex of the costa are spotted with black; cilia pale grey. l'osterior wings pale grey, with paler cilia.

Common among birches in May and Junc. The larva fects between united leaves of birch in September.

39. notatella, Hüb. Tin. 3.1 (1516); Treit.; Licnig; Dongl.proximella, var. $\beta$. \%cll. Alis anticis griseis, salurutius noblosis, nobnlis tribus costar, prima basali, secundo ante, tertia pone medium, nebula majore dorsi (in quo puncta duo ante medium), punctis duobus in medio, duobusque disci pone medium nigris. Exp. al. 6 $1-7$ lin.

Ifead and face grey. Palpi grey; tcrminal joint paler, with the base and two rings black. Antenne pale grey, anmulated with dark fiuscous. Anterior wings grey, with numerous dark grey clouds, threc of which are on the costa (one at the base, one before, and the third beyond the middle); almost at the base on the fold is a small black spot; a large clond oecupies nearly the whole of the inner margin, on it are two black spots before the middle (one on the fold, the oflher anterior on the dise); in the middle are two other black sjots, one on the fold, the other, above it, rather clongate on the dise; beyond the widlle are two other small black spots on the dise; on the hinder margin and apex of the costa are some small dark fuscous spots; cilia grey. Postcrior wings grey, with pale grey cilia.

Not uncommon among sallows in May. The larva fects on sallows in Siptember, between united leaves of the smooth-leaved species, and burowing in the wool on the underside of the leaves of the woolly-leaved sprecies. 
4.0. humeralis, 7cll. Isis, 1839. p. 200 ; Dougl.-I,yellella (Curt.); Westw.-decorelle, Ilaw.? Alis anticis anguslulis, albidis (interclum omnino fuscis), striola lumerali costali nigra, puncto costre mediac parvo fusco, macula pone medium costie saturate fusea, striola ci opjosita transversali disci, puncto antcriorc oblongo supra plicam, puncto altero basim versus, his punctis satmrite fuscis in maculan magnan dorsalem interdum inclusis. Exp. al. $6 \frac{1}{2}$ lin.

Hlead and fice yellowish or dark fuscous. Palpi yellowish; terminal joint with a fuscous ring betore the ajex, frequently with another fuscous ring near the base. Antenua fuscous, unmmulated. Anterior wings rather narrow, of variable ground-colour, from yellowish-white to dark fuscous, with a black streal at lhe base of the costa; in the midclle of the costa is a small fuscous clondy spot, and beyond it a more distinct dark fuscous spot; opposite the latter is a dark fuscous transverse spot on the dise, before which is an oblong dark fuscous spot above the fold; between this and the base is a somewhat irregular dark fuscous spot on the fold; the last three spots are sometimes included in a large dark blolch on the inner margin; on the hinder margin and apex of the costa are some fuscous spots; cilia greyish-fuscous. Posterior wings pale grey, with greyish-fuscous cilia.

An extremely variable insect; appears in July and August; not unfrequent in the New l'orest; searec in other localities.

4. vulgella, IIüb. Tin. 31.6 (1816); \%ell.; W. V.? I)up.?aspera, Haw. ; Step. Mlis anticis griseis, nebulis tribus costre, nebulnque in medio dorsi saturate rrises, punetis duobus in medio scrabris nigris albido-cinctis, macula lransversali scabra nigra ad angulum analem, fascia postica indistincta angulata clilutiore. Exp. al. 6 lin.

Head grey. Face palcr. P'alpi grey; terminal joint pale ochreous, with two fuscous rings. Antenna fuscous, with palcr annulations. Anterior wings grey, with three dark grey clonds on the costa (the first near the bise, the second in the middle, the third beyomi the middlle), and a dark grey cloud near the midldle of the inner margin; in the middle of the wing are tro raised black spots, surrounded by whitish (onc on the disc, the other mather posterior on the fold); abeve the anal angle is a linuswerse raised black spot reaching more than half across the wing; beyond is a faintly inclicated palc angulated fascia; the hinder margin and apex of the wing are spotted with black; eilia grey. Posterior wings grey, with paler cilia.

Common among hawthorn in Jume and July. 'The larva feeds (I believe) in the young shoots of hawthorn in May.

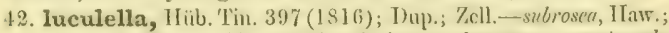

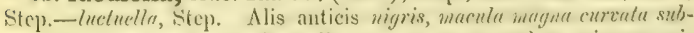
rosere ante merlium. coste fere plicam tangente, masulan minorem nifram costa includente, maculis posticis oppositis, costali majore, albiclis. Exp. al. 6 lin.

Head and face grey. Palpi greyish-fuscous; the terninal joint with 
two pale ochreons rings. Antenna fuscous, with indistinct paler annulations. Anterior wings blach, with a large curved pale yellow blotch before the middle of the costa, reaching half across the wing, where it is tinged with rosy; on the costa it includes a small black spot; towards the hinder margin are two whitish opposite spots, of which that on the costa is the larger; cilia very dark grey. Posterior wings greyish-fuscous, with paler cilia.

Very common round London, on the stems of oaks in June.

43. scriptella, IIüb. Tin. 132 (1801); Treit.; Zell.; Dup.?Blallaria, Haw. - tremolla, Step. Alis inticis albis, costam versts cxalbiclis, maculis coste tribus (prima basali, secunda media, tertia pone medium) nigria, dorso usque pone medium late fuseo, prenclo oblongo pliere metire, strivla posteriore disci, striolaque transwersali disci pone medium scabris nigris. Exp. al, $6 \frac{1}{2}$ lin.

Ifead and ficc white. Palpi whitish ; tcrminal joint with two black rings. Antenua whitish, ammulated with dark fuscous. Anterior wings white, towards the costa with a slight ochrcons tinge, with the bise of the costa, a spot in the middle, and a larerer spot beyond the middle of the costa black; the inner margin is broally fuscous from near the base to beyond the middle; in the middle of the fold is a long black spot of raised srates, a short curvent streak lies on the disc valleer beyond, and a transwerse strak is on the dise opposite to the last costal spot, but not reaching beyond the fold; these are likewise composed of raisent black scales; the apical portion of the wing is elonded with fuscons, with some darker spots towards the hinder margin; cilia whitish. P'osterior wings pale grey, with palcr cilia.

Common anong maples in May and June. The larva feeds on the leaves of the maple in September, turning down at portion, sccuring the leaf' in its folder position by several strong cables of silk, and then devouring the folded portion half through; they are extremely subject to the attacks of the lchnemmonilie.

14. fugitivella, Zell. Isis, 1839, p. 200; Dougl. - pullatella, Eicrs.? Mlis anticis cinereis, saturute fusco-nebulosis, basi dorsi, apiceque execptis, ncbulis trilus costre (prima basali, secumda ante, tertia poue medium) punctis duobus subscabris plice (altero ante medimm, altero in medio) nebulaque dorsali prope basim nigris. Exp. al. 6 lin.

Ifead and face grey. Palpi grey; terminal joint with two dark liuscous rings. Antennix grey, annulated with dark fuscous. Anterior wings eshy-grey, much clouded voilh durk, fuscons, only a small patch at the base of the inner maryin, and towarls the apex of the wing remuining anclouded; along the costa are three almost black blotches, one at the base, one before, and one beyond the middle, and in the fold are two black rather raiserl spots, one before and one in the middle; on the inner margin not far from the base is a suall black bloteh; a fuscous cloud lies in the grey apical portion of the wing, and several 
fuscous spots are on the hinler margin; cilia grcyish. Posterior wings greyish-fuscous, with paler cilia.

Not scarce among elins in. June and July. 'The larva (according to Lienig) feeds on nut, maple, and elm, in May.

45. Athiops (West.), IIunp. and West. 13. MI. ii. 192. pl. 107. f. 13 (1845); Dougl. Alis anticis nigris, punclis scaluris nigris (primo disci ante mediun, secundo majore, tertioque minore plicas, quarta obliqua disci in medio, quinto pone medium transversali), fascia postica angulata diluta obsolelissima. Exp. al. 8 lin.

IIead and face black. l'alpi black, intemally ratber paler; terminil] joint with a grey ring before the apex. Antenne black. Anterior wines blacli, wilh several raised lufts of black seales, one before the midlle on the dise, a scend more conspienons, at little posterior on the fold, two are in the mildtle (one on the fold, the other rither oblinucly placed on the dise); a fifth is transversely placed beyoud the middle rither above the fold; beyond are some extremely faint indieations of a pale angulated fascia; cilia dark grey. P'osterior wings pale greyish-fuscous, with greyish-fuscous cilia.

()ccurs on moors in the north of Lngland, in June, sitting on the black places that have been burnt.

4.6. Solutella (F, v. R.), Zell. Isis, 1839. p. 199; Dup.?-fuirosellu, Dougl. Alis anticis saturatissime fuscis, punelis qualuor niqris, primo plica prope basim, secundo plica, tertio disci paullo ante metium, quarto disei pone incelium, fascia postica diluta angulata obsoletissima. Exp. al. $9 \frac{x}{2}$ lin.

Ifead, face, palpi, and antennx dark fuscous. Anterior wings very dark fuscors, with four black spols; the first on the fold not fir from the base, the sccond on the fold, and the third on the dise, a little before the middle, the fourth on the dise beyond the middle; there are hardly any inclications of a pale angulated fascia; cilia palc oclırcous, intersecterl by a dark fuscous line. P'osterior wings pale grey, with greyish-ochreous cilia.

$\Lambda$ single specimen was taken in $185 \mathrm{l}$, by $\mathrm{Mr}$. Weaver, in Pertllshire; it is in Mr. Doubleday's collection.

47. distinctella, /cll. Isis, 1839, p. 199; T. v. 12. pl. 80. f. 2; Dougl.; Dup.? Alis anticis fusco-brumneis, puncto obliquo costali prope basim, macula costali pone medium, salurate fuscis (interdum obsoletis), puncto uno plice, alicro posteriore disci, tertioque disci pone medium, nigris albido-notalis, fascia postica subangulala dilutiore subobsoleln. Exp. al. 7 슬 $\mathrm{in}$.

IIcad aud face greyish-fuseous. Palpi greyish-fuscous, internally pale ochreous; the tip of the terminal joint pale ochreous. Antennas? fuscous. Anterior wimers dark brononish-fuscous, with an oblinue dark fuscous blolele from near the buse of the custa, aud a dint fuscous blotch on the costa beyond the midille (these markings are sometimes almost VoL. III. 
lost, in the dirk ground-colour); on the fold is a black spot, and another, rather posterior, on the dise hefore the midlle, a third is on the dise beyond the middle; these spots are gencrally preceded and followed by some whilish scales; towards the hinder margin is a slighily anguluted palex but not very distinet fascin; on the hinder margin and apex of the costa are some scattered black scales, and a fero whitish scales lie lowards the apex of the hinder margin; cilia fuscous, intersected by a darker line. Posterior wings grey, with greyish-fuscous cilia.

Occurs on the downs beyond Croyelon, anong the junipers, in July and August; also in the Isle of Portland, but not common.

48. celerella (1)ongl.), Sta. Sup. Cat. 1) 5 (1851); Dongl. $\Lambda$ lis anticis fusco-griseis, slrin obliqua coster prope basim, macula magna triangulari in molio costo inferius in plicam terwinata, naculaque costa sublianszersali jone wedium salurnte fuscis, puncto uno plicse, altero posteriore disci ante, tertioque disci pone medimu nigris, albido-nolatis,

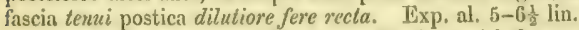

llead and face greyish-fuscous. Palpi greyish-fuscous, internally pale ochreous; tip of the terminal joint pale ochreous. Antenna fuscous. Anterior wings greyish-fuscous, with a short oblique fuscons strerk from the costa near the base, a large triangular fuscous blotch in the middle of the costa, terminatine on the fold, and beyond the middle is a lark fuscous costal bloteh, almost reaching across the wing; a black spot lies on the fold, a second rather postcrior on the dise before the middle, a third on the dise beyond the midalle; thery are grenerally preceded and folloned by some whitish scales; towards the hinder margin are two prile opposite spots, almost united into a slender straight fuscia; in the dark apex of the wing are a fuw whitsh seales; cilia pale fuscous, intersected by a darker line. Posterior wings pale grey, with greyish-fuscous cilia.

$\Lambda$ few specimens hare becu taken in September among the sandhills of the Chestire coast, by Mr. Cooke and Mr. Gregson.

49. costella (St(p)), IIump. and West. 13. M. ii. 192. pl. 107. f. $15(1815)$; l)ougl. Alis anticis rufo-ocheres, apicem versus fusco-suffusis, macula magna costre fere ex basi usque ad fuscium posticam producla, ante medium plicam tangente, postice angustata, nigra, fascia postica distincte angulata dilute rufo-ochrea. Exp. al. $6 \frac{1}{2}$ lin.

Ilead dirli gravish-ochreous. liace pitle greyish-ochreous. Palpí reddish-fuscous, internally whitish ; terminal joint pale ochreous, with two dark fuscous rimgs. Autcmine fuscous, with paler annulations. Auterior wings reddish-ochreous, with a large black blolch on the costa, beginnisy not far from the base, and reaching to the hinder fascia, it is broaks st before the mialdle, where it tonches the fold, and is attenuated ponteriorly; the pale linder faseia is distinctly angulated, reddishochreous; the apical portion of the wing is much sulfused with fuscous; and the hinder margin and apex of the costa are alternately fuscous and reddish-ochreous; cilia fuscous. P'osterior wings greyish-fuscous, with paler cilia. 
Not uncommon in hedges where Solanum Dulcamara grows, in May, August, and September. The larva mines the leaves, and feeds in the berries and stems of the Solanum, in July and $A$ ugust.

50. maculea, IIaw. L. B. 552 (1829).-maculella, Step.-Ulundella, Dougl. Ent. 'Trans. ii. 11. s. 77. pl. x. f. 2. Alis anticis albirlis fuscescenle-suffusis, apicem versus fusco-suftusis, atomis nigris prope basim, macula oblonige nigra ante mediun costee, plicam fere langente, postice producta, punctis duobus disci, altero ante, altero pone medium nigris, fascia postica alba nounihil angulata et dentata. Exp. al. $5_{2}^{1}$ lin.

ITead, face, and palpi creamy-white. Antenne whitish, ammlated with dark fuscous, Anterior wings whitish, somerchat suffirsed wilh pale fuscous; a few black dots lic near the bise, an oblique black strenle arises before the midllle of the costa, reaches nearly to the fold, and is rather. mrorluced posteriorly; above its apex is a small black spot on the dise, and beyond the middle is another small black spot on the dise; the pale hinder fascia is white, slightly angulated and indented; the apienl portion of the wing is more suffused with fuscous, the hinder maroin and apex of the costa are varied with black and white seales; cilia prile grey. Posterior wings pale grey, with greyish-fuscous cilia.

Not uncommon in July in hedges where: Stelluria huturtea grows. The larva, when young, mines the leaves, afterwards foeds in the terminal shoots, and at a later period feeds in the seeds of the Stelluric holostere; it may be met with in May and June.

51. tricolorella, Haw. Tr. lint. i. $338(1812)$; Step.-contiyna, Haw.; Step.; Dougl. Ent. Trans. ii. n. s. 76. pl. x. f. l. Alis anticis dilute nufo-brunneis, basi fusca, stria brevi coste jurepe bisim exalbicha, macula magna nigra costre "s strin nsque ad Jascient posticrme catensa, plicam tangente postice angustata, strium ad itorsm pone merliun enittente, maculis posticis opposilis cxal'silis, fasciun angulatan formantibus, costali majore ac posteriore. Lixp. al. 6 lin.

IIearl dark fuscous. Face greyish-ochreous. l'alpi dark fuscous; internally, and the tip of the terminal joint, pale ochreous. Antemne fuscous. Anterior wings rather pale reuldisti-broen, with the base fuscous; a short oblique streak from the costa near the base is ycllowishwhite; beyond this is a large black costal bloteh, wethich extends to the hinder fascia, it reaches to the fold, hut is posteriorly narrower, and beyond the middle it emils a black strukt to the inner naryin; the yelloacish-white opposite spots, of which that on the costa is the larger and posterior, form an angulated fascia; the apical portion of the wing is black, the hinder margin and apex of the costa being alternately blachish and whitish; cilia dark fuscous, with the tips paler. j'osterior wings greyish-fuscous, with paler cilia.

Not scarce in fuly in lierlges where Shellaria holustea crows. Ihe larva, when young, mines the leaves, afterwards fecding in 
the terminal shoots, and devouring the flower-buds of the Stellarice holostea, in the beginning of spring.

52. fraternella, Dougl. Ent. Trans, j. n. s. 101 (1851); Id. Ent. Trans. ii. n. s. 77. pl. x. f. 3. Alis anticis rufo-brunecis, fusco-su!fusis, puncto supra plican prope basim, nebula obliqua ante medium coske plicam tangente, nebula pone mediun dorsi (apiec cum puncto nigro disci eonnexo), saturate fuscis, maculis oppositis albidis fere fasciam vix angu-

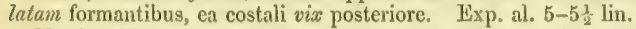

Ilead reddish-brown. Face palc grcyish-ochreons. l'alpi fuscous, internally pale oclureous; terminal joint dark fuscous, internally and the tip pale ochreous. Antenna dark fuscous, with paler ammulations. Anterior wings reddish-broven, more or less suffiused will fuscous, with a dark fuscous spot above the fold near the base, a dark fuscons blotch fiom the costa before the middle, entending obliquely to the fold, and a dark fuscons blotch on the inner margin beyond the middle, at the apex of which is a black spot on the dise; beyond are two whitis/e opposite spots, almost forming a slightly anyulated fascia (that on the costa is rather posterior); the apical portion of the wing is almost entirely dark fuscous; cilia pale grey, varied with fuscous. Posterior wings pale grey, with greyish-fuscous cilin.

Not uncommon in July, in hedges and weedy banks where Stellaria uliginosa grows, but very retired in its labits, and not ensily dislodged. The larva feeds in May in the young terminal shoots of Stellaria uliginosa, which thereby assume a singular knobbed and contorted appearance.

53. maculiferella (Mann), Dougł. Ent. Trans. i. n. s. 102 (1851).-proxima, llaw.; Step, Alis anticis yriseo-fuscis, costam versus rufo-brunnco sullisis, macula oblique nigra ante medium coster, plican tangente, interne cum puncto niyro plicer, externe cun puncto nigro disci connexu, puncto disci pone medium cum striola transversali snpra plicam connexo, nigris, fuscia postica dilute ochere interrupta subangulata. Exp. al. 5 lin.

Ilead dark fuscous. Face pale ochreous. Palpi dark fuscous, interually pale ochreous. Antennas pale fuscons, annulated with dark fuscous. Anterior wings greyish-fuscous, somewhat sultused with reddish-brown towarts the costil, wilh a broud oblique black streat from the costa brfore the middle, not reaching bryond the fold, connecter internally will a bleck spot on the fold, and externally with a black spot on thes dise; beyond the middle is a blick spot on the disc, connected with a short transwerse streak rather aljove the fold; the pele ochrevus hinder firscia is interrupted and slighlly angulated; beyond it the apex of the wing is dark fuscons; the hinder margin and ajex of the costa being varied with dark fuscous, and pale ochreous; cilin grey. P'osterior wings palc grey, with pale grcyish-fuscous cilia.

Taken occasionally in July in weedy banks, but scarce. 
54. junctella, 1)ougl. Fint. Trnn s. i. n. s. 103 (185]). Alis anticis abbido-griseis, apicem versus siturate fuscis, costam verszes rufobrume-nebulosis, maculn costali plicam tangente ante medinn, puncto disei pone medium nigris, maculu rufo-brunnea, ante fasciam parun curvatam albidam. Ixxp. al. $4 \frac{x}{2}$ lin.

Ilead shining bronze. Fice paler. Palpi dark fuscous, internally whitish. Antennæ whitish, annulated with dirk fuscous. Anterior wings whitish-grey, towoards the costa rather clonded with reddish-brown, with a black costal spot before the middle reaching to the fold, and a small black spot on the dise beyond the middle, followed by a reddishbrown blotch; beyond this is a pale yellowish-rlhile, slightly curved fascia; the apical portion of the wing is almost entirely dark fuscous, nearly black; cilia grey. l'ostcrior wings greyish-fuscous; cilia paler.

Has occurred in Epping and IIainault l'orests, on the trumks of oaks, in August.

55. vicinella, Dougl. Ent. Trans. i, n. s. 102 (1851). Mlis anticis fuscis, maculis una prope basim, altera obliqua costali ante medinm, lertia posteriore disci nigris, plaga magna simuata dorsi (antice costan tangente) albida, maculis posticis oppositis albidis. Exp. al. 6 lin.

IIead greyish-fuscous. Face pale ochrcous. Palpi fuscous, intermally pale ochreous; terminal joint dark fuscous. Antemme dirk fitscous, with paler annulations. Antcrior wings dark fuscous, with a black spot near the base, an oblique black bloteh before the middle of the costa, and a black blolch on the disc beyond the middle; on the inner. margin is a large yellowish-while blolch exteuding from near the base to beyond the middle, at first it almost touches the costa (there appearing as at fascia), but beyond it is much indented with the dark gromelcolour, but posteriorly it again widens aud crosses the fold; towards the hinder margin are two whitish opposile spols, of which the costal spot is rather posterior; cilia pale fuscous. P'osterior wings whitishgrey, with pale fuscous cilia.

Three specimens only liave occurred; these were found at Bclfist and Brighton, in August and September. In my own and Mr. Douglas's collections.

56. Hübneri, Haw. I. 13. 551 (1829) ; Stcp.; Dougl. Alis anticis albidu-griseis, dilute roseo-suffesis, macula coste basima versus, cum macula plice ante nealium (fere striam obliquam formante), punctis duobus disci, altero ante, allero (cum striola supma plicam connexo), pone medium nigris; nebula costio pone medium saturate fusea, filscia postica parum angulata et dentata albida. Exp. al. 6 lin.

Ilead and face whitish-grey. Palpi palc fuscous, internally whitish ; terminal joint dark fuscous, internally whitish. Antemme whitish, with fuscous ammulations. Anterior wings whitish-yrey, with a slight rosy lint, will a black spot on the costa not far from the base, and obliquely beyond it a larger bluck spot on the fold (the troo nearly forminy an oblique striga); on the dise are two small black spots, one before, the 
olher beyond the middle, the latter is connected will a short lransverse black slreak aboee the fold; on the costa beyond the midllle is a rlark fuscous blotch, followed by a slightly angulited, ralker indented whitish fascia ; the hinder margin and apex of the costa are varied with whitish and black seales; cilia pale fuscous. I'osterior wings grey, with greyish-fuscous cilia.

$\Lambda$ scarce species; most of our specimens lave been taken in the north of England, on the trunks of oaks in July and August.

57. marmorea, IIaw. L. B. 553 (1829); Step.; Curt.; Dougl. - Mannielle, Zell.? Alis anticis angustulis rufo-brunneis, fusco-su/(/usis, dorso dilutiore, punctis duobus albidis cum duobus aliis saturate fuscis alternantibus supra plicam, stria nigra disci in medio, fascia postica fere recta, parum obliqua, et interrupta albida. Wxp. al. $5 \frac{2}{2} \mathrm{lin}$.

Ilead and face pale greyish-fuscous. Palpi dark fuscous, intemally whitish. Antenne fuscous. Anterior wings rather narrow, reddishbrowen, suffused with fuscous, the inner margin paler, with two whitish spots above the fold, each preceded by a dark fuscous spot (the first not far from the base, the other in the middle of the wing); above the sccond is a black streak on the dise; towards the hinder margin is $a$ nearly straight, rather oblique, slightly interrupted, whilish fuscia; the hinder margin is dark fuscous; cilia greyish-ochreous, varied with fuscous. Posterior wings pale grey, with greyish-ochreous cilia.

Common on sandy coasts, amougst the short grass, from June to September.

58. instabilella, Dougl. Zool. 1270. f. 10 (1846). Alis anticis rufo-ochreis, stria obliqua coske ante medium fusca, in plicam desinente, punctis tribus plice, tribus disci saturate fuscis, fascia postica dilutiore aurulata obsoleta, Exp. al. 7 lin.

IIead and face greyish-ochreous. I'alpi pale ochreous, beneath fuscous. Antenne pale fuscous, with darker aunulations. Anterior wings reddisth-ocherous, with a short oblique finscous streak from the costa before the middle, not reaching beyond the fold; on the fold are three black spols, the space between the first and sccond is grenter than that between the second and the third, which latter is in the middle of the wing; on the dise are three dark fuscous spots, the first a little beyoud the second spot of the fold, the other two very near torether beyond the iniddle; the palc angulated fiscia is rather indistinet; beyond it the apieal portion of the wing is elouded with fuscous; the hinder margin and apex of the costa are spottcd with dark fuscous; cilia greyish-ochreous, varied with fuscous. l'osterior wings whitish-grey, with ochreousgrey cilia.

Occurs on the coast in July and $\Lambda$ ugust; St. Osyth and Brighton. Mr. Douglas bred this species last autumn from larvac he found at 13righton, in August, feeding on Salicomia herbacea and Chenopodium maritinum. 
59. Atriplicella, T. v. R. 223. pl. 78 (1839); Dougl.; Dup.? Alis anticis griseo-fuscis, stria oblique saturatiore costre ante medium, plicam tangente, punclis tribus plice, duobus disci saturate fuscis, fascia postica dilutiore angulata subdistincta. Exp. al. 7 lin.

IIcad and face greyish-fuscous. Palpi fuscous, internally pale ochreous. Antenne fuscous. Anterior wings greyish-fuscous, wilh a darker oblique streak from the costa not far from the base, reaching to the fold; along the fold are three dark fiescons spots, and on the disc are two others obliquely above the sceond and third of the fold, the last being a little beyond the middle of the wing; the pale hinder fascia is not very distinet, it is angulated; the hinder margin and apex of the costa are varied with pale and dark fuscous; cilia palc fuscous. Posterior wings pale greyish-fuscous, with paler cilia.

Common in July and $\Lambda$ ugust, in many places, among Atriplex and Chenopodinm. The larva feeds from May to July, on the leaves and flowers of those plants.

60. obsoletella, F. v. R. 225. pl. 79 (1.840); Dougl.; Dup.clongella, W. V.? Hlüls,? Alis anticis dilute griseo-ochreis, fuscescentesuffusis, puncto plice, punctoque uno postcriore disci ante medium, punctis dnobus disci pone medium, interdum comnexis, fuscis, fiscia postica dilutiore angulata indistincta. Ẻxp. al. 6 lin.

Head and face pale greyish-ochreous. Palpi palc greyish-ochreous, with a dark fuscous ring before the apex of the terminal joint. Anteme pale greyish-ochreous, annulated with dark fuscous. Anterior wings pule greyish-ochreons, more or less clouled with pale fuscous; on the folil before the midlde is a fuscous spot; on the dise is another rather postcrior, and beyond the middle are teco smaller fuscons spots on the disc (the posterior being nearer the inner margin), and in some specimens they are united; the pale angulated fascia is rather indistinct; the hinder nurgin and apex of the costa are spotted with pale fuscous; cilia pale ochrcous. l'osterior wings whitish, with palc ochreous eilia.

Abundant in the Isle of Portland in August, among Chenopodium maritimum. The larva (according to lisscher) feeds from May to August in the stems of Atriplex and Chenopodium.

61. littorella, Dougl. Ent. Trans. i. n. s. 67 (1550). Alis anticis albidis, leviter fusco-suffusis, linere plice lineaque disci pone mectium lutescentibus, ntraque punctis duolus nigris notata, basi costie, punctoque prope costam ante medium fuscis. 1Exp. al. 5: lin.

Ilend and face whitish-grey. Palpi pale grey; terminal joint darker. Sutemine whitish, amulated with fuscous. Anterior wings whitish, slighlly suffused with pale fuscous, with a yellortish strath on the fold, and one on the disc beyourl the midlle; on each of these streatis are two bluck spots; the base of the costa is fuscous, and a fuscons spot lies not fir from the costa before the middle of the wing; cilia yellow ish-white. Posterior wings greyish-white, with yellowish cilia. 


\section{Wikken by Mr. Stevens, in Mizy, on the coast of the Isle of Wight.}

62. sequasx, Haw. J. 13. 552 (1S29); Stcp.; Dougl-—apicis/rigella, Dup.? Alis anticis fuscis, fescion obliqua ante medium al dorsum thilatala (introrsum costam versus nigro-scuamata), fuscinque posticn olsoletat dilule griseis, punctis dunbus disci in medio, punctis duobus: aute faschitu postican (altero clorsum versus, altero transversali disci), lineolaque apicis nigris. Exp. al. 6 lin.

Ifead and fiter whitish-gery. Palpi whitish; terminal joint with two black rings. Antcune whitish, annulated with dark fuscous. Anterior wings fuscons, wilh an oblique prets grey fuscia before the midalle, broadest on the inmer ataryin, internally with some black scales from the costa to the lold ; towards the lineler mirgin is a rather indistinct straight palc grey fascia; on the dise in the midelle are two small black spots, two other black spots (one near the inner margin, the other tratustersely placed on the dise) precede the hinder fiscia; towards the apex is a short black streak; ceilia greyish-fuscous. P'osterior wings pale grey, with paler cilia.

Occur's at Sinderstead and $\Lambda$ rthur's Seat, in July and $\Lambda$ uggust, among Iletianthemum vulgarc. 'I'he larva (first observed by Mr. Logain) feeds in the terminal shoots of that plant in May and June.

63. aleella, Fab. H. S. iii. 2. 317. 136 (179.1); 7ell.-allemella, Ilüb.; Step.—ullerna, Haw.-bicolorellu, 'Treit.; 1)up. xi. pl. 298. f. 1. $\Lambda$ lis anticis niveis, fascia obliqua ante medium, maculis quatuor (duabus costie, terdia dorsi, quarta apicalis), punctis disci, marginisque postici nigris. Exp. al. 6 lin.

Ilead and face white. Palpi white; terminal joint with two black rings. Antenn: whitish, anmulated with black. Anterior wingrs snowywhite, with black markings; viz. a slight intermuted striga very near the base, an oblique fiscria a little beyond, a triamgular spot on the costa before the midldle, a small round spot opposite to it on the fold, a spot on the costa beyond the middle, a nearly triangular spot opposite to it on the imer margin (between them is a sinall spot on the disc), a large spot towards the apex of the wing, and several small spots along the hinder margin; cilia grey. l'osterior wings grey, with paler cilia.

Occurs on the trunks of onks in May and Junc, at West Wickliam Wood; not common. It is casily seen from a distance, from the strong contrast of the black markings on a white ground.

64. Ieucatella, Lim. I'. S. 14\% (1761); Tab); IIib). Tin. 146;

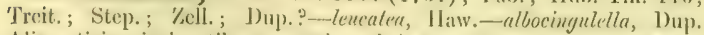
Alis anticis nigricantibus, punctis scabris atris, faseia lata obliqua ante necliun, maculisque duabus posticis oppositis albis. Fxp. al. G $6_{3}^{1}$ lin.

Ilead and face white. Pillpi white; terminal joint with two pale fuscous rings. Antemar black, with whitish anumlations. Anterior 
wings blackish, with a broad rather oblique white fascia before the middle, narrower towards the costa, and with two opposite white spots (of which that on the immer margin is the larger and slightly posterior) towards the hinder margin; on the fold on cach side of the firscia is a raised deep black spot, and a third is a little above the fold beyond the middle; on the linder margin and apex of the costa are some minute black spots; cilia dark fuscons. P'ostcrior wings grey, with palcr cilia.

Frequents hawthorn liedges in June and July. The larva (accortling to Lienig) feeds in May between united apple-leaves, in a felted mass, which bears a resemblance to moss.

65. albiceps, Zcll. Isis, 1839. p. 202.-n nua, IIaw.-ateellu, Step. Alis anticis griseo-nigris, puncto coste basali albilo, fascia oblique ante medium, in medio attenuata, in dorsum valde dilatata, macula in medio coste, maculisque posticis oppositis per lincam in fasciam angulatam connexis albis. Exp. al. $5-5 \frac{1}{3}$ lin.

Head amd face white. Palpi white; terminal joint with two black rings. Antenne white, anmulated with black. Anterior wings greyishblack, with a small whitish spot at the base of the costa, an oblique qolite fescia before the middle, extremely attenuated on the fold, but much expanded on the inner margin; on the widelle of the costa is a white spot; and beyoud are two opposite white spots, comected by a slender line, so as to form an angulated fascia; beyond this is an irregular black spot; scveral black spots are on the dise, but indistinct from the deep ground-colour; cilia whitish, with some fuscous lines. Posterior wings grey, with greyish-fuscous cilia.

Uccurs, not uncommonly, on fences round orehards in August.

66. nanella, Hüb. Tin. 267 (1S12); Kell.; Dир.; W. V.?-nena, var. $\beta$. Haw. Alis anticis griseis, fusco-pulveratis, fiscia obliqua prope basim, maculis cluabus costie (altera ante, altera pone medium), lineis duabus posticis longitudinalibus disci, punctisque rotundis pliean versus, fere connexis, saturate fuscis. Exp. al. $5 \frac{1}{2}$ lin.

Head and face white, mixed with grey. Palpi whitc; terminal joint with two dark fuscons rings. Antenne white, ammulated with black. Anterior wings greyish, powdered with fuscous, with several dark fuscous markings, vi\%. an oblique fascia arising on the costa ncir the base, a small spot on the costa before the middle, and a smaller spot on the costa beyond the middle; on the thise is a shor longiludinal streak, nearly in the middle, and another follorvs beyond the middle, two small round spots lie immediately below these streaks; the hinder margin is dark fuscons; cilia whitish, with some fuscous lines. l'osterior wings pale grey, with palcr greyish-fuscous cilia.

Not uncoinmon in orchards in July. The larva (detected by Mr. Wing) fecds in Mity on the pear, making a gallery across the flowers, with pieces of the petals and stamens interwoven with silk.

VOL. III. 
67. Mouffetella, WV. V. 110. 57 (1776); Tüb. Tin. 21.5; Treit.; Step.; Dougl.; I,imn.? Tab.?-punclifera, IInw. Alis anticis rufescenle-cinercis, punclis duobus conspicnis ante medium. (altero plicu, altero postcriore disci), punclisque duobns approximalis oblique positis, disci, pone welium nigris, fascia postiea dilutiore angulata valde indistincta. Exp. al. 8 lin.

IIcad and face palc grey. Palpi grey, beneath darker; terminal joint paler, with a broad fuscous ring before the apex. Antenux pale grey, with fuscous ammulations. Anterior wings pale ashy-grey, rith a slight reddish linge, with some indistinct black spots towards the base, along the fold and along the subrostal vein; nearly in the midlde of the ring are tro conspienous black spots, one on the fold, the other, rather posterior, on the dise; beyond the middle are tro other conspienons bluck spols, wearer togellier, but more obliquely placed; beyond them may sometimes be secu faint inclications of a pale angulated fascia; some small black spots are on the hinder margin and apex of the costa; cilia greyish-fuscous. Posterior wings grey, with greyish-fuscous cilia.

()ecurs in helges among honeysuckle in Jume and July, but not frequently met witl. The larva feeds in May, betwcen united leaves of the honeysuckle, forming a white silken web, which fits tightly to its body.

68. dodecella, Linn. S. N. (10) 539. 27\% (1759); De Geer;

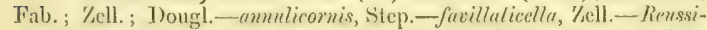
ella, liatz. Alis anticis griseis, fasciis fuatuor ncbulosis saturatioribus, punctis scabris tribus plice majoribus, tribus disci minoribus nignis. Exp). al. $6 \frac{1}{2}$ lin.

Head and face grey. Palpi grey ; terminal joint with two darker fuscous rings. Antcuna grey, amulated with dark fuscous. Anterior wings grey, with four darker eloudy fascie (one at the base, one before, another beyond the middle, and the fourth towards the hinder matroin); along the fold are three distinct raised blact spots, and on the dise abore thent are three ollhers, less sharply defined; between the third and fourth cloudy dark fascia the ground-colour appears as a pale angulated fascia ; on the hincler margin and apex of the costa are some short black streaks; cilia grey. Posterior wings greyish-fuscous, with paler cilia.

Very common among Scoteh firs (P'inus sylecstris) in June and July. The larva feeds in May in the terminal shoots of those trees.

69. triparella, 7.ll. Isis, 1839. p. 200 ; 1up.?-dodecen, Haw. -iloclecella, step. Alis anticis somdide oclreis, apice fusco-ncbulosis, nebulis tribus coste fuscis, punclis sex disci per paria obliqua dispositis nigris, fascia postica dilutiore angulata. Exp. al. $6 \frac{1}{3}$ lin.

Head and face greyish-ochreous. Palpi greyish-ochrcons; terminal joint palcr, with two black rings. Antenne ochreous, ammulated with dark fuscous. Anterior wings dingy-oclireous, the costa with three cloudy 
finscous sprots (one at the base, the second in the middle, the third beyond the middle); along the disc are three puirs of black spots (the first not far from the base, the sccond in the middle, and the third pair beyoud the midclle); in each pair the lower spot is posterior to the upper spot; beyond them is a faint angulated pale fascia ; the apical portion of the wing is rather suflused with fuscons, with some dark fuscons spots round the margin; cilia pale ochreous. l'osterior wings pale grey, with greyish-oclureous cilia.

Not scarce among oaks in May and June. The larva feeds in August and September between united oak-leaves, fastening them by several strong silken cables.

70. tenebrella, Ilüb. 'T'in. 434 (1816); Treit.; 1)ıp.; Zell.; 1)ougl. - subcuprella, Step.—unicolorella, Dup. Alis anticis viriliconcis, purpure-tinctis, antemis unicoloribus fuscis. Exp. al. $5 \frac{t}{3}$ lin.

Head and face bronzy, with a purplish tint. Palpi bronzy. Antemne unannulated, whicolorous fuscous. Anterior wings unicolorous bronzy-gren, with more or less of a purple tint; cilia fuscous. I'osterior wings greyish, with paler cilia.

Common on dry gravelly and sandy banks in many places, in June.

71. tenebrosella (F. v. R.), Zell. Isis, 1839. p. 201; Dougl. $\Lambda$ lis anticis virili-coneis, purpurco-linctis, antennis fuscis apice albo. Ėxp. al. 5 lin.

II cad shining bronzy, with a slight purplish tint. Face and palpi bronzy. Antenux derk fuscous, unammulated, with the tip white. Antcrior wings unicolorous shining bronzy-green, with a purple lint; cilia fuscous, Posterior wings pale grey, with greyish cilia.

Less common than tenelrella, but frequenting the same localities in June and July.

72. ligulella, Zcll. Isis, 1839, p. 201 ; Dougl.; IV. V.?-cinctella, Limn.?-vorlicella, Scop).? 'Treit.? 1)up.?-albistrigella, Step. Alis anticis nigris, basim versus vix dilutioribus, fascia lenui vix obliqua alba pone medium, sublus prater maculan coste minutum evanescenle. Exp. al. 6 lin.

IIead dark fuscous. Face greyish-fuscous. Palpi pale yellowish; terminal joint dark fuscous, with a whitish line on each side. Antemne white, ammulated with dark fuscous. Anterior wings black, towards the base hardly paler, with a slender white fascia beyond the middle, placed rather obliquely, being nearer the base on the inner margin; cilia blackish. Posterior wings grey, with greyish-fuscous cilia. On the underside the fascia of the anterior wings only uppears as a small spot on the coste.

Not uncommon in flowery meadows in June and July. The larva (according to 'Tischer) feeds between united leaves of Lotus comiculalus in May. 
73. vorticella, Zell. Isis, 1839. p. 201 ; Dougl. Alis anticis nigris, basim versus riv dilutionilus, fascia fere recla, alba pone medium sublus preder waculam costre minulam evanescente. Exp. al. $5 !$ lin.

Head dark fuscous. Face grey. Palpi pale yellowish; terminal joint fuscous, with a white line on each side. Antenne whitish, annulated with dark fuscous. Anterior wing black, towards the base leardly paler, with a nearly straight white fascia beyond the middle, broader on the costa than on the inner margin; cilia blackish. Posterior wings greyishlfuscous, with pater cilia. On the underside, the fascia of the anterior wings only appears as a small spot on the costa.

'Taken near l'cmbury by MIr. Weir, and near Tipping by Mr. 1) oubleday, in June. The larva (according to Zeller) fecds in May on Genista tinctoria.

7.t. troniolella (Treit.), 7ell. Isis, 1839. p. 201; Dougl.-cinctella, Step.? Alis anticis nigris, basim versus dilutioribns, fascia fere recta alba pone medium, subtus distincta et in maculam albidan alarum posticarum continuata. Exp. al. $5 \frac{1}{2} \mathrm{lin}$.

Head dark fuscous. Face greyish-fuscous. Palpi palc yellowish; terminal joint dark fuscous, with a whitish line on ench side. Antennae white, amulated with dark fuscons. Anterior wings black, towards the base rather paler, with a nearly straight whitish fascia beyond the midclie, of variable breadth; cilia blackish. P'ostcrior wings dark greyish-fuscous, with paler cilia. On the underside, the fuscia of the anterior wings is distinct throngthout, and is continued as a whitish spot on the posterior wings.

Comnoner than either of the preceding in chalky places; occurs at Sanderstead and Mickleham, in July.

75. Sircomella, n. sp. Nlis anticis nigricantiuns, postice atris, puncto atro plice ante medium; antennis in dorso toto-fuscis, infra albopunctatis. Exp. al. $4 \frac{1}{3}$ lin.

IIead and face dark grey. Palpi fuscous, internally asliy. Antenna cntircly fuscous above, bencath spotted with white. Anterior wings daik greyish-fuscons, posteriorly shading into black, with a black spot on the fold before the middle of the wing; cilia dark fuscous. I'ostcrior wings greyish-fuscous, with paler cilia.

'I'wo specimens in Mr. Vaughan's collection, taken near Bristol, in June. 'The first was taken by Mr. Sircom (who considered it as a singular variety of taniolella).

76. immaculatella, Dougl. Lnt. Trans. i. n. s. 67 (1850). Alis anticis nilidis, fusco-nigris, puncto obsoleto plice, punctoque posteriore disci saturatioribus. Exp. al. 5 lin.

Head and face greyish-brown. Palpi grey; terminal joint fuscous. Autemine unammulated fuscous. Anterior wings shining unicolorous fuscous-bluck ("with a violet tinge when alive," Dougl. MS.), with a minute nearly obsolete dark spot on the middle of the fold, and another. 
posterior to it on the disc; cilia rather paler. Posterior wings whitishgrey, with yellowish-grey cilia.

Unique in Mr. Douglas's collection; taken at West Wickham wood in August, 1819 .

77. nigritella, 7cll. Isis, 1847. p. 857 ; Dougl. Alis anticis angustulis fusco-nigris, maculis posticis opposilis obsoletis lutescentibus, costali obliqua ac posteriore, puncto in medio plicre minutissimo lutescente; antennis fuscis, non annulatis. Exp. al. 6 lin.

Thead dark fuscous. Thace grey. Palpi grey; terminal joint black. Antenuce unicolorous fuscous. Anterior wings rather narrow, blackish, wilh two very faint yellowish opposite spots beyond the middle, of which that on the costa is decidedly posterior and rather oblique; about the centre of the fold is a very minute linear yellowish dot; cilia creyishfuscous, Posterior wings pale grey, with pale fuscous cilia.

A specimen, of the capture of which there is no record, is in Mr. Douglas's collection.

78. Coronillella (Tischer), Trcit. E. S. ix. 2. 87. 1833; Dup.; Dougl. Alis anticis fusco-nigris, postice nigris, maculis posticis parvis oppositis costali majore vix posteriore albidis ; antennis albidis fusco-an-

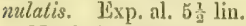

IIead dark fuscous. Face pale grey. Palpi grey; terminal joint dark fuscous, with a white line on each side. Antenno whilish, annulated with black. Antcrior wings fuscous-black, posteriorly darker; beyond the midllle are two small whilish opposite spots, of which that on the costa is the larger and slightly posterior; cilia fuscous. Posterior wings unusually broad, greyish-fuscous, with paler cilia.

Not common; occurs at Mickleham in June and July. The larva (according to Tischer) feeds between united leaves of Coronilla varia.

79. Anthyllidella, IIüb. Tin. 330 (1816); Zell.; Dup. ; Dougl. $\Lambda$ lis anticis nigris, puncto minuto, interdum obsoleto, in medio plice, punctis posticis oppositis (costali majore ac posteriore) flavescentibus; antennis in dorso toto-fuscis, infra albo-punctatis. Exp. al. 5? lin.

IIead dark fuscous. Face grey. Palpi grey; terminal joint dark fiscous, with a white line on each side. Antenne entirely fuscous above, beneath spotted with whitish; the basal joint beneath with a white streak. Anterior wings black, wilh a minute yellow spot on the middle of the fold (frequently almost obsolete), and beyond the middle are two yellow opposite spots, that on the inner margin being very indistinct, that on the costa larger and rather posterior; cilia dark fuscous. l'osterior wings grey, with greyish-fuscous cilia.

Common in May and August among several papilionaccous plants. The larva feeds in $\Lambda$ pril and July in a turned-down leaf, which it cats half through. I have found it on Onobryctis, Anthyllis, and purple clover. 
80. atrella, IInw. I. B. 567 (1829); Dougl.; Schr.P Alis anticis nilidis, saturate fuscis, maculis posticis opposilis (costali posteriore) luleis; antenuis fuscis obsolete dilutius amulatis. Exp. al. $5-5)_{2}^{1}$ lin.

Head dark fuscous. Face pale grey. Palpi yellowish. Antenna fuscous, with hardly perecptible palcr amulations. Anterior wingg shining, dark fuscous, wilh lwo yellorvish spols beyond the middle, one on the inner margin at the anal angle, the other beyond it on the costa ; cilia fuscous. Posterior winers pale grey, with greyish-ochreous cilia. bushes.

Occurs in various localities in July; gencrally among furzc-

81. bifractella (Mann), Dougl. Ent. Trans. i. n. s. 66 (1850). Alis anticis late brumeis, macula dorsali prope basim, striola plice medise, fasciaque postica valde dentata, aurantiis, punctis duobus in striola plice saturate fuscis; capile, fronte, palpisque curuntiis. Exp. al, 4$5 \frac{1}{2}$ lin.

IYead, face, and palpi orange. Antennsc fuseous, with harlly perceptible paler amulations. Anterior winers brown, with a spot on the inner margin ncar the base, a streat in the middle of the fold, and a much indented fascia towards the hinder margin orange; in the streak on the fold are two minute dark fuscous spots; cilia greyish-brown. Posterior wings fuscous, with paler cilia.

Not scarce in July and Angust among Inula dysenterica and Conyza squarrosa. The larva feeds during the winter in the seeds of those plants, agglomerating them by some glutinous secretion, and preventing them from falling.

82. suffusella, Dougl. Ent. Trans, i. n. s. 64 (1850). Alis anticis albido-ochreis, postice saturatioribus, mencto minuto costre pone medium, puncloque posteriore disci, subetevatis nigris. Exp. al. 6 lin.

Ilead and face whitish. Palpi whitish; terminal joint with a dark fuscous ring before the apex. Antenna whitish, aunulated with fuscous. Auterior wings whilish-ochreous, posteriorly darker, with a small black spot on the costa at the commencement of the cilia, and one rather posterior to it on the disc (both, but particularly the costal spot, slightly raised); cilia whitish-ochrcous. R'osterior wings greyish-white, with pale ochrcous cilia.

Occurs in the Cambridgeshire fens in June.

83. Iucidella, Step. II. iv. 221 (1S31); Curt.; Dougl. Alis anticis ochreis, prater spatimi oblongum supra angulun analem, brunneosuffusis, puncto postico saturate fusco. Lxp. al. $6 \frac{2}{2}$ lin.

Head and face brown. Palpi ochreous; terninal joint fuscous. Antenna fuscous, with hardly perecptible pale annulations. Anterior wings darl oclireous, su[fused, with the exception of an oblong patch above the anal angle, with brown; at the hinder cud of this oblong pateh is a dark fuscous or black spot; cilia varicd oclureous and brown, at the anal angle greyish-ochreous. P'osterior wings grey, with paler cilia. 
$\Lambda$ ppears in July, frequenting wet places, such as the IIammersmith marshes.

84. Iutulentella, / $/$ ell. Isis, 1839. p. 201; Dougl. Alis anticis unicoloribus ochreo-brunneis, puncto postico disci fusco. Wxp. al. 8 lin.

Head, facc, and palpi oclureous-brown. Antennx fuscous, with hardly pereeptible paler anmulations. Anterior wings menicolorous ockreous-brown, with a small fuscons spot on the disc above the anal angle; cilia brownish-ochreous. Postcrior wings whitish, with dark ochreous cilia.

'Threc specimens have oecurred; one I took at Ham Common, and another at Dartford Ileath, in July; Mr. A. Mill met with onc near Bristol.

85. cerealella, Oliv. Encycl. Nethod. Ent. i. p. 121 (1759); Lam.; Dup.; Dougl. Alis anticis angnestis acumimatis, obscure ochreis, postice saluralioribus, punctis nomullis indistinetis plice fuscis. Exp). al. $6 \frac{1}{2}$ lin.

IIead and face whitish. Palpi pale yellowish; terminal joint with a fuscous ring before the apcx. Antemne whitish, annulated with fuscous. Anterior wings narrow, poinled, dull ockreous, posteriorly a lillle darke?, with some indistinct fuscous spots on the fold; cilia ochreous. Posterior wings grey, with greyish-ochreous cilia.

Several specimens were bred last summer by MIr. Scott; previously the insect had been extremcly rare with us. The larva (according to lićaumur) feeds in winter in the interior of grains of barley and wheat, preferring the former, and, forming its cocoon within the grain, there assumes the pupa state.

86. nigricostella (F. v. R.), Dup. L. F. Sup, iv. 2S8. pl. 74. f. 9 $(18+2)$; 1)ougl. Nlis anticis angustulis luteis, plica et disco aurantiosuffusis, costa usque ponc modium, apice, plagis duaburs dorsi (altera ante medium, altera ad angulum analem) saturate fuscis, punctis tribus (primo prope basim, secundo medio prope costam, tertio posteriore prope dorsum) nigris. Exp. al. š lin.

IIcad and face ycllowish. Palpi yellowish; terminal joint with two black rings. Antenue yellowish, ammlated with dark fuscous. Anterior wings rather narrow, yellow, linged ath orunge along the fold and, on the disc; the costa to beyond the middle, the apex, and heo spots on the inner maryin (one before the middle, the other at the anal angle) are dark fuscons; nen the base is a small black spot, a sccond lics near the middle of the costa, and a third above the anal angle; cilia ycllowish. P'ostcrior wings pale grey, with yellowish cilia.

Taken by Mr. E. Shepherd, at Wicken Fen, Cambridgeshure, at the end of June.

57. gemmella, Linn. F. S. 1388 (1761); Id. S. N. P-nivea, Haw. - nivella, Step.-nigrovillella, Dup. L. F. xi. pl. 298. f. 5.-lepidella, 
Kell. Alis anticis albidis, fusco-variegatis, maculis tribus parvis costex, quatuor dorsi fuscis, macula tertin dorsi suluratiore, srepe cum lertin costce in fasciam connexa. Lxp. al. $5 \frac{1}{2} \mathrm{lin}$.

IIead and face white. Palpi white; terminal joint with two black rings. Antenma white, anmulated with black. Anterior wings whitish, with numerons irregularly-formed fuseous spots, of which thee are on the custa (one at the base, one before, and the other beyond the middle), and four are on the inmer margin (one at the base, very sinall, a second before the middle, a third darker in the middle, rerehing more than half across the wing, and frequently uniting will the third costal spot to form an oblique fascin, the fouth is at the anal angle); cilia white, with some dark fuscous lines. Posterior wings grey, with greyish-ochreous cilia.

Occasionally met with in mixed liedges in July and August, but not common.

It is doubtful whether the gemmella of the 'Systema Natura' be identical with that of the "liama Suecica," and as the "Ifolitat intra Ruereus folia suluculenea" appears in the former, from which it is copied, with the 1)iagnosis, in the 'Tauna Succica,' it may be that the larva of this species does not mine in oak-leaves. The inference to be drawn from the specimen and pupu-stin in the Linnean Cabinet, is that Limneus was acquainted with the hubitat of the larva.

88. naviferella (Zell.), T)up. L. T. Sup. iv. 455. pl. 85. f. 4 (18.12); 1)ougl.-Knockella, IIaw.? Step.?-miscella, IIaw.? Alis anticis nigricantibus, fascia media obscura saturatiore, puncto plicie pone modium, triangulo parvo dorsi ad angulum analem, trianguloque costæ posteriore aureis. Exp. al. $4-4 \frac{\pi}{2}$ lin.

IIead and face bronzy-grey. T'alpi dark fuscous. $\Lambda$ ntenme fuscous, with bardly perceptible paler annulations. Anterior wings shining dark bronzy-grey, inclining to black, with three small golden-yellow spots (one on the fold beyond the middle, one rather triangular at the anal angle, and a larger triangular spot posterior to it on the costa; below this latter a very small golden-yellow spot is sometimes perceptible); cilia bronzy-grey, with the tips paler. Postcrior wings grey, with paler cilia.

Not uncommon in waste places where Atriplex and Chenonodizm grow, appearing in May and August; fine specimens are rarely met with in the perfect state. 'The larva mines, in June and October, in the leaves of the Atriplex and Chenopodium, preferring those growing in sheltered places; hence it is very partial to those plants growing in stubble-ficlds, where, before the corn was cut, it was completely sheltered; the places mined by it become white.

89. Hermannella, Fab. S. I. ii. 509 (1781); 'Treit.; Dup.; 
1.ell.-Schefferella, 1)on.; Step.; Fab. ?-Zinckeella, Jü̈b. Tin. f. 401, 1.02 ; Step.? Alis anticis rufo-iturantiis, basi et margine postico nigris, fiscia ante molium, utrinque nigro-marginata, striisque tribus posticis longitudinalibus argenteis. Exp. al. $4-4 \frac{x}{3}$ lin.

Tleat and face bronzy-grey. Palpi yellow; tip of the terminal joint fuscous. Anteme fuscons. Anterior wings reddish-orange, with the base black; a short oblique streak on the costa near the base, and a small spot near the inner margin are silvery; before the middle is an oblique silvery fascia, slightly margined with black; beyond the middle are three short loneritudinal silvery streaks (one on the fold, one on the dise, and one on the costa); on the costa before the apex is a short oblique silvery streak, and some silvery scales are perceptible at the anal angle and along the hinder margin, the remainder of the hisder margin being black; cilia dark fuscous. Posterior wines greyish-violet, with paler cilia.

F'ound at the same times and in the same places as the last. The larva likewise mines the leaves of the same plant, but the mined place is dirty greenish, with a mottled appearance. (The assertion that this larva afterwarls constructs a case of the blossom, in the 'Entomologists' Companion,' p). 63 and G(i, is incorrect.)

90. pictella, '/cll. Isis, 1439. p. 202 ; I)ougl. Alis anticis nitidis, saturate brumncis, strigulis duabus obliquis coste, fascia postica, punctisyue marginis postici arginteis; capite palpisque albis; antemis fuscis, apice albo. Exp, al, 5 lin.

Head, face, and palpi whitish. Antenne fuscons, with palex anuulations, the tip entirely white. Antorior wings shining dark brown, with two oblique silvery streaks from the costil, not reaching beyond the fold, an oblique silvery fascia towards the apex, and sone silvery spots along the hinder margin; cilia fuscous. l'osterior wings whitish, with greyish cilia.

Whis pretty speeies appears in May and August; it has been met with at Southend (in Lissex), and on Barnes Common.

91. Brizella (Tischer), Treit. E. S. ix. 2. 173 (1833); Dup. I. F. xi. pl. 306 . f. 5 ; Dougl. Alis anticis flavidis, costam et marginen posticum versus brumesecutibus, strigis quatuor angulatis ante dorsum cranescentibus argenteis, punctis duobus disci nigris. Exp. al. 5.2 lin.

Head and face ochreous, mixed with hrownish. l'alpi pale ochreous; sccond joint with two black rings; the third with the base and two rings black. Antenna whitish, amulated with dark fuscous. Anterior wings yellowish-grey, with the costa and hinder margin brownish; on the costa are four silvery streaks sloping obliquely outwarle, and nearly merting some silvery seales on the inner marem, with which they would form amgulated strigre; a black spot lies in the midtlle of the fold, and another is on the clise beyond the middle, a smaller one is sometimes VOL, III. 
perecptible on the imner marein at the end of the fold; in the dark hinder marein and alsex of the costa are several silvery streaks; cilia pile greyish-fnseons, intersected by two dark fuscous lines. Posterior. wings grevish-fuscous, with paler cilia.

Appears in (Mity? and) August; occurs on the const among Statice Armeria at Soullend and Brighton. The larva feeding in antumn in the stems beneath the flower-heads of the Shatice.

92. ericinella, 1)up. L. F. xi. 497. pl. 306. f. 1, 2 (1838); Zell. -micellu, Ilüb. ; Treit. Mlis anticis rufis, costa fuscu, strigula coste basili, strieris duabus obliquis secunda cum striga recta ad dorsum connexa viridi-argenteis, mareulis posticis opjositis (costali distinctiore) punctis marginis postici lutco-argenteis. Exp. al. 6 lin.

Ilead and face grey. Palpi fuscous; terminal joint yellowish, with two brown rings. Antenne yellowish, ammulated with fuscous. Anterior winers reddish-broven, duilere towards the coste, with a short streak at the base of the eosta, and two oblique strigie (the sceond meeting a stritight one on the inne margin) silvery-(green; before the apex are two silvery yellow opposile spots which nearly mect (that on the costa is the more (listinct); along the hinder margin are several small spots silvery-yellow; cilii fuscons. Posterior wings grey, with paler cilia.

Abumdant on leaths in the south of lingland, in July. The larva must feed on lieatli in June, Mr. Douglas having bred the insect from a bunch of blooming heath he had gathered.

93. paupella, \%ell. Isis, 1847. p. 858 ; 1)ougl. Alis anticis albis, stria prope costam, striaque plice a basi fere usque ad medium luteis, stria disci pone medium, stria postica exteme fiusco-marginata luteis. Lxp. al. $5 \frac{3}{2}$ lin.

ITead, face, and palpi whitish. Antemne whitish, anmulated with fuscous. Anterior wings white, with a fine yellow streak from the base near the costa, and in second fro.n the base along the fold, ncither of these reaches the middle of the wing; a third yellow streak lies on the dise leyoud the middle, and a fourth externally with some fuscous seales lies near the hinder margin; cilia whitish, with some fitscous seales round the apex of the wing. Posterior wings pale grey, with ycllowishgrey cilia.

$\Lambda$ single specimen in M[r. Douglas's collection, taken by lim at Folkstonc, in July.

91. inopella, Zcll. Isis, 1939. p. 201 ; Dougl.-Inulella, Curt. $\Lambda$ lis anticis albidis, lincis clisci, strigulaque obliqua ante apicen ochraceis. Txp. al, $4 \frac{1}{2}-5$ lin.

Ifead, fire, and palpi whitish. Antenna whitish, anmulated with fuscous. Anterior wings whitish, with several fine streaks on the dise, atud a broader transverse one before the apex dirty ochreous; cilia whitish, with a dark fuseous line. Posterior winge pale grey, with erreyish-ochrcous cilia. 
A scaree species; appears in dune and foly anoug Tuule dyseneerice; li:us occurred at Folkstone and near Bristol. Severid specimens have been bred from the flower-lieads of the Inula, gathered during the winter.

95. subccellea, Stcp. II. iv. 21. (183+); Dongl.-intemella, Lienig. Alis anticis albis, dorso fuseo, costa apiceque fusco-nebulosis, maculis duabus longis prope angulum analem, lineisque oppositis obliquis ante apicem saturate fuscis, puncto upicis subocelluto vigro. Wxp. al. $5-5 \frac{2}{2} \operatorname{lin}$.

IIcad and face white. Palpi white, beneath fuscescent. Anteme fuscous. Anterior wings white, with the imer margin fuscous, and the costa and anex of the wing more or less clonderl with fuscous; near the anal angle are two clongate dark fuscous spots, and before the appex are two oblique opposite dark fuscous lines; at the cetreme apen is a black spot, folloned by two dark lines in the athitish cilia. Posterior wings pale grey, with greyish-ochreous cilia.

Common among marjoram (Origanum vulyare) in July. The singular larva was first detected by Mr. Jordan, in $\Lambda$ ugust, feeding on the flowers of the Origumm, and construeting a case of the blossom, hence very difficult to distinguish from the blossoms when in its young state; as it increases in size, it cularges its case by the addition of other flowers, till by the middle of winter its case will be found to consist of four or five flowers, insertcl one in another; it is then easily detected on the dry flower-heads by those who have had a little practice. The case las not the complete finish of a Coleophora case.

How unuy similar instanees of wonderful contrivance, to cusure concealnent, may yet remain undiscovered!

\section{Genus 1X. PARASIA.}

Parasia, Dup. Cat. 350 (1844). Recurvaria p., Haw, Cleodora p., Step. Gelechia p., Zell.

Gapilli depressi. Ocelli mulli. Antenne articulis coufertis, vix denticulatis. Haustellum medioere, squamatum. Palpi maxillares brevissimi. Palpi labiales mediocres, reflexi, articulo secundo longo squamis appressis, terlio brevi squamis appressis, ipso apice lovi acmininato. Alat anteriores clongatie, posteriores trapezoidales ante apicem mofunde emarginater, longe ciliatic ; anteriores: vena apiealis lrifielu, infira cam vene qualuor e cellula discoilali; posteriores: vena appicalis simplex in apicem exit, infra eam veñe dua c veunla transversa, cellula costalis ante medium desinente.

IIead suooth. Ocelli none. Intenne with the joints thickly set, 
hardly denticulate. Tonguc of moderate length, clothed with seales. Maxillary palpi very short. Labial palpi of moderate length, reflexed; the second joint long, wilh appressed seales; the third joint short, with appressed scules, the extreme apex only being smooth and pointed. Anterior wings clongate; posterior wings trapezoidal, deceply cmaryinate below the apex, with long cilia. In the anterior wings the apjoal vein is trifid, two branches rumuing into the costa and one into the hinder margin, below it are four veins from the discoidal cell. In the posterior wings the simple apical vein terumiuates in the prolonged aprex; below it are two veins from the transverse vein; the costal cell terminates before the middle of the wing.

But few species (only four British) are yet known in this genus; but from the extremely retired habits of the perfect insects of those that have been inet with, it is by no me:ans improbable that several other species may herenfter be delected. I'arasic Inajpella was a rarily, and but in few collections, and laal been bred by no linglish collector, at the time that the authoress of the 'Episudes of Insect Life' zublished a notice of the habits of the larva. Parasia Carlinetla was cntiredy unlinomu till Mr. Doughlas bred it in abumtunce from the hearls of Corline vulyaris, gathered at Folkstone, in December.

The mode of feediug of the larve of these species is rery different; both feed, it is true, in the heals of Composite plants,

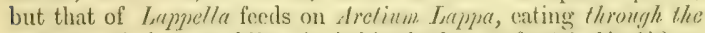
seerls (precisely resembling in habit the larva of Gelectia bifiactella), whereas the larva of Curlinella, foeding in Curlina rulguris, leaves the sects untouched and derouss the rereptate betow the seeds. 'The habils of the larve of $P$. Melaneriella and neuroplethe are not yet known.

1. Lappella, Limn. S. N. (10) 537. 200 (1758); Fab.; Loew, E. Z. 1841. pl. i. f. 19-21. 1842. p. 257; 'Lell. E. 'L. 184.2. p. 259; Dougl.-silncert, Ilaw.; Curt.--silucellu, Step.-restivellu, Zoll. Isis, 1839. Alis anticis ochreis, macula oblouga coste basali, macula parva ante, maeulaque pone medium coste, brumseis, maresine postico brunnco-sufluso, venis nonnullis griseis, punctis bribus disci nigris. Exp. al. 8 lin.

IIcad and face ochreous. Palpi pale ochreous, bencath darker. Antennfe fuscons, with darker ammulations. Anterior wings ochreous, with a long patch at the base of the costa, a small spot on the costa before and one beyond the midlle, brownish; the hinder margin is sulfised with palc brownish; secerel of the veins appear grey; on the dise are three black spots (one on the fold before the middle, one beyond it nearer the costa, and one at the end of the discoidal cell); cilia pale ochreous, darker near the hinder margin. Posterior wings grey, with ochreousgrey cilia. 
'The perfect insect appears in June and July, but is rarely met with. The larva is abundant in the seeds of burdock (Arctium Lappa) in the autumn and winter.

2. Metzneriella (Dougl.), Sta. Sup. Cat. p. 5 (1851).-pancipunchello, Dougl.-silacee, var. $\beta$. I Law. Alis anticis acuminalis subfalcalis ditute ochereis, costa margineque postico fusco-brumeove suffusis, renis ommibus griseis, punctis tribus thsci nigris. Lxp. al. 7 lin.

Ilead and face pale ochreous. Palpi pale ochreous, bencath darker. Anteme pale fuscous, with darker annulations. Anterior wings narrow, pointed, somowhat faleate, pale ochreous, suffused with brownish along the costa and hinder margin, wilh all lise weins grey, and with three black spots on the dise (one on the fold a little before the middle, the second beyond it towards the costa, and the third at the end of the discoidal ccli); before the dark himer margin the pale sround-colour apperars as an oblique fascin; cilia pale ochreons, darker near the hinder margin. l'osterior wings grey, with greyish-ochreous cilia.

Searce, the food of the larva not having been detected; occurs at Charlton, Micklcham, etc., in July and August.

3. Carlinella (1)ougl.), Sti. Sup. Cat. p. 5 (1S5̌1); Dougl. $\Lambda$ lis anticis dilute ochreis, costa late margineque postico fitlo-sutlusis, dorso ct fascia postica oblinna non suffusis, venis nomullis grisco-squanalis. Exp. al. 6-6 $\frac{7}{2}$ lin.

Ilead and face pale ochreous. Palpi pale ochreous, beneath dark ochreous. Antenne brown, with pale ochreous annulations. Anterior wings pale ochreons, suflused with fulvous along the costa and hinder margin; before the latter the paler ground-colow of the wings forms an obliqne fascia; many of the veins are indicated by greyish scales; cilia pale ochreous, with the tips and a line near the hinder margin fulvous. Posterior wings grey, with paler cilia.

The perfect insect has been but rarcly met with; it appears in July and August. The larva feeds during the winter in the receptacle of Cithlina vulyaris, and is very plentiful at Folkstone; also occurring at Mickleliam.

4. neuropterella (F.v. R.), Zcll. 1sis, 1839. p. 202 ; Dup. I. F. Sup iv. pl. 72. f. 1; Dougl. Alis auticis ockreis, costa margincque postico cinnamomcis, venis onmibus dislincte cinnamomeis. Pixp. al. 8! lin.

Ilead and face dark oclıreous. Palpi dark oclircous, bencath brownish. Antenua pale brown, with darker ammulations. Anterior wings ochreous, suffused with cimmanon-brown along the costa and towards the hinder margin, with all the veins distinclly cimamon-brown; cilia fuscous, with a darker line near the hinder margin. l'osterior wings bright grey, with greyish-fuscous cilia.

$\Lambda$ scarec species, occurring in July and August, near Mickleham and near Deal. 


\section{Genus X. CLEODORA.}

Cleodora p., Curt. B. E. fo. 671 (1837).

Capilli depressi. Ocelli nulli. Antennx articulis elongatis (apicem versus obtuse et remote dentata), articulo basili elongato. II iustellum mediocre, squamatum. Palpi labiales mediocres, articulo sccundo infrin scopiformi, pilis antice valde productis, articulo terminali aculeiformi reflexo. Mla clongata, longe ciliate; posteriores antc apicem profunde emarginata; anteriores: cellula discoidalis elongata; vena apicalis trifida, infra eam rami quatuor; posteriores: cellula costalis valde angusta; vena subcostalis simplex; medianat trifida.

Head smooth. Ocelli none. Antemne with clongate joints (towarls the apex obtuscly and remotely (lentate); basal joint elongate. 'ougne of moderate length, clothed with scales. I abial palpi moilcrately long; the second joint beneath like a brush, the hairs anteriorly mech prolonged; terminal joint slender, pointed, reflexed. Wings elongate, with long cilia; the postcrior decply emarginate before the apex. In the anterior wings the discoidal cell is clongate, the apical vein trifid, beneath it are four veins from the discoidal cell. In the posterior wings the costal cell is extremely narrow; the subcostal vein is simple; the median vein is trifid.

Although several species of this genus occur on the continent, but one representative of it las yet been met with here. 'The larva of none of the species are known.

1. Cytisella, Curt. 33. E. fo. 671 (1837).-fuscipennis, Westw.-Wralkeriella, Dounl. Alis anticis lutescentibus, costan versus saturatioribus, vel brunescentibus, strigulis posticis oppositis obliquis pallidis, costali longrore ac posteriore; ciliis griseo-fuscis, apjec bis saturatius-cinctis, Exp. al. $5 \frac{1}{2}$ tin.

IIead and fice yellow. Palpi whitisli-ycllow. Antenne pale fuscons. Anterior wings yellowish, towards the costin clarker, more or less brownish, with two oblique opposite pale streaks towards the hinder margin, that on the costa is the longer and rather posterior; eilia greyish-fuscous, with two dark lines rumning round the apex of the wing. Posterior wings greyish-fuscous, with paler cilit.

This pretty succics is not uncommon at Dartford Ifeath, in July, anongst fern and broom; it is rather restless in the net, running about with its wings half expanded.

\section{Genus XI. CHELARIA.}

Cinelair., Haw. L. B. 526 (1829); Curt.; Step.; 1)up. Gelechia p., Zell. 
(a)pilli depresai. Ocelli nulli. Autenna articulis confertis, vix denticulatis. Thanstellum merlioere, squanatum. Palpi maxillares brevissimi. T'alpi labiales longi, reflexi, articulo secundo infra in fascienlum producto, tertio squamis apmessis, apicen versus lovi acuminato. Alre elongate, posteriores ante apicen leviler simeale, mediocritcr ciliatoe.

- Head smooth. Oedli none. Antenne with the joints thickly set, hardly denticulate. 'Tonguc of moderate length, elothed with scales. Maxillary paljpi extremely short. I abbial palpi long, retlexed; the second joint beneath prolonged into a tuft ; the lhird juint with appressed scales, tovards the apex sinooth and pointed. Wings elongate; the posterior slightly simuated before the ajex, with moderately lone cilia.

But one species is known in this gemus; and although the perlect insect is not uncommonly found on the trunks of poplars, the larva has not yet been observed. It is true that Malame Lienig has described a lavia as belonging to this species, which she says lives in June on birches, making looles in the leaves; but some crror is probable here, as the perfect insect seems cxclusively attached to poplars.

1. Hübnerella, Don. B. I. xi. pl. $3 \$ 2$ (1S06).-conscriptella, IIẗb.; 'Zell.-conscripta, INaw.-rhomboidella, Curt. B. E. fo. 368 ; Step.; Dup. Alis anticis cincreis, macula costic medixe triangulari, striolaque apicis atris. Exp. al. $7 \frac{\pi}{2}-8 \frac{1}{2}$ lin.

Ifend and face grey. Palpi yellowish, the projecting tuft of the sccond joint pale gres, with a dark grey streak on the side; the terminal joint with a broad dark fuscous ring. Antemne yellowish, annulated with fuscous. Anterior wings pale grey, darker along the inner margin near the base; a triangular black spot lies on the costa in the midalle, and a short straight black streak is immediately before the apex of the wing (on the costa are two or three mimute dark fuscous spots); cilia grey, varied with fuscous. P'osterior wings palc grey, with paler cilia.

Common on the trunks of Lombardy poplars, in September and October.

\section{Genus XII. ANARSIA.}

AnarsiA, Zell. Isis, 1839. p. 190 ; Dup. Cat. Aplota p., Curt.

Capilli depressi. Frons convexa. Ocelli unulli. Antenna remote denticulatie. IHaustellum mediocre, squamatum. Palpi labiales mediocres, articulus secundus infra longe squamato-fasciculatus, fasciculo antice prolucto; tertins of subnullus, $q$ aculeiformis laevis adsecndens. Ala clongatie mediocriter ciliate, posteriores trapeziforme's ante apicen levissime retuse; anteriores: vena apiealis furcata ante 
apicem exit; ramus mediana primus a secundo valde distat; venw subdorsalis ramus inferior delefus; posteriores: vena apicalis prope basim fureata; venx mediane ramus primus valde distat a secundo; cellula costalis lata, postice valde coarctata.

Head smooth, rather convex in front. Ocelli none. Antennx remotely denticulate. Tongue of moderate length, elothed with seales. Labial palpi of moderate length; the second joint bencath with a tuft of scales, which is prolonged in front; terminal joint of the of very short (concealed in the long scales of the second joint); of the \& smooth, pointed, and ascending. Wings clongate, with cilia of moderate length, the posterior trapezoidal, very slightly retuse before the apex. In the anterior wings the furcate apical rein rums into the costa before the apex; the first branch of the median vein is very distant from the sceond branch; the lower branch of the subdorsal vein is obsolete. In the posterior wings the apical vein is furcale near the base; the first branch of the median vein is very distant from the sceond; the costal cell is broad, posteriouly extremely narrow.

In this genus we have only two British species (on the continent are two other's, one of which is injurious to apricots and peaches); they frequent heaths, and take short straight flights. Is we find to be the case in other generin of Tincina, two nearly allied plants (Spurtium Seopurium and Genista lineloria) scrve as food for the larve of two nearly allied species.

1. Spartiella, Sclur. F. B. ii. 10 t. 1798 (1902); /.cll.; T.v. R.-. Rolyertsmella, Curt. B. L. fo. 655 . Alis anticis dilute griseis, paullulum fusco-suflusis, striis mumcrosis obliquis coste fuscis, maculit plice ante medium, macula disci in medio, tertiaque disci pone medium fuscis. Exp. al. 7 lin.

IIead, fitce, and palpi pale grey. Antemme pale grecy, anmulated with dark fuscous. Anterior wings pale grey, rather sullused with fuscous, with several short oblique fuscous streaks along the costa, and with a spot on the lold before the middle, one on the dise in the middle, and one on the dise beyond the midklle fuscous (oceasionally with a few dark fuscous seales); at the apex of the hinder margin are two or three dirk fuscous spots; cilia greyish-fuscous. Posterior wings pale grey, with pale fuscous cilia.

Common in many places in July, anong broom and furze. 'Whe larva feets in May and June, in the terminal shoots of broom (Spartium Scoparium).

2. Genistze, n. sp. Alis anticis saturatissime griseis, dilutc griseoirroratis, costa basim versus dilutiore, stria obliqua medie costre saturatissime grisea, nigrave. Exp. al. 7 lin.

IIead, fice, and palpi rather dark grey. Antennx pale grey, annulated with dark grey. Anterior wings erry derle grey, slightly irrorated will pale grey; the costa towards the base is rather paler; from the 
middle of the costa is a very dark grey or black oblique streak, but there are no other definite markings; cilia dark grey. l'osterior wings grey, with pale fuscous cilia.

IItherto scarce; but Mr. Weir has bred the species in July, from larve feeding in the shoots of Genista tirctoria, in June. Mr. Weir found them at Pembury, near Tuubrilge W Vells.

\section{Genus XIII. YPSOLOPHUS.}

Ypsolopluus p., IIaw.; Zell. Rhinosia p., Treit.; Dup. Macrochila p., Step.

Capilli depressi. Ocelli mulli. Antenne setacen, remote denticulator, ơ microseope ciliatas. II austellum medioerc, squanatum. Palpi labiales articulo secundo infra scopiformi, pilis antice productis, $a r$ liculo "llimo lovi, aculeiformi, recurvo. Alie elongate, mediucriler ciliatc, posteriores trapeziformes ante apicem levissime retusae; anterioxes: vena apicalis fureata ante apiecm exit; cellula sccumdaria nulla; vena mediana in furcan terminatur; subdorsalis furcata; submediana non incrassata; posteriores: cellula costalis normalis; vena subcostalis o vemula transversali furenta; mediana trifida.

Head smooth. Oeelli none. Antenne setnecous, remotely denticulate (of the $\delta$, viewed through a lens, ciliated). Tongue of moderate length, clothed with scales. Labial palpi, with the second joint beneath, formed like a brush, with the hairs produced in front; the last joint smooth, pointed, recurved. Wings clongate, with moderate cilin; the posterior trapeziform, very slightly retuse betore the apex. In the anterior wings the fureate ayjeal vein runs into the costa before the apex; the secondary cell is not indicated; the median vein terminates in a fork; the subdorsal vein is furcate; the subnedian is not thickcuct. In the posterior wings the costal cell is without any peculiarity; the subeostal vein is furcate from the trausverse vein; the unedian vein is trifid.

Of five continental species, only two have been observed in this country. 'The habits of the perfect insect are very similat to those of the preceling genus. 'The labit of the larva of $Y \%$. MTurginellus is to feed near the ends of the juniper twigs, in a considerable mass of web, which at first sight appears extremely like the abode of a spider. Whether this labit prevails in all the other species of the genus, I am not arare (Fischer's figure of the larva of Juniperellus shows a complete accordance with the hitbit of the larva of Marginellus).

1. fasciellus, Hüb. 'Tin. 111 (1S01); Niı.; Treit.; Dup.; Stcp. Curt. Alis anticis dilute rufo-fuscis, dorso late fusco-suffusis, puetis VOL. III. 
tribus obsoletis (uno pliee, altero disei ante medium, tertio disci pone modium) saturate fuscis, fuscia pone medium anguleta fusca. lixp. al. $10 \mathrm{lin.}$

Ilead and fice dark greyish-ochrcons. Palpi rechlish-fuscons, internally pale greyish-ochreous; terminal joint pale greyish-ochrous, externally with a dark fuscous line. Antenuae pale fitscous. Anterior wings pale reddish-fuscous, with the inner margin to beyond the middle broadly sullised with fuseous, and with three obsolete dark fuscous spots (one on the fold, one rather posterior on the dise before the micldle, and one on the disc beyoud the middle); beyond the midlle is a fuscons anguluterl fascir ; cilia pale reddish-fuscous. P'ostcrior wings greyish-fuscous, with paler cilia.

'The perfect insect appears in May, and has recently been taken by Mr. Tompkins, near Lewes. 'The larva (according to 'Tischer) feeds in September, in rolled-up leaves of the sloe.

2. Marginellus, Fib. S. I. ii. 307. S (1781); Don.; Maw.; Step.; Curt.-strialella, Miib. Tin. 154.-clarella, Treit.; 1)up, Alis anticis nitide ochreo-fuscis, costa dorsoque niveis. Tixp. al. 7! lin.

IIead and face white. P'alpi white; the second joint beneath dark fuscous; the terminal joint white externally, with a dark fuscous line. Antenue clark fuscous. Anterior wings bright ochrcous-fuscous, with a white streak along the costa (but not tonching the costa beyond the middle), terminating in a point before the apex, and a white streak along the imser margin terminating in the hinder margin; there are a few dark fuscous spots along the hinder margin; cilia greyish-fuscous. Posterior wings greyish-fuscous, with paler cilia.

Not searce, anong jumipers, in July and August. The larva fecels in Junc in a web near the ends of the twigs of the juniperbushes.

\section{Genus XIV, APLOTA.}

Artots, Step. II. iv. 225 (1834). Ypsolophus p., Haw.

Capilli depressi. Ocelli nulli. Antenne denticulatar, microscope pubescentes. IIaustellum mediocre, squarnatum. Palpi labiales mediocres, articulus secundus infra longe squamato-fasciculatus, fasciculo antice producto, lertius suburllus. Alæc anteriores oblongo-clongatie, sub apicen levissime reluse, posteriores clongato-ovatie, mediocriter ciliatic.

Ilead smooth. Oeclli none. Antemas denticulate, microscopically pubescent. Tongue of moderate length, elothed with seales. Labial palpi moderately long; the second joint bencath with a tuft of seales which is produced in froint; third joint extrenely stort, concealed in the huirs of the second joint. Autcrior wings oblong-clongate, very slightly 
retuse betoro the apex; postcrior wings clongate-ovate, with moderatcly long cilia.

Only one species is known in this genus; it is exclusively British, not having hitherto been detected on the continent.

1. palpella, IIaw. L. 13. 545 (1829); Stcp.; Curt. Alis anticis fuscis, luteo-squamatis, punctis tribus (uno disci, sccundo vix posteriore plica ante medium, tertio disci pone medium) saturate fuscis. Exp. al. 6 lin.

IIead and face yellowish, mixed with fuscous. Palpi dark fuscous; internally towards the base yellowish; tip of the terminal joint white. Antenne fuscous. Anterior wings fuscous, with numerous ycllowish scales, with three dark fuscous spots (one on the dise, one a little posterior on the fold before the middle, and one on the dise beyond the middle); cilia greyish-fuscous. Posterior wings dark fuscous, with paler cilia.

Very rare; in Mr. Shepherd's collection, and in the collection of the British Museum; it has been taken near Ripley among clover, and in IIainault Forest, in August.

\section{Genus XV. NOTHRIS.}

Nothris p., IIüb. V. 411 (1816). Ipsolophus p., Zell.

Capilli depressi. Ocelli nulli. Antenme setacex, articulis oblongis, vix: distinctis, on non nodulosis, pubescente-ciliatis. Haustellum mediocre, squamatum. Palpi labialcs, articulo secundo infra scopiformi, pilis antice productis; articulo ultimo levi, aculeiformi, recurvo. Ale clongat:e mediocriler ciliate; anteriores, cilin circa apicen non produc$t \mathrm{~nm}$, non picte; posteriores trapeziformes, ante apicem levissime retusie; anteriores: vena apicnlis fureata ante apicem exit; cellula sccundaria nulla; venie mediana ramus primus a sečndo valde distat; suldorsalis fureata ; submediana non incrassata ; posteriores : cellula costalis normalis; vena subcostalis longe furcala; uediana trifida.

1Iead smooth. Oeelli none. Antenne setaccous, will the joints oblony, searcely distinct; in the of not knotty, with pubescent ciliations. 'l'ongue of moderate lengeth, clothed with seales. Labial palpi with the second joint beneath formed like a brush, with the hairs produced in front; the terminal joint smooth, pointed, recurved. Wings clongate, wille moderate cilies; the cilia round the not-prodnced apex of the antrior wings are not adorned with marlings; the postcrior wings trapeziform, before the apex very slightly retuse. In the anterior wings the furcate apical rein runs into the costa before the apex; the scconclary cell is not indicated; the first branch of the median vein is at a considerable distence from the second brench; the subdorsal vein is fureate; the submedian is not thickened. In the posterior wings the costal cell is 
of the ordinary form; the subcostal vein is furcate for a long distance; the median vein is trifid.

Of the three species referable to this genus, two are British; both recently added to our ' F'auna.' Durlhamella was first taken by Mr. Sircom a few years back, and has since been met with by Mir. C. Jordan. Terbascella was bred only last summer by Mr. IIing, from larve accidentally brought into his garden on some plants of Ferbascum pulverulentum, from the neighbourhood of Norwich.

1. Verbascella, W. V. 136. 36 (1776); Irüb. Tin. 99; Schr.; Treit.; Bouche; J)up.; \%ell. Alis anticis dilute ochreis, squamis syarsis fuseis, puncto basali coste, puncto minuto plica ante medium, puncto majore disci pone medium, punctisque marginis postici saturate fuscis. Exp. al. 10 lin.

Head and face pale ochrcous. Palpi pale ochreous; tuft of the sccond joint bencath dark fuscous. Antenuie pale ochreous. Anterior wings pale ochrcous, with a few seattered dark fuscous seales, with a small dark finscous spot at the base of the costil, a smaller one on the fold before the mildle, and a more conspicuous one on the disc beyond the middle; along the hinder unargin and apex of the costa are a few small dark fuscous spots; cilia palc ochreous. Posterior wings pale grey, with pale ochrcous cilia.

Bred last July by Mr. Wing, from larva on $/ \mathrm{erbascum}$. The latrae may he fomol ncarly throughout the year on the plants they frerpent; Mr. Wing found them on $/$ crbascum pulverulentum near Norwich.

2. Durdhamella, Sta. Cat. p. 12 (1819). Alis anticis ochrcis, puncto pliere, punctoque minore disci ante medium, puncto parvo disci pone medium, nigris, miteula pliea angulum analem versus fusca, fascia postica nebulosa fusca. Exp. al. 7즘 lin.

IIead and lace ochreous. Palpi pale ochreous; the sccond joint externatly towards the base dark fuscous. Antennac pale ochrcous. Anterior wings ochreous, with a black spot on the fold, and a smaller onc above it before the middle, another small black spot is on the lise beyoud the misille; on the fold before the anal angle is a clark fuscous b)lotelı; beyond the middle is a cloudy fuscous fascia, and the apex of the hinder margin is dark fuscous; cilia pale ochrcous. P'osterior wings palc grey, with paler cilia.

Apjears in July; has occurred on Durdham Downs, near Bristol, and at 'leignmouth.

\section{Genus XVI. SOPHRONIA.}

Sopleronie et I'leurola P., Hïb. V. H)7. tof (1816). Ipsolophus p., 
IFaw.; Zcll. Palpula p., Treit.; Dup. AFachroclita p., Step. Aplota p., Curt.

Capilli depressi. Occlli nulli. Antenne setacex, articulis oblongis vix clistinctis, ot non nadnelosis, pubescente-ciliatis. Haustellum mediocre, squamatum. Palpi labiales articulo secundo infin scopiformi, pilis antice productis; articulo ultimo lævi, aculciformi, recurvo. Alæc elongate longines ciliala, anteriores, cilie ciren apicen productun picta, posteriores trapeziformes ante apiecm levissime retuse; anteriores: vena apicalis fureata ante apicem exit, cellula sccundaria mulla, vente mediaua ramus prinus a secundo valde distat; subdorsalis furcati: submediana non incrassata; posteriores: cellula costalis normalis; vena subcostalis prope basim furcata ; mediana trificla.

Ifead smooth. Ocelli none. Antenna setaceous, roith the joints oblong, scarcely distinct; in the of not linotty, with pubescent ciliutions. Tongue of moderate length, elothed with scales. Labial palpi with the second joint beneath formed like a brush, with the latirs produed in front; the terminal joint smooth, pointed, recurved. Wings elongate, soilh ratker long cilia; the cilia of the anterior wings round the produced apex are adorned with markings; posterior wings trapezoillal, very slightly retuse before the apex. In the anterior wings the furcate apical vein runs into the costa before the apex, the sccondary cell is not indicated, the first brench of the median vein is at a considerable distonce from the second; the sublorsal vein is furrate; the submedian is not thickened. In the posterior wings the costal cell is of the ordinary form; the subcostal vein is furcate from near the base; the median vein is trifid.

We have only two species in this genus, which may readily be distinguished as follows:-

a. With no streaks from the costa before the apex. Species 1 . a a. With several streaks from the costa before the apex. Species 2 .

(There are several other continental species in the latter section.) Very little is known of the habits of the perfect insects, and none of the larve are known.

1. parenthesella, Linn. T. S. 1435 (1761); Tab.; IIaw. ; Slcp.; Curt.-Cenistella, Illig.; WV. V.?-semicostella, Hü̈b. Tin, 395 ; Treit.; 1)up. Alis anticis brumeis, griseo-suffusis, costa usque pone medium amguste alba, macula oblonga plice ante, punctisque duobus disci pone medium saturate fuscis, venis posticis albido-squamatis, puncto apieali saturate fusco. Exp. al. 8 lin.

Head and face pale grey. Palpi pale grey; terminal joint at the apex fuscous. Antenne clark fuscous. Anterior wings brown, rather sudlused with grey, especially along the inner margin, the costa to beyond the midclle narrowly white; on the fold before the middle is an oblong dark fuseous spot, and beyond the middle are two dark fuscous spots on the dise, beyond the lower of which some of the veins are in- 
dieated by whitish scales; in the extreme apex is a dark fuscous spot; cilia pale grey, traversed by dark fuscous lines. Posterior wings greyish-fuscous, with paler cilia.

The perfect insect is not uncommon at West Wickham Wood, and in ILeadley Lane, in June and July. The wings are rather couroluted in repose.

2. humerella, IIüb. Tin. 292 ; Dup.; TV. V.? Alis anticis nitide fuscis, stria basali costie ante medium a costa deflcxa, strigulis tribus costre, unaque dorsi, pone medium albis, puncto apicis nigro. Wxp. al. 5 lin.

Ifead and face pale grey. Palpi pale grcy ; tip of the terminal joint

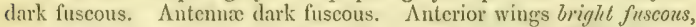
with a white streak along the costa beginning at the base, deflexed from the costa a little before the middle, terminating on the dise beyond the micille; beyond the middle of the costa are three white streaks, the first is narrow and obliģue, pointing posteriorly, and almost meeting a less distinct white streak from the anal angle; the other two streaks are shorter, pointing internally; a slender short black streak lies on the disc beyond the middle, and at the extreme apex is a black spot; cilia greyish-fuscous. Posterior wings greyish-fuscous, with paler cilia. known.

I'wo specimens, in Mr. Doubleday's collection; locality un-

\section{Genus XVII. PLEUROTA.}

Pleurota p., llüb. V. 406 (1816). Palpula p., Treit.; Dup. Macrochila p., Step. Aplota p., Curt. Anchinia p., Zell.

(apilli decumbentes, ultra frontem producto. Ocelli nulli. Antenna articulis distinctis, of ciliata. P'alpi maxillares breves, filiformes. P'alpi labiales recti, longinsculi, compressi, articulo secunclo valde piloso, basi tenui, articulo tertio tenui, lavi, aculeiformi, brevi. Ala elongale acuta, posteriores trape\%oidali-lanceolate, prope angulun analem leviter sinuatre, longius ciliate; anteriores: venxe apicalis ramus inferior infra apicem exit; medianso ramus primus parum curvus; submediana a mediana distat; vena subdorsalis furenta.

Ilairs of the head decumbent, produced in front. Occlli none. Antemne with distinct joints, ciliated in the of. Maxillary palpi short, filiform. Inabial palpi struight, rether long, compressed, the second joint extrenely hairy, slender at the base, the remainder uniform, the terminal joint slender, sinooth, pointed, short. Wings elongate, acute, the posterior trapezoidal-lanceolate, towards the antal angle slightly sinuated, with rather long cilia. In the anterior wings the lower branch of the fureate appical vein xums into the hinder margin below the 
apex; the first branch of the median vein is sliglitly creved; the sub)median is remote from the median; the subdorsal vein is furcate.

'This genus has only one representative in this country, which is found commonly on heaths in June and July. Nothing is known of its primary states.

1. bicostella, Linn. F. S. 14.3S (1761); Scop.; I[iil). Tin. 115 ; IIaw.; Treit.; 1)up.; Step.; Curt.-marginella, lab.-viduella, Scop.? $\Lambda$ is anticis albis, grisco-fusco valke suflusis, precipuc dorsun versus, stria (juxta costam albam non sulfusam) a basi usque ad apicem fusca, punctis duobus disci, uno ante, altero pone medium nigris. Lxp. al. 10-11 lin.

IIead and face white, mixed with grey. Palpi greyish-white; terminal joint white, with the base and apex grey. nutemme dark fuscous. Anterior wings white, nuch dusted with greyish-fitscous, especially towards the inner margin; the costa alone remaining narrowly pure white; inmediately below it is a fuscous streak from the hase to the apex; beneath it are two black spots on the dise, one before and the other begond the middle; under the first is a small dark fuseous spot on the fold, and moder the second a fuscous cloud; the hinder margin is spotted wilh dark fuscous; cilia greyish-white. Posterior wings pale greyish-fuscous, with paler cilia.

Common throughout the country on heaths, from the end of May to the middle of July.

\section{Genus XVIII. FARPEILA.}

IIArpelta, Schr. F. B. ii. 168 (1802); Zell. Alabonia, Step. Einicostoma, Dup. Alabonia p., Ilüb. Recurvaria p., Ilaw. Adela p., Treit.

Capilli depressi, postice suberecti; frons lata. Ocelli nulli. Antennæ tenues, corpore non breviores, $\delta$ ciliati, Palpi labiales longi compressi, articulo sceundo parum curvato, pilis appressis, tertio temi adscendente acuto. Haustellum breve, squamatum. Ale anteriores oblongae, posteriores oblongo-ovate mediocriter ciliatx; anteriores: vene apiealis ramus inferior in apiecm exil; cellula secundaria nulla; vena subelorsalis furcata; submediana a mediana distat, in apice incrassatur.

Ilead smooth, with the seales behind slightly erect; forehead broad. Ocelli none. Antenna slender, not shorter than the body; in the $\delta$ ciliated. Labial palpi long, compressed; the second joint slightly curved with appressed scales; the third joint slender, ascending, pointed. Tongue short, clothed with scales. Anterior wings oblong; posterior wings oblong-ovate, with moderately long cilia. In the anterior wings the lower branch of the apical vein terminates in the apex (in some of 
the contimental species of this genus it terminates above the apex); the secondary cell is not indicated; the subdorsal vein is fureate; the submedian, posteriorly thickencel, is remote from the median vein.

'The syecies of this gemus are large, showy insects, and appear to delight to fly in the sunshine. Only one occurs in this country, and of that the larva is unknown. Of a continental species however, II. forficella, the larwa has long been known as feeding in decayed wood, hence probably our English species has similar habits.

1. Geoffrella, Limn. S. N. (12) 896.430 (1767); Dup. xi. pl. 303. f. 2 ; /cll. (E. 7. 1850).-Geollroyella, Step.; Sta.; Tab.?Geoffroyi, Haw. Alis anticis flavis, in medio saturatioribus, apicem versus fusco-suflusis et nigro-striatis, striis duabus ex basi, striolaque ex medio costre plumbeo-crerulcis, maculis posticis sub oppositis (costali posteriore) dilute luteis. Exp, al. $9 \frac{7}{2}$ lin.

IIead yellow, with a dark fuscons blotch in the middle. Face dark fuscous. Palpi dark fuscous; the last two-thirds of the terminal joint whitish. Antenna yellowish-white, annulated with fuscous. Anterior wings bright yellow, darker in the middle, and towards the apex suffused with fuscous; from the middle of the base is a straight leadenblue streak, which before the middle of the wing is deflected, and terminates on the inner margin about the midlle, where it meets a narrower leaden-blue streak from the base below the fold; the costa at the base is narrowly dark fuscous, and on the middle of the costa is a dark fuscous blotch, in which arises a rather oblique lcaden-blue streak, rumning half across the wing; beyond the middle of the inner margin is a conspicuous triangular palc ycllow spot, and a smaller pale yellow triangular spot is on the costa rather posterior; on the inner margin of both of these spots are some leaden-blue scalcs; the veins in the apical portion of the wing are indicated by black scales; cilia dark fuscous, the tips paler. Postcrior wings dark fuscous, with paler cilia.

From the middle of May to the middle of June, this beautiful insect is generally abundant, in mixed hedges and in woods; the slow, undulating flight has some rescmblance to that of an Alcla; it delights to fly in the early morning, preferring sumny mornings.

\section{Genus XIX, HYPFRCAI,LA.}

IIypencartı, Step. II. iv. 19.4 (183.); Zell. Carcina p., IUüb. Lampros p., 'Treit.

Capilli decumbentes, antice ultra frontem producti, postice ererti. ()eelli mulli. Antenne mediocres, articulis distinctis, $\delta$ ciliatie. IIaustellum breve, squanatura. Palpi labiales longi, compressi, pilis 
appressis, articulo sccundo longissimo, subcurvo, aquali, tertio tenui recto acuminato. Nlie late, mediocriter ciliata, anteriores acutie, posteriores trapezoidales; anteriores: venac apicalis ramus inferior sub apice exit; vena uncliana ramus primus valde curvus; submediana juxta medianam postice recedit et incrassatur.

Hairs of the head decumbent, produced in front beyond the forchead, behind ercet. Ocelli none. Antennac moderate, with distinct joints, ciliated in the $\sigma^{\pi}$. Tongue short, clothed with scales. Labial palpi long, compressed, wilh appressed scales; the second joint very long, slightly curved, equal throughout; the third joint slender, straight, pointed. Wings broal, with moderate cilia; the anterior acute; the posterior trapezoidal. In the anterior wings the lower branch of the apical vein runs into the hinder marrin beloro the apex; the first branch of the median vein is very much curved; the subinedian is close to the median, but receles posteriorly, where it is thickened.

Only one species in this genus is kmown; its larva las not been detected.

1. Christiernana, Lim. S. N. (12) 877.303 (1767); Fab.; IV. V.; Hüb. Tort. 152; Step. pl. 38. f. 2; Dup.-Cliristiernella, Ilüb. ; Treit.-citrinalis, Scop.? Nis anticis dilute luteis, strigis coccineis reticulatis, punctisque parvis coccineis. Exp. al. $8 \frac{1}{2}$ lin.

IIead and face pale yellow. Palpi pale yellow; terminal joint beneath pale fuscous. Antenne whitish, annulated with fuscous. Antcrior wings pale yellow, almost reticulated with searlet streaks; the first along the costa at the base, will two oblique projections from it, the second of which meets another streak from the middle of the costa, which appears to be continucl to the inucr marenin near the base, a branch from it ruming to the inner margin beyond the middle; from the middle of the costa is another streak directed outwards, meeting an oblique streak from the costa running inwardly; below it are some scarlet spots, and there is a small scarlet spot at the base of the inner margin; before the hinder margin is a nearly straight searlet fascia, terminating in the apex; cilia very pale ycllow. Posterior wings greyish-fuscous, with paler cilia.

Very rare in this country; has occurred near Darenth Wood, at Grecnhithe, and at Castle Eden ])ean; it appears at the end of June and begimning of July.

\section{Genus XX DASYCERA.}

Dasycerns, Haw. L. B. 524 (1829). Wicophorn, Curt.; Sicp. Dasywra et Stenoptera, Dup. Gicophora p., Lat. Esperiu p. ct Alabonie. p., Hüb.

Capilli depressi. Frons inter antennas subangusta. Oeelli nulli. AnvOL. III. 
tennx basim versus incrassale, dorso e basi squamalo-piloso, apice untdiusculo. IIaustellum mediocre, squamatum. Palpi labiales vix thoracis longitudinc, reflexi, articulo secundo compresso, pilis appressis, tertio tenui, acuto, prioris fere longilndine. Ala clongater, posteriores ovate, angulo anali obtuso; anteriores: venx apicalis ramus inferior supra apicem exit; cellula secundaria nulla; vena subdorsalis furcata; posteriores: vene dua e venula transversa procedunt.

Head smooth. Forehead, between the antennx, rather narrow. Occlli none. Antenna towards the base thichened, with hairy scales on the buck at the base, with the apes companatively naked. T'ongroc of moderate length, elothed with seales. Labial palpi hardly as long as the thorax, reflexed; the second joint compressed, with appressed scales; the third joint slender, pointed, nerrly as long as the second. Wines clongate, the posterior orate, with obtuse anal angle. In the anterior wings the lower branch of the apical vein rums into the costa before the apex; there is no secondary cell, and the sublorsal vein is furcate; in the postcrior wings two veins proceed from the transverse vein.

We have but two species in this genus (a third, closely allied to Oliviclla, has been met with in $\Lambda$ sia Minor); being of gay colours, they fly during the day (it being found an almost invariable rule, that the richly-coloured species of hepiloptera thy during the day, when their colours may be exposed to view); the flight of 7$)$. sulfulerelle is rather striight and sharp, but that of 7). (tivirlla is undulating and sluggish. The larva of $\mathbf{l}$. sulplenrellu has becn known for some time; it feeds in recayed and decaying wood, proferring to place itself immediately beneath the bark, but not distaining to penetrate decp into the wood itsclf; it is of an unusually clongated form.

1. sulphurella, Fab. S. L. 670. 19 (1775): Curt. B. K. fo. 4.0S; Step,-annulifera, Four.-cornutella, Fab.-orbonella, IIüb.; Dup.; \%ell. Nis anticis fuscis, dilute luter-irroratis, maeijue apicem versis, stria brevi basali juxta costam, stria altera brevi plica ( $q$ ultra medium productia) maculisque oppositis (costiali minore, obsoletiore) pone melium ditute Inteis; alis pos lecis dilute luteis, saturate fusco-limbriatis. Exp. al. $7 \frac{1}{2}$ lin.

IIsad bronzy, with a fow yellow hairs. Taes bronzy. P'alpi bright yellow; terminal joint dlatk fuscous. Antcrume dark fuseons, almost black, with three white anmukations a little beyoud the muldle. Anterior wiugs fuscous, with mumcrous pale yellow seales, especially towards the hinder margin; from the base is a short yellow streak near the eosta, and another on the fold (eontinued to beyond the middle in the $f$ ); on the inner maryin, beyond the middle, is a triangular pale yellon: spot, and on the costre nearly opposite is a smaller but distinct pale 
yelluzo spot; some iridescent seales mark the course of the veins to beyond the middle, and also indieate the termination of the discoidal ecil ; cilia fuscous, iridescent in certain lights. Posterior wings pale yrllow, with the anterion and hinder margins dark fuscous, and a slight fuscous cloud at the base; cilia pale fuscous.

Very common in the south of England, appearing with the first setting in of summery weather; it delights to fly in the daytime along old hedges. The larva is to be found throughout the winter, under the bark of old posts and decaying trees.

2. Oliviella, Fab. E. S. iii. 2. 316.132 (1791); Lat.; Curt. ; Stcp.; I) ир. xi. pl. 303. f. 1; Zell.-Olivieri, I Law.-remulellu, Iü̈b.; Treit.-Uractella, lab.?-crassicornis, liour.? Alis anticis nigris, postice albido-squanatis, macula triaugulari basali prope dorsum, fesciaque pone medium (ull dorsum repandula, costam non langente) dilute luteis, striga ante medium, striga curvata (plicau tangente) pone fasciam lutcam, iridescentibus; alis posticis salurale purpureo-fuscis. Exp. al. 8 lin.

TIead and face very dark metallic-purple. Palpi ycllow; terminal joint externally dark fuscous. Antennie black to beyoud the middle, then white, with the tips black. Anterior wings purplish-black, with a triangular pale yellow spot at the base towards the inner margin, and a pate yellow fascia (rather erpanded on the inner margin, and not reaching to the cost $(1)$ beyond the middle; before the mirldle is an iridescent striga, and beyond the yellow fascia is another slightly curved iridescent striga, not reaching beyond the fold; beyond it are numerous seattered whitish seales; cilia dark purplish-fuscous. Posterior wings dark purplish-fuscous, with paler cilia.

Not uncommon among oaks, from the end of June to the beginning of August.

\section{Genus XXI. ECOPHORA.}

Ecophora p., Zell. Isis, 1839. p. 191; Dup. Cat. Recurvaria p., Haw. Lampros p., Treit. Anacampsis p. et Batia, Step. Pancalia p. et Batia, Curt. Borlhansenia, Denisia p., et Schiffermülleria p., Ilüb.

Capilli depressi. Frons lata, convexa. Oeclli mulli. Antenne tenues, of ciliate. Palpi labiales reflexi, rix thoracis longitudine, articulo secundo longiore compresso, squamis appressis; tertio tenui acuto. Ilaustellum mediocre, squamatum. Nlac oblonge vel clongatie, longius ciliate, posteriores angulo anali obtuso; anteriores: venic apicalis ramus inferior supra apiecm exit; vena subelorsalis furcata; posteriores: e venula transversa venæ dux procedunt.

Ifend sinooth. Forehcad broad, convex. Ocelli none. Antemua stender, in the of ciliated. Labial palpi reffewed, hardly as long as the 
thorar ; the longer second joint compressed and with appressed seales; terminal joint slender and pointed. 'Tongue of moderate length, clothed with seales. Wings oblong or clongate, with rather long cilia, the posterior with obtuse anal angle. In the anterior wings the lower branch of the apical rein runs into the costa before the apex; the subdorsal rein is furcate; in the posterior wings two veins proced from the transverse vein.

This gemus, as now restricted, still contains species of various aspects and different habits, though in structure they show a complete agrecment. Some of the speries are so brightly coloured, they might be expeeted to be day-flying species, which I am not aware to be the case; others are of a dingy sombre appearance. L'ripunclu and finsesecens have a peculiar hovering flight, and rum about in the net with their wings slightly raised, almost invariably dying with their wings over the back (thereby trying the paticnce of the collector). Unilclle lias a partiality for standing almost perpendicularly on its head, a position which (I believe) lunaris also sometimes assumes; but more frequently lunaris reposes parallel to the surface on which it rests, with its pretty annulated forelegs stretched out before it, like a Cerura.

The larva of mimutelle is probably, like that of psendo-sprelella, a general feeder on all sorts of dry goods; the latter, from its large size, must do a considerable amount of injury where it obtains a footing, and, though formerly unknom, is now abundant, throughont London, and has appeared in many of the provincial towns; it may orginally have been imported, but it will probably continue British, as long as there is trade and population in these islands. As an instance of the voracity of the larva of pseurlospretella, Mr. II. Doubleday, who lias been much tormented with them in his breeding-cages, has known them devour a living pupa of Smerinthus popult. The larve of all the other species probably feed in decayed wood, and, as it is not likely that they attack healthy trees, cannot be considered as injurious to us; but are more to be considered in the light of scavengers employed in removing that which is decayed and useless.

'lhere are seventeen species in this genus which have occurred in this country; these species may be arranged in the following table:-

a. Anterior wings black or dark fuscous.

b. With two yellow spots. Species 1,2.

b b. With threc yellowish spots. Species 3,4 .

$b \quad b$. With yellowish fasciac. Species 5 .

" a. Anterior wings dark orange, with black narks on the margins. Spuceies 6, 7 . 
a $a$ a. Anterior wings pale orange.

c. With oblique marginal white streaks. Specics 8 .

c c. With a black spot at the anal angle. Species 9,10 .

a $a$ a $a$. Anterior wings ochreous (pale or dark) or fuscous.

d. With black spots on the dise. Species 11, 15-17.

d d. Unspotted. Species 12-14.

1. minutella, Jimu. S. N. (10) 537.256 (1758); Schr.; Dup.-opposilella, liab.; ILüb.; Haw.; Treit.; Stej.; I)щр. xi. pl. 300 . f. 9. -Mays, four. Alis anticis fuscis, macula transversa dorsi pone medium, maculaque obliqua posteriore coste luteis. Exp. al. $5 \frac{3}{2}$ lin.

IIead greyish-fuscous. lace greyish-ochreous. Palpi fuscons, internally whitish. Antemne fuscous. Anterior wing's fuscous, with a conspicuous transverse yellow spot on the imer margin beyond. the middle, ind a smaller rather oblique yellow spot on the costu, a little posterior; cilia pale fuscous. P'osterior wings pale greyish-fuscous, with paler cilia.

Found not uncommonly in louses and outhouses in May and Junc. I lave bred it from a larva found by Mr. l'reston, fceding on the seeds of celery during the winter.

2. flavimaculella, Sta. Cat. p. 13 (1849).-minulellu, IIaw.; Step). Mlis anticis saturatc fuscis, maculis duabus dilute llavis, altera obliqua in medio dorsi, allera rotunda disci pono medium. Exp. al. s lin.

Ilead, face, palpi, and antemne dark fuscous. Anterior wings dark fuscous, with two pale yellow spots, one rather oblique on the middle of the inner maryin, the other rounded on the disc beyond the middle; cilia pale fuscous. l'ostcrior wings greyish-fuscous, with paler cilia.

Occurs near ITuddersficld and at Duddingstone, in June and July; also in other places, but not common. Mr. Logan finds the larva feeding on the seeds of Angelica sylecstris in August and September.

3. tripuneta, Haw. L. B. 557 (1829).-tripunctella, Step.-trimaculella, Duj). xi. pl. 303. f. 8.-Lrisignellu, Zell. Alis anticis saturate fuscis, maculis tribus luteo-albis, nue costee in melio, altera costie apicem versus, tertia intermedia plica. Exp. al. 6 lin.

Ilead dark fuscous. Fiace pale ochreous. Palpi yellowish-white. Anteme dark fuscons, the tips yellowish-whitc. Anterior wings dark fuscous, with three yellowish-white spots, one on the costa in the middle, one on the costa towards the apex, the third intermediate between these two, on the fold, almost connected with the inner margin by some scattered yellowish-white scales; cilia dark fuscous, with the tips whitish. Posterior wiugs grey, with paler cilia.

Very common in old liedges in sereral places near London, in May and June; it appears to frequent brambles.

4. similella, 1Liils. 'Tin. 182 (1801); Treit.; Zell.; Richter (E. \%. 1850 ) ; Dup.?-stipella, (l.? Alis anticis salurale fuscis, sulphureo- 
irroratis, maculis tribus sulphureis, una plica prope basim, altera dorsali pone medium, tertia mediocri costie apicem versus; capite luteo, strict fusca. Exp, al. 6 ${ }_{2}^{\lambda}$ lin.

IIend pale yellow, with a fuscons streak along the middle. Face palc yellow. lalpi pale yellow, the sccond joint internally dark fuscous; terminal joint with a broad fuscous ring before the apex. Anterior wings dur fuscons, with numerous senttered sulphur seales, and with three sulphur spots, one on the fold near the base, and connceted with the base along the fold, one on the inner margin beyond the middle, and one on the costa before the apex, not reaching half across the wing; at the anal angle are a few sulphur seales; cilia fuscous, varied with sulphur. Posterior wings greyish-fuscous, with paler cilia.

Occurs in Mlay and June on the trumks of tir-trees in the north of Eingland and Scotland. IIerr Richter found the larva under the bark of dead fir-trees, in the autumn.

5. augustella, Ifüb. Tin. 177 (1801),-auynsta, IIaw.-angustclla, Step.-mostella, ILüb.-var. albinuculea, Ifaw.; Step.; Sta.funestella, Dup. xi. pl. 298. f. 12.-luctuosella, 1)up. $\quad$ Mlis anticis saturate fuscis, fascia prope basim, ad dorsum latiore, fascia media in plica attenuata, macula minore dorsi, maculaque majore posteriore costre apicem versus, dilute luteis; (viriat, fasciis angustioribus, macula costali minore, albido-luteis.) Exp. al. $5-5 \frac{3}{2}$ lin.

Back of the head dark fuscous. Tront of the head and face whitish. Palpi dark fuscous, the end of the second and third joints whitish. Antenne white, ammulated with dark fuscous, the tip cutirely white. Antcrior wings dark fuscous, with a fascia not far from the base, broadest on the inner mangin, a second fascia in the middle rather attemuated on the fold, a small spot on the inuer margin, and a larger spot on the costa posterior to it pale yellow; cilia fuscous. Posterior wings greyish-fuscous, with paler cilia.

In the variety albimaculea, the fasciae are narrower, the sccond more attenuated in the fold, the costal spot is smaller, and fascix and spots are whitish-yellow.

Common in June on the trunks of trees in Iyde Park; the typical form of the species is comparatively scarce in this country.

6. Woodiella, Curt. B. E. fo. 30 \% (1830); Stcp. Alis anticis aurantiis, maculis duabus basi, tertia oblongra in medio dorsi, quarta cunciformi costix pone medium, margineque postico saturate fuscis. Exp. al. $6_{\frac{2}{2}}^{2}$ lin.

IIead and face dark fuscous. Palpi greyish-ochreous; tip of the terminal joint fuscous. Antenne unicolorous dark fuscous. Anterior wings bright orange, rather paler towarls the inner margin, with five dark fuscous spots, viz. two at the base (one above the fold, the other on the inner margin), an oblong one on the middle of the inner marfrin, one posteriorly attenuated on the costa beyond the middle, and a latger irregular one, commencing before the anal angle, occupies the 
npex of the wing; in each of thesc spots are a few iridescent scales; cilia fuscous. Posterior wings dark-fuscous, with paler cilia.

In Mr. Curtis's collection; taken in June, 1829, by Mr. R. Wood, on Kersall Moor, near Manchester.

7. grandis, Desvignes, Entom. 312 (181.2). Alis anticis flavis, macula saturate fusen basali per costam anguste usque ad mediun proclucla, costa anguste pone medinu saturate fusca, macula coste medie, maculapue costee pone medium introrsnu sprectunte dilule lulcis, dorso anguste, margine postico late saturate fuscis, macula triangulari flava dorsali pone menlinm, striga basim versus, striis tribus longitudinalibus in modio disci cxruleis, $\operatorname{Exp}$, al. $6 \frac{2}{2}$ lin.

Ilead and face dark fuscous. l'alpi yellow ; terminal joint interually with a fuscous band. Antenne dark fuscous, the tips white. Anterior wings decp yellow, inclining to orange, with a dark fuscous blotch at the basc, continued namowly along the costa to a liltle before the middle; beyond the middle the costa is again dark fuscous to near the apex; in the middle of the costa is a small pale yellow spot, and a longer olslique one pointing invardly lies beyond the middle of the costa; the inner margin from near the base narrowly, and the hinder marrin broally, are dark fuscous; before the anal angle is a triangular bright yellowo spot; not far from the base is a slender bluish strign, and on the dise in the middle are three short longitudinal bluish streaks margined with dark fuscous; cilia dark fuscous. Posterior wings rather dark fuscous, with paler cilia.

In the collections of Mr. Desvignes and Mr. Shepherd; threc specineus were taken in Bewdley Forest, by Mr. L. Baugh.

8. formosella, W. V. 140. 17 (1776); Fab.; Hüb. Tin. 218; Treit.; 1)up. Alis anticis lutcis, macula parva obliqua dorsi ante medium, maculacye majore coster, luteo-lrumeis, utrinque tenuissime albo-marginatis, macula postiea costali luteo-brumneo. Exp. al. 6 lin.

IIead and face dark tuscous. Palpi bright yellow; terminal joint whitc, with a black line externally, and a black ring below the apex.

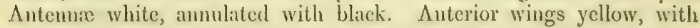
yellowish-brown markings, first, a small blotch on the inner margin near the middle, preeded by a short white streak, and followed by a longer curved white streak; on the costa before the middle is an oblique blotch reaching to the anal angle, it is preceded by a slender rather curved white streak (which does not touch the costa, and terminates on the fold), and is followed by a palc yellow streak (expanded on the costa and not reaching half across the wing); a third yellowishbrown bloteh lies on the costa before the apex; cilia pale yellow. Posterior wings greyish-fuscous, with paler cilia. July.

Taken by Mr. Robertson on palings at Wanstcal; appears in

9. Iunaxis, IIaw. L. 13. 556 (1829); Step.; Curt. B. F. fo. $5+3$. 
-.... Vetzuerella, I'reit.-Begrandella, 1)up. Alis anticis dilute luteis, costa dorsoque angusle, margine postico late, saturate luteis, costa ipsat usque pone medium salurate fusca, macula dorsi pone medium triangulari, apice postice producto, nigra. Exp. al. 5 lin.

Ilead and face white, mixed with dark fuscous. Palpi pale fuscous, interually whitish; terminal joint whitish, with a fuscous ring before the apex. Antenue whitish, ammulated with dark fuscous. Anterior wings pale yellow, with the costa and inner margin rather namowly, and the hinder margin broally, deep yellow; the extreme costa is durle finscons to beyond the middle; on the inner margin beyond the middle is a triangular black spot, of which the apex is produced posteriorly parallel to the hinder margin; cilia pale yellow. P'osterior wings rather pale grey, with pale greyish-fuscous cilia.

Found in various localities on the trunks of trees and palings, in July and August.

10. Lambdella, Don. T3. I. ii. 57 (1792); Step.; Curt.-Lambdu, Inaw. Alis antieis dilute luteis, costa anguste, dorso margiueque postico lale saturate luteis, costa jpsa usque pone medium nigre, macula magne in metio dorsi fere triangulari, apice postice producto, nigra. Tixp, al. $7 \frac{x}{3}$ lin.

Head and face pale yellowish, mixed with dark fuscous. Palpi dark fuseous, internally pale yellowish ; terminal joint pale yellowish, with a ring at the base and a ring before the apex dark fuscous, Antenna whitish, annulated with dark fuscous. Anterior wings pale yellow, with the costa narrowly and the inner" and hinder margins bromdly deep yellow; the extreme costa is black to beyond the middle; on the middle of the inner margin is a large somewhat triangular black spot, with the apex pointing postcriorly; cilia palc yellow. Posterior wing's dark greyishfuscous, with paler cilia.

Scarce; occurs in Jume and July; sometimes met with at Clarlton; originally found in plenty in a furze-bush in Epping lorest.

11. subaquilea (Edl.), Sta. Cat. p. 14.(1S19). Alis anticis dilute ochreis, paullulum fusco-suflusis, puncto plice et stria disci ante medium, puncto dorsi, punctisque duobus disci pone medium saturate fuscis. Exp. al. 6 lin.

Ilead and face greyish-ochrcous. Palpi pale fuscous, internally pale ochrcous. Antemue fuscous. Antcrior wings pale ochrcous, rather suffused with fuscous, with a dark fuscous spot on the fold, a dark fuscous streak above it before the middle, and with three dark fuscous spots beyond the middle, one on the inner margin, and two almost united on the dise; beyoud is a fuscous bloteh at the anal angle; the hinder margin is spotted with dark fuscous; cilia pale ochrcous. Posterior wings pale grey, with paler cilia.

()ecurs on heaths in the north of England, in May and June. 
12. Panzerella, Step. H. iv. 292 (1834). Alis auticis dilute ochreis, fusco-suflusis; palpis brevibus dilute ochreis. Kxp. al. 7: lin.

IIead and face pale greyish-ochreous. Palpi short, pale ochrcous. Antennes pale ochreons, anmulated with fuscous. Anterior wings pale ochreous, sufluser with fuscous; cilia paler. l'osterior wines greyishfuscous, with paler cilia.

Not common; appenrs in June and July ; lias oceurred at West Wickham Wood, and near Lewes.

13. tinctella, Treit. E. S. ix. 2.21 (1833); 1) 1up. xi. pl. 299. f. 7 ; \%cll.-Iutarella, step.-arietella, Sta. Alis anticis dilute achreis, paullulum fusco-suflusis, pracipue costam versus; palpis longis, dilute ochreis, articulo tertio fuscescente. Exp. al. 7 lin.

Head and face pale ochreous, Palpi long, pale ochreous, terminal joint with a slight fuscous tinge. Antenue whitish-ochrcous. Antcrior wings pale ochreous, ratlier suflused with fuscous, esjecially along the costa and towards the apex; cilia ocheous, with a slight fuseous tinge. Posterior wings dark greyish-fuscous, with paler cilia.

Not uncommon in May and Jume, in West Wickham Wood, nmong oaks.

11. unitella, Hüb. Tin. 14.7 (1801); Step.; Sta.-fusco-eturella, 1 Inw, - arietella, Ycll. Alis anticis aurco-brenneis, posticis nigrienutibus, palpis longis ochreis, articulo tertio salurale fusco. Txp. al. $6 \frac{1}{3}$ lin.

IIead and face dark yellow. Palpi long, bright ochreous ; terminal joint dar fuscous. Antemue dark fuscous. Anterior wings unicolorous golden-broun; cilia the same colour, with a slight fuscous tinge. Posterior wings dark fuscous, almost black, with paler cilia.

Not uncommon in Augusi, in old helges. Mr. Wing deteeted the larva last spring, feeding in old pea-sticks; it became full-fed in May.

15. Aavifrontella, Hïb. Tin. 126 (1801); Treit.; Stcp); Fab.? Ilis anticis nilidis griseo-fusris, pumetis tribus fere obsoletis siturite fuscis. Exp. al. 10 lin.

Head and face yellow. Palpi fuscous. Antenur pale fuscous. Antcrior wings shiming greyish-fuscons, with three rather obsolete darker spots, one on the dise before the misldle, one almost beneath it on the foltl, and one on the dise beyoul the midelle; cilia fuscous. Pusterior wings greyish-fuscous, with paler cilia.

Not scarce in old hedges in June; it appears to frequent the hedge-roses.

16. fuscescens, Inaw. I. H. 55 (IS29); Step. Alis anticis dilute ochreis, fusco valde suffiesis, punctis tribus saturate fuscis (uno disci, altero plice vix posteriore, ante medium, tertio majore disei pone medium). Exp. al. 5 lin.

Ilead dark fuseous. Iace pale brownish-ochreous. Parlpi fuscous; tip of the teminal joint pale ochreous. Antenne pale fuscous. An- 


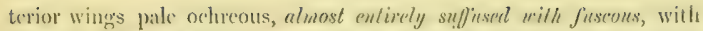
three dark fiseous spots, one on the dise, one on the fold rather posterior before the middle, and a laresere one on the dise heyoud the middle; cilia fuscous. Posterior wings pale greyish-fusenus, with palk' cilia.

Very abundant in old hedges in July and August.

77. pseudo-spretella, Sta. Ciat. p. 1* (1819). Mis anticis dilute ochreis, fusco valde su/fusis, punctis tribus safurate fuscis (uno disci, altero plice vix posteriore ante medium, tertio disci pone medium); margine postico, npicerque coste saturate fusco-punctalis. Lixy. al. 10 lin.

Head brownish-ochreous. Face pale brownish-ochreous. Palpi pale ochreous, intemally spotted with dark fuscons. Antemne fuscous. Auterior wings pale ochreous, much suffiesed wilh fuscons, with three clark fuscous spots, one on the dise, one on the fold hartly posterior to it before the midlle, and one on the disc beyond the middle; the hinder maryin and apex of the costa are spothe with dert fuscous; cilia ochureous-fuscous. Posterior wings whitish-grey, with paler cilia.

Abundant in London and in many parts of the country, in July and August. Mr. II. Moubleday sent me a number of the larvic last January, fecding on dry peas.

\section{Genus XXII. CEGOCONIA.}

EGoconIs, Guencé in lit. Aecoptura p., Zell.

Capilli depressi, postice suberecti. Ocelli nulli. Antennac crassiuscule, articulo basali incrassato. IIaustellum mediocre, squamatum. Palpi maxillares breves, filiformes. Palpi labiales reflexi, compressi, articulo terminali temui, acuto. Ale clongatac, posteriores angulo anali distineto, plaga basali nuda mulln; anteriores: venre apiealis ramus inferior supra apicen exit; vene subdorsalis furcala; posteriores: cellula costalis elongala, postice altenuala; vena apicalis furcala; e venula transversa vena unica procedit.

Head smooth, behind rather ronylh. Ocelli nonc. Antenne ralher thick, with thickened basal joint. Tougue molerately loner, clothed with scales. Maxillary palpi short, filiform. Labial palpi reflexed, coinpressed; terminal joint slender, pointed. Wings elongate; the posterior with distinct anal angle, with no bare basal patels. In the anterior wings the lower branch of the apical vein rums into the costa before the apex; the subdorsal vein is furcule; in the posterior wings the rongale costal cell is posteriorly attematerl; the apical vein is furcate, and a single vein proceeds from the transverse vein.

Only one species is known in this genus, which, from its habits, I had anticipated would be congeneric with Fulmosis fenestrella; the above characters sufliciently distinguish it. 
1. quadripuncta, IIaw. J. 13. 557 (1929); Step.: thifasiella, Step. - Kindermenniella, Kell. Mis anticis saturate luscis, basi, macula obliqua costa ante medium, fascia recta dentata in medio, maculis oppositis (costali majore) apicem versus dilute luteis. Fip. al. 6? lin.

Ilead dark fuscous. Faee pale yellowish. Palpi pale yellowish; the terminal joint with a faint fuscesis ring at the base. Antenne fuscons, the tips pa!e yellowish. Interior wings lark fuscons, with the extreme base, a ratier oblique blotch on the costa near the base, a nearly straight but indented fiseia in the middle, and two opposite spots (of which the larger is on the costa) towards the hinder margin, pale ycllowish; cilia pale grey. Posterior wings whitish-grey, with paler cilia.

Sometimes occurs in houses, in July and August.

\section{Genus XXIII. ENDROSIS.}

Endrosis p., Hüb. V. 401 (1816). Eicoptora p., Zell.

(appilli ippressi, fronte lata. Occlli mulli. Antenna setacex, articulo basali clongata, subelavato. If iustellum mediocre, squamatum. Jalpi maxillares breves, filiformes. Palpi labiales reflexi, compressi, articulo terminali tenui, acuto. Alw elongatw, anteriores subtus penicillo mullo, postcriores angulo anali distincto, plaga basali nuda; anteriores : vente apicalis ramus inferior supra apicen exit; mediana ramus primus a secundo valde distat; subdorsalis simplex sed furcatat indicatit; posteriores: cellula costalis abbreviata (ante merlium vena sulicostalis subito definit); e venula transversa vena unica procedit; vena apicalis simplex.

Ilead smooth; the forehead broad. Oeclli none. Antemne setaceous, with the basal joint elougate, subelavale. 'Tongue of moderate length, clothed with scales. Maxillary palpi short, filiform. I abial palpi reflexed, compressed; the terminal joint slender, pointed. Wings elongate; the anterior with no brusk beneath; the posterior with distinet anal angle, mith a naked patch at the base. In the anterior wings the lower branch of the apical vein runs into the costa before the apex; the first branch of the median vein is remote from the second; the subdor'sal vein is simple, but there are inclications of a fork; in the posterior wings the costal cell is abbreviated, ceasing abruptly in the midale of the subcostil veiu; a single vein proceeds from the transverse vein; the apical vein is simple.

'There is only one specoes in this genus; if a rarity it would be considered extremely beantiful, but unfortmately being cxcesssively alumblant, and in all our houses, it is despised for less beantiful insects of greater ratrity. It is however rarely seen in gooul condition, which me acemut for the neghere it experienees, 
being an extremely active insect, flying about our rooms at night, getting into the milk (thenee called lucteellue), and in the daytime sitting in the window's (whrnee the mane fenestrella); it is relentlessly pursued by carcful housckeepers as a clolles-molh, its conspicuous white liear causing it to be casily observed; whilst. the true culprits, Tinen puellioncella and biselliella, remain unlurt in their places of concealment. The larva of fr. fenesticlle feeds on various dry goods, peas, secels, elc., ind, according to Matame lienig, even on salt. I an not aware that it attacks clothes of any kind; the notices in previous writers to that efiect having been copied from Jimecus, who, if this be his sureilethe, must have fillen into some similar error, as he male with respeet to lis vestianella.

1. fenestrella, Scop. F. C. 252.653 (1763).-lurlellu, IV. V.lacleella, Lienig. -Betulinella, IIüb. 'l'in. 20. 448; 'Treit.; Dup.-sarcitella, Lin.? Step.? Curt.?-sarcitea, IIaw.?-domeslicella, Scop.? Alis anticis griscis fusco-ncbulosis, basi albal, punetis disci saturate fuscis. Lixp. al. 7 ? -9 lin.

Ifead and face white. Palpi white; terminal joint with a ring at the base and another before the apex, black. Intenna fuscous. Anterior wings dirty grey, eloulded with fusenus, with the extreme base white; beyoud is a moderately broid fusens fiscia, a fuscous blotech is on the costa beyoud the middle, a smatler one is above the anal angle, and another lies in the apex of the wing, preced by an indistinet oblique whitish lascia; a dark finseous sprot on the dise, and one beyond it on the fold are before the midklle of the wing, two larger dark fuscous spots are on the dise beyond the middle; the hinder nairgin and alpex of the costa are spotted with whitish-grey; cilia greyish-fuscons. Postcrior wings whitish-grey, with paler cilia.

Abundant in honses throughout the year; and during summer, on the trunks of trees near houses. The larva may likewise be found thromghout the year, feeding on various dry goorls.

\section{Genus XXIV. BUTALIS.}

Butuds, Treit. E. s. ix. 2108 (18:3:3). Astyutges p., Step. Thutalis p., Dup. Ecoptiora p., Zell. Oxybelia p. et Galanthia p., Hüb.

Caput oblusum, retracticm, squamis appressis. Ocelli nulli. Antenna articulis coufertis, o pubescentc-riliatæ, vix stib apicem serrulatx. Ifaustellum mediocre, squamatum. P'alpi breviusculi, adscendentes, subcompressi, acuminiti. Alæ elongate, antcriores subtus penicillo basali; posteriores acuminate; anteriores: infra venam apicalem venæ tantum qualuor e cellula discoidali prodeunt; posteriores: e venula transversa vena unica procedit. 
IIead obtuse, retracted, with appressed scalcs. Ocelli none. $\Lambda$ fonmes with thickly-set joints, in the of pubescent-ciliated, before the apex slightitly semated. 'Jongue of moderate length, clothed with seales. l'alpi ralker shorl, ascending, rather compressed, acumbute. Wings clongate; the anterior beneath with a brush at the base; the posterior acuminate. In the antcrior wings only four veins proceed from the discoidat cell below the apical vein; in the posterior wings a single vein proceeds from the transverse vein.

The two last species I have placed in this genns, exhibit several discrepancies: in torynulella the anterior wings are oblong; the apex of the posterior wings is obtuse; the tongue is malied; the shorter palpi are not ascencling, with the apex almost obtuse. luronyruella has the anteme rather thick, fire veins from the discoidal eell of the anterior wings to the hinder margin, and two vcins from the transverse vein of the posterior wings.

"ille remaining species form an extremely natural genus, of which the most remarkable peculiarity is the position in which the perfect insects sit, when at rest; the wings being almost folded round the short thick body, mecting belind it nearly in a point, which the thick blunt head of the insect renders more prominent; they frepuent grassy places and are ratler active, flying close to the eround; the females of most of the species have at pale spot on the muderside of the abilomen. (O) none, exrepting (Yhenopodicllo, is the larva known; of that species the larva feeds in a web between united leaves of Chenoprolimm and Atriglex, where it spins a white oval cocoon provious to its transformation; it only frequents those plants which grow in sheltered situations.

There seems to be a great variety of closely allicel species on the continent, but only seren of the typical form of the genus have occurred in this country; they may be armanged as follows :-

a. Anterior wings unicolorous. Succies 1, 2, 4.

a ". Anterior wings with scattered whitish seales, not forming distinet spots. Species 3,5 .

a a $a$. Anterior wings with distinct white or whitish spots. Sp. 6, 7.

1. Eraxdipenuis, Ilaw. I. 13. 5336 (1829); Step. Mlis anticis viridi-fuscis, postice squamis sparsis albidis. Exp. al. ơ $8 \frac{1}{3}, q 7 \mathrm{lin}$.

Ilead, face, palpi, and antennæe dark fuscous. Anterior wings wrecenish-fuscoms, posteriorly with a few whitish seales; ciliat palk greenisli-linsous. P'onterior wings grey, with pate fuscous eilia. Mhidonen of the $\&$ beneath with a large dirty yellow spot.

('ommon on lientlis, among fume-buslies in May and Junc.

2. fusco-renea, IIaw. L, 13. 537 (1829); Curt.; Step.; Sta. $\Lambda$ lis anticis viridi-cueis, postice fusco-tinctis. Exp. al. 7 lin. 
Ilead and face dark brownish-lotonze. Paljoi and antemue dirk finscons. Anterior wings bronzy-green, posteriorly a little darker; cilia jaler. Posterior wings fuscous, with paler cilia.

I scarce species, appearing in Juno; has occurred near Grassington, Yorkshire.

3. senescens, Sta. Ent. 'Trans. i. n. s. 22 (1850).-Seliniella, Sita. (Cat.) Nlis anticis salumale viridi-fuscis, syuanis sparsis mumerosis albidis, procipue apicem ver'sus. Exp. al. 5

Ilead, face, palpi, and antenno dark greenish-fuscons. Anterior wings dark grecnish-fuscous, with unnerous seattered whitish scalse, especially towards the apex; cilia fuscous. I'osterior wings dark greyish-fuscons, with paler cilia. Abdomen of the $q$ beneath with a large white spot.

Common on the downs at Mickleham, in July.

1. fusco-cuprea, IIaw. I. B. 537 (1829); Curt.; Step. ; Sta. Alis anticis saturate viridi-fuscis, squamis albis mellis. Exp. al. $4 !$ lin.

I [ead, face, palpi, and antemne dark treenish-fuscous. Anterior wings dark grecuish-fuscous, with no white seales; cilia fuscous. P'osterior' wings dark greyish-fuscous, with paler cilia.

Formorly taken by $1 \mathrm{r}$. sircom, near Brislington; perhaps not specifically distinct from the preceding.

5. Cicadella, Yroll. Isis, 1839. p. 193. Nlis anticis fuscis, olivucro-linclis, syuninis sparsis albis, maculam dorsali basim versus, maculam dorsali in nodio, striamme apreis, formantibus, stria plice interdum obsoleta alba, luteave. Exp. al. $5 \frac{1}{2}$ lin.

Head, face, palpi, and antenno greyish-fuscous. Anterior wings fuscous, with a slight olivaceous tint, with numerous scattred white scales, forming a spot on the inner margin near the base, another on the inner mergin about the michlle, and generally a short streat towerds the apex; along the fisld is usually a white or yellowish streat; ; cilia fuscous. l'osterior wing's greyish-fuscons, with palcr cilia.

A single specimen, taken by Mr. Duming, at Brandon, in Sullolk, in July.

6. variella, Step. 11. iv. 27.4. (18:34).--inspersella, \%cll.--pien penuis. Jaw.? Sicp.? Alis anticis nigrescentibus, squamis sparsis allielis, juncto plieix ponc medium, punctoque ad angulum analem allsis. Lixp. al. s. lin.

Ilead, lace, palyi, and antenne blackish. Antcrior wings blachish, with a few scattered white seales, a white spot on the fold beyoud the middle, and another at the anal angle; cilia dark grey. P'osterior winers very dark grey, with fuscous cilia.

Hrequents sand-pits in the south of England, in June.

7. Chenopodiella, Ilüb. 'Tin. 320 (1816); F. v. R. jl. 71. pl. 72. f. 1; Zell.-tristella, Treit.; Dup.-variella, W. V.?-cylin- 


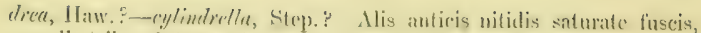
maculis tribus lutescentibus prope dorsum. Exp. al. 7 lin.

Ilead and face dark fuscous. Palpi whitish, with a ring at the end of the second joint, and another at the end of the terminal joint dark fuscons. Antroure dark fiscous. Anterior wings shining dark firecous, with thee yelloreish spots near the inner margin, one before the micldle enmected with the base by a narrow yellowish streak atong the fold, another nearly in the midelle, and the (hird close besond it at the anal angle; cilia dark fuscous. l'osterior wings dank greyish-fuscous, with dark fuscous cilin.

Oecurs from Jume to ()etober, in waste ground, among Chenoporlimin and Alriplex; the larva fecoling on those plants from April to Augrust.

8. torquatella, Licnig ct \%cll. Isis, 18.16. p. 279.- fuscifrontella, Sta. Alis anticis silurate fuscis, maculis tribus dilute luters, ume plices

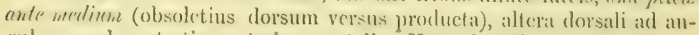
gulum analem, tertia posteriore costali. IXxp. al. 5 lin.

ITtud, faee, palpi, and antcnnie dark fuscous. Anterior wings dark fiscous, with three pale yellowish spots, one on the fold bufore the midtle (indistinetly produced fowards the inner margin), one on the inner margin at the anal angle, and onc, posterior to it, on the costa; cilin pale fuscous, the tips whitish. P'osterior wings palc greyish-fuscous, with palcr cilia. July.

Among mixed mulerwood at Torwood, and near Kilmun, in

9. incongruella, Sta. C'at. p. 15 (1849). Alis anticis nitidulis fuscis. Lixp. al. 5 lin.

Ilead and face dark fuscous. Palpi ratlier paler. Anteuna greyishfuscous. Auterior wings mallier gloxy fuscons, with paler cilia. P'osterior wings pale grey, with palcr cilia.

Not searce in March aud Aprit, on the moors in the north of England.

\section{Genus XXV. PANCALIA.}

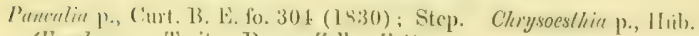
(Ecophora P., I'reit.; I) up.; Zell.; 'Zett.

Caput retractum, capillis appressis, fronte obtusa. Ocelli nulli. Antennas articulis confertis, compressis, apicem versus attenuate. Ilaustcllam mediocre. Palpi reflexi, articulo secundo compresso, lacvi, articulo terminali neuto. Alse elongata, apice producto, posfurores angulo anali obtuso; anteriores: celludi discoislalis angustat, valde elongata; vence apicalis ramus inferior supra apicem cxit; 
vena subdorsalis simplex; posteriores: e venula transversa vena mmica procedit.

Ilead retracted, with appressed seales, in front obtuse. ()eelli none. Intrume with thickly-set, compressed joints, attenuated towards the apex (in one continental species with ereet projecting seales in thr miclalle, Fodosello). 'Tongue of moderate lengrth, with a few sciles towarits the base. Palpi reflexed; the second joint compressed, smooth; the terninal joint pointed. Wings elongate, with the apex protuecel: 1lue posterior with obtuse anal angle. In the anterior wings the nitrenw, discoilal cell is extremely clongate; the lower branch of the apient vein rums into the costa before the apex; the subdorsal vein is siupte; in the posterior wings a single vein procech from the transverse vein.

Nie lave but two species of this genus in this country; they are excedingly similar, the main point of difference being in the antermac. $\Lambda$ third species is known on the continent, also differing in the antenux. 'The larva of none of the species are known;

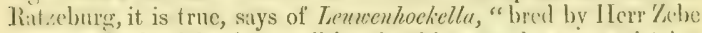
from the biuk of larch-trees," but in this must be some mistake, as the perfect insects are not found amongst trees, but frejuent njen flowery places amongst short grass.

1. Latreillella, Curt. B. L. fo. 30 1 (1830); Step.; Sta. Alis anticis saturate aurantiis, basi, costa, dorso, margineque postico saturate fuscis, maculis tribus costa (tertia ad costam dilute luteo-alba) cluabus plice, unaque dorsi viridi-aureis; antennis Lotnm fuscis. Exp. al. fi lin.

Itead and face very dark bronzy-green. Palpi dark fuscous, internally birty whitish. Antenure entirely dart fuscons. Anterior wings deep orange, with the base, costa, inner and hinder margins dark fiscous, with six golden-green spots, the first rather transverse on the costa near the base, the seeond on the costa before the middlle, the third clongated, pointing inwardly, near the costa towards the apex (prodnered on the eosta as a pale yellowish-white spot), the fourth on the fold below the first costal spot, and almost united with it, the fifth on the fold before the midelle is sinaller, and the sixth is larger on the inner margin beyond the middle; above the anal angle are some golden-erecen seales not forming a definite spot; cilia fuscous. P'osterior wings fuscous, with a slight bronzy tinge, with pale fuscous cilia.

$\Lambda$ specimen is in Mr. Curtis's collection; and I have seen a few others.

2. Leuwenhoekella, Lin. F. S. 1400 (1761); Wr. V.; Tab.; Haw.; Step.; Zett.; Zell.; Sta.-Schmidlella, Treit.; Dup.-metallella, W. V.P-Schoarzella, F'ab.? Alis anticis saturate nuruntiis, basi, costa, dorso, marginerue postico saturate fuscis, maculis tribus costar (tertia ad costan dilute lutco-allsa) duabus plicis, maţum dorsi viridi-aureis; antennis fuscis, infra apicem albis. lixp. al. $5 \frac{1}{2}$ lin. 
Differs only from the preceding in the antenne, which have a broad white ring before the apex.

Common in dry grassy places among flowers, in May and June.

\section{Family VI. GLYPHIPTERYGID AE.}

Caput plerisque lavissimum. Palpi maxillares brevissimi. $\Lambda$ læe anteriores oblongac vel elongatre, posteriores ovata vel lanceolatx. Volatus diurnus.

Ilead mostly extremely smooth. Maxillary palpi very short, rarely perceptible. Anterior wings oblong or clongate; the posterior ovate or lanceolate. Illight diumal.

$\Lambda$ rather natural family, of which many of the species are of gay colours, delighting to fly in the hot sumshine. 'The sjocies of the smaller genera are brilliant little insects, running about with great activity on the leaves of the plants they frequent; the species of the genus Glyphipleryx, remarkable for the rich colouring of the anterior wings, have the peculiarity of alternately raising and depressing their wings, as thongh fanning themselves, when at rest. Most of the gencra appear in the summer, but some species of the genus derolepria appear at the end of autumn, and, hybernating, are met with early in spring. The lave of fiöslerstammia, Acrolepiu, and Glyphipterys $x$ have been observed, but do not cxhibit any peculiarity, aud would readily pass for larvo of the previous family.

\section{Genus I. ACROLEPIA.}

Acnolersa, Curt. B. L. 679 (1838). Rösterstammia p., Zell.; Dup. Capilli in verlice et occipite lirsuli, creterum levignti. Occlli nulli. Antenne tenucs, corpore breviores. IIaustellum mediocre, nudum. Palpi labiales arcuati, crassiusculi, subcompressi; articulo ultimo precedentem longitudine superante, acuminato. Ale anteriores plerungue clongate, posteriores ovato-lanceolate, longius ciliatic; anteriores: vena apicalis simplex, infra cam rami 6 , inter se distantes; cellula secundaria perfecta ; submedianse apex incrassatus; subdorsalis longius furcata; posteriores: cellula costalis clongata, subito coarctuta ; vena aprealis simplex, iufra eam vena furcala; vense discoidalis rami duo ultimi in furcam coaliti.

The crown and back of the head rough, the remainder smooth. Oeelli none. Antenne slender, shorter than the body. Tongue of moderate length, naked. Labial palpi arehed, rather thick, slightly compressed; 
the terminal joint longer thim the second, pointed. Anterior wings generally clongate (in one species oblong), the posterior ovate-lanceolate, with rather long eilia. In the anterior wings the apical vein is simple, below it are six veins at cyual distances; the secondary cell is complete; the apex of the submedian vein is thickened; the subdozsal has a rather long fork. In the posterior wings the elongate costal cell is suddenly narrowed; the apical vein is simple, below it is a furcule rein; the two last branches of the discoidal vein are united at their origin.

I have secn but three British species in this genus, though I have $n 0$ reason to doubt that Belulelle truly betongs here; and I belicve Mr. Curtis las specimens of a fifth species, which appeared to me too wasted to describe. The perfect insects ippear of a very (quict disposition, more especially on their first quitting the pupa state, and are more frequently met with on the wing after lybernation; pyymeane will remain motionless nearly throughout the winter; granitclla also hyberuates, but I am not aware whether perlepidellat and Betulellu do likewise, though I think it extremely probable.

The larve of the two former only are known; they may be found in summer and beginning of autumn, mining the leaves of Solunnit I) nlcamara and Inula dysenterica respectively; pygmaeana, from the numerous large whitish blotches it makes, being very easily detected; both species construct delicate open network cocoins.

The pale spot in the cilia of the anterior wings appears to indicate an affinity to the species of the genus Glyphipteryx.

The genus may bo thus subdivided:-

a. Anterior wings oblong. Species 1 .

a a. Anterior wings elongate. Species 2-4.

1. perlepidella, Sti. Cat. p. 19 (1849). Alis anticis aurantiis nimro-suflusis, fascia fere reta ante merlium lutea (squamis cerulco-griseis in medio interrupta), fascia obliqua postica lutea (squamis ceruleogriscis valde interrupta), maculis duabus posticis costa luteis, apice carulco-atro. Exp, al. 5 lin.

IIcad ferruginous. Face fuscous. Palpi yellowish. Antcrma yellowish, aunulated with fuscons. Anterior wings orange, much suffused with black, especially towards the base and along the costa, with a pale ycllow nearly straight fascia before the middle (which appears somewhat interrupted by some bluish-errey seales in the middle); beyond it is a sceond pale yellow fascia more obliquely placed (the central portion of which is cntircly suffused with bluish-grey, leaving only a distinct pale yellow spot on each margin); beyoud this are two small pale yellow spots on the costa, which soon unite, and are continued as a bluish fascia nearly across the wing; the entire apical portion of the wing is 
nearly filled up with bluish-black; cilia orange, mixed with bluish-grey. Posterior wings grey, with paler cilia.

This beautiful species is extremely rare; a specinen recently taken at Darenth W'ood, in May, is in Mr. Shepherd's collection. Mr. Douglas lias a speciuen, of the locality of which he is not aware.

2. granitella, Treit. E. S. ix. 2. 265 (1833); F. v. R. pl. 8 ; Zell.; Dup.? Alis anticis griseo, albo, fuscoque marmoratis, macula fusea dorsali ante medium, utrinque albido-maculata, macula altera fusca, maculam parvam albam includente, ad angulun analem. Exp. al. 6 lin.

Head greyish-fuscous. Face grey. Palpi grey, with two fuscous rings. Antenne whitish, annulated with fuscous. Anterior wings marbled with grey, white and fuscous, with two more conspicuous fuscous spots on the inner margin, one before the middle reaching to the fold, with a whitish spot on each sicle of it, the other towards the aund angle not crossing the fold, and including a small white spot on the inner margin; beyond the middle of the costa are four or five fuscous spots, the two hast of which are preceled by whitish spots; cilia arryish-fuscous. Posterior wings grey, with paler cilia.

$\Lambda$ ppears in July among Inula dysenteriea, continuing throughout the autumn, hybernated specimens occurring as late as Jume, when the larva are already nearly full-fed, mining the leaves of that plant.

3. pygmaeana, IIaw. L. B. 1.38 (1812).-antumitula, Curt.Lefebvriella, Dup. xi. pl. 290. f. 11.-ILeleniella, Lell.; 11.-S.-Vigeliella, J)up.? Alis anticis brumeo albidonue marmoratis, macula triangulari squamas nomullas nigras includente, in medio dorsi, albicla, macula obliqua costa pone medium nigra, stria postica disci nigra. Exp, al. $5 \frac{1}{2}$ lin.

Ilead ferruginous. Face fuscous. Palpi whitish, with two faint fuscous rings. Antenne whitisli, ammated with fuscous. Antcrior wings marbled with pale brown and whitish, with a rather conspicuons triangular whitish spot, including some black scales on the midelle of the juner margin; on the costa a little beyom the middle is a short oblique black spot; towards the apex are three small whitish spots on the costa and two on the inner margin; on the lise near the apex is a short black streak, followed by some bluish-grey seales; eilia fuscous, with a pale yellowish dash in the mirlde of the binder margin. Posterior wings grey, paler at the basc, with paler grey cilia.

$\Lambda$ plears in the autumn, but rarcly met with till the spring, when they are occasionally seen flying on hot sumny aftemoons. [ well remember finding three specimens on such an afternoon, on the $3 \mathrm{rd}$ of $A$ pril, $184 \mathrm{~s}$. The larva may be met with from July to September, mining the leaves of Sulanum Duleoment, 
rather gregariously, there being gencrally twenty or more on one plant.

4. Betulella, Curt. B. E. fo. 679 (1838).

Taken by Mr. Dale on birch-trees at Castle Eden Dene, in August; unique in his collection.

\section{Genus II. RÖSLERSTAMIMIA.}

Rüslerslammia p., Zell. Isis, 1839. p. 202 ; Dup. Adela p., Treit.

Capilli in occipile et vertice hirsuti, cxtcrum rlecumbentes. Ocelli nulli. Antenne crussirescule, filiformes, microscope pubescente-ciliate, corpore longiores. Haustellum mediocre, nudum. Palpi labiales, filiformes, meliocres, penduli vel subporrecti, articnlo tertio precedentem longitudine et crassitie subequante, acuto. Alas oblongar, posteriores ovatix, ciliis mediocribus; anteriores: vena apicalis furcata, infra cam rami 5 inter se distantes; cellula sccundaria bene indicata ; submediante apex incrassatus; vena subdorsalis longe furcita; posteriores: cellula costalis clongata; vena apicalis simplex, infra eam venie duæ simplices; vene discoidalis rami duo ultimi fuream formant.

The croon and back of the lesed rough, the remainder with decumbent scales. Ocelli none. Antenna rather thick, filiform (viewed through a lens, with pubescent eiliations), longer than the botly. Tongue of moderate length, naked. Labial palpi filiform, of moderate length, drooping or rather porrect; the third joint nearly equal in lengtl and thickness to the second, pointed. Wings oblong, the posterior ovate, with moderate cilia. In the anterior wings the apical vein is furcate, below it are five veins at equal distances; the sccondary cell is well indicated; the apex of the submedian vein is thickened; the subdorsal vein has a long fork. In the posterior wings the costal cell is elongate; the apical vein is simple, below it are two simple veins; the two last branches of the discoidal vein form a fork.

There is only one species in this genus, which has some resemblance to an Adela.

1. Erxlebella, Fib. Man. ii. 256. 27 (1757).-fusco-cuprella, IIaw.; Step.—clirysilella, Treit.-rneclla, Jup.?-Erxlebeniella, Licnig? Alis anticis nitide cupreis, dorsum versus dilutioribus. Exp. al. $6 \frac{1}{2} \operatorname{lin}$

IIead dark yellow. Face and palpi pale ycllow. Antemme black, a short space before the apex white. Anterior wings bright-coppery, towards the inner margin rather paler; cilia coppery-grey. Posterior wings violet-fuscous, with paler cilia.

Appears in June, on heaths, but hitherto very scarce.

(Ac- 
cording to Tischer, the larva feeds on henth, drawing the leaves together by its silken threads, and is full-grown at the end of June; the perfect insect appears in July or August. Lienig says that the larva lives on the underside of the leaves of the lime in May and September. From the habitats of the insect with us, Tischer's account is more probably correct.)

\section{Genus III. GLYPHIPTERYX.}

Glypliptery.x p., IHüb. V. 421 (1816). Ekchmia p., Trcit.; Dup.; Zell. Écophora p., Zett. Ilevibeia et Callisto p., Step.

Caput levigatum. Frons lata. Ocelli magni, pone oculos. Antenne tentes, corpore breviores, articulis distinctis. Haustellum mediocre, nudurn. I'alpi labiales arcuati, crassiusculi, infra setoso-pilosuli, articulo tertio acuminato, precelentem longitudine xquantc. Alæ oblonga vel elongatix, mediocriter ciliatix, posteriores subovatæe vel lanceolate; anteriores: vena apicalis simplex ante apicem excurrit, infra cam rani 6 discreti; cellula secundaria bene indienta; submediana rarius incrassata; subdorsalis breviter fureata ; posteriores : ccllula costalis elongata; vena apicalis simplex, infra cam venæ duæ separato.

Ilead smootl. Forehend broad. Ocelli large, behind the eyes. Antenne slender, shorter than the body, with distinct joints. Tongrue of moderate length, naked. Labial palpi arehed, rather thick, beneath with rather bristly hairs; terminal joint pointed, as long as the sccond. Wings oblong or elongate, with moderately long eilia; the posterior rather ovatc, or lanceolate. In the anterior wings the simple apical vein runs into the costa before the apex; below it are six separate veins; the secondary cell is well indicated; the submedian vein is rarely thickoned towards the apex (slightly so in fuscoriridella and Thrasonella, but not at all in the other species); the subdorsal vcin has a short fork (in fuscoviridella and Thrasonella, being simple in the remaining species). In the posterior wings the costal cell is elongate; the apical vein is simple; below it are two separate veins.

It is difficult to subdivide this genus, the change from one species to another being so gradual; thus fuscovirildlla agrees with Thrasonella, in having the antenmæ pubeseent; yet Thrasovella differs from fuscoviridella in having the anterior wings slightly retuse below the rounded apex, in which respect it agrees with Ilaworthana, equitella, etc.; again Ilaworthana has rather ovate posterior wings, with only moderate cilin; whereas equitella and the following species have lanceolate posterior wings with longer cilia. 
In habit all the perfect insects of this genus are true dayfliers, flying in the sunshine from May to July; and when at rest alternately raising and depressing the wings, which characteristic may ensily be observed with Thirasonella, which may be found swarming amongst rushes everywhere in June; fuscoviridella has the same peculiarity, though in a less degree than the other species, it frequents flowery places among short grass, in May and Jume; the little Fischeriella shows no especial partiality for any particular plant, but I have often observed it sitting on the flowers of Anthriscus sylvestris, the white petals of which served to show off to advantage the nearly black wings of the elegant species; I have also observed it swarming round the twigs of young fir-trees.

None of the larve of this genus were known till Mr. Weir discovered last summer that of equitella, feeding inside the shoots of the Sedum acre; it exhibited no peculiarity in structure; the larvæ of the other species still remain undiscovered.

1. fuscoviridella, Ilaw. L. B. 569 (1829); Step.-albicostella, Dup. xi. pl. 302. f. 3. Alis anticis viridi-2neis, ipsa costa pone medium alba. Exp. al. 6-6 $\frac{2}{3}$ lin.

Head and face dark brouzy-green. Palpi fuscous. Antenuæ dark fuscous. Anterior wings shining bronzy-green, with the extreme $\mathrm{c}$ ista beyond the middle white; cilia pale bronzy-oreen, with the tips white. Posterior wings grey, with paler cilia.

Very abundant in flowery meadows, and in open places in woods, from the middle of May to the middle of June.

2. Thrasonella, Scop. F. C. 253. 658 (1763); Dup. xi. pl. 30b. f. 1, 2; F. v. IR. pl. 83. f. 1.-F'uestella, Fab.-F'yeslella, Fab.; Step. -Seppella, Hüb.-trigultella, Don.-Aillyella, Ilüb.-equitella, var. Seppella, Treit. Alis anticis saturate viridi-aencis, strigulis quinque coste (ad costam ipsan albis) strigulisque duabus dorsi ( prima medin fere obsoleta) caruleo-argenteis, macula oblonga ad angulum analem atra, puncta tria violaceo-argentea includente, apice saturate fusco-squamato. Exp. al. 6-6 $\frac{1}{2}$ lin.

IIcad and face dark fuscous. Palpi whitish, with two dark fuscous rings. Antcnnæ fuscous. Antcrior wings dark bronzy-green, with five bluish-silvery streaks from the costa, which are white immediately on the costa, with a faint bluish-silvery streal from the middle of the inner margin, and a more distinet one towards the aual angle; above the anal angle is a black blotch, enclosing three silvery-violet spots; at the apex are a few dark fuscous seales; cilia greenish-bronze, with the tips whitish. Posterior wings grey, with paler cilia.

Very abundant amongst rushes in June and July, throughout the country. There is considerable diversity in the size of the 
specimens, and the distinctness of the markings, but I lave been unable to distinguish more than one species.

3. Haworthana, Step. II. iv. 262. pl. 39. f. 2 (1834).-Zonella, Zett. $\Lambda$ lis anticis saturate viridi-ancis, strigula distinctiore curvala alba in medio dorsi, strigulis posticis quiuque costie, una dorsi ad angulum analcm, albis, apicibus argenteis, maculis tribus supra angulum analem argenteis, apice atro-squamato. Lxp. al. 6 lin.

Head and face dark fuscous. 1alpi white, beneath fuscous. Antenne fuscous. Anterior wings dark bronzy-green, with a conspicuons curved white streak on the middle of the inner margin; beyond are five short wolite streaks from the costa and one from the inner margin at the anal angle, all with silvery apices; above the anal angle are three silvery spots; at the apex of the wing are a few black scules, not forming a round spot; an inconspicuous dark hook runs through the cilia; cilia dark fuscous, the tips whitish. Posterior wings grey, with whitish cilia.

Occurs on heaths, in the north of England, in May and July.

4. equitella, Scop. F. C. 254.659 (1763); Treit.; Zell.; F.v.R. pl. 82. f.2.- II lemanclla, Fab.-Forsterella, Fab.? Haw.?- humerella, Step.? Alis anticis saturate aenco-griscis, basine versus dilutioribus, strigula curvata in medio dorsi, strigulaque opposita obliqua costa, distinctioribus albis, strigulis posticis quatuor costr, ma dorsi ad angulum analem, albis, apicibus argenteis, maculis duabus supra angulum analem violacco-argenteis, puncto apicis atro. Exp. al. 4 $\frac{x}{2}$ lin.

IIead dark fuscous. Face grey. Palpi whitc, with four black rings. Antenne dark fuscous. Anterior wings dark bronzy-grey, paler at the base, with a conspicuous curved white streak from the middle of the imer margin, terminating in the middle of the wing, where it nearly meets a conspicuous oblique white streak: from the costa; beyond the latter are four short, nearly straight, white strenks, with silvery apices, and from the anal angle is a white streak with a silvery apex, almost meeting the second costal streak; above the anal angle are two silveryviolet spots; in the apex is a round black spot, above which is a black hook projecting through the cilia ; cilia very dark brown, tips whitish. l'osterior wings grey, with a slight violet tint, with paler cilia.

Abundant at the end of June and beginning of July, flying over the blossoms of stonecrop (Selum acre). I'he larva burrows in the sloots of that plant in May.

5. oculatella, 7ell. Ent. Ztg. 1850. p. 157; II.-S. Tin. pl. 39. f. 265 ; Sta.-Lucusella, Dup.? Alis anticis saturate renco-brumeis, strigula in medio dorsi subcurvata distinctiore alba, strigulis posticis quinque coste, una dorsi ad angulum analem albis, apicibus argenteis, maculis tribus supra angulum analem violaceo-argenteis, puncto apicis alro argenteo-pupillato. Exp. al. $4 \frac{1}{2}$ lin.

Head and face dark fuscous. Palpi whitish. Antenne dark fuscous. Anterior wings dark bronzy-brown, with a conspicuous slightly 
curved white streak on the middle of the inner margin; beyond are five short white streaks from the costa with silvery apices, and a small white streak from the anal angle with its apex silvery; above the anal angle are three silvery-violet spots, and in the apex of the wing is a round black spot, with a silvery pupil; above this a little black hook projects through the cilia ; cilia dark brown, the tips whitish. Posterior wings grevish-brown, with paler cilia.

'Taken by MLr. Weir, near Pembury, in Junc, among Eupatorium cannabinum.

6. Fischeriella, Zell. Isis, 1839. p. 204.-Röslerstammella, T.v. R. (desiderella), pl. 82.f. 3 ; 1)up.-Cdesideratella, Dup.-Forsterella, Step.? - Forsterella, var. B. IIaw.?- simplicrlla, Step.?-cognatella, Step.? - equitella, Dup.?-Aichmiella, Dup.? Alis anticis saturatissime crneogriseis, strigulis quinque costa, duabus dorsi (prima in medio curvata), albis, apicibus argenteis, macula supra angulum analem violacea, puncto apicis atro. Exp. al. $3 \frac{2}{2}-4$ lin.

Head and face dark fuscous. P'alpi white, with four black rings. Antenna fuscous. Anterior wings very dark bronzy-yrey, with two white streaks on the inner margin, the first near the middle curved and pointing towards the apex of the wing, the second at the anal angle short and nearly straight; on the costa are five white streaks, the first about the middle, placed obliquely pointing towards the anal angle, the second is less obliquely placed, and the other threc are shorter and nearly straight; all these streaks have their apices silvery; above the aual angle is a violet spot, and at the apex of the wing is a round black spot, above which is a little blach look projecting through the cilia; cilia dark brown, the tips whitish. P'osterior wings violet-grey, with paler cilia.

From May to July, this species is frecuently abundant among flowers, in most localitics.

\section{Genus IV. AECHMIA.}

Aichmia p., Zell. Isis, 1839. p. 203.

Capilli depressi. Frons lata. Ocelli nulli. Antenne crassiuscula, filiformes (microscope pubescentes), articulo basali brevi. Maustellum subnullum. Palpi maxillares filiformes, conniventes. Palpi labiales breves, jenduli, filiformes, articulo tertio distincto acuminato. Nla longe ciliates, anteriores latinsculo ciliis valde dilatatie, dorso dentem squamarm gerente, posteriores lanceolato-ovate; anteriores: cellula discoidalis obtusa, sccundaria nulla; vena apicalis furcata, infia cam 5 valde distantes; submediana vix incrassata; sublorsalis longe furcata; posteriores: cellula costalis clongata, angusta ; vena ipjicalis simplex, infia cam vena dune discretæ; venæ discoidalis rami duo ultimi scparati. 
Head smooth. Forehead broad. Ocelli none. Antennæ rather thick, filiform (viewed through a lens, pubescent), the basal joint short. Tongue very short, barcly perecptible. Maxillary palpi filiform, connivent. Labial palpi short, drooping, filiform, the third joint distinct, pointed. Wings with long cilia, the anterior rather broad, appearing considerably broader from the cilia, the inner margin braring a projecting toolk of scales, the posterior ovate-lanceolate. In the anterior wings the discoidal cell is obtuse; there is no secondary cell; the apical vein is forked; below it are five remote veins; the submedian is hardly thickened; the subdorsal has a long fork. In the posterior wings the costal cell is narrow and elongate, the apical vein is simple, below it are two separate veins; the two last branches of the discoirlal ecll are not united in a fork.

Only a single species is known in this genus, and little is known of its habits; the larva is entircly unknown.

1. dentella, Zoll. Isis, 1839, p. 204; F. v. R. pl. 83. f. 3.-subdentella, Sta.-atrella, Step. Alis anticis saturate fuscis, albido-irroratis, maculis duabus obsoletis dorsi dilutioribus, dente e medio dorsi saturate fusca. Exp. al. $4 \frac{x}{2}$ lin.

IIead and face dark fuscous. Palpi grey. Antenux fuscous. Anterior wing's dark fuscous, irrorated with whitish seales, with two indistinet pale spots on the inner margin, one a little before the middle, the other at the anal angle; in the middle of the inner margin is a projecting tooth of dark fuscous scales; cilia dark fuscous. P'osterior wings dark grey, with paler cilia.

Not common; occurs at Sanderstead, in May. I met with it near Chudleigh, in June, flying from a hawthorn hedge.

\section{Genus V. PERITTLA, n. g.}

Capilli depressi. Ocelli nulli. Antemme tenues, mediocres. IIaustellum merliocre, squamatum. Palpi labiales mediocres, tennes, filitormes, acuti, penduli. Ala longe ciliata, anteriores elongata, posteriores lanceolate; anteriores: cellula discoidalis acuta, ex angulo suo apicali furcam in aloo apicem emittens, in costam venas duns, in marginem posticum venas tres; cellula secundaria nulla; submediaua breviter incrassata; subdorsalis simplex; posteriores: cellula costalis perangusta ponc medium desinens; vence subdorsalis et mediana furcate, inter cas vena unica e venula transversa procedit.

Head smooth. Ocelli none. Antennx slender, moderately long. Tongue of moderate length, elothed with scales. I abial palpi moderatcly long, slender, filiform, pointed, drooping. Wirgs with long cilia, the anterior elongate, the posterior lanceolate. In the anterior wings the acute discoidal cell emits from its apieal amgle a fork into the apex of the wing, two veins to the costa, and three to the hinder margin; vol. III. 
there is no sceondary cell; the submedian is thickened for a short distance; the sublorsal rein is simple. In the posterior wings the very narrow costal cell terminates beyoud the midclle, the subdorsal and median veins are furcate, between them a single vein proceeds from the transverse vein.

There is only one species in this genus; it appears early in the spring, and flies willingly in the afternoon among mixed hedges; when at rest it has a singular bull-headed appcarance, with a slight resemblance to a Butulis. Its larva is unknown.

1. obscurepunctella, Sta. Zool. 1818. p. 2161. -olece, I Iaw.?oleclla, Step.? Alis anticis nitidis grisco-fuscis, punctis duobus obsoletis (altero plice median, altero posteriore disci) fuscis. Wixp. al. 1.! lin.

Head and face greyish-fuscous. Palpi paler. Antenne fuscous. Anterior wings shining greyish-fuscous, with two indistinct fuscous spots, one in the middle on the fold, followed by a few whitish seales, the other on the dise rather beyond the midalle; cilia greyish-fuscous. Posterior wings pale grey, witl paler cilia.

Not scarce near London early in May; also oceurs near Bristol.

\section{Genus VI. TINAGMA.}

Tinagma, Dup. Cat. 361 (18.4). Alicrosetia p., Step. Aichinia p., Zell.

Capilli depressi. Frons lata. Ocelli nulli. Antenne breses, cressere, valde compressce. Ilaustellum mullum. I'alpi maxillares breves, acuti. Palpi labiales breves, filiformes, acuti, penduli. Alis longe ciliatie, anteriores postice eiliis dilatatis, posteriores lanecolate; anteriores: cellula discoidalis acuta, $\mathrm{ex}$ angulo suo apicali furcam in alae apiccm emittens, in costam venas duas, in marginem posticum venas tres; ccllula secundaria nulla; submediana non incrassata; vena subdorsalis crassa, simplex; posteriores : cellula costalis perangusta in medio desincns; vene subdorsalis et mediana simplices, inter eas vena libera unica in marginem posticum exit.

IIend smooth. Forchead broad. Ocelli none. Antennx short, thick, very much compressed. Tongue none. Maxillary palpi short, pointed. Labial palpi slort, filiform, pointed, drooping. Wings with long cilia, the anterior with the cilia expanded posteriorly; the posterior lanecolate. In the anterior wings the acute discoidal cell emits from its apical angle a fork into the apex of the wing, tro veins to the costa, and three to the hinder margin; there is no secondary cell; the submedian vein is not thickened; the thick subtorsal vein is simple. In the posterior wings the extremcly narrow costal cell terminates in the middle; the subdorsal and mediau reins are simple; between them a single free vein runs into the linder margin. 
'Threc closely-allied Pritish species are known in this genus; they fly in the hot sunshine, and when they alight on a leaf run nimbly on it, frequently making short jerking movements. The position of the wings in repose is rather peculiar, as they form a very acute angle at their union over the back, as in Cilix spinula. None of the larva have yet been discovered.

1. sericiellum, Haw. L. B. 585 (1829): Step. - metallicella,

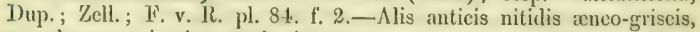
macula parva dorsi prope basim, macularque majore dorsi pone medium albidis. Exp, al, $3 \frac{x}{2}$ lin.

Head, face, and palpi dark greenish-bronze. Autemnre dark fuscous. Anterior wings shining, bronzy-errey, with a small whitish sjot on the inner margin nenr the base, and a large one beyond the middle of the inner manerin; cilia pale bronzy-ercy. Posterior wings violet-grey, with pale grey cilia.

Abundant among oaks in May.

2. Stanneellum, F. v. R. 245. Anm. (1840); Sta. Alis anticis nitidis dilute anco-griscis, macula obsoleta dorsi pone medium albida. Exp. al. $2 \frac{1}{2}-3$ lin.

IIcad, face, and palpi pale bronzy-grcy. Antenne dark fuscous. Anterior wings shining, pale bronzy-grey, with a fuint whitish spot on the imer margin beyond the middle; cilia pale bronzy-grey. Posterior wings violet-grey, with pale grey cilia.

Oecurs, with the preceding, among oaks in May, but less abundant.

3. resplendellum (Dougl.), Sta. Sup. Cat. p. 6. 1851.-metallicella, sta. Alis anticis nitidis saturatissime anco-griscis, macula parva dorsi prope basim, maculaque majore dorsi pone medium albis. Exp. al. $2 \frac{x}{2}-3 \mathrm{lin}$.

IIcad, face, and palpi dark bronzy-rrey. Antennie dark fuscous. Anterior wings shining, very dark bronzy-grey, with a small white spot on the inner margin near the basc, and a larger while spot on the inner margin beyond the midelle; cilia bronzy-rrey. Postcrior wings violetgrey, with paler cilia.

Taken at West Wickliam, Dartford Heatl, and near Bristol, towards the end of June, among oaks.

\section{Genus VII. DOUGLASIA.}

Caput lxvigatum. Ocelli mulli. Antenux crassinsculie, alarum anteriorum dimidium superantes. IIaustellum nudum. Palpi labiales subpenduli, squamis incrassati, apicc obtuso. Nle longe ciliatac, anteriores elongalc, posteriores acuminate; anteriores: cellula dis. 
coidalis venas tres in costam, venam furcatam in apiecm, venas tres in marginem posticum enittit; subdorsalis furenta; posteriores: vena discoidalis trifida, ramum unum in costam, ramos duos in marginem posticum mittens, infra cam vena unica libera.

Head smooth. Ocelli none. Anteuna rather thick, longer than the half of the anterior wings. Tongue naked. Labial palpi rather drooping, thickened with seales, with the apex blunt. Wings with long cilia, the anterior elongale, the posterior acuminale. In the anterior wings the cliscoidal cell emits from its apical angle three veins to the costa, a furcate vein to the apex of the wing, and three to the hinder margin; the subdorsal vein is furcate; in the posterior wings the discoidal vein is trifid, sending one branch to the costa and two to the hinder margin; below it is a single free vein.

Only one species is known in this genus, which unites the habits, as it combines the structure, of Tinagma and Gracilaria; having the anterior part of the body slightly raised in repose, yet laving the sharp jerking motions of a Tinugma; it frequents the Echinu vulgare when in blossom; its larva is unknown.

1. Ocnerostomella, Sta. Ent. Trans. i. n. s. Proc. 6 (1850). $\Lambda$ lis anticis nitide griscis, macula dilutiore obsoleta dorsali pone medium. Exp. al. $3 \frac{\pi}{2}-4$ lin.

IIead and face shining grey. Palpi pale grey. Antennx fuscous. Anterior wings shining grey, with an obsolete paler spot bevout the middle of the inner margin; cilia grey, mixed with paler and darker seales. Posterior wings greyish-fuscous, with greyish-ochreous cilia.

Common among SEchium vulyare, at the begimning of July, flying at dusk. I lave taken it abundantly at 13ox IIill.

\section{FAMTry VII, ARGYRESTHIDA.}

Capilli hirsuti, epistomio laviguto. Palpi maxillares nulli. Palpi labiales breviusculi, articulo terminali subacuto vel obtuso. Alæ anteriores elongata, posteriores lanceolatx, longe ciliatx.

Ileat rough; the face smooth. Maxillary palpi none. Iabial palpi rather short; the terminal joint hardly acute, or obtuse. Anterior wings elongate; the posterior lanceolate, with long cilia.

The four genera in this family have considerable affinity with each other, though differing in several points; they may be readily distinguished as follows:-

a. Anterior wings not subfalcatc.

b. Palpi rather short, with appressed seales; terminal joint rather pointed. 1. ARGYHESTHA.

6 6. Palpi shorter, thicker, and hairy. 2. Cedestis. 
b 6 b. Palpi extremely short. 3. OcNerostoma.

a $a$. Anterior wings subfalcate. Palpi rather short and thick; the terminal joint obtuse. 4. '/ELLERIA.

\section{Genus I. ARGYRESTHIA.}

Argyresthia p., IIüb. V. 422 (1816); Zell. Idderesa (ct Argyrosetia), Curt. Eicophora p., Trcit.; Dup.; Zett. Erminea p. et Tinea p., Haw. Ismene et Aryyrosetia, Step.

Capilli hirsuti, cpistomio lavigato. Antcmm alis anterioribus breviores (articulo basali elongato, incrassato), articulis distinctis. IIaustellum breve, nudum. Palpi labiales penduli vel subporrceti, squamis appressis, articulo sccundo apice incrassato, articulo terminali subacuto. Ala longe ciliatx, anteriores clongate, posteriores lanceolate; anteriores: vene ex cellula discoidalis parte postica novem octove oriuntur, apicalis simplex vel furcata ; subdorsalis simplex; posteriores: vena apicalis ante apicem exit, infra can vena fureata, et venæ dux simplices e venula transversa.

Head rough; the face smooth. Antenna shorter than the anterior wings, with distinet joints; the elongate basal joint is thickened. Tongue short and naked. Labial palpi drooping or rather porrected, with appressed seales; the second joint with the apex thickencd; the terminal joint rather acule. WVings with long cilia, the anterior clongate, the posterior lanceolate. In the anterior wingrs cight or nine veins arise from the hinder portion of the discoidal cell; the apical vein is simple or furcate; the subdorsal is simple. In the posterior wings the arpical vein runs into the costa before the apex; below it are a furcato vein, and two simple veins from the transverse vein.

The perfect insects of this genus may be at once recognized when at rest, as the hind pair of legs are laid alongside of the body, which is elevated at an angle of $15^{\circ}$, the head of the inscet being almost in contact with the substance on which it rests; they thus stand on the first four legs only, whence Limueus named one of the species tetrapodella. The species are found in hedges, trees, and buslics, from May to September, each species generally keeping vut for a long time, and, as they very readily fly, they soon get wasted. 'The larve feed in the leat-buds, destroying or erippling the growth of a young shoot, yet the luxuriance of vegetation is so great that no apparent ill eflects are produced by a considerable number of the larve feeding on the same plant; of some species (according to latzeburg) the larva assume the pupa-state inside the shoot, but more generally the larvae descend by their silken threads to the ground (nitidella may often be seen so descending from a hawthorn hedge in May), and form on the ground amongst leaves a rather open network cocoon. 
There is considerable similarity anong the species, but they may be arranged in the following table:-

1. Anterior wings with a white streak along the inner margin, interrupted in the middle. Specics 1-10.

a a. Anterior wings with no dorsal streak (a variety of Species $20 \mathrm{cx}$ cepted).

b. Anterior wings with numcrous fuscous spots, and with a transverse blotch on the dise, or fascia, beyond the midelle. Sp. 11, 15, 16 .

$b \quad$. Anterior wings without spots.

c. With no fascia near the base. Species 14 .

$c c$. With a fascia or fasciatorm bloteh, near the basc. Species $17-20$.

l 6 b. Anterior wings of a marbled appearance. Species 12, 13.

$6<6 b$. Antcrior wings unicolorous, Species 21-23.

b $b$ b $b$ b. Anterior wings white, with two dark streaks from the base. Species 24.

1. ephippella, Fab. G. I. 297 (1776); Sta.-Prruniella, IUüb. Tin. 175 ; Treit.; Dup.; Zcll.; Linn.?-Letrapodella, Step.-comelln, Scop.? Alis anticis oclureo-brumeis, dorso albo, pone medium fuscia subobligut salurate fusca interrupto, strigulis tribus coste apiecm versus albis, Exp. al. $5 \frac{1}{2}$ lin.

IIcad, face, and palpi white. Antenne white, annulated with dark fuscous. Anterior wings ochreousebrouch, with the inner margin white, interrupted beyond the middle by a dark brown, nearly perpendicularly placed spot, which can be traced rather obliquely across the wing as a fascin, terminating on the costa; beyond it the imner margin is whitish to the anal angle, and on the costn are three small white spots: cilia greyish-brown. P'osterior wings grey, with paler cilia.

Common in the south of Fingliand, but more abundant in the north; frecuenting gardens and hedges in June and July. Mr. Juogan has bred it from larva feeding in the shoots of the cherry.

2. nitidella, Tab. Man. ii. 241. 12 (1787); Zell.; Sta.; W. V.? -Pruni, Ilaw.-Pruniella, Step.; W. V.?-tetrapodella, linn.?-curvellu, "Zett.?-var. ossert, llaw.; Step. Alis anticis dilulissime ochrcobrumeis, stria ex medio bascos saturatiore, dorso albo, fascia curvata snturate brumea in apicem ducla pone medium interrupto, strigulis tribus costox apicem versus albidis. Exp. al. $5 \frac{1}{2}$ lin.

Var. Alis anticis lacteis, dorso niveo, stria basali, maculaque dorsali obsoletis.

Ilead, faee, and palpi white. Antenue whitc, annulated with dark fuscous. Anterior wings very pale ochreous-brown, with a darker streak from the micldle of the base; the imner margin is white, interrupted beyond the middle by a curved dark brown fascia, which terminules in the apex of the wing; above it are two or three small whitish 
spots on the cosfa ; cilia greyish-ochrcous. Posterior wings grey, with paler cilia.

In the varicty ossea the anterior wings are cream-colour, the inner marcin remaining white, and the dark basal streak and dark spot on the inner margin becoming rather obsolete.

Very abundant among hawthom in June and July. The larva feeds in the leaf-buds of the hawthorn in May.

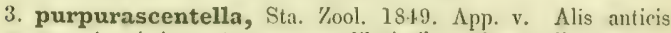
purpurascenle-griseis, costan versus dilutioribus, dorso albo, macula obliqua fusea in apicem obsolctius producta, pone medium interrupto, punctis duobus costx apicem versus albis. Exp. al. 5 lin.

IIead white, with a few grey hairs. Finee and palpi white. Antenne white, anmulated with dark fuscous. Anterior wings greyish-purple, paler on the costa, with the inner margin white, interrupted beyond the mirldle by an obliquely placed fuscous spot, which, though very indistinctly, appears to be continued towards the apex of the wing; on the eosta before the apex are two or three small white spots; cilia greyish-purplc. Posterior wings grey, with paler cilia.

I have only two specimeus taken near Shefficld and in the south of Scotland, in July. I do not feel quite confident that it is distinct from nitidella.

4. semitestacella, Curt. Ent. Mag. i. 191 (1833); Id. B. E. fo. 719 ; Step.; Sta.-parenthesella, \%. g. S. ? Alis anticis ochreis, dorso usque medium niveo, macula saturate ochrea terminato. Exp. al. 6$6 \frac{1}{2}$ lin.

IIcad white, with a few yellowish hairs. Face white. Palpi yellowish. Antenure white, anumlated with dark fuscons. Anterior wings ochreous, with the inner margin white to the middle, where there is a dark ochreous spot, beyond which are only a few whitish scales on the inner margin; cilia rreyish-ochrcous. Posterior wings grey, with paler cilia.

Common among beeches in $\Lambda$ ugust and September.

5. spiniella, Zcll. Isis, 1839, p. 204; Sta. Alis anticis luteobrunneis, dorso albo, macula saturate fusea (sepe ut fascia obliqua obsolete producta) pone medium interrupto, costa albo fuscoque punctata, strigulis duabus ante apicem albidis. Exp. al, 6-6⿳亠丷厂 lin.

IIead whitish. lace and palpi pale yellowish. Antenne whitc, ammulated with dark fuscous. Anterior wings yellowish-broron, with the inner margin white, interrupted by a dark fuscous spot beyond the middle, which can sometimes be traced indistinclly across the wing as an oblique fuscia; the costa is delicately spotted alternately white and fuscous, with two larger whitish spots before the apex; cilia greyishbrown, at the anal angle grey. P'osterior wings grey, with paler cilia.

Occurs in the north of lingrland and Scotland, among mountainash, in August and September. 
6. albistria, IIaw. L. B. 517 (1829); Stcp.; Sta.-fagetella, Zell. $\Lambda$ lis anticis saturate ochreo-brumeis, purpurco-su(jilsis, dorso angusle usque ad medium albo, macula fusea abrupte terminato. Exp. al. $4.1-5$ lin.

IIead, fice, and palpi white (sometimes yellowish). Antemne white, anmulated with dark fuscous. Anterior wings dark ochreous-broun, with more or less of a purplish linge, with the inner maryin narroxly white to the middle, where it is abruptly terminated by a dark fuscons spot; cilia ochreous-brown. Posterior winers grey, with paler cilia.

Very common in hedges in June and July. I have found the larve in the shoots of the sloe in May.

7. conjugella, Zell. Isis, 1839. p. 20 L; Id. L. T. ii. pl. 2. f. 3 ; Sta.-semifusca, Step.? Mlis anticis purpureo-fuscis, dorso albido, macula saturate fusca (sxpe fasciam obliquam formante) pone medium interrupto, macula in medio coste saturate fusca, strigulis duabus coste ante apicem albidis; capillis tutescentibus. Exp. al. 6 lin.

IIead, face, and palpi yelloxish. Antenne white, annulated with fuscous. Anterior wings purplish-fuscous, with the inner margin whitish, interrupted beyond the middle by a dark fuscous spot (sometimes continued obliquely across the wing); nearly opposite this spot, rather nearer the base of the wing, is a dark fuscous spot on the costa, and on the costa towards the apex are two conspicuous whitish spots; cilia purplish-fuscous at the apex, then whitish, and at the anal angle palo grey. Posterior wings pale grey, with paler cilia.

Not scarce among mountain-ash, from the middle of May to the beginning of July.

8. semifusca, Haw. L. B. 517 (1829); Sta.-semipurpurella, Step.-Pruniella, Don. 13. I. ii. pl. 58. 59; Cl.? Alis anticis bruneopurpureis, dorso niveo, macula saturate purpureo-fusea pone medium interrupto, strigulis tribus costa apicem versus albis. Exp. al. 6 lin.

IIead, facc, and palpi white. Antenne white, annulated with black. Anterior wings dark broxenisth-purple, with the inner margin white, interrupted beyond the middle by a dark fuscous-purple spot, which cannot be traced as a fascia across the wing; on the costa are three or four white spots before the apex; cilia at the apex brownish-purple, then white, at the anal angle errey. Posterior wings grey, with palcr cilia.

I have met with this in mixed liedges in August, and also among becches and Clematis Vitalba, but it is not common.

9. mendica, Haw. L. B. 517 (1829).-mendicella, Step.-casiella, Treit.—Pruniella, Zett.; Bjerk.?-Letrapodella, Zell.; 1)up.-Spinosella, Sta. Alis anticis purpureo-yjiscis, basi ochracea, dorso niveo, fascia saturate fusca fere recla pone medium interrupta, punctis nomnullis conspicuis costx albis. Exp. al. $5 \frac{2}{3}$ lin.

Ilead white. Face and palpi yellowish-white. Antennæe whitc, with fuscous annulations. Anterior wings gurplish-grey, at the base ochreous, 
with the inner margin white, interrupted beyond the middle by a dark fuscous nearly straight fascia, which, although indistinet in the miclde of the wing, is again pereptible on the costa, where it is defiucd by a white spot on each side; two or three sinaller white spots are on the costa towards the apex; cilia greyish-purple. Posterior wings grey, with paler cilia.

Very common among sloe-bushes, at the end of May and beginning of June. The larva in the shoots of sloc, carly in May.

10. glaucinella, Zell. Isis, 1839 , p. 205 ; Sta. Alis anticis griseo-cencis, dor'so anguste albido, ad fasciam saturatiorem utrinque repandato, strigulis parvis transversis fuscis; capillis albido-luteis, Lixp. al. 4 lin.

Ifead white, mixed with yale yellowish. Face and palpi whitish. Anteme ycllowish-white, with slightly darker annulations. Anterjor wings groyish-bronze, with the imer margin rekitish, broadest on each side of the nearly perpendicular dark fascia; several swall transecerse finscons spots ean be observed in the patle imer margin; cilia fuscous. l'osterior wings pale grey, with paler cilia.

A scarce species, appearing in Jume and July; has occurred at Camberwell and Beckenham, near London, near Bristol, also in Wales.

11. retinella, 1/cll. Isis, 1839, p. 205; Sta.-ocell'a, Stcp.?Comella, Evers.? $\Lambda$ lis anticis albis, fusco transverse-reticulitis, costam versus fuscescentibus, macula oblique plicre pone medium, maculaque apicem versus fuscis, puncto apicis nigro. Exp. al. 5 lin.

Ilead white, with a few grey hairs. Face and palpi white. Antenna whitish, with pale fuscous amnulitions. Anterior wings white, with numerous transverse fuscous spots, and towards the costa ahmost chtirely suflused with pale fuscous; beyond the middle of the fold is a large fuscous spot, oblignely placed, and anoller. large fuscones spot lies towards the apex of the wing; at the cxtreme apex is a black spot; cilia greyish-fuscous. Posterior wings dark grey, with paler cilia.

Common among birches in June and July.

12. abdominalis, Kell. Isis, 1839. p. 205 ; Sta. ; Lienig? Alis anticis allis, striis duabus e basi, macula obliqua dorsali ponc medium, punctisque sparsis posticis disei luteis, squanis apicis atris. Lxp. al. 4. lin.

IIead, face, and palpi whitc. Antenne whitish, amulated with pale fuscous. Abdomen rufous. Anterior wings vehite, with two ycllowish streaks from the base, one near the imner margin stopping abruptly before the midlle, the other near the costa, less sharply defined and reaching beyoud the middle; beyond the middle of the inner marrin is a yellowish spot, eurving oubwardy, aud several seattered yellowish spots lie in the apical portion of the wing, some black scales are at the rxtreme apex; cilia pale yellowish. l'osterior wings whitish, witl paler cilia.

VOL. III. 
Not uncommon anong junipers, at the end of Junc and beginning of July.

13. dilectella, Zell. I. E. ii. 272 (18.17); Sta. Alis anticis nitidis dilute aureis, dilutissime violaceo-suffusis, dorso an basim albo, striis duabus e basi distinetius aureis, macula transversali dorsali pone modium maculisque duabus costa fuscis, puncto apicis atro. Fxp. al. $4 \frac{\pi}{2}$ lin.

Head, face, and palpi white. Antennx white, annulated with dark fuscous. Abrlomen rufous. Anterior wings shining pale golden, with a frint violet tint; the base of the inner margin is white; two streaks from the basc, one near the inner margin, the other near the costa extendiner to the middle of the wing are more distinetly golden; beyond the middle of the inner margin is a fuscous spot reaching nearly half across the wing, and at the anal angle is a smaller fuscous spot; at litte before the middle of the eosta is a small fuscous spot, and a larger one a little beyond the middle, which almost meets the larger spot from the inner margin; two small fuscous spots lie on the costa immediately before the apical black spot; cilia pale yellowisl-grey. Posterior wings pale grey, with paler cilia.

Very common among juniper-bushes in July. Mr. Logan met with the larva last summer.

14. Andereggiella ( $\mathrm{F}$. v. R.), Dup. L. F. xi. 469. pl. 305. f. 9 (1838); F. v. R. pl. 74. f. 2; Zell.; Sta.-I. V-ella, Haw.; Step. Alis anticis abbis, maculi trausversali quadrata in medio dorsi, postice ad costan oblique producta, fiscia tenui obliqua apicem rersus, striolam in apicem emittente aureo-brunneis. Exp. al. 5 lin.

Ilead, face, and palpi white. Antemie white, ammulated with dark fuscons. Anterior wing white, with an oblong transverse dark goldenbrown spot on the middle of the inner margin, the posterior angle of which is produced obliquely to the costa, where it meets a slender oblique golden-brown fiscia, from which a streak proceeds to the apex of the wing; cilia at the apex golden-brown, at the anal augle pale grey. Posterior wings grey, with paler cilia.

Occurs among wild apple-bushes in July and $\Lambda$ ugust.

15. curvella, Lin. I'. S. 1397 (176]); Step.; Sta.-curva, IIaw. -Comella, Fab.; Trcit.; F. v. R. pl. 15. f. 3 ; Dup.; Zcll. L. W. ii.sparsella, \%ell. Isis, 1839. Alis anticis niveis, fueco-reticulatis, precipue costan versus, maculis parva lorsi ante melium, maculaque majore obliqua dorsi pone medium suturale fuscis, uebula postica costre, maculaque ex angulo anali in apicem desinente fuscis; capillis allis. Tixp. al. $5 \frac{1}{2}$ lin.

IIead, face, and palpi white. Antemae white, ammlated with clark fuscous. Anterior wings white, reticulated with fuscous, especially alomg the costa, with a small dark fiescons spot on the inner margin before the middle, and a larger obliquely-phlacel dark fuscous spot beyond the middle of the inner margin; opposite the latter is a fuscous blotch on 
the costa; a fuscous spot from the anal angle goes partly across the wing, and then terminates in the apex; cilia grey. Posterior wings grey, with paler cilia.

Common among apple and pear trees in June and July.

16. Sorbiella, Treit. I. S. ix. 2. 160 (1533); F. v. R. pl. 15. 1. 2 ; /cll.; Lienig; Sti.; 1)up.? Alis anticis albidis, dorsum versus albis, costam versus dilute arreo-brumeo reticulatis, maculis tribus dorsi (prima ante medium, altera majore obliqua fere costam atlingente pone medium, tertin minore ad angulum analem) anre-fuscis; capillis albidis. Exp. al. 6 lin.

IIcad, fiee, and palpi whitish. Antenne white, annulated with fuscous. Anterior wings yellozish-uhite, whiter on the inuer margin, towards the costa retieulated with pale golden-brown; on the inner margin are three golden-fuscons spots, the first before the middle, the sccond larger and obliquely placed, beyond the midlle, almost reaching to the costa, the third smaller at the anal angle; cilia pale yellowish-grey. l'osterior wings grcy, with paler cilia.

Common in June and July, among (Sorlnes Aucuparia) mountain-ash and (Sorbus dria) the white beam-tree. 'The larva feeds in the leaf-buds of those plants in May.

17. pygmaella, Itïb. 353 (1816); Trcit.; T. v. R. pl. 15. f. 1; Lienig; //cll.; Sta.-semifasciella, Ilaw.; Step. Alis anticis nitidis viridi-albis, dorsum versus dilutioribus, macula recta dorsali ante medium per plicam ad basim ducta, macula obliqua majore pone medium dorsi (costam non altingente) macułaque minorc ad angulum analem dilute aureo-brunneis, Exp. al. 6! lin.

Ifead white. Face inclining to pale bronze. Palpi white. Antennxe white, anmulated with fuscons. Anterior wings shining greenish-white, paler along the imner margin; before the middle of the inner margin is a pale golden-brown spot, perpendicularly plased and venited to the base of the wing by a streat along the fold.; beyoud the micldle of the inner marein is an oblique palc golden-brown spot, reaching more than half across the wing, and at the amal angle is a smaller spot; cilia greenishwhite. Posterior wings pale grey, with paler cilia.

Common among sallows in Jume and July. 'The larva feeds in the young shoots of the sallow in May.

18. Goedartella, Lin. S. N. (10) 5\%1. 291 (1758); Fab.; IIüb. Tin. 133; Haw.; 'Treit.; Step.; Dup.-semiargentella, Don. Alis anticis albis (interdum aureo-sufiusis), fascia obliqua e basi costa, fiscia media ad costam furcata, fasciaquc posticn aurcis; capillis albido-lutcis. Exp. al. 6 lin.

IJead yellowish-white. Fiace and palpi white. Antemnat white, annulated with fuscous. Anterior wings white (sometimes suffused with golden), with an oblique golden faseia from the base of the costa, a golden fascia in the middle fureate on the costa (one arm reaching the 
costa rather before the midlle, the other reaching the costa a little before the apex, and between them are generally a few golden spots on the costa); beyond is another golden fascia, which indeed oceupies the whole of the apex of the wing, except a small white spot on cach margin; cilia pale greyish-brown. I'osterior wings grrey, with paler cilia. (l'he anterior wings are sometimes so much suftused with pale golden that the markings are almost obliterated.)

Common among birches in June and July. The larva feeds under the bark and in the young shoots of the birch, in March and April.

19. literella, IIaw. I. B. 570 (1529); Step.; Sta. Alis anticis albidis, fascia ante medium, fascia media fureata, fascia postiea in apicen desinente aurcis, costam nou altingentibus; capillis albidis. Hxp. al. 5 ? lin.

IIead whitish. Face and palpi white. Antenne white, annulated with fuscous. Anterior wings whitish, with a slender golden faseia from the imer margin, not far from the base, sloping inwards, a furcate fiscia from the middle of the imer margin, neither reaching to the costre, and a third golden fascia from the anal angle, which, after reaching half across the wing, is deflected, and terminates in the apex of the wing; cilia pale ochreous. Posterior wings purplish-grey, with paler cilia.

Very rare; lins been taken in Darenth Wood, in June. In the collection of the British Museum, and in that of Mr. B. Standish.

20. Brockeella, Hüb. Tin. 362 (1816) ; Treit.; Step.; Dup. ; Yell.; Sta.-1.IV-ella, Haw.-Rajella, Lin.?-var. aurivillella, IIaw.; Stcp. Nlis anticis aurco-brunneis, macula basali dorsi, fascia al costam attenuata, ante mediun, macula majore ad anrulum analem, mneulisyne tribus coste niveis; capillis niveis. Var. alis anticis dorso toto niveo, fascia ac prima macula costali confluentibus. Exp. al. $5 !$ lin.

1Tead, face, and palpi white. Antenne white, ammulated with pale fuscous. Anterior wing's shining golden-brown, with a spot at the base on the inner margin, a fascia before the midclle attenuated on the costa, a large spot at the anal angle, and three spots on the costa (the last of which is small and lies immediately before the apex) shining snowy-white; cilia greyish-brown. Postcrior wings grey, with paler cilia. In the variety aurivillella, the inner margin of the anterior wings is entircly white, and the fascia and first costal spot are frequently confluent; intermedinte specimens also occur.

Common among birches in June and July. 'The larva feeds in the young shoots in March and April.

21. arceuthina, Zell. Isis, 1839. p. 205; Sta. Alis anticis nitidis viridi-reneis; capillis (ac thorace) niveis. Exp. al. $4 \frac{1}{2}$ lin.

Head white, Face greenish-bronze. Palpi whitish. Antemne white, ammulated with fuscous. Anterior wings unicolorous shining bromygreen, with paler cilia. Posterior wings pale grey, with paler cilia.

Not scarce among junipers, in May. 
22. praecocella, Zell. Isis, 1839. p. 205; Sta. Alis anticis $n i-$ tidis ochreis, violaceo-suffusis; capillis ditute luteis. Exp. al. 5 lin.

IIead whitish-yellow. Face and palpi pale ochrcous. Antenne whitish, annulated with pale fuscous. Anterior wings shining ochreous, with " slight violet tinge; cilia palcr. Postcrior wiugs rather broad, very pale grey, with paler cilia.

Occurs, not uncommonly, among junipers, in May.

23. aurulentella (/cll.), Sta. Zool. 1S $49 . \Lambda$ p. xl. Alis anticis nitidis ochreis, violncco-suftusis, dorso anguste albo; capillis niveis. Exp. al. 4 lin.

IJead rleite. Face and palpi yellowish-white. Antenne white, with fuscous anmulations. Anterior wings shining-ochrcous, with a slight violet tinge, the inner margin narrowly while; cilia whitish-ochreous. l'osterior wings pearly-whitish, with pale ochreous cilia.

Very common among junipers, in July and August.

21. decimella, Sta. Sup. Cat. p. 10 (1851). Alis anticis albis, striola costix ex basi ad medium, in fisciam obliquam transcunte, striolaque breviore ex basi prope dorsum aureo-brunncis, puncto apicis nigro. Exp. al. 3 lin.

IIcarl, face, and palpi white. Antenno whitish. Anterior wings white, with a golden-brown streak along the costa from the base to a little before the middle of the wing, where it is deflected, and forms an oblique posteriorly-angulated fascia; near the inner margin at the base is another short golden-hrown streak; in the npex of the wing is a small black spot; cilia white, but round the apieal black spot they are golden, with the tips dark fuscous. P'osterior wings pale grey, with paler cilia.

Unique in Mr. Weir's collection; taken on a fence at Camberwell, in June, 1850.

I am by no means certain that it should be referred to this genus, but the structure of the palpi, which remove it from Fila. chista, allow of its being placed in the genus Argyresthin, and the rough head may liave been rendered invisible by the distorted mode in which the insect was pinned.

\section{Genus II. CEDESTIS.}

Gicophora p., Dup. Argyresthia p., Zell.

Capilli hirsuti, epistomio levigato. Antenue alis anterioribus breviores, anticulo basali elongato incrassato, articulis distinctis. Ifaustellum nullum. Palpi labiales breviuscnli, incrassati, pilosuli. Ale longe ciliate, anteriores clongalie, posteriores lanceolate; anteriores : vena ex cellular discoidalis parte postica sex, octove oriuntur, apicalis sim- 
plex; subdorsalis simplex; posteriores: vena apicalis ante apicen exit, infra cam vena simplex, et vente altere dux simplices e venula transversa.

IIead rough, the face smooth. Antenne shorter than the anterior wings, with distinet joints, the basal joint elongate and thickened. Tongue none. Labial palpi rather short, thichened, leairy. Wings with long cilia, the anterior elongate, the posterior lanceolate. In the anterior wings six or eight veins procecd from the hinder portion of the discoidal cell; the apical vein is simple; the subdorsal vein is simple. In the posterior wings the simple apical vein terminates above the apex; below it is a simple vein, and two other simple veins from the transverse vein.

Only two species are known in this genus; they frequent firtrees in the middle of summer; in repose they sit appressed to the surface on which they rest.

1. farinatella ('/cll.), Dup. L. F. xi. 473. pl. 305. f. 11 (1838); F. V. R. pl. 74. f. 4; Zell.; Sta.-sulfasciella, Step.? Alis anticis albilo-griseis, fusco-pulveratis, fascia ante medium, nebulaque postica fuscis. Exp. al. $5 \frac{1}{3}$ lin.

Head whitish-grey, with some darker hairs in front. Face and palpi grey. Antenne white, aunulated with fuscous. Anterior wiugs whitishgrey, much irrorated with fuscous, with a fuscons fascia before the midile, followed by a whitish fascia of the undusted ground-colour; the remainder of the wing is nearly entircly, fuscous, except a whitish spot on each margin before the apex; cilin greyish-white. Posterior wings rather broad, pale grey, with paler cilia.

Common among fir-trees in June and July. Illustrations of the transformations of this species are promised in the forthcoming number of Mr. I,ogan's 'Illustrations of Scottish Lepidoptera.'

2. Gysselinella (Kuhl.), Dup. I. T'. xi. 4.61. pl. 305. f. 4 (1838). -Gysseleniella, F. v. R. pl. 74.f. 3; Zell.; Licnig; Sta. Alis anticis albido-griseis, grisco-pulveratis, fascin lata obsoleta basali, fascia distinctiore ante medium, nebulisque posticis dilule aureo-brumeis. Exp. al. $5 \frac{\pi}{2} \operatorname{lin}$.

IIead whitish-grey. Face and palpi white. Antenne whitish, with palc fuscous ammulations. Anterior wings whitish-grey, dusted with grey, with a rather indistinct pale golden-brown fascia near the base, and another more defined just before the middle, and some pale goldenbrown blotches beyond the middle and at the ajex; cilia greyish-fuscous. Posterior wings pale grcy, with paler cilia.

Occurs among fir-trees in June and July. The only British specimen I have seen is in Mr. Allis's collection; it was taken by NIr. Weaver. 


\section{Genus III. OCNEROSTOMA.}

Ocnenostoma, Zell. L. E. ii. 298 (18.17). Argyresthia p., Zell. Isis, 1839.

Caput comosum, cpistomio lavi. Antennac alis anterioribus breviores, sctacea, articulo basali crassiusculo. Haustellum brevissimum. Palpi brevissimi, Unlbilliformes. Ala anteriores acuminata, posteriores lanceolatit; anteriores : cellula discoidalis acuninata, postice imperfecta, venas quinque cmittente; subdorsalis simplex; posteriores: vena infra apicalem furcala; mediana furcata.

Ilead rough; the face smooth. Antennic shorter than the anterior wings, sctirecous; the basal joint rather thick. Tongue hardly perceptible. P'alpi very short, bulbilliform. Autcrior wings acuminate; posterior wings lanceolate. In the anterior wings the acuminate discoidal cell is posteriorly imperfect and emits five veins; the subdorsal vein is simple; in the posterior wings there is a furcate vein below the apical vein and the median vein is furcate.

Only one species is known in this genus; it appears in carly spring and again in summer, but it is doubtful whether it be double-brooded, the spring specimens having probably hybernated; it reposes appressed to the surface on which it rests.

1. piniariella, Zcll. I. T. ii. 299 (18.7) ; Sta.—argentella, Zell.; Lienig,-galaclitella, Evers.? Alis anticis nitidis, argenteo-griscis; capillis griseis; antennis totis fuscis. Exp. al, $5 \frac{1}{3}$ lin.

Ilead pale grey. Fice and palpi dark grey. Antenne unicolorous fuscous. Anterior wings unicolorous, shining silvery-grey, with paler cilia. Posterior wings pale grey, with paler cilia.

Common among fir-trees in April, June, and July.

\section{Genus IV. ZELI.ERIA.}

Zelieria, Sta. Cat, p. 22 (1849).

Capilli hirsui, cpistomio lievigato. Ocelli nulli. Antennx alis anterioribus breviores, crassiusculæ. Ifanstcllum nudum. Palpi labiales porrecti, vel fere adscendentes, brevinsculi, squamis incrassati, articulo tertio obtuso. Ala lougo ciliale, anteriores subfalcate, posteriores lanceolatie; anteriores: vena apicalis simplex ante apicem exit, infra cam vene quinque, quarum penultima ct antepenultima ex eodem puncto prodeunt; subdorsalis simplex: submediane apex incrassatus; posteriores: vent apicalis longe furcata supra et infra apicem exit; mediana trifida.

Ilead rough; the face smooth. Ocelli none. Antenne shorter than the anterior wings, rather thick. Tongue naked. Labial palpi por- 
rected, or almost ascending, ruther short, thickenet with scal's; the terminal joint blunt. Wings with long cilia, the anterior subfilcate, the posterior lnnecolate. In the anterior wings, the simple apical vein runs into the costa before the apex; below it are five veins, of which the jenultimate and the antepenultimate proceed from the sime point; the subdorsal vein is furcate; the apex of the submedian vein is thickened; in the posterior wings the apical vein has a long fork terminating above and below the apex; the median vein is trifid.

Only three species are known in this genns, if indeed there be more than than two, as it is not improbable that hepariella and in. signipennelle may ultimately not prove specifically distinct. The larve of none of them are known, though (to my slame be it said) I have myself bred hepariella, but have no recollection whatever of the larva; in the cage in which I bred it was an ash-leaf, that had evidently been caten; it emerged from its thick white cocoon on the 27 th of July, 1852*.

The first two species appear at the end of summer and autumn, and, hybernating, are occasionally met with in the spring; fuscicepennella, taken by Mr. Logan among I accinium Myrtillus, on the P'ntlands, in September, may probably likewise liybernate.

1. hepariella (Mann), Sta. Cat. p. 22 (1819).-gryplipennella, IIaw.? Alis anticis rufo-ochraccis, postice fuscescentibus, punclo obsoleto supra angulum analem fusco; capillis luteis. Exp. al. $5_{2}^{1}$ lin.

Ilead, face, and palpi luteous. Antemne fuscous, with paler anmulations. Abdomen above grey, beneath reddish-orange, the sides white. Anterior wings rufous-ochrcous, posteriorly somewhat fuscous, with an appearance of a small darker spot above the anal angle; cilia rufousochrcous at the apex, grey at the anal angle. Posterior wings dark grey, with grey cilia.

Oecasionally met with in the south of England, from August, to October, and again in spring, but nowhere common.

2. insignipennella, Sta. Cat. p. 22 (18.19). Alis anticis rufoochreis (dorsun interdum dilutiore), postice saturatioribus, nebula fus-

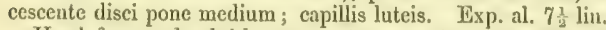

IIead, face, and palpi luteous. Antcunce fuscous, with paler ammulations. Anterior wings rufons-ochreous (frequently paler towards the inner margin), postcriorly dark, with an obscure fuscous bloteh on the dise beyond the middle; cilia rufous-ochreous at the apex, grey at the mal angle. Posterior wings dark grey, with grey cilia.

Appears in autumn and again in spring; has occurred at Mickleham and Dartford IIeath.

3. fasciapennella (Logan), Sta. Cat. p. 22 (1849). Alis anticis dilute griseis, obscuriore nebulosis, atomis nigris in scriebus quattor

* The day on which Professor Zeller finished his visit to England. 
longitudinalibus dispositis, fascia obliqua ante medium fusca; capillis griseis. Lxp. al. 8-9 lin.

Head, face, and palpi light grey, mixed with dark grey. Antenne grey, with paler anmulations. Abdomen above grey, benenth silverywhite, Anterior wings pale grey, clouded with dark grey, with four longitudinal rows of black sjots, the first on the costa terminating in the middle of the wing, the second near the costa terminating a little before the apex of the wing, the third and fourth run one on each side of the fold to the anal angle; before the middle of the wing is an oblique (nearest to the base on the inmer margin) eloudy dark fascia; before the apex is a white costal spot, followed by a black one; cilia grey, intermixed with white; the extreme apex dark fuscous. Posterior wings pale grey, with grey cilia.

Oceurs on the Pentlands, among Taccinium MIyrtillus, in September and October.

\section{Family VIII. GRACILARIIDE.}

Capilli levigati, vel hirsuti. Antenne alarum anteriorum longitudine. aquantes. Palpi maxillares longiusculi, filiformes. Palpi labiales tenues, articulo tertio acnminato. $\Lambda$ lx longe ciliatie, anteriores elongatre, posteriores lanceolatx.

Hend smooth or rough. Antenne as long as the anterior wings. AIaxillary palpi rather long, filiform. Isabial palpi slender; the third joint acuminate. Wings with long cilia; the anterior elongate; the posterior lanceolate.

In direct opposition to the mode of sitting of the insects of the principal genus of the preceding family, which may be said to sit on their heals, the species of this family sit on their tails, having the head considerably raised from the surface on which they repose, the anterior pair of legs being put forward, the middle pair rather stretched out sideways, and the posterior pair placed close beside the abdomen; by this peculiarity any species of this family may be immediately recognized if seen at rest.

The three genera of this family may be at once distinguished as follows :-

a. Head smooth.

b. Sccond joint of labial palpi with no projecting tuft, 1. GraclIAARIA.

$b$ b. Sccond joint of the labial palpi with a projecting tuft. 2, CoRISCIUM.

$a \alpha$. Head rough. 3. OnNix.

VoL. III.

2 c 


\section{Genus I. GRACILARIA.}

Gracularia, Zcll. Isis, 1839 . p. 208. Gracillaria, Dup. Cat. Grucillaria p., IIaw.; Curt.; Dup. L. F. xi. Omix p., Treit.; 'Lett. Gracillaria p. et Enspilapteryx, Step.

Caput superne ac in fronte levigalum. Occlli nulli. Antenna alarum auteriorum longitudine aequantes, tenucs, articulo basali elongato, incrassato. IIaustellum squamatum. Palpi maxillares longiusculi, filiformes. Palpi labiales tenues, adscendentes, cylindrici, articulo sceundo squamis appressis, non fusciculato, articulo tertio acuminato. $\Lambda$ lie longe ciliatre, anteriores clongate, posteriores lanceolatie; anteriores: vena subcostalis basim versus intermuta, c collulic discoidalis parte postica venx novem oriuntur, quatuor in costam, quinque in maryinetu posticum cxcuntibus; subdorsalis simplex; posteriores: vena apicalis ante apiecm exit, infra cam vena furcata, vena mediana trifida.

Head above and in front smooth. Ocelli none. Antennx as long as the anterior wings, slender; the basal joint elongate, thickened. 'J'ongue clothes with scales. Maxillary palpi ratler long, filiform. Labial palpi stender, ascending; cylindrical; the second joint with appressed seales, not tufted; the terminal joint pointed. Wings with long cilia, the anterior clongate, the posterior lanceolate. In the anterior wings the subcostal vein is interupted towards the base; from the hinder portion of the discoidal eell nine veins procecel, of which four go into the costa, and five into the hinder margin; the subdorsal vein is sinple; in the posterior wings the apical vein terminates above the apex, below it is a furcate vein; the median vein is trific.

In the small suecies of this genus, the maxillary palpi are less developed, and the labial palpi are almost drooping.

The species of this genus are elegant in form and frequently gaily coloured, or prettily mottled. Some species are doublebrooded, the autumnal brood generally hybernating, and being met with in wasted condition in the spring; they feed upon low plants, as well as upon slirubs and trees. 'The larva have only fourteen feet; when young they mine the leaves, but at a later period of growth many of the species construct concs, by rolling up a portion of a leal; they devour the inner portion of these cones, which thus become discoloured and are easily observed.

The species of the genus may be arranged in the following table :-

a. Large specics.

6. Anterior wings wilh a distinct paler trigonal mark on the costa. Species 1, 2.

$b \quad b$. Anterior wings with a more or Icss distinctly margined, but hardly paler trigonal mark on the costa. Species 3-8. 
$b b$ b. Anterior wings with no trigonal mark on the costa. Sp. 9, 10 . a $a$. Small species.

c. Anterior wings with fasciaform markings. Species 11.

c c. Anterior wings with pale spots on the costa and imer margin. Species 12-14.

c c c. Anterior wings with numerous silvery spots. Species 15,16 .

1. Swederella, Schalén ('T'hun.), M. N. A. U. 6. 80 (1758).-

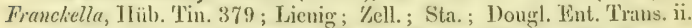
n. s. pl. xiv. f. 1.-hilaripennella, Treit.; 1)up.-Thumberyella, Step.Thenberyii, IIaw.? $\Lambda$ lis anticis rufis, violacco-nitidis, dorso prope basim, trianguloque costali plicam superantc, ad costam apicem versus producto, flavidis, Exp. al, 6글 lin.

II and reddish-brown. Thec pale yellow. Palpi pale yellow, with a darker ring before the apex. Antemne pale yellow, with brown ammulations. Anterior wings bright reddish, with a violet gloss; at the base alour the inner maryin is a pale yellow streak; the costal triangle is pale ycllow, it reaches nearly across the wing and extends along the costa nearly to the apex; at the anal angle are a few pale yellow seales; cilia recldish at the apex, more ycllowish towards the anal angle. P'osterior wings shining grey, with paler cilia.

Common among oaks in Mity, June, and August. The larva is very common in cones on oak-leaves in September and October, and probably there is another brood in July.

2. stigmatella, Fal. G. I. ii. 295. 34 (1791); Sclr.; Step.; Lienig; Zell.; Sta.; Dougl. Ent. Trans. ii. n, s. 124, pl, xiv. f. 2.-

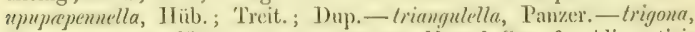
IIaw.-ochracea, IIaw.; Step.-purpurea, Haw.? Step.? Alis anticis rufo-brumeis, triangulo costali albido, plicam tangente, apsice postice producto. Exp: al. 7 lin.

Head and face reddish-grey. Palpi resldish-brown, the tips yellowish. Antenne pale yellowish, with brown ammutations. Anterior wings reddish-brown, darkest along the margins of the costal triangle; the costal triangle is whitish-vellow with a few seatteresl dark scales, it reaches to the fold, where its apex is produced a lithe in the direction of the linder maryin; cilia at the apex ruious, towards the anal angle grey. Posterior wings grey, with paler cilia.

Coumon among sallows; appears in the antumn, but then rarely met with; most frecuently found in spring after lybernation. The litrva may he found in $\Lambda$ ugust and September, in cones on the leaves of sallows, willows, and poplars.

3. stramineella, Sta. Fut. Trans, i. n. s. 121. pl. xiv. f. 9 (1851). $\Lambda$ lis anticis stramincis, punctis sparsis rufo-brumeis, duobus distinctioribus quasi nargines trianguli costalis, non dilutioris, formantibus. Exp. al. $6 \frac{1}{5}$ lin.

Ilead and face pale straw-ycllow. Palpi pale straw-yellow; the ter- 
minal joint rufous-brown before the apex. Antenne pale yellowish, with brown annulations. Anterior wings pale stran-colour, with numerous reddish-brown spots, of which the two most conspicuous form, as it were, the margins of the usual costal triangle, which however is not paler than the rest of the wing; cilia of the hinder margin strawcolour, mixed with redelish, of the imner margin grey. Posterior wings shining grey, with grey cilia.

I have specimens taken in Torwood, in September. There are also specimens in the collection of Mr. Mllis, and in that of the British Museum.

4. hemidactylella, IIüb. Tin. 276 (1812) ; Dup.; Zell.; Sta.; W. V.? Fab.? Step.? Alis anticis dilute oclereis rufo-ochrco mixtis, triangulo costali distincto plieam tangente dilute ochreo, punctis costee parvis fuscis; capitc cum palpis rufo-ochreo, horum apice albido. Lxp. al. 6 lin.

IIead and face pale ochreons, mixed with reddish-ochreous. Palpi reddish-ochreous, the extreme tip whitish. Antenna pale fuscous, with whitish annulations. Anterior wings pale ochreous, inarbled with reddish-ochreous, with a distinct costal triangle of the paler groundcolour, not crossing the fold; on the costa are some small fuscous spots ; cilia pale ochreous, mixed with reddish-ochrcous. Posterior wings grey, with paler cilia.

A scarce species; occurs at Whittlebury, in September.

5. falconipennella, IIüb. Tir. 317 (1816); Trcit.; Zcll.; Sta. Alis anticis rwfo-brunneis, triangulo costali indistincto dilutiore, punctis salurale fuscis costce albidx dor'sique; capite rufo-brunnco; palpis dilutioribus, apice articuli sccundi, amnulo ante apicem albidum articuli tertii saturatioribus. Exp. al. $6 \frac{x}{6}$ lin.

Ilead and face reddish-brown. P'ilpi pale reddish-brown, the end of the second joint and a broad ring before the whitish tip of the terminal joint darker. Antcmux fuscous, with whitish anuulations. Anterior wings redlisk-brown, with a faintly indicated paler costal triangle and some durk fuscous spots along the whitish costa, and along the inner margin; cilia of the hinder margin redelish-brown, of the inner margin grey. Posterior wings grey, with paler cilia.

$\Lambda$ scarce species; appearing in autumn. Specimens are in the collections of Mr. Bedell, Mr. Shepherd, and the British Muscum.

6. semifascia, Ilaw. L. B. 528 (1829); Step.; Sta. Lint. Trans. i. n. s. pl. xiv. f. 13.-picipennella, Zell. $\Lambda$ lis anticis dilute luteis, rufo-brunneo variergatis (vel omnino rufo-brunncis), strigula obliqua ante medium dilute lutea, plicam tangente ct super can currente, punctis numerosis costre saturate fuscis. Exp. al. 5 lin.

IIead and face pale yellowish, mixed with reddish-brown. Palpi palc ycllowish; terminal joint dark fuscous, the tip pale yellowish. Anteune dark fuscous, with whitish annulations. Anterior wings pale yellowish, irregularly varied with reddish-brown (or almost entircly 
reddish-brown), with an oblique pale yellowish streak from the costa before the middle, it does not reach beyond the fold, and is deflected along $i t$; on the costa are several small dark fuscous or black spots; cilia of the hinder margin reddish- or brownish-grey, of the inner margin grey. Posterior wings grey, with paler cilia.

Appears in September and October; has occurred at Micklelam, at Whittlebury, and near Bristol.

7. populetorum, Zell. Isis, 1839.p. 209 ; Sta. Ent. Trans. i. n. s. pl. xiv. f. 11.-violacea, Haw.? Step.? Alis anticis dilute ochreis, purpurasecnte tiuctis, nebulis subfasciatis obscurioribus, punctis numerosis costre nigris, -uno in medio majore, punctis tribus fuscis disci. Exp. al. 5 冬 lin.

Ilead and face dirty-whitish, mixed with fuscous. Palpi dirty white, the end of the second joint and a broad ring on the third fuscous. Autemne fuscous, with whitish annulations. Anterior wings pale ochreous, tinged (more or less) with purple, with some nebulous fasciaform darker markings; on the costa are several small black spots, one in the middle, being larger, is conspicuous; above the fold at nearly regular intervals are three fuscous spots; cilia greyish-fuscous. Posterior wings grey, with greyish-fuscous cilia.

Appears in September among poplar-trees; hitherto scarce. The larva feeds (according to lischer) on birch and aspen.

8. elongella, Linn. F. S. 1436 (1761) ; Fab.: Step.; Licnig; 'Zell.; Sta.-pnenctella, Linn.; Fab.-signipennella, Hüb. Tin. 196 ; Treit.; Dup.-lemidaclyla, IIaw.-roscipennella, Trcit.; Dup.; Hüb. ? -inconstans, Sta. Ent. Trans. i. 1. s.-pl. xiv. f. 1-7. Alis anticis rufoochrcis, triangulo costali truncato, vix dilutiore, brunneo-rufo marginato, nebulis posticis fuscis. Lixp. al. $6 \frac{7}{2}-7 \frac{2}{2}$ lin.

IIcad reddish-ochreous. Face pale ochrcons. Palpi pale ochreous; the terminal joint redilish-ochrcous. Antenux fuscous, annulated with whitish. Anterior wings reddish-ochrcous, irregularly varied with darker makkings, in which a truncrte costal triangle, hardly pater than the ground-colour, may generally be lraced; it has sometimes a dark fuscons spot on each side above the fold; cilia of the hinder margin reddish-ochreons, of the inner margin grey. l'osterior wings grey, with paler cilia.

This extremely variable species is not scarec in many localitics; taken in plenty by Mr. Cooke, of Warrington, in June. Mr. Shield found the larva in rolled-up alder-leaves near 1)ublin, last August. According to Lienig the larva also feeds in May.

9. tringipennella, Kell. Isis, 1839 p. 209; Sta.-fringilella, Dup. L. F. Sup. pl. 75. f. 11.-roscipennis, IIaw.?-roscipennella, Step.? Alis anticis dilute ochreis, costam versus livide grisesecntibus, seu osseis, seriebus tribus longitudinalibus punctorum nigrorum. Lxp. al. $6 \frac{1}{2}$ lin.

Itead pale ochrcous. Face greyish-fuscous. Palpi grevish-ochreous; 
terminal joint fuscous, Antenne greyish-ochrcous. Anterior wings pale octureous, along the costa livid greyish or pale white, with threc longitudinal rows of black spots, one near the costa, one on the dise, and one on the fold; the latier is frequently obliterated, or the number of spots does not execed two or threc; cilia palc ochrcous. P'osterior wings grey, with paler cilia.

Not uncommon in meadors among Plantago lanecolata, in May and August. The larva, discovered by Mr. Shicld, mines the upper surface of the leaves of the Plantago lanceolata; one brood begins to feed in Oetober, changing to pupa in May; the other brood feeds up in June and July.

10. Syringella, Fab. L. S. iii. 2. 328. 177 (1791); Schr.; Bouché; Step.; Zell.; Dup.; Sta,-anastomosis, Ilaw.; Curt. B. I.. fo. 479.-ardecepenuella, Treit.; Dup. Alis anticis albido-lutcis, basi, macula dorsali, fasciis tribus obliquis (prima ac secunda angulatis, sceunda tertiaque connexis) apiceque lete brunacis. Exp. al, 6 lin.

Head greyish-ochreous. Face whitish. Palpi whitish; terminal joint with a narrow fuscous ring near the base, and a broader one before the apex. Antenne fuscous, ammlated with white. Anterior wings yellowish-white, with the base dark fuscons, and with several brown markings; the first, a blotch on the inner margin not far from the base, the second, an oblique fascia angulated in the middle, the third is a paler angulated fascia comeeted in the middle with another oblique fascia, which terminates in the anal angle; the apical portion of the wing is cutirely brownish-fuscous, except two whitish spots on the costa; cilia of the hindex margin whitish, externally with two dark lines; of the inner margin grey. l'osterior wings grey, with paler cilia.

In abundant species in gardens, among lilaes, in Nay and July. The larva, when young, mines the leaves of the lilac, gregariously, several larva being in the same mine; when nearly fullgrown, they frequently ccase mining, and roll up the leaves, but many remain as mincrs throughout the period of their existence in the larva state. At times they become real pests from their numbers, disfiguring the lilac-bushes by turning the leaves whitishbrown; the best way to thin their numbers is to pluck the leaves whilst the young larva are mining gregariously. 'The larva may be met with in June and September; they feed on ash and privet, as well as on the lilac. The young mining larva have the three pair of ventral and two anal prolegs, as in the other larvo of this genus, but to see them requires a good microscope.

11. omissella (1)ougl.), Sta. \%ool, 1848. p. 2163 ; Id. Fut. Trans. i. n. s. pl. 15 f. 1. Alis anticis fuscescente-yriseis, vel ochrcis, strigis quinque costa (ultima in apice) maculisque duabus dorsi (priorc oblonga basali, altera in medio) albis, Exp. al. 4 lin. 
IIead and face whitish. Palpi white, the end of the sceond joint and a ring before the apex of the terminal joint dark fuscous. Antenne fuscous. Anterior wings greyish-fuscous or ochreous, with five while streaks from the costa, the first four oblique and nearly at equal distances, the fifth in the extreme apex ruming ont into the hinder margin; along the base of the inner margin is a white blotch, which almost meets the first costal streak, and below the apex of the second costal streak is a small white spot on the middle of the inner margin; cilia of the apex whitish, with a dark outer line, of the inucr margin grey. Postcrior wings grey, with palcr cilia.

Common at Dirtford IIeath, at the end of July, among Artemisia vulgaris. The larva mines the leaves of that plant, not contorting them, but giving them an inflated appearance, at the end of June and beginning of July, and again in the autumn. A brood of the perfect insect probably appears in May.

12. phasianipennella, Hüb. 321 (1816); Id. Larra?; Trcit.; 7cll.; Sta. Alis anticis nitidis brunncis, maculis duabus dorsi, tribus coste (prima obliqua ante, secunda curvata pone medium, tertia obsoleta ante apicem) albidis (interdum dilute brunncis) fusco-marginatis. Exp. al. 5 lin.

llead and face brown. Palpi brown, the base and tip of the terminal joint paler. Antenne brown. Anterior wings shiming brown, with two whitish spots on the inner margin (onc near the base and onc in the midelle), and three on the costa (the first oblique before the middle, the second curved posteriorly beyond the middle, the third very indistinct just before the apex); these spots are rarely distinet, and at times hardly distinguishable except by their dark margins; cilia brown. P'osterior wings grey, with paler cilia.

$\Lambda$ ppears in September and October, among Polygonn IIydropiper. Taken by Mr. Weaver in Scotland, and by Mr. Boyd in the New Forest. The larva feeds in August and September on the leaves of the Polygonnm IIydropiper; it cuts a strip from the side of a leaf, and rolls it up, taking care not to separate it from the leaf; this rolled-up portion of leaf is generally placed perpendicularly to the lower surface of the leaf; the larva feeds within it, and when its provisions fall short, procecels to treat another leaf in a similar mamner; when full-fed it spins a fine white cocoon within the rolled picee of leaf. (The only larva known to feed in a similar manner is that mentioned by liéumur as fecting in September on the leaves of the sorrel, but this has not been met with by any subsequent writer, and the species which it produces is unknown to us.)

13. auroguttella, Step. II. iv. 274 (1834); Sta.; Dougl. Ent. Trans. ii. n. s. 124. pl. 14. f. 3.-lacertella, Zell.-stipella, Ilaw.?- 
plumbella, Dup,? Alis anticis salurate aneo-griscis, maculis quatuor anreis, prima dorsi basali, sccunda ante medium prope costnm, tertia dorsi ante angulum aualem, quarta coste ante apicem. Txp. al. 4-4! lin.

Heal and face shining bronzy-grey. Palpi brown-grey, the extreme tip whitc. Antenne dark fuscous, with the tip white. Anterior wings darl bronzy-yrey, with four ummargined golden yellow spots, one at the base on the inner maryin, a second near the costa before the midrle, a third on the imer margin before the anal angle, and a fourth on the costa before the apex; cilia greyish-fuscous. l'osterior wings fuscous, with grey cilia.

Common in May, and again in July and August, among IIypericum. 'The Jarva fects on several species of IIypericum (principally perforatum), in Jume, and in September and October; when very young it mines the leaves, giving them a slight pucker; it afterwards rolls the leaves up into cones, of which it eats the immer substance, whereby the cones, which are at first green, become whitish or brownish; when full-fed, it rolls up a short leaf longitudinally, and therein spins its cocoon, and assumes the pupa state.

14. quadruplella, Zcll. Isis, 1839. p. 209 ; Sta. Ent. Trans. i. n. s. pl. 15. f. 5.-aurogullella, Step. Alis anticis nilidis lutescente-fuscis, maculis quatnor sulplureis, fusco-marginatis, prima dorsi prope basin triangulari, secunda coste ante medium obliqua, tenui, plicam fere tangente, tertia dorsi pone medium triangulari, quarta costa ante apicem brevi. Exp. al. $4 \frac{1}{2}$ lin.

Head yellowish-brown. Face paler. Palpi yellowish-brown; the base and apex of the terminal joint whitish. Antenue fuscous, with paler anuulations. Anterior wings rather shining yellowish-brown, with four sulpluer-coloured dark margined spots; the first on the inner margin near the base, rather triangular, the second on the costa before the middle, obliquely placed and slender, reaching nearly to the fold, the third triangular on the inner margin beyond the middle, and the fourth rather short on the costa before the apex; eilia of the apex fuscous, of the inner margin gaey. Posterior wings grey, with paler cilia.

$\Lambda$ single specimen is in the collection of the British Museum, being that formerly in the collection of the late Mr. Stephens, who took it at Ripley, in June, 1827. ('I'wenty-seven years ago, and still unique !) *

15. Ononidis, Zell. Isis, 1839. p. 209 ; Sta. Ent. Trans. i. n. s. pl. 15. f. 7.-Ononiella, Dup.-moniliella, T'engstr.-argentipnenctella,

* Since writing the abore, haring had an opportunity of comparing this specimen with some brightly-markel specimens of phasiznipennella, I am of opinion that quadruple/le is not a distinct species, but merely a strongly-marked variety of plicesianipennelle. 
Sta. Alis anticis saturate brunneis, punclis novem (uno prope dorsun, tribus dorsi, quatuor costx, uno apicis) argenteis, nigro-marrinatis. Exp. al. 4 lin.

Head brown. Face silvery. Palpi white. Antennx brown, annulated with white. Anterior wings dark brown, with nine silvery spols, margined with black; one is near the inner marrin towards the base, three are on the imner matrgin, four on the costa, and one in the apex of the wing; cilia brown. Posterior wings greyish-brown, with paler cilia.

Occurs at Pembury among Genista tinctoria, and near Mickleham, in June, July, and Augrust. The larva mines the leaves of Ononis spinosa in April and May.

16. imperialella, Mamn. L. E. ii. 365. Amm. (1817); Sta. Alis anticis aureis, fascia abbreviata prope basim oblicjua, strigis tribus costar, maculis duabus dorsi (cum strigis prima et secunda coste fere in fiscias conncxis) maculaque minore ante apiem argenteis. Lxp. al. 3? lin.

1lead yellowish. Face and palpi suowy-white. Antemse pale grey. Anterior wings shining-golden, with an oblique abbreviated silvery fascia near the base, and beyond are three silvery streaks, from the custa, of which the third reaches to the imer margin ; two small silvery spots lic on the inner margin opposite the apices of the first and second costal streaks; a small silvery spot lies immediately before the apex of the wing; cilia of the hinder margin whitish with two dark fuscons lines, of the inner margin grey. P'osterior wing's pale grey, with paler cilia.

Taken by Mr. Dale at Glanville's Wootton, in May, 18 1.0. A specimen is in Mr. Shepherd's collection.

\section{Genus II. CORISCIUM.}

Conrscrum, Zell. Isis, 1839. p. 210 ; Dup. Cat. Trichotripis p., IIüb. Gracillaria p., Ilaw.; Step. Elachista p., Dup. L. I. xi.

Caput superne ac in fronte lexigalum. Ocelli nulli. Antemue alas anteriores longitudine equantes, tenues, articulo basali clongato, incrassato. If́ustellum mediocre, nuclum, Palpi maxillares longiusculi, filiformes. Palpi labiales temues, adscendentes, articulo spcundo infia fersciculo pilonm, tertio tenui acuminato. Whe longe? ciliate, anteriores elongate, posteriores lanecolate; nnteriores: veua subcostalis basim versus interrupta ; cellula discoidalis obtusa postice venas novem emittit; vena subdorsalis simplex; posteriores: vena apicalis ante apicem exit, infra eam vena furenta; vena mediana trifida.

Ilead above and in front smooth. Occli none. Antema as long as the anterior wings, slender, the basal joint elongate, thickened. 'Tunguc VOL. III. 
of moderate length, naked. Maxillary palpi rather long, filiform. Labial palpi slender, ascending, the second joint beneath veith a tuft of hairs, the terminal joint slender, pointed. Wings with long cilia, the anterior elongate, the posterior lanceolate. In the anterior wings the subeostal vein is interrupted towards the base; the discoidal cell is obtuse, and emits nine veins posteriorly (in C. Brongniardellum the discoidal cell is acule, and cmits eight verins posteriorly); the subdorsal vein is simple; in the posterior wings the apical vein terminates above the apex, below it is a furcate vein; the median vein is trifid.

The species of this genus, three in number, resemble the $G$ racilaria in habits. The larvæ mine or roll up leaves.

The genus may be thus subdivided:-

a. With a hook in the cilia of tho anterior wings. Species 1. a a. With no hook in the cilia of the anterior wings. Species 2, 3.

1. Brongniardellum, Fab. E. S. Sup. 496. 83 (1798).-substriga, Inaw.; Stcp.-Curtisella, Dup. L. F. xi. pl. 309. f. d.-quercetellum, '/ell. Alis anticis grisco-brumneis, strigulis quatuor obliquis costre albidis, introrsum fusco-marginatis, prima cum strigula dorsi in fasciam angulatam connexa, strigula altcra albida in medio dorsi, squamis albiclis fuscisque ad angulum analem; cilis apicis in condulam nigram produclis. Exp. al. $4 \frac{1}{g}$ lin.

Head greyish-brown. Face grey. Palpi whitish; terminal joint fuscous. Antenne dark fuscous, anuulated with whitish. Anterior wings greyish-brown, with four oblique whitish streaks from the eosta, marrined towards the base with dark fuscous; the first not far from the base of the wing meets a short whitish streak from the inner margin, forming with it an angulated faseia; on the mirllle of the inner margin is another short whitish streak, dark-marrined towarls its apex; at the anal angle are a few whitish seales, followed by some fuscons scales; cilia of the hinder margin whitish, with a dark line extcmally, and a black hook from the apex; cilia of the imner margin grey. l'osterior wings fuscous, with grey cilia.

Not uncommon in many places among o.2ks, in $\Lambda$ pril, June,

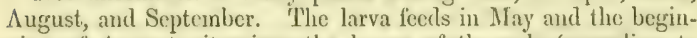
ning of August; it mines the leaves of the oak (according to Réaumur), mining when young, several in one leaf, in galleries, afterwards forming a common blotel of considerable size.

2. cuculipennellum, Hïb. Tarve, iii.; 'Treit.; Evers.; Irïb. Tin. 192 ?-cineren, Haw.; Step.-almedella, 1)up. I. F. xi. pl. 308. f. 1 ; \%ell. L. L. ii.-Ligustrinella, Zcll. Isis, 1838, 1839. Nlis anticis albidis fusco-mixtis, fasciis lribus obliquis, prima prope basim interrupta, secunda ante, tertia pone medium plicam tangente, maculisque posticis saturate fuscis. Hxp. al. 6 lin.

IIeal pale grey, mixed with fuscous. Face whitish. Palpi whitish; terminal joint dark fuscous. Anterior wings pale grey, or whitish, 
inixed with fuscons, with three oblique dark fuscous fuscia, which are nearest the base on the costa, the first near the base sometimes interrupted, the second before the middle, the third a little beyond the midalle reaching only to the fold; beyond are several dark fuscons spots; cilia of the hinder margin pale erey, varied with dark fuscous, of the inner margin pale fuscous. l'osterior wings grey, with paler cilia.

Appears in September and Octol)er, and hybernated specimens occur in the spring; not uncommon at Whittebury, also occurs at 1)artford lleath. 'The larva feeds on the privet in August (according to IIiibner), rolling up the lenves into cones.

3. sulphurellum, IIaw. L. B3. 564 (1829); Step.?-lencapennella, Step,-citrinella, F. v. R. pl. 70. f. 2; \%ell. Alis anticis dilute sutphureis, atomis numerosis sparsis fuscis, interdum in maculas confluentibus. Exp. al. 6-7 lin.

Hearl, face, and palpi pale sulphur. Antenue fuscous, ammulated with whitish. Anterior wings pale snlpher, intermixed with numerous dark fuscous atoms, which are sometimes confluent, and form dark blotches; cilia of the hinder margin pale sulphur, of the inner margin fuscous. Postcrior wings dark grey, with fuscous cilia.

Not uncommon in the autumn in the New Forest, and at Whittlebury; lybernated specimens oceur in the spring.

\section{Genus III. ORNIX.}

Onnrx, Zell. Isis, 1839. p. 210; Dup. Cat. Trichotripis p., Hüb. Ornix p., Treit.

Capilli sujerme comosi, in fronte decumbentes. Ocelli nulli. Antemse alas anteriores longitudiue avquantes, tenues, articulo basali clongato, incrassato. Haustellum nudum. Palpi maxillares longiusculi, filiformes. P’alyi labiales tenues, subpenduli, eylindrici, articulo secundo squamis appressis, articulo tertio acuminato. $\Lambda$ læ longe ciliate, anteriores oblongo-ovate, posteriores lanceolatie; anteriores: c cellula discoidalis parte postica venae septem oriuntur, apicalis furcata; subcostalis basim versus obsoleta ; subdorsalis simplex; posteriores: vena apicalis ante apicem exit, infra cam vena fureata; vena mediana trifida.

Irral above hairy, in front smooth. Occlli none. Antenue as long as the anterior wings, sleuder, the basal joint clongate, thickened. Tongue naked. Maxillary palpi rather long, filiform. Labial palp̧i slender, ratler drooping, cylindrienl, the second joint with appressed scales, the terminal joint pointed. Wings with long cilia, the anterior oblong-ovale, the posterior laneeolate. In the anterior wings seren veins arise from the hinder portion of the discoidal ceil; the apical 
vein is furcate; the subcostal vein is obsolete towards the base; the subilorsal vein is simple. In the posterior wings the apical vein terminates above the apex, below it is a furcate vein; the median vein is trifid.

The habits of the perfect insects of this genus are very similar to those of the Gracilarie, but the smaller species are far more frecuently observed on the wing. None of this genus pass the winter in the perfect state, all being then in pupa. The larva, when young, are true miners, and their mines can with difliculty be distinguished from those of a Lithocolletis larva; but as soon as the larva leaves the mine, the fact of its being untenanted, and 110 pmpa-skin protruding, sufficiently demonstrates that it is no liblhocollelis mine. After quitting its mine, the larva turns down a piece of the edge of the leaf, and feeds witlin the cavity thus formed; except in the case of the larva, which feeds on the hawthorn, this turned-elown place does not assume the conical form so prevalent with the larve of Gracilaria; when full-led, the larva tarns down a smaller portion of the edge of the leaf, and spins therein a firm, rather flat, ochreous cocoon.

I enumerate only nine British species of this genus, though probably 1 have individual specimens of two or three others, but the extreme similarity of many of the species renders it extremely unsafe to describe from single caught specimens; one of the strongest cliaracters for discriminating the species lying in the extreme tip of the cilia of the anterior wings, which can rarely be well seen except in bred specimens. On the continent are four or five other distinct species.

The genus may be thus subdivided :-

a. Anterior winers with mumerous short whitish or white streaks from the costa. Species 1-8.

a $a$. Anterior wings with threc triangular yellowish marks on the costa. Species 9.

1. Avellanella, Sta.-meleogripennella, Sta. Ent. Trans. i. n. s. 88.- Luxtla, Curt.? Alis anticis dilute griscis, dorso albo-farinato, strignlis unnerosis costie albitis, maculis duabus plice, una posteriore disci fuseis, puncto apjicis fusco; ciliis albidis, lineis duabus inlegris fuscis ub apice usque arl angulum anilem; palpis albis, articuli tertii basi annuloque ante apicem fuscis. 1xp. al. 4 lin.

Head whitish, mixed with fuscous. Face grey. Patpi whitish, the lust joint with the base and a ring before the apex fuscous. Antennace lark fuscous, anmulated with white. Anterior wings pale grey, intermixed with white, especially along the immer margin; along the costa are numerous short whitisli streaks, obliguely placed till near the apex, the three immodiately betore the apex nearly straight; in the fold are 
two dark fuscous spots, one before, the other beyond the middle; beyond the latter is a dark spot on the dise; in the apex of the wing is a minute dark spot; cilia whitish, with two entire curved dark lines from the apex to the anal angle. Posterior wings pale grey, with paler cilia.

Common among nut-bushes in May and August. The larva abundant in nut-leaves in July, September, and October.

2. Devoniella, Sta. Hint. Trans. i. n. s. 89 (1850). Alis anticis octreets, dorso albido-farinato, strigulis numerosis costre obsolctis, macula fusca plicic pone medium, puncto apicis alro; palpis albis. Exp. al. $4^{x}$ lin.

Ilead ochrcous. Face whitish. Palpi white. Antemux whitc, with darker annulations. Anterior wings ochereus, mixed with whitish, especially along the inuer margin; along the costa are numerous indistinct short whitish streaks; in the fold of the wing is a fuscous spot beyond the middle, and at the apex a distincl dark brown or black spot. Posterior wings pale grey, with ochreous cilia. shire.

A single specimen, taken May 1st, near Dawlish, in Devon-

3. Anglicella, Sta. Ent. Trans. i.n. s. 92 (1850).-neלulea, IIaw.? Stcp.?-meleagripennella, Haw.? Step.? Alis anticis saturale griseis, dorso albido-farinato, strigulis numerosis costac albidis, maculis duabus plice, una posteriore disei fusco-nigris, puncto apicis atro; ciliis albidis, externe bis fusco-cinctis; palpis albis, articuli secundi apice fusco, tertii annulo lato nigro. Ixp. al. 5 lin.

IIead ochreous, mixed with fuscous. Face grey. Palpi white, the extresnity of the sccond joint fuscons; terminal joint will a broad black ring. Antenne dark fuscous, with whitish annulatious. Anterior wings $d a r k$ grey, intermixed with white, especially along the inner margin; along the costa are numerous short whitish streaks, those towards the apex being the most distinct, the last one being continued round the apical black spot into the cilia of the hinder margin; in the fold are two dark fuscous spots, one before, the other beyond the middle; beyond the latter on the dise is a smaller dark fuscous spot, bounded cxternally by a whitish streak; cilia whitish, cxternally with two entire darli fuscons lines from the apex to the anal angle. Posterior wings grey, with paler cilia.

$\Lambda$ most abuudant species in hedges in the south of Fngland, appearing at the end of April (one of the harbingers of summer), ant in May, and again in August. I have bred it from larve off sloe, and 1 believe it also feeds on the hawthorn. The larva may be found in July and September.

4. Betuløe, n. sp. Alis anticis saturate griscis, dorso albido-farinato, strigulis uumerosis costac albidis, maculis duabus pliere, una posteriore disci nigris, puncto apicis nigro; ciliis griseis, linca saturate 
fusen ab apiecm, linea secunda sub apicen. usque ad angulum analcm, ciliis apicis saterne albis; palpis albis, articuli tertii amuelo lato salurale fusco. Exp. al. 4 lin.

IIearl greyish-fuscous. Tace grey. Palpi white; terminal joint with a broal dark fiescous ring before the apex. $\Lambda$ ntemue dark fuscous, with paler anmulations. Anterior wings durk grey, irrorated with whitish, more especially towards the inuer margin, with numerous short whitish streaks from the costa; on the fold are two oblong black spots, the seeond almost in the middle, another lies on the dise beyond the middle; at the apex is a small black spot; cilia grey, with a dark grey line from the apex to the anal angle, and another beyond it below the apex; the tip of the apical cilin being while. l'ostcrior wings palc grey, with palo greyish-ochreous cilia.

I have twice bred this from larva found on birch, in July. $\Lambda$ second brood of larva feeds in the birch-leaves in September and October.

5. scutulatella, n. sp. $\Lambda$ lis anticis fusco-yriseis, albo-farinato, precipute dorsum versus, strigulis numerosis costio albis, macula duabus oblongis plice, una posteriore disci fusco-nigris, puncto apicis alro; ciliis albidis, linca saturate fusea ab apicem, linea secunda sub apicem usque ad angulum analem, ciliis apicis externe albis; palpis allis, immaculatis. lixp, al. $4 \frac{3}{3}$ lin.

If and whitish, mixed with fuscous. Facc grey. Palpi while, unspotted. Anteme fuscous, with whitish amulations. Anterior wings greyis/t-fuscous, irrorated with while, especially along the inner margin (having a more speckled appearanee than any of its congeners); along the costa are numcrous short volite streaks, the last of which passes round the appical black spot to the hinder margin; in the fold are two oblong dark fuscous spots, and beyond is a lesser one on the dise; cilia whitish, with a curved dark line from the apex to the anal angle, beyond which is a second dark line below the apex, but the tips of the apical cilia are white. Posterior wings pale grey, with paler cilia.

I have taken this on the Dartford 1leath fence in Juwe. It is also in the collections of Mr. Douglas and Mr. Weir.

6. torquillella, /cll. Ent. //g. 1850. p. 161; Sta.-meleagripenmallu, Ilibb.? Dup.? Evers.? $\Lambda$ lis anticis salurate griseis, glaucescentibue, clorso albido, strigulis numcrosis costa albidis, ducubus ultimis albis, maculis dualuus plice, una posteriore disci nigris, puncto apicis atro; ciliis albidis, externe bis fusco-cinctis; capillis ochreo-fuscis, fronte grisea; palpis albis immaculatis. Kxp. al. 5 lin:

II and ochrous, mixed with fuscous. Face grey. Palpi white, immaculate. Antenua dark fuscous, with paler ammulations. Anterior wings derk grey, wilh a slight purple gloss, with the imser margin whitish, and with numerous short obligue whilish streaks along the costa, ant two nearly straight short white streaks from the costa before the apex, the latter of which is continued round the apieal black spot 
to the linder margin; in the fold are two oblong black spots, one before, the other beyoul the middle, and beyond them is a small dark spot on the dise, preceding the continuation of the costal streak fifth from the apex; cilia whitish, externally with two curved dark lines from the apex to the anal angle. Posterior wings pale grey, with paler cilia.

Not common; appears in May and August. The larva feeds in sloc-leaves in July and September; it has becn reared by $\mathrm{Mr}$. Logan and myself.

7. Scoticella, Sta. Int. Trans, i. n. s. 94 (1850).-meleagripennella, Treit.? Alis anticis salurale griseis, basi dorsoque albo-farinatis, strigulis numcrosis costa albis, maculis duabus plica, una disci posteriore fusco-nigris, puncto apicis atro; ciliis albidis, externe bis fuscocinctis; capillis allis fusco-mixl is, fronte palpisque albis. Exp. al. 5 lin.

Ilead white, mixed with fuscous. Tiace white. Palpi white, immaculate. Antenne fuscous, ammulated with white. Anterior wings dark grey, irrorated with white at the berse and along the inncr marrin, with numerous short wlite strcaks from the costa, the last of which is continued round the apieal black spot to the hinder margin; in the fold are two oblong blackish spots, and beyond is a smaller blackish spot on the dise, followed by a short white streak; cilia whitish, with two curved darl lines from the apex to the anal angle. Posterior wings grey, with paler cilia.

Abundart in Scotland among mountain-ash, in June. The larva feeds in the leaves of the mountain-ash in August and September. I am not aware that it is double-brooded.

8. Loganella, Sta. Zool. 1848. p. 2162. Alis anticis uigro-fuscis, strigulis numerosis costac, maculis duabus dorsi, strigulaque disci posteriore albis, purcto apicis atro; ciliis albidis, externe fusco-cinctis. Wxp. al. $4^{\frac{\pi}{2}}$ lin.

IIead greyish, mixerl with brown. Face grey. 1'alpi white. $\Lambda$ ntemue fuscous, with palcr annulations. Anterior wings blackish, with numerous short white streaks along the costa, and two larger whitish spots on the inner margin, one before, the other beyond the midllle, beyond the latter on the dise is a short white streut; at the cxtreme apex is a small black spot; cilia whitish, with a eurved dark line from the apex to the anal angle. Postcrior wings grey, with greyish-ochrcous cilia.

$\Lambda$ scarce species; appears in June and July. It has been taken in several localities in the west of Scotland, and also in Cumberland.

9. guttea, Ilaw. T. B. 531 (1829); Step,-gulliferello, 1)up. L. T. xi. pl. 306. f. 12 ; '/ell-malinella, Itüb. Larve?-marginimnculella, Evers.? Alis anticis brumeis, guttis tribus coste triangularibus, cum duabus dorsi alternantibus, albidis. Exp. al. $5_{\frac{1}{3}}^{1}$ lin.

IIead dark ochreous. Face rather palcr. Palpi white. Antemne 
dark fuscons, with palcr annulations. Anterior wings dark brown, with three triangular whitish spots on the costa, allernating with two others on the inner margin; cilia brown, with a few whitish seales on the costa before the apex, and in the middle of the hinder margin, and with two rows of darker seales round the apex. Posterior wings greyish-fuscous, with paler cilia.

Common among apple-trees in May and June. The larva fects in apple-lcaves in July and $\Lambda$ ugust.

\section{Famli IX. COLEOPHORIDA.}

Caput superne ac in fronte lacvigatum. Antenne articulo basali plerumque penicillato, in quiete porrecte. Palpi maxillares nulli, Palpi labiales tenues, articulo tertio acuminato. Alce elongale lanceolater.

Head above and in front smooth. Antennce porrected in repose, the basal joint frequently with a tuft of hair. Maxillary palpi none. Labial palpi sleneter, terminal joint acuminate. Wings clongate, lanceolate.

There are only two genera in this family, and one of those contains only one species (Goniodoma aurogullella), not at present known as British; consequently we have only the remaining genus to consider.

\section{Genus I, COLEOPHORA.}

Connoriona, Zcll. Isis, 1839, p. 206; 1)up. Cat. Porrectaria p., Haw. Ornix p., Treit. Damophila et Porrectaria, Curt. Ormix et Gracillaria p., Dup. L. F. xi. Astyages p., Metalloselia et Porrectaria, Step.

Caput superne ac in fionte levigatum. Ocelli nulli. Antenne articulo basali clongato, incrassato, plerumque penicillato, interlum usque medium squamis incrassate. ILaustcllum squamatum. Palpi labiales tenues, subporrecti, articulo secundo fasciculo tenui producto, articulo tertio acuminato. Nlae elongatic, lanecolatic, longe ciliatie; anteriores: vena subcostalis basim versus obsolcta; venx e cellula discoidalis in costam tres, in apicem una, in marginem posticum tres; vena subdorsalis longe furcata; posteriores: vena apicalis furcata supra et infra apicem exit; vena discoidalis simplex, mediana bifida. Larva saccophora, metamorphosis intra saccum.

Head above and in front smooth. Ocelli none. Antennx sometimes thickened with seales to the middlle, basal joint elongate and thickened, frequently with a tuft of hair. Tongue seated. Labial palpi slender, rather porrected, with a slenter prolonged tuft from the second joint, 
the third joint pointed. Wings clongate, lanecolate, with long cilia. In the anterior wings the subeostal vein is obsolete towarls the bitse; from the discoidal cell three veins run to the conta, one to the alpex, and three to the hinder margin; the subdorsal vein has a loming fork. In the posterior wings the fureate apical vein terminates above and loclow the apex; the discoidal vein is smple; the median bifid. The larva a case-bcarer, changing to a pupa within the case.

The species of this genus are rather numcrous, no less than forty-one Britisl being alrealy known, and many others ocenr on the contincnt. 'The perfect insects of' some species may be found commonly on palings and trunks of tres, but the grenter part lead a very retired life, and are rarely seen; the tres-fecting species may be observed in windy weather, flying on the lec-side of the trees, endeavouring to resume lheir position on the branches, from which the agitation of the foliage had dislodged them; the other species are rarely met with on the wing, and fly only for short distances if accidentally started from their retreats. Some of the species are of brilliant metallic colours, otlers of a miform brown or ochreous, but the greater part are distingmished by pale longitudinal streaks upon a dark ground. The larvie are especially distinguished by their cases and their mode of feeding. Tlic cases are construeted either entirely of silk, or of two culicles of a mined leaf fastened together and lined with silk; the form of the case is extremely varied, and is frespently of scrvice to distinguish elosely-allied species. The very young larve are in most instances miners till they have mined a suflicient portion of leaf to furnish them with a case; they then cut out their case, and attach it to the underside of the leaf, when they make a circular hole in the lower cuticle of the leaf, and proced to devour the pareuchyma, gradually inserting a langer portion of their body into the leal as they consume the parenchyma near the entrince-hole, and have to reach further : thus they not unfrecpuent? maty be found quite out of the case, and wholly within the leal; this always happens when they are prejouring to make a fresh case; then they eat in one continuous direction till they lave excavaled a suflicient portion, which they sew together and cut out, leiving the old case attached to the leaf. 'The mined places are frecpuently very conspicuous, being whitish or brown, and the ronmel hole in the cuticle of the leaf sufliciently shows it to be the work of a Coleopleore larva, even though the larvia be not there. I'Je larvas of some of the species feed on seeds, attaching the case to the outside, and boring in. All the specie's appear lo remain a long time in the latrvis state (some as moleh as nine montlis), and to be in that state during the winter months.

VOL. III. 
The British species of the genus may be arranged in the following table:-

a. Anterior wings brilliant metallic grecnish, or bronze. Species 1-5. a $a$. Anterior wings not greenish or bronze, and not unicolorous.

i. Antenme much thickened with scales towards the base. Sp. 6-9.

$b$. Antenuxe hardly thickened with scales towards the base, or quite bare.

c. Anteunæe with a tuft of hair at the basal joint. Specics 10-17, and 20.

c c. Antenne with no tuft of hair at the basal joint. Specics 18, 19, 21-29.

a a $a$. Anterior wings not greenish or bronzc, quite unicolorous, or only with the costa slightly paler. Species $30-41$.

Many of the species are so extremely similar, and yet each specics has a considcrable range of variation, that it is no easy matter to decide from single specimens taken on the wing (and frequently in rather wasted condition) to which species they should be referred, or whether they are not, in fact, new species; to pronounce with certainty on such points, we require to know the larve. It thus happens that many species I had previously catalogued as distinct, I have here united as synonyms of one species; yet that I am correct in so doing can only be proved by the discovery of the larve being identical. Of some species, which I have no doubt are distinct from any here cnumerated, I possess specinens, but in a condition too wasted to crable me to describe them.

1. Fabriciella, Vill. E. L. ii. 527. 1077 (1789).-spissicornis, IIaw.; Curt.; Step. pl. t1. f. 1.-Mayrella, Zcll.; Ilüb. 322?-Tuscinirepennella, Evers. Mlis anticis nitidis viricli-iencis, apicem versus cupreis; antemnis dimidio basali squamis cupreis dense vestito, cecterten albo nigro-annulato. Exp. al. $5 \frac{1}{2}$ lin.

IIead, face, and palpi grecnish-bronze. Antenne thickly clolked with coppery scales to the middle, then sharply anmulatert black and while. Anterior wings shining bronzy-green, towards the apex coppery; eilia purplish-grey. Posterior wings grey, with paler cilia.

Appears in June and July; sometimes very plentiful in meadows, and in dry flowcry plices.

2. deauratella, Lienig, Isis, 1816, p. 295; Zcll.; Sta.-Trifolii, Step.? Alis anticis nitidlis viridli-iencis, apice cupreo; antemnis fuscis, arliculo basali ue sequentibus squanis cupreis vestilis, apice albo. Lxp. al, $6-6$ lin.

IFend, faee, and palpi dark brouzy-green. Antemue dark fuscous, the bessal joint much lhichened, and several of the suereeding joints slightly so will coppery seates, the upex white. Anterior wings bronzy-yrcen, 
the apex coppery; cilia purplish. Postcrior wings dark grey, with paler cilia.

Occurs in July among clover, but scarce.

3. alcyonipennella, Kollar, Verz. der nicd. ost. Schm. p. 99 ; Dup.; Zell.; Sta.; Dougl. Ent. Trans. ii. n. s. 80. pl. xi. f. 2. Alis anticis viridi-ancis; antemis articulo basali vire incrassulo, saturate viridi-aneis, arliculis septem ultimis albis. Exp. al. $5 \frac{2}{3}$ lin.

Ilead, face, and palpi dark bronzy-green. Autemurs will the basal joint only very slightly thickened, dark bronzy-green, the last seven joints mhite. Anterior wings shining bronzy-green; cilia greyish-bronzc. P'osterior wings grey, with grey cilia.

Appears in July among Centurrea vigra, but the perfect insect is rarely mot with. The larva is more rcadily found, and is nearly full-fed in May; it has a nearly straight cylindrical dark brown ease, and makes ratler transparent pale brownish blotches on the leaves of the Centaurca nigra. It has been found in various parts of the country, near Liverpool, Dublin, Mickleham, etc.

4. Frischella, Linn. S. N. (10) 5.11. 289 (175S); IV. V.; Zell.; Sta.-Trifolii, Curt. 13. E. fo. 391. Alis anticis nitidissimis viridiancis apice cupreo; antemnis, articulo basali vix incrassato, fuscis, apice albo. Exp. al. 8-9 lin.

IIead, face, and palpi bronzy-green. Antennxe fuscous, with the terminal joints white, the basal joint hardly thickened with bronzy-green seales. Anterior wings extrenety shining, bronzy-green, with the apex coppery; cilia purplish-grey. l'osterior wings grey, with paler cilia.

Mr. Dale met with this species rather plentifully among trefoil flowers, near the shore in the Isle of P'ortland, and at Charmoutl, in Dorsetshire, July 11th and 14th, 1831.

5. paripennella (F. v. 1R.), Zcll. Isis, 1839, p. 208; Sta. Mlis anticis fusco-acneis; antennis fuscis, apice albo. Exp. al. 5 lin.

Ilead blackish-green. Face rather silvery. Palpi yellowish. Antenne dark fuscous, with the apex white, the basal joint seareely thickcncd. Anterior wings fuscous-bronze (comparatively short and broad), with palcr cilia. Posterior wings grey, with paler cilia.

Appears in June, and found occasionally in hedges and on fences. The cases containing the full-fed larva or pupa are found in $\Lambda$ pril or Mity attached to palings, trunks of trees, ete. ; they may be immeliately recognized by the rugose projections on the upper side, the mouth is turned round nearly at right angles, whereby the case is parallel to the surface to which it is attached, and is much less casily seen than if it projected, as usual, at an angle of about $15^{\circ}$; in other respects the case has no peculiarity, being rather short, straight, eylindric, but rather attemated behind. 'lhe larva which, I believe, belongs to this species, fecds 
up in autumn; it is polyphagous, and I lave found it on sloc, nut, birch, bramble, etc.

6. Wockeella, Zill. L. F. iv. 215 (1819); Sta. Alis anticis brumneis, apjee produeto, venis albidis, costa tenuissime alba, postice dilute-ochrea; antemis albis, nigro-ammulatis, apicc albo, dimidio basali in clorso longins piloso cristato, articuli basalis penicillo griseo. Exp. al. 10 lin.

II and and face pale greyish-brown. Palpi whitish. Anteune whitish, aumulated with blick to near the apex, the busal half clolked with long derk hairs on the lucke, the basal joint with a little grey tuft. Anterior wings brown, with the apex produced; the prineipal veins are fiintly white; the costa is narrowly white, posteriorly pale ochrcous; cilia brown. l'osterior wings grey, with paler cilia.

Two specimens were taken by Mr. Weir, at Pembury, a few years back. Jast summer he bred i third from a dark brown slightly curved calse he found attached to a leaf of Genistu tinetoria, although there were no symptoms that the larva lad fed upon that plant.

7. ochrea, Haw. I. 13. 533 (1829) ; Step. ; 7/ll. L. E. iv.; Sta. —argentipennella, Dup. L. T. xi. pl. 310. f. 3 ; 'Zell. Isis, 1847.—lapsellu, Zell. lsis, 1839. Alis anticis ochreis, costam versus saturatioribus, dorwo angusle linentue plicere aryenteis; antennis albis (penicillo basali longo ochreo), sq̣uamis ochreis usque medium vestitis. Exp. al. 9 lin.

IIead, face, and palpi ochrcous. Antenna clothed with ochreous hairs to near the mistdle, then unieslorous white, the basal joint with a long ochreous tuft. Anterior wings ochreous, rather darker towards the costa, with a silver streak along the fold, and a narrow one on the inner mergin; cilial grcyish-ochreous. P'osterior wings fuscous, with paler cilia.

()ecers at: Riddillesdown in July and August, but more commonly near Bristol. 'l'he cases have been found on the seeds of Polentilla argentea.

8. binotapennella (F. v. R.), Dup. T, F. Sup. iv. 295. pl. 75. f. 3 (1812),-Einolatella, Zell.; Sta. Alis anticis obscure ochreis, penclis duobus obsoletis, uno in medio plicx, altero posteriore disci, sulurule feteris ; imlennis albis, flesco-imnulatis, basim versus squamis verhe is in alorso vestitis, articuli basalis penicillo brevi ochreo. Exp. al. $6 \frac{1}{2}$ lin.

IIend, face, and palpi ochrcous. Antennæ white, annulated with fuscous, clothed with ochreous seales on the back towards the base, with a rather short ochreous tuft at the basal joint. Anterior wings dull ochreous, will two indistinct dark fuscons spols, one about the middle of the fold, the other on the dise towards the hinder margin; rilia dull ochreons. Pesterior wings pale grey, with pale ochreous cilia. 
Taken in August last, on the coast near Brighton, by Mr. He'mmings and M̂r. Douglas, among Salicornia and Chenojodium maritimum.

9. Lixella, Zcll. L. E. iv. 231 (1849); Sta.-ornatca, IIaw.onatipennella, Step.; Dup.? Alis anticis dilute luteis, apice ineurvo producto, linca plice, lineola disci, lineolis quinque obliquis costam versus argentcis, fusco-marginatis; antennis albis, basim versus squamis albis vestitis, articuli basalis penicillo longo albido. Fxp. al. $8 \frac{1}{2}$ lin.

IIead, face, and palpi white. Antemae white, slightly clothed with white scalcs near the base, with a long ycllowish-white tuft at the basal joint. Anterior wings with the apex prolonged and curved, pale yellow, with a silvery streak along the fold, a short one a little above it on the dise, and five short oblique silvery strenks towards the costa; all these streaks are margined wilh fuscous; the inner margin is also narrowly silvery; cilia palc fuscous. P'osterior wings fuscous, with palcr cilia.

Occur's at Micklelam, Sanderstead, and near Bristol, at the end of June and beginning of July. The larva feeds (according to Zeller) on the leaves of Ilolcus lanatus.

10. vibicella, Ilüb. $30 S$ (1816); Zell.; Sta. - vilucipennella, Treit.; Dup.; Hevers.; Weaver. Alis anticis ochreis, lineola obliqua pone medium juxta costam lineola ámulata disci (spatio interjecto brumnescente), lincolacpue plice, argenteis; antennis albis, articuli basalis penicillo longo ochreo. Lxp. al. 92 lin.

Head ochreous. Face and palpi silvery. Antennec white, with a long orfhreous tuft at the basal joint. Anterior wings ochreous, with three silvery streaks, one on the subcostal vein commencing near the middle of the wing, not reaching to the costa, one slightly angulated on the dise (the spatee between these two is brownish, which colour is confimed to the apex of the wing), and one along the fold termintating before the anal angle; cilia grey. Posterior wings grey, with paler cilia.

I. an not aware of any collcetor having defeeted this insect in this country, except Ml. Weaver, who found the larve in 'Trench Wood, Worcestershime, in the first wrek of June, 1S14. The linvie foed on the Genista timetoria, in firm, shining black cases, which, as Mr. Weaver remarks, are not unlike the ripe pods of some papilionaccous plants.

11. conspicuella (Mamm.), Zcll. T. E. iv. 236 (1S49); Sta. Alis anticis dilule luleis, linca prope costam a basi usque apicem lincola amgulatia disei (spatio interjerto brumescente), linea plices, dorsoque anyuste argenteis; antennis albis, articuli basalis penicillo longo albido. Lxp. al. 9 lin.

llead, face, and palpi rthilish. Antenne white, with a long volilish tuft at the basal joint. Anterior wines pale yellow, will the inner margin narowly wilcery, and with three silyery streaks, one near the costa, commencing at the base, and continued to immediately before the apex, 
one slightly angulated on the dise before the anal angle (the space between these two is brownish), the third is on the fold; cilia palc grey. Posterior wings pale grey, with ochreous-grey cilia.

$\Lambda$ single specimen was taken by MTr. Bedell, in Headley-lane, near Mickleham, July 12th, 18.1. The larva fects on Centurtea seubiosa, in a rather large, slightly-curved, somewhat flattened brown case. Mr. S. Stevens has twice found it in the lilly field at Ileadley-lane, in June, but has not succeded in brecding the perfect iusect.

12. pyrrhulipennella (Tischer), Zell. Isis, IS39, p. 206 ; Sta.vilicigerellu, Dup.? Alis anticis grisco-ochreis, costam versus saturatioribus, costa, lincola parm angulata disci, linea plica, dorsoque niveis ; antemis albis fusco annulatis, articuli basalis penicillo grisco. Exp. al. 6 lin.

IIead and face greyish-ochreous. Palpi whitc. Antenno white, annulated with dark fuscous, the basal joint with a grey tuft. Anterior wings greyish-ochreous, darker towarls the costa, with the costa and imer margin snowy white, a slighlly anguluted snowy white streak on the dise above the anal angle, and a snowy white streak along the fold reaching to the anal angle, where it appears to run into the white hinder margin; cilia greyish-ochreous. losterior wings dark grey, with paler cilial.

Oceurs in June and July on heaths; has been taken at Dartford Ileatl, Wimbledon Common, and near IIuddersficld. 'The larva feeds on Callena vulyaris and Errica cincrea in autumm and spring, and the shining black cases of the full-fed larva may be found in May.

13. albicosta, IYaw. L. 13. 535 (1829); Step.; Curt. B. E. fo. 6S7; /ell.; Sta. Nlis anticis dilute grisco-ochreis, costam versus saturatioribus, costa lincola fere recta disei, lineaque plica albis; antennis albis, fusco-imuulatis, articuli basalis penicillo brevi octureo. Ixp. al. 7 lin.

Ilead greyish-oclireous. Thee and palpi whitish. Antemes white, ammulated with fuscous, the basal joint with a steort ockercons tuft. $\Lambda \mathrm{n}$ terior wings pale greyish-ochreous, darker towards the costa, with the cosia velile, and with a short white streak on the dise conmencing near the middle of the wing, and a white streak on the fold; a short white streak runs along the himder margin at the apex; cilia greyish-ochrcous. l'osterior wings grey, with greyish-ochreous cilia. June.

Very common anongst furze-buslies at the end of May and in

14. Vulneraria, /ell. Isis, 1839, p. 207 ; Sta.-icterella, 1)up.? $\Lambda$ lis anticis dilute lutris, costa, lincola disci fere recta, linea plice, dorsopue argenteo-albidis, squamis fuscis pare maryinalis; antennis albis fuseo-annulatis, basion versus squamis albidis vestitis, arliculi basalis penicillo breviusculo albido. Exp. al. 6 lin. 
IIead, face, and palpi white. Autenne white, annulated with dark grey, the three first joints slightly thickencel with whitish seales, the basal joint with a rather short whitish tuft. Anterior wings palc yellow, with the costa and inncr margin, a nearly straight streak on the dise beyond the middle, and a streak along the fold silvery white, wilh some dark fuscous scales on the margins of these streaks; cilia pale fuscous. Posterior wings dark greyish-fuscous, with paler cilia. Deal.

Appears in June and July; specimens have occurred near

15. anatipennella, Hüb. Tin. 156 (1801); Trcit.; Step.—Tiliella, Schr.; Zell.; Sta.—anatipennis, IIaw.? Alis anticis albis, squanis sparsis fuscis, procipue apicem versus; antennis albis, fuscescente annulatis, articuli basalis penicillo longo albido. Exp. al. $7 \frac{2}{2}$ lin.

IIcad, face, and palpi white. Antennx white, annulated with palc fuscous, the basal joint with a long whitish tuft. $\Lambda$ nterior wings white, woith mumerous scaltered fuscous scules, especially towards the apex; cilia white, with the ends fuscous. Postcrior wines fuscous, with palcr cilia.

Not uncommon in hedges in June and July. The larva has a brown-black case, somewhat in the form of a pistol, which (necording to Rićaumur's observations) is entirely constructed of silk spun by the larva, and afterwards coloured by a peeuliar viseid secretion of the larva; the larva is not uncommon in Miny, on sloe and other trees.

16. palliatella, Zincken, g. S. Germ. Mag. i. 40 (1813); Zcll.; Sta.-palliipennella, 'Treit.; Dup.? Alis anticis albis, postice renis obsolete fuscis, costa ipsa fusea; antennis albis fusco-annulatis, articuli basalis penicillo longo albido. Exp. al. 8 lin.

Ilead, face, and palpi white. Antenue white, annulated with fuscous, the basal joint with a long whitish tuft. Anterior wings white, with the reins towards the apex indistinclly fuscons, and the cxtreme costa fuscous; cilia palc fuscous. Posterior wings fuscous, with paler cilia.

Not an uncommon specics, appearing in Junc and July. The larva is polyphlagous. Mr. Bond met with it plentifully on sallow a few years back; the case somewhat resembles that of the preceding, but lias in addition a large appendage or flap on cach side, almost entirely concealing the actual case; these llaps, like the case, are (according to Réaumur's obscrvations) entircly formed of silk.

17. currucipennella (F. v. 1R.), Zcll. Isis, 1839, p. 247; Sta. Alis anticis niveis, renis late luteis, postice brunnescontibus; antemis albis fusco-annulatis, articuli basalis penicillo longo oehreo. Exp. al. 7 lin.

Ilead, face, and palpi whitish. Antemme white, ammulated with fus- 
cous, the basal joint with a lonw ochreous tuft. Anterior wings white, wilh the veins brondly yellowish, towards the apex inclining to brown; costal cilia brown, at the tips white; hinder marginal cilia pale fuscous. losterior wings fuscous, with palcr cilia.

Appears in June and July, but nowhere common. 'The larvil, which feeds on oak, is full-fed in May; the case is somewhat like that of anatipennella, but las several little projections on the back; it has been found at Lipping and Wrimbledon Common.

18. niveicostella (F. v. R.), Zell. Isis, 1839, p. 208 ; Sta, ; T) 1р.? $\Lambda$ lis anticis ochreis, costan versus saturatioribus, costa nivea; antennis albis, articulo basali incrassato, non penicillulo, ochreo. Exp. al. $6 \frac{1}{2}$ lin.

Head and face pale ochrcous. Palpi whitish. Antenne while, the basal joint thickened, will no tuft, ochreous. Anterior wiugs ochrcous, darker towards the costil; the costa narrowly white to near the apex; cilia pale ochreous. Posterior wings grey, with paler cilia.

Has occurred at Micklchan and at Dartford Ileath, in June and July.

19. discordella, Zell. J. E. iv. 301 (18.9); Sta.-gallipemis, Ilaw.?-galipenuella, Step,? 'Trcit.? Alis anticis ocheres, costam versus saturatioribus, costa, linea lemeissima plicre, dorsoqne angneste nivers; antennis albis fusco-iumulatis, articulo basali incrassato, vix penicillato, grisco. Lxp. al. 6 lin.

Head greyish-ochreous. Face and palpi whitish. Antenne white, annulated with fuscous, the basal joint grey, slightly thickened, with it few projecting scales bencath, but hardly suflicient to be considered a tuft. Anterior wings oclereous, diurker towards the costa, with the costa nearly to the apex white, and with a very slender white streak along the fold and the inner nargin nurrowly while; cilia greyish-ocheous. P'osterior wings grey, with paler cilia.

The perfect insect is occasionally met with in Junc and July, and has occurred in various localities, but is nowlere abmudant. Mr. Shield, who discovered the larva of this species, finds the cases abundantly on Tolus comiculatus, near Jublin, in May. 'The young larva begin feeding in autumn; the brown case is rather curved, almost hooked at the end, and hias a flouneed appearance; the mined leaves appear very white.

20. saturatella, Sta. Zool. 1850. App. xciii. Alis anticis salurate brunneo-ochrcis, costa latius, lineola angulate intermptuque disci, linea tenuissima plicae, dorsoque anguste niveis; antennis albis, articuli basalis grisei penicillo brevi griseo. Exp. al. 7 lin.

Ilead greyish-white. Face and palpi white. Antenne white, the basal joint grey, with a short groy tuft. Anterion wings dert lrounishochreous, with the costa to near the apex rather broally white, an ex-

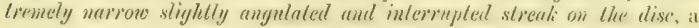


very narrow streak on the fold, and the inner margin narrowly white; cilia at the apex dark fuscous, below paler. Posterior wings pale grey, with paler cilia.

Occasionally met with amongst broom in July.

21. Onosmella, Bralım, Scriba's Beit. ii. 133-140. pl. 9. f. 7, 8 (1791); '/ell.; Sta.-struthionipennella, Treit.; Step.; 1)up.; Ilüb. Tin. 209 ?-pennella, W. V.? Alis anticis albis, venis tenuibus ochraceis; antennis albis, subtus fusco-junctatis, articulo basali incrassato, vix griseo-penicillato, Exp. al. 9-10 lin.

Ilead, face, and palpi whitish. Antenna whitc, spotted with fuscous beneath, the basal joint slightly thickened, with a few projecting greyish seales beneath. Anterior wings white, with slender ochrcous veins; cilia greyish. Posterior wings grey, with greyish-fuscous cilia.

Common among Felizm vulgare in July. The larva feels on that plant from autumn to Junc, in cases formed of pieces of the mined leaves; these cases are very broad, almost triangular, dirty grey, and from the prominent still hairs of the leaves have a singular appearance; the young larve, in autumn, mine suflicient for the construction of the case, but do not detach it from the leaf till the spring, it consequently only appears as a portion of withered leaf. The larva was first observed by Bralım on Onosma echioides; it feeds also on Anchusa.

22. therinella (Zell.), Tengström, F. F.-F. 141. 7 (1847); Zell.; Sta. Alis anticis angustulis albis, veuis dilatatis ochreis, postice confluentibus, costa angustc alba; antennis albidis fusecscentc-ammulatis, artieulo basali incrassato, non penicillato. Exp. al. 7 lin.

Ilead, face, and palpi pale ochreous. Antemne whitish, ammulated with pale fuscous, the basal joint slightly thickened, not tufted. $\Lambda \mathrm{n}$ tcrior wings narrow, white, unspotted, with the veins rather broadly ochreous, postcriorly confluent; the costa is narrowly white to near the apex; cilia ochreous. Posterior wings grey, with palcr cilia.

Appears in June and July in grassy places, but hitherto very scarce; I only know of two specimens which I can unhesitatingly refer to this species, of which one is in Mr. Wilkinson's collection, and the other in my own.

23. troglodytella, Zcll. L. E. iv. 322 (1819); Stn.; Dup.?Var.? Inulce, Dougl.; Sta. Alis anticis latiusculis argenteo-albis, renis distinctis ochreis; antennis albis fusco-ammulatis, articulo basali incrassato, non penicillato. Exp, al. 7 lin.

IHead, face, and palpi ochrcons-whitc. Antenne white, annulated with fuscous, the basal joint slightly thickened, not tufted. Anterior wings rather broad, silvery white, unspotted, with the veins bright ochreous; the costa is narrowly white to near the apex; cilia greyishochreous. Posterior wings grey, with paler cilia.

VOL. III. 
Not commonly met with in the perfect state, appearing in Junc and July amongst Liupatorium cannabinum and Inula dysenterica, on the leaves of which plants the larva feeds in May, in a long, nearly straight, cylindrical case of a uniform dirty-ochreous colour, except a brown patch on the basal half of the back. 'The specimens Mr. 1)ouglas bred from the Inula have narrower anterior wings than the typical insect, which I have bred both from Inule and Eupatorium, and the cases, though similar in form and colour, were much smaller; it is possible it may yet prove a distinct species.

24. lineolea, Haw. L. B. 534 (1829); Step.; Sta.-crocogrammos, Zell. Alis anticis latinsculis albis, venis dilatatis ochreis, postice conflucntibus, costa late usque medium alba; alis posticis griscis, ciliis oclereo-griseis; antemnis albis totis, vel fuscescenti-annulatis, articulo basali incrassato, non penicillato. Exp. al. $6 \frac{1}{2} \mathrm{lin}$.

IIend, face, and palpi palc ochreous. Antemne white, unannulated or anmulated with pale fuscous, the basal joint slightly thickened, not tufted. Anterior wings rather broad, white, with the veins pale ochreous, posteriorly confluent; the costa is broudly white nearly to the middle; cilia greyish-ochreous. l'osterior wings grrey, with ochreousgrey cilia.

Common in June and July among Stachys sylvatica and Ballota nigra, on which plants the larva may be found from March to May. It fecds on the leaves; the places mined by it are of a pale brown colour; the case is rather llat, angulated at each side, and is extremely liairy.

25. murinipennella (F, v. I.), Zell. I. E. iv. 334 (1849); Sta. -leucapennis, lfuw.?-lencapennella, Step?? Alis anticis angustis albidis, venis dilatatis griseo-ochreis, postice conlluentibus ; antennis albis, fuscoannulatis, articulo basali vix incrassato albido, non penicillato. Exp. al. 6 lin.

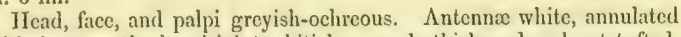
with fuscous, the basal joint whitish, searecly thickened and not tufted. Anterior wings narrow, white, with the veins rather broally greyishockreous, posteriorly confluent, and, in the male especially, much conccaling the ground-colour; cilia palc greyish-ochrcous. Postcrior wings grey, with paler cilia.

Common in flowery meadows in May and June.

26. crespititiella, Zcll. Isis, 1839, p. 208; Sta._Var. Pallicolella, Zcll.; Sta.-Var.? lacunicolella, Zcll.; Sta. Alis auticis angustis acutis nilidis, grisco-ochreis, vel grisco-lutcis, costa anguste alba ; antennis albis fuseo-innulatis, articulo basali fuscescente parum incrassato, non penicillato. Exp. al. $5_{\frac{2}{2}}^{2}$ lin.

IIead, face, and palpi greyish-ochreous. Antennex white, annulated 
with fuscous to near the apex, the basal joint pale fuscous, slightly thickened, not tufted. Anterior wings narrono, acute, slining, greyishockreous or greyish-yellow, with the costa narrowly white to near the npex, where it is lost in the whitish-ochreous cilia. P'osterior wings grey, with paler cilia.

Specimens in which the costa of the anterior wings is only paler, and not distinctly white, have been reputed distinct spceics, but I fancy improperly.

Very common amongst rushes in June. The larva feeds from September to May on the seeds of the rush, frequently completely quitting its small whitish case to burrow into the secds.

27. annulatella (Nylander), Tengström, F. F.-F. 143. I2 (1847); Zell.; Sta.-vestianella, Lin.? Fab.? Alis anticis acuminatis, griscoochrcis, inter venas squamis nigris albisque sparsis, costa anguste albida; antennis albis fusco-annulatis, articulo basali fuscescente, non penicillato. Exp. al. 7 lin.

Ilead and face greyish-ochreous. Palpi white. Antennx white, anmulated wilh fuscous, the basal joint pale fuscous, not tufted. Anterior wings acuminate, greyish-ochrcous, or dark greyish-ochreous, with some scaltered black and white scales betneen the veins; the costa is narrowly dirty-white to beyond the middle; cilia greyish-ochreous. Posterior wings grey, with paler cilia.

Very common in July and August among Chenopodium and Atriplex; the larva feeds in the autumn on the secds of those plants in a rather short whitish-grey silken case, exterually covered with grains of sand.

This species, like many of its congeners, is extremely variable, and I strongly suspect that Fluvaginella, Lienig (Zell. L. F. iv. $353)$, is only one of the phases of it.

28. argentula, Zell. I. E. iv. 368 (1849); Sta.; Step.?-otidipenuella, Hüb. T'in. 133? Dup.? Alis anticis latiusculis, albis, venis dilatatis ochreis, interstiliis albis parce fusco-squamalis; antennis albis fusco-annulatis, articulo basali inerassato albido, non penicillato. Exp. al. 6 lin.

Tlead and face pale greyish-ochreous. Palpi whitish. Antenux white, anmulated with fuscous, the basal joint somewhat thickened, whitish, not tufted. Anterior wings rather broad, white, with the veins broadly ochrcous; in the intervening white spaces are a fero scattered dark fuscous scales; the costa is marrowly white to beyond the middle; cilia greyish-ochreous. Posterior wings grey, with paler cilia.

Not common; occurs amongst yarrow (Ichillea Millofolium) in July. The larva feeds in the autumn on the seeds of the yarrow in a rather short whitish case; it remains in the larva state throughout the winter and spring. 
29. hemerobiella, Scop. T. C. 252. 650 (1763); Sclır.; Zell, ; F. v. R. pl. 69. pl. 70. f. 1.-anseripennella, Hüb. 'Tin. 319; Treit.; Stę); Duj). Alis anticis albis fusco-irroratis, puncto postico fusco; antemis albidis nigro-ammulatis, articulo basali grisco-fusco non penicillato. Exp. al. 8 lin.

IIead pale grey. Face and palpi dark grey. Antenue whitish, ammulated with dark fuscous; the basal joint greyish-fuscous, slightly thickened, not tufted. Anterior wings white, with numerous seattered fuscous scales, and with a more conspicuous fuscous spot above the anal angle; cilia greyish-fuscous. Postcrior wings fuscous, with paler cilia.

Appears in orchards in July; occurs at Putncy and IIammcrsmith plentifully in the larva state. The larva has a large, nearly straight, cylindrical, dark brown case; it feeds on the pear, plum, and cherry in May.

30. juncicolella, Sta. Sup. Cat. p. 7 (1851). Alis anticis ocluregriseis, unicoloribus; antennis fuscis, articulo basali vix incrassato, non penicillato. Exp. al. $3 \frac{1}{\mathrm{~g}}$ lin.

13ead, face, and palpi ochreous-grey. Antenne unannulated, dark fuscous; the basal joint slightly thickened, not tufted. Anterior wings ochreous-grey, with paler cilia. Posterior wings grey, the apex extremely pointed, with pale grey cilia.

Has occurred in July among rushes at Kilmun and near Folkstone; in Mr. Douglas's collection and in my own.

31. Laricella, Ilüb. Tin. 427 (1816); Dup.; Zcll, ; Sta.-laricinella, Ratz.—argyropennella, Treit. Alis anticis fusco-griscis unicoloribus; antenuis of fuscis, $q$ albidis fusco-anmulatis, articulo basali vix incrassato, fusco, non penicillato. Exp. al. 4-5 lin.

Ilead, face, and palpi shining grey. Antenne of the of fuscous, of the of whitish, annulated with fuscous; the basal joint slightly thickcned, fuscous, not tufted. Anterior wings greyisli-fuscous, with paler cilia. Posterior wings pale grey, with paler cilia.

Common among larches in June; the larva has a short, dirtywhite case, and feeds on the leaves of the larch in autumn and spring.

32. albitarsella, Zell. I. E. iv. 378 (1849); Sta.; Dougl. Ent. Trins. ii. n. s. 79. pl. xi. f. 1.-monacelln, Schr.? Alis anticis nitidis violaceo-nigris; antennis albis nigro-annulatis, basim versus violacconigrris, apice longe albo, articulo basali parum incrassato, penicillo brevi; pedibus griseis, tarsis albis. Exp. al. 5-6 lin.

Ilead violet-black. Face and palpi silvery-grey. Antenne with the slightly enlarged basal joint and several of the sueceeding joints violet-frrey, then white, annulated with black; the apex cntirely white. Anterior wings shining violet-black, with paler cilia. Posterior wings grey, with paler cilia. Legs shining grey; the larsi volite. 
Appears in June and July among ground-ivy (Glechoma hederacen), but marely met with in the perfect state. The larva feeds from November to $\Lambda$ pril on the leaves of the ground-ivy, but only on such plants as grow completely in the shelter of a hedge; the minced places are at first whitish, but afterwards become of a pale dirty-brown; the ease is rather long, slightly curved, dark brown. The larva also (according to Bruand) fecds on Origanum.

33. nigricella, Stcp.; Sta.-luscinicpennella, Bouchć-coracipennella, Zell.; IIüb.? Dup.? Step. ?-serratella, Lin.?-spinella, Sclir.? $\Lambda$ lis anticis fusco-nigris, unicoloribus; antennis albis fusco-annulatis, articulo basali incrassato fusco-grisco, non penicillato. Exp. al. 5 lin.

IIcad and face greyish-brown. Palpi paler. Antennæe white, annulated with dark fuscous; the basal joint slightly thickened, greyish-brown, not tufted. Antcrior wings unicolorous, fuscous-black, with paler cilia. Posterior wings dark grey, with paler cilia.

Abundant among hawthorn in June and July. The larva feeds on the leaves of the hawthorn, apple, pear, and sloc in May, in nearly straight cylindrical brown-black cases; the case of the young larva, which commences fecding in autumn, is curved, somewliat like a cornucopia. $\Lambda$ larva probably also refcrable to this species feeds in May on the leaves of the birch.

34. fuscedinella, Zell. S. E. iv. 383 (1849); Sta.-obscurea, IIaw. P-obscurella, Step. ? Alis anticis fusco-griscis unicoloribus; antennis albidis, fusco-annulatis, apiec albido, articulo basali incrassato fusco, non penicillato. Exp. al. 6 lin.

Ilead, face, and palpi brownish-grey. Antenne whitish, annulated with fuscous, more faintly so towards the apex; the basal joint slightly thickened, fuscous, not tufted. Anterior wings unicolorous fuscous, more or less tinted with grey, with palcr cilia. Posterior wings fuscous, with paler cilia.

Abundant among elms and alders in July. The larva feeds in May and June on the leaves of those trees in a brown case, rather stouter than that of nigricella; the young larva has a curved case.

It is of the larva of this species that Mr. Spence has described the operations, from his own observations, on some larva upon the alders in the IIull Botanic Garden (Kirby and Spence, 4th edit. vol. i. p. 459). Iarva probably referable to this species feed on the nut and hornbeam.

35. orbitella, Zcll. L. E. iv. 385 (1819); Sta. Alis anticis nitidis griseo-fuscis unicoloribus; antennis niveis fusco-annulatis, apice albo, articulo basali graciliore, griseo-fusco, non penicillato. Exp. al. 6 lin.

IIcad and face greyish-brown. Palpi paler. Antemmo snowy- 
white, annulated with dark fuseous; the apex white; the rather slender basal joint is greyish-fuscous, not tufted. Anterior wings shining greyish-fuscous, with paler cilia. P'osterior wings grey, with palcr cilia.

I have four specimens, taken at West Wickham, at Lewisham, and in the Isle of Arran, in June and July.

36. gryphipennella, Bouché, Naturgcschichtc, 131 (1834)-rhodophagella, Koll.-luscinicopennella, Zcll.; Sta. Alis anticis lalinsculis, ochrco-griscis ( $q$ fere ochreis); antennis niveis niyro-annulatis, articulo basali graciliorc, ochreo-griseo, non penicillato. Exp. al. 6 lin.

Ilead, face, and palpi greyish-ochrcous. Antenna snowy-rohite, annulated wilh black; the slender basal joint greyish-ochreous, not tufted. Anterior wings ralher broad, greyish-ochreous (the latter colour prevailing in the $f$ ); the cilia unicolorous with the wing. Posterior wings grey, with paler cilia.

Common among roses in June. The larva feeds in April and May on the leaves of the rose, and is sometimes so numerous as to be rather a pest in gardens, disfiguring the plants, from the bleached appearance of the mined leaves; the case is dirty greyish-ochreous, slightly curved, strongly scrrated on the back; the young larva commences feeding in the autumn, but attaches itself to the stem on the fall of the leaves, remaining inactive till the spring.

As this species is one casily to be met with, and being a garden insect more exposed to observation than many others, I proceed to give a description of the mode of operating of the larva, which has been drawn up by Mr. Shicld. "The larva, immediately on its exclusion from the egg, begins at one and the same time to feed and to construct its case ; for this purpose it commenees to gnaw at the side of the midrib so as to eflect an entrance between the skins of the leaf, having done which it proceeds to devour the inner substance of the leaf, thus clearing out a space for its body : when it has arrived at the edge of the leaf, or at the point which it intends should be the top of its ease, it turns round and retraces its steps, cutting off in its progress the mined portion of the leaf, and joining the edges together and at the same time slightly curving the skins so as to afford it a more spacious habitation; having arrived at the spot where it originally entered the Ieaf, its case is perfectly detached, and it either mounts on to the leaf or descends by its silken thread to another. When its ease lias become too sinall for it, it attaches itself to the side of the midrib of some leaf and procecds to opcrate as in the previous instamee, leaving the old case attached to the leaf and walking away with the new one." It takes the precaution to make its new case 
much larger than it appears to have any occasion for, which is to allow for the growth of the larva; a new-made case is extremely transparent, lut the larva soon sets to work to line it with silk, being aware that it would stand small cliance of escaping the numerous and ubiquitous Ichneumons if it lived in a glass house.

37. viminetella (v. IIeyclen), Zell. L. E. iv. 393. Anm. i. (1849); Sta.-luscinimpennella, Treit.? Dup.? Alis anticis angustulis ochreogriseis, apicem versus paullulum saturatioribus; antemis albis, fuscoannulatis, articulo basali grisco-ochrco, non penicillato. Exp. al. 6 lin.

Head, face, and palpi greyish-ochrcous. Antennx white, annulated with fuscous; the basal joint greyish-ochreous, not tufted. Anterior wings rather narrow (very variable in colour), genexally greyish-ochreous, slightly darker towards the apex. Posterior wings grey, with paler cilia.

Not uncommon among sallows and osiers in June and July. The larva feeds in autumn and spring on the leaves of those plants; its case is very peculiar, being made of pieces of leaf added at different times; it is not uniform in colour or size, being generally darkest towards the top, and of course broadest towards the bottom. The perfect insect can sometimes hardly be distinguished from the allied species; a fact which ought to make us extremely cautious in concluding that because we can see no distinction between species, they are therefore identical; not till the entire habits and history of the different specimens are known can we pronounce decidedly that they are not distinct.

38. olivaceella, n. sp. Alis anticis olivaceo-griscis, dorsum versus saturatioribus; antennis albis fusco-annulatis, articulo basali graciliore olivaceo-griseo, non penicillato. Exp. al. 6 lin.

IIead, face, and palpi olive-grey. Antennx white, annulated with fuscous; the annulations hardly perceptible before the apex; the basal joint rather slender, olive-yrey, not tufted. Anterior wings olive-grey, inclining to dark grey along the inner margin; cilia pale olive-grey. Posterior wings darl grey, with paler cilia.

Two specimens taken by Mr. Allis, of which one is in my own collection.

39. solitariella, Zell. L. E. iv. 397 (1849); Sta.; Dougl. Ent. Trans. ii. n. s. 81 . pl. xi. f. 3 . Alis anticis angustulis, ochreo-flavis, nitidis; ciliis apicis ochreo-llavis, anguli analis salurate griseis; antennis niveis, nigro-annulatis, articulo basali ochrco-flavo non penicillato. Exp. al. $5 \frac{x}{2}$ lin.

Head, face, and palpi ochreous-ycllow. Antenna snowy-white, annulated with black; the basal joint ochrcous-yellow, not tufted. Anterior wings rather narrow, shining, ochreous-yellow; the cilia at the 
apex of the same colour, at the anal angle dark grey. Posterior wings dark grey, with paler cilia.

Not rare among Stellaria holostea; appears in July, but seldom met with in the perfect state; the larva feeds on the leaves of the Stellaria holostea, from November to June, in a whitish cylindrical case, with a darker patch on the back.

40. Iutipennella, Zell. Isis, 1838, p. 713; Dup.?-Zutaren, Sta.; Ilaw.? Step.?-ochroleteella, Step.? Nis anticis ochreo-flavis, grosse squanatis; ciliis apicis ochreo-flavis, anguli analis dilutioribus; antennis albidis, nigro-annulatis, articulo basali ochreo-flavo, non penicillato. Exp. al. 6 lin.

Head, face, and palpi ochreous-yellow. Antenna whitish, annulated with dark fuscous or black; the basal joint pale ochreous-yellow, not tufted. Anterior wings coarsely scaled, ochreous-yellow; cilia at the apex ochrcous-ycllow, paler at the anal angle. Postcrior wings pale grey, with ochreous-grey cilia.

Common among oaks in June and July. The larva fecds in May on the leaves of the onk (and also on the birch), in a straight, nearly cylindrical, yellowish-brown case.

41. badiipennella (F. v. 1R.), Zcll. I. E. iv. 4.01 (18.49); Sta. $\Lambda$ lis anticis salurate ochreo-griseis, costa angusle albida, postice ochrea ; antcunis albis fusco-annulatis, articulo basali robusto ochreo-grisco, non penicillato. Exp. al. $4 \frac{2}{2}$ lin.

Head, face, and palpi pale greyish-ochrcous. Antenna white, annulated with fuscous; the rather short basal joint greyish-ochreous, not tufted. Anterior wings dark greyish-ochureous, the costa narrowly whitish to near the apex, where it runs into the ochreous cilia; cilia of the hinder margin grey. Posterior wings pale grey, with paler cilia.

Not uncommon among elms and ash-trees in June and July. The larva-case is rather short, cylindrical, dark brown, with the mouth turned round nearly at right angles. Mr. Preston once found one of the larva fecding on an ash-leaf early in May.

\section{FAMILY $X$, ELACHISTID}

Capilli lovigati. Palpi labiales tenues, fliformes, acuminati. Alæ anteriores oblonge, vel clongate; posteriores lanceolatx vel linearilanceolate.

Ilead smooth (at least as the rule, Bedellia and Tischerin are exceptions). Labial palpi slender, filiform, mostly recurved and pointed. Anterior wings oblong or clongate; the posterior wings lanccolate or linear-lanceolate. 
The position of the perfect insects in repose is also rather characteristic, for in most of the genera they sit closely appressed to the surface on which they rest.

The individuals of many of the species in this family are extremely numerous, making up for their small size by their greater numbers; some are rather gaily coloured, but the greater proportion are variously shaded with grey or black, varied with white or whitish; in a few the markings are metallic. 'The perfect insects mostly fly at dusk, soine may be met with flying in little swarms in the afternoon; a few are of retired habits and rarely seen on the wing. The larva are most frequently leaf-miners, some few are however external feeders. They have sixteen fect, though in Tischeria the development both of the legs and prolegs is very slight. The pupa is sometimes enclosed in a firm cocoon, sometimes in one of open network, but not unfrequently the pupa is naked, affixed by the cautal extrenity, with a belt of silk round the middle, like some of the RHopalociras; and in Betcllia the similarity is still more striking, the pupa being angulated, and like that of a Pieris in miniature.

The genera of this family represented here are fourteen in number, and may be tabulated in the following way:-

a. Posterior wings extremely narrow, almost setiform.

b. Head rough. 1. BEDELLIA.

$b$ b. Head smooth.

c. Antennx with long slender hairs. 2. STaxmsropoda.

c c. Antennx naked.

d. Basal joint of the antennx long. 3. Cosmopteryx.

$d d$. Basal joint of the antenne short. 4. Batraciedra.

a a. Posterior wings lanceolate or linear-lanceolate.

$e$. Head rough in front. 5. OrNopinila.

$e$ e. Ilead smooth.

f. Anterior wings with projecting tufts of seales from the inner margin. 6. Chauliodus.

$f f . \Lambda$ nterior wings with no projecting tufts from the inner margin. g. Anterior wings with raised tufts on the disc.

h. The tufts not metallic. 7. LAVERNa.

$h h$. The tufts metallic. 8. Cinrsoclista.

$g \mathrm{~g}$. Anterior wings smooth, not retuse below the apex, nor posteriorly appearing from the cilia broader.

i. Labial palpi short and thick. 9. IIELroornes.

$i$ i. Labial palpi slender, of moderate length.

k. Antennæ rather thick. 10. ANYBIA.

$k k$. Antennec slender, $11 . \Lambda$ SYcirNa.

$g g \%$. Anterior wings smooth, the costa slightly retuse. 12. CHRYSOCORYs. 
g g g g. Anterior wings smooth, postcriorly appearing from the cilia bronder. 13. Ela CIISTA.

e e e. Head rough behind. 14. 'T'iscireria.

\section{Genus I. BEDFLLIA.}

Bepeltia, Sta. Cat. p. 23 (1849).

Capilli superne ac in fronte hirsuti, epistomio lavigato. Ocelli nulli. Palpi labiales breviusculi, sulporrecti, acuminati. IIaustellum nudum. Antenna alas anteriores longitudine requantes, tenues, articulo basali clongato, crassiusculo. Ala longe ciliate, anteriorcs angustre, posteriores angustissime; anteriores: cellula discoidalis acuminata, venas duas in costam, venam apicalem furcatam (cujus ramus inferior trifidus), venam unicam in marginem posticum mittit; subdorsalis apex obsoletus; prosteriores : venæ subcostalis ct subdorsalis distinctæ, reliqua obsolctæ.

Ilead above and in front hairy; the face smooth. Ocelli nonc. Labial palpi rather short, almost porrected, pointed. Tongue naked. Antennae as long as the anterior wings, slender, the basal joint elongate and rather thickened. Wings with long cilia, the anterior narrow, the posterior extremely narrow. In the anterior wings the acuminate discoidal cell cmits two vcins to the costa, a furcate apical vein (of which the lower branch is trifid) and a single vein into the linder margin; the apex of the subelorsal vein is obsolete. In the posterior wings the subcostal and subdorsal veins are distinct, the remainder are obsolete.

Only one species is known in this genus, which, though of recent discovery, is ahready ascertained to occur in Sicily, in $\Lambda$ ustria, and in the south of England. The perfect insect reposes with its fore logs drawn in beneath it, and its head but slightly elevated from the surface on which it rests. There are two broods in the year, one in August and the other in October; the latter brood probably hybernates, as Professor Zeller met with the insect in the spring. 'The larva is extremely beantiful, and in motion reminds one of a half-looper Noctuina larva; it mines in the leaves of Conrolvulus arvensis (sometimes, but very rarely, in $C$. Sepium), frequenting only those plants which grow complctely in the shelter of hedges; it makes large whity-brown blotches in the lenves, and is extremely carcful to make its excrement outside its mine, for this purpose retreating to the opening in the leaf, and exserting its anal extremity. The naked angulated pupa is suspended at the jumetion of two or three cross silken threads, or suspended by threads fastened to the two extremitics.

1. somnulentella, Zell. Isis, 18.17. p. 894; Dougl. Ent. Trans. 
ii. 11. s. 208. pl. xvii, f. 1.-Orpheella, Sta. Alis anticis obscure ochreis, fusco-irroratis, dorso dilutiore. Exp. al. $4 \frac{2}{2}$ lin.

IIend greyish-ochrcous. Tiace dark fuscous. Palpi fuscous, terminal joint dirty ochreous. Antenne dark fuscous. Anterior wings dirty ochreous, coarsely irrorated with fuscous, palest along the inner margin; cilia pale grey. Postcrior wing grey, with paler cilia.

Appears in August and Oetober among Convolvulus arvensis, but so retired in liabit that it is rarely seen. The larva mines the leaves of the $C$. arvensis in the beginning of August and middle of Septcmber; sometimes it is very plentiful.

\section{Genus 1I. STATHMOPODA.}

Statmoroda, Zell. (in litt.) Cosmopteryx p., IIüb.; Zcll. Isis, 1839 ; Dup. Cat. Ellachista p., Dup. L. F. xi.

Capilli lievigati, frons obtusa. Antenne corporis longitudine, setacex, articulis elongatis, of tenerrine longe pilose. Palpi labiales longiusculi, loves, tenues, recurvi, acuti, articulo secundo compresso. Ilaustellum breve, squanatum. Tibie postice pilis incrassala, longe spinose. Ale longissime ciliatie, anteriores anguste, posteriores angustissime; anteriores : cellula discoidalis elongata, postice non clausa ; rami quatuor postremi basi libera; venæ mediane rami tres clongati; submediana postice incrassata; suldorsalis simplex; posteriores: vena costalis (?) furcata, ramo altero in costam, altero in marginem posticum exeunte; mediana ramos quatuor in marginem posticum cmittit.

IIead smooth, the forchead obtuse. Antenux as long as the body, setaccous, with elongate joints, in the of will very delicate long hair's. Liblial palpi rather long, smooth, slender, recurved, acute, the seeond joint compressed. Tongue short, elothed with scales. The hinder tibie thickened wilh hairs, with long spines. Wings with very long cilia, the antcrior narrow, the posterior extremcly narrow. In the anterior wings the clongate discoidal cell is not closed posteriorly; the four last branches have the base free; three elongate branches proced from the median vein; the submediun vein is posteriorly thickened; the subdorsal vein is simple. In the posterior wings the costal (?) vein is furcate, one branch running into the costa, and the other into the hinder margin; the median vein emits four branches to the hinder margin.

Only one species is at present known in this genus; it lias long been known abroad (though in this country very rare), yet its preparatory states still are unascertained; the Limnean assertion, "Wabitat in Alni foliis subentanca," not having been confirmed, may be entirely erroneous, like the "Habilat in F'agi foliis 
subcutanea," given for Schefferella, and may therefore only put us on the wrong seent. The perfeet insect in repose extends its hind legs (according to the obscrvations of Limmous and Zeller) in a horizontal direction.

1. pedella, Lin. F. S. $1+33$ (1761),-cylindrella, Tab.-cylindricus, Panz. 1. G. 24-angustipennella, IIüb.; Treit.; Dup. L. F. xi. pl. 309. f. 10. Alis anticis dilute luteis, costa fusca, maculis tribus dorsi fuscis prima basali, secunda ante, tertia pone medium, sccunda tertiaque costan versus linea fusca conjunctis. Exp. al. $4, \frac{1}{2}-5$ lin.

Head, face, and palpi pale yellow. Antennæ pale fuscous. Anterior wings pale yellow, with the costa fuscous, and three fuscous sjots on the inner margin; the first at the base, the second before the middle, and the third beyond the middle; the second and third are united towards the costa by a slender fuscous streak; in the apex is a small fuscous spot; cilia fuscous. Posterior wings fuscous, with paler cilia.

Appears in July, frequenting alders. A specimen taken near Brandon, by Mr. Dunning, is in his collection.

\section{Genus III. COSMOPTERYX.}

Cosmoptery. p., IIüb. v. 424 (1816); Zell.; Dup. Gracillaria p., Haw. Glyphipteryx p., Step.

Capilli levigati, frons valde convexa. Antennx corporis longitudinc, setacex, articulo basali valde longo, clavato, reliquis valde confertis, crassiusculix, nudax. Palpi labiales longinsculi, tenues, recurvi, articuli secundi apice incrassato. Haustellum mediocre, squamatum. Tiljie posticx parum inerassatæ, fasciculate, spinis mediocribus crassiusculis. Ale longissime ciliate, antcriores anguste, posteriores setacere; anteriores: cellula discoidalis clongata, postice non clausa; rami apicales tenues, basi libera; vene mediana rami tres clongati; submediana simplex, juxta subdorsalem furcatain; posteriores : venæ ramique plane obsoleti.

Ifead smooth; the forchead extremely convex. Antenne as long as the body, setaceous, with the basal joint very long and clavale, the remainder very thickly set together, rather thick, without hairs. Labial palpi rather long, slender, reeurved, the apex of the second joint thickened. Tongue moderate, clothed with scales. The hinder tibine slightly thickened, tufted, with modcrately long, rather thick spincs. Wings with very long cilia, the antcrior narrow, the posterior sctaceous. In the anterior wings the elongate discoidal cell is posteriorly not elosed; the slender apieal veins lave the base free; from the median vein three elongate brauches proceed; the simple subnedian vein 
is close to the furcate subdorsal vein. In the posterior wings the and branches are obsolete.

'I'iree species of surpassing beauty constitute this genus, but one of them has not yet been found in Britain. The larvac of none are known; but the larva of Diurella is pretty strongly suspected: it mines in the leaves of the hop in September, when full fed yuitting the leaf and forming a finc white cocoon, within which the larva remains unchanged cluring the winter, hence the perfect insect is difficult to rear. Mr. Douglas had collected a number of these larva in the autumn of 1852 , but many escaped from his breeding cage, and the remainder died; in the following July he found a specimen of the perfect insect on the window of the room where he had kept his larve; subsequently Mr. Wing discovered sume of the perfect insect (not previously known to occur in this locality) by beating the hop-plant, the leaves of which had furnished the mining larva the previous autumn. I therefore conclude that these miners are the larvo of Drurella, but that they are so is not yet proved.

1. Drurella, Fab. S. It. 666. 64 (1775).-Druryella, Zcll. Ent. Ztg. 1850.-Zieglerella, Hüb. Tin. 306; Evers.-eximia, IIaw.; Step. $\Lambda$ lis anticis atris, fascia obliqua argentea prope basim, fascia recta in medio, fasciaque posteriorc obliqua violaceo-argenteis, spatium triangulare saturate aurantium includentibus, strigulis duabus argenteis, altera supra angulum analem, altera in ipso apice. Exp. al. 4 lin.

Ilead dark fuseous, metallic. Face and palpi rather silvery. Antennæ black, with a ring before the apex, and the apex white. Anterior wings black, with an oblique silvery fascia near the base (ncarcst the base on the costa), a nearly straight fascia in the middle, and an oblique fascia beyoud the middle silvery-violet (this last fascia is nearest the base on the inner margin); the triangular space included between these two fascia is decp orange, margined with black; above the anal angle is a short silvery streak, and another is in the cxtreme apex of the blackish cilia. Posterior wings blackish, with paler cilia.

'Truly, as Haworth says, "species formosissima;" it has occurred in some plenty in several localities near London in July; it was reputed to frequent a willow-tree at Hackney, probably because some hops grew in the vicinity.

2. Irienigiella, Zell. Isis, 1816. p. 298; Sta. Mlis anticis $s a-$ turale ochreis, strigulis tribus tenuibus ex basi albo-argenteis, prima costali mox deflexa et ante medium desinente, secunda supra plicam, tertiaque dorsali in medio desinentibus, macula in medio costie albida, punctis quinque plumbeo-argenteis ponc medium in circulo positis, pone hice strigula argenteo-ilba in apice extremo decurrente. Lxp, al. $+4 \frac{2}{2}-5$ lin. 
Ilead dark oclureous, a palc line on each side behind the cyes. Face whitish. Palpi whitish, terminal joint palc fuscous. Antenne clark fuscous. Anterior wings dark ochreous, with three slender silvery white streaks from the base, one along the costa, which is soon deflected, and ceases before the middle of the wing, another runs above the fold, and the third along the inner margin to the middle; in the middle of the costa is a whitish spot, not sharply defined; beyond the middle of the wing are five small leaden-silvery spots placed almost in a circle; beyond them a silvery white streak runs at the apex of the wing through the cilia, separated from the whitish costal cilia by a narrow fuscous streak; cilia of the inner margin pale grey. Posterior wings grey, with paler cilia.

This species, which to my notions is even more elegant than the preceding, occurs in the Cambridgeshire fens in June and July.

\section{Genus IV. BATRACHEDRA.}

Gracillaria p., Haw.; Step. Ornix p., Treit. Cosmoptery.x p., Kcll.

Capilli lavigati; frons angustula, obtusa. Antenna corporis longitudine, setacea, articulo basali brevi, religuis confertis, nude. Palpi labiales mediocres, recurvi, acuti, articulo secundo compresso, subclavato. Ilaustellum mediocre, squamatum. Tibix postice parum incrassatx. Nac longe ciliate, anteriores angustic, posteriores angustissimx, fasciculo coste prope basin; anteriores: cellula discoidalis valde elongata vix clausa; rami apicales attenuati, subobsoleti; medianæ ramus primus brevissimus, obliquıs; submediana simplex; subdorsalis simplex, furea basim versus indicata; posteriores: vena mediana tantum postice distinctior, ramis nullis.

Head smooth; the forehead rather narrow, obtuse. Antennxe as long as the body, setaccous, the bisal joint short, the remainder thickly set together, wilhout huirs. Labial palpi morlerately long, recurved, acute, the sceond joint eompressed, subelavate. 'Iongue of moderate length, elothed with scales. The hinder tibire slightly thickened. Wings with long cilia, the anterior narrow, the posterior extremely narrow, with a tuft projecting from the costa near the base. In the anterior wings the extrencly clongate discoidal cell is liardly closed posteriorly; the attenuated apical veins are almost obsolete; the first branch of the median vein is very short and oblique; the submedian vein is simple; the subdorsal vein is simple, but there are indications of a fork towards the basc. In the posterior wings the median vein is only more distinct posteriorly, wilh no branches.

Only two species are at present known in this genus : one, preangusta, is very common among willows and poplars in July, and 
may frequently be observed sitting on the trunks of those trees with the anterior feet put back, like Bedellia, not forwards like Gracilariu, and the liead a little raiscd; the larva has been observed by Lienig, who records it as feeding between united aspenleaves. Of the larva of pinicolella we have no record, in spite of Duponchel's amusing remarks (Cat. 374.), "that Fischer de Röslerstamm had written him word that the larva of pinicolella lived in the catkins of the poplar, but that it appeared, from $a$ case placed in his collection, beside that of pinicolella, these larvo lived in moveable cases like those of the genus Coleophora."

1. proangusta, Haw. L. B. 530 (1829); Step.-Uurdipennella, Trcit.; 1)up. L. F. xi. pl. 310. f. 7; Zell.; Licnig. Nlis anticis cxalbidis, fusco-varicgatis, basi juxta costam pallila, lincolis duabus nigris osseo-cinctis, priore plicx ante medium, altera disci pone medium. Exp. al. 7 lin.

Head and face dirty-whitish. Palpi dirty-whitish, the last joint with two dark fuscous rings. Antenne fuscous annulated with whitish. Anterior wings dirty-whitish, varied with fuscons, only the basal portion of the wing towards the costa remaining of the palc groundcolour; on the fold before the middle is a short black line surrounded by the pale ground-colour, and a similar ocellated mark lies midway between this and the apex of the wing; cilin grey. Posterior wings grey, with paler cilia.

Common in July on the stems of willows and poplars; the larva (according to Licnig) in May between united poplar leaves.

2. pinicolella (\%cll.), Dup. L. F. xi. 579. pl. 310. f. 13 (1833); Zcll.; Sta. Alis anticis ochreis, squamis sparsis fuscis, costa fusca praecipue apicen versus, puncto prope angulum analem fusco. Exp. al. 5-6 lin.

IIead pale ochreous, tinged with bronze. Face whitish. Palpi whitish, terminal joint fuscous. Antenue palc fuscous, with darker nnnulations. Anterior wings ochrcons, with seattered fuscous scales; the costa dark fuscous, especially towards the apex; near the anal angle is a small fuscous spot; cilia dark fuscous. Posterior wings pale grey, with palcr cilia.

Among fir-trees in June and July; has occurred at West Wickham, at Dartford Heath, and at Weybridge.

\section{Genus V. OINOPHILA.}

Oinopius, Step. Ent. Trans. V. proc. xli. (191\$). Gracillaria p., IIaw.; Step.

Capilli in fronte hirsuli, superue licvigati, epistomio lavigato. Ocelli 
nulli. Palpi labiales brevinseuli, subporrecti, articulo secunclo setis paucis instructo, articulo tertio subacuto. IIaustellum breve. $\Lambda \mathrm{n}$ temne alas anteriores longitudine fere xquantes, tenues. Tibix postice valde pilose. Alec longe ciliatie, anteriores anguste, subcendale, posteriores lanceolatie. Anteriores : vena subcostalis basim versus obsoleta, cellula discoidalis imperfecte clausa, venas quatuor in costam mittit, unam in marginem posticum, subdorsalis simplex; posteriores: venæ subcostalis et subdorsalis basim versus indicatix, rami obsoleti.

IIead hairy in front; the top of the head and the face smooth. Ocelli none. Labial palpi rather short, slightly porrected; the second joint provided with a fero bristles; the terminal joint almost acute. Tongue short. Anteme slender, nearly as long as the anterior wings. IInder tibie very hairy. Wings with long cilia, the anterior narrow, subcaudate, the posterior lanceolate. In the anterior wings the subcostal vein is obsolete towards the base, the imperfectly closed discoidal cell sends four veins to the costa, one to the linder margin; the subdorsal vein is simple; in the posterior wings there are indications of the subeostal and subdorsal veins towards the base, but their branches are obsolete.

Only one species of this genus is known; it inhabits winevaults and wine-cellars. The larva has been reputed to fecd on the fungus which grows in wine-vaults, and also on the corks in the bottles; but further investigations are still wanted fully to elucidate the natural history of this singular insect.

1. V-flava, ILaw. L. B. 530 (1829); Step. Alis anticis fuscis, fascia angulata in medio, angulo ipso apicem versus producto, naculis posticis oppositis stepe in fasciam conjunctis, flavidis. Exp. al. 4-5 lin.

Ilead fuscous; the frontal tuft dirty-ochreous. Face and palpi

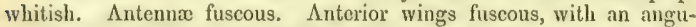
lated yellow fascia in the middle, the angulation being towards the apex of the wing and somewhat produced; on the costa towarls the apex is a yellow spot, and a smaller one on the inner margin rather anterior is sometimes united to it, forming a fascia ; cilia grey, with some yellow seales immediately below the apex of the wing. Posterior wings pale grey, with yellowish-grey cilia.

Occurs in winc-vaults and winc-cellars in July and August.

\section{Genus VI. CHAULIODUS.}

Cirnumonus, Treit. T. S. ix. 2. 31 (1833); Dup. Jophonolus, Step. Elachista p., Zcll. Epermeniu, Calolripis p., et Trichotripis p., ILüb.

Capilli leves, frons obtusa. Antemne abrlomine longiores, setacese, articulis breviusculis (basali brevi) confertis, breviler pilosa. Palpi 
labiales mediocres, crassiusculi, recurvi, articulo secundo subclavato, terminali multo breviore, subacuto. IIaustellum breve, mulum. Alie longe ciliate, interiores elongate, in dorso squemato-dentate, posteriores lanceolate; anteriores: cellula secundaria indicula; vena apicalis furcata supra et infra apicem exit, infra cam rami quinque; submediana simplex; vena subdorsalis brevis, furca subobsoleta ; posteriores: cellula costalis valde angustata : cellula mediana clausa in costam unicam, in marginem postienm quinque venas emittit, inter se non connexas.

Ilcad smooth; the forchead obtuse. Antemne longer than the abdomen, setaccous, with rather short, closely set joints (the basal joint short), with short hairs. Labial palpi of morlerate length, rather thick, recurved; the second joint subclavate; the terminal joint much shorter, rather acute. Tongue short and naked. Wings with lone cilia, the anterior clongate, with tooth-like projections of scales on the inner margin, the posterior lanecolate. In the anterior wings the secondary ecll is indicaled; the fureate apical vein terminates above and below the apex, below it are five veins; the submedian vein is simple; the suldorsal short, with a rather obsolete fork; in the posterior wings the costal cell is extremely narrow, the closed median call emits one vein to the costa and five separate veins to the hinder margin.

Of this genus we have three species; several others are known to occur on the contincnt. (One of our species, insceurellus, shors a slight discrepancy in the ncuration of the wings; the apical vein of the anterior wings being simple, and below it are six veins; the apex of the submedian is also thiclienerl.) Little is known of the habits of any of the species except Cherophyllellus; this is double-brooted, tho larva feeding at the end of June and begimning of July, and in September, on several species of $U_{m}$. bellifere; they generally occur in companies of rarely less than ten on a plant, sometimes as many as fifty; when very young the larva mine the leaves, but when more fully grown they come from within the cuticles, and devour the lower half of the leal", the upper portion consequently becomes discoloured and furns brown. The larva spin a number of small threads about the plant on which they feed, and these threads are covered with a glutinons secretion which collects in minute globules, reminding one, as De Geer expressed it, of a spider's web in a fog. When the larva is full-fed it spins an open network cocoon and changes therein to at pupa. The perfect insect appears towards the end of July aud begiming of $\Lambda$ ugust, and in Oetober; the latter brood is far the most numerous, but the specimens are more retired in habit, and are rarely met with till the spring, after lybermation, and of course in wisted condition. The perfect insects of the summer brood may sometimes be met with flying on calm evenings, with VoL. III. 
a rather wavy flight. Of the other species of the genus we are not aware of more than one brood, though by amalogy a hybernating antumnal brood is extremely probable. The larva of $1 / l i$ gerellus (according to Fischer's observations in 'Treitschke) differs considerably in liabit, fecling simgly on Alyoportium Podagraria between several leaves drawn together.

1. insecurellus, Sta. Cat. p. 2.1. (1849).-Illigerellus, Sta. Zool. 18.18. Alis anticis obsewe albidis, prostice fusco et ustulato suffusis fascia in medio ustriata, prope costam fusca, maculis duabus dorsi, una disci, una costa albidis, macula disci puncto nigro applieata, fasciculis tribus nigro-squamatis c dorso prominulis. Exp. al. 4\% lin.

Ilead and fice dirty-erey. P'alpi grey. Antema fuscous. Anterior wings dirly-rethitish, with a tawny fusein in the midlle, darkest on the costa; beyond which the wing is mneh suflused with tawny and fuscous, leaving only two spots on the inner margin, one on the dise and one on the costa of the whitish ground-colour; immediately below the sjot on the dise is a black dot; the basal portion of the wing is much suffused with grey, and two or threc darker spots are sometines conspicuous; three tufts of black seales project from the inner margin; cilia greyish-tawny. Posterior wings grey, with paler cilia.

Ilas occurred sparingly on the downs beyond Croydon (at Stoat's-nest), at the end of July and begimning of August.

2. Illigerellus, Iliib. Tin. 333 (1816); 'Treit.; Dup. L. T. xi. pl. 294. f. 1.-falciformis, Haw.; Step.; Curt. Nis anticis dilute ochereis, fusco irregnlariter variegatis, striga obliqua prope basim a dor'so ferc at costam, striga fuscirformi anle medium ante costan curvata et ramulum in angulum analem emiltente, apiecque fuscis, punctis dnobus nigris in disco, fasciculis duobus nigro-scuuanatis e dorso prominulis. Exp. al. 6 lin.

Head and face ochreous. Palpi ochrcous; the third joint with a broad fuscous ring. Antenne greyish-fuscous. Anterior wings pale ocheous, irregularly varied with fuscous; a dark streak extends obliquely from the inner margin near the base more than half across towards the costa; before the middle is a fuscous fascieform streati curved and capanded on the costa, and emilling a branch to the anat angle; there is also a fuscous blotch on the apex of the wing; on the disc are two black spots, one before, the other beyond the middle; from the inner wargin project two tufts of black seales; cilia fuscous, variced with ochreous, and having a decidedly falcate appearance. P'osterior wings fuscous, with paler cilia.

Appears in July; the larva fecling (according to Fischer) on Aigopodinm P'orlagiariu in May. IIas occurred in several localities near Hastings, Brighton, in the Cambridgeshire fens, etc.

3. Chærophyllellus, (ioize, E. B. iii. \$. 169. 292 (1783).--lestaceellu, Hrïb.; Yell.; Dup.-fasciculellus, Step. pl. 39. f. 1. Alis an- 
ticis saturate fuscis, oclurco-vuricgatis, squamis sparsis albis, macula prope costam ante apicem albida (vel alis anticis usque ad medium albidlis, fascia latit fusca pone medium, macula costic ante apjicem albicla), fisciculis tribus ustulatis seu fuscis c dorso prominulis. Wxp. al. 6 lin.

Ilead and face dark grey. Palpi grey; the end of the third joint ochreous. Antenne dark fuscous, \ntcrior wings dark fuscous, varied with ochrcous, with seattered white scales; near the costa before the apex is a conspicuous whitish spot (or anterior wings with the basal lalf cutirely whitish or dirty-yellowish, beyond which is a broad fuscous fiscii, followed by tawny towards the costa, the white spot before the apex occurring as in the (lark variety); from the inner margin project three tufts of tawny or fuseous seales; cilia dark fuscous, with a light spot below the apex. Posterior wings grey, with paler cilia.

Appears in July and August, and October, lyybernated specimens occurring in spring; it frequents Umbellifere among hedges. The larva feeds at the eud of Jume and beginning of September on various Unbellifere; I have found it on Anthrisens syluestris, Torilis Anthriscus, Sison Amonum, IIcracleum Sphondylium, and Angelica sylvestris.

\section{Genus VII. IAVERNA.}

\section{Laverna p., Curt. 13. W. fo. 735 (1839). Elachisla 1., Zell.; Dup.}

Capilli leves, frons obtusa. Antenna abdomine longiores, setacea, articulo batsali elongato, clavato, crissiuseulie. T'alpi labiales mediocres, recurvi, articulo secundo apicem versus laxe squamato, subclavato, tertio breviore acnto. II auslellum mediocre, paree squamatum. $\Lambda$ lie longissime riliata, anteriores inberculuto-squamater, tuberculis non metallicis, dorso non dentato; posteriores lineari-lanceolatse.

Head smooth; the forehead obtuse. Antemia longer thin the abdomen, setaccous, rather thick, with the basal joint clongate, clarate. Labial palpi moderately long, recurved; the second joint subclavate, towards the.apex looscly scaled; the thitd joint shorter', acute. 'Tongue of moderate lengih, sparingly sealed. Wings with very long cilia, the anterior with luifls of scules, the tufts not wetullic, the immer margin without projecting tufts; the posterior wings linear-lanceolate.

The limits of this and several of the following genera are by no means satisfactorily settled. The present gemus admits of being readily divided into three groups.

A. Anterior wings with a distinct pale costal spot; the fureate apical vein runs into the costa before the apex; betow it fiee veins procecd to the hinder margin; the subdorsal vein furcate at each end, the basal fork lorg, the apicul fork slorter. 'This singular appearance no doubt arise's from the thickened apex of the submedian rein be- 
coming confluent with the subdorsal. In the posterior wings five veins proceed from the discoidal cell to the hinder margin, one to the costa. Species 1-4.

(In species 4, Slephensi, the second joint of the palpi can searcely be called loosely scaled.)

B. The pale costal spot of the anterior wings obsolete; the tufts of seales extremcly small; the apex of the subilorsal vein simple, the thickened apex of the submedian not connected with it. Specics $5-9$.

(In species 6, ochraceella, the apex of the subdorsal vein is fureate, as in section A. I place species 7, Phargmitelln, here, though 1 had previously made a distinct genus of it, Limnocia: it accords well with ochraceclla, only cxaggerating the peculiarities from its larger size.)

c. The anterior wings with no pale costal spot; below the furcate apieal rein three reins rum into the hinder margin; the subdorsal vein only furcate at the base; the submedian not thickened. Sp. 10, 11. Many of the species of this genus are very beautiful, the anterior wings being frequently of varied colours, and the tufts on them give them, when seen at rest, a singular appearance; the perfect insects are rather sluggish, and some are consecpuently rarely met with; some which only appear towards the ent of the summer, such as Fipilotiella, are more frequently met with in the spring after liybermation. Most of the species have probably only one brood, but Steintoni is double-brooded. The few known larve are citlier leaf-miners, or feed in the terminal shoots of plants.

1. propinquella, Sta. Sup. Cat. p. 8 (1851): Alis anticis crrulco-fuscis, ochracco marmoratis, macula dorsi basali fere costam tangente, fuscinque obliqua postien interrupta albis, maculis tuberculatis nigris, tribus plica, tribus disci; capite cum fronte albo, palpis albis, articuli tertii annulo ante apicem fusco. Exp. al. 6 lin.

Head and fice white. Palpi white, the terminal joint with a fuscous ring before the apex. Antemne fuscous. Anterior wings bluish-fuscous, marbled with ochrcous; a large basal spot which is expanded on the inner margin and almost touches the costa, and an interrupted oblique hinder fascia, are schite; a slender white streak arises in the middle of the costa, and after passing under a round black spot on the dise, runs into the white fascia, which is interrupted in its middle by a grey and a tawny spot; threc tufts of black seales lie on the fold, and three others above them; cilia tawny fuscous. Postcrior wings fuscous, with paler cilia.

Ifas occurred in various localities at Deal, Fulham, near Bristol, in the south of Scotland, and in the Cambridgeshire fens in July; but nowhere coinmon.

2. lacteella, Step. H. iv. 210 (1834).-gibliferella, Zell.; Lienig. 
$\Lambda$ lis anticis corulco-fuscis, ochracco-marmoratis, macula dorsi basali, maculis oppositis ante apicm dilute ochraceis, albidise, maculis tuberculatis nigris, tribus plica, tribus disci; capite cum fronte dilute ochreo, palpis dilute ochreis, articuli tertii annulis duobus fuscis. Exp. al. 5 lin.

IIcad and face pale ochreous. Palpi pale ochreous, the last joint with tico fuscous rings. Antenna fuscous. Auterior wings bluishfuscous, tinged with ochreous towards the inner margin, with a large spot on the inner margrin at the base, and two opposite spots towards the apex, pale ochreous or whitish; near the middle of the costa are a few whitish seales, and others are scattered over the dise and towards the apex; three tufts of black seales lie along the fold and three others above them; cilia greyish-fuscous. Posterior wings fuscous, with paler cilia.

Occurs in various localitics in June and July, more commonly than the preceding; I have fancied it was attached to the sallow.

3. Staintoni, Sircom, Zool. 1848. p. 2038.-miscella, W. V.P; Ifüb. 'lin. 273? Alis anticis yriscis, ustulato varicgatis, maculis duabus prope costam luteis, prima in medio, secumla ante apicem, maculis duabus prope dorsum tubereulatis, atris; capite griseo, fronte argenteogrisea, palpis griseis. Exp. al. $3-4 \frac{1}{2}$ lin.

Head grey. Tiace silvery grey. Palpi grey. Antennw grey. Anterior wings grey, varied with tawny, with two yellowish spots towards the costa, onc in the middle, the otlier near the apex, and with two tufts of black seales near the inner margin; cilia grcy. Posterior wings grey, with paler cilia.

Common on many of the chalk downs of the south of England, among Ilelianthemum vulgare in May and Junc, and I believe again in August. The fat rather short larva mines the leaves of the Helianthemum in March and April, moving successively from leaf to leaf' as it finds occasion, and quitting the leaf before changing to the pupa state. I imagine there is a second brood of the larva in July.

4. Stephensi, Sta. Cat. p. 24 (18/9). Alis anticis albis, maculis tribus costie griseis, prima basali oblonga, sceunda pone modium, tertia apicali, sceunda tertiaque stria ustulata connexis, maculis duabus prope dorsum tuberculatis atris; capite cum fronte albo, palpis albis, articuli secundi apice, articuli tertii annulo ante apicem nigris. Exp. al. \& liu.

IIead and face white. Palpi while; the end of the sceond joint, and a ring before the apex of the terminal joint, black. Antenna fuscous, anmulated with white. Anterior wings while, with three rrey blotehes along the costa, the first reaching nearly to the middle, the sceoud lying beyond the middle, and the third in the apex; the second and third are united by a tawny streak on the dise; near the inner margin are two tufts of black scales, the first before the middle, the sccond 
towards the anal angle; cilia grey. Posterior wings pale grey, with paler cilia.

$\Lambda$ few specimens of this pretty species were taken by $\mathrm{Mr}$. 13ouchard in Ilamault Forest, among old hawthorm-bushics, in August.

5. Epilobiella, Schr. F. B. ii. 126. 1853 (1S02); Bouché; Treit.; F. v. IR. pl. 73. pl. 74. f. 1.; W. V.? Dup.?-fitvescens, IIaw.; Step.-nebulellu, Step. Alis anticis dilute ochere, fusco-nebulosis, procipue sub costam et apicem versus, maculis posticis oppositis dilutioribus, maculis duabus tubcrculatis fuscis, prima dorsi ante, secunda plicie pone medium. Exp. al. $5 \frac{2}{2}$ lin.

Ilead and face ochroous. Palpi ochreous, the terminal joint with two fuscous rings. Autenne fuscous. Anterior wings pale ochreous, clouted wilk fuscons, especially along the costa and towarls the apex, with an appearance of two paler opposite spots before the apex, and with two tufts of fuscous seales, the first near the imer margin before the midlle, the second in the fold beyond the middle; cilia greyishochrcous. P'osterior wings grey, with paler cilia.

$\Lambda$ plears in August among Epilobium hirsutum, but more frequenily met with after lybernation in May. The larva is abundant in the tops of the Ejpilobintm in Jume and July, serewing up the unexpanded flower- and lenf-buds.

6. ochraceella, Curt. B. E. fo. 735 (1839).-clandestinella, Schr.? Alis anticis angustulis dilute lutcis, sulurate luleo valde suffusis. Exp. al. 7 lin.

IIead, face, and palpi pale yellow. Antenne pale vellow, with pale fuscous aunulations. Anterior wings ralher narrow, jale yellow, wueh sul|jised will dork yellow, so that the pale colour appears on the darker ground as indistinct spots, of which two are on the inner margin and one near the costa, before the middle, and two smaller ones are towards the costa beyond the middlle; cilia yellowish. l'osterior wings pale whitish-grey, with very pale ochreous cilia.

'This beantiful insect had been taken in several loenlitics in June, in moist places, but was considered a rarity, till last summer Mr. Charles Jordan was so fortunate as to discover the larva in May, mining the leaves of the Epilobium hirsulum; and on our ascertaining, from breeding a specinen, the value of the newly found larve, we were esabled to collect a comsiderable number of the pupa, on the leaves of the Ejpilotium, in their clongate, rather firm, pale buff cocoons.

7. Phragmitella (Bentlcy), Sta. Sup. Cat. p. 4. (18ól), Mlis anticis dilute ochreis, stria disci postica fusere, in unu puncla dua sa-

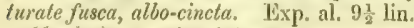

Ilead, face, and palpi pale ochreous. Antenna palc ochreous, an- 
nulated with fuscous. Antcrior wings pale ochrcous, with a fuscons streak on the disc posteriorly, in which are tro dark fuscons spols encircled with white, one in the middle and the other beyond the middle; cilia palc greyish-ochrcous. P'osterior wings pale grey, with paler cilia.

'T'wo specimens, in rather wasted condition, have been taken in marshy places in July; one is in Mr. Shepherd's, the other in Mr. Stevens' collection.

8. decorella, Step. II. iv. 213 (183\%). Alis anticis fuscis, dorso late usque pone medium, fasciaque oblirua postica albis, macula majore

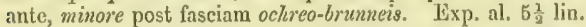

Head grey. Face white. Palpi white, the last joint with a ring, and the apex fuscous. Antennx fuscous. Anterior wings fuscous, with the inner margin broadly white to beyond the middle, and with an oblique white fiscia before the apex; a tawny blotch lics ou the dise before the fascia, and beyond the fiscia is a smaller tawny bloteh ; cilin grey. Posterior wings fuscous, with paler cilia.

Oecurs in many localities at the end of autumn, hybernated specinens occurring in the spring; like some other lybernating species, it is not unfrequently found in houses and out-houses.

9. subbistrigella, IIaw. L. 13. 581 (1829).-sturnipennella, Treit.; Zcll. $\Lambda$ lis anticis fuscis, macula obsoleta dituliore dorsi prope basim, inacula triangulari albida ante medium dorsi, costam tangrente, fascia postica obliqua alba subinterrupta. Exp. al. $5_{\frac{1}{2}}^{1}$ lin.

IIead grey. Face white. Palpi white, the last joint with a ring, and the tip fuscous. Antenma fuscous. Anterior wings fuscous, will an obscure pales' spot on the inner margin near the basp, a large triangular whitish spot on the immer margin before the middle reaching to the costa, and beyond the middle with an oblique white fascia, almost intermpted; cilia greyish-fuscous. Posterior wings fuscous, with paler cilia.

I met with this among sallows, at Chudleigh, in June; it has also occurred in other localities, but having been reputed a variety of decorella, its habits have been little noticed.

10. atra, Haw. I. B. 553 (1829); Step.; Curt--IIellerella, D) . L. F. xi. p. 293. f. 11.-putripennella, Zell. Alis anticis nigris, dorso sinuate albo, fascia alba postica, ramos cmittcutc, unum antice, duos postice, apicem nigrum in maculas tres dividentes, maculis duabus tuberculitis atris, prima plice in mecho, altera supra angulum analem (alis anticis sæepe ommino nigris). Exp. al. 6 lin.

Ilead and face white, with a few grey scales. Palpi white, the end of the sccond joint, and a ring before tho apex of the terminal joint, fuscous. Antemie fuscous, with paler anmulations. Anterior wings black, the imner margin white to beyond the midclle, where an irregular oblique white fascia procceds towarls tho apex; the black forming a blotch along the costa, very narrow at the base, but expanding towards 
the middle, where it nearly reaches the inner margin (towards the inner margin it is much tinged with tawny); it is indented by a short white streak from the oblique hinder fascia; the black apical portion of the wing is divided into three nearly equal portions by two branches from the white faseia; there are two tufts of black seales, one on the fold near the middle, the other above the anal angle; cilit grey. (In some specimens the anterior wings are almost entirely suffused with black, and the head, fice, and palpi are also darker.) l'osterior wings grey, with paler cilia.

Not scarce in June among white-thorn; the dark varicty appears exclusively attached to the apple, it is possible it may be a distinct species.

11. Rhamniella, 7sll. Isis, 1839. p. 211.-lophyrella, Dougl. Zool. 1846. p. 1270. f. 9. Alis anticis fuscis, ochreo-variegatis, maculis quatuor tuberculatis nigris, prima pliere prope basim, sceunda costa ante medium, tertia dorsi medii, quarta supra angulum analem. Exp. al. $5 \frac{1}{3}$ lin.

IIead and face grey. Palpi grey, terminal joint fuscous. Antenna fuscous, annulated with whitish. Anterior wings fuscous, mixed with ochreous, with four tufts of black seales, one in the fold near the base, the second on the costa before the middle, the third in the middle of the inner margin, and the fourth above the anal angle; cilia grey. Posterior wings grey, with paler cilia.

Hitherto scarce; lias occurred at Sanderstead and Box 1lill, among buckthorn, in July.

\section{Genus VIII, CHRYSOCLISTA.}

Ecophora p., Lat. G. C. and I. iv. 222, 180\%. Glyphiptery. p., Curt.; Step. Tinea p., IIaw. Elachista p., Zell.; Dup.

Capilli levigati, frons obtusa. Antenne setacese, corporis fere longitudinc, articulo basali longiusculo, clavato. T'alpi labiales necliocres, recurvi, graciles, articulo secundo compresso, tertio tenuiore acuto. Ilaustellum medioere, squamatum. Ala longissine ciliate, anteriores clongate, tuberculis metallicis ornatre, posteriores lanccolatic, angulo anali distincto; anteriores: cellula discoidalis postice dilatala, imperfecte clausa, cellula secundaria indicale; vena apicalis bifida, infra ean renæe quatuor; subelorsalis in basi anguste fureati, in apice subbifida; submediana simplex; posteriores: vena mediana trifida; vena discoidalis ramos duos in marginem posticun mittit; vena apicalis simplex.

Head smooth, the forchead obtuse. Antenne setaccous, almost the length of the body, the basal joint rather loug, clavate. Labial palpi of moderate length, recurved, slender, the second joint compressed, 
the terminal joint thinner, acute. Tongue of moderate length, clothed with scales. Wingrs with very long cilia, the anterior elongate, adorned with melallic tufts, the posterior lanceolate, with a distinct anal angle. In the anterior wings the discoidal cell is posteriorly dilated, imperfectly closed; the secondary cell is indicated; the apical vein is furcate, and below it are four veins; the sublorsal has a narrow fork at the base, and at its apex has rather a tendency to become furente; the submedian is not thickened; in the posterior wings the median vein is trifid, the discoidal vein sends two branches to the hinder margin, the apical vein is simple.

The species of this genus do not exhibit an entire accordance : in Limneella the apex of the subdorsal vein of the anterior wings is quite simple; Schranliclla has no anal angle to the posterior wings, and in this, as also in flavicapnt, the apical vein of the posterior wings is connected with the discoidal. Jlutionpul is besides destitute of the metallic tufts of the anterior wings.

The perfect insect of Linneclla is rarely seen on the wing, generally resting on the trunks of lime-trees; flavicamel flies frecly in the afternoon along hawthorn hedgres. The larva of tinneclla feeds on the inner bark of the lime during the winter and spring (as observed by Mr. Boyd and Mr. Wing last year); it has the third and fourth scgments somewhat enlarged. The larva of Sehrantiella, discovered by Mr. Scott, mines the leaves of the Epilobium alsinefolium in May.

The species may be tabulated as follows:-

a. Anterior wings orange and black.

b. Yostcrior wings with distinct anal angle. Species 1, 2.

b b. Postcrior wings with no anal angle. Species 3.

a $a$. Anterior wings entirely black. Species 4 .

1. Linneella, Clerck, I. pl. xii. f. 8 (1759); Tinn.; Fab.; Iat.; Curt. 13. I. fo. 152 ; Step.; Dup.; F. v. li. pl. 88. f. 2.-Linnoella, /ell. Alis anticis saturate aurantiis, basi, costa, dorsoque anguste, apice late nigris, punctis tribus tuberculatis argenteo-nigris, primo subdorsali ante medium, sccundo in medio subcostali, tertio plica supra angulum analem. Exp. al. 5e lin.

Heat and face shining black. Palpi whitish, the terminal joint black. Antenne black, with white tips. Anterior wings deep orange, with the base, costa, and immer margin narrowly black, and the apex broadly black, thus leaving a longish elliptic patch of the groundcolour, into which a short black dash runs from the base above the fold; along the costa and at the apex are numerous silvery scales; there are threc round tufts of black and silvery seales, the first near the inner margin before the middle, the sccond vear the costa in the milldle, the third in the fold towards the anal angle; cilia blackish.

VOL. III. 
Postcrior wings blackish-purple, with blackish cilia. ( $\Lambda$ varicty occurs with the orange of the anterior wings replaced by fuscous.)

Abundant in July and August, on the trunks of limes in St. James's Park, and in many of the suburbs of 1,ondon; the larva feeds under the bark of the lime, during the winter and spring. Specimens of the fuscous variety are in Mr. Shepherd's collection.

2. bimaculella, Haw. L. B. 575 (1829); Step.; Sta. Alis anticis nigris, macula oblonga prope basim supra plicam, macula majore irregulari pone medium a plica ad costam fere extensa, apice suo costam tangente, aurantiis, macula sccunda punctis duobus tuberculatis argenteo-nigris interne narginata, puncto tertio supra plicau prope angulum analem. Exp. al. $5 \frac{2}{2}$ lin.

IIcad and face shining black. Palpi whitish. Antennæ black, with white tips. Anterior wings black, with an oblong orange spot ncar the base, above the fold, and a larger irregular one beyond the middle, extending from the fold to near the costa, its apex running into the costa; on the margin of this spot, towards the base, are two silveryblack tufts, and a similar tuft above the fold projects into the orange blotch in the middle of its length; cilia blackish. Posterior wings blackish-purple, with blackish cilia.

Mr. Desvignes beat a specimen from a sallow at Black Park, at the end of June; Mr. Doubleday has also a specineu taken near London.

3. Schrankella, IIüb. Tin. 264. 1812 ; Schr.?-locupletella, F. v. R. pl. 88 . f. 3 ; W. V.? Alis anticis aurantiis, basi apiceque nigris, ipsa basi argentca, fascia obliqua ante medium argentco-grisea, macula nigra dorsi medii in maculam transversalem argentco-griseam excunte, macula costa media argenteo-grisea, maculib parva costali

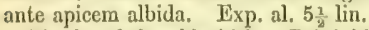

Hend and face blackish. Palpi black. Antenne black, with white tips. Anterior wings bright orange, with the base and apex black; the extreme base rather silvery; the black at the base extends furthest along the costa, and from it is a silvery-grcy fascia, which runs obliquely into a black spot on the middle of the imner margin, and from the hinder end of this black spot a silvery-nrey bloteh procecds towards the costa; on the costa about the middle is a silvery-grey spot, and a sinall whitish spot immediately before the black apex; cilia blackish. Posterior wings dark fuscous, with paler cilia.

Appears in July among Eprilobium alsinefulium; occurs near Renfrew, and has been taken in Devonshire and Sussex. The larva feeds in May, minimg the leaves of the Fipilobium.

4. flavicaput, IIaw. L. B. 536 (1839); Step.-anrifrontella, IIüh. 'Tin. 469? $\Lambda$ lis anticis nigris, tubcrculis duobus nigris, uno in medio plice, altero pone medium; capite, apicibusque palporum flavis. Exp. al. 6-7 lin. 
IIcad and face bright yelloro. Palpi at the base black, the tip bright yellow. Anterior wings black, with a tuft of black scales in the middle of the fold, and a smaller tuft on the disc beyond the middle; cilia black. Posterior wings dark grey, with paler cilia.

Common in June among hawthorn.

\section{Genus IX. HELIODINES.}

IIelonines, n. g. Chrysoesthia p., IIüb. Gicophora p., Trcit.; Dup. Elactista p., Zell.

Capilli levigati, frons obtusa. Antennac setacen, corporis fere longitudine, articulo basali brevi, clavato. Palpi labiales parvi, crassiusculi, acuminati. Haustellum mediocre. Abdomen crassiusculum, breve. Ala longissime ciliate, anteriores elongate, melallice maculater, posteriores lineari-lanceolate; anteriores: cellula discoidalis postice dilatata, vix clausa; cellula secundaria mulla; vena apicalis furcata, ramo altero in apicem, altero in marginem posticum cxcunte, infra carn vene quatuor; subdorsalis simplex; submediana non ircrassata; posteriores: vena mediana trifida; vena discoidalis simplex; vena apicalis simplex.

Head smooth, the forchead obtuse. Antenna setaceous, almost as long as the body, the basal joint short, clavate. I abial palpi small, rather thich, acuminate. Tongue of moderate length. Abdomen rather thick, short. Wings with very long cilia, the anterior elongate, with metallic spots, the posterior linear-lanceolate. In the anterior wings the discoidal cell is expanded posteriorly, and hardly closed; there is no secondary ecll; the furcate apical vein terminates in the apex and in the hinder margin, below it are four veins; the subdorsal is simple; the submedian not thickened; in the posterior wings the median vein is trifid, the discoidal vein is simple, and the apical vein is simple.

'This genus only contains a single species, of which no specimens have been taken in this comiry for probably the last thirty years. According to the observations of I'ischer and IIeeger, the larve feed in June, rather gregariously, on Chcnopodium, Atriplex, etc., drawing several leaves together by a number of silken threads; the perfect insect appears in July, and is frequently again met with in May after hybernation.

It is hardly necessary to add that the Limean habitat, "in Mali foliis subcutance," is founded on a misconception that I)e. Geer's figure of a Lithocolletis, to which he refers, represents this insect; subsequent authors have copicd Limmeus in indicating apple as the food of the larva, without verifying his obscrvation, or noticing the evident cause of his error. 
1. Roesella, Linn. T. S. 1406 (1761); Tab.; IHüb. Tin. 399, 400; Ilaw.; Treit.; Step.; I)up.; Hecger (Isis, 18+8). Nlis anticis aurantiis, macula oblonga basali prope costam, fascia angulata ante mediun, maculis tribus parvis costic, una majore dorsi, argenteis, fiscia interne nigro-marginata, dorso costaque inter maculas nigro-squamatis. Exp. al. 5 lin.

Ilead and face metallic, dark fuscous. Palpi whitish. Antennæe dark fuscous, the extreme tips whitish. Anterior wings bright orange, with an oblong silvery spot at the base near the costa, and with a silvery slightly angulated faseia before the middle, internally margined with black; on the costa are three equidistant silvery spots, gradually diminishing in size, and nearly opposite the second is a larger silvery spot on the inner margin; along the inner margin and costa, between the spots, are some black seales; cilia fuscous, preceded by a few silvery scales. Postcrior wings fuscous, with paler cilia.

Old specimens of this insect are in the collections of $\mathrm{Mr}$. Ingall, Mr. Allis, and the British Museum.

\section{Genus X. ANYBIA.}

\section{ANrBia, n. g. Elachista p., Zell.}

Capilli lreves, frons obtusa. Antenna abdomine longiores, setacex, articulo basali elongato, clavato, crassiuscula. laalpi labiales mediocres, recurvi, articulo sceundo compresso, subchavato, tertio breviore acuto. Haustellum mediocre. Alæ longissime ciliatæ, anteriores leves, dorso non dentato, posteriores lineari-lanceolatie; anteriores: vena apicalis furcata, infra cam vente quinque in maxginem posticum exeuntes; vena subdorsalis in bisi longe furcata, in apice non longe distat ab apice submcdiante incrassato; posteriores : e cellula discoidali venx quinque subobsolete in marginem posticum exeunt, in costam una.

1lead smooth, the forchead obtusc. Anteune longer than the abdomen, setaccous, rather thick, the basal joint elongate, clavate. Labial palpi of moderate length, recurved, the second joint compressed, subclavate, the third joint shorter, pointed. Tongue of moderate length. Wings with very long cilia, the anterior smoolh, with no projections from the inner margin; the posterior linear-lanceolatc. In the anterior wings the apical vein is furcate, below it five veins run into the hinder margin; the subdorsal vein has a long fork towards the base, its apex is not far distant from the thickened apex of the submedian vein; in the posterior wings five rather obsolete veins proceed from the discoidal cell to the hinder margin, one to the costa.

'This genus at present only conlains a single species, which is extremely scaree in this country, and conseguently we know 
nothing of its habits. Schliiger says of it, "The larva mines the leaves of Epilotium hirsutum, occurring at the same time as Eipiloliclla. The perfect insect appears at the end of July and in August: it is uncommonly abundant, since there are often from thirty to forty larva on one plant."

1. langiella, Hüb. Tin. 187 (1801); Zell.; Schlïger, Bericht. 1847; Treit.?-niveipunctella, Sta. Alis anticis nitidis orichalccis, macula transversa supra plicam pone medium nivea. Exp. al. $4 \frac{1}{3}$ liu.

Head bronze. Face white. Palpi, the second joint white, the terminal joint black. Antennx dark fuscous. Anterior wings shining bronze, with a transverse snow-vohile spot above the fold, beyond the middle; between this and the base are a few white seales in the fold, and a few others lie between it and the apex of the wing; cilia bronzygrey. Posterior wings bronzy-grey, with grey cilia.

A. specimen is in Mr. Shepherd's collection, and one in the collection of the British Museum.

\section{Genus XI. ASYCHNA.}

Asyoirs , n. g. Elachista p., Zell.

Capilli leves. Antenna setacex, articulo basali clongato, clavato. Palpi labiales mediocres, eurvi, articulo secundo compresso, tertio breviore acuto. Haustellum mediocre, squamatum. Ala longissime ciliatx, anteriores unicolores, metallice, anguster, posteriores lincarilinceolate. Anteriores : vena apicalis furcata, supra et infra apiccu exit, infra cam vens duc, cellula discoidalis postice dilatata; subdorsalis furcata, furca imperfecta; submediana non incrassata; posteriores: vena mediana rami tres, obsoleti, reua discoidalis simplex, apicalis simplex.

Ilend smooth. Antenna setaccous, the basal joint clongate, clavate. I tabial palpi of moderate length, curved, the second joint compressed, the third joint shorter, acute. 'Tongue of moderate length, clothed with scalcs. Wings with very long cilia, the anterior unicolorous, metallic, narrow, the posterior linear-lanecolate. In the anterior wings the furcate apical vein ruus out above and below the apex, below it are two veins; the discoidal cell is dilated posteriorly, the subclorsal vein is fureate, but the lower branch of the fork is abbreviated, the submedian is not thickened; in the posterior wings the median vein has three obsolete branches, the discoidal and apical veins are simple.

Of the four species I have placed in this genus, the first two only really belong here, the other two showing several discrejancics; I was unwiling to multiply the genera here to so great an extent as the formation of separate genera for ceratella and 
terminella wonld have required. $\Lambda$ some future period the discovery of other species perfectly agrecing with them in structure would render the construction of independent genera necessary. In aratella the palpi are short, thick, and drooping, the antemne short and thick, and in the anterior wings the discoidal cell is not closed. In terminella the palpi are acute, fliform, ascending, the anteunx are rather thick, and the anterior wings are not unicolorous, but adorned with metallic spots.

None of the larve of these species are known, and, excepting modestella, all the species are extremely rare.

1. modestella, 1)up. L. F. xi. 347. pl. 299. f. 8 (1838); Sta. - splendidella, Lienig.--serratella, Step.? Alis anticis dilute viridirencis, unicoloribus; posticis fusco-griscis, oclure-ciliatis. Exp. al. $5-5 \frac{2}{2} \operatorname{lin}$.

Head and face dark bronzy-green. Palpi whitish, terminal joint

- fuscous. Antenne fuscous, the tips whitish. Anterior wings unicolorous, pale bronzy-green, with greyish-yellow cilia. Posterior wings greyish-fuscous, with ochreous cilia.

Common in May, in mixed hedges among oaks; frequently found resting on the flowers of Stellaria holostea.

2. fuscociliella, Sta. Ent. Trans. i. n. s. 25 (1850).-cratella, Sta. Cat. $\quad$ lis anticis viridi-iencis, unicoloribus; posticis fusco-griscis,

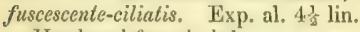

Ilead and face dark bronzy-green. Palpi whitish, the tip of the terminal joint darker. Antemue fuscous, the tips white. Anterior wings unicolorous, bronzy-green; cilia greenish-grey. Posterior wings greyishfuscous, with pale fuscous cilia.

Occurs near Bristol, on Durdham Downs, in May and Junc.

3. æratella, Zell. Isis, 1339. p. 212.-metallella, Stcp.? Alis anticis salurale viridi-eneis, antennis fuscis, brevibus. Exp. al. 4.13 lin.

Head, face, and palpi dark bronzy-green. Antenne dark fuscous, litlle more than half the lenglh of the anterior vings. Anterior wings dark bronzy-green, somewhat irideseent; cilia fuscous. Posterior wings grey, with paler cilia.

Appears in June and July, among flowers on the borders of corn-fields; has occurred at Ripley and near Reigate.

4. terminella (Dale), IIump. and West. B. M. ii. 216 (pl. 113. f. 11 ?) (1845).-patriciella, Sta. Alis anticis metallice brunueis, vel saturate croceis, striga basali arrentea per dorsum producta, deinde costam versus reflexa, punctis tribus plicx, duobus disci argenteis, macula argentco-ilba costali ante apiccm, squamis argenteis ad angulum analem; antennis brevibus, fuscis, apice albo. Lxp. al. 4 lin.

Ilead dark bronze. Fiace silvery. P'alpi whitish, terminal joint pale fuscous. Antenux short, dark fuscous, the tips whitc. Antcrior wings 
rich metallic brown, or very dark saffron, with a silvery mark at the base, extending a short distance along the inner margin, and then turning up towards the costa; beyond are three silvery spots on the fold and two on the disc; a silvery white spot is on the costa before the apex; at the anal angle are also some silvery seales; cilia fuscous. Posterior wings fuscous, with paler cilia.

This beautiful species is a great rarity; M[r. Dale met with it in Dorsetshire, Mr. Weir in Sussex, and Mr. Allen Hill near Bristol; it appears in June and July, in moist places among alders.

\section{Genus XII. CHRYSOCORYS.}

Cirnysoconys, Curt. Ent. MIag. i. 191 (1833); Id. B. E.; Step. Schreckensteinia, IIüb. V. Elachista p., Zell.

Capilli levigati, frons convexa. Antemme abdomine vix longiores, setacex, articulo basali brevi, crassituscula. Palpi labiales mediocres, subcurvi, tenues, acnti, articuli secundi apice pilis parum incrassato, tertio longitudine subaequali. Haustellum mediocre, nudum. Mle longe ciliatre, anteriores angustre, cosia subretusa, ante apiceni convexa, posteriores lanceolatic. Anteriores: cellula discoidalis postice dilitata, truncata; vena apicalis simplex, infra eam venæ sex in marginem posticum; subdorsalis simplex paulo post medium dorsi exit; submediana non inerassata; posteriores: cellula costalis longissima, angustissima, venx in dorsum sex, quarum tres e cellulie termino.

IIcad smooth, the forchead convex. Antenua hardly longer than the abdomen, setaceous, rather thick, with the basal joint sliort. 'Tongue of moderate length, naked. Labial palpi morlerately long, rather curved, slender, pointed, the apex of the second joint slightly thickened with hairs, the third joint nearly of equal length. Wings with long cilia, the anterior narrow, the costa almost retuse, convex before the apex; the postcrior lanceolate. In the anterior wings the discoidal cell is dilated posteriorly and truncate; the apieal vein is simple, below it are six veins to the hinder margin; the sublorsal is simple, terminating a litlle beyond the midelle of the inner margin; the submedian is not thickened; in the posterior wings the costal cell is very long and extremely narrow, six veins run into the hinder nargin, of which three from the end of the cell.

'This genus only contaius one species, which has a peculiar jerking flight, as it were, hopping on the wing. Hiibner has figured a larva and pupa as of this species; but though lis figures have been on several occasions copicel, no subsequent writer has verified his observations, and conseyuently it is hardly safe to conclude that the larva and pupa are really as singular as he has 
represented them. The perfect insect appears rather attached to brambles; and if the bristly larva feeds under the leaves of the bramble, as IIübner has represented it, there sliould be no difficulty in re-discovering it.

1. festaliella, Hüb. Tin. 449 (1822); Treit.; Zell.; Sta. ; Dup.?-scisscella, IIaw.-scissella, Curt. 13. I. fo. 663.-angustipennella, Step.-Montandonella, Dup. Alis anticis flavido-ancis, costa fusca, linea a basi per plicam et marginem posticum ducta, linea altera disei ad apiecm producta, in medio valde incrassata, saturate fuscis. Exp. al. 6 lin.

Head and face bronzy-green. Palpi and antennac fuscous. $\Lambda n$ terior wings bronzy yellowish-green, with the costa fuscous, a dark fuscous line runs from the base along the fold and hinder margin, and another clirk fuscous line begins on the dise, not far from the base, and is continued to the apex of the wing, in the middle of its length it is much thickened; cilia pale fuscous. Posterior wings greyish-fuscous, with paler cilia.

Common in many places, in May and June, among brambles.

\section{Genus XIII, ELACHISTA.}

Elachista p., Treit. E. S. ix. 2. 177 (1833); Dup.; Zell. Porrectaria p. et Tinea p., Haw. Microsetia p., Aphelosetia p., et Amaurosetia p., Step.

('apilli lnvigati, frons obtusa. Antenna setacere, crassiuscule, subserratx, subcompressex, articulo basali breviusculo, incrassato. I/austellum mediocre. Palpi labiales breviusculi vel mediocres, subarcuati, articulo secundo nomihil crassiore, tertio acuto. $\Lambda$ lie longissime ciliate, anteriores postice ciliis ampliale, posteriores lincarilanceolate. Antcriores: cellula discoilalis acuminata, venas duas vel tres in costam, unam ex apice trifidam vel bifidam, tres vel duas in marginem posticum mittit; subdorsalis simplex; submediuma apex incrassatus; posteriores: vena mediana et discoidalis distinctre.

IIead smooth; the forchead olstuse. Antennac setaceous, rather thick, slightly scraate, and somewhat compressed; the basal joint thickened and rather short. 'Tongne of moderate length. Labial paipi rather short, or of moderate length, slightly curved; the second joint a little thicker; the terminal joint acutc. Wings with very long cilia, the anterior appearing from the cilia to be dilated posteriorly, the posterior linearlanccolate. In the anterior wings the acuminate discoidal cell sends tero or three veins to the costa, a brifid or bifid vein from its apex, and three or two veins to the hinder margin; the subdorsal vein is simple; the apex of the submedian is thickened (in a few cases it is not thick- 
ened); in the posterior wings the median and discoidal veins are distinct.

From the variation in the neuration of the anterior wings, as above mentioned, it is extremely probalile that, matural as this genus at first sight appears, it may hereafter be capable of subdivision. The perfect insects are not unfrecuently met with in little swarms, being actively on the wing during the afternoon or evening; when at rest they sit very closely appressed to the leaf, blade of glass, or other substance on which they liappen to repose, and appear perfectly sluggish; but the moment the collector in attempting to cateh the inert specimen agitates the foliage, or brenthes too roughly on its resting-place, quickly the antenna, which had lain couchant by the side of the insect, start forward, are briskly agitated, and the insect, now completely roused from its secming torpor, runs forward, spreads its wings, and is-gone. "We think we lave it, but yet we have it not." Most of the species appear to be double-brooded, appearing in May and $\mathrm{Au}$ gust; some, which we only meet with in Junc or July, have probably only a single brood in the year; yet of the double-brooded species the $\Lambda$ ugust brood seems far less numerous than the May brood, which is no doubt owing to the perfect insects kepping themselves more concealed, as we have observed to be the case in other latc-appearing species.

The fortunate discovery by Mr. Logan of the larva of one of the species, has alrearly led to the discovery of a considerable number; no less than eighteen different larve having been al. ready distinguished, sereral of which have been reared. From these we find that the labit of the larve of this genus is to mine in the leaves, and down the stems of grass ; but there is considerable diversity in the mode of mining, some species remaining always at the top of the leaf, others descending down the stem towards the root; in the mines of some species the leaf remains flat, in others it has an inflated or puckered appearance. The larve of the May brood may be found throughout the winter and early spring; the larva of those species which do not appear in the perfect state till June or July, may be met with in April and May; the larva of the August brood, feeding up at the end of June, are less easily observed, from the general luxuriance of regetation at the time. The larva when full-fed quits the mine and changes to a naked, rather angulated pupa, on the stem or leaf of grass, or some neighbouring plant; a belt of silk is generally placed round the middle of the pupa, which is also attached by its tail, but no outer covering of silk is made by any of the voL, III. 
species we have yet observed, exepting E. mfocinerea, of which, though the larva has not been found, the pupa lias on several occasions been met with and reared.

The species of this genus are extremely numerous, and forty are alrealy known as British, which may be arranged in the following table :-

a. Anterior wings dark brown or black, with sharp metallic fascis and spots. Species 1-5.

a a. Anterior wings dark brown or black, with a distinct pale fascia and spots. Species 6-11.

a $a$ a. Anterior wings grey or black, with an indistinct pale faseia and spots, or with spots only. Species 12-21.

a a $a$ a. Anterior wings dark fuscous or black, with a single distinct white, whitish, or yellowish fascia.

ర. IIead dark. Species 22-24.

b b. Head pale. Species 25-28.

a a a a a. Anterior wings white or grcy, with a distinct dark spot on the fold in the middle. Species 29-33.

a $a$ a $a$ a $a$. Anterior wings white, with a few distinct dark spots. Species 34, 35 .

a a a a a a a. Anterior wings white or whitish, irrorated with dark atoms. Species $36-38$.

a $a$ a a a $a$ a $a$. Anterior wings unicolorous. Species $39,40$.

1. Pfeifferella, IIüb. Tin. 398 (1816); Step.; \%cll.; Sta.quadriguttella, IIaw. Nlis anticis nitidis aureo-brunncis, fiscia angulata ante mediun, maculis duabus suboppositis triangularibus pone nedium nitidis aureis. Exp. al. 4 lin.

Hend, face, and palpi golden-brown. Antemne fuseons. Anterior wings glossy golden-brown, with a slender angulated bright golden fascia before the middle, nearest to the base on the imer margin; beyond the middle is a triangular golden spot on the imner margin, and neavly opposite to it, but placed a litlle posteriorly, is a larger spot of the same colour on the costa; cilia golden-brown, at the extreme apex grey. Posterior wings greyish-purple, with grey cilia.

Not uncommon in many localities in May; it secms rather partial to a chalky soil, yet I have found it on clay.

2. Treitschlkiella, F. v. R. 297. pl. 100. f. J. (18.43); Sta.; Dup.? $\Lambda$ lis anticis nitidis aureo-brumeis, fiscia arcuata ante medium, macula triangulari dorsali pone medium, macula trimgulari costali posteriore, nitidis aureis. Exp. al. 3 lin.

IIead, face, and palpi golden-lurown. Antemne fuscous (annulated with whitish? ?). Anterior wings shining golden-brown, with a slender, slightly curved, pale golden faseia before the middle, nearest the base on the imer marrin; beyond the middle is a triangular pale golden spot on the inner margin, and beyond it is a costal spot, nenrly trian- 
gular, of the same colour; cilia golden-bromn. Posterior wings greyish-fuscous, with paler cilia.

'The perfect insect ajpears in May, and was thought to freguent the dog-wood. 'T'wo old specimens of this insect are in Mr. Doubleday's collection.

3. Gleichenella, Fab. S. I. ii. 303. 81 (1781).-Gleichella, Fab. F. S.; IIaw.; Step.; Sta.-trifasciclla, Tengstr. Alis anticis bruneomigris, bresi, fascia recta in medio, fuscia angulate ante apicem nilidis, aureis: antennis fuscis. Exp. al. $3_{2}^{\lambda}$ lin.

Ilead, face, and palpi bronzy. Antenne fuscous. Anterior wings broun-blact, the bese bright golden, a bright golden, nearly straight fiscia in the middlic, and a bright golden, angulated fascia before the aper, composed, as it were, of two opposite spots united by a third spot beyond them on the dise; cilia fuscous. Posterior wings grey, with paler cilia.

Not uncommon in Jume and July, flying over the short grass, under the shelter of furze-bushes, etc.; it occurs at Dartford Ileath, at Mickleham, and near Bristol.

4. Brunnichella, Iim. S. N. (12), 898. 448 (1767).-magni-

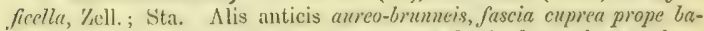
sint, fascia recta in medio, macula transversa dorsi ad angulum analem, mecula posteriore costre obliqua, auratis; antennis fuscis, ante apicen albis. Exp. al. 3-3슴 lin.

Ifead, fice, and paljpi bronzy-fuscous. Antennac dark fuscous, with a broad white ring brfore the apex. Anterior wings golden-brown, close to the base is a coppery fascin; in the midlle is a straight grolden fascia; at the anal angle is a tringular yolden spot reaching half across the wing, and beyond it on the costa is an oblique golden spot, pointing inrards, but not reaching the apex of the dorsal spot; cilia greyishbrown. Posterior wings grey, with grey cilia.

'This pretty species lias been frequently taken by Mr. Douglas, in the hilly ficld at Headley Lane, by sweeping; it appears to be double-brooded, having occurred in May and $\Lambda$ ugust.

5. magnificella, Teugstr. F. F.-T. 11.7 (18.77).-regificella, Sircom, \%ool. 18 1.9. App. xlii. Alis anticis aurco-brunneis, fascia recta argenteu prope basim, macula transversali ntrinque abbreviata in medio, macula tenui transversa dorsi pone medium, macula transwersa costie posteriore, argenteis. Exp. al. 4 lin.

IIead and face fuscous. Palpi whitish. Antenna fuscous. Anterior wings golden-brown, with a silvery fascia near the base, a transverse silvery spot in the middle, not reaching either margin; at the anal angle is a narrow silvery spot reaching half across the wing, and beyond it on the costa is another silvery spot also reaching half across the wing; cilia fuscous. Postcrior wings brown-grey, with paler cilia. 
Taken at the end of July and beginning of August, by Mr. Sircom and Mr. Vaughan, at Brislington, near Bristol.

6. apicipunctella, Sta. Cat. 13. 26 (1819). Alis anticis nigris fascia obliqua ante medium, maculisque duabus oppositis, cum tertia apicali sepe connexis, argentco-albis ( $q$ alis anticis atris, fascia maculisque argenteis, basi etiam argeutea); capite cum palpis argenteoalbo. Exp. al. $4-4 \frac{\lambda}{3}$ lin.

Ilead, race, and palpi silvery-white. Antennx fuscous, the tips whitish. Anterior wings blackish, with an oblique silvery-white fascia before the midctle (nearest the base of the wing on the costa where it is broadest); beyond the middle are two silvery white spots, one on the imner margin and one rather posterior on the costa; beyond them lies a third spot on the apeic of the wing, by which they are frequently wnited into an angutated fascia; cilia dark grey, with black hinder marginal line. (In the female the anterior wings are black, the silvery markings brighter, and the extrene base of the wing is also silvery.) Posterior wings grey, with grey cilia. June.

Common on mosses, or bogs, in the south of Scotland, in

7. albifrontella, IIüb. Tin. 432 (1816); Zell.; Sta.; Step. ?quadrelln, Haw.; Step. Alis anticis nigris, fascia fere recta ante medium ( $\delta$ stepe interrupta), maculis duabus suboppositis antc apicem, costali posteriore argenteo-albis; capite, cum palpis, argenteo-albo. Exp). al. $4-4 \frac{1}{2}$ lin.

Ifead, face, and palpi silvery-white. Antenne dark fuscous. Antcrior wings brown-black, with a slightly obligue silvery-white fascia before the middle, nearest the base of the wing on the costa (in the $\delta$ this is generally interrupted on the fold); on the inner margin at the anal angle is a silcery-white triangular spot, and beyond it on the costa is a similar larger onc; cilia grey, with some black scales. Posterior wings grey, with paler cilia.

Very common in woods in June. The larva was found by Mr. Scott, last May, feeding in the upper part of the leaves of Lire caspitosa.

8. Foldenella, Edleston in lit. Alis anticis grisco-nigris, postice situratioribus, fascia obliqua ante medium, maculaque triangulari ad angulum analem, albiclis, macula costuli ante apiccm quadrata, alba; capite griseo, palpis albidis. Exp. al. 5 lin.

Ilead and face grey. Palpi whitish. Antenna fuscous, with paler annulations. Anterior wings greyish-black, darker towards the apex; a little before the midclle is an oblique whitish fascia nearest the base of the wing on the costa; at the anal angle is a triangular whitish spot, and beyond it on the costa is at more distinct whiter spot, which is not triangular, its apex being truncale; cilia pale grey. Posterior wings grey, with paler cilia. 
In Mr. Edleston's collection, is a single specimen, taken near Loudon.

9. atricomella, Stn. Cat. p. 25 (1849).- + alienella, Sta.-exiguella, Step.? Alis anticis nigris, fascia interrupla angulata ante medium, raaculis duabus suboppositis, costali posteriore, ante apiccm albidis; capite nigro, palpis griscis. ( $q$ alis anticis ad basim griseis, postice grisco-nigris, fascia obliqua ante medium, maculisque duabus triangularibus subopposilis ante apicem albis; capite griseo, palpis albidis.) Exp. al. $4 \frac{1}{2}-5$ lin.

IIead greyish-black. Face and palpi grey. Antennx dark grey. Anterior wings greyish-black, with an intermpled slightly angulated fascia before the middle, and two opposite spots towards the apex whitish; the fascia being nearer the base of the wing on the costa, and the costal spot being posterior to the dorsal spot, and also larger; cilia grey, with some blackish scales. P'osterior wings grey, with paler cilia. (In the female the head is dark grey, the face and palpi whitish; the anterior wings are grey at the basc, postcriorly greyish-black; before the middle is a volite, slightly oblique fascia, and towards the apex are twoo triangular volite, nearly opposite spots.)

Occurs near London, not uncommonly, at the end of May and in June, in herlges and on palings. The larva feeds at the begrinning of May, on Daclylis glomerata, mining down the leaves, and then down the stem.

10. luticomella, Zcll. Isis, 1839. p. 212 ; Sta.-guttella, ILaw.? Step.? Alis anticis brunneis, fascia ante medium ( $\delta$ angusta, $q$ lata) maculis duabus oppositis ( $q$ majoribus) ante apicem flavidis; capite, cum palpis, luteo. Exp. al. $4 \frac{1}{2}-5$ lin.

IIead, face, and palpi yellow. Antennac fuscous, Anterior wings brown, with a yelloweish fiscia before the middle (narrow and slightly curved in the male, broad aud straight in the female), and two yollowish nearly opposite spots towards the apex (these spots are small in the male, larger and triangular in the female); cilia greyish-brown. l'osterior wings brownish-grey, with grey cilia.

Not uncommon in many localities at the end of June and beginning of July. The larva feeds on Dactylis glomerala in May, and the perfect insect has been reared by Mrr. Logan and Mr. Scott; the former promises drawings of its transformations in his forthcoming 'Illustrations of Scottish Lepidoptera.'

11. Kilmunella, Str. Cat. p. 25 (1819). Alis anticis saturate obscure griscis, fascia recta alba ante medium, maculis ante apicem dunbus in fascian seepe connexis albis ( $q$ basi tota alba, sub costa tantum cincrea) ; capitc, cum paipis, saturate grisco. Exp. al. $4 \frac{1}{2}-5$ lin.

Head, face, and palpi dark grey. Antenne lark grey. Anterior wings dingy dark grey, with a nearly straight white fascia in the midlle, and two nearly opposite whice spols before the apex, frequently united 
into a fuscia; cilia grey, at the apex whitish. (In the female the entire base of the wing is white, with the exception of a grey streak along the costa.) l'osterior wings grey, with paler cilia.

Common on bogs and mosses in June and July; on the summit of the hill above Kilmun it is extremely plentiful, fying freely in the afterwoon, threading its way between the stems of grass or rushes, and oceasionally settling for an instant.

12. alpinella, Elleston in lit. Alis anticis fuscis, maculis tribus inclistinetis albidis, una dorsali ante mediun, secunda ad angulum analem, tertia costali ante apicem; capite fusco. Exp. al. $4 \frac{2}{2}$ lin.

IIead, face, and palpi fuscous. Antenux fuscous. Anterior wings fuscous, with three indistinet whitish spots, one on the inner margin before the middle, one at the anal angle, and one rather beyond it on the costar ; cilia pale fuscous. Posterior wing grey, with paler cilia.

'liken by Mr. Litleston, on moors ncal Manchester, in August.

13. cinereo-punctella, Haw. I. 13. 582 (1829); Stcp.; Sta. Alis anticis saturate griscis, macula obliqua coste ante medinm, maculit parra ad angulum analem, macularge coste ante apicein albidis, puncto upicis nigro; capite griseo, fronte palpisque albidis. Exp. al. 3?-4 lin.

INead grcy. Face and palpi whitisl. Antenna grey. Anterior wings dark grey; in the middle is an oblique whitish spot from the costa reaching more than half across the wing; at the anal angle is a very small whitish spot, and on the costa inmedialely before the apee is another whitish spot, which precedes an apical bluck spol; cilia grey. Posterior wings grey, with paler cilia.

$\Lambda$ plears at the end of May and begimning of June; plentiful on the chalk downs beyond C'roydon, also on Durdham Downs, ncar Bristol.

14. trapeziella, Sta. Cat. p. 26 (1549), -yuttifera, IIaw.? Alis anticis brunnco-nimris, stria plice basali, punctis duobus in medio, altero costac, allero plice, punclo tertio plice supra anyulum analem, puncto quarto apicis argenteo-albis; capitc albido, frontc palpisque albis. Exp. al. $4-4 \frac{2}{2}$ lin.

IIead whitish. Face and palpi white. Antenne fuscous. Anterior" wings dark brown-black, with a short silvery-white streak at the base along the fold; in the midldle are two small silvery-white spots, one on the costa, the olher on the fold, a third spot lies on the fold chove the anal angle, and a fouth in the apex of the wing; cilia fuscous. Posterior wings fuscous, with paler cilia.

A specimen taken at West Wickham Wood, in June, is in Mr. Bedell's collection. Mr. Douglas and I have ench a specimen, the localities of which are unknown.

15. nigrella, Ilïb. 285 (1816); Ilaw.; Ircit.; Sta.; Stcp.? 
7ell. $P$ Alis anticis ( $\delta$ ) griseis, fuscia fere recta albilla obsolcta ante medium, maculis duabus ante apicem oppositis, quarum apices postice spectant in fasciam conjunctis, apice volunduto, ciliis griseis, cirea apicem externe albidis ( $q$ alis anticis ad basim saturate griscis, postice nigris, fascia maculisque albis distinclis, macula costali non pone maculam dorsalem); eapite grisco, fronte argenteo-grisca, palpis dilute griseis. Exp. al, 4 lin.

Jead grey. Thace silvery-grey. Palpi pale grey. Antenne fuscous, Anterior wings (of the $\delta$ ) grey, with an iudistinct nearly straighte whitish fascia before the middle, and an angulated faseia (composed of two whitish opposite spots, with their apices sloping posteriorly) towards the apex; a somewhat rounded dark linder warginal line runs through the grey cilia, which at the apex are whitish. (In the o the anterior wings are dark grey at the base, and beyond the first fascia black; the first fascin is whiter and more distinct, and the opposite spots towards the apex are much whiter and more distinct; the costal spot is scercely posterior to the dorsal spot.) Posterior wings grey, with paler cilia.

Not uncommon in May and August, generally occurring near herlges. The larva feeds in the upper part of a slight-growing grass (perlaps Poa trivialis) in April and July.

16. subnigrella, Dougl. Ent. Trans. ii. n. s. 210. pl. xriii. f. ] (1854). Alis anticis ( $\sigma^{*}$ ) grisceis, fascia obliqua albida obsolcla ante medium, fascia angulata albida obsolcta ante apjecm, quasi c maculis duabus compositn, ciliis apicis truncati griseis ( $q$ alis postice suturatioribus, fascia unaculisque latioribus, albidioribus, maculu costali distincte post maculam dorsalem); capite griseo, fronte argentea, palpis griscis. Exp. al. $3 \frac{1}{2}$ lin.

IIead grey. Face rather silvery. Palpi pale grey. Antennx fuscous. Suterior wings (of the $\delta$ ) dingy grey, with an indistinct rather oblinue whitish forscia a little before the middle, being nearest the base on the costa ; towards the apex is a whitish angulated fascia, composed, as it were, of two indistinct opposite spots; cilia at the ralher truncate apex grey. (In the of the anterior wings are darker, especinlly posteriorly, and the fiscia and spots are whiter and broader; the costal spot is decidedly posterior to the dorsal spot.) Posterior wings grey, with paler cilia.

Common at the beginning of Jume and in August, on the old tram-road beyoud Croydon. The larva feels in $\Lambda$ pril, May, and July, in the leaves of Bromus erectus, not descenting the stems; the mined places assume a purplish tinge; the pupa may frequently be found on the upper side of the leaf, close to where it quits the stem.

17. occuitella, Dougl. Fnt. Trans, i. n. s. l'roc. 7 (1850); Sta. $\Lambda$ lis anticis grisco-fuscis, fascia angulata albida valde obsolcta ante me- 
dium, maculis duabus triangularibus subdistinctis, antc apicem albidis, non confluentibus, apice non truncalo; ciliis griscis; capite, cum palpis, griseo. Exp. al. 3 ? -4 lin.

Head, face, and palpi grey, rather shining. Antennx fuscous. Anterior wings shining greyish-fuscous, with a very indistinct whitish fascia a little before the micldle; the fascia is angulated on the fold, and is nearest the base on the costa; towards the apex are two rather conspicuons triangular whitish spots, that on the costa being nearest to the apex; they are distinctly separalcel by the intervening ground-colour of the reing; the apex of the wing is rounded, with a dark hinder marginal line in the grey cilia. P'osterior wings grey, with paler cilia.

Mr. Donglas discovered this species on the 25 th of May, 18 1.8, flying plentifully over some long grass growing under trees in a damp part of West Wickham Wood.

18. consortella, Sta. Sup. Cat. p. 9 (1S51). Alis anticis ( $\left.\sigma^{7}\right)$ angustis, griscis, puncto parvo albido plice ante medium, stria vigra plice in medio, inaculis oppositis ante apicern albidis, fere in fasciam angulatam confluentibus, striola albida in apice ducta ( + fascia media albida distincta, maculis oppositis fere in fasciam oblinucun connexis); capite grisco. Exp. al. $3-3 \frac{2}{2}$ lin.

Ilead, face, and palpi grey. Antenna dark grey. Anterior wings narrow, (of the $\delta$ ) (litk grey, with apparently no trace of the medial fascia, but on the fold is a small whitish spot, followed by a short black streak; the opposite spots towards the apex are whitish, and nearly form an angulated fiscial from their wnion some whitish seales are conlinned into the apex of the cilit; cilia grey, except the whitish apex. (In the $q$ the medial fascia is distinct, and the opposite spots nearly unite to form an oblique fascia.) l'osterior wings grey, with paler cilia,

Taken by Mr. Logan in March, amongst grass, on Mrthur's Sent.

19. pulchella, IIaw. I. B. 582 (1829); Step.; Sta. Alis auticis ad basin albis, postice nigris, macula costa prope basim elongata grisea, maculis duabus triangularibus suboppositis, ante apicem albis; capite, cum palpis, albo. Exp. al. 3 lin.

IIcad, face, and palpi while. Antennæ fuscous. Anterior wings with the basal lealf enlirely while (cxecpt a longitudinal grey patch along the costa, which terminates before the middle of the wing, so as to leave an entire white fascia), the apical half dark greyish-black, with two triangular nearly opposite white spots, that on the costa being rather nearer the apex; cilia grey, with a dark hinder marginal line. Posterior wings pale grey, with paler cilia.

Occurs singly among grass in May and June; as all the specimens with which we are acquainted are females, it is probably the female of some other known species, possibly of obscurella. 
20. Bedellella, Sircom, Zool. 184.8. p. 2057; Sta. - nigrella, Dup. Alis anticis latiusculis, postice truncalis, $(\delta)$ mriseis ( $q$ albidioribus), fascia recta ante, fascin angulata pone medium albidis; capite cum palpis grisco. Lxp. al. $3 \frac{1}{2}$ lin.

Ilead, face, and palpi grey. Antenue dark fuscous. Anterior wings rather broad and posteriorly truncale, (of the $\delta$ ) grey, (of the of paler, and at the base almost whitish), with a striight whitish fascia before the middle, and an angulated whitish fascia towards the apex, both rather indistinet; at the apex is a dark hinder-marginal line, which is almost straight, giving the wings a truncate appearance; cilia grey, at the apex whitish. Posterior wings grey, with paler cilia.

Very abundant in May and $\Lambda$ ugust among the short grass of the chalk downs; occurs at Sanderstead and near Bristol.

21. obscurella, Sta. Cat. p. 26 (1819). Alis anticis dilute griseis, obscurius squamatis, fascia media, maculisque duabus oppositis ante apicem dilutioribus, obsoletissimis; capite cum palpis griseo. Lxp. al. 4. ${ }_{3}$ lin. (Var. Fascia maculisque subdistinctis; capite cum palpis albido. Exp. al. $3 \frac{1}{2}$ lin.)

Head, face, and palpi pale grey. Antennæ dark grey. Anterior wings grey, with darker scales, and with very faint indications of a paler fascia in the middle, and two paler opposite spots before the apex. (The smaller summer brood has the fascia and spots more distinct.) Posterior wings pale grey, with paler cilia.

Abundant on meadows and among grass, near hedges, in May, and again in August, but, as above mentioned, the summer specimens differ slightly from those taken in spring; the female of this species has not yet been observed, unless it be pulchella.

22. Albinella, Sta. Cat. p. 27 (1819); Ilaw.? Step.? Mlis anticis fuscis, fuscia media recta latinsculn flasida, in plica aurantia, ciliis

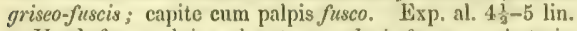

Head, face, palpi, and antenne dark fuscous. Anterior wings dark fuscous, with a straight, rather. broud, yellowish fuscia in the middle, stighlly suffused will orange on the fold; cilin greyish-fuscous. Postcrior wings brown-grey, with grey cilia.

I am not aware of the localities where this species has been taken. I have a specimen, and there is one in Mr. Bond's collection.

23. zonariella, Tengström, F. F.-F. 150 (1847).-Lisulcella, \%ell.; Sta. Alis anticis fuscis, fascia media recliuscula favida, cxterne arrantia, ad dorsum latiore; ciliis apicis albidis; capite cum palpis brunneo. Lxp. al. 4 lin.

IIend, face, and palpi brown. Antenne greyish-fuscous. Anterior wings dark fuscons, with a yellorcish fascia in the middle; the fascia is nearly straight, broadest on the inner margin, and is toseards the apen of the wing of an orange colour; cilia grey, but at the apex beyond the

VOL. III. 
dark hinder marginal line akhitish. Postcrior wings brown-grey, with palcr cilia.

Formerly taken by Mr. Sircom in August, near Bristol. Mr. Scott bred a specimen last summer from a larva he found near Renfrew, mining in May the leaves of (he believes) Lira ceespitosa.

24. gangabella (F. v. R.), Zcll. Ent. Ztg. 1850, p. 202 ; Sta. $\Lambda$ lis anticis fuscis, fascin media flava sub coslam atlenuata, maculan trigonam dorsi simulante; ciliis fusco-griseis; capite cum palpis fusco. Exp. al, 4 lin.

IIead, face, palpi, and antennxe dark fuscous. Anterior wings dark fuscous, with a straight yellow fuscin in the middle, very narrow towards the costa, but swetling out to a triangular spot on the inner margin; cilia greyish-fuscous. Posterior wings grey, with paler cilia.

A searce species, taken by Mr. Douglas in Ileadley Lane, and by myself at Dartford Heath, in June.

25. obliquella, Edleston in lit. Alis anticis fuscis, fascin fere rectu luten paulo post modium; ciliis apicis dilute luteis; eapite cum palpis luteo ; antennis fuscis albo-annulatis. Exp. al. $4 \frac{2}{2}$ lin.

IIcad, face, and palpi luteous. Antenne dark fuscous, anmulatent with white. Antcrior wimgs dark fuscous, with a nearly straight, yellowish fuscia, rather beyond the middle; apical citia pale yellowish beyond a dark hinder marginal line; cilia at the anal angle fuscous. Posterior wings fuscous, with paler cilia.

Two specimens in Mr. Ldleston's collection, taken near London.

26. abruptella, n. sp. Nlis anticis fuscis, fuscia fere recta ponc medium albra; ciliis apicis truncati albidis; capite cum palpis albo; antennis fuscis. Exp, al, $4 \frac{1}{2}$ lin.

Head, face, and palpi white. Antennic fuscous. Anterior wings fuscous, with a nearly straight white fuscia a little beyond the middle; the cilia at the truncate apex are whitish. P'osterior wings grey, with paler cilia.

Two specimens in Mr. Allis's collection.

27. Megerlella, Sta. Cat. p. 27 (1849); Zcll.; Dougl. Ent. Trans. ii. n. 8. 2. pl. xviii. f. 2; Step.?-unifasciella, Haw. P Alis anticis griseo-fuscis, fascin media temi flavida, superius recta, inferius basim versus flexa; eiliis apicis flavidis; canpite cum palpis albido; antennis fuscis. Exp. al. 6 lin.

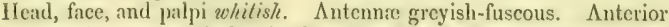
wings greyish-fuscous (darker in the o), with a yelloxcish fascin in the middle; this fascia is very slender, when it first leaves the costa it is nearly straight, but after reaching the fold it turns a little towards the base of the wing, it is broadest on the imner margin, its outer edge 
which is less sharply defined than the inner elge being very nearly straight; cilia grey, but at the apex, beyond the dark hinder marginal line, yellowish, Posterior wings grey, with paler cilia.

Common in hedges in May and August. The larva fects in March and April, in the upper part of the leaves of a coarsegrowing grass (I had thought this grass was Melica uniflora, but am now doubtful on that point; it is not a very casy matter to distinguish each species of grass from an examination of the leaf only); its mines are rather puckered and brownish; the summer brood of the larva $\mathrm{I}$ have not observed.

2.. adscitella, Sta. Sup. Cat. p. 10 (1851). Alis anticis dilute grisco-fuscis, fascia media tenui albida intermpta; cilis apicis albidis ; capite cum palpis albido. Exp. al. $5 \frac{x}{2}$ lin.

ITead, face, and palpi whitish. Antenue fuscous. Antcrior wings pale greyish-fuscous, woith two stender whitish opposite spots in the middle, forming an intervupted fascia; the dorsal spot is rather the larger of the two; eilia grey, but at the apex beyond the dark hinder marginal line volitish. Posteriol wings grey, with paler cilia.

Occurs near Clesterficld in Junc; Mr. Allis has now distributed it in several collections.

29. cerusella, IIüb. 183 (1801); IIaw.; Step.-cerussella, Zell. Alis anticis albidis, atomis fuscis leviter irroratis, fascia interrupta pone medium, allera integra ante apicem fuscis, priore maculam nigran interne gerente, apice fusco; ciliis grisco-fuscis; capite cum palpis albido. Exp. al. 5 lin.

Ilcad, face, and palpi whitish. Antenna whitish. Anterior wings whitish, with some scallered fuscous scales, will an interrupted fuscous fuscia beyond the middle, internally with a black spot on the fold, and an unintermpted fascia lozoards the apex, with a minute black spot internally; apex of the wing fuscous; cilia greyish-fuscous. P'osterior wings grey, with paler cilia.

Common in marshy ground in May and at the end of Augrust; the larva feeds in the upper part of the leaves of the common reed (Anulo Plhagmites) at the begiming of August; the spring brood of the larva has not yet been observed.

30. Rhynchosporella, Sta. Zool. 154.8, p. 2165. Nlis anticis albidis, puncto in melio plicie nigro, costa, dorso, fascin extrorsum angulata pone medium, macula costali ante apicen majore, maculaque dorsali ad angulum analem minore, obscure griscis; capite cum palpis albo vel albido. Exp. al. $4 \frac{\pi}{3}$ lin.

IIead, fice, and palpi while or whilish. Antenne fuscous. Anterior wings dirty-uhilish, with a dirty-grey streak along the costa to beyond the middle, and a dirty-grey streak along the inner margin; beyond the middle is a dirty-grey fascia, angulated posteriorly; a rather large 
costal spot before the apex, and a small spot at the anal angle are dirtygrey; cilia grey. I'osterior wings dirty-grey, with paler cilia.

Common in the North, on mosses and bogs; also occurs in the Cambridgeshire fens, and met with last summer by Mr. 13oyd in the New liorest, who observed it to frequent the cotton-grass (Eriophorum); appears in June and July.

31. Eleochariella, Sta. Sup. Cat. p. 10 (1851). Alis anticis griseis, pliea albida, puncto in medio nigro, strigula obliqua costa apicem versus, punctoque opposito dorsi albidis; capite cum palpis $s a-$ turate griseo. Exp. al. $3 \frac{1}{2}$ lin.

Ilead, face, and palpi dark grey. Antennx dark fuscous. Anterior wings grey, with a whitish line along the fold interrupted by a black spot in the middle; fowards the apex is a whitish streak on the eosta sloping towards the hinder margin, and beneath it on the immer margin is a small whitish spot; cilia pale grey. Posterior wings grey, with paler cilia.

I met with this in July among rushes, on the top of the hill above Kilmun.

32. biatomella, Sta. Zool. 184.8, p. 2165. Alis anticis griseoochreis, puncto fusco plica albida medie, strigula obliçua costali pone merlium, in puncto altero fusco terminata, punctoque obsoleto costali ante apicen albidis; capite ochreo-griseo; fronte palpisque albidis. Exp. al. $3 \frac{x}{2}$ lin.

Ilcad greyish-ochreous. Face and palpi whitish. Antenna fuscous. Anterior wings greyish-ochreous, with a whitish streak along the fold, in which is a fuscous spot about the middle of the wing and whitish oblique (sloping posteriorly) streak from the costa beyond the middle, having at its termination another fuscous spot; on the costa immediately before the apex is a small whitish spot; cilia, beyond a fuscous hinder-marginal line, grey. Posterior wings grey, with palcr cilia.

Occurs rather frecly on Durdham Downs, ucar Bristol, from May to July.

33. serricornis, Logan in lit. Alis anticis griscis, puncto nigro plica prone medium, striguda brevi obliqua costali albida ante apicem; capite eum palpis grisco; antennis apicew versus serratis. Exp. al. $3 \frac{x}{2}$ lin.

Head, face, and palpi grey. Antenwe towarls the apex much serraled, dark grey, with palcr annulations. Auterior wings grey, with a black spot on the fold beyond the middle, and a short obligue (sloping posteriorly) whitish streak from the costa, before the apex, internally margined with dark grey; cilia, beyoud a darker hinder-marginat line, grey. Posterior wings grey, with palcr cilia.

T'wo specimens, one in Mr. Weir's and one in Mr. Logan's collection. 
31. triatomea, IIaw. L. B. 535 (1829); Step.-dispilella, Zell, Sti.-bipunctella, Treit.? Alis anticis albis, punctis duobus nigris, altero plice ante medium, altero disei pone medium; capite cum palpis albo. Exp. al. 4-4 $\frac{1}{2}$ lin.

Head, face, and palpi white. Antenne grey. Anterior wings white, with two small black spots, one on the fold a little before the midclle, the other midway between that and the apex; at the anal angle are frequently a few black scales (forming Haworth's "third atom"); cilia whitish, with a few greyish seales. Posterior wings greyish-white, with paler cilia.

Not uncommon among grass in chalky places in June and July.

35. triseriatella, n. sp. Alis anticis albis, seriebus tribus atomorum nigrorum disci; capite cum palpis albo. Exp. al. 3? lin.

Head, face, and palpi white. Antennx fuscous. Anterior wings white, with three rows of black scales on the dise; cilia whitish. Posterior wings grey, with whitish cilia.

A specimen of this insect is in the collection of Mr. Vaughan, who took it, June 26,1849 , by sweeping the short grass on the top of St. Vincent's Rocks, Durdliam Downs.

36. collitella (F. v. R.), Dup. L. F. Sup. iv. 327. pl. 77. f. 9 (1842).-subocellea, Step.? Alis anticis albis, fasciis tribus ochreis, prima basim versus obsolela, secunda pone medium, lertia saturatiore ante apicem, disci parce nigro-squamato, serieque squamarum nigrarum ad marginem posticum truncatum; capite albo. Exp. al. 4 lin.

Ilead, face, and palpi white. Antenna fuscous, ammulated with white. Anterior wings white, with threc dirty-ochrcous fasciac; the first, near the base, very indistinct, the second bryond the middle, and the third, and darkest, towats the apex; on the disc are a few seattered black scales, and there is a roro of black scales along the truncate hinder maryin; cilia whitish, the tips fuscous. l'osterior wings grey, with paler cilia.

Occurs on Durdham Downs, near Bristol, in July.

37. pollinariella (\%ell.), 1)up. L. F. xi. 50s. pl. 307. f. 5 (1838); Zcll.; Sta. Alis anticis albis, fasciis tribus ochreis, costan versus fuscescentibus, prima basim versus, secunda in medio, tertia ante apicem, disco parce fusco-squamato; capite albo. Exp. al. 4-5 lin.

Ilead, faee, and palpi white. Antennie fuscous. Anterior wings white, with three dirty-ochrcous fascie, darkest towards the costa; the first is near the base, the second in the middle, and the third towards the anex; on the dise, and along the fold, are some senttered fuscous scales; cilia whitish, with a dark fuscous hinder-nauginal line, the extreme tips grey. Posterior wings grey, with paler cilia.

()ceurs at sanderstead, Micklehnm, and Durdham Downs, in June and July. 
38. rufocinerea, IIaw. L. B. 535 (1829); Step.; Zell.- - floslactis, IIaw.; Step. Alis anticis ( $\delta^{*}$ ) albidis brunnescente suffusis; posticis griseis. ( $q$ alis anticis albis dilutissime lutescente suffusis; posticis dilute griseis.) Exp. al. 4-5 lin.

ơ Head, face, and palpi whitish. Antenne brownish. Anterior wings whitish, very much suffused with browuish, the inner margin and diseoidal cell only remaining of the ground-colour; cilia dirtywhitish, with dark fuscous seales. Postcrior wings dark grey, with greyish-ochreous cilia.

o Ilead, face, and palpi white. Antenna whitish, annulated with fuscous. Anterior wings whitish, with numerous scattered scales of a very pale yellowish tint; cilia whitish, with some fuscous scales. Posterior wings pale grey, with yellowish cilia.

$\Lambda$ most abundant species throughout the country; it appears at the end of April, directly the first warm weather sets in, and continues throughout May; it especially frequents the sides of hedges and ditches, where the males may be seen flying briskly along, about sunset, just above the tops of the grass, in search of the females, which may frequently be observed perched on the summit of a blade of grass, with the wings in continual vibration. In spite of the excessive abundance of this insect, we liave hitherto failed in our attempts to find the larva; but the pupa has, on three separate occasions, been met with: once on the stem of a dock by Mr. Douglas, and I once found it under a leaf of Veronica Chanredrys, and once on the upper side of an ivy-leaf, where it lay conveniently in the angle of the leaf, with a silken awning spread over it.

39. ochreella, Sta. Cat. p. 27 (1849).-var. nebulella, Sta. Alis anticis ochreis, costam versus fuscescentibus; posticis fuscis, ochreociliatis. Exp. al. 5 lin.

Head, face, and palpi yellowish-ochrcous. Antenne fuscous. $\Lambda$ nterior wings yellowish-ochreous, somewhat fuscous along the costa, especially at the base; cilia yellowish-ochrcous. Posterior wings fuscous, with ochreous cilia.

IIas occurred in the Cambridgeshire fens, and in the north of England, in Junc.

40. cygnipennella, Hüb. Tin. 207 (1801); Zell.; Dougl. Ent. Trans. ji. n. s. 211. pl, xviii. f. 3.-cygnipennis, llaw.-cygnella, Treit.; Dup.- o cygnipennelln, Step.- $\delta$ semialbella, Step. $\Lambda$ lis anticis albis immaculatis; posticis $\left(\sigma^{*}\right)$ fuscis, albido-ciliatis ( $q$ albidis, albo-

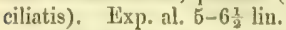

IIcad, face, palpi, and antenne white. Anterior wings immaculate, white ; cilia white. Posterior wings (of the of) fuscons, with whitish cilia (of the of whitish, with white cilia). 
Common at Sanderstead, and in many other localities, in June; the perfeet insects appear very sluggish. 'The larva mines the upper part of the leaves of the Dactylis glomerala in May.

\section{Genus XIV, TISCHERIA.}

Tiscueris, Zell. Isis, 1839, p. 219 ; Dup. Cat. Elackista p., Trcit.; Dup. L. F. Aplelosetia p., Step.

Capilli occipitales suberecti; frontales depressi. Palpi labiales breves, filiformes, penduli. Ifausicllum mediocre, squamatum. Antemes alis anterioribus breviores, of piloso-ciliatre, of nudx, articulo basali dentem pilosum gerentc. Alec longe ciliatic, anteriores subeaudulatæ, posteriores lanceolatæ. Tibix postice pilosæ. Nlx anteriores: cellula discoidalis postice aperta, vena subcostalis in basi longissime obsoleta, ramos quinque in costam, mediana tres in marginem posticum crnittit, vena subdorsalis simplex; posteriores: ven $x$ simplices.

Mead behind with ralker erect hairs, in front smooth. Labial palpi short, filiform, drooping. Tongne of moderate length, clothed with scales. Antenne considerably shorter than the anterior wings, in the $\delta$ with pitose cilialions, in the of simple, the basal joint furnished with a projceting tuft of hair. Wings with long cilia, the anterior pointed, hardly caudulate, the posterior lanceolate. Hinder tibie hairy. In the anterior wings the discoidal cell is not closed, the subcostal vein is obsolete for a considerable length towards the base; it sends five veins to the costa, the median einits three to the hinder margin, the subdorsal vein is simple; in the posterior wings the veins are simple.

$\Lambda$ rather singular genus, of which only two species have occurred in this country (two or three others are known on the continent); the perfect insects sit with the head slightly raised, the tips of the wings firmly pressed against the substance on which the insect is sitting. The larve are leaf-miners, and remarkable for their extremely undeveloped legs, which require to be seen by the aid of a microseope; the habits of our two species exhibit considerable differences.

1. complanella, IHüb. Tin. 428 (1816); Treit.; Dup.; Zcll.; Ratz. T. I. ii. pl. xii. f. 4; Sta.-mfipennella, Step.-Miillerellu, Vill.? -rufipennis, Ilaw.?-fulvescens, Step.? Alis anticis luteis, marrine postico late, costaque angustissime fuscescentibus. Wxp. al. $3 \frac{1}{-1}-5$ lin.

IJead, face, and palpi yellowish. Antenne grcyish-ycllow. Anterior wings bright yellowish, towards the hinder margin and along the costa fuscescent; cilia yellowish at the apex, grey at the anal angle. Posterior wings grey, with yellowish-grey cilia. 
Very common among oaks in Junc. The larva (according to Ratzeburg) mines in the autunn in oak-leaves, making large white blotehes, within which the larva may be observed in a curved position; the mined leaves remain perfectly flat. The larra, when full-fecl, spins its cocoon within the leaf, but remains unchangerl till spring; there does not appear to be more than one brood in the year. (I have repeatedly met with the larvie, but have not hitherto succeeded in rearing them.)

2. marginea, Haw. I. B. 556 (1829); Step.-Emyella, Dup. L. F. xi. pl. 309. f. 6; Zell. Alis anticis luteis, costa anguste, apicem versus latius, marwineque postico late firscis, puncto rolundo atro mar-

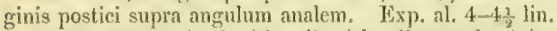

Ilead fuceous, mixed with yellowish. l'ace and palpi ycllowish. $\Lambda \mathrm{n}$ tenne fuscous. Anterior wings bright yellowish, with the costa narrowly fuscous at the base, more broally towards the apex, the hinder margin broally fuscous, with a round black spot above the anal angle; cilin at the apex oclureous, at the anal angle grey. Posterior wings fuscous, with paler cilia.

Common among brambles in May and August. The Iarva mines the leaves of the bramble in autumn and winter, and in July; the mines appear as whitish blotches, palest at their origin, of a cornucopia shape; they pucker the leaf a little; the larva changes to a pupa in the mine, not forming a cocoon; the pupa is extremely active.

\section{FAMILY XI. LITHOCOLLETIDA。}

Capilli hirsuti. Palpi labiales filiformes, penduli. Nla longe ciliate, anteriores elongutre, postice acuminater, posteriores linrari-lanerolate.

Hearl rough. Labial palpi filiform, drooping. Wings with long cilia, the anterior elongate, posteriorly acmminate, the posterior linearlanceolate.

T'his family, at present, only contains one genus.

\section{Genus I. LITHOCOLLETIS.}

Litrocollfisis, 7ell. Isis, 1S39, p. 216 ; Dup. Cat. Tinea p., Haw. Argyromiges p., Curt.; Step. Blachista p., 'Treil.; 1)up. L. F. xi.; Zett. Chrysoesltia p., Lilhocolletis p., et Lucestis, Hüb. V.

Capilli hirsuti, epistomio lavigato. Antenna alis anterioribus vix breviores, articulo basali modice inerassato. Ilaustellum mediocre, nudum. Palpi labiales filiformes, penduli. Ale longe ciliate, an- 
teriores clongatx, postice acuminatre; posteriores lincari-lanccolatx. Anteriores: vena subcostalis longe intermunta, cellula discoidalis venas duas in costam, unam in apicem, duas in marginem posticum emittit, sublorsalis simplex; posteriores: vena mediana bifida in utrumque marginem exit, subdorsalis simplex.

IIead rough, the face smooth. Antemure hardly shorter than the anterior wings, the basal joint molerately thickened, not expanded into an eye-cap. Tongue of moderate length, naked. Labial palpi filiform, drooping. Wing with long cilia, the anterior elongate, posteriorly acuminate (yet appearing from the cilia of an elliptic form); the posterior linear-lanceolate. In the anterior wings the subcostal vein las a long interruption; the discoidal cell sends two reins to the costat, one to the apex, and two to the binder margin; the subdorsal vein is simple. In the postcrior wings the median vein is bifid, terminating on each margin; the subdorsal vein is simple.

This is in all probability the most elegant genus of the Tincina; the graceful form of the perfect insects, the slarpmess of the designs on the anterior wings, and the rich, freyuently metallic lustre of the scales, impart to them a brilliancy which attracts the attention of the most superficial. Unfortumately the small size of these little gems, and the extreme similarity of many of them, have caused considerable ambiguity with regard to the descriptions of the carlier authors, so that our accurate knowledge of few of the species dates further back than 1816, when the appearance of the first volume of the 'Limmea Kintomologica,' with Keller's monograph of this genus, caused a complete revolution in this departinent of Fintomological science. Hilaborate as was that monograph, and immensely in advance of all that had previously been written on the subject, the impetus it grave to the study of this group has been so great, that it has already become antiquated and out of date. Von Nicelli, whose remarks on the habits of the Pomeranian species of this genus show that lie is fully competent for such a task, has undertaken to write a monograph of the genus as it stands at the present time, and I believe his monograph is now ready for publication.

The perfect insects rest with their head slightly elevated (a single species (Sclirelerella) has a directly contrary habit, inclining its head to the surface on which it rests at an angle of fully $30^{\circ}$ ) ; the antenne are laid back generally under the wings; the flight is gentle, or with occasional jerks. The larva have only fourteen feet, and mine in leaves, having no power to quit their mine, but changing thercin to a pupa, and the empty pupa-skin may be found protruding through the skin of the leaf after the perfect jusect has escaped. Some of the larve mine beneath the 
upper cuticle, some beneath the under cuticle, but the larva of no species is known to mine indifferently the upper or under side of a leaf. The larra, in the process of its mine, contorts the leaf more or less, the leaf curving towards the side on which the larva is at work; the larva carpets the loosened skin with silk, and purposely pulls it so tight as to cause the loosened skin to pucker, whereby the opposite side of the leaf naturally curves. MIr. Boyd has suggested that the natural shrinkage of the silk may, without any extraneous assistance from the larva, cause the puckering of the loosened skin. Mamy of the larva have the third and fourth segments considerably enlarged. The larva of some species form cocoons of silk, sometimes of very fine texture; others interweave the grains of excrement into the cocoon; a few do not construct any cocoon. Mlost of the species are double-brooded, appearing in the perfect state in May and August, and the larre feeding in July and October; a few of the latter brood remain in the larva state throughout the winter, but in most of the species the pupa state is assumed before the commencement of winter, and many a withered brown leaf blown hither and thither, at the mercy of every gust, contains throughout the winter a living pupa, to appear in the following spring as onc of thesc splendid insects.

The genus may be tabulated as follows:-

a. Anterior wings with a hook in the cilia. Species 1-3.

a a. Anterior wings with no hook in the cilia.

b. Anterior wings dark, with a white, whitish, or silwery basal streak.

c. The basal streak dauk-margined on both sides. Species $4-9$, $19,20$.

c $c$. The basal streak dark-margined only towards the costa. Species $10,12,17,26$.

c c c. The basal streak with no dark margin. Species 11, 13, $14-16,18,21-25$.

b b. Anterior wings white, with dark strcaks or fascix. Species 2730,41 .

666 . Anterior wings dark, with no defined basal streak, but with two or more pale fascix. Species $31-40$.

1. Roboris, 7cll. Isis, 1839 , p. 217; Id. L. E. i. 174. pl. 1. f. 4 . -Roborella, Sta_-Roborifoliella, Dup. Alis anticis niveis, macula parva dorsali aureo-brumnea basim versus, fuscin lata obliqua a basi costa fere ad medium dorsi, aureo-brunnea, pone inedium lineis quatuor costie, una dorsi nigris introrsum fuscescente-marginatis, puncto rotundo apice atro, caudulam ciliarum emiltente. Exp. al, 4 lin.

IIead white, with a few fuscous hairs. Face and palpi white. $\Lambda_{n-}$ tenne whitish, with fuscous annulations. Anterior wings white, with a small golden-brown blotch on the inner margin near the base; an 
oblique golden-brown fascia commenees at the base of the costa, it is at first very broad, but crradually becomes thimer, terminating before the niddle of the iuner margin, on its outer side are some fuseous seales; beyond the middle of the wing are four short black lines from the costa, and a longer one from the imner margin internally margined with pale golden-brown; at the apex is a round black spot, from which the long black seales, which form the hook in the cilia, project; cilia white. Posterior wings grey, with whitish cilia.

Appears in May and August. The larva feeds on the underside of oak-leaves. It has occurred at Leatherhead, Huddersfield, and Doncaster.

2. hortella, Fab. E. S. iii. 2. 327. 174 (1794); JIaw.; Sta.Saportella, Dup.; Zell. L. E. i. 177. pl. 1. f. 6 ; v. Nicelli,-Kullweiniella, Zell. Isis, 1839. Alis anticis albis, fasciis tribus angulatis, secunda interrupta, ochreo-aureis utrinque nigro-marginatis, strigulis duabus costic ochrco-aurcis, extrorsum nigro-matrinatis, in striolam apicis ochreo-fuscam decurrentibus. Exp. al. 4 lin.

Head whitish. Face and palpi white. Antenne white, with fuscous ammulations. Anterior wings white, with three angulated fascire and two costal spots, oclireons-yellow, somewhat gulden; the first fascia is slightly augulated, externally dark margined aud internally partially so; the second fascia is more angulated and frequently interrupted, the costal half projecting beyond the dorsal half, it is dark-margined on both sides, as is also the third fascia, which is still more angulated and the prolongation of its angle forms the apical streak, which is ochrcousgolden, with only a few black scales; the two costal spots rum into the apical streak and have dark margins externally; a black hinder marginal line goes round the apex of the wing; cilia white, the extremities of the costall half black, thus forming a hook. Posterior wings very pale grey, with whitish cilia.

Appears in May and $\Lambda$ ugust. The larva feeds in onk-lenves. It lias occurred at Oxford, Shrewsbury, and near London.

3. Amyotella, Dup. L. F. xi. 54.4. pl. 309. f. 2 (1838); 7cll. L. E. i. 180. pl. 1. f. 7; v. Nicelli; Sircom.-Mïlleriella, Zell. Isis, 1839. Alis anticis croceis, strigulis duabus costre, tribns dorsi obliruis albis, prima costie in medio, prima secundargue dorsi utringue fuscomarminatis, sccunda tertiaque dorsi introrsum fusco-marginatis, striola apicis nigra, squamis supra cam albis ad caudulam fuscam ciliorum propagatis. tixp. al. 4 lin.

Head saffron-yellow. Face and palpi white. Antemae whitish, anmulated with fuscous. Anterior wings bright saffrous-yellow, with two costal and there dorsal streaks white; the first costul stowak is near the midelle and is opposite the second dorsal streak, it is dark-margined on both sides; the two tirst dorsal straks arc dark-margined on both sides, the apex of the second is considerably prolonged; the second 
costal is opposite the third dorsal streak, they are dark-margined intcrmally; in the apex of the wing is a black strcak, above it are some white seales which run into the fuscous hook of the cilia; a dark hinder-marginal line runs round the apex of the wing ; cilia pale ochreous. Posterior wings grey, with paler cilia.

Appears in May and August. The larva feeds in oak-leaves. It has occurred near Bristol, and near Keswick.

4. Iantanella, Schr. I. B. ii. 136. 1888 (1802).-elatella, Zell. L. E. i. 190. pl. i. f'. 12 ; Stit. Mlis anticis dilute croceis, linea basali utrinque nigro-marginata, strigulis qualuor costa, tribus dorsi introlsum fusco-marginatis, argenteo-albis, striola apicis clongata atra. Exp. al. 4 lin.

Head pale saffron. Face and palpi white. Autenux whitish, with darker anuulations. Anterior wings shining, pale saffron, with a basal streak, four costal and three dorsal streaks silvery-white; the basal streak is dark-margined towards the costa, and its hinder half is darkmargined towarls the inner margin; the costal spots are all small and have dark margins towards the base of the wing; the first dorsal spot is the longest, it is curvel, it is dark-margined internally and romd its apex, which is rather prolonged as a black streak; the second dorsal spot is triangular, it is dark-margined on both sides; the apical black streak is rather long and thin, and has frequently on its upper side white scales, forming a contimuation of the fourth costal spot. Postcrior wings grey, with paler cilia.

Appears in May and August. The larva feeds in the underside of the leaves of 7 iburnum Lantana; the autumnal larve do not change to pupe till spring. It has occurred at Micklcham, and near T'eignmouth.

5. triguttella, Sta. Zool. 1850, p. 2896. Alis anticis croceis, linca temui basali utrinque fusco-marginata, strigulis tribus coshe, tribus dorsi, introrsum fusco-marginatis, albis, squanis fuscis disci pone medium, striola apicis nigra. Exp. al. 4t lin.

Head pale saffron. Face and palpi white. Anterior wings shining saffron, the basal streak rather slender, dark-margined on both sides; on the costa are lluree white streaks (a fourlh is tolally weanting), and three others are on the inner margin, are all dark-maryincel towards the base, the first pair most strongly; some dark seales lie on the dise beyond the midelle; beyond the apex of the third costal streak commenecs the apical black streak; some clark scales in the cilia run round the apex of the wing. Posteriol wings leaden-grey; cilia paler.

$\Lambda$ single specimen, taken at Sanderstead in May, by Mr. Douglas, is in his collection.

6. quinqueguttella, Sta. Sup. Cat. p. 12 (1851). Alis anticis croceis, linca basali argenteo-alba, utrinque fusco-marginata, strigula ad 
costan applicata prope basim fusco-marginata, strigulis quatuor costæ, tribus dorsi, introrsum fusco-marginatis, argenteo-albis, striola apicis nigra. Exp. al. 3 lin.

IIead saffron. Face and palpi white. Antenna fuscons, with whitish annulations. Anterior wings bright saffron, basal streak silvery-white, dark-margined on both sides; above it along the costa is a silvery-rolite streak, quite detached from the next costal spot and wilh a distinct dark margin; beyond are the ordinary four costal and three dorsal spots, all internally dark-margined, except the last costal spot, which is situated in the apex immediately above the apical black streak; below it are some black scales in the cilia reaching to the anal angle. Posterior wings grey, with paler cilia.

Taken among sallows in May and July, by Mr. Hodgkinson and Mr. C. S. Gregson.

7. nigrescentella, Logan, Ent. Trans. i. n. s. 182. pl. xv. f. 9 (1851). Alis anticis fusco-nigris, linea basali utrinque fusco-marginata argentea, strigulis quatuor costw, tribus dorsi argenteis, prima costa cum prima ac sccunda dorsi conflucnte, puncto apicis ovato nigro. Exp.al. $4 \frac{x}{2}$ lin.

IIead brownish-black. Face and palpi metallic. Antenne brownishblack, the tip white. Anterior wings dark brown, inclining to black; the silvery basal streak is dark-maryined on bol/h sides; on the costa are four silvery spots, and on the inner margin are three, none are dark-margined; the first pair of spots meeting form an angulated fascia, and the apex of the dorsal spot is continued towards the apex of the second costal spot; the apical black spot is slightly of an oval form (very nearly round). Posterior wings brownish-grey; cilia paler, striking paler at their origin.

A single specimen, taken near Morpeth in May, by Mr. Scott.

8. irradiella, Scott, n. sp. Alis anticis olivaceo-fuscis, linca basali tenui abbreviata argentea, strigulis tribus abbreviatis costze, tribus dorsi (ultima parva) argenteis, apice atro-squamato. Exp. al. 3 lin.

Ilead black. Fack and palpi silvery. Antemna dark fuscous, before the apex white. Anterior wings olivaceous-firscous, with a slender, short, silvery basal streak, and three short costal streaks and three dorsal streaks silvery; the last dorsal streak is small and inconspicuous; at the apex are a few biack scales, beyond which the eilia are rather iridescent; beyond the dark hinder-marginal line the cilia are fuscous. Posterior wings dark grey, with paler cilia.

$\Lambda$ single specimen, taken by Mr. Scott in the beginning of July, near Renfrew, amongst birches. Mr. Scott, with the view that the information to be derived from the sight of the unique specimens of this and the preceding species, might be more widely disseminated than if they remaincel in his own collection, has with extreme libcrality placed them in mine. 
9. lautella, 7ell. I. F. i. 194. pl. 1. f. 14 (1846); Sta.; v. Nicelli. Alis anticis rufo-aurantiis, linea basali abbreviata argenter, utrinque nigro-inarginala, strigulis quatuor costic (ultima interdum obsoleti) duabus dorsi argenteis, introrsum nigro-marginatis, prima coste, duabusque dorsi utringue nigro-marginatis, squanis nomullis argenteis supra angılum analem, striola apicis ovata nigra. Exp. al. $3 \frac{1}{3}-4$ lin.

IIead black. Face and palpi metallic. Antenna black, before the apex white. Anterior wings very bright reddish-orange, with a short silvery basal streak dark-margined on both sides; from the costa are four silvery streaks (the last frequently obsolete), the first is dark-margined on both sides, the others only on the side towards the base of the wing; on the inner margin are two silvery streaks, dark-margined on both sides, the first is almost perpendicular and nearly meets the first costal streak; above the anal angle are a few silvery scales; the apical black streak is somewhat oval, but not very distinct; cilia beyond the dark hinder-marginal line grey. Posterior wings dark grey, with paler cilia.

Appears in May and August. The larva feeds in oak-leaves; it forms an elongate, very fine cocoon.

10. pomifoliella, Zell. L. E. i. 196. pl. i. f. 15 (1816); Sta.var.? Junoniella, Sta. Alis anticis croccis, linca basali postice acule terminala, costam versus fusco-marginata, alba, strigulis quatuor costic, tribus dorsi introrsum, prima coste, prima secundarue dorsi utrinque fusco-marginatis, albis, striola apicis obsoleta nigra. Exp. al. 3-4 lin.

Head bright safiron-ycllow. Face and palpi white. Antenua white, annulated with fuscous. Ilinder tarsi whitish, spotted with dark fuscous. Anterior wings bright saftron-yellow, varying to golden-brown; the basal streak is white, it gradually thickens to beyoud its middle and then terminates in a point; the side lowards the costra and the underside of the apex are dark-margined; on the costa are four white streaks and on the inner margin are three, all are internally dark-margined; the first costal and two first dorsal streaks are dark-margined on both sides; beyond these are some dark seales on the dise, and at the ancex of the wing is an obscure black streak. l'ostcrior wings grey, with paler cilia.

Abundant in May and August. The larva mines the underside of the leaves of whitethorn (and apple?).

11. Coryli, v. Nicclli, Ent. 1/tg. 1851, p. 26; Sta. Alis anticis ochreis vel ochreo-brunneis, linea basali nivea, non obscrere maryinala, strigulis quatuor costc, tribus dorsi niveis introrsun fusco-marginatis, striola apicis nigra. Exp. al. $3 \frac{1}{2}$ lin.

Ilead dull ochreous. Face and palpi white. Antenna white, faintly ammulated with pale fuscous. IIinder tarsi white, spolled wilh dirk fuscous. Auterior wings ockreous or ochreous-brown, with a straight snowy-white basal streak with no dark margin, and with four costal and 
three dorsal streaks snowy-white, dark-margined towards the base of the wing; the apical black streak is rather short. T'osterior wings grey, with paler cilia.

Abundant in May and $\Lambda$ ugust. The larva mines the upper side of the leaves of the mut; the large white blotehes it makes are very conspicuous; when full-fed it causes the leaf to pucker very considerably, consequently, by the distortion of the leaf, the age of the larva may be known.

12. spinicolella (Kollar), Zell. T. E. i. 203. Anm. l (1846).Pomonella (spinicolella), Sta.-Var.? Pomonella (deflexella), Stat. Alis anticis dilute croceis, linea tenui basali alba, costam versus fusco-marginatis, strigulis quatuor costa, tribus dorsi introrsum fusco-marginatis, striola apicis nigra. Exp. al, $3-3 \frac{1}{2}$ lin.

Ilead pale saffron. Tace and palpi white. Antenne white, with faintly darker annulations. ITinder tarsi white, enspotted. Anterior wings shining pale saffron-ycllow, with a slender white basal streak dark-margined towards the costa, and with four costal and three dorsal streaks white, with dark margins (sometimcs very faint) towards the base of the wing; the apical streak is ovate and blackish. Posterior wings pale grey, with paler cilia.

Common in August. The larva mines the underside of the sloc-leaves in July. The variety? deflexella (which differs only in laving the anterior wings irrorated with palc fuscous, and the basal streak deflected into the first dorsal streak,) is common among sloc-bushes in May; it is probably only the other brood of spinicolella.

13. Faginella (Mann), Zell. L. F. i. 204. Anm. iii. (18.16); Sta. - Sugifoliella, Sircom.-P'omonella, Sta. (Zool. 1848); v. Nicelli,--var. securiferella, Sta.-MIcrstingella, Müller? Alis anticis dilute croceis, linea basali alba non obscure marginata, strigulis quatuor clorsi, introrsum late fusco-marginatis albis, striola apicis nigra. Hxp. al. $3 \frac{1}{2}-1 \cdot \frac{1}{3}$ lin.

Ilead pale saffron-yellow. Tace and palpi white. Antenne white, annulated with very pale fuscous. Ilinder tarsi entirely whitish, or spotted with very pale fuscous. Anterior wings pale saftron-yellow, with a straight, ummargined, white basal streak, nnd with four costal and three dorsal white streaks, which have distinct and broad derk margins towards the base of the wing; between the second pair of spots are frequently some dark seales on the disc; the black apieal streak is rather oval, Posterior wings pale grey, with ochreous-grey cilia.

Abundant in May and August. The larva mines the underside of the bech-leaves in autumn and July.

14. salicicolella, Sircom, 7ool. 1818, p. 2271 ; Sta.-Capraclla, v. Nicelli. Alis anticis dilute octreis vel ochreo-brunneis, linca basali 
tenuissima alba non obscure marginata, strigulis quatuor costc, tribus dorsi introrsum fusco-marginatis, albis albidisve, squamis sparsis nigris disci, puncto ovato apicis nigro. Exp. al. $3 \frac{\lambda}{2}-4$ 즘.

Head saffron-yellow, more or less mixed with brownish. Fiace and palpi white. Anteuna whitish, with darker annulations, beforc the apex white. Hinder tarsi whitish, sometimes spotted pale fuscous. Anterior wings shining pale saffron-yellow, or ochreous-brown, with a very slender, unmaryined, white or whitish basal streak; on the imer margin near the base is an inconspicuous white spot or streak, which does not reach the basal streak; on the costa are four and on the inner margin are three white or whitish streaks, all are dark-margined towards the base of the wing; the first pair of spots frequently unite and form an angulated fascia; between these and the third pair of spots are numerous black scales on the dise; at the apex is an ovate, rarely streak-formed black spot. Posterior wings pale grey, with ochrcousgrey cilia.

This species is susceptible of considerable variation; it is common in May and August. The larva mines the underside of the leaves of the sallow in autumn and July.

15. viminetorum, n. sp. Alis anticis octureo-brunneis, linea basali tenuissima alba, non obscure maryinata, cum apice trianguli dorsalis albi (non obscure marginati) coufluente, fascia angulata in medio, strigulis tribus costix, duabus dorsi albis, puncto ovato apicis nigro. Exp. al. $3 \frac{1}{3}-4 \frac{7}{2}$ lin.

Head saffron-yellow, mixed with brownish. Face and palpi whitish. Antenne whitish, with darker anmulationis, the apex white. Antcrior wings dull ochrous-brown, with a very slender, unmargined, white basal streak; on the inner margin near the base is an unmargined volite triangle, the apex of which reaches to the basal streak; in the middle is an angulated white faseia, slightly margined with dark scales internally; beyond are three costal and two dorsal white streaks, the first pair of which only are distinct, and internally dark-margined; at the apex is an ovate black spot. Posterior wingrs grey, with paler cilia,

I bred many hundreds of this from larva mining in the underside of the leaves of the osier in autumn; all the specimens thus bred, though showing some slight variation, are constant in their differences from the preceding, and I cannot but think it specifically distinct.

16. Carpinicolella, Sta. Sup. Cat. p. 13 (1851).-ilicifolielln, Sta. (Yool. 181.8).-Mespilella, Ilaw.? Step)? Alis anticis dilute croceis, linca basali recta alba non obscure marginala, strigulis quatuor costac, tribus dorsi albis, introrsum fusco-marginatis, prima coslo excepta, que per costam basim versus producta est. Exp. al. 4 lin.

IIead pale saffron. Fice and palpi white. Antenne whitish, annulated with palc fuscons. Hinder tarsi whitish, spotted with dark 
fuscous. Anterior wings pale saffron-yclow, with a straight white $u n$ margined basal streak, and four costal and threc dorsal white streaks; all these have dark margins towards the base of the wing, except the first costal streak, which is continued along the costa towards the bese of the wing; at the apex is a short black strenk. Posterior wings pale grey, with ochreous-grey cilia.

Not uncommon in May and August. The larva mines in the upper side of the leaves of the hornbeam in autumn and July.

17. ulmifoliella, Ilüb. Tin. 44. (1816); Treit.; Dup.; Zell. L. E. i. 210 . pl. 1. f. 18; Sta.; v. Nicelli. Alis anticis saturate croceis, linea basali recta albicla costam versus nigro-marginata, fascia angulata ante modium, strigulis tribus costa (Lertia apicali), duabus dorsi, introrsum nigro-marginatis, albidis, punclo rolundo apicis atro. Exp. al. 4 lin.

IIcad dark saffron or brownish. Face white, inclining to metallic. Palpi white. Antemne fuscous, before the apex white. Interior wings deep saffron, inclining to brownish, with a straight, rather short, whitish basal streak, dark-margined lowards the costa, with an angulated whitish fasciu, internally dark-margined; beyoud are three costal and two dorsal whitish streaks, internally dark-margined; the last costal streak is immediatsly over the round apical black spot. Posterior wings grey, with paler cilia.

Abundant in May and August. The larva mines the underside of the leaves of the birch in autumn and July.

18. Spinolella, Dup. L. F. xi. 535. pl. 308. f. 8 (1838); Sta.; v. Nicelli,-hilarella, \%ett.? Alis anticis croceis, paullulum grisen-irroratis, linea brevi basali alba non obscure marginata, fascia arcuala ante, strigulis tribus costa, duabus dorsi pone medium, introrsum fusco-marginatis, albis, squamis nigris disci, striola apicis ovata nigra. Exp. al. $3 \frac{1}{2}-4 \frac{\pi}{2}$ lin.

Head yellowish-white. Face and palpi white. Antennx whitish, anmulated with fuscous, before the apex white. Anterior wings saflionyellow, more or less suffused with grey, with a short unmurgined white basal streak, a sligfelly-curved white fuscio before the middle, internally dark-margined, and beyond the middle three costal and two dorsil white streaks, internally dark-margined; between the first piar of spots are some dark seales on the dise; the apical black spot is ratlier small and oval, Posterior wings grey, with paler cilia.

Local; it oceurs at Bristol, II uddersficld, and in the south of Scotland. Common in May and August. 'The larva mines in the leaves of the sallow in autumn and July.

19. quercifoliella (H. v. R.), Kell. Isis, 1539, p. 217; IU. L. L. i. 218 . pl. 1. f. 22; Sti.; v. Nicelli; 1)up. ?-ITarrisella, var. $\beta$, Haw. -Harrisella, Step.? Alis anticis dilute croceis vel pallide ochreis, linea basali longu, laned pallidione, utringue fusco-murginala, strientis

VOL. III. 
quatuor costre, tribus dorsi, introrsum fusco-marginatis, albidis, puncto apicis rotundo atro. Exp. al. $3 \frac{x}{2}-4$ lin.

Ilead pale saffron-yellow. Fiace and palpi silvery-whitc. Antemac yellowish, ammulated with fuscous. Anterior wings pale saffron-yellow or very pale ochrcous, wilh a basal line of the ground-colour, dark-margined on both sides, terminating in the fold beyond the middle, and with four costal and three dorsal streaks paler, internally with dark margins; the first costal strcak is dark-marrined on both sides; between the second and third pairs of streaks are some dark seales on the dise; the black apical spot is round. Postcrior wings grey, with paler cilia.

Abundant in May and August. The larva mines the underside of the leaves of the oak in autumn and July.

20. Messaniella, Zell. L. E. i. 221. pl. 1. f. 23 (1846); Sta. $\Lambda$ lis anticis dilute croceis, linea basali haud pallidiore, ulrinque fuscomaryinata, strigulis quatuor costa, tribus dorsi (prima longa, apice ultra secundam producto), introrsum fusco-marginatis albidis, puncto apicis rotundo atro. Exp. al. $4-4 \frac{2}{2}$ lin.

IIead saffron-yellow. Face and palpi whitish. Antenna whitish, ammulated with fuscous. Anterior wings saffron-ycllow, with a straight basal line hardly paler than the ground-colone, dark-margined on both sides, terminating before the middle, and with four costal and three dorsal streaks yellowish-white; the first costal is dark-margined on both sides, the others only internally; the first dorsal streak is very long and curved, its apex reaching over the apex of the second dorsat spot, its apical half is dark-marginer on both sides, the other spots are only dark-margined interually; the third dorsal spot is very intistinct; the black apical spot is rouml. Josterior wings grey, with palcr cilia.

Very abumdant in the south of England, appearing in May, August, and November. The larva mines by preference the underside of the leaves of the evergreen oak, during the winter and spring, and in July and October, but it also feeds on oak, hornbeam, chestrut, etc.

21. corylifoliella, IIaw. I. 13. 580 (1929); Step.; Sta.; IIïb.? -ulmifoticlla, Step.? Alis anticis ochro-rufis, linca lemuissima basali, strigulis oppositis obliquis tenuissimis in medio, strigula parva dorsi prope angulum analem, strigularye minore coste apicem versus, albidis, striola apicis cinerea. Exp. ai. $4, \frac{2}{2}$ lin.

Head reddish-ochreous. Face aud palpi whitish. Antenne whitish, annulated with fuscous. ILinder tarsi whitish, spotted with dark fuscons. Anterior wings reddish-ockrcous, with a very slender ummargined whitish basal streak; in the middle are two very slender obliqnely-placed opposite whilish streaks; both are preceded by " fietn dark scules, which are continued along the marrins towards the base of the wing; beyond the streak are two (sometimes united) dark grey patehes, one on the eosta, the oflier benenth the apex of the dorsal streak, this is frequently continuel towards the apex of the wing; on the immer margin near the 
anal angle is a small whitish spot, precederl by a few dark seales, and on the costa near the apex is a still smaller whitish spot. Posterior wings dark grey, with paler cilia.

Common in the south of lingland, in May and $\Lambda$ ugust. The larva mines the upper side of the leaves of the hawthorn, forming of it one large blister, and by the contraction of the upper side, when full-fed, completely folding the leaf; it may be met with in autumn, and in July.

22. Caledoniella, Sta. Sup, Cat. p. 12 (1851). Alis anticis ochuceo-rufis, postice nigro-synemmetis, linea tenuissima basali, strigulis oppositis obliguis tenuissimis in medio, strigula parva dorsi ad augulum analem, strigulaque minore coste apicen versus albis, striola apicis nigra, Exp. al, $4 \frac{7}{2}$ lin.

Head reddish-ochreous. Face and palpi white. Antemne whitish, with darker ammulations. Ilinder tarsi whitish, unspotted. Anterior wings reddish-ochreous, posteriorly much suffinsed wilh black scales, with a very stender unmargined white basal streak; in the middle are two very slender obliquely-placed opposite while streaks, interually broadly margined with black scales, externally the black scales form an angulated fascin, from the angle of which produced the apical streak is formed; there is a small white spot at the anal angle, and another immediately above the apical streak. Posterior wings grey, with paler cilia.

Has occurred, though sparingly, in the north of England and south of Scotland, in May and Jume, among oaks and honeysuckle.

23. viminiella, Sircom, Zool. 1848 , p. 2271 ; Sta. Alis anticis obscure ochreis, linca teuui basali, strigulis quatuor costre, tribus dorsi ditutioribus, sccunda costie, secundaque dorsi introrsum fusco-marginatis, tertia quartaque costæ, tertiaque dorsi obsoletissimis, squamis nigris disci in striolam nigram apicis exeuntibus. Exp. al. 4 lin.

IIead ochreons. I'ace and palpi white. Antemme whitish, ammulated with pale fuscous. Hinder tarsi whitish, with faint fuseous spots. Anterior wings dull-ochreons, with a slender basal streak, four costal and three dorsal streaks very pale ochreous; the second pair of strealis are internally dark-margincel, and some dark seales at their apices are continued to the apical black streak; the two last costal streaks and the third dorsal streak are frequently very indistinet. l'osterior wings grey, with ochreous-grey cilia.

Rare near London; common in the west of Fingland (Bristol and Devonshire), in May and $\Lambda$ ugust. The larva mines the underside of the leaves of the sallow, in autumn and July.

24. Scopariella (Tischer), Zell. I. F. i. 227. pl. 1. f. 26 (18.6); Sta. Alis anticis obscure croccis, linea temui basali, seppe crm strigulre prima coste conjuncta, strigulis quatuor coste, tribus dorsi albis, striola parva apicis nigra. Exp. al. $3 \frac{1}{3}-4$ lin. 
IJend whitish, mixed with ochreous. Face and palpi white. Anteme: with pale fuscous anuulations. Anterior wings dull safron-yellow, with a slender basal streak, four costal and three dorsal streaks, white and unmargined; the basal streak is at first straight, but afterwards turns towards the costil, and frequently uniles woith the first costal streak, which is obliquely placed and rather lomy, frequently uniting with the first dorsal streak; between the apices of the second pair of streaks are some dark seales, and a small black streak is in the apex of the wing; cilia pale ochreous and whitish, with no dark hinder-marginal line. I'osterior wings grey, with paler cilia.

Occurs among broom in June and July. I have met with it at Dartford Heath, and near Airthrey.

25. ulicicolella (Vaughan), Sta. Sup. Cat. p. 12 (1851). Alis anticis nitidis, croceis, linea tenui basali, strigulis quatuor coste, tribus dorsi nitidis albis, striola parva apicis nigra. Exp. al. $3_{3}^{3}$ lin.

Head safiron-yellow. Face and palpi white. Antenna dark fuscous, with paler ammulations, before the apex white. Anterior wings shining saffiron-yellow, with a basal streak, four costal and threc dorsal streaks shining white and unmargined; the hasal streak is slender, and ruus near the costa, and almost parallel to it; the costal streaks are all short; the first dorsal streak is long, obliquely placed, reaching beyond the middle of the wing ; between the third pair of spots are a few dark scales; at the apex is a small black streak; a dark hinder marginal line yoes round the apex of the voing; cilia grey. l'osterior wings grey, with ochreous-grey cilia.

Discovered by Mr. Vaughan among furzc-bushes, near Bristol, at the end of Jume. I have since found it anong furze-bushes on Dartford Ieath, in July.

26. alnifoliella, IIüb. 'Tin. 193 (1801); Dup.; Sta.--Alniella, Zell. L. E. i. 229, pl, 1. f. 27 ; v. Nicelli-Cramerella, Fab. (G. I.)? Dup.? Alis anticis albidis fuseisve, linea basali latiusculn alba, costam vorsus fusco-marginata, strigulis quatuor costr, tribus dorsi albis, introrsum fusco-marginatis, puncto rolundo apicis atro. Exp. al. $3 \frac{1}{2}-4$ lin.

Head whitish or dark brown. Face and palpi white. Anteuna whitish, with darker annulations. Anterior wings varying in colour from whitish to dark fuscous, with a basal streak, four costal and three dorsal streaks white; the basal streak is rather broad, gradually pointed, nearer to the costa than to the inner margin, towards the costa it is dark-maryined, the costal and dorsal streaks are all dark-margined towards the base of the wing; the first costal streak is dark-margined on both sides, it is long, reashing more than half across the wing; the first dorsal streak is very broad at its base, not reaching as far across the wing as the second dorsal streak; the apical spot is round and black. l'osterior wings grey, with paler cilia.

Abundant in May and August. The Larva mines the under- 
side of the lenves of alders in autumn and July; it constructs a firm cocoon of an ochreous colour.

27. Feegeriella, \%ell. L. E. i. 232. pl. 1. f. 28 (1816); Sta.; v. Nicclli.-lenella, Sta. Zool. 1848, p. 2152. Alis anticis albis, linea basali fusca, lincis qualuor coste, lribus dorsi fuscis, introrsum fuscescente marginatis, puncto ovato apicis atro. Exp. al. $3 \frac{3}{3}$ lin.

IIcad, face, palpi, and antenne whitc. Anterior wings white, with a brownish-black basal line, and four similarly coloured lines from the costa, and lleree from the inner margin, all more or less broadly bordered internally with pale fuscous, their exterior margins being white; the black apical spol is oval. Posterior wings pale grey, with whitish cilia.

Not uncommon, appearing in May and August. The larva mines in the leaves of the oak in autumn and July.

28. Cramerella, Fab. IS. S. iii. 2.327. 173 (1794); IIar.; Step.; Yell.; Sta.; v. Nicelli. $\Lambda$ lis anticis albidis, lineis tribus costix, duabus dorsi fusco-nigris, introrsum fuscescente-marginatis, punclo rolundo apicis atro. Exp. al. $3 \frac{\lambda}{2}-4 \frac{2}{2}$ lin.

Head, face, palpi, and antenne white. Anterior wings pearly-white, with three dark fuscous lines from the costa and troo from the inner margin, all internally bordered with pale fuscous, sometimes very broadly, thus making the apical half of the wing pale fuscous, with uncrely white spots on the cxterior margins of these lines; the black apical spot is round. Posterior wings grey, with paler cilia.

Very abundant in May and August. The larva mines the underside of the leaves of the oak in autumn and July; owing to the number of the oak-feeding species, the individual mines of each have not yet been sufficiently distinguished. Looking at the infinite variety in every department of nature, it is probable that the mine of each species has some distinetive peculiarity.

29. tenella, Zell. L. E. i. 236. pl. 1. f. 30 (1846); Sta. Alis anticis albis, strigulis quatuor costa, lribns dorsi ocfuraceo-favidis, extrorsum fusco-marginatis, linea apieis postice incrassata atra. Exp. al. $3 \frac{1}{2} \operatorname{lin}$.

Head whitish. Face and palpi white. Antenne whitish, ammulated with fuscous. Anterior wings white or whitish, with four yelloreish streaks from the costa, and three from the inner margin, all are extermally dark-margined; at the apex is a short black streat, internally pointed, extemally rounded; above and below it the wing is entirely ochreous. Posterior wings pale grey, with paler cilia.

Not scarce in May and August. The larva mines the underside of the leaves of the hornbeam in autumn and July.

30. sylvella, IIaw. J. B. 579 (IS29); Step); Sta.--acerifoliellu, Zcll. 1. I. i. 239. pl. 1. f. 32, 33.- "tcernellu, Dup. Alis anticis albis 
strigis duabus fuscis, fasciis duabus ochraceis angulatis fusco-marginatis, secunda postice cum lertia recla coherente, maculis parvis ochraceofuscis, duabus costre, una dorsi striola apicis nigra. Exp. al. 3-4 lin.

Ilcad whitish. Face and palpi whitc. Antenne whitish, annulated with dark fuscous. Anterior wings white; at the extreme base are one or two dark fuscous spots, beyond are two transverse dark fuscous streaks; a litile before the middle is an augulated oclireous-bronon faseia, followed by a second more acutely angulated, frequently with a projecting tooth towards the previons fascia, both these are dirk-margined on both sides; meeting the angle of the second fascia is a straight, rather oblique third fascia, less distinctly dark-margined; beyond are two small ochreous-brown spots on the costa, and one on the inner margin; the apical black streak is long and narrow. Posterior wings grey, with paler cilia.

Common in May and August. The larva mines the underside of the leaves of the maple in autumn and $\mathrm{July}$; it is almost invariably at the edge of the leaf.

31. emberizaepennella, Bouché, Natur. 132 (1834); Zell. I. F. i. 241. pl. 1. f. 3t; Sta.; v. Nicelli; Dougl. Ent. 'Trans. ii. n. s. 122. pl. 13. f. 3; Dup.? Nis anticis croceis, linea abbreviala basali albida, fasciis duabus, priore arcuata, sceunda angulata, albidis, introrsum nigro-marginatis, strigulis duabus costie, tribus dorsi albidis, prima coste primaque dorsi introrsum nigro-marginatis, squamis inter cas nomullis nigris disci apicem versus. Exp. al. 4-5 lin.

Head ochreous-saftron. Face and palpi white. Antenna whitish, with darker anmulations. Autcrior wings saffron-ycllow, with a very short, ummargined, whitish basal streak; immediately beyond it is a slightly curved whitish fascia, and in the middle is an angulated whitish fascia, both are internally dark-margined; beyond are two costal, and three dorsal whitish streaks, the first pair are internally dark-margineal, and between them are some black seales on the dise continued towards the apex. Posterior wings grey, with ochreous cilia.

Not scarce in the larva state; the perfect insect is less frequently met with. It appears jis May and August; the larva mines the underside of the leaves of the honeysuckle, making its mine nearly as large as the leaf, which it does not contort at a right angle laterally.

32. Frölichiella, Zcll. Isis, 1839, p. 218 ; Id.J. I. i. 213. pl. 1. f. 35 ; v. Nicclli; Sta. Kool. 18.1 ; 1) up.? Alis anticis lutioribus, salurale croceis (basi pallidiore), fasciis tribus argenteo-flavidis (prima sccundarue fere rectis, tertia angulata c maculis duabus oppositis composita), strigulis duabus costa, una dorsi introrsum fusco-marginatis, striola apicis obscura. Exp. al. 4, lin.

Ilearl reddish-orange. Hace and palpi white. Antemne dark brown, with paler andulations, the tip whitish. Anterior wings rather broad, 
reddish-orange (the extreme base paler), with three yellowish-silvery fascie; the first slightly curved, the second nearly straight, the thirit distinetly angulated, composed of two opposite spots, between the, apices of which are some dark scales, all these are dark-margincd towards the base of the wing, and their dark margins fade gradually into the ground-colour; beyond are two small silvery streaks on the costa and one at the anal angle; the dark apical strent is not collected into a regular form. Posterior wings grey, with paler cilia.

IItherto very scarce in this country; I once took a specimen near York, among alders in May. 'The larva (according to v. Nicelli) mines the underside of the leaves of alders.

33. Dunningiella, Sta. Ent. Ztg. 1852, p. 88.-Frölichiclla, Sta. \%ool. 184.8. Alis anticis angustulis, rufo-brumneis, fasciis duabus argenteo-flavidis fere rectis, strigulis tribus costa, duabus dorsi argenteo-flavidis, introrsum fusco-marginatis, striola apicis nigra. Exp. al. 4 lin.

IIead dark reddish-brown. Face and palpi whitc. Antennæe dark brown, the tip whitish. Anterior wings narrow, dark reddish-brown (the extreme base paler), with two slightly curved fascice, there costal and two dorsal streaks silvery, yet rather of a yellowish tinge; all these markings are dark-margined on the side towards the base; the first costal streak is rather anterior to the first dorsal streak, hence they have not so much the appearance of an angulated fascia as in Fröticliella; the apical black streak is oval and more collected into a regular form than in Frölichiella. Postcrior wings grcy, with paler cilia.

Appears in May and August; occurring in the vicinity of oaks and nut-bushes.

34. Nicellii (Zcll.), Sta. Zool. 1851, App. clxxii.-lristigella, v. Nicelli.-Avellanella, Schr.? Alis anticis nilidis croceis, fasciis duabus parum areuatis, strigulis tribus costw, duabus dorsi, argenteo-albidis, introrsum fusco-margiuntis, striola apicis elongato-ovato atro. Exp. al. $3 \frac{x}{2} \operatorname{lin}$.

Head bright saftron. Face and palpi white. Antenna whitish, annulated with fuscous nearly to the tip). Anterior wings slining saflron, with two slightly curved and one angulated silvery-whitish fascix, internally narrowly margined with dark fuscous; before the apex are some black seales forming nearly an elongale-oval streak, above theru are two short silvery-whitish streaks from the costa, and beneath is a smaller one from the anal anglc. Posterior wings grey, with greyishochreous cilia.

llitherto searce; appears in May and $\Lambda$ ugust. The larva mines the underside of the leaves of the nut in antumn and July. The larve have been found by Mr. Wilkinson near I lackncy, and the perfect insect bred by lim.

35. Stettinensis, v. Nicelli, Eint. Ztgo. 1852, p. 219. Alis anticis 
nitidis saturate rufo-an antiis, fasciis duabus vix angulatis ante, strigulis tribus costre, duabus dorsi pone medium, lutco-argenteis, introrsum

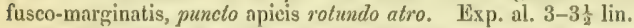

Ilead dark fuscous. Face and palpi silvery-grey. Antenuæ dark fuscous, the tip whitish. Anterior wings shining, deep reddish-orange, towards the base rather obscured with fuscous, with two yellowish-silvery slightly-angulated fascia before the middle, internaliy dark-marerined, and beyond the middle with three yellowish silvery streaks from the costa, and two from the inuer marein, the last on each margin is very minute, the others are dark-margined towards the base of the wing; in the atpex is a round black spot. Posterior wings grey, with paler cilia.

I Iitherto scarce; appears in May and August. The larva (detected last July by Mr. Boyd, and found in the autumn by Mr. Wilkinson) mines the npper side of the leaves of the alder; the mine is rather small, and placed cxactly along a rib (not as usually between two ribs).

36. Klemannella, Fab. S. I. ii. 509 (1781); Ilaw.; Stcp.; IIïb.? -Kleemannella, Zcll. L. E. i. 24. pl. i. f. 36 ; v. Nicelli. Mlis anticis saturate fuscis, fasciis luabus fere rectis aute, strigulis duebus coste, duabus dorsi pone medium, luteo-argenteis, introrsum fusco-marginatis, puncto apicis rotundo atro. Exp, al. $2 \frac{1}{2}-3$ lin.

Ilead dark fuscons. Face and palpi silvery-grey. Antenne dlecp fuscous, the tip whitish. Anterior wings shining dark fuscous, with two yellowish-silvery nearly straight fasciac before the middle, internally dark-margined, and beyond the middle with two costal and two dorsal streaks, yellowish-silvery and dark-margined towards the base of the wing; the second dorsal streak is very small and indistinet; in the apex of the wing is a roum black spot. Posterior wings grey, with paler cilia.

Mr. Hodgkinson has three specimens decidedly referable to this species; they were taken in company with Slettinensis. The larva feeds (according to $\mathrm{v}$. Nieclli) in the underside of alderleaves, its mine resembling that of alnifoliella.

37. Schreberella, Tab. S. I. ii. 30\%. 80 (1781); IIaw.; Step.; Sta.; I)up.?-Kleenamella, Panzer.-ulminella, Kell. L. E. i. 216. pl. 1. f. 37 ; v. Nicelli. Alis anticis rufo-aurantiis, basi obseuriore, fasciis duabus argenteis, introrsum, strigulaque postica costre utrincue nigromarginatis, strigula dorsi aryentera usque all striolam apicis aryenteo-fuscam producta. Exp. al. 3 lin.

Head black. Face and palpi metallic. Antenno black, the tip white. Anterior wings rich reddish-orange, at the base almost black; an oblique and slightly-curved fascia before the middle, and an almost straight fascia in the middle are silvery, and have dark margins towards the base of the wing; on the eosta at the commenement of the cilia is a silvery-quhite streak, margined on both sides with black scales; 
opposite to it on the inner margin is a small sitvery streak, terminating in a metallic streak, which runs to the apex of the wings. P'osterior wings grey, with paler cilia.

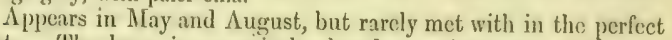
state. The larva is excessively abundant, mining the under side of the Ieaves of the cln in autumn and in July; it forms a bluishgreen cocoon.

38. tristrigella, Haw. I. B. 576 (1829); Step.; Sta.-var. strigifusciella, sta. Alis anticis ochrco-vel brmmeo-rufis, fasciis tribns albidis introrsum fusco-marginatis, cluabus prioribus fere rectis, terl ia angulata, ex angulo strigulan albultum. costan versus emillente, squamis nonnullis nigris infra strigulam. Exp. al. $3 \frac{1}{2}-4$ lin.

IIead reddish-ochrcous. Face and palpi white. Antenne whitish, annulated with fuscous, the tip white. Anterior wings redelish-ochreous, inclining to brownish ; in the middle of the base is a small ummargined yellowish spot, then follow three whitish fiscix, all with dark margins intemally, gradually shading off to the gromud-colour, the two first are nouly straight, the third is angulated, and from its angle a whitish streak mens into the costa at the apex; beneath this streak lie the apical black seales. P'osterior wing's grey, with paler cilia.

Not uncommon in May and August. It has been bred by Mr. Grant and Mr. Dunning, from larva found in elm-leaves in autumn, and not distinguished at the time from the larve of Schreberella. I believe I have bred it both from elm and havolhorn!

39. trifasciella, IIaw. T. B. 576 (1929); Step.; Stil.; Dougl. Int. Trans. ii. n. s. 120 . pl. 13. f. 1.-alnifoliella, Step.-IIrydenii, ZeH. T. E. i. 247. pl. l. f. 38 . Alis anticis mefo-ocheres, fasciis tribus, secunda tertiague angulatis, albidis, introrsum (ad costam latius) nigro margiuntis, strigula albida costie apicem versus, strigula nigra ad augulum analem, striola parva apicis nigra. Exp. al. 4 lin.

IIead reddish-ochreous. Face and palpi whitish. Antenna whitish, ammulated with fuscous. Anterior wings refldish-oclereous, with three slender whitish fiscie, bordered with black towarls the base of the wing, most broally on the costa; the first fascia is only slightly curved, the second is angulated above the middle, the third is angulated and frequently interrupted in the middle, whence some black seales are continued to the anal angle; on the costa before the apex is a short whitish streak, preeded by a few black seales; below it are the black seales of the apex of the wing. Posterior wings grey, with paler cilia,

Common generally, but very abundant in J)evonshire; appears in May, August, and November. 'The larva feeds in April, July, and autumn, in the under side of the lenves of the honcysuckle; its mine is rather small, and it twists the leaf at a right angle.

40. Scabiosella, Dougl. Wint. Trans. ii. 11. 9. 121. pl. 13. f. 2. Alis anticis nitidis cuprev-brummis, linen basali brevi temui alba, fasciis

VOL. III. 
duabus, secunda angulata, allis nitidis, introrsum (ad costam latius) nigro-marginatis, strigulis duabus coste, una dorsi (fere cum prima costali coharente) albis, introrsum nigro-marginatis, strigula nigra ad angulum analem, striola apicis nigra. Exp. al. $3 \frac{1}{2}-4$ lin.

Ilead coppery-brown. Face silvery-grey. Palpi silvery-white. Antenne dark fuscous, with palcr annulations. Anterior wings shining coppery-brown, wilh a very short and narrow numaryined white basal streak, and with two shining white fascix, the first nearly straight, the second angulated above the micllle, both are internally margined with black seales, most broadly on the costa; beyond are two white costal streaks and onc dorsal streak, which almost unites with the first costal streak, they are dark-margined internally, and between them lic some black scales, which are extended towarls the anal angle; at the apex of the wing are some black seales. P'osterior wings grey, with paler cilia.

$\Lambda$ ppears at the end of May and end of August; lias occurred on the old tram-road beyond Croydon, and at Ileadley Lane. 'The larva mines the underside of the radical leaves of Scaliosa columbaria during the winter and spring, and at the end of July and beginning of $\Lambda$ ugust.

4. L. comparella (F. v. 12.), Zell. L. E. i. 257. pl. 1. f. 42 ; Sti.; Dup.? Alis anticis albis fusco-irroratis, strigulis obliquis costce tribus ochreo-fuscis, cum strigrulis tribus dorsi ochreo-fuscis alternantibus, duibus posticis dorsi, costacque extrorsum nigro-marginatis, striola apicis nigra. Exp, al. 4 lin.

IIead whitish. Face and palpi white. Antenna whitish, annulated with fuscous. Anterior wings white, irrorated with unucrous fuscous atoms, sometimes causing the ground-colour to appear pale fuscous; on the costa are three shorl oblique ochreous-brown streaks equidistant and parallel, and alternating the three similar smaller streaks on the inner margin; the two last of each arc extcrnally dark-margined; at the apex is a black streak, above which are two small ochrcous-brown spots on the costa. Posterior wings grey, with paler cilia.

Not common; has occurred in May and Lugust among white poplars, in several localities round London.

\section{Famer XII. LYONETID A.}

Antenne dimidio alarum anteriorum longiores, conchula basali instrucle.

Capilli plerisque levigati. Palpi labiales breves, penduli, vel nulli. Ale angusta, anteriores sape caudulatix, posteriores lanceolatie.

Antenne longer than the half of the anterior zeings; the busal joint cxpanded into an cye-cap. Head mostly smooth (Bucculatrix is the only genus with a really rough head). Labial palpi short, drooping, or 
entirely wanting. Wing narrow, the anterior often caudulate, the posterior lanceolate.

The insects of this fnmily are mostly rather sluggish; Bucculatrix shows more activity than any of the other genera. They may frequently be observed at rest on palings, trunks of trees, etc., and when disturbed generally content themselves with a single sudden movement to a fresh place of rest; even when on the wing their movements are slow. The larva, as far as known, are all miners; but in Buccululrix it is only the young larva that mines. The larve, when full-fed, quit the mine (excepting in Phyllocnistis), and form a silken cocoon, at some convenient place.

a. Anteunæ as long as the anterior wings, 1. Lyonetia.

This family comprises only five genexa, which may be arranged

a. Anteunæ as long as the anterior wings. 1 .
a $a$. Antennæe shorter than the anterior wings.

b. Head quite smooth.

c. Labial palpi filiform. 2. Piylzocnistis.

c c. Labial palpi none. 3. Cemiostona.

$b$ b. Head with a tuft on the crown.

d. Labial palpi filiform. 4. Opostega.

$d d$. Labial palpi none. 5 . Bucculatrix.

\section{Genus I, LYONETIA.}

Iyonetis, Iüb. V. 423 (1816); Zell. L. E. iii. Argyromiges p., Curt.; Stcp.? Elachista p., Treit.; Dup. L. T. xi. Lyonetia p., Zell. Isis, I839; Dup. Cat.

Capilli squamacei, appressi, occipitales tenues suberceti. Antennæ alarum longitudine, tenues, conchula basali mediocri. Palpi labiales breves, penduli. Ala angustre, anteriores caudale, posteriores setaces; anteriores: cellula discoidalis clongata, tenuis, acuminata, postice quinque ramos cmittit, veua subdorsalis in basi furcata; posteriores: vena subcostalis ac mediana non cum marginibus coalesentes.

IIcad smooth, with appressed senles, at the back with slender slightly crect scalcs. Antenne as long as the anterior wings, slender, with a moderate-sized basal cyc-cap. Labial palpi short, drooping. Wings narrow, the antcrior caudate, the posterior setaceous. In the anterior wings the clongate, slender, pointed discoidal cell cmits five veins postcriorly; the subdorsal vein is furcate at the base; in the posterior wings the subcostal and median veins specdily become confluent with the inargins.

The insects of this genus have, from the elongate anterior wings and long antenne, some resemblanec with the Grocilurice; but their different position when at rest coupletely destroys the 
similarity. We have only two British species. Of one, Clercliclle, the larva has been observed; it mines in the leaves of apple (and, according to (urtis, elm); it has sixteen legs; it quits the leaf when full-fed and spins a silken cocoon, which it suspends in a horizontal position by silken threads.

1. Clerckella, Limı. S. N. (10), 542. 299 (1758); Treit.; Dup.; Zell.; Sta.-cerasifoliella, Irüb. 'Tin. 190._MFalella, Schr._antumuella, Curt. 13. E. fo. 28.t ; Step.-nivella, Step.—var. creella, Treit.-semianella, Step. - Fonscolombella, Dup. Alis anticis albis vel albidis, vel xncis, macula disci pone medium longitudinali fusca, striolis costic posticis fuscis in maculam fuscam ante apicem decurrentibus, puncto apicis atro. Exp. al. 4 lin.

IIead white or whitish. Face and palpi white. Antennæ fuscous; the basal joint white. Anterior wings white; beyond the middle is a longitudinal fuscons blotch on the disc, beyond which is a narrow fuscous fascia, followed by three short fuscons costal streaks, which unite with a fuscous bloteh; at the apex of the wing is a deep black spot, from which two short fuscous streaks diverge into the grey cilia. 'T'he wings are sometimes entirely of a deep bronzy-fuscous, when, except the apical spot and costal streaks, no markings are apparent, and there are various intermediate varieties. P’osterior wings grey, with grey cilia.

Not uncommon in many places; appearing in June and August, and hybernated specimens in the spring. The larva makes long tortuous flat mines in the leaves of apple-trees in July, September, and October.

2. padifoliella, Sta. Zool. 1848, p. 2160 ; ILüb.? Treit.? Bouché? -acerfoliclla, Curt.-albella, Evers.? Nlis anticis niveis, villa lata costali fusca, dorsum versus sinuata et salurate fusca, striga obliqua pone medium dorsi apicem versus producta saturato fusca, puncto apicis atro caudulam emittente. Exp. al. $4 \frac{1}{2}$ lin.

Ilead, face, and palpi white. Antenne fuscons; the basal joint white. Anterior wings snowy-white, along the cosla broadly fuscous; this fuscous streak is, towards the imner margin, sinualed, and is here very dark fuscous, much darker than on the costa; beyoud the middle of the inner margin is a dark fuscons streak, which runs obliquely towards the apex of the wing; at the anal angle is a small dark fuscons patch; at the extreme apex is a deep black spet; costal cilia whitish, with four short fuscous streals, the last of which is also contimued through the cilia of the hinder margin; there is a dark fuscous arch round the apical black spot, whence a dark fuscous hook also arises. Posterior wings grey, with paler cilia.

This elegant little species has only hitherto occurred among maple, at Whittlebury Forest, in Scptember and October. 


\section{Genus II, PHYLLOCNISTIS.}

PHYluocistis, '/ell. L. E. iii. 26t (18.8). Opostega p., Zell. Isis, 1839 ; Dup.

Capilli lavigati. Antennn alis anterioribus brcviores, conchula parva instructic. Palpi labiales penduli, filiformes. Ala anteriores caudulate, posteriores lauceolato-lincares; anteriores: cellula discoidalis acuta venulas tres in costam, unam in apicem, unam in unarginem posticum emittit; vena subdorsalis simplex; posteriores: vena mediana dorso proxima venulas tres emittit.

Head smoolle. Antenna shorter than the anterior wings, with a small cyc-cap. Labial palpi drooping, filiform. Anterior wings caudulate, the posterior linear-lancolnte. In the anterjor wings the acute discoidal cell emits three veins to the costa, one to the apex, one to the hinder margin; the sublorsal vein is simple; in the posterior wings the median vein which runs near the inner margin emits three veins.

This genus resembles the preceding in the habit of the perfect insect; but the larva (according to Zeller) is apod, and does not quit the mine, but forms its cocoon within the leaf. Only two very closely allied species are known.

1. suffusella, Zell. Isis, 1817, p. 994 ; Ill. I. F.; iii. 266 . ii. pl. 2. f. 32 ; Sta. $\Lambda$ lis anticis latiuseulis albis, nebula fusca disci pone medium, striolis quatuor costre, duabus dorsi fuscis, puncto apicis atro. Exp. al. $3 \frac{x}{2} \operatorname{lin}$.

IIead, face, and palpi white. Antenne pale fuscous; basal joint white. Anterior wings white, with a fuscous blotch on the disc beyond the midlle, and above it on the costa a short fuscous streak obliquely placed, and beyond are three other sliort streaks, nearly straight, the first of which unites with one from the inner margin, forming with it a sligbtly angulated transverse line; at the apex is a deep lulack spot, from which three fuscous streake radiate in the white cilia, and below it is a fuscous hinder-marginal line. $\lambda t$ the base of the wing on the imer margin is sometimes a fuscous bloteh, and the cutire wing is frecuuently more or less suftused with pale fuscous. P'osterior wings grey, with whitish cilia.

Hitherto senee; appears in July and autumn, hybernated specimens occurring in spring; the larva mines in great blotches the leaves of poplars in June and August.

2. saligna, Zell. L. E. iii. 270 (1848); Sta_ccrasifolidla, Sta. Zool. 1848.- Znipunclella, Step.? Alis anticis angustulis albis, linea geminata ex basi ultra medium productu, maculam fuscam includente, striolis quatuor coste, duabus dorsi fuscis, puncto apicis atro. Exp. al. 3 lin. 
IIcad whitish. Face and palpi white. Antennæ pale fuscous; the basal joint white. Anterior wings white, with two somewhat indistinct fitscous lines from the base to beyond. the middle, including between them posteriorly a fuscous bloteh; a smaller fuscous blotch lies at the base of the inner margin; beyond the middle is an angulated fuscous streak from the costa which renches only to the fold, beyoud it is another less angulated fuscous streak which reaches to the immer margin; beyond this are two other short costal streaks; at the apex of the wing is a black spot, from which three fuscous streaks rarliate in the white cilia, and below it is a fuscous hinder-margiual line; the apical portion of the wing is frequently suffused with pale fuscous. Posterior wings whitish, with white cilia.

IItherto scarce; appears in July and autumn, hybernated specimens occurring in the spring. The larva fects in June, Lugust, and September, in the underside of smooth-leaved willows (priucipally on Sulix helix), making a large blotch.

\section{Genus III. CEMIOSTOMA.}

Cemrostoma, Zell. L. E. iii. 272 (1848). Lencoptera p., Ilüb. A)gyromiges p., Step. Opostega p., Zell. Isis, 1839; Dup.

Capilli squamacei, appressi. Antenno alis anterioribus breviores, concluula basali mcliocri. Palpi uulli. Ales anteriores caudulatx, postcriores anguste lanccolate; anteriores: cellula discoidalis venas duas in costam emittit, vena mediana in marginem posticum excurrit, vena subdorsalis simplex; posteriores: vena mediana in tres ramos divisa.

Ilead smooth, with appressed scales. Antennac shortcr than the anterior wings, the basal joint forming a moderate-sized cye-cap. Palpi none. Anterior wings eaululate, the posterior narrow, lanccolate. In the anterior wings the discoidal cell emits two veins to the costa ; the median vein runs into the hinder margin; the subdorsal vein is simple. In the posterior wings the median vein divisles into three branclies.

Scilella differs from the characters above laid down, in laving the slender scales at the back of the liead crect, and in the anterior wings the discoidal cell cmits a furcate vein to the costa, a simple one before the apex, and three (two of them obsolete) to the linder margin, and in the posterior wings the encdian vein has two branches obsolete.

The insects of this genus, of which very few are at present known, and we liave only threc British species, are remarkable for their beauty. The radiating dark lines in the cilia are more developed in this than in the preceding genus. The larva are 
lenf-miners, forming flat blotches in the leaves; that of $C$. spartifoliella however has a different habit, mining under the bark of the stems of broom.

The genus may be thus divided:-

a. Anterior wings white. Species 1, 2.

a $a$. Anterior wings leaden-grey. Species 3.

The first two species are so similar in the perfect state as to be harrlly distinguishable; (another white species frecuenting aspens, and a leaden-grey species frequenting Ilypericum, occur on the continent.)

1. spartifoliella, IIüb. Tin. 335 (1816); Step.; Dıр.; '/ell.; Sta.-punctaurella, Haw.-Mrrrisella, Linn.? Alis anticis albis, macula coste pone mediun dilute flava fusco-marginata, macula altera costa apicem versus lateribus convergentibus, macula atra violiceo-pupillata ad angulun analem, striis tribus fuscis per cilia radiantibus. Lxp. al. $3 \frac{1}{2}$ lin.

Ilead and face white. Antennx fuscous, the tip and basal joint white. $\Lambda$ nterior wings white; on the costa beyond the middle is a pale yellow spot obliquely placed, pointing towards the anal angle, and margined on both sides with fuscons; towards the apex is another spot on the costa placed more perpendicularly, its converging sides are margined with fuscous; below it is a black spot with a violet pupil; the apex of the wing is yellow, with a small fuscous spot; cilia white, with three dark fuscous streaks, one towards the costa, one to the extreme apex, and the other, originating at the same point, drooping. Posterior wings white, with white cilia.

Abundant from the middle of June to the end of July, among broom. Ilhe larva feeds in the spring under the bark of broom, making long, nearly straight galleries; when full-fed it emerges from its subcortical burrow, and spins its snow-white cocoon on the stem, under the shelter of a projecting bud. The cocoons may be advantageously collected at the begiming of June.

2. Laburnella (v. Meyden); Sta. Sup. Cat. p. 11 (1851). Alis anticis albis, macula coste pone medium dilute flava fusco-marginata, macula altern costie apicen versus, lateribus parallelis fusco-marginatis, macula atra violacco-pupillata ad angulum analem, striis tribus fuscis per cilia radiantibus. Exp. al. $3 \frac{1}{2}$ lin.

Ilead and face white. Antemne fuscous, the tip and basal joint white. Anterior wings white; on the costa beyond the mildle is a pale yellow spot obliquely placed, pointing towards the anal angle, margined on both sides with fuscous; towarts the apex is another yellow spot on the costa placed more perpendienlarly, its parallel sidess are margined with fuscous; below it is a black spot with a violet pupil; the apex of the wing is yellow, with a small fuscous spot; cilia white, 
with three dark fuscous strenks, one towards the costa, one to the extreme apex, and one originating at the same point, drooping. Posterior wings white, with white cilia.

Abundant in May and August. The larva mines the leaves of the laburnum in autumn and July, making large greenish-white blotehes, which, when they have been made some time, become almost white; the larva quits the leaf when full-fed, and spins its white cocoon in some convenicnt nook.

3. scitella, Zell. Isis, 1839, p. 21\%; Sti.-Clercletla, Step.; Fab.? IIaw.? Alis anticis plumbeis, postice cupreis, maculis duabus costa albis, macula atra violaceo-pupillata ad angulum analcm, ciliis albidis cum striis quatuor radiantibus fuscis, Exp. al. 3 lin.

TIead and fitee lenden-rrey. Antemixe black, basal joint lendengrey. Anterior wings leaden-grey; from the costa bryond the middle is i brownish streak, which reaches obliquely across the wing; beyond it are two short white streaks on the costa, separated by at coppercoloured portion, which reaches more than half across the wing; at the anal angle is a large black spot with a violet pupil; eilia whitish, with four radiating dark lines, two towards the costa, one continued to the extreme apex, the fourth rather drooping. Posterior wings palc leadengrey, with grey cilia.

An abundant species in many localities in June and July. The larva mines the leaves of the hawthom, apple, and pear, causing large flat dark brown blotehes, and frequently to such an extent as to cause the herlges to appear of a brownislt-green colour; when full-fed, in August or September, it quits the leaf, and spins its fine white cocoon, and after changing to pupa, it ejects the shrivelled larva-skin through a slit in the cocoon left for that purpose.

It is difficult to conceive a more beantiful insect than this! Goëzc's rhapsodies at the sight of this (or a clusely-allied species), in the fifth volume of the 'Naturforscher,' do not appenr' at all exaggerated, and are well worth perusal.

\section{Genus IV. OPOSTEGA.}

Orostra., Zell. L. E. iii. 279 (1848). Tencoplera p., Müb. Elachista p., Treit.; Dup. L. F. xi. Aphelosetia p., Step. Opostega p., Zell. Isis, 1839 ; Dup. Cat.

Capilli verticales subrigidi, occipitales depressi. Antenne alis anterioribus breviores, crassiuscula, conchula beasali nategna. ['alpi labiales breves, penduli. $\Lambda$ le anteriores non caudulate, posteriores angustix, 
lanceolate; anteriores: cellula uulla, venis quatuor longitudinalibus simplicibus; posteriores: vena mediana in tres ramos divisa.

Head in front with rather erect hairs, at the back smooth. Antenna shorter than the anterior wings, the eye-cap of the busal joint large. Isabial palpi short, drooping. Anterior wings slightly pointed, not candulate, the posterior narrow, lanceolate. In the anterior wings there are only four simple longitudinal veins, thus no discoidal cell. In the posterior wings the median vein divides into three branches.

Little is yet known of the habits of the insects of this genus, and the larva of none have yet been discovered. We have only three British species, which are readily distinguished.

1. salaciella, Treit. E. S. ix. 2. 180 (1833); Dup.; Zell.; Sta. $\Lambda$ lis anticis immaculatis albidis. Exp. al. 5 lin.

Ifead and fuce whitish. Palpi white. Antenna pale fuscous; basal joint whitish. Anterior wings immaculale, whitish, having a fint yellowish tinge; cilia white. Posterior wings pale grey, with whitish cilia.

Occasionally met with among grass in June and July; I lave ' taken it at Dartford Heath.

2. auritella, Ifüb. 'Tin. 387 (1816); Zcll.; Sta, Mlis anticis albis, macula in medio dorsi oblique posila fusca, striolis tribus costae, duabus dorsi adversus punctum apicis atrum convergentibus. Exp. al. $4 \frac{\pi}{2}$ lin.

Ilead white. Face whitish. Palpi white. Antenux pale fuscous ; basal joint white. Anterior wings white, with a fuscous spot on the middle of the inner margin obliquely placed, pointing towards the apex of the wing; at the apex is a black spot, from which arise three short fuscous streaks towards the costa, two towards the inner margin, and two in the whitish cilia. Posterior wings grey, with paler cilia.

In the collections of Mr. Shepherd and Mr. Waring; the speeimens were taken in the Cambridgeshire fens in June.

3. crepusculella (F. v. R.), Zcll. Isis, 1839, p. 214 ; Id. I. L. iii. 284. ii. pl. 2. f. 41; Dup.?-anritella, Step. Alis anticis albis, strigula parva dorsi ante, slrigula majore cosle pone medium fuscis, strigulis duabus parvis costa apicem versus fuscis, puncto apicis atro. Exp. al. 4 lin.

Head white. Face whitish. Palpi white. Antennse white, annulated with fuscous; basal joint white. Anteriol wings white; on the inner margin a little before the middle is a small fuscons streat, obliquely placed, pointing towards the apex of the wing; beyond it is a broader fuscons streak on the costa pointing towards the anal angle; towards the apex of the wingre are two fuscous streaks on the costa, and at the extreme apex is a black spot; cilia white, with two fuscous transverse streaks, one on each side of the apical black spot. P'osterior wings grey, with palcr cilia.

VOL, III. 
()ccurs in marshy places at the end of June and beginning of July. Fischer observed this species to fly only at dusk, lience the name; but later observations show that it also flics earlier in the afternoon, especially if the weather be dull.

\section{Genus V. BUCCULATRIX.}

Bucculatrrx, Zell. L. E. iii. 286 (1848). Tinea p., Haw. Elachista p., Treit.; Dup. L. F. xi. Argyromiges p., Step. Lyonetic p., Zell. Isis, 1839; Dup. Cat.

Capilli hirsuti, epistomio levigato. Antennæ breviuscula, conclutla basali parvela. Palpi melli. Haustellum breve, nudum. Alec anteriores caudulate, posteriores lancolatic; anteriorcs: cellula discoidalis acuta, potsice venas sex cmittit, vena subcostalis longissime obsoleta, subdorsalis simplex; posteriores; vena mediana in tres ramos divisa, subdorsalis simplex.

Head rough, tufted; the face smooth. Antennæ rather short, with a rather small eye-cap to the basal joint. Palpi none. Tongue short and naked. Anterior wings caudulate, the posterior lanceolate. In the anterior wings the acute discoidal ecll posteriorly emits six veins; the subeostal vein is obsolete for a considerable distance; the subdorsal vein is simple; in the posterior wings the median vein divides into three branches; the subdorsal vein is simple.

This genus oflers several points of resemblance with the next family, but the larva have six well-developed true leess. The perfect insects are rather active, and frequently fly in little swarms round the plants on which the larva feed. The larvæ have a very singular habit, at least it has been obstrved in Cratergi and Franguilella, and probably it prevails throughout the genus: these larve when very young are true miners, that of Crategi forms a short tortnous mine; that of Frangutella a spiral one, forming brownish-purple blotches on the leaf; at a certain age the larva quits the mine, and on the underside of the leaf spins a delicate whitish web or cocoon, within which the larva remains quite motionless and in a horse-shoe shape for a considerable time; it then emerges from this cocoon totally different in appearance to what it was as a leaf-miner, and procecls to eat the epidermis of the leaf, which formerly it mined. 'The deserted cocoon will be found to contain the previous skin of the larva. The externalfeding larva has a singular shagreen appearance; when full-fed it descends to the ground, or some convenient comer, and spins an clongate ribbed cocoon, within which it remains unchanged for a considerable time. 
Of the eleven British spccies, the first ten are so closely allied, and the gradation of species so imperecptible, that they do not admit of a tabular arrangement; the elcrenth, crislatella, is distinguished by its unicolorous anterior wings. (Another unicolorous species occurs on the continent.)

1. aurimaculella, Sti. Cat. p. 28 (18+9). Alis anticis dilute griseo-aneis, maculis dunbus costæ, duabus dorsi ( prima basim versus per plicam producha) albido-luteis; capillis salurate purpureis. Exp. al. 4 lin.

Ifead deep purple. Face bronzy. Antennæ fuscous; basal joint whitish-yellow. Anterior wings palc greyish-bronze, with two yellowishwhile spots on thic costa and two on the inner margin ; the first costal spot is placed a little before, the second a little beyoud the middle of the wing; the dorsal spots are anterior to the costal spots, and the first one does not touch the imner margin, and is continued along the fold tosoards the base of the wing; none of these spots are sharply margined; cilia greyish. Posterior wings grey, with paler cilia.

Not common; occurs on the downs beyond Croydon, and near 3ristol, appearing in May and August. It has been thought to frequent Carices.

2. cidarella (Tischer), Zell. Isis, 1839, p. 216 ; Sta. Alis anticis purpurascente-brunneis, maculis duabus costa, duabus dorsi albidis, suboppositis; capillis ferngineis. Exp. al. 4. lin.

Ilead ferruginous. Face yellowish. Antennæ fuscous; basal joint yellowish. Anterior wings purplish-brovon, with two whitish spots on the costa, and two on the inner margin; the first costal spot is a little before the middle, the second is half-way between that and the apex; the dorsal spots are nearer the base of the wing than the costal spots; cilia browbish. Posterior wings grey, with paler cilia.

Appears in June, but hitherto rarely met with; it appears to frequent alders.

3. Ulmella (Mann), Zell. L. E. iii. 288 (18.8); Sta,-Sircomellu, Sta,-cuculipennella, var. $\delta$, IIaw,-ovylliroduclyla, W. V. P Alis auticis ochreis, maculis qualuor costie obliqquis fuscis, sccunda abbreviata, maculis duabus dorsi fuscis, priore obsoleta, sccunda media ovata distinctiore; capillis fulvis. Exp. al. $3 \frac{1}{2}$ lin,

Ilead fulvons. Face pale yellowish. Antcune fuscous; basal joint pale yellowish. Antcrior wings yellowish-oclueous, with four fuscous spots on the costa obliquely placed, and two on the inner margin; the first costal spot begins at the base of the wing and terminates in the fold, the second is very small, reaching only a very little way from the costa, the third is broad and distinct, extending somctimes to the anal angle, the fourth is in the apex of the wing; between the two last is a small black spot on the dise; the first dorsal spot is near the base of the wing and is rather indistinct, the second lies beyond the midelle, is 
of an oval shape and very distinct; cilia pale ochreous, with some fuscous scales. Posterior wings grey, with paler cilia.

Common in May, June, and August, among oaks; here it never frequents elms. According to Mann's observations, the larva descends when full-fed in September, from the elms, of the leaves of which it eats the upper and lower epidermis. I have twice found a Bucculatrix larva on oak-leaves, probably of this species; but have not hitherto observed a mine in the oak-leaves, such as these larve may be expected to make.

4. vetustella (Mann), Sta. Cat. p. 28 (1849). Alis nnticis dilute octreis, maculis quatuor costre obliquis brumeis, sccunda abloreviata, maculis duabus dorsi, priore cum prima costali confluente, secunda media fusca, introrsum nigro-squanata ; capillis fulvis. Exp. al. $3 \frac{1}{2}$ lin.

Ifead fulvons. Face pale yellowish. Antennx fuscous; basal joint pale yellowish. Anterior wings pale yellowish-ochreous, with four brownish spots on the costa and two on the inner margin; the first costal spot is sometimes confluent with the first dorsal spot, forming a broad angulated fascia, the second costal spot is very small, the third is darker than the others, and is continued to the anal angle, the fourtly is in the apex of the wing; between the two last is a small black spot on the dise; in the middle of the inner margin is an oval fuscous spot, on its inner edge will some black scales; cilia palc ochreous. Posterior wings pale grey, with paler cilia.

l'erliaps not specifically distinct from the preceding; I have a specimen taken among oaks in August.

5. Cratzegi, Zell. Isis, 1839. p. 216.-cratagifoliella, Dup.; Sta. -cuculipemella, var. $\gamma$, IIaw. Alis anticis albidis, fusco-pulveratis, maculis tribus costee, duabus dorsi fuscis, sceunda dorsi introrsum nigro-squamato, lineola disci ante apicem nigra; capillis griseis fuscisve. Exp. al, 4 lin.

IIead pale grey or fuscous. Face whitish. Antennx fuscous, basal joint whitish. Anterior wings dirly soleitish, much irrorated voith fuscous; a fuscous patch extends along the costa to the middle of the wing, beyond this are troo fuscous spots on the costa, which are joined together on the disc by a small black dash; near the base of the inner margin is a cloudy fuscous patch; towards the anal angle is a fuscous oval spot, on its inner side margined with black; in the apex of the wing is a black spot, and some black scales are carried round it through the pale ochreous cilia. Posterior wings pale grcy, with paler cilia.

Abundant in hedges in May and June. The larva at first mines within, subsequently feeding externally on the leaves of the hawthorn; the pale ochrcous ribbed cocoon is more elongate than in Ulmella.

6. Demaryella, Sta, Zool. 1818, p. 2157 ; Dup.? Alis anticis 
grisco-fuscis, maculis duabus costx, duabus dorsi obliquis oppositis, in fascias angulatas confluentibus, spatio interjecto obscuriore; capillis fuscis. Exp. al. 4 lin.

Head fuscous. Face whitish. Antennæ fuscous, basal joint whitish. Anterior wings fuscous, with two pairs of obliquely-placed opposite streaks, forming angulated fascio, the first before the middle, the second before the apex; between them the ground-colour of the wing is darker fuscous; cilia fuscous. Posterior wings grey, with paler cilia.

Ilitherto scarce; has occurred in the south of Scotland in June, among nut-bushes. Mr. Douglas took a specimen at West Wickham Wood.

7. maritima, Sta. Sup. Cat. p. 11 (1851). Alis anticis ochreis fuscisve, maculis duabus costx, duabus dorsi obliquis oppositis, lineolaque ex basi albis albidisve, punctulo pone maculam priorem dorsi nigro, punctulo altero ad apicem macula secunda costalis nigro, tertio angulum analem versus, quarto ante apicem, macula albida costali in apicem producta; capillis fulvis griseisve. Exp. al. $3 \frac{2}{2}$ lin.

Head fulvous, or greyish. Face whitish. Antenne fuscons, basal joint whitish. Anterior wings extremcly variable in colour and markings; in distinetly-marked specimens they are fuscous, with two pairs of obliquely-placed opposite white spots, and a white basal streak; in other specimens they are dirty ochreous, with these markings only faintly indicated; there is a blick dot on the disc outside the first dorsal spot, and another at the apex of the second costal spot; between this and the anal angle is a third; in the apex of the wing is another white or vohitish costal spot, and beyond it another black dot; eilia ochreous-grey, with a distinct row of black scales from the last costal spot to the anal angle. Posterior wings pale grey, with paler cilia.

Oecurs carly in July, on the coast at St. Osyth, and in the Isle of Sheppey.

8. Boyerella, Dup. L. F. xi. s48. pl. 309. f. 3 (1838); Zell. ; Sta._albedinella, Zell.; Dup._cuculipennella p., Haw.; Step. Alis anticis albis fusco-pulveratis, maculis tribus costic obliquis fuscis, prima abbreviata, secunda tertiaque in striolas nigras desinentibus, macula dorsi pone medium fusea, introrsum nigro-squamata; capillis albidis; antennis albis, fuseo-annulatis. Exp. al. 4 lin.

Head volitish-grey. Face white. Antenne whitc, annulated with fuscous, the basal joint white. Anterior wings white, irrorated with fuscous, with three oblique fuscous streaks from the costa, the first in the middle abbreviated, the second beyond the middle continued nearly to the anal angle, having before ils apex a black streak, the third is in the apex of the wing, and terminates in a black streak; on the inner margin is an indistinct fuscous mark near the base of the wing, and beyond the middle is a fuscous spot internally margined with black; cilia greyish-white, with some fuscous scales round the apex. Posterior wings fuscous, with palcr cilia. 
Occurs among elms in May and June. I have seen at the end of August minute mines on elm-leaves, probably caused by this species, but was unable to meet with the larva. The larvæ wcre found by Mann on elms.

9. Frangutella, Goëze, E. B. iii. 4. 169. 291 (1783).-Frangulella, Zell.-Alnella, Vill.-rhamnifoliella, Treit.; F. v. R. pl. 7; Sta. Alis anticis albis, maculis quatuor costx obliquis fuscis, macula dorsi medii majore fusca, punctulo nigro plice, punctulo altero nigro disci ante apicem; capillis albis. Exp. al, $3 \frac{\lambda}{2}$ lin.

IIead and face white. Antenne white, annulated with fuscous. Anterior wings white, towards the apex irrorated with fuscous, with four costal spots and one dorsal spot fuscous; the first costal spot is near the base and very small (sometimes entirely wanting), the second and third are obliquely placed, one on cach side of the middle, the fourth lies in the apex; the dorsal spot is opposite the second and third costal spots, and uniting with them forms an angulated fascia; on the inner edge of this spot in the fold is a black dot, and a black dot lies beyond the apex of the third costal spot; cilial whitish, traversed by two dark hinder-marginal lines. Posterior wings grey, with paler cilia.

Abundant in June and July among buckthorn, the leaves of which plant are at first mined, and afterwards caten from the exterior, by the larve in August and September.

10. Hippocastanella, Dup. L. F. xi. 530. pl. 306. f. 4 (1838); Lienig; Zell.; Sta. Alis anticis griseo-fuscis, macula basali, macula dorsi ante medium, macula costæ medix, maculaque ad angulum analem majore per striam brumeam internupta flavidis; capillis lutcis. Exp. al. 3 lin.

Head whitish. Face silvery. Antennæ dark fuscous, basal joint white. Antcrior wings greyish-fuscous, with a yellowish-white spot at the base, a similar spot on the inner margin before the middle, and onc on the costa in the middle, and a larger yellowish-white pateh at the anal angle, which is intersected by a narrozo streak of the groundcolour runniug into the extreme apex of the wing; cilia grey. Posterior wings pale grey, with paler cilia.

IIitherto scarce; has been taken in Leigh Wood, near Bristol, and in the neighbourhood of Burton-on-Trent. $\Lambda$ ppears in May and August; the larva feeding on limes and horsc-cliestnuts (according to Licnig, also on birch and alder), in June and August.

11. cristatella (F. v. R.), Zell. Isis, 1839, p. 214; Sta. Alis anticis nitidis, dilute griseis, unicoloribus; capillis luteis. Exp. al. 3 lin.

Head luteous. Face grey. Antennx dark fuscous, basal joint whitish. Anterior wings unicolorous, shining pale grey; cilia yellowishgrey. Posterior wings grey, with paler cilia. 
Appears at the beginning of June and beginning of August; the only locality where it has hitherto occurred is the old tramroad near Croydon, where it has occasionally been taken by sweeping.

\section{Famly XIII. NEPTIOULIDA.}

Capilli superne ac in fronte hirsuti. Antennæ breves, crasse, conchula modica instructec. Palpi maxillares longiusculi, plicati, articulis ultimis pendulis. Palpi labiales breves, subporrecte. Alie anteriores latiuscula, breves, grosse-squamatx; posteriores lanceolatx.

Head hairy above and in front. Antenne short and thick, the basal joint furnished with a moderately-sized eye-cap. Maxillary palpi rather long, folded, the last joints drooping. Labial palpi short, subporrect. Anterior wings rather broad, short, coarsely sealed; the posterior wings lanceolate.

This family contains at present only two genera, the distinctive character of which lies in the neuration of the wings.

\section{Genus I. NEPTICUI.A.}

Nepticula, Zcll. L. E. iii. 301 (1848). Tinea p., Haw. Microsetis p., Stcp. Iyonetia p., Zell. Isis, 1839; Dup. Cat.

Capili superne ac in fronte hirsuti. Antenna breves, crassa, nudre, conchula modica instructre. Palpi maxillares longiusculi, plicati, articulis ultimis pendulis. Palpi labiales breves, subporrecti. Alæ anteriores breves, grosse-squamatre, posteriores ovato-lanceolatæ; anteriores: vena subcostalis furcata, ramo inferiore cum mediana per venula cohrerente, vena mediana postice in tres ramos divisa, subdorsalis in basi furcata; posteriores : vena mediana longissime furcata.

IIcad hairy above and in front. Antenna short, thick, naked, the basal joint furnished with a moderate-sized cyc-cap. Maxillary palpi rather long, folded, the last joints drooping. Labial palpi sloort, subporrect. Anterior wings short, coarscly scaled, the posterior ovatelanceolate. In the anterior wings the subcostal vein is furcate, and the lower branch is connected by a transverse vein with the median vein; the median vein divides postcriorly into three branches, the subdorsal vein is furcale at the base. In the posterior wings the median vein is furcate.

The resemblance in this genus to Microptenyx, as shown by the short antenna, folded maxillary palpi, and transverse commecting vein of the anterior wings, is very singular. 
The habits of this genus are very interesting. The perfect insects repose on the trunks of treees, on palings, etc., but unless the collector be cautious, he will find on his too near approach they take alarm; they run exceedingly nimbly, and keep swaggering a little from side to side as they run, looking the very impersonation of minute importance; when on the wing they fly rather quickly (though nothing in comparison to their alacrity in running), and have much the appearance of minute Diptera. Some species fly of their own accord in the early morning: thus $N \cdot p y g-$ maella is on the wing about sunrise in August; and when everything is quiet on a calm dewy morning, - the spiders'-webs with their spangled drops reflecting the beams of the rising sun,-it is a pleasant sight to see this minute insect darting backwards and forwards among the hawthorn-leaves, evidently in the acme of enjoyment. It happens that this species is not remarkable for the brilliancy of its colours, but in this genus are to be found the humming-birds of the TrNeINa; and the lovely $N$. gratiosella, reflecting nearly all the colours of the rainbow, dauces in little swarms round the twigs of hawthorn, in the blaze of the mid-day sun.

The larve of this genus are very peculiar : the six anterior legs so universally present in Lepidopterous larva are wanting, and they are replaced by membranous processes or prolegs, yet neither on these segments, nor on the remaining segments, each of which is furnished with a pair of prolegs (making eighteen in all) have the prolegs the usual coronet of little hooks; these larva are consequently bad hands at walking, which nevertheless they have to do when full-fed, for then they quit the mine in which they have hitherto lived, and seek a fit place for their cocoon. 'T'he mines are always flat, generally of an irregular serpentine form, though sometimes spiral, and sometimes forming a complete blotch; when held to the light, the larve can be distinctly seen, and their colour and markings recognized. The cocoons are, I believe, generally formed on the ground amongst the fallen leaves; at any rate, in such situations the larva form them in our breeding cages; and it is a very singular fact that, though solitary in the larva state, we always find that the cocoons are mado in company, sometimes a dozen between two leaves. The cocoons vary considerably in colour, texture, and form, according to the species.

'The species of this genus are excedingly numerous. I have no doubt I have several others than those here enumerated, though to enable me to describe them I require more specimens, in finer 
condition, and especially bred specimens, as the habit of the larva, its colour, and the form and colour of its cocoon, frepuently are invaluable helps to prove the distinctness of species, and it is only during the last two years that we have learnt how to collect these larve, so that this branch of the study is completely in its infancy.

The twenty-nine British species may be arranged in the following table:-

a. Anterior wings without spots or fascix. Species 1-6.

a a. Anterior wings with pale spots, no fascia.

b. With a single minute pale spot on the inner margin. Species 7-9.

$b$ b. With two opposite pale spots. Species 10-13.

86 b. With two opprosite pale spots and a broad basal streak. Species 14.

6666. With three pale spots. Species 15.

a $a$ a. Anterior wings with pale spots and a pale fascia. Species I6.

a a a $a$. Anterior wings with a pale fascia.

c. The fascia indistinct and rather dull. Species $17,18$.

c c. The fascia distinet, bright, frequently metallic. Sp. 19-29.

1. atricapitella, IIaw. L. T3. 555 (1<29); Stcp).; Sta.—samintella $\sigma$, Zell.? Alis anticis saturate reneis, postice violaceis; rapillis atris. Exp. al. 3 lin.

Head black. liace ycllowish. Palpi whitish. Antenna black, basal joint whitish. Anterior wings dark bronze, posteriorly shading to violet; cilia pale grey. Posterior wings grey, with paler cilin.

Common in May on the trunks of oaks, of on fences; oceurs more sparingly in $\Lambda$ ugust. The larva mines the leaves of the oak in July, September, and October, but has not jet been distinguished from other larva of a similar habit.

2. ruficapitella, IIaw. L. B. 586 (1S29); Strp.; Sta.-samiatella o, Zell.? Alis anticis dilute aneis, apicem versus violaceis; capillis fermyineis. Exp. al. 3 lin.

Head and face reddish-yellow. Palpi whitish. Antenne fuscous, basal joint whitish. Anterior wings rether pale bronze, with the apex violet; cilia greyish. P'osterior wings pale grey, with paler cilia.

Common on the trunks of oak, or on fenees, in May; also appears, though less plentifully, in August. The larva mines the leaves of the oak in July, and in September and October.

3. anomalella, Gö\%, L. 13. iii. 4. 168.290 (1783) ; Sta.-Rosella, Schr-ruficapitella, Lewis (Lnt. Mag. i. 422). Alis anticis dilutissime aneis, pone medimm dilutioribns, apice obscure violaceo; capillis luteis (interdum atris). Exp. nl. $2 \frac{1}{\text { lin. }}$

Head and face bright yellow (sometimes black). Palpi whitish. Antena fuscous, basal joint whitish. Antcrior wings very pale bronze,

VOL. III. 
a lillle paler beyond the midlle, the apex dull violet; cilia greyish. Posterior wings pale grey, with pale grey cilia.

Abundant in garlens and hedges in May and August, but rarely seen in the perfect state. The yellorish larva is very conspicuous, mining in long tortnons galleries in the leaves of the rose in July and autumn; the orange or brown cocoon is frequently made in the foot-stalk of the leaf, sometimes on the stem, under the shelter of a projecting thom; its outer covering projects beyond it like a tent, making it appear much larger than it really is. This species has an historical interest, having becn observed by 1)e Geer, (iö̈ze, and $I_{\text {cewis }}$ and the exhibition by Mr. Westwood of some beed specimens of this species, at the September meeting of the Fintomologieal Society in 1551, led to the attention of Micro-Lepidopterists being drawn to the larve of this genus, and was the proximate cause of all the discoveries that lave since been made respecting them.

4. pygmaella, IInw. L. B. 586 (1829); Sta.; Step.? Alis anticis cinercis, postice dilutissime violacco-tinctis; capillis luteis. Exp. al. 2-3 lin.

IIcad and face yellowish. Palpi whitish. Antcunx fuscous, basal joint whitish. Anterior wiugs pale asky-grey, with a very slight violet tinge towards the apex; cilia paler. P'ostcrior wings whitish-grey, with whitish-grey cilia.

Common in IIay and $\Lambda$ ugust, flying along hawthom hedges at 5 ム.M. The yellowish larva mines the leaves of the hawthorn in July and autumn.

5. Oxyacanthella, n. sp. Nlis anticis fuscis purpurco-linclis, postice purpureis; capillis luteis. Exp. al. $2 \frac{1}{2} \mathrm{lin}$.

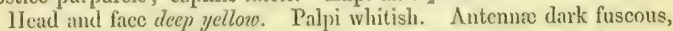
with the basal joint whitish. Antcrior wings fuscons, tinged with purple, bcyond the middle almost entirely purple. Posterior wings pale grey, with pale grey cilia.

Appears in May, but not hitherto observed in the perfect state. The bright green larva is very common in hawthorn-leaves in autumn, making long yalleries; it mines also (I belicve) in the leaves of the wild apple.

6. viscerella (Dougl.), Sta. \%ool. 1853. p. 3958. Alis anticis olivaceis, postice snturatioribus; ceipillis luteis, fusco-mixtis. Exp. al. $2 \frac{2}{2} \operatorname{lin}$.

IIead and face yellowish, inlermixed with fuscous. Antennic fuscous, basal joint whitish. Anterior wings rather of an olive tint, posteriorly darker, with whitish cilia. P'osterior wings whitish-grey, with whitishgrey cilia.

$\Lambda$ ppears in May (?), but not litherto met with in the perfect 
state. The bright green larva mines the leaves of the elm in autumn, making the convolutions of its narrow mine so close tosether that they form brown blolches; it is cxcessively abuudant in many localities.

7. Catharticella, Sta. Zool. 1853. p. 3958. Alis anticis nigris, dilutissime purpureo-tinctis, puncto minuto dorsi pone medium albo; capillis ferrugincis; tarsis posticis albidis, fusco-annulatis. Exp. al. $2 \frac{1}{2} \operatorname{lin}$.

IIend and face reldish-yellow. Palpi whitish. Antenna fuscous, basal joint whitish. IIinder tarsi whitish, annulated rith durk fuscous. Anterior wings black, with a very faint purple tinge, with a minule white spot on the inner margin near the anal angle; cilia whitish. l'osterior wings pale grey, with pale grey cilia.

Aplears in May (?) and August, but not hitherto met with in the perfect state. Hhe larva lecds in autumn and July, on the leaves of Rhammus catharticus, making rather broad galleries; it is excessively abundant on several bushes in my own neighbourhood, yet, though I have searched and beaten for the perfect insect, when 1 expected it should be out, at various hours of the day, I never succecled in finding a single specimen.

8. Septembrella, Sta. Cat. p. 29 (15.19). Alis anticis nigris, macula triangulari dorsi pone modium albida, capillis ferrugincis; antemis fuscis; tarsis posticis unicoloribus albidis. Exp. al. 2 lin.

Ilead and face reddish-yellow. Palpi whitish. Antenne fuseous, basal joint whitish. Hinder tarsi unicolorous uhitish. Anterior wings black, with a ralher triangular whitish spot on the inner margin beyond the middle; cilia whitish. Posterior wings whitish-grey, with paler cilia.

'The original specimen was taken by Mr. Bedell, at West Wicklam Wood, in September; it probably appears in Nay and $\Lambda u$ gust, but a summer brood of the larva has not yet been observed. The larve mine the lazves of $1 / y$ pericum julchrum. in autumn, making extremely slenter mines, and going several times round and across the small leaves they inhabit; when full-fed they pucker the leaf a little, and form their cocoon inside it, never quitting the mine till they assume the perfect stute, thus quite abnormal to the ordinary habits of the genus.

9. intimella, Zell. L. E. iii. 323 (18!S); Sta.; Sircom. Mlis anticis saturate fuscis, macula dorsi paullo post medium lulescente; capillis luteis; antennis lutescentibus. Exp. al. 3 lin.

Ilead and face yellowish. l'alpi whitish. Antenne dirty pale yelloncish, basal joint whitish. Anterior wings dark fuscous, with a yellowish spot on the immer margin, a litle beyond the middle; cilia greyish-fuscous. Posterior wings grey, with paler cilia. 
Taken by Mr. Sircom, near Bristol, in June, among sallows, by swecping the upper branches; also oceurs at Dartford IIcath.

10. Feadleyella, n. sp. Alis anticis griseis, grosse squamatis, maculis duabus partis aryentco-albidis, oppositis pone medium, costali anteriore; capillis lutco-griseis. Exp. al. 2 lin.

IIead and face luteons, mixed with grey. P'alpi whitish. Antenno grcy, basal joint whitish. Anterior wings rather coarscly sealed, dark grey, with two small whilish-silvery opposite spots beyond the micldile, that on the costa being nearer to the base; between these spots is a considcrable breadth of the ground-colour; cilia grey. P'usterior wings grey, with paler cilia.

Two specimens taken by Mr. Doughas, in the hilly field at Ileadley Lane, early in August.

11. subbimaculella, IIaw. L. 13. 583 (1829); Step.; Stiı,-cursoriella, Zell.-nigrociliellu, Step.? $\Lambda$ lis anticis nigris, macula basuli per dorsum producta, macula costali in medio, maculetue dorsi pone medium luteo-albidis; capillis fulvis. Exp. al, 3 lin.

IIead and face oriuge-lutrous. Palpi palc. Antenne dark fuscous, basal joint whitish. Anterior wings black, with a whitish patch at the buse extcnding along the inner margin ; in the middle on the costa is a rather triangular whitish-yellow spot, and beyond ib on the inner margin is a larger triangular whitish-yellow spot; cilia whitish. Posterior wings pale grey, with palcr cilia.

A bundant among oaks in June. The pale greenish-white larva mines the leaves of the oaks in autumn; it kecps close to a rib of the leaf, and though its mine is narrow, it turns mpon itself so as to form a small bloteh. It is a singular fact in vegetable physiology, that when the leaves are turning brown, the spots tenanted by these larve remain green much longer than the remainder of the leaf, and this may frecuently be observed in the leaves after they have fallen.

12. argyropeza, Zell. Isis, 1839 , p. 215 ; Id. L. L. iii. 320. Alis anticis nigrescentibus, macula parva costre ante medium, macula dorsi post medium majore albidis; capillis fulvis. Éxp. al. 3 lin.

Ilead and fice deep luteous. Palpi whitish. Antennæe dark fuscous, basal joint whitish. Anterior wings blackish, with a small whitish spot on the cosla, ralher before the middle, and a larger one on the inner margin bryond the middle; cilia whitish. Posterior wings grey, with paler cilia.

Has occurred in May, on a fence near Beckenham.

13. apicella, n. sp.-aryyropeza, Sta.-argyropeza, var. $\beta$, Yell. Alis auticis nigricanli-griveis, maculis duabus albillis oppositis, paullo post neediun; capillis fulvis, Exp. al. 3-3를 lin.

Ilead and face deep lutcous. Palpi whitish. Autenue grey, basal 
joint whitish. Anterior wings dark grey, beyond the middle are two opposite whitish spots, that on the inner margin is the larger; cilia whitish. Posterior wings pale grey, with paler cilia.

IIas occurred on the stem of a poplar-trec, at Woodhead Moors in June, and on a fence near Beckenham in May.

1. trimaculella, IIaw. J. 13. 583 (1829); Sta.-rufulla, \%ell. $\Lambda$ lis anticis fuscis, linee late albide a basi usque metium, maculis oppositis triangularibus ponc medium albidis; capillis luteis, Exp. al. 2! lin.

IIcad and face ycllowish. Palpi fuseous. Antenne fuscous, basal joint whitish. Abdomen and hind legs grey in the $q$, redilish in the $\delta$. Anterior wings dark fuscous, will a broad basal streak, taking up half the breadth of the wing and reaching to the middle, and with two triangular whitish opposite spots beyond the midlle, not unfrequently uniting across the wing; cilia palc ochreous-grey. l'usterior wings pale grey, with paler cilia.

Appears in May and August, frecuenting the stems of poplars, but not common.

15. quinquella, Betcll, Zool. 1848, p. 1986. Alis anticis nigris, maculis tribus argenteo-albidis, prima costic ante, secunda dorsi pone medium, tertia disci apicem versus; capillis nigris. Exp. al. 2즌 lin.

Head and face black. Palpi whitish. Anteme blick, basal joint yellowish. Anterior wings black, with there whitish, ratler silvery spots, the first on the costa before the middle rather triangular, reacliing a little obliquely half across the wing, the second, on the inner margin beyond the middle, is in the form of a right-angled triangle; between it and the apex of the wing is the third spol, which is small and round; cilia silvery-grey. Postcrior wings grey, with palcr cilia.

Has occurred in June and July, on the trunks of oaks at West Wicklam Wood, and on palings near Beckenham.

16. sericopeza, Zcll. Isis, 1839, p. 215 ; Sta._I (uryma, Dup.? - Lonisella, Sircom? Alis anticis saturatissime fuscis, basi, fuscin olliqua ante, maculis oppositis pone medium albidis; capillis fuscis. Exp. al. $2 \frac{2}{2}$ lin.

Head fuscous. Tace ycllowish. l'alp̧i whitish. Antenne fuscous, basal joint whitish. Anterior wings very dark fuseons, almost black, with the base, an oblique fuscia before the mildle (brondest on the inner margin), and two opposite spots beyond the midlde (that on the inner margin, the posterior), whitish; cilia fuscous. P'osterior wings palc grey, with paler cilia.

I lave two specimens taken on the Dartford ILeath fence in June; Mr. Sircom took his Lonisella near Bristol.

17. floslactella, Maw. I. 13. 555, (1829); Stcp.-hemaryyndlu, Kell.? Alis anticis luteis, basin eersus fusco-irroratis, apjicum versus 
fuscis, fascia fusea paullo post medium, fasciam totam luteam procedente; capillis luteis. Exp. al, $2 \frac{1}{2}-3$ lin.

Ilead and face bright lutcous. Palpi whitish. Antenne fuscous, basal joint whitish. Suterior wings yellowish, sparingly irrorated will firscors toucurds the base; the fuscous scales form a fiscia a little beyoud the middle, which immediately precedes an uninterrupted fiscia of the ground-colour; the apical portion of the wing is entirely fuscous, with a faint violet tinge; cilia whitish-yellow. Postcrior wings pale grey, with pale grey cilia.

Appears in May and August. The moderale-sized yellowish larva make broal tortuous galleries in the leaves of the nut and hombeam, occurring in autumn and July; there are rarely more than half-a-dozen in one leal.' The cocoon is very flossy, and of a whitish or pale yellowish colour.

18. Salicis, n. sp. Alis anticis fuscis, dilnte luteo parun irroratis, postice saturatioribus et violaceo-tinctis, maculis duabus dilute luteis pone medinm, fasciam obsoletam obliquam formantibus; capillis ferrugincis. Exp. al. $2 \frac{x}{3}-3$ lin.

Inead and face rechish-ycllow. Palpi whitish. Antenne fuscous, basal joint whitish. Anterior wings fuscous, slighlly imoraled wilh pale luteons, posteriorly darker and with a faint violet tinge; beyond the middle are two ill-defined, pale lulcons spots, forming an indistinct oblique fuscia; the costal spot is anterior to the dorsal spot; cilia pale luteous. Posterior wings pale grey, with pale grey cilia.

$\Lambda$ ppears in May and August. 'The yellowish larva makes small tortuous mines, rescmbling blotches in the leaves of sallows in autumn and in July.

19. microtheriella, WVing, n. sp. Alis anticis fuscis, paullulum purpureo-linctis, precipue apicem versus, fuscin tenui, suboblicjua pone medium albida; capillis luteis, fusco-mixtis. Lxp. al. $1 \frac{3}{4}$ lin.

Head and face yellowish, slightly mixed with fuscous. Palpi whitish. Antenne fuscous, basal joint whitish. Anterior wings fuscous, slightly tinged with purple, especially towards the apex; beyond the middle is a slightly oblique, rather slender whitish fuscia; cilia fuscous. Posterior wings grey, with paler cilia.

'The smallest known Lepidopterous insect! Appears in May and August, but rarcly met with in the perfect state; the small yellowish-green larva inakes extremely narrow tortuous galleries in the leaves of the nut and liornbeam, occurring in aulumn and July. It is sometimes so abundant that upwards of thirty may be found in a single leaf! The rather firm cocoon is of a pale buff colour.

20. ignobilella, Sta, Cat. p. 29 (1519).-aurella, var. $\beta$. Ilaw.? -posticella, Step.? Alis anticis dilute aureo-brunneis, apicen versus 
purpurco-tinctis, fascia recta pone medium, parum nilida, Inteo-albida ; capillis ferrugineis. Exp. al, $2 \frac{1}{4}$ lin.

Ilead and face reddish-yellow. Palpi whitish. Antennac fuscous, basal joint whitish. Anterior wings pale golden-brown; beyond the middle is a straight, yellowish-zchite, slightly shining fascia; the apex of the wing has a purplish tirere; cilia fuscous. Posterior wings pale grey, with pale grey cilia.

Appears in Mlay and $\Lambda$ ugust, but not frequently met with. The yellowish larva mines in hawthorn-leaves in autumn and July, but has not at present been distinguished from the larva of pygmecella and gratiosella.

21. argentipedella, Zell. Isis, 1839, p. 215; Sta.-mediofasciella, Ilaw.? Step.?-minimella, Zett.? Alis anticis violaceo-nirgris, fuscia latiuscula albida pone medium; capillis nigris. Exp. al. 3? lin.

Head and face black. Palpi dark grey. Antennx fuscous, basal joint whitish. Anterior wings black, with a violet gloss, with a ralher broad whitish fascia beyond the middle, placed rather obliquely, being nearest the base of the wing on the costa; in the middle it is sometimes interupted; cilia grey. I'osterior wings grey, with paler cilia.

Occurs among birches in May and June, but not common. It has been bred by IIerr Bouché, from larve mining in birchleaves.

22. Acetosae (Sta.), Shicld, Kool. 1853, p. 4.153. Alis anticis nitidis fuscis, pone medium violaceo-tinctis, fascin fere recta pone medium nitida alba; capillis fuscis. Exp. al. 2 lin.

IIead fuscous. Antennæ fuscous, basal joint whitish. Anterior wings shining fuscous, with a faint violet linge beyond the midalle; beyond the middle is a nearly straight, shining, whitish fascia; cilia fuscous. Posterior wings pale grey, with pale grey cilia.

Appears in May and Lugust. The larva mines the leaves of the sorrel in autumn and in July; the mine is very peculiar; it makes a series of coneentric circles till, as though the centrifugal force at length became too great, it flies off at a tangent into an irregular tortuous gallery. It has only hitherto been met with by Mr. Shich, near Dublin, in some sorrel-plants growiug among furze-bushes, conseguently in sheltered situations. Mr. Shield las only succeeded in rearing a single specimen, which, with the view of disseminating information, he has very liberally placed in my collection; as it is cxtremely hazardous to describe Nepticulre from single specimens, the above deseription of the perfect insect must be looked at as an approximation only; from the habit of the larva, no doubt can attach to its bcing a distinct species.

23. plagicolella, n. sp. Alis anticis nitidis fuseis, postice pur- 
purco-tinctis, fascia ferc recta pone medium nitida, albida, parum argentea: capillis ferrugineis. Exp. al. 2 lin.

Ilead and face reddish-yellow. Palpi whitish. Antenne fuscous, bisal joint whitish. Anterior wings shining fuscous, with a purple tinge rehich begins before the middle of the wing; beyoud the middle is a nearly straight, shining; whitish, rather silvery fiscia; cilia fuscous. Posterior wings pale grey, with pale grey cilia.

Appears in May and $\Lambda$ ugust, but I believe not hitherto met with in the perfect state. The larva mines in the leaves of the sloe in autumn and July, making lurge whitish blotches; in some places it is exceedingly plentiful; the cocoon is rather llat.

21. Tityrella, Douglas, n. sp. Alis anticis nitidlis fuscis, vix olivacco-tinctis, postice saturatiorilus, fascia subolliyna pone medium dilute aurea, ad dorsum latiore; capillis luteis. Exp. al. $2 \frac{\pi}{2}$ lin.

Head and face luteous. Palpi pale luteous. Antennæ fuscous, basal joint pale luteous. Antcrior wings shining fuscous, with a very faint olive tinge, darker towards the apex, wilh a pale golden, rather oblique fasrin beyoul the middle, brondest on the inner margin, and its posterior elge enteave; cilia very pale grey. Posterior wings pale grey, with pale grey cilia.

Appears in May and August. The larva makes rather broad galleries towards lice margins of the leaves of the beceh, in autumn and July.

25. Malella, n. sp. Alis anticis snlurate fuscis, fasciu subobliqua pone medium alba, parum nilida; capillis ferrugincis. Exp. al. 2 lin.

Head aul face reddish-yellow, slightly mixed with fuscous. Anteune fuscous, basal joint whitish. Auterior wings darl fuscous, with a slighlly oblique, almost white, slighlly shining fascia beyond the middle; cilia fuscous. Posterior wings pale grey, with pale grey cilia.

Appears in May and August, but not litherto met with in the perfect state. The yellow larva mines in antumn and July in the leaves of the wild apple, making long galleries; the cocoon is bright yellow.

26. angulifasciella, Sta. Cat. p. 29 (1849).-Centifoliella, Zell.? $\Lambda$ lis anticis nigris, maculis cluabus oppositis in medio argenteo-albis, in fasciam angulatam confluentibus; capillis luteis. Exp. al. $2 \frac{1}{2}$ lin.

Head and face deep luteous. Palpi whitish. Antennæ dark fuscous, basal joint whitısh. Anterior wings black, with a silvery-erhite spot on the costa about the midelle, and a similar silvery-rehile spot on the midllie of the inner margin; these spots fiequently unite to form a slender angulated fuscia; cilia whitish. l'osterior wings grey, with paler cilia.

llas occurrerl on fruces and in hedges in June, but hitherto very scarce. 'l'he larva (which I believe belongs to this species) 
feeds in the rose-leaves in autumn, making large blotches; it is pale greenish, and it makes a dark blackish-yreen cocoon.

27. gratiosella, Sta. Cat. p. 29 (18.49); Dup.? Nlis anticis dilute aureo-brumneis, postice violaccis, fascia fere recta pone incdium cerulescente-argentea; capillis atris. Exp. al. 2 lin.

Head and face black. Palpi whitish. Antenme dark fuscous; basal joint white. Anterior wings palc golden-brown, with a nearly straight bluish-silvery fascia beyond the middle, the apex of the wing violet; cilia fuscous. Posterior wings grey, with paler cilia.

Not uncommon in May, flying round the hawthorn-twigs, in the sunshime, also plentiful on palings at Beckenham. The larva is one of the yellomish larvæ which mine the leaves of harthorn in autumn.

28. marginicolella, Sta. Zool. 1853, p. 3958.-Centifoliella, Sta. Cat.-aurella, var. $\gamma$. Haw,-lemmiscella, 'Zcll, ? Alis anticis locle aureo-brunneis, pone medium purpureo-tinctis, apice saturate purpureo, fascia obliqua pone medium argenteo-alba; capillis ot atris, of ferrugineis. Exp. al. $2 \frac{1}{2}-3$ lin.

II ad of the of black, of the o reddish-yellow. P'alpi whitish. $\Lambda \mathrm{n}$ tonna fuscous; basal joint whitish. Anterior wings rich golden-brown, with a purple tinge beyond the middle; beyond the middle is a rather oblique silvery-xehile fascia; the apex of the wing is deep purple; cilia pale fuscous. Tosterior wings grey, with grey cilia.

$\Lambda$ ppears in May and $\Lambda$ ugust, but hitherto only met with in the perfeet state on a fence near Beckenham in May. The ycllowish larva mines in autumu and July the leaves of the elm, making a long, not intertwinet gallery, frequently at the ellge of the leaf, going in and out of each serrature.

29. aurella, Tab. S. Li. 666. 65 (1775); ILaw.; Step.; Zell.; Sta. Alis anticis late anre-brunneis, pone medimu purpureo-tinctis, apice suturate violaceo, fascia recta pone moclium tilute aurea; capillis ferrugineis. Exp. al. $3-3 \frac{1}{2}$ lin.

Head and fatce reddish-yellow. Palpi whitish. Autcumæ fuscons; basal joint whitish. Anterior wings rich golden-brown, beyond the middle with a purple tinge; beyond the middie is a nearly straight, pale golden fascia ; the apical portion of the wing is deep violet; cilia fuscous. Posterior wings grey, with grey cilia.

This is the largest and best-known species of the genus; it occurs nearly throughout the year, being however most plentiful in May and August. 'The larva mines the leaves of the brambie, making long tortuous galleries; I believe it may be found in every month of the year; it makes a singular flattencd cocoon, with scalloped edges. 


\section{Genus II. TRIFURCUIA.}

Trifunoula, Zell. L. E. iii. 330 (1848). Lyonetin p., Zell. Isis, 1839.

Capilli superne et in fronte hirsuti. Autenna breviuscula, nudre, concluda modica instructe. Palpi maxillares longiusculi, plicati, articulis ultimis pendulis. I'alpi labiales breves, subporrecti. Alie anteriores breves, grossc-squamatre, posteriores ovato-linceolatic; antcriores: vena subcostalis furcata, vena mediana arcuala trifida, vena subdorsalis simplex; posteriorcs: reun mediana trifida, subdorsalis longiuscula,

IIead above and in front hairy. Antennx rather short, naked, the basal joint furnished with a moderate-sized eye-cap. Maxillary palpi rather long, folded, the last joints drooping. Labial palpi short, subporrected. Anterior wings short, conrsely scaled, the posterior ovatelanceolate. In the anterior wings the subcostal vein is furcate, the arched median vein is trifid, and the subdorsal vein is simple. In the posterior wings the median vein is trifid, the subdorsal vein rather long.

The investigation of the generic characters of these inscets is rendered extremely difficult, from their small size and hairy hends ; smooth-licaded species of equal size would be far more easily cxamined; it is also difficult to cxamine the neuration of the wings, and $I \mathrm{am}$ thercfore doubtful whether the distinctness of this genus from the preceding has been sufficiently established. On the other hand, it may be that it would be more correct to divide the Nepticulide into a greater number of genera*.

The four species placed in this genus all agree in the absence of definite markings, such as spots and fascix, and are best distinguished by their coarsely-scaled, irrorated appearance.

1. atrifrontella, Sta. Sup. Cat. p. 11 (1851). Alis anticis luteoalbidis, fusco suflusis, basi costre tantum sine squamis fuscis; capillis atris. Exp. al. 4 lin.

Ilead and face black. Palpi whitish. Antennæ dark fuscous, basal joint whitish. Anterior wings ycllowish-white, almost entirely suffused with dark fuscous scales, only the base of the costa remaining of the groundcolour; cilia greyish. Posterior wings pale grey, with paler cilia.

'I'wo specimens in Mr. Bedell's collection. I have a specimen taken at Lewisham from a mixed hedge, in August.

* Here I must mention the singular insect taken by Mr. Boyd nmong alders, in the New Forest, last summer, and which I cannot consider Lepidopterous, though so completely Nepticuliform. Its louger antenna, longer legs, differently-shaped broader posterior wings, and neuration of the anterior and posterior wings, would clearly place it in a distinct genus, if admitted as Lepilopterous; but the more polished appearance of the anterior wings, and its general facies, induce me to think it Trichopterous. Many of the smaller Trichoptera are continually being taken for Tineina, but, except in the prescut instance, I am not aware that any difficulty has been found in ultimately distinguishing them. 
2. squamatella, sta. (at. p. 30 (18+5). Alis anticis allidis urisco-squamatis, squamis costre dorsique rarioribus, linea longitudinati tenui curvata disci altida; capillis luteis. Ixp. al. + lin.

IIead and face luteous. P'alpi whitish. Autemme fuscous, basal joint whitish. Anterior wings whitish, irrorated with grey scales, the costa and inner margin being less suffused, and a very slender curved longitudinal line on the disc, uninterruptedly vohitish; cilia whitish. Posterior wings pale grey; cilia whitish.

A few specimens liave occurred among broom in August, in company with the following, of which perhaps it is only a variety.

3. immundella, Zcll. Isis, 1839 , p. 215,339 ; Sta. $\Lambda$ lis anticis albidis ubique griseo-squanatis; capillis luleis aut violaceis. Exp. al. $3 \frac{1}{2}-4 \cdot \operatorname{lin}$

Hearl and face luteous, sometimes violet. Palpi whitish. Antennæe grey, basal joint whitish. Anterior wings whitish, irrorated with grey scales throughout; cilia whitish. Posterior wings pale grey, with yellowish cilia.

Common amongst broom in July, and at the beginning of $\Lambda u$ gust; has occurred at Charlton, Dartford Ileath, etc., and in the south of Scotland.

4. pulverosella, Sta. Cat. p. 30 (18+9). Alis anticis albis, grosse cinereo-squamatis, eapillis ferrugineis. Exp. al. 3 lin.

Ilead and face firmuginous. Palpi whitish. Antenuse grey, basal joint whitish. Anterior wings with course dark ashy-grey scales, upon a paler ground; cilia ycllowish-white. Posterior wings pale grey, with yellowish-white cilia.

A few specimens have occurred in May and June, anong wild apple-bushes. 


\section{R R A'T.}

Page 1, line 4 from bottom, for Heterogyius read Heterogynis.

" 3, 1. 7 from bottom, for will apply read well apply.

", 5, 1. 6 from bottom, for tribus tarius read tribus, rarius.

"22, 1. 26, for Dactylus glomeratus read Dactylis glomerata.

", 22, 1. 28, for Dactylus read Daclylis.

" 23, 1. 9, for Dactylus glomeratus read Dactylis glomerala.

" 39, 1.12 from bottom, for Bruaud read Braand.

" 47, 1. 20, for dilutis read dilute.

", 52, 1. 23, for there brilliant coppery read then brilliant coppery.

" 57, 1. 23, for the simplex read the simple.

" 61, bottom line, for elongated read elongate.

", 75, 1. 4 from bottom, for remarkably read remarkable.

" 76, 1. 27, for P'Horicoptena read P'soricoptera.

" 118, 1.18 from bottom, for in quo read in qua.

" 128, 1.16 from bottom, for a slight interrupted read a slightly interrupted.

", 130, 1. 13 from bottom, for cloudy dark fascia read cloudy dark fascioe.

" 131, 1. 14 from bottom, for albisirigella, Step., read albistrigella, Step.?

", 134, 1.5 from bottom, for pale annulations read paler anuulations.

" 137, 1. 20, after in the insert First Edition of the.

"150, 1. 16 from bottom, for producto read producti.

"179,1. 13, for a large one read a larger one.

", 180,1. 18 and 1. 26, for AEclivium read Echium.

", 192, 1. 8 from bottom, for posteriorly dark read posteriorly darker.

", 213, 1. 21, after costnm insert a comms.

"213, 1.8 , after apicem insert a comma.

"216,1. 19, for galipennella rend gallipennella.

"233, 1. 20, for median call read median cell.

" 260,1. 19 from bottom, after and insert with a.

", 265, 1. 9, for Wing read Wings.

"269, 1. 18 from bottom, for striking paler read strikingly pales.

", 272, 1. 6, after spotted insert with.

"281, 1. 2, for wings read wing.

", 283, 1. 1, for Wing read Wings.

", 283, 1. 13 from bottom, for non cum read mox cum.

"303, 1. 10, for larva read larve. 


\section{NDEX.}

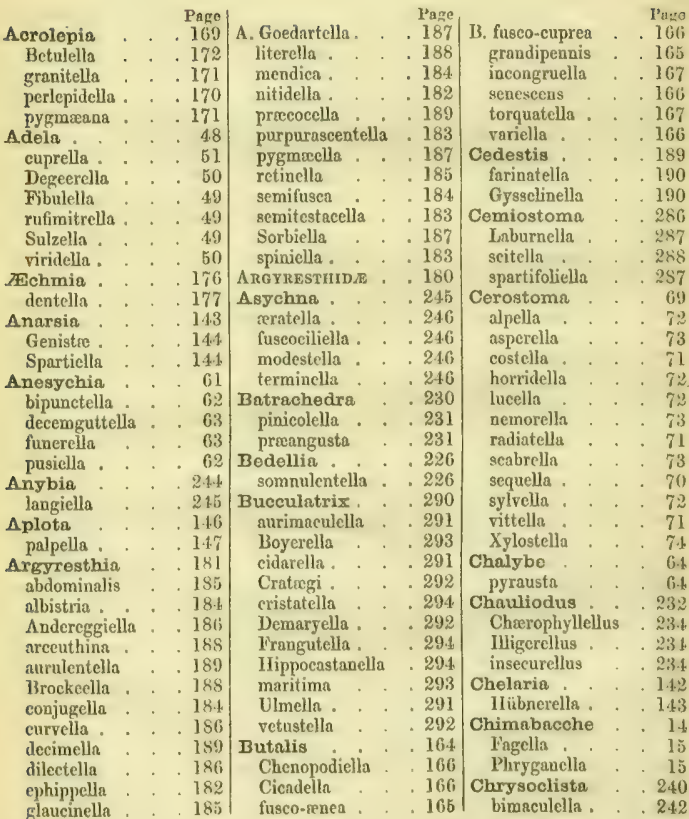




\begin{tabular}{|c|c|c|c|c|c|c|}
\hline tharicaput & $\begin{array}{l}l^{2} \text { age } \\
242\end{array}$ & C. Drurella & 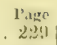 & E. Albinella & & Puge \\
\hline Linneella & 241 & Lienigiella & .229 & alpinella. & & 25.4 \\
\hline Schrsnkella & 242 & Dasycera. & 153 & apicipunctella & & \\
\hline Hhrysocorys & 247 & Oliviella & 155 & atricomella . & - & \\
\hline & 248 & sulphurella & .151 & Bedellella & & \\
\hline leodora. & .142 & Dasystoma & . 13 & biatomella . & . & 260 \\
\hline Cytisella . & 142 & Salicella & 13 & Brunnichella & & \\
\hline Coleophora . & . 208 & Depressaria. & 83 & cerusella & & 59 \\
\hline & 214 & & & cinereopunctell & & \\
\hline & 220 & Alstrcemeriana . & 88 & & & \\
\hline nella & & Angelicella . . & & consortella . & & \\
\hline & & & 93 & cygnipennella & . & 62 \\
\hline & & & 87 & & & \\
\hline & & lella & 86 & & & \\
\hline & & & 86 & & & \\
\hline & & & 99 & & . & \\
\hline & & lella. & & & & \\
\hline & & & 91 & & & \\
\hline & & & 98 & & & \\
\hline & & & 93 & & & \\
\hline & & nella & 89 & & & \\
\hline & & & 90 & & & \\
\hline & & & 84 & & & \\
\hline fn & & de & $9 \mathrm{t}$ & & & \\
\hline & & & 97 & & & \\
\hline & & & 96 & & & \\
\hline & & & 94 & & & \\
\hline & & & & & & \\
\hline & & & & sporell & & \\
\hline & & & & & & \\
\hline nella & & & 86 & & . & \\
\hline & & & & & & \\
\hline & & & & & & \\
\hline & & & & & & \\
\hline & & & 95 & & & \\
\hline & & & & & & \\
\hline 0 & & & 87 & & & \\
\hline & & & & & & \\
\hline & & & 89 & & & \\
\hline & & & & & & \\
\hline aella & & quella & 88 & En & & \\
\hline & & na. . & 85 & & & \\
\hline & & & 98 & Eu & & \\
\hline & & & 97 & & & \\
\hline & & & 92 & Ex: & & \\
\hline & & Dipl & 20 & & & \\
\hline & & anctell & & Fxa & & \\
\hline & & Dou & & & & \\
\hline & & nella & & & & \\
\hline & & Eida & 66 & & & \\
\hline & & & 66 & & & \\
\hline ellum & & & 248 & & & \\
\hline & & & & & & \\
\hline & & & & & & \\
\hline Cosmopteryx & & albifrontella & & albiceps & & \\
\hline
\end{tabular}




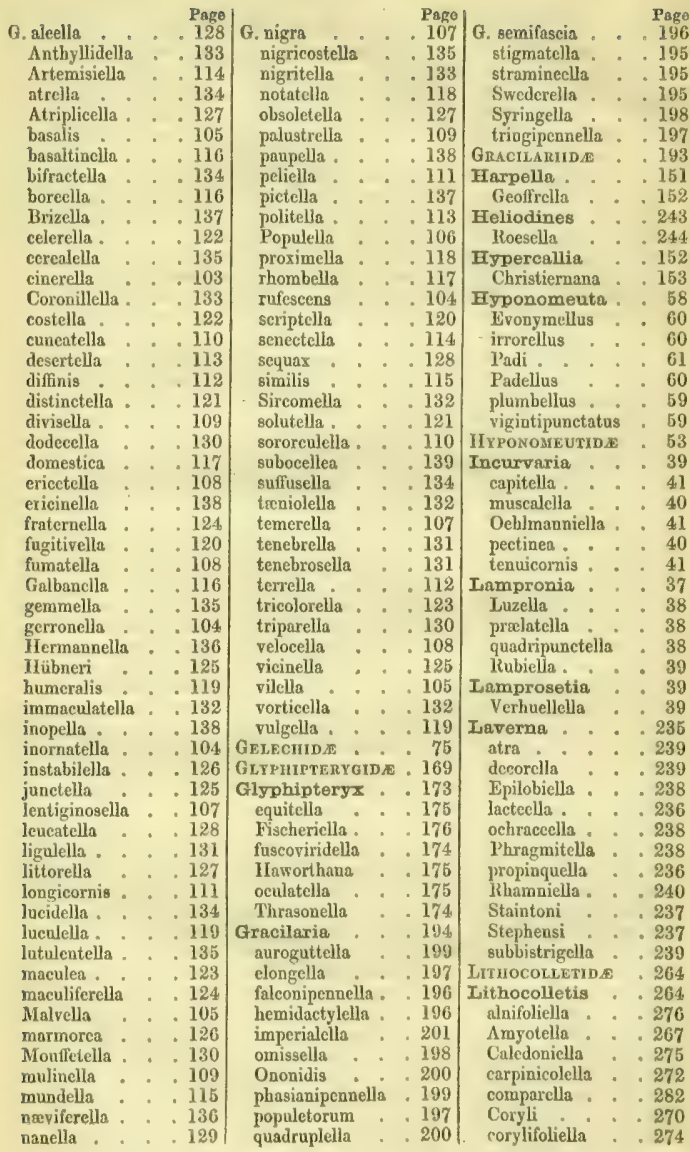




\begin{tabular}{|c|c|c|c|c|c|c|c|c|}
\hline & & anco & & & Pag & & & Pä \\
\hline & & 277 & N. Schwarziella & & 47 & dE. lunaris . & & .160 \\
\hline Dunningiella & & .279 & Swammerdamm & mella & 47 & minutella & . & . 157 \\
\hline zicpennel & & .279 & Nemotois & . . & 51 & Panzerella. & & .161 \\
\hline illa. & . & .271 & cupriacellus & . & 52 & pseudo-sprete & ella & \\
\hline hiella. & & .278 & fasciellus. & & 52 & & & \\
\hline Ellia . & . & .277 & minimellus . & $\vdots$ & . 53 & subaquilea & & 160 \\
\hline & & & Scabiosellus & & & & & \\
\hline & & . 269 & Nepticula & . & .295 & tripuncta & & .157 \\
\hline & & 280 & & . & . 303 & unitclla. & & \\
\hline & . & 268 & angulifasciella & . & 304 & Woodiella & & \\
\hline & . & & & . & .297 & Gigoconia . & & \\
\hline & & & & . & 300 & neta & & \\
\hline & & & edella & . & .303 & Oinc & & \\
\hline & & & & . & 300 & & & \\
\hline & & & & . & .297 & Opo & & \\
\hline & & & & . & & & & \\
\hline & & & & . & & lella & & \\
\hline & & & & . & .301 & & & \\
\hline & & 27 & & . & 305 & Orn & & \\
\hline & & & & . & 300 & & & \\
\hline & & & ig & . & & ella & & \\
\hline & & & & . & & & & \\
\hline & & & & . & & ella & & \\
\hline & & & & . & & & & \\
\hline & & & & . & & & & \\
\hline & . & & & . & & & & \\
\hline & & & & . & & & & \\
\hline & & & & . & & & & \\
\hline & & & & . & & Ort & & \\
\hline & . & & & . & & & & \\
\hline & & & & . & 302 & Par & & \\
\hline & . & & & . & & ella & & \\
\hline & & & & . & & locke & & \\
\hline & & & & & & & & \\
\hline & & & & . & & & & \\
\hline & & & & . & & & & \\
\hline & & & & & & riella & & \\
\hline & & & & & & rella & & \\
\hline & . & 1 & & & 17 & Per & & \\
\hline & & & & & & & & \\
\hline & & & & & & Phit & & \\
\hline & & 42 & ieris & & & & & \\
\hline & & 43 & & . & 22 & nistis & & 85 \\
\hline & & & & & & & & \\
\hline & & 4.4 & & & - 23 & & & \\
\hline & & 4 & Oen & . & 191 & & & \\
\hline & & 4 & & & & & & \\
\hline & & & & & & & & \\
\hline & & & & & & elln & & \\
\hline & & & & & & rarum & & \\
\hline & & & & & & & & \\
\hline oxa. & & & & . & 1 & ctella & & \\
\hline & & & & & & Plutellidro & & \\
\hline & & 30 & & . & 159 & Prays . . & & \\
\hline & & & Lambdella. & & & Curtiselluy . & & \\
\hline
\end{tabular}




\begin{tabular}{|c|c|c|c|c|c|c|}
\hline & & P'uge & & & & \\
\hline Psoricoptera & . & .100 & Tinagma . & .178 & T. pellionella ... & 33 \\
\hline gibbosella & & .101 & resplendellum & .179 & picarella. & $2 s$ \\
\hline Röslerstammia & & .172 & sericiellum . & .179 & ruricolella & 31 \\
\hline Frxlebella . & . & .172 & Stannecllum & .179 & rasticella. & 27 \\
\hline Seythropia . & . & 57 & Tinea . . & . 21 & semifulvella . & $3 \pi$ \\
\hline Cratagella. & . & 57 & albipunctelda & $3:$ & simplicella. & 3.5 \\
\hline Semioscopis & . & 78 & arcclla. & 24 & subammanella & 36 \\
\hline Avellanclla . & & 79 & areutella . & 29) & tapetzella & 28 \\
\hline Stcinkellneriana & & 79 & argentimaculella & 36 & TINEIDA: . & - 16 \\
\hline Solenobia & . & 19 & bisclliella & 31. & Tischoria. . & . 2063 \\
\hline Douglasii . & & 19 & bistrigella . & 35 & complanella. & . $26 i 3$ \\
\hline pieuella & - & . 19 & mulgella & 32 & marginea & 261 \\
\hline Sophronia . & . & .148 & cloacella. & 31 & Trifurcula & .306 \\
\hline ella. & & .160 & Cochylidella & 32 & atrifrontella & .306 \\
\hline icsclla & & .149 & cor & $2 !$ & immundella. & .307 \\
\hline opoda & . & .227 & ferruginella . & $2 f i$ & pulverosella. & .307 \\
\hline . . . & & .228 & itclla & 31 & atella. & .307 \\
\hline Swammerdamia & & . 51 & fultimitrella & $2 \pi$ & Xysmatodoma & - 20 \\
\hline apicclla . . & & 55 & inctella & 33 & melanella & . 21 \\
\hline Cosiclla . & & 5ั5 & Granclla. . & 30 & Ypsolophus . & .145 \\
\hline eocapitella & & 56 & imella. & 26 & fasciellus. . & .115 \\
\hline lutarea . & • & 56 & Lapella. & 31 & Marginellus & .146 \\
\hline Pyrella . & & 50 & misclla . & 33 & Zellerin . & .191 \\
\hline Taloporia & & 17 & monachella. & $2 \pi$ & fasciapennclla & .192 \\
\hline pscudobombyecl & & 18 & nigripunetella & 3.5 & hepariclla & .192 \\
\hline rnis . & & 18 & ochracedla. & $3 i$ & insignipennella & .192 \\
\hline Theris & & 74 & pallescentella & 34 & & \\
\hline caudella . & & 74 & parasitclla. & . 30 & & \\
\hline
\end{tabular}




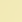





\section{PLATEL.}

\section{FAMILY 1. EXAPATID死.}

Gexus 1. Exapate. Fig. 1 a, anterior wing of Exapate gelatella; $1 b$, posterior wing; $1 c$, head; $1 d$, portion of antenna.

Ginus 2. Dasystoma. Fig. 2 a, auterior wing of Dasystoma Salicella; $2 b$, posterior wing; $2 c$, head.

Genus 3. Chimabacche. Tig. 3 a, anterior wing of Chimabacche Fagella; $3 b$, posterior wing; $3 d$, portion of antenna; $3 e$, palpus; $3^{\prime} c$, head of Chimabacche Phryganella.

\section{FAMILY II, TINEID .}

Gexus 1. Talaeporia. Fig. 4 , anterior wing of Talaporire psenctobombycella; $4 b$, posterior wing; $4 c$, head; 4 ' $c$, head of Talceporia pubicornis; $4^{\prime} d$, portion of antenaa.

Ginus 2. Solenobia. Fig. $5 a$, anterior wing of Solenobia inconspicuella; $5 b$, posterior wing; $5 c$, head.

Genus 3. Diplodoma. Tig. $6 a$, anterior wing of Diplodoma margine-punclella; $6 \mathrm{~b}$, posterior wing; $6 c$, head; $6 \mathrm{~d}$, portion of antenna.

Gisus 4. Xysmatodoma. Fig. $7 a$, anterior wing of Xysmatorloma melanella; $7 b$, posterior wing; $7 c$, head.

Genus 5. Ochscnheimeria. Fig. $8 a$, antcrior wing of Ochsenheimeria Birdella; $8 b$, posterior wing; $8 c$, head.

Genus 6. Euplocamus. Fig. $9 \mathrm{c}$, head of Fiuplocamus Buleli $q$; $9 d$, portion of antenna of $\delta$.

GicNus 7. Tinea. Tig. $10 a$, anterior wing of Tines Lapella; $10 \mathrm{~b}$, posterior wing : $10 \mathrm{c}$, head; $10^{\prime} a$, anterior wing of Tinea Viselliella; $10^{\prime} b$, posterior wing; $10^{\prime} c$, head; $10^{\prime \prime} a$, anterior wing of Tinea bistrigella; $10^{\prime \prime} b$, postcrior wing; $10^{\prime \prime} c$, head; $10^{\prime \prime \prime} c$, head of Tinea ochraceella. 

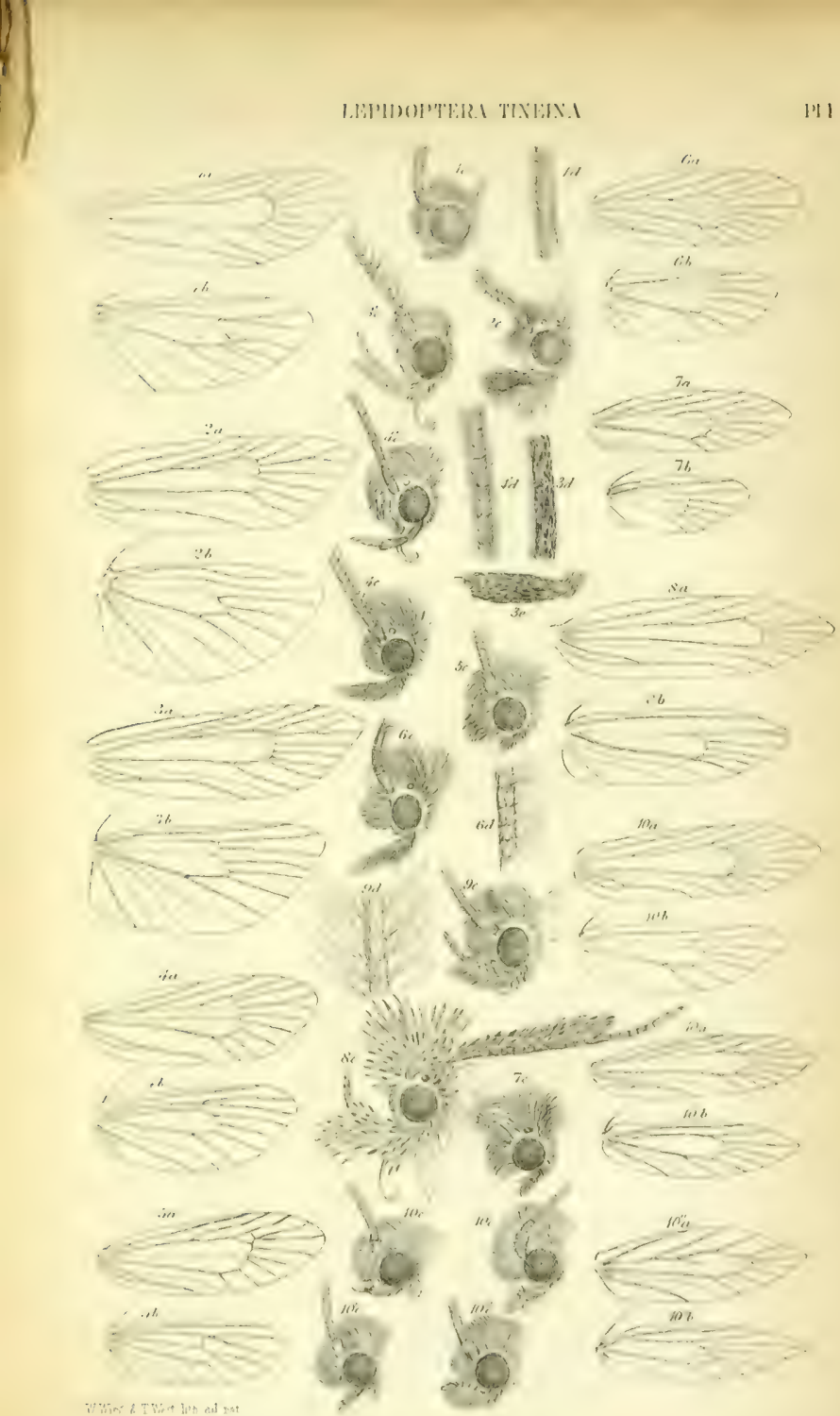

iv) 1 ily"

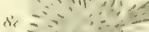

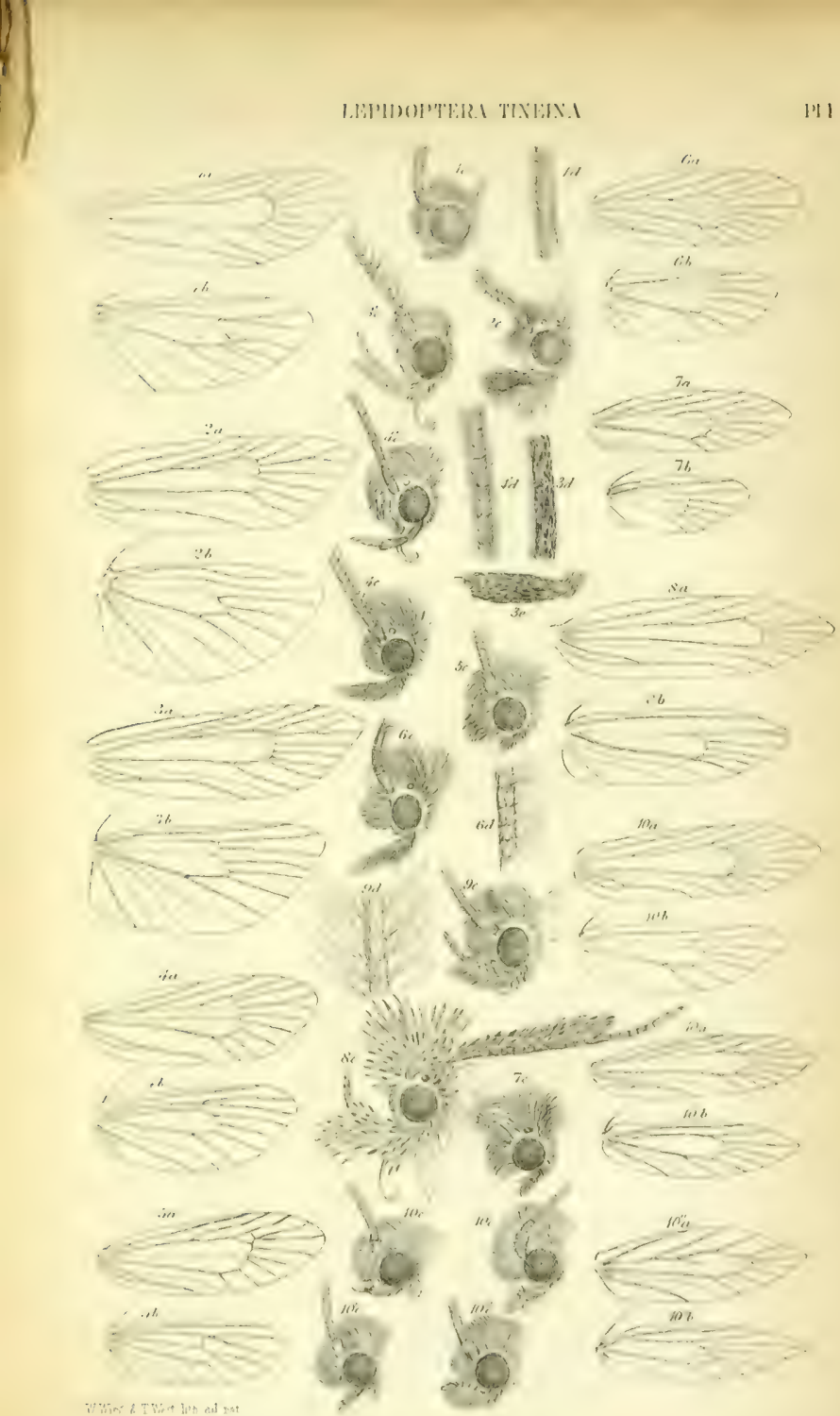

$\pm=-0_{0}$
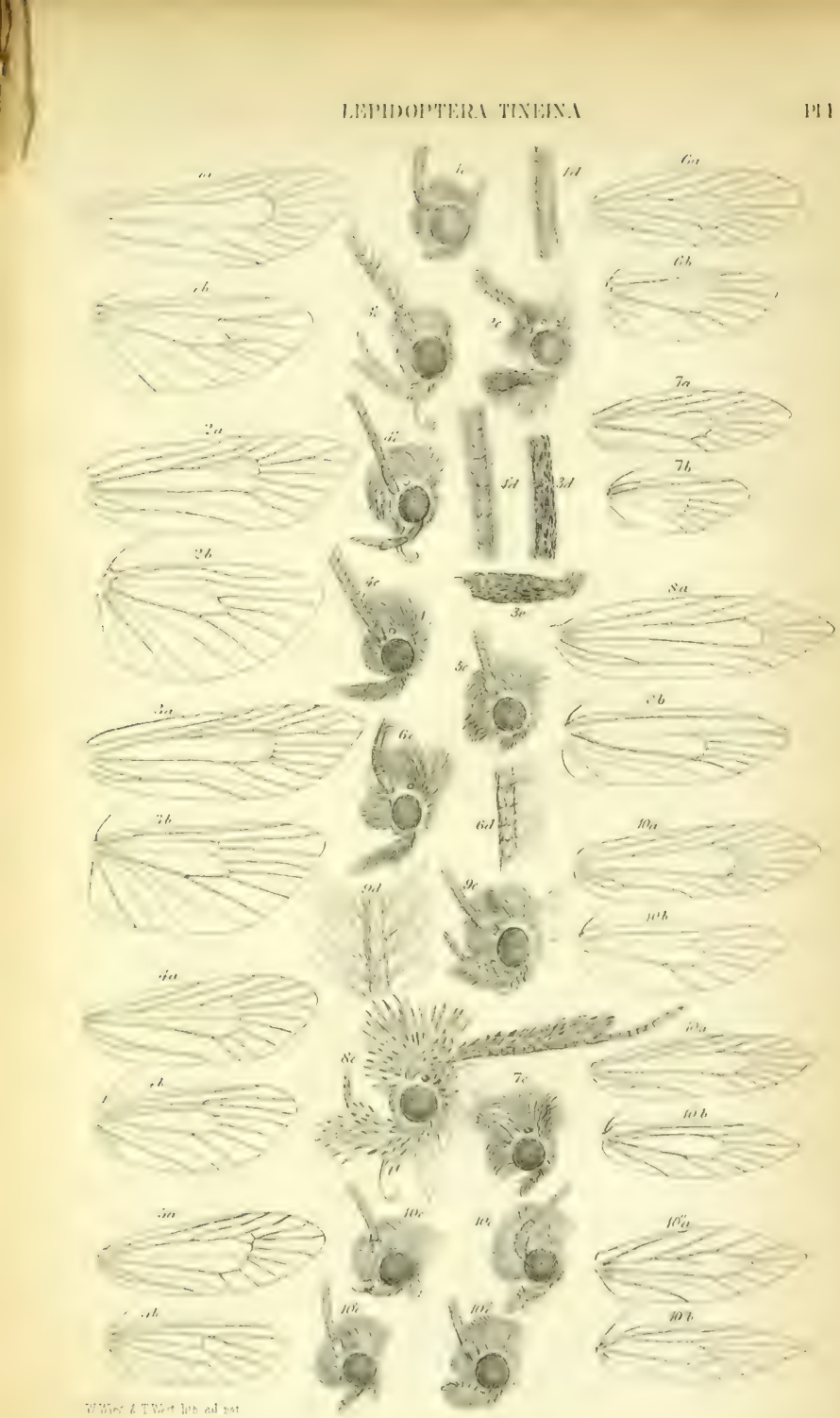




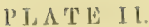

\section{FAMILX II. TINEIDE (continued),}

Gisus 8. Lampronia. Fig. 1 , head of Lampronia pretatella ; $1^{\prime} a$, anterior wing of Lampronin quadripunctella; 1 'b, posterior wing.

Genus 9. Lamprosetia. Fig. $2 c$, head of Lamprosetia Verluellella.

Genus 10. Incurvaria. Tig. 36 , posterior wing (umdenuald) of Incurvaria muscalella; $3 c$, head of $\delta ; 3$; 3 , anterior wing of Incurvaria capilelle; 3 ' 6 , posterior wing; $3^{\prime} b$, posterior wing (undenuded); 3 'c, head.

Genus 11. Micropterym. Fig. th $a$, anterior wing of Microptery. Allionella; $4, b$, posterior wing ; $4 c$, liead; 4 ' $^{\prime} a$, anterior wing of Micropteryx semipuspurella; 4 ' $b$, posterior wing.

Genus 12. Nemophora. Trig. 5 a, anterior wing of Nenopliora Suamanerdammella; 56 , posterior wing ; $5 b^{\prime}$, postcrior wing (undenuded); $5 c$, head; $5^{\prime} b$, postcrior wing (undenuded) of $\Lambda^{r} e m o-$ phora pilella.

Gicxus 13. Adela. Fig. (5 $a$, anterior wing of Adela viridella; is $b$, posterior wing; $6 c$, head of $\delta^{\circ} ; 6^{\prime} c$, liead of Adcla Fibulellat $6 " c$, head of Adela Degeerella on.

Ginus 14. Nemotois. lïg. $7 a$, anterior wing of Nemolois Scabiosellus; $7 b$, posterior wing; $7 c$, head of $\sigma^{\circ} ; 7^{\prime} c$, head of Nemotois fasciellus, + .

\section{FAMILY III. HYPONOMEUTID H.}

Genus 1. Swammerdamia. Tig. 8 a, anterior wing of Sieammerdamia cersiellu; $8 l$, posterior wing; $8 b^{\prime}$, posterior wing (undenuded); $8 \mathrm{c}$, head. 

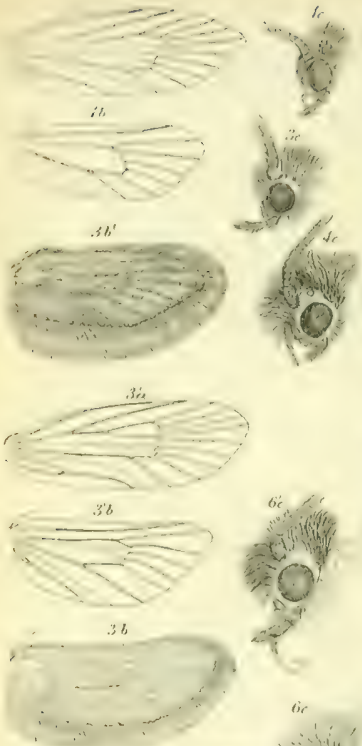

ir
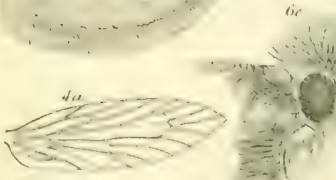

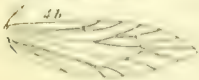

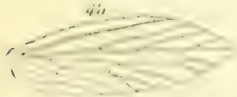

$\angle 0$

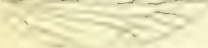
$\therefore 6$

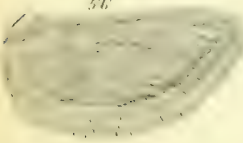

Wither kThet lith al art

10
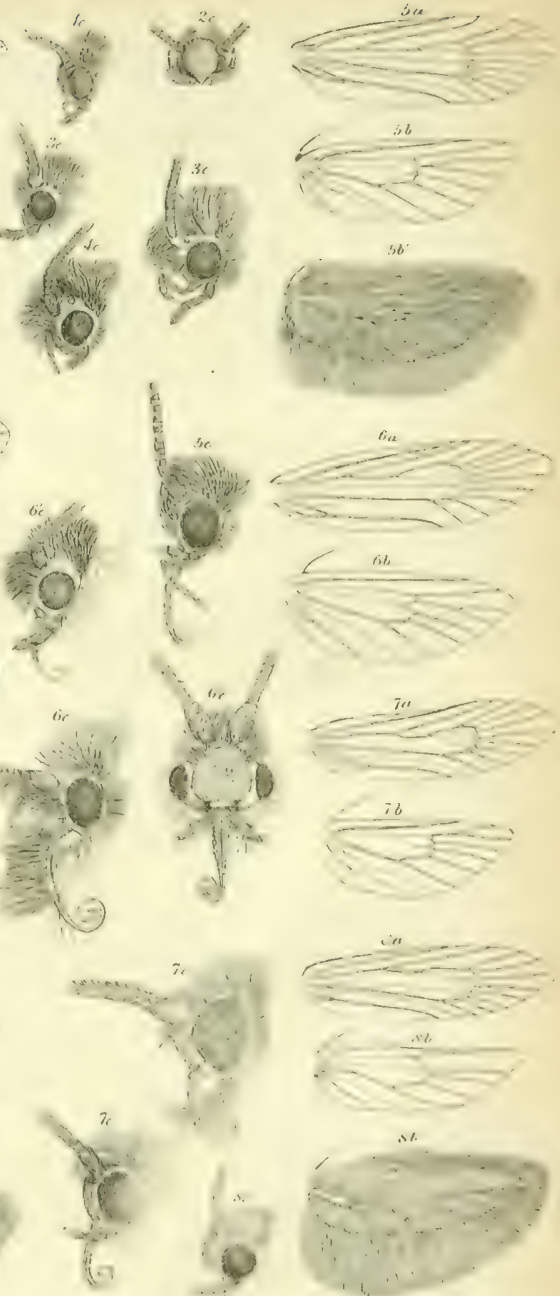

7
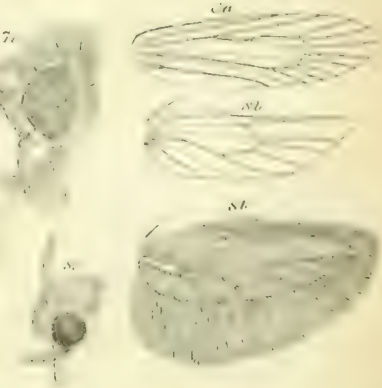




\section{FAMIX III. HYPONOMEUTIDA (continued).}

Genus 2. Scythropia. Fig. 1 a, anterior wing of Scylleropic Cralagella; 16 , posterior wing; $1 c$, head.

GiEvus 3. Fiyponomeuta. Fig. 2 a, anterior wing of IIyponomenta Padellus; $2 b$, posterior wing; $2 b^{\prime}$, posterior wing (undenuded); $2^{\prime} c$, head of Hyponomeuta cognatellus.

Genus 4. Anesychia. Fig. $3 a$, anterior wing of Anesychia funerella; $3 b$, posterior wing; $3 c$, head.

Gindos 6. Prays. Tig. $4 a$, anterior wing of Prays Curtisellus; 4.6 , posterior wing; $4 c$, head.

\section{FaMiLY IV, PLUTELLIDA.}

Genus 1. Eidophasia. Fig. 5 a, anterior wing of Eidophasia Messingiella; $5 b$, posterior wing; $5 c$, head.

Genus 2. Plutella. Fig. 6 a, anterior wing of Plutella Cruciferamum; $6 b$, posterior wing; $6 c$, head; $6^{\prime} b$, posterior wing of Plutella Dalella; 6'e, palpus.

Genus 3. Cerostoma. Fig. 7 a, anterior wing of Cerostoma radiatella; $7 b$, posterior wing; $7 c$, head; $7^{\prime} a$, anterior wing of $\mathrm{C}_{c}=$ rostoma lucella; 7 " $a$, anterior wing of Cerostome scabrella; 7 "' $a$, anterior wing of Cerostoma nemorella ; $7^{\prime \prime \prime} b$, posterior wing; $7^{\prime \prime \prime} c$, head of Cerostoma Xylostella.

Genes 4. Theristis. Fig. $8 a$, anterior wing of Theristis caudella; $8 b$, posterior wing; $8 c$, head.

\section{FAMILY V. GELECHID ג.}

Gives 1. Orthotalia. Fig. 9 c, head of Orthotelin Sparyanella.

Cisxus 2. Semioscopis. lig. 10 a, anterior wing of Scmioscopis Steinlellneriunu; $10 \mathrm{~b}$, posterior wing; $10 \mathrm{e}$, palpus; $10^{\prime} \mathrm{c}$, head of Semioscopis Avellanella.

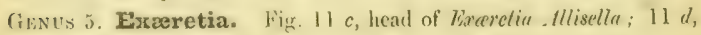
portion of antenna. 
I.IJUOHTER TINEINA
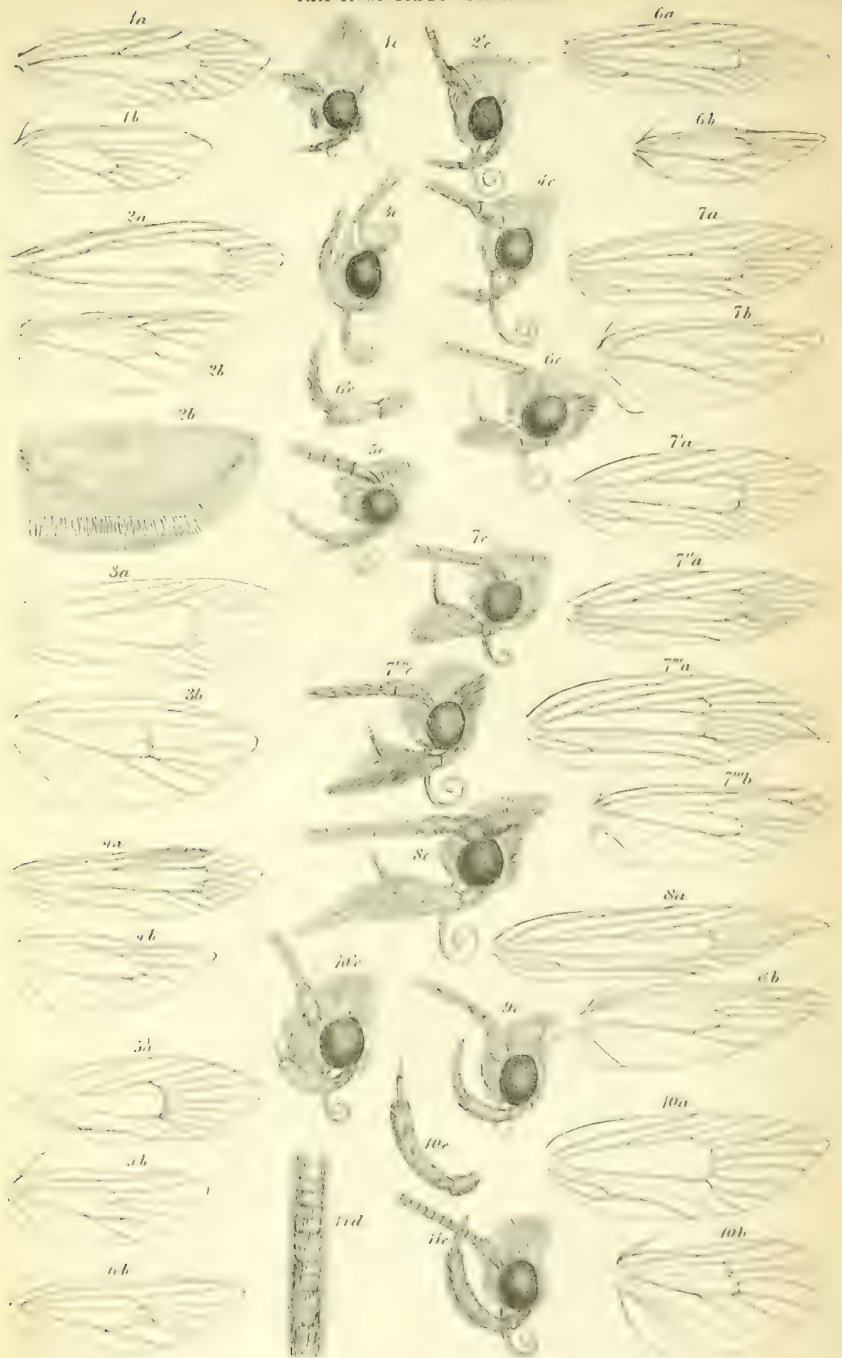


Family V. GELECHID (continued).

Genus 3. Enicostoma. Fig. $1 \%$, anterior wing of linicostoma 70 bella; $1 \mathrm{~b}$, posterior wing; $1 \mathrm{c}$, head.

Gixus 4. Phibalocera. Fig. $2 a$, anterior wing of Phibalocert Quercana; $2 b$, posterior wing; $2 c$, head.

Gexus 6. Depressaria. Fig. $3 a$, anterior wing of Depressaria applana; $3 b$, posterior wing; $3 c$, head.

Gexus 7. Psoricoptera. Fig. $4 c$, head of Psoricoptera giblosella.

Giscus 8. Gelechia. lïg. 5 a, anterior wing of Getechia rufescens; 5 6 , posterior wing; 5 c, licad; 5 ' $\alpha$, anterior wing of Gelechia l'opulella; 5'6, posterior wing; 5 " $c$, licad; 5 "c, head of Celeckia taniolella; $5^{\prime \prime} c$, head of Gelechia neviferella; $5^{m \prime \prime} a$, anterior wing of Gelechia subocellea; $5^{\text {"n' }} b$, posterior wing; $5^{\prime \prime \prime \prime} c$, head.

Genus 9. Parasia. Hig. $6 a$, anterior wing of Parasia Carlinella; $6 b$, postcrior wing; $6^{\prime} c$, head of Prasia Lappella.

Genus 10. Cleodora. Fig. 7 a, anterior wing of Cleodora cylisella; $7 b$, posterior wing; $7 c$, head.

(ínes 11. Chelaria. Fig. $8 c$, head of Chelaria IIünerella.

Grivus 12. Anarsia. Fig. 9 ", anterior wing of . Intrsia Sparliella ; 98 , posterior wing; $9 \mathrm{c}$, head of $q ; 9 e$, palpus of $\delta$.

GeNus 13. Ypsolophus. Tig. $10 a$, anterior wing of Ipsolopluts marginellus; 106 , posterior wing; $10 \mathrm{c}$, head.

Genus 14. Aplota. Fig. 11 , head of Aplota palpella.

Gunes 15. Wothris. Fig. 12 a, anterior wing of Nolluris Verbascella; $12 b$, posterior wing; $12 c$, licad. 

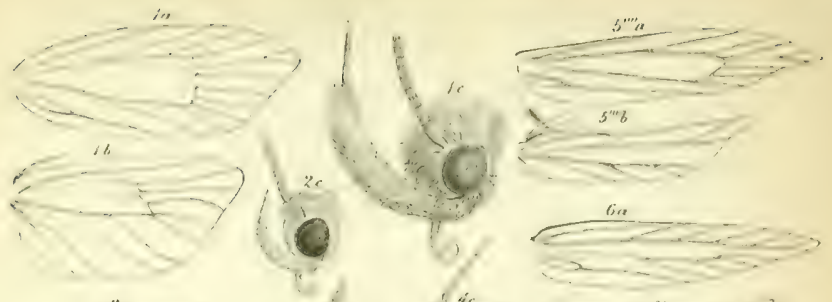

$\because$

is
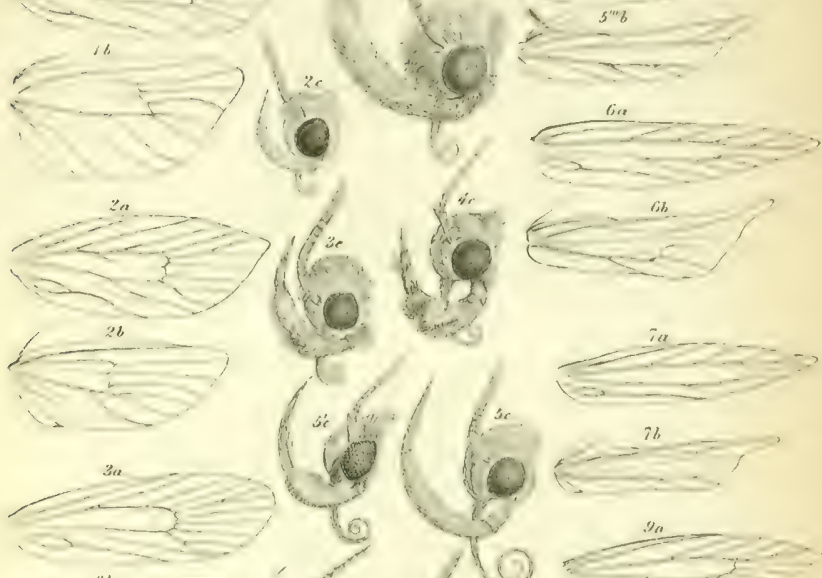

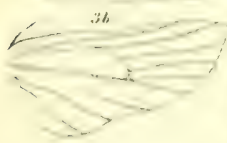
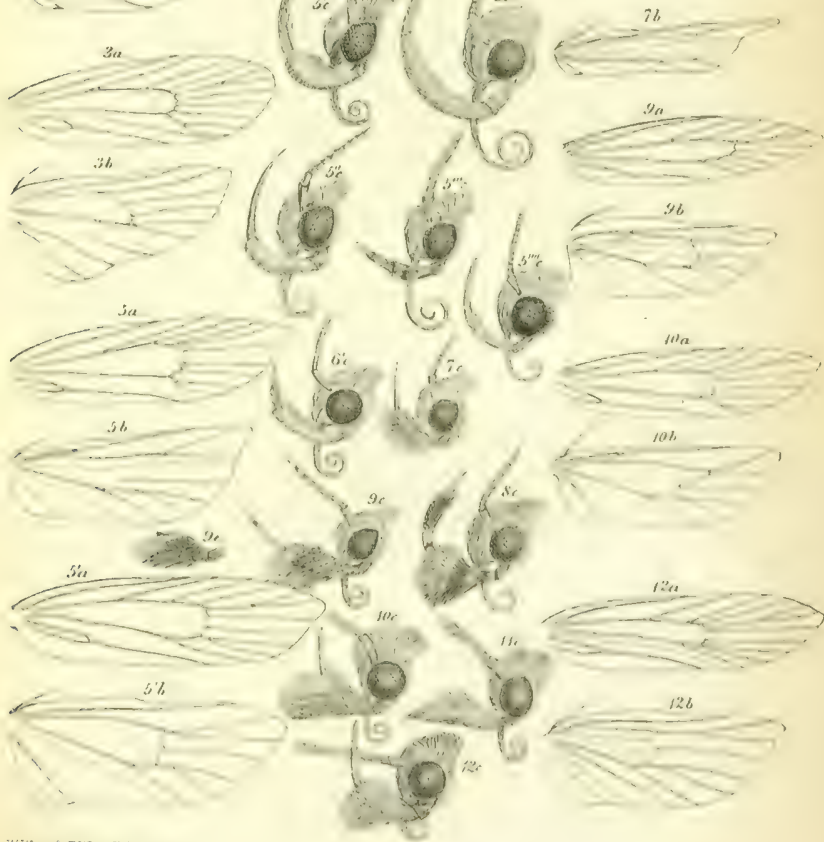


FAMILY V. GELECHIDE (continued).

GLNUS 16. Sophronia. Fig. $1 a$, anterior wing of Sophronia prrenthesella; $1 b$, posterior wing; $1 c$, head.

Ginus 17. Pleurota. lig. 2 ", anterior wing of Plenrola bicostellu; $2 b$, posterior wing; $2 c$, head.

Genus 18. Farpella. Fig. 3 a anterior wing of IIarpella Geoffrella; $3 b$, posterior wing; $3 c$, head.

Gexus 19. Hypercallia. Fig. 4 a, anterior wing of Ilypercallia Christiemana; 4 b, posterior wing; $4 . c$, head.

Guxus 20. Dasycera. Tig. 5 a, antcrior wing of Dasycera sulplurella; $5 b$, posterior wing; $5 c$, head.

Genus 21. Acophora. Fig. (o a, anterior wing of Gicophora pseudospretella; $6 \mathrm{~b}$, posterior wing ; $6 \mathrm{c}$, head.

Genus 22. OEgoconia. Fig. 7 a, anterior wing of Gigoconia quadripuncta; 78 , posterior wing; $7 c$, head.

Gexus 23. Endrosis. liig. 8 a, anterior wing of lindrosis fenestrella; $8 b$, posterior wing; $8 b$ ', posterior wing (undenuded); $8 c$, head.

Gexus 2\%. Butaliz. Fig. 9 a, anterior wing of Bulalis yrandipennis; $9 b$, posterior wing; $9 c$, head; $9^{\prime} c$, hend of Bulalis tor. quatella; 9" $a$, anterior wing of Butalis incongruella; 9" $b$, posterior wing; 9" $c$, head.

Genus 25. Pancalia. Fig. $10 a$, anterior wing of Pancalia Lencenlookella; $10 \mathrm{~b}$, posterior wing; $10 \mathrm{c}$, hcad.

\section{FAMIIY VI. GLYPIIIPTERYGIDA.}

Gevus 1. Acrolepia. Figr. 11 u, anterior wing of Acrolepia granitella; $11 \mathrm{~b}$, postcrior wing; $11 \mathrm{c}$, head.

Ginus 2. Röslerstammia. Fig. 12 a, anterior wing of Rösterstammia Erxlébella; $12 b$, posterior wing; $12 c$, head. 

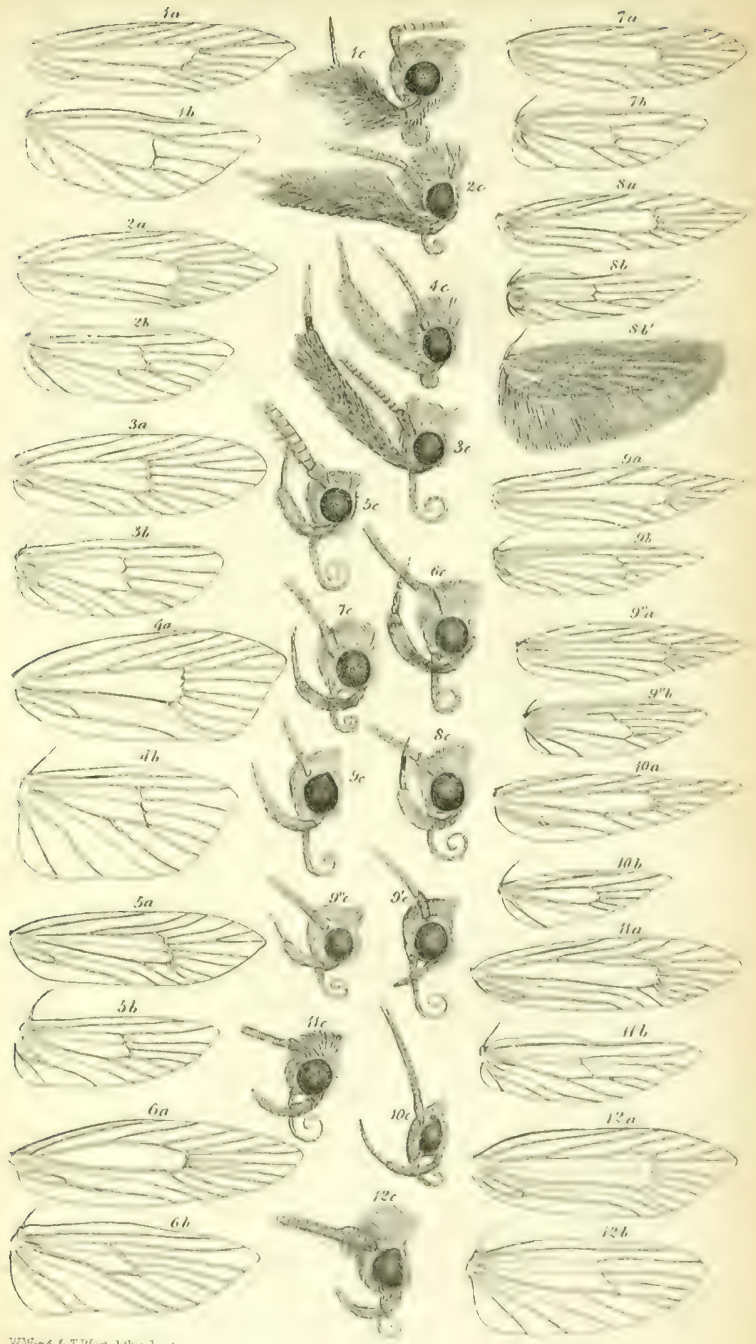

WWing \& I West bth ad nut.

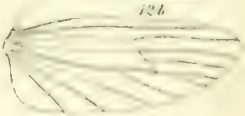






\section{FAMILY VI, GLYPHIPTERYGIDA (continued).}

Grovs 3. Glyphipteryx. Fig. $1 \alpha$, anterior wing of Glyphipteryx fuscoviridella; $1 \quad b$, postcrior wing; 1 'c, head of Glyphipteryx Thrusonella; 1 'd, portion of antenna.

Grovs 4. FEchmia. Fig. $2 a$, anterior wing of Itchinia dentella; 26 , posterior wing; $2 c$, head.

Genus 5. Perittia. Fig. $3 a$, anterior wing of Perittia obscurepunctella; $3 b$, posterior wing; $3 c$, lead.

Genus 6. Tinagma. Fig. $4 a$, anterior wing of Tinagma sericiellum; 4. $b$, posterior wing; $4 c$, hend.

Genus 7. Douglasia. Fig. 5 , anterior wing of Douglasia ocnerostomella; $5 b$, posterior wing; $5 c$, head.

\section{FAMILY VII, ARGYRESTHIDAE.}

Genus 1. Argyresthia. Fig. $6 a$, antcrior wing of Argyresthia nitidella; $6 b$, posterior wing; $6^{\prime} c$, licad of Argyresthice ephippella; 6 " $a$, anterior wing of Argyresthia arcenthina.

Genus 2. Cedestis. Fig. 7 a, anterior wing of Cedestis farinatella; $7 b$, posterior wing; $7 c$, head (front view); $7 c^{\prime}$, head (side view).

Genus 3. Ocnerostoma. Fig. $8 a$, anterior wing of Ocnerostoma piniariella; $8 b$, posterior wing; $8 c$, head.

Genus 4. Zelleria. Fig. $9 a$, anterior wing of Zellevia hepariella; 96 , posterior wing; $9 c$, head.

\section{FAMILX VIII. GRACILARIIDA.}

Gunus 1. Gracilaria. Fig. $10 a$, anterior wing of Gracilarin stigmatella; $10 \mathrm{~b}$, posterior wing; $10 \mathrm{c}$, head ; 10 " $"$, anterior wing of Gracilaria omissella; $10^{\prime} \mathrm{b}$, posterior wing; $10^{\prime} \mathrm{c}$, head.

Genus 2. Coriscium. Fig. 11 , anterior wing of Coriscium Bronyniardellum; $11 \mathrm{~b}$, posterior wing; $11 \mathrm{c}$, head; $11{ }^{\prime} e$, palpus of Coriscium sulphurellum.

Grevus 3. Omix. Fig. 12 ", anterior wing of Ornix Anglicelle; $12 \mathrm{~b}$, posterior wing; $12^{\prime} \mathrm{c}$, heal of Omix Scoticella. 

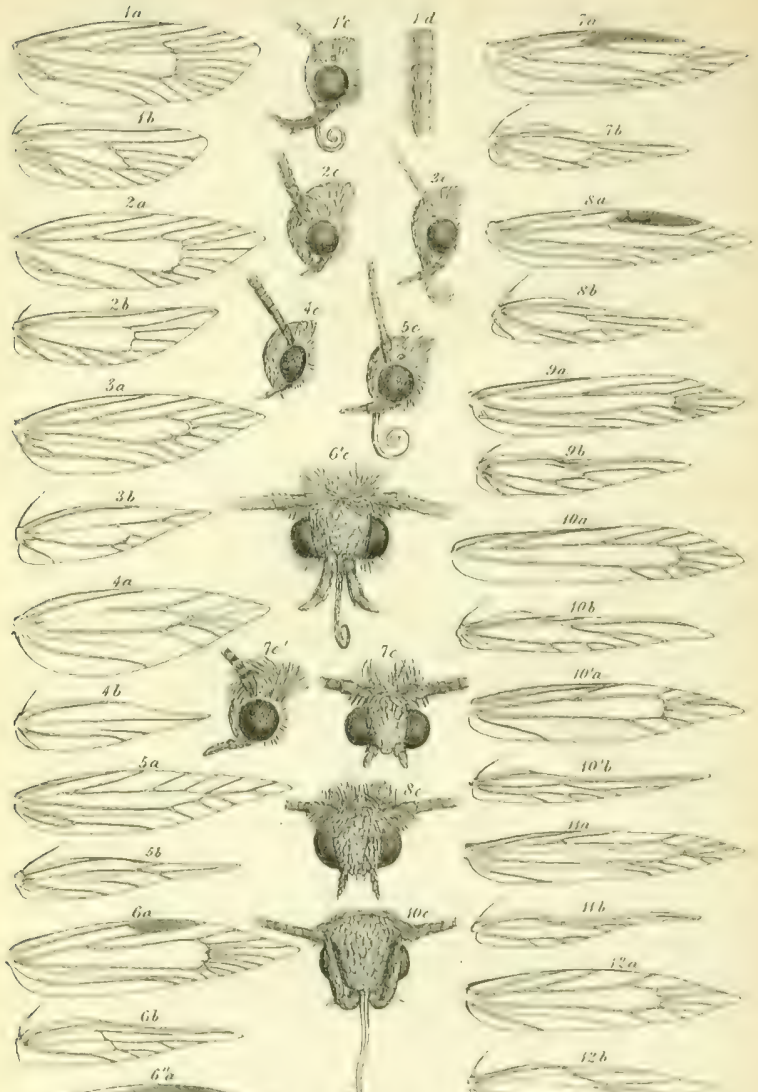

(5in
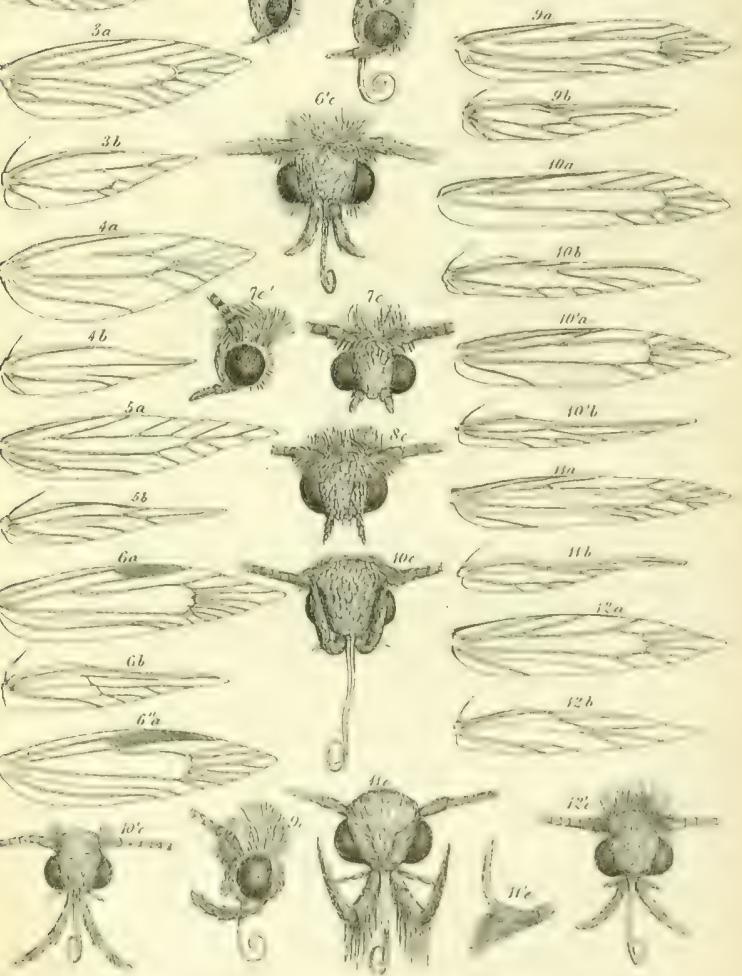

FAMIIY IX. COLEOPHOLIDAs.

Gunvs 1. Coleophora. Fig. 1 anterior wing of Colcophora anulipennella: $1 b$, posterior wing; 1 ' $c$, head of Coleophora Fabriciellu; 1 "d, portion of antenna of ('oleophora paripennella; $I^{\prime \prime \prime} d$, portion of antenna of Coleophora ochrea.

\section{FAMLY X. ELACHISTIDA.}

Ginves 1. Bedellia. Tijg. $2 a$, anterior wing of Bedellire sommilentella; $2 b$, posterior wing; $2 c$, hend.

Gixts 2. Stathmopoda. Fig. $3 \alpha$, anterior wing of Stathmopoda pedella; $3 b$, posterior wing; $3 c$, head; $3 d$, portion of antenua.

Gexus 3. Cosmopteryzs. Fig. 4 a, anterior wing of Cosmopteryx Drurella; $4 . b$, posterior wing; $4 c$, head; $4 h$, hind leg.

Gives +. Batrachedra. Fig, 5 a, anterior wing of Butrachedra pracangusta; $5 \quad b$, posterior wing; $5 c$, head.

Ginus 5. Oinophila. Fig. $6 a$, antcrior wing of Oinophila $V$-flava; $6 b$, posterior wing; $6 c$, head.

Genus 6. Chauliodus. Fig. 7 a, anterior wing of Chauliodus Cheroplayllelles ; $7 b$, postcrior wing; $7 c$, head; $7^{\prime} a$, anterior wing of Chauliodus insecurellus.

Gisve 7. Laverna. Fig. 8 a, antorior wing of Laverna Staintoni; $8 \mathrm{~b}$, postcrior wing; 8'c, head of Lawerna lacteclla; 8 " 4 , anterior wing of Laverna Epilobiella; 8 "b, posterior wing; 8 "' $c$, lead of Laverna ochraceella; $8^{\prime \prime \prime} a$, anterior wing of Laverna atra; $8^{\prime \prime \prime \prime} b$, posterior wing.

Genus 8. Chrysoclista. Fig. 9 a, anterior wing of Chrysoclista Linneell $a ; 9 b$, posterior wing; $9 c$, head; $9 ' b$, posterior wing of Chrysoclista Schrankella; $9 " b$, posterior wing of Chrysoclista flavicaput; 9 "c, head.

Grnus 9. Feliodines. Fig. 10 ", anterior wing of IIclionlines Roesella; $10 \mathrm{~b}$, posterior wing; $10 \mathrm{c}$, head.

(iENus 10. Anybia. Tig. 11 a, antcrior wing of Amylia langiella; $11 b$, postcrior wing; $11 c$, head. 

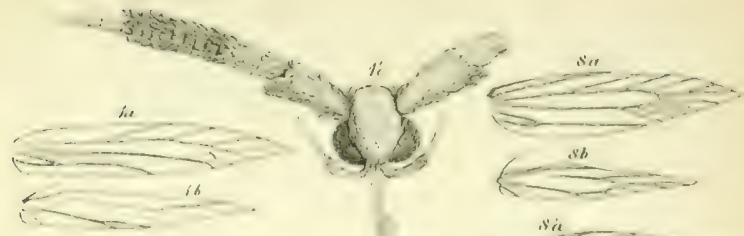

\section{itis}
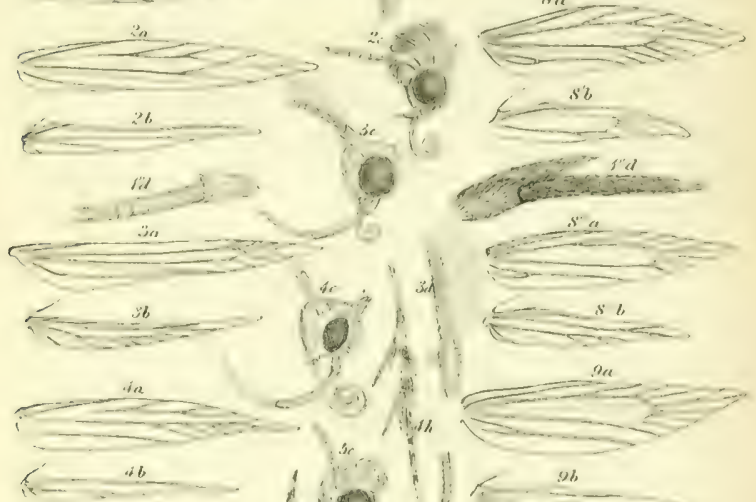

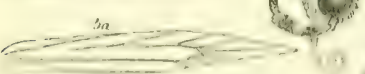
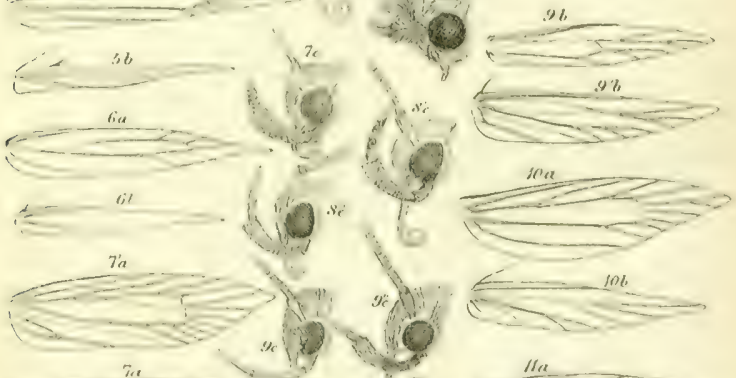

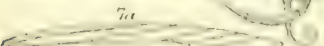
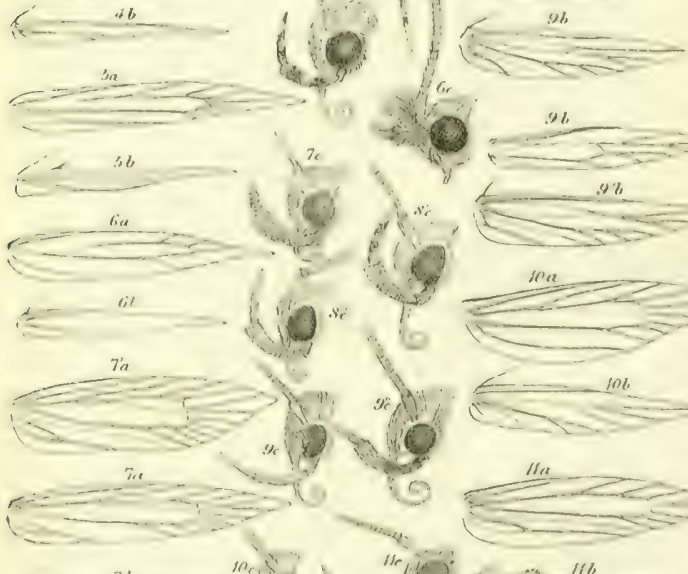

$$
\text { . }
$$






\section{FAanLY X. ELACHISTIDA (continued).}

(iives 1]. Asychna. Tiig. I a, anterior wing of Asychna modestella; 16 , posterior wing; $1 \mathrm{c}$, head; $1^{\prime} a$, anterior wing of Asychua cratella; $1^{\prime} b$, posterior wing; $1^{\prime} c$, head; 1 "c, head of Asychna terminella.

Gileve 12. Chrysocorys. Fig. 2 ", anterior wing of Chrysocurys. festaliella; $2 b$, posterior wing ; $2 c$, head.

(ivnus 13. Elachista. Fig. 3 a, anterior wing of Elachista obscurella; $3 b$, posterior wing; $3 c$, head.

Genus 14. Tischeria. Fig. to anterior wing of Tischeria complanella; $4, b$, posterior iving; $4 \mathrm{c}$, head of $\delta$.

\section{Famur XI. LiTiIOCOLLWTID di.}

GENus 1. Lithocolletis. Fig. $5 a$, antcrior wing of lithocolletis Messaniella; 5 b, posterior wing; $5 c$, head.

\section{FAMIX XII. LYONETIDA.}

(iends 1. Lyonetia. Fig. $6 a$, anterior wing of Lyonetia Clerchellu; $6 . b$, posterior wing; $6 \mathrm{c}$, head (front view); $6 c^{\prime}$, head (side view).

Givus 2. Phyllocnistis. Tig. 7 a, anterior wing of Phyllomistis suffitsella; $7 \mathrm{~b}$, posterior wing; $7 \mathrm{c}$, head.

Gext's 3. Cemiostoma. Fig. 8 a, anterior wing of Cimiostoma Laburmella; $\mathrm{S} b$, posterior wing ; $8 \mathrm{c}$, head; $8^{\prime}$ ", anterior winer of Cemiostoma scitella; $8^{\prime} \mathrm{b}$, posterior wing; $8^{\prime} c$, head.

(iEvus 4. Opostega. Iig. 9 a, anterior wing of Opostega saluciella ; $9 b$, posterior wing; $9 c$, head.

Graves 5. Bucculatrix. Fig. $10 a$, anterior wing of Bucculatria Cratagi; 10 b, postcrior wing; $10 c$, head.

\section{FAMILY XIII. NEPTICULIDA.}

Gisnus 1. Nepticula. Iig. 11 ", anterion wing of Nepticnla grotimsella; 11 b, posterior wingr ; 11'c, head of Niplirula aurellu : 11 " $a$, antcrior wing of Nepticula subbimaculella.

Gexus 2. Trifurcula. Fig. $12 a$, anterior wing of Trifurcula immundella; $12 b$, posterior wing; $12 \mathrm{c}$, head. 

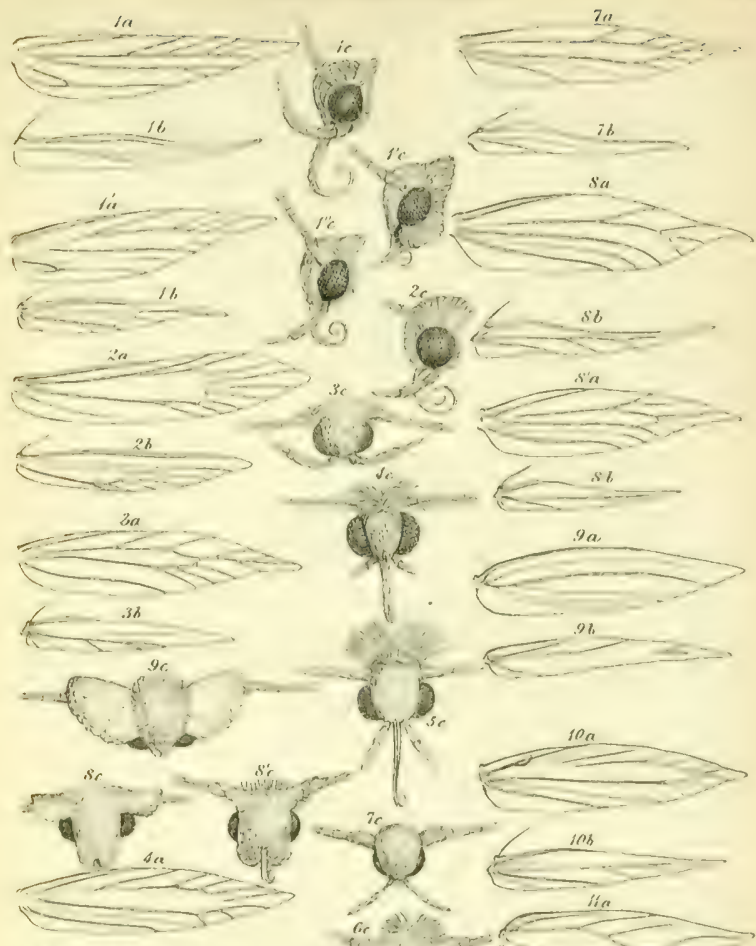

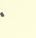



\section{PI A I'E IX.}

Fig.

1. Exapate gelatella.

2. Ochsenheimeria Birdella.

3. Tinea Lapella.

4. Micropteryx Salopiella.

5. Nemotois Scabiosellus.

6. Swammerdamia Pyrella.

7. Hyponomeuta vigintipunctatus

8. Plutella Crucifcrarum.

9. Cerostoma Xylostella.

10. Depressaria Alstrœmeriana.

11. Gelechia Malvella.

12. Gelechia Hermannella.

13. Sophronia parenthesella.

14. CLcophora grandis.

15. Butalis grandipenuis.
Hig.

16. Glyphipteryx cquitella.

17. Tinagma resplendellum.

18. Argyresthia nitidella.

19. Gracilaria Swederella.

20. Coleophora lineolea.

21. Bedellia somnulentella.

22. Cosmopteryx Lienigiella.

23. Laverna propinquella.

24. Elachista gangabella.

25. Elachista cerusella.

26. Tischeria marginea.

27. Lithocolletis sylvella.

28. Lithocolletis Stettinensis.

29. Cemiostoma scitella.

30. Nepticula sericopeza. 

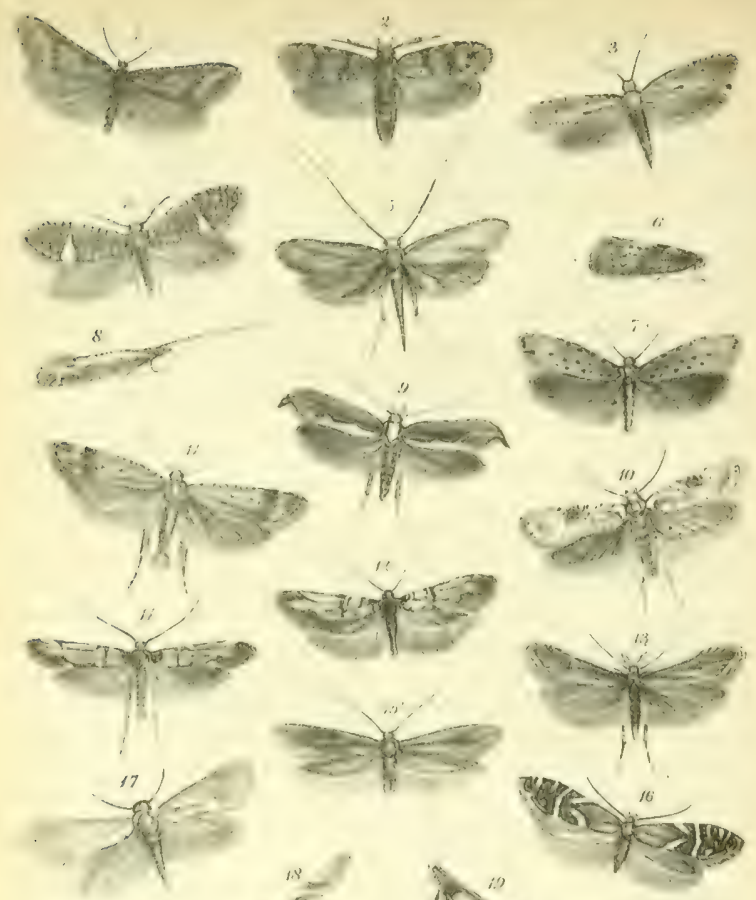

. 20
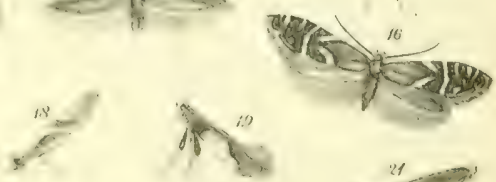

(a)
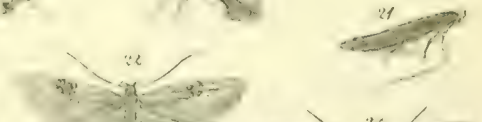

23

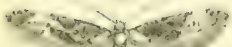

?
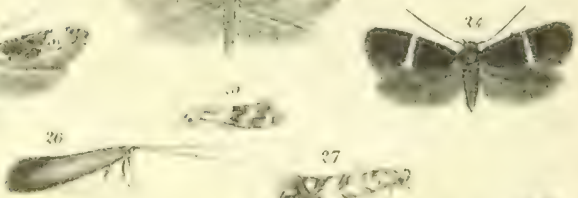

\section{$: 7$}

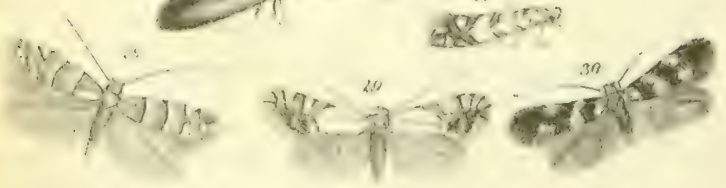



Fig. 1, larva of Chimabacche Fayella; 1 a, united birch-leaves, showing the larva between them.

liig. 2, larva of a Solenobir (the species is not known, no males having been bred); $2 a$, the cases attached to lichen on a fence; $2 b$, the case, much magnified.

Fig. 3, larva of Ochsenheimeria Birdella; $3 a$, section of a grass-stem, showing the larva burrowing down the centre.

Fig. + , larva of Tinea biselliella; $+a$, gallery formed by the larva fecding among feathers; $t^{\prime} b$, case of Tinea pellionelli on a feather.

Fig. 5, larva of Lampronia prolatella; 5 a, leaf of wild strawberry eaten by the larva, with the case attached to the under-side; $5 b$, the case, much magnified.

Fig. 6, Iarva of Incurvaria pectinea; $6 a$, the larva in its case, feeding on a fallen oak-leaf.

Fig. 7, larva of Incurvaria capitella; $7 a$, a currant-shoot withering from the effect of a larva of Incurvariu capitella feeding in the stem.

Fig. 8, larva of Suamnerdamia pyrella; $8 a$, the larva in its web, between united cherry-leaves.

Fig. 9, larva of Plutelln porrectella; $9 a$, the larva feeding on a leaf of ITesperis matronalis.

Fig. 10, larva of Orthotclia Sparganella; $10 a$, stem of Sparganium, eaten by the larva.

Fig. 11, larva of a Depressaria, which fects on Cenlaurea nigra (the species is not known, the perfect insect not having been bred); $11 a$, leaf of Centaurea nigra, contorted by the larva.

Fig. 12, larva of Gelechia pernigrella; $12 a$, shoot of sallow tenanted by the larva.

lig. 13, larva of Parasia Carlinella; $13 a$, section of secd-head of Carlina vulgaris, showing the larva feeding bolow the seeds.

fig. 14, larva of Uscophora unitella; 1.t a, picec of decayed wood burrowed by the larva.

Fig. 15, larva of Glyphiptery.x equitella; 15 a, shoots of Sedum acre, the middle one bleached by the excavations of the larva.

Pig. 16, larva of Argyresthia nitidella; 36 a, shoots of hawthorn, enten by the larva.

rig. 17, larva of Gracilaria Swederella; $17 a$, cone on an oak-leaf, formed by the Iarva.

Fig. 18, larva of Omix Anglicella; $18 \alpha$, cone on hawthorn-leaf, formed by the larva. 
lig. 19, larva of Coleophora troglodytella; 19 a, leaf of Eupatoria cannabinum mined by the larva; $19 b$, ease, much magnified.

Fig. 20, larva of Bedellia somnulentella; $20 a$, leaf of Convolvulus arvensis mined by the larva.

Fig. 21, larva of Chauliodus Chorophyllellus; 21 a, piece of a leaf of Anthriscus sylvestris eaten half through by the larva.

Jig. 22, larva of Chrysoclisla Limeella; $23 a$, piece of inner bark of the lime-tree burrowed by the larva.

Fig. 23, larva of Elachista cerusella ; 23 a, leaf of Arundo Phrugniles mined by the larva.

Fig 24, larva of Tischeria marginea ; $24 a$, bramble-leaf mined by the larva.

Fig. 25, larva of Lilhocolletis carpinicolella; $25 a$, leaf of hornbeam mined by the larva.

Fig. 26, larva of Cemiostoma Laburnella ; $26 a$, mine of the larva in a laburnum-leaf.

Fig. 27, adult larva of Bucculatrix Cralogi; $27 a$, hawthorn-leaf eaten balf through by the larva.

Nig. 28, larva of a Nepticula, which feeds on Potentilla fragariustrmin (the species is not known, the perfect insect not having been l)red); 28 , leif of Potentilla fragariastrum, with the mine of the larra. 


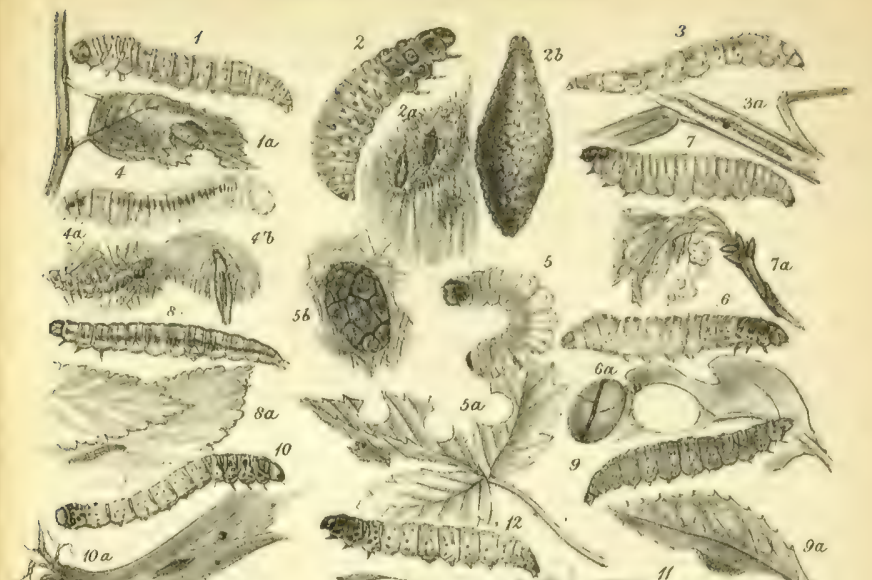

H.

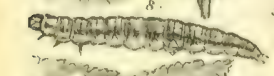

27.

$\leq>3$

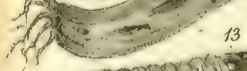

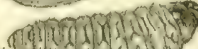

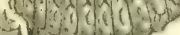

Lat $13 a$
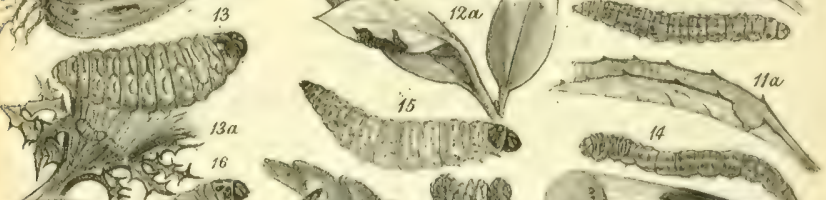

1. - 11 is
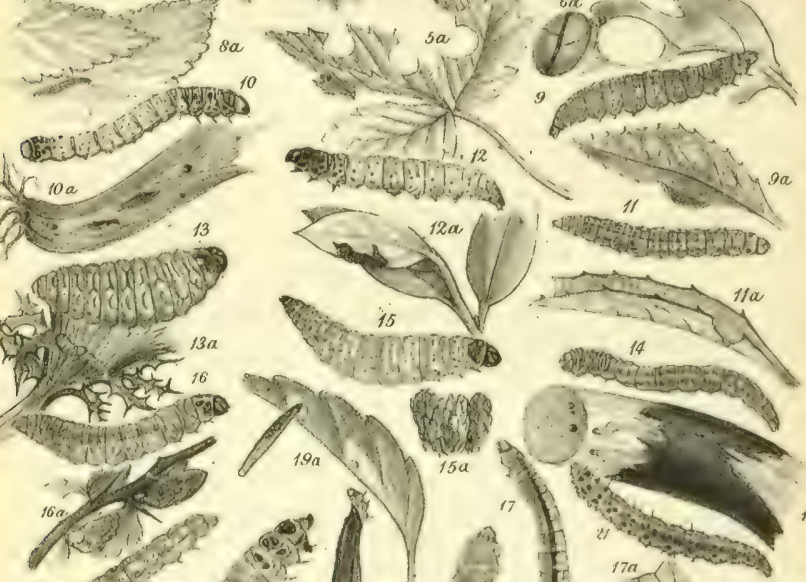

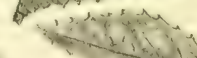

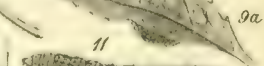




\title{
LIST OF WORKS
}

\section{PRINCIPALLY ON NATURAI, IIISTORY,}

\author{
PUBI.ISIIFD BY
}

\section{LOVELL REEVE,}

\author{
5, HENRIETTA STREET, COVISN' GARDEN.
}

\section{BOTANY.}

PIIYCOTOGIA BRITANNICA; or, History of the ]3ritish Seawceds; containing coloured figures, and deseriptions, of all the species of Algae inhabiting the shores of the 13ritish Islands. By Professsor HAnveY, M.D., M.R.I.A., Keeper of the Ilerbarium of the University of Dublin, and Professor of Botany to the Dublin Society. The price of the work, complete, strongly bound in cloth, is as follows:-

In three vols. royal $8 \mathrm{vo}$, arranged in the $\} \notin 7126$

$\left.\begin{array}{c}\text { In four vols. royal 8vo, arranged systema- } \\ \text { tically according to the Synopsis ....... }\end{array}\right\} \& 7 \quad 17$

A fero Copies lave been printed on large paper.

"The 'Ifistory of British Sea-weeds' we can most faithfully recommend for its scientific, its pietorial, and its popular value; the professed botanist will fint it a work of the highest character, whilst those who desire rticrely to know the names and history of the lovely plants which they gather on the sea-shore, will find in it the faithful portraiture of every one of them."--Annals and Hergazine of Natural History.

"The drawings are beautifully executed by the author himself on stone, the disscetions carefully prepared, and the whole uecount of the species drawn up in such $n$ way as camiot fail to be instrmetive, cven to those who are well aequaiuted will the subject. 'The greater part of our more cummon $A$ lge have never becn illustrated in a manner ugreenble to the present state of Algology." - Cardenters' Chrovicle.

NEREIS AUSTRALIS; or; Illustrations of the Algae of the Southern Ocean. By Professor Hanvey, M.D., M.R.I.A. To be completed in four P'arts, each containing twenty-five plates, imp. 8vo. Price 1l. 1s, coloured. Parts I. and II. recently published,

"Of this most important contribution to our knowledge of exntic Algx, we know not if we cam pay it a higher compliment than hy saying it is worlhy of the 
anthor. It shonll he observed that the work is not a selection of certain species, but an nrrauged system of all that is known of Australian $\Lambda \mathrm{Igr}$, accompanici by figures of the new and rare ones, especially of those most remarkable for beauty of form and colour." - London Journal of Botany.

\section{TILE RIIODODENIRONS OF SIKKLI-IIMILAYA. With} drawings and descriptions madc on the spot, By J. D. Hooker, M.1., F.R.S. Edited by Sir W. J. Ноoker, D.C.I., F.R.S. In handsome imperial folio, with thirty plates. Price 3l. 16s. coloured.

"In this work we have the first results of Dr. Honker's botanical mission to India. The annomement is calculated to starlle some of onr readers when they know that it was only last. Jamuary twelvemonths that the Doctor arrived in Calcutta. 'That he should have ascended the Ilimalaya, discovered a number of plants, and that they should be published in England in an almost UNEQUALLED STYLE OF MAGNIFICENT ILLUSTRATION, in less than eightcen months-is one of the marvels of aur time." - Athencenm.

"A most beautiful example of fine drawing and skilful colouring, while the letter-press furnished by the talented author possesses very high interest. Of the species of IRhododendron which he has found in his adveuturous journey, some are quite univalled in magnificence of appearance." - Gardeners' Chronicle.

POPLILAR ECONOMIC BOTANY; or, 1)eseription of the Bofanical and Commercial Characters of the Principal Articles of Vegetable Origrin, used for lood, Clothing, T'unning, Dyeing, Building, Medicine, Perfumery, etc. Hlustrated from the Liverpool Collection of the Great Exhibition. By T'. C. ArCuER, Collector of Economic Botany to the New Crystal Palace. loyal $16 \mathrm{mo}$, with twenty plates of figures. Pricc 10s. $6 d$. coloured.

"Mr. Areher's volnme, we are surprised to find, is the first popular book that has been devoted exclusively to the commercial products of the Vegetable Kingdom-of that which constitntes nine-twelfths of the whole commeree in raw produce giving employment to our vast mereantile marine... We can hearfily recommend this most useful and entrrtaining little book." - Krrominer.

"Every production of the vegetable world which tends to the use, the com. fort, or the luxury of mankind, is noticed in its pages. . . . 'The illustrated figures of the principal among them have been executed in a style hitherto only to be found in the most eostly works of descriptive Jolany." - Jeceestershive Merewry.

"Practically and scieutifically qualificd for his task, Mr. Areher has succeeded in giving his information with elearuess and conciseness, so vital to the sucecss of every popular manual."-Britannia.

POPULAR IISTORY OF BRITISII SEA-WEEDS, comprising all the Marine Plants. By the Rev. DAvm Landosirougi, A.1.S., Member of the Wernerian Society of Edinburgh. Second Edition. With twenty-two plates by Fitch. Royal 16 mo, Price 108, 6rl. coloured.

"A work of much general interest. The deseriptions are scientific as well as popular, and the plates are clear and explicit. Not ouly the forms, but the uses of 
Alge, are minutely described. It is a worthy SLA-sIDe: COMPANION-a handbook for every occasional or permanent resident on the sea-shore." - Economist.

"Those who wish to make themselves acquainted with British Sea-wceds, cannot do better than begin with this elegantly illustrated manual." -- Cilube.

"This elegant work, though intended for berinuers, is well worthy the perusal of those advanced in the science."-Jorning Herald.

\section{POPULAR IIISTORY OF BRITISIT FERNS, comprising all} the Species. By Tromas Moore, F.I,S. With twenty plates by Fitch. Royal $16 \mathrm{mo}$. Price $10 \mathrm{~s}, 6 \mathrm{~d}$. coloured.

"Mr. Moore's 'I'opular Ilistory of British Ferns' forms one of the numerous edegant and instructive books by which Messrs. Reeve and Co. have cudeavoured to popularize the study of Natural IIistory. In the volume before us, Mr. Moore gives a clear account of the British lierns, with directions for theirenltivation; accompanied by munerous coloured plates nently illustrated, and preceted by a general introduction on the natuml character of this graecfil elass of plants," - Spectator.

"We have rarely seen a publication relatim to plants where the object aimed at is more fully accomplished than in this elegant volume."--Inoker's formal.

"A prettily got-up book, and fit for a drawing-room table." - The Friend.

"Twenty elegant colourcd plates give figures of nearly all our choicest British Ferns, accompanied by a deseription in an easy and interesting siyle: besides which, the scientific elassification and nomenclafure is given for the binelit of the more advanced studedt." - Liverpool Standard.

POPULAR FHETh) BO'TANY; containing a familiar and technical description of the plants most eommon to the British Isles, adapted to the study of either the Artificial or Natural Systems. By AgNes CATLow. Third Edition. Arranged in twelve chapters, each being the Botanical lesson for the month. With twenty plates of figures. Royal $16 \mathrm{mo}$. Price 10s. 6d. coloured.

"The design of this work is to furnish young persons with a Self-instructor in Botany, enabling them with little ditliculy to diseover the serentifie names of the common plants they may find in their coiutry rambles, to which are appendcil a few facts respecting their uses, babits, \&c. The plants are classed in months, the illustrations are nicely colourerl, and the book is altogether an elegant, as woll as useful present." - Illustrated London News.

\section{(Under the Anthority of the Lords Commissioners of the Admiralty.)}

FLORA ANTARCTICA; or, Botany of the Antartic Vovine of II.M. Discovery Ships Jiethrs and Terror, during the year's 1839-1843, under the command of Capt. Sir James Clark Ross, R.N., T.R.S. Вy J. 1). НоокER, M.J)., I.R.S., \&c., Botanist to the Expedition. In two rols. Royal 4to, cloth, containing two hundred plates. Price $10 \mathrm{l}$. I5s. coloured; 7l. 10s, plain.

*** The Cryptogamic portion of this work may be had sepa- 
rately, in one volume, royal 4to, with seventy-four plates. Price 4. 48. coloured; 2l. 17s. plain.

"The descriptions of the plnats in this work are carefnlly drawn up, and much interesting matter, eritical, explanal ory, ant historical, is added in the form of notes. "The drawings of the plants are ndmirably executed by Mr. Titeh; and we know of no prodnctions from his pencil, or, in fact, any hotanical illustrations at all, that are superior in faithful representation and botanical correctness." - Altienceum.

\section{(Under the Authority of the Lords Commissioners of the Admiralty.)}

TLORA OE NEIY ZE.ILAN1). By 1)r. J. D. ILOOKER, R.R.S. Publisherl in Parts, each containing Twenty l'lates. Price 31s. 6d. coloured; 21s. plain.

"When completed, this will be the most important work that has yet apreared in illustration of the vegetation of the l3ritish Australian possessions. . . . Let us add, that the beautiful execution of the work renders it a 'library-book, even to those who are not interested about natural history." - Gardeners' Chronicle.

CURTLS'S BOTANIC.ML MIRIZINE (eommeneed in 1786); Continued by Sir W. J. Поокеn, W.T.S., D.C.L., Sce., Director of the Royal Gardens of Kew.

* * Published in monthly numbers, each containing six plates, price 3 s. $6 d$. coloured; and in anuual volumes, price 428.

HOOKLR'S JOURYAL, OF BOTANY and KLW GARDENS

Miscellany. Edited by $\operatorname{Sir}$ W. J. Hooken, 1).O.I., T.12.S., Director of the Royal Gardens, Kew.

This Botanical Journal, in addition to original papers by Eminent Botanists, contains the Botanical News of the month, Communications from Botanieal Travellers, Notices of New Books, \&c.

: * In monthly numbers, with a plate, price 28.

THE LONDON JOURNAL OF BOT:NY. Edited by Sir W. J. IоокеR, D.C.I., I.R.S., etc. Vol. VII, completing the series. 8vo, with twenty-three plates. Price 30s. plain.

ICONLS PIAN'TARUM; or, Figures, with brief descriptive characters and remarks, of new and rare Plants. 8vo. New Series, Vol. V. With two hundred plates. 318.6d. plain.

ILLUSTRATIONS OF BRITISII MYCOLOGY; containing ligures and Descriptions of the liunguses of interest and novelty indienous to Britain. First Series. By Mt's. Musser. 4to, cloth gilt, with ninety benutifully drawings. Price 77. $12 s, 6 d$. coloured.

"This talented lady and her sister were in the first instance induced to draw some of the more striking luugi, mercly as picturesque objects. Their collection 
of drawings at length became important from their number aud aceuracy, aud a long continued study of the uutritive properties of liungi has induced the former to lay the resilts. of her iuvestigations before the public, under the form of illustrations of the more useful and iuteresting species. The figures are so faithful that there can be no difliculty in at once determining with certainty the objects they are intended to represent; and the observntions will be found of much interest to the gencral reader." - Gardeners' Chronicle.

"This is an elegant and interesting book: it would be sn ornament to the lrawing-room table; but it must not, therefore, be supposed that the value of the work is not intrinsic, for a great deal of new and valuable matter accompanies the plates, which are not fancy sketches, but so individualized and life-like, that to mistake any species secms impossible. The accessorics of each aro significant of site, soil, and scason of growth, so that the botanist may study with advantage what the artist nay inspect with admiration." - Morning Post.

ILLUSTRATIONS ()F BRITISII MYCOLOGY; containing Figures and Deseriptions of the Finguses of interest and novelty indigenous to 13ritain. Second Series. By Mrs. IIvsser. Publishing in Manthly l'arts, coloured drawings, price $5 s$.

VOICES FROM TILE WOODTANDS; or, History of Forest Trees, Lichens, Mosses, and Ferns. By Mary Roberts. Elegantly bound. With twenty Plates of Forest Scenery, by liscu. Royal $16 \mathrm{mo}$. Price 10s.6d. coloured.

"This work includes $n$ wide range of genera, from the lichen to the oak, and by way of giving variety to a subject so commonplace, the several plants are sup. posed to tell their own stories, and describe their own family peculiarities." - Atlas.

"The fair authorcss of this pretty volume has shown more than the usual good taste of hex sex in the sclection of her mode of conveying to the young interesting instruction upon pleasing topics. She bids them join in a ramble thromgh the sylvam wilds, and at her command the linagile lichen, the guaterl oak, the towcring bech, the graceful chestaut, and the waving poplar discourse cloquently, and tell their respective histories and uses." - Britannia.

THE VICTORIA REGLA. By Sir W. J. IIooken, F.R.A., I).C.L. In elephant folio, Illustrated on a large scale by W. Fitch. Reduced to 21 s.

The work on the Royal Water Lily contains four plates of very large size, expensively coloured, illustrative of the different stages of flowering and fruiting, wilh analyses of structure, as follows:-

1. $\Lambda$ view of the entire plant, flower, fruit, and leaves, on the water.

2. A flower of the nulural size in progress of expanding, together with as much of the enormous foliage as the broad dimensions of the paper will admit.

3. A fully expanded llower of the natural size, with foliage, \&c.

4. A vertical section of the fully developed flower, with various dissections and amalyses.

"Although many works have been devoted to the illustration nnd deseription 
of the Victoria regia, it scemed still to want one which, whilst it gave an accurate botanical description of the plant, should at the sime time show the natural size of ity gigantic flowers. This objet has hees aimed at by the combined labours of Sir W. Hooker and Mr. Fitch, and with distinguished suecess. 'I'he illustrations are everything that could be elesired in the shape of botanieal drawings. 'They are accurate, and they are beautiful." - Athenaum.

\section{A CEN'UURY OF OR(HII)ACEOUS PLANT'S, selected from} those most worthy of eultivation figured in Curtis's Botanical Magazine, with coloured figures and dissections, chiefly executed by Mr. Fiscu; the deseriptions (entirely re-written) by $\operatorname{Sir}$ WV. J. Ноокек, T.IR.S., D.C.L. With an introduction on the culture of Orchidacea generally, and on the treatment of each genus; by J. C. LxoNs, Esq. lioyal tto, containing one hundred plates. Price Five Guineas, coloured.

"In the exquisite illustrations to this splendid volume full justice has been rendered to the oddly formed and often brilliantly coloured flowers of this eurious and interesting tribe of plants." - Wrstminster and Forcign Quarlerly Review.

"A very acceptable ardition to our knowledge of the Urchis tribe. "The plates are beantifully exceuted, and have been selected with great carc. Each species has a brief character attached, and to each geuus botanical and practical observations, from the pen of Sir William Hooker, are prefixed. The work is enriched with a prefatory memoir by $\mathrm{M}_{1}$. Iyons, full of sound judgment and experience, on the most approved method of growing Orchids." - Literary Gazette.

THE ESCULFNT FUNGUSES OF ENGLAND; a treatise on their Ilistory, Uses, Structure, Nutritious l'roperties, Mode of Cooking, Preserving, \&c. By the Rev. Dr. Badisar. Super-royal 8vo, with twenty-one plates. Price 21s, coloured.

"There is no reason why we should eschew frogs and relish turtle; still less is there for our caling one or two of the numerous edible funguses which our island produces, and condemning all the rest. To draw attention to this fact, and to supply an accurate areount, with a correct dehineation, of the esenlent species of this family in Great Britain, are the objects of the book before us. Sueh a work was a desideratom in this country."-Athenoum.

PARKS AND PLEASURE-GROUNDS; or, Practical Notes on Country Residences, Villas, Public Parks, aud Gardens. By Cinarles H. J. Smitu, Landscape Gardener. Crown Svo. Price 6s.

Contents:- The House and Oflices-The $A$ pproach - Pleasure Grounds and H'lower Gardens-The Park - Ornamental Character of 'Irrees detached and iu combination-Planting-liences of the Park and Pleasure GroundsWater-The Kitehen, Fruit, and Forcing Gardens-P'lublic Parks and Gardens-The Villa-The Laying-out and Improvement of Grounds.-The Arboretun-The Pinetum.

"Mr. Smith expresses himself with frankness as well as precision, and with such an evident reliance on the sympathy of his realers, as to make him a favourite with those who are familiar with his pages. In short, his book is what was 
really wanted in these busy times to bring the elegant in country residences abreast of the useful." - North British Agriculturist.

"In deseribing the characters and requirements of the various deseriptions of ornamental groumds, Mr. Smith has happily chosen language so plain, and rules so simple, that he leaves nothing to be wished for." - Liverpool Standard.

"'The author gives the result of some twenty years' study and observation in a methodical form and practical style." - Lberdeen Journal.

"Mr. Smith, who is a landscape-gardener and garden-arehitect of great experience, has worked out his design with ability and judgment." -Globe.

"The character of this publication is altogether practical, from the opening hints upon the house and offices, to the closing directions about the arborctum and the pinctum,"-Spectator.

"Mr. Smith is an experienced landscape-gardener, and a man of much good sense. His opinions are therefore entitled to attention." -Gardeners' Chronicle.

\section{SANDERS'S PRACTICAL TREATISE ON THE CULTURF}

OF THE VINE, as well under Glass as in the Open $\Lambda$ ir.

With plates, 8vo. Price 5s. plain.

"Mr. Assheton Sinith's place at 'Tedworth las long possessed a great English reputation for the excellence of its fruit and vegetables: one is continually hearing in socicty of the cxtraordinary abundance and perfeetion of its produce at scasons when common gardens are empty, and the great world seems to harc arrived at the conclusion that the kitchen gardening and forcing there are nowhere excelled. We have, therefore, examined with no common interest the work before us, for it will be strange indeed, if a man who ean act so skilfully as Mr. Sanders should be unable to offer advice of corresponding value. We have not been disappointed. Mrr. Sanders's direetions are as plain as words can inake them; and, we will add, as judicious as his long cxperience had ted us to expect. After a careful perusal of his little treatise, we find nothing to object to, and much to priise." - Gardeners' Chronicle.

"A elever, well-written, and nicely illustrated horticultural pamphlet, telling us all we want to know on the subject." - Guardian.

(Under the Authority of the Lords Commissioners of the Admiralty.)

BO'TANY OF THE VOYAGE OF' It.MI.S. HERALD, under the

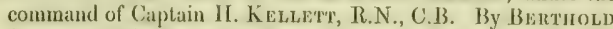
Šemane, Member of the Imperial Academy Nat. Curiosorum. To be completed in Ten Parts. Plates. 4to. Price 10s. plain.

THE TOURIST'S FLORA. A Descriptive Catalogne of the Flowering Plants and Ferns of the British Islands, France, Germany, Switzerland, and Italy. BYy Josepit WooDs, F.L.S., H.G.S. 8vo. Price $18 s$.

"The appearance of this bock has been loug expectet by us ; and we cun just!y state that it has quite fulfilled all our cxpectations, and will support the high reputation of its author. Mr. Woods is known to have spent many years in collect. ing and arranging the materials for the present work, with a view to which he has, we believe, visited all the most interesting localities mentionel in it. 'This amount of labour, combined with extensive botanical knowlelige, has enabled him to produce u volume such as fow, if auy other, botanists were capable of writing." - Annals of Natural Itistory. 


\section{ZOOLOGY.}

(Under the Authority of the Lords Commissioners of the Admiralty.)

ZOOLOGY OF TIIE VOYAGE OF H.M.S. SAMARANG. Elited by Antrur ADAms, F.L.S., Assistant-Surgeon, R.N., attached to the Expedition.

Ventebrata. By Join Enward Gray, F.R.S., Keeper of the Zoological Department of the British Muscum. One Part. Price 10s. 6d.

Fisues. By Sir Jonn Ricriardson, M.1)., F.lR.S. One Part. Price 10s. 6rl.

Moluesca. By the Givitor and Iovelt Reeve, T.L.S., T.G.S. Including the anatomy of the Spircla, by Prof. Owen, F.R.S. Three Parts. Price $1 l, 11 s, 6 d$.

Crustacea. By the Editor and Adam Wirte, F.L.S. Two Parts. Price 18s, 6d.

*** Complete in one handsome royal tto volume, containing 55 plates. Price, strongly bound in cloth, 3l. 10s.

POPULAR IIISTORY OF MAMMAIIA. BY AnAM WIITE, T.L.S., Assistant in the \%oological 1)(partment of the I3ritish Museum. With sixteen Plates of Quadrupeds, Sc. By B. W. HAw KINs, F.L.S. Thoyal 16mo. Price 10s.6d." coloured.

"The present increase of our sfores of ancedotal matter respecting every kiad of animal has been used with much tact by Mr. White, who has a terse chatty way of putting down his reflections, mingled with that ensy familiarity which every one accustomed daily to zoological pursuits is sure to attain. The book is profusely illustrated." - Atlas.

"No book can better answer its purpose: the descriptions are as bright as the pictures, and the kind-hearted playfulness of the style will make it an copecial favourito; nulike most popular manuals, it is the product of first-rate science."-Presbyterian Messenger.

POPULAR IIISTORY OH MOJJUSCA; or, Shells and their Animal Inhabitants. By MARr RoBerts. With eighteen plates by Wing. Royal $16 \mathrm{mo}$. Price $10 \mathrm{~s} .6 \mathrm{~d}$. coloured.

"This volume forms another of the excellent series of illustrated works on various depariments of Natural History, for which the public is indebted to Mr. Reere. .... When we add, that the plates contain no fewer than ninety figures of shells, with their animal inhabitants, all of them well, and several admirably, exceuted, and that the text is written thronghout in a readable and even 
clegant style, with such digressions in poetry and prose as serve to relieve its seientifie details, we think that we have said enough to justify the favourable opinion we hnve expressed." - British and Forcign Mlerlico-Chirurgienl Review.

"To the lovers of Conchology this volume cannot fail to prove a most acceptable winter offering. It gives a most comprehensive account of the whole testaceous family - from the poetic nautilus to the prosaic oyster; from the trumpet of the fabled 'Triton to the snail with which the younger Pliny used to regale his luxurious guests." -Globe.

"We expected to find a useful and entertaining volume. We have not been disappointed. .... The work is illustrated with eighteen plates; beautifully coloured, in most instances affording a view of the strueture of the animal," Atheneum.

POPULAR BRITISII ORNITIIOLOGY ; comprising a familiar and technical description of the Birds of the British Isles. By P. 11. Gossv. Second Edilion. In twelve chapters, each being the Omithological lesson for the month. With twenty plates of figures. Iloyal $16 \mathrm{mo}$. Price 10s, 6d. coloured.

"T'o reuder the subject of ornithology clear, and its study attractive, has been the grent aim of the nuthor of this benutiful little volnme. . . . It is embellished by upwards of 70 tigures of British birds beautifully coloured,"-Morning Herald.

"We can answer for this compret and eleyant little volume being beautifully got up, and written in a manuer likely to attract the interest of the youtleful student." - Globe.

POPULAR SCRIPTURE \%OOLOGY; or, History of the Animals mentioned in the Bible. By Maria E. Catlow. With Sixteen Plates. Royal $16 \mathrm{mo}$. Price $10 \mathrm{~s}, 6 d$. coloured.

"It contains a short and clear account of the animals mentioned in the Bible, classed according to their genera, and illuslrated by a mumber of well-executed and characteristic coloured plates. It is a scasonable addition to a very nice set of books,"-Guardian.

"Aliss Catlow's abilities as a naturalist, and her tact in popularizing any subject she undertakes, are too wcll known to need reiteration on this oceasion." Notes and Queries.

"It is a pleasant mixture of popular and scientific matter. . . The book is illustrated by characteristic colourcd plates."-Spectator.

POPULAR BRITISII ENTONOLOGY, comprising a familiar and technical description of the Insects most common to the British Isles, By Maria E. Catrow. Second Eidition. In twelve chapters, each being the lintomological lesson for the month. With sixteen plates. Royal $16 \mathrm{mo}$. 10s. $6 \mathrm{~d}$. coloured.

"Jndicionsly crecuted, with excellent figures of the connoner species, for the use of young beginners."-Address of the President of the Entomotogical Society.

"Miss Catlow's ' Popular British Eutomology' contains an introductory chanter or two on chassitiention, which are followed by brief generie and specific deseriptions in Finglish of above 200 of the eommoner British species, fogether with accurate figures of abont 70 of those described; and will be quite a treasure to any one just commencing the study of this fuscinating seience." - Westminster and Foreign Quarterly Ileview. 
CONCHOLOGIA ICONICA; or, Figures and Descriptions of the Shells of Molluscous Animals, with eritical remarks on their synonyms, affinities, and circumstances of habitation. By Lovell ReEve, F.L.S., F.G.S.

** Demy +to. P'ublished monthly, in Parts, each containing cight plates." Price 10s. coloured.

\section{SOLD ALSO IN MONOCRAPHS:}

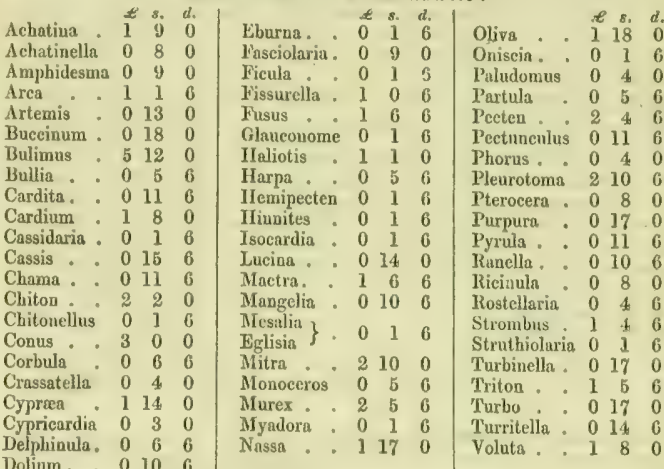

The genus Heux is in course of publication.

SOLD ALSO IN VOLUMES:

Vol. I. Conus

Phorus
Pectuncurus
Cardita

DHLPIIINUIA

Pleurotoma Tectunculus Cxpricardia

Crassatella Cardita Harpa

[122 Plates, price 7l.16s, 6d. half-bound.]

$\begin{array}{cll}\text { Vor. II. Corbula } & \text { Glauconode } & \text { Mrtra } \\ \text { Arca } & \text { Myadora } & \text { Cardium } \\ \text { Triton } & \text { Ranella } & \text { Isocarnia }\end{array}$

[114 Plates, price 7l.6s.6d. Itulf-bound.]

$\begin{array}{lll}\text { Vol. III. Muiex } & \text { Mangelia } & \text { Monockros } \\ \text { Cypliea } & \text { Puiruta } & \text { Builia } \\ \text { Halotis } & \text { Ricinuta } & \text { Buccinum }\end{array}$

[129 1'lates, price 8l. 58.6d. half-bound.]

Vor. IV, Chama

$\begin{array}{lll}\text { Chama } & \text { Ficula } & \text { Fusus } \\ \text { Chmonellus } & \text { Pyrula } & \text { Paludome } \\ & \text { Turbinelia } & \text { T'urbo } \\ & \text { Fasciolaria } & \end{array}$

[110 Plabes, price $7 l .18 .6 d$, hrlf-bound.] 


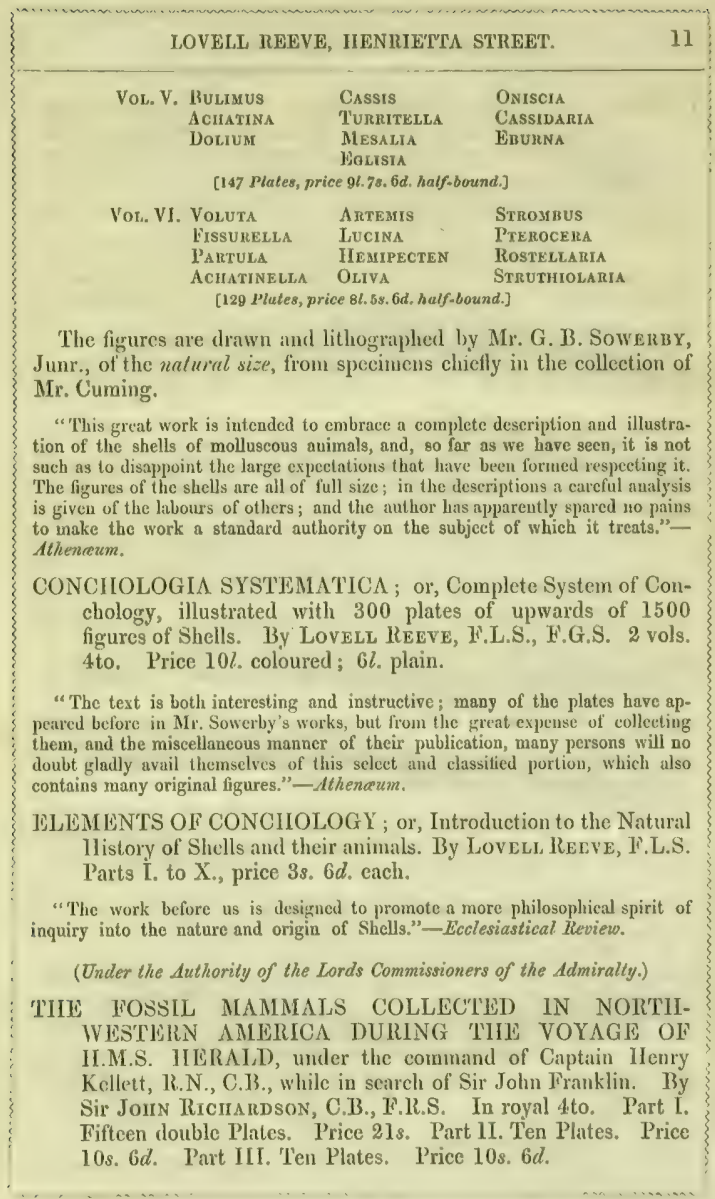


CUR'TIS'S BRITISII ENTOMOLOGY, being Illustrations and Descriptions of the Genera of Insects found in Great Britain and Ireland, comprising coloured figures, from nature, of the most rare and beautiful spccies, and, in many instances, of the plants upon which they are found. By Jown CunTis, F.L.S.

The 'British Entomology' was origrinally brought out in Monthly Numbers, size royal $8 \mathrm{vo}$, at $4 s$. $6 \%$, each containing four coloured plates with text. It was commeneed in 1824, and completed in 1840 , in 193 Numbers, forming 16 volumes, price $\$ 4316 s$.

The work is now offered new, and in the best condition:Price to Subseribers for complete copies in sixteen volumes, $£ 21$. Price of the new issue, and of odd Numbers . . 3s. $6 d$. per No. ** Vols. I. II. III. IV. and V. of the New Issue are now ready for delivery.

INSECTA BRTTANNICA. Diptera. By W. Wazken, Fsq., F.L.S. Vol. I. and II. Illustrated with plates. Price $25 \mathrm{~s}$. plain.

\section{THE ARTITICIAI, PRODUCTION OF FISII. By PISOAIIUS. Third Edition. Price 18.}

"The object of this little book is to make known the means by which fish of all descriptions may be multiplicd in rivers to an almost incalculable extent. .... 'This principle of inerease l'isearins has parrich out by argument and experiment in his little treatise, which, we think, is worthy the attention of the legislator, the country gentleman, and the clergyman; for it shows how an immense addition may be made to the people's food with searcely any expense." - Era.

POPULAR IISTORY OF BRITISH ZOOIPIYTES. By the Rev. Dr. Landsborovgr. With Twenty. Plates. Royal $16 \mathrm{mo}$. Price 10s. 6d. coloured.

"This work constitutes unc of the popular scries of scientific treatises which, from the simplicity of their style, and the artistie excellence and correctness of their numerous illustutions, has arquired at celchrity beyoud that of any other series of modern chenp works. With this manual of Zoophytes, and that upon Seaweeds by the same author, the student can ramble along the sen-shores and glean knowledge from every heap of tangled woed that lies in his pathway." - Liverpool Slandard.

"Parents who sojourn for a few months at the sea-side will find him a safe and profitable companion for their children. . He will tcll them not only to see, but to think; and he is moreover a cheerful, and at times a merry teller of incidents belonging to his subject.".-Belfast Mercury.

"We can cordially recommend this beautiful little book to our readers as one which will greatly add to the interest of a temporary or permanent residence by 
the sea-side, and which will give to those who have no opportunity of studying the ereatures themselves, an excellent iusight into the exteut and beauty of this section of the deep." -Weekly Neros.

\section{VOYAGES AND TRAVELS.}

TRAVELS ON TIIE AIIKZON AND RIO NEGRO. By ALFRed R. WALLace, Lise. With Remarks on the Vocabularies of Amazonian Languages, by R. G. LATHLM, M.D., F.1R.S. With Plates and Maps. 8vo, 18 s.

"Mr. Wallace has given us a most lively and interesting description of the glories of the magnifieent river. Venezuela, Columbia, Ecuador, Peru, Bolivia, and 13razil, six mighty States, spreading over an area far more exteusive than Burope herself, eontribute their aid in forming the flood up which he toiled. For twenty-eight days consecutively he breasted the stream of the Amazon. . . . He enters, with all the zest of a naturalist, into the history of the living things which fly, run, or ereep over the surface of the country. Iis sketches of the natives, their appearance, habils, and disposition, are quite original, and therefore instructive and interesting." - Brilannia.

"Mr. Wallace's explorations on the Imazon and lio Negro, the northern brazch of that mighty river, form, an enchanting work. In the novelty of its scenery and manuers, in the trutliful, albeit somewhat literal, picture of what the traveller snw and felt, in the quiet earnestuess by which obstacles were surmounted, by 'lalleyrmil's favourite rule of waitiog, and in the patience with which sickuess, sulicring, and privation were submitted to, "T'ravels on the Amazon and Rio Negro remind as of the simplicily of the old voyagers." - Syee. tator.

WESTEIR IIILITAYA AND TIBLE; the Narative of a Journey through the Mountains of Northern India, during the Years 18.7-8. By Thoms T'momson, M.D. With 'Tinted Lithographs and a new Map by l'etermann. 8\%o, 158.

"Few more valuable volumes of travels than this by Dr. Thomson have been for a long time past published. Long after the interest which its novelty wil create slaall have passed away, it will be a standard book of reference on account of the valuable fucts which it contains, and of the spirit of sound observation in which it is written." - Alhenaum.

"The work is one of durable importance. The most general reader will not find $\mathrm{Dr}$. Thomson's journey tedious..... We have in this volume matter which will inform every man who reads it steadily, and follows the author's route with attention to the Map." - Eraminer.

"'To all those who desire to judge seicntifically of what is possible in the eultivation of the Indo-Alpiue Florn, which is now so rapidly enriching our gardens, works of this description have great interest." - Gardeners' Chronicle.

"We ean most cordially recommend Dr. Thomson's work to all those who wish to obtain a clear iden of this magnifiecnt and interesting region, to which our late conquest in the Punjaub has brought us into such close contigaity." Guardian.

"This is a valuable contribution to our knowledge of a remote and lately explored tract of the earth's surface." - Adverliser. 
CIRCUMNAVIGATION OF THE GLOBE, being the NARRATIVE OF 'THE VOYAGE OF II.M.S. IIERALD, under the command of Captain Ilenry Kellett, R.N., C.B., during the years 1845-1851. By Bertuold Senmann, Member of the Imperial Academy Nat. Curiosorum. In 'T'wo Volumes, 8vo, with 'Tinted Lithographs and a New Map by Petermann.

"With extensive knowledge in geography and its cognate sciences, Mr. Scemum possesses a close and vivid style, which expresses his ideas not ouly with clearness but animation." - Spectator.

"Mr. Seemana is always a lively and agreeable companion, and has the merit of directing the attention of the general reader to ajplied Natural History rather than to questions interesting only to the student of pure seience; he now appears as the narrator of an important circumuavigation of the globe." - Gardeners' Chronicle.

TRAVELS IN TIE INTERIOR OF BRAZIL; prineipally through the Northern Provinces and the Gold and Diamond Districts, during the years 1836-41. By the late Georae Grnkder, M.I)., F.I.S., Superintendent of the Royal Botanic Gardens of Ceylon. Second and cheaper Edition. IVith a Map of the Author's Route and View of the Organ Mountains. Price 12s. cloth; $18 s$. bound.

"When enmping ont on the montain-tops or in the wilderness; roughing it in his long journeys through the interior; observing the very singular mode of life there presented to his notice; deseribing the curious characters that fell noder his observation, the arts or substitutes for arts of the people, and the natural productions of the country - these Travels are full of attraction. The book, like the country it describes, is full of new matter." - Spectator.

"This volume is from the pen of an able naturalist, whose heart is in his occupation. . ... Some of the regions he visited have seldom been trodden by Europeans-never by Englishmen; so that his observations derive value from the novelty of the maiter to which they relate."-Athencum.

\section{MISCELLANEOUS.}

POPULAR PIIYSICAL GEOLOGY. Illustrated on a new and striking plan by twenty double-tinted Tithograph Landseapes, each depicting some special geological phenomenon, drawn and coloured from nature. By J. BEETE JuKEs, lisq., M.A., F.R.S., Loenl Director of the Geological Survey of Ireland, and President of the Geological Society of Dublin. Royal $16 \mathrm{mo}$. Price $108.6 \mathrm{~d}$.

"Mr. J. Becte Jukes's 'P'opular P'hysical Geology' is one of the best of the popular seientific mamals which have been published in a scries by Messrs. Reeve and Co."-Guardian.

"Mr. Beete Jukes is well known as a froologist, and he has given the public n work at once popular and original. By original, we do not mean to intimate 
that he has propounded in it new theories or original discoveries, but that the book is a writing ont of his own experience, without abridgment or re-writing of other books. The result is admirable for perspicuity, for charm of exposition, and for solid instruction. The book is illustrated with twenty tinted lithograplis, from drawings by Mr. Jukes and Mr. Dunoyer, who is himself a Geologist, and they are of rare excellence as illustrations; altogether it is an introduction to the study of Geology to be most emphatically recommended." - Leader.

"This is one of the most remarkable works on Geology which have yet been published; Mr. Jukes has struck out a new path for the geological student, and has doue more to remove the difficulties which iurpeded his progress than any previous author. Rarely, indeed, have we perused any introductory manual with freater plensure; every word we have read has conveyed the impression that Mr. Jukes is an original observer, thoroughly conversant with his subject, and aware of the difliculties to be overcome. His language is graceful, simple, and free from cverything like scientific pedantry." - Liverpool Courier.

\section{POPUSAR MLNERALGGY; a Familiar accomnt of Minerals and} their Uses, By HENRY SOWERBY. With T'wenty plates of figures. Royal $16 \mathrm{mo}$. Price 10s, 6d. coloured.

"Mr. Suwerby las endeavoured to throw around his subject every nttraction. His work is fully and carcfully illustrated with coloured plates." - Spectator.

\section{T'ALPA; or, TIIE CHRONICLLS OF A CLAY FARM : an} Agricultural lragment. By Cuandos Wrex lloskx's, lise. Third and cleaper edition. $12 \mathrm{mo}$. Price $3 s, 6 d$. Of the original edition, at $8 . s$, illustrated by George Crunsulak, only a few copies remain.

"If there still remains a real living unsatisfied Protectionist, we in all heartiness and goodwill recommend to him the nmusing and instructive 'Chronicles' before us."- Sherborne Journal.

"'The writer handles this subject in such a masterly manner-his style is so piquant, as well as forcible, so scholarly, yet so raey - his wit and his wisdom are so skilfully blended- - he has so eleverly worked out his motto, Ridentem dicere verum, by telling the truth langhingly - that the reader finds himself irresistibly carried alone, and he and the book part not company until he has made himsclf master of the tale that he has to unfold."-Lciceslershive Mercury.

"This is a rare little volume. Wo don't know which to admire most, the anthor's humour or his wisdom. Te has set himself the task of illustrating, in an agreeable manuer, the evils of Custom, Prejudice, and Feadalism, as they exist anong asriculturists. It will create much laughter among the merry, and convey many a lesson to the tiller of the soil." - Era.

"Cleverly written in a vein of pleasantry, the work persereringly uproots the prejuctice of the past, and demonstrates that scientific knowledge is an important element in successful tillage." - Lincoln Mercury.

"The vignettes of Mr. Cruikshank are the happicst proofs we have lately seen that the genius of this fine artist's earlier day is still fresh and unimpaired. The farners should be very grateful to have such a nice little book provided for their especial use, entertaimment, aud profit."-Exraminer. 
DROPS OF WATER; their marvellous and beantiful Inhabitants displayed by the Microscope. 'By $\Lambda$ GNes Catrow. Square $12 \mathrm{mo}$, with plates. Price 7s, 6d. coloured.

" 'Drops of Water' is an introduction to onc of Nature's inexhaustible sources of wonder and delight, performed in a very ellicient and satisfactory manner. . . . As a specimen of typography, it is of a superior eharneter; and the plates are indicative of no small degree of artistic shill as well as science."-Observer.

"An elegant little book, both in the getting up and its literature. ... The text is accompanicd by coloured plates, that ex hibit the most remarkable ereatures of the watery world." - Snectutor.

"Of the manner in which this work is crecuted, wo can say that, like Miss Catlow's previous productions on Natural Ilistory, it displays an accurate aequaintance with the subject, and a keen delight in tho contemplation of the objects to which it is devoted. As far as the living beings which inhabit "Drops of Water' are concerned, we know of no better introduction to the use of the microscope than the present volume." - Athenceum.

ILLUSTRATIONS of the WISIOON and BBNEVOLENCE of the 1) LITY, as manifested in Nature. By II. Euwands, LL.D. $16 \mathrm{mo}$. Price 2s. 6d.

"A little excursion in the track of Paley and the broad road of the Bridgewater Treatises. Animals, Atmosphere, Organic Matter, Light, and Electricity are the natural elements out of which the author deduces his pious lessons, leading to a First Canse in wouder, adaniration, and worship."-Literary Gazette.

\section{THE PLANETARY ANI) STELIAR UNIVERSE. By}

RonerT J.MLS M.ANN. With fifty astronomical Dingrams and Maps of the Circumpolar Constellations. F'cap. Price 58.

" $A$ bricf abstract of the diseoveries of Newton, clearly explained and elegantly illustrated." -Westminster and Foreign Quarterly Review.

\section{N E W W O R K S}

\section{Preparing for Publication.}

POPUTAR BRI'ISII CONCHOLOGY, comprising all the British Mollusks and Shells. By G. B. SowerBy, Jun., F.L.S.

POPULAR HISTORY OH IBRITISII MOSSLS, comprising all the British Species. By R. M. Stark, Esq.

Printed by J. F. Taylor, Little Queen-street, Lineoln's Inn Fields. 


JUN $=1987$ 


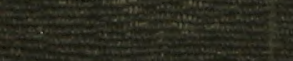

